MARCO ANTONIO DA COSTA SABINO

\title{
POLÍTICAS PÚBLICAS, JUDICIÁRIO E SAÚDE: LIMITES, EXCESSOS E REMÉDIOS
}

\author{
Tese apresentada para a obtenção do Título \\ de Doutor em Direito \\ Departamento de Direito Processual \\ Orientadora: Professora Titular Ada \\ Pellegrini Grinover
}

Faculdade de Direito da Universidade de São Paulo

São Paulo

2014 


\section{POLÍTICAS PÚBLICAS, JUDICIÁRIO E SAÚDE: LIMITES, EXCESSOS E REMÉDIOS}

Tese apresentada à Faculdade de Direito da Universidade de São Paulo para a obtenção do Título de Doutor em Direito

Departamento de Direito Processual

Orientadora: Professora Titular Ada Pellegrini Grinover 
Autorizo a reprodução parcial do conteúdo deste trabalho, nos termos da Resolução CoPGr $n^{\circ}$ 5401, de 17.4.2007, exclusivamente para fins de estudo e pesquisa e sob inarredável condição de citação da fonte. 
ERRATA (OPCIONAL) 


\section{POLÍTICAS PÚBLICAS, JUDICIÁRIO E SAÚDE: LIMITES, EXCESSOS E REMÉDIOS}
Tese de Doutorado apresentada na Faculdade de Direito da Universidade de São Paulo Requisito parcial para obtenção do titulo de Doutor em Direito Área de Direito Processual

APROVADO EM:

BANCA EXAMINADORA:

1) Prof. Dr.

Instituição:

Julgamento: Assinatura:

2) Prof. Dr.

Instituição:

Julgamento: Assinatura:

3) Prof. Dr.

Instituição:

Julgamento: Assinatura:

4) Prof. Dr.

Instituição:

Julgamento: Assinatura:

5) Prof. Dr.

Instituição:

Julgamento: Assinatura: 
À Luciana, luz da minha vida

À pequena Beatriz, princesa que me faz feliz À dona Glória, que glorifica meus dias Ao velho Sabino, que me deu o saber 


\section{AGRADECIMENTOS}

Opto por redigir estes agradecimentos em forma de prosa, mais ou menos contando a minha história. Daí o leitor poderá entender melhor os agraciamentos pela longa jornada que, creio, levar-me-á a obter a titulação de Doutor em Direito Processual.

Já na graduação eu mirava a docência. No quarto ano, fui honrosamente convidado a monitorar as aulas de Direito Constitucional a cargo da Professora Flávia Piovesan, que me tornou um apaixonado defensor da Constituição e das constituições. Uma vez formado, continuei por cinco anos como assistente informal dessa grande constitucionalista cujo nome é sempre lembrado para ocupar posto no Supremo Tribunal Federal. Não por acaso que, ato contínuo à colação de grau, inscrevi-me a concorrer a uma vaga no Mestrado em Direito Constitucional da Pontifícia Universidade Católica de São Paulo - o que não deu certo e me motivou a, antes, tentar e cursar a Pós-graduação em sentido largo. Hoje, sei que isso fez toda a diferença.

Eu tinha um foco, contudo: o doutoramento na Faculdade de Direito da Universidade de São Paulo. Quando era estudante, descobrindo e me envolvendo com as leis e normas, muitos vaticinavam ser minha missão inglória, pugnando maior dificuldade para um graduado engrossar os quadros do Mestrado na USP do que para ser admitido em concursos da magistratura. Se fosse da PUC, como eu era, pior ainda. Acreditem, confirmei na pele a hipótese, embora não seja juiz. Sem nenhum antecedente familiar ou profissional, sem qualquer relacionamento com acadêmicos e docentes da Velha Academia, a tarefa parecia, mesmo, hercúlea. Em 2005, ainda pendente a Especialização em Direito de Processo na PUC, ano em que conheci minha amada esposa, submeti-me ao rigoroso processo seletivo de admissão a uma das vagas do Mestrado em Processo da USP. Admitido na prova de línguas e, depois, na prova específica, percorri as listas de orientadores e vagas disponíveis. Tentei pensar estrategicamente. Mirei nos nomes pouco conhecidos do público. Um deles era um professor que ostentava apenas uma vaga, a ser preenchida por mestrando ou doutorando. No ano anterior, esse mesmo professor não teve qualquer inscrito. Não tive dúvida: apresentei a ele meu projeto. Pensei - com uma lógica pueril, confesso - que, também em 2005, a concorrência seria baixa. Ledo engano. Havia oito pessoas concorrendo para a mesma vaga. Todos pensaram como eu. O que me confortava é que dito docente faria uma prova para admitir seu orientando. Assim, cheio de brios por ter sido aprovado nas etapas anteriores e tendo apresentado um projeto que 
julguei interessante, realizei prova naquela famosa sala do quinto andar do prédio anexo ao Edifício Histórico, onde fica o Departamento de Processo - sala aquela que ainda me veria mais vezes. Ora, por que não poderia ser eu o escolhido? Afinal, se o professor em tela realizou uma prova além mesmo das protocolares, é porque, claro, ele não tinha ninguém em vista. Sendo a seleção imparcial, minhas chances eram aumentadas.

Bem, se tivesse eu angariado a vaga, não precisaria contar a história até aqui. É claro que fracassei. Foi minha primeira derrota. Quem abocanhou a vaga, anos depois, tornou-se grande amiga minha, e, ironia do destino, sagrar-me-ei doutor antes mesmo dela. Ela, por sinal, ignora os precedentes de nossa amizade.

Como é cediço, contudo, as provas de línguas e específicas têm validade bienal na Faculdade do Largo São Francisco, então me pus firme na tarefa de conquistar meu ingresso no Mestrado. Durante o ano, desenvolvi um projeto e procurei cercar-me de informações. Baseado no depoimento de um amigo, direcionei minhas esperanças a um famoso professor, que, naquele ano de 2006, tinha aberto nada menos do que dez vagas (professores titulares tinham esse direito, enquanto que professores doutores, naquela altura, podiam oferecer somente duas vagas, tanto para Mestrado quanto para Doutorado). Semanas antes de depositar o projeto, conversei com o mestre e passei a frequentar suas aulas no Pós às quintas-feiras, por ele convidado. Mostrei a ele o projeto, tido por interessante, e perguntei-lhe se eu poderia submetê-lo a ele. A resposta foi imediatamente afirmativa. Sabedor que muitos professores adotam critérios de chegada para aceitarem seus múltiplos candidatos, muitos deles realmente aptos a desenvolver pesquisas ímpares, indaguei se aquele docente possuía candidatos na fila de espera. Disse-me ele, em um primeiro momento, que não, que a escolha dos alunos seria realizada por critérios objetivos e que, provavelmente, realizar-se-ia uma prova. Acalmei-me e, diante dessas palavras, submeti minha candidatura ao indigitado professor.

Compareci às aulas no crepúsculo de 2006. Descobri que nem sempre era o professor a conduzir os trabalhos, dividindo-o com outros dois dos mais fabulosos mestres da Faculdade. Para mim, era uma honra circular nesse meio. Tive mais um ou dois encontros com ele. Perguntei sobre a prova. A resposta foi inconclusiva, mas garantida a grande possibilidade do exame ocorrer. As aulas se encerraram. A data da divulgação da aceitação dos resultados se avizinhava. Nada de prova. Fiquei temeroso, mas esperançoso, já que, afinal, o professor havia me sinalizado pelo interesse pelo projeto - àquela altura, a análise da constitucionalidade da recém-introduzida possibilidade de julgamento definitivo da inicial quando houvesse precedentes pela improcedência. Quando, enfim, saiu a lista, 
meu nome não estava nela. Nova decepção: a segunda derrota. Liguei para o professor. Conversando com ele, disse-me que dentre os mais de trinta candidatos, eu era um dos que ele gostaria de orientar, que o projeto era muito bom, mas que ele já tinha destinatários para suas dez vagas. Pediu-me desculpas, fazendo, contudo, uma oferta: no ano seguinte, eu poderia cursar integralmente sua disciplina como ouvinte. Perguntei se ele não me aceitaria como aluno especial, eis que poderia aproveitar o crédito no futuro Mestrado protocolar. Afirmando não haver vagas para especiais, ele insistiu que eu apenas ouvisse, mas que também participasse dos seminários e atividades. Um pouco contrariado e vivenciando sentimento paradoxal, aceitei. No ano seguinte, em 2007, comecei a frequentar a clássica disciplina de quinta-feira na área de Processo Civil.

Nem preciso dizer que havia, na turma, três alunos especiais.

A disciplina era estruturada por aulas com uma parte dialética conduzida pelo professor e outra parte consistente em seminário apresentado pelos alunos. No primeiro encontro definir-se-iam os seminários e seminaristas. Quem coordenava os trabalhos era Carlos Alberto de Salles, professor que, por absoluta ignorância minha, desconhecia, tendo apenas dele rasamente ouvido falar. Os temas foram distribuídos e os alunos se colocaram a escolhê-los. Timidamente, com o receio daqueles a quem legitimidade não socorre, dirigi-me ao professor e contei-lhe o que havia tratado com o docente titular da matéria que havia me convidado como ouvinte. Depois de relutar a entregar a coparticipação de um ouvinte na condução de seminário, Salles me aceitou, e, por fim, apresentei o último trabalho do semestre. Estudei todo o material, frequentei todas as aulas, embora muito acanhadamente, participei como podia. Era uma turma grande em matéria disputada, muitos alunos com longa tradição jurídica. Eu era apenas um ouvinte sem ninguém a recorrer no universo do Direito.

No semestre subsequente, de novo estava na turma. Na primeira aula, Salles já advertiu que, naquela oportunidade, ouvintes não poderiam ser seminaristas, já que a turma estava ainda mais lotada. Não esqueço seu olhar. Entendi o recado e me recatei. Agi como no primeiro semestre com relação às aulas, com a diferença que se aproximava a data da submissão das candidaturas de Mestrado e a tensão estava no ar - que projeto apresentar? Para quem? Quem, afinal, abrirá vagas? Essa pessoa já possuirá candidatos em vista? Minha ideia, desde que iniciei minha auricular participação no curso, era submeter minha admissão ao mesmo professor do ano anterior, tanto que com ele me encontrei duas vezes - oportunidades em que, engraçado, parecia que ele não se lembrava tanto de mim. Dele ouvi o que pareceu ser um mantra no meu percurso rumo à vaga: "mas... você é da 
PUC. Por que não faz o Mestrado lá?”. Esse mantra foi entoado pelas mais variadas bocas, sempre a me frustrar e a exigir-me resposta sem graça. Paciência. Enfim, conduzi meu projeto e meu pensamento para apresentar o projeto àquele docente. A matéria prosseguiu e, no dia da prova final, compareci e quis fazer o exame. Salles me viu e disparou: "você é mesmo insistente!". Eu era. E sou. Essa insistência se mostrou decisiva para que meus objetivos acadêmicos fossem alcançados.

Foi então, faltando poucas semanas para submissão das candidaturas, que um amigo me contou que aquele professor cogitado não abriria vagas, já que recentemente preenchidas todas as suas dez. Desesperei-me, embora a culpa fosse completamente minha, eu que deveria ter checado a mecânica de vagas no programa de Pós-graduação da Faculdade de Direito da USP. Enfim, era tarde. Pouco depois, foi divulgada a lista com professores que abriram lugares. Dentre eles nenhum me dizia qualquer coisa, ao menos, no que tocava ao ingresso no programa, exceto um: Carlos Alberto de Salles. Ele abrira duas vagas, uma para o Mestrado, outra para o Doutorado. Analisei sua linha de pesquisa e vibrei: ali estavam os processos coletivos, assunto que estudei sobremaneira, inclusive na graduação, e que sempre me entusiasmou. Pensei em um tema e fui conversar com ele. Disse-me que uma das vagas - do Doutorado - estava destinada a um de seus alunos recentemente titulado mestre - que se tornou meu amigo, mas a outra estava aberta. Disseme mais, que realizaria uma prova e que somente aqueles que atingissem a nota mínima de sete teriam seu projeto examinado e seriam chamados para uma entrevista. Advertiu-me que essa era, para ele, a forma mais republicana de lidar com a coisa pública. Gostei. Topei. Provas não me davam medo; ao contrário, enchiam-me de esperanças. Apresentei a candidatura, entreguei o projeto, realizei e fui aprovado na prova e parti para a entrevista. Eram quatro candidatos para a vaga.

Quando sentei frente a frente com Salles, àquela altura, ele já me conhecia. Foi cândido e simpático. Olhou meu projeto e dirigiu-me uma pergunta, seguida de uma afirmação: "Marco Antonio, o que você pretende com este projeto, porque, confesso-lhe, não o entendi direito". Salles tinha razão. Ele não havia compreendido e eu não sabia explicar a proposta. $\mathrm{O}$ projeto era ruim, eu queria estudar a súmula vinculante e o recurso especial repetitivo e ligá-los à tutela coletiva, mas de uma maneira confusa, digna da correria em que o ele foi escrito. Era uma bomba. Mesmo assim, tentei explicar. Saí da sala, Salles entrevistou os demais e, ultimados os encontros, chamou todos, deu sua decisão e justificou o porquê, comentando as provas, entrevistas e projetos, um a um. Havia escolhido um aluno especial que cursou a Disciplina de Processos Coletivos em 
2007, que também viria a ser meu amigo. Saí da sala triste, mas satisfeito: enfim, um processo seletivo de fôlego e transparente. Mas, afinal, era minha terceira derrota. Pior que isso: o prazo de validade das provas de 2005 se encerrava com aquela tentativa. Para prosseguir, teria de, novamente, ser aprovado na prova de inglês e na específica de Processo Civil. Mas eu continuaria. E continuei, mais animado do que nunca: sabia que Salles, por ter se demonstrado um professor exemplar, culto e estudioso de assuntos a mim caros, seria em quem investiria.

No início de 2008, enviei e-mail a Salles e pedi para ser aluno especial na Disciplina de Processos Coletivos, que tinha lugar às segundas-feiras e, como docentes, além dele próprio, os cultuados professores Ada Pellegrini Grinover e Kazuo Watanabe. Para mim, a tentativa poderia se revelar profícua, como ocorrera com o aluno aprovado no ano anterior, além de ser uma coisa incrível cursar matéria com esses nomes do Processo Civil. Para minha surpresa, ele me respondeu dizendo que recomendaria à professora Ada que eu fosse aceito. Não acreditei. Inscrevi-me e a entrevista com os candidatos foi agendada. Na mesma sala do Departamento de Processo (aquela sala de reuniões ao lado da diretoria do Departamento) em que, dois meses antes, Salles recusou minha candidatura, ele, Ada e Kazuo entrevistavam os candidatos. Quando chegou minha vez, não pude conter a emoção, sobretudo quando Salles me recomendou à Ada na minha frente, dizendo que eu havia sido seu aluno na matéria de quinta-feira e a havia cursado com brilhantismo, um gracioso e endereçado exagero, decerto. Chegou o dia da divulgação dos resultados. Eu havia sido escolhido. Pela primeira vez, meu nome figurava em uma lista oficial de admitidos na Faculdade de Direito da USP. Que felicidade. Esse foi o primeiro e claro passo para a trajetória acadêmica que culminará na titulação de doutor.

O ano de 2008 foi incrível. A turma era menor, a matéria, excepcional, ali fiz bons amigos, era considerado igual aos demais - embora aluno especial - e todos tinham a certeza que, no final do ano, eu seria admitido. Adquiri confiança. Ao longo do ano e com apoio no material e nas discussões, desenhei o projeto de pesquisa que deu lastro a esta tese de doutoramento. Fiz as provas ordinárias pela segunda vez. Passei em ambas. Fui aceito como aluno especial também para o segundo semestre. Obtive conceito “A” nos dois períodos. O árduo trabalho começava a ser recompensado.

Ao fim de 2008, foram divulgadas as vagas. Salles tinha apenas uma, para Mestrado. Kazuo não abriu e Ada, apenas uma, para Mestrado ou Doutorado. Nem me atrevi a tentar com a professora Ada, que deveria ser concorridíssima. Apontei Salles - ele havia se mostrado um docente admirável, seu processo seletivo era conhecido e, em 2008, 
meu projeto estava bem melhor que o fracassado material de 2007. No dia marcado para a prova, no mesmo Departamento de Processo, na fatídica sala de 2005, havia cinco candidatos. Antes de distribuir a prova, Salles entrou na sala e disse-nos que havia ocorrido um fato inusitado: a professora Ada não havia recebido nenhuma candidatura, e, por isso, ela pediu a Salles para escolher um de seus candidatos, com o que ele perguntou quem se interessava. Evidentemente que todos. Incrível! A professora certamente não teve candidaturas porque ninguém queria mitigar suas próprias chances, todos ciosos da dificuldade de serem por ela escolhidos, Ada, sem dúvida, a maior processualista dentre os maiores processualistas. Fiz a prova. Fui aprovado com mais dois candidatos. Eram três para duas vagas, uma com Salles, outra com Ada. Eu havia sido aluno especial. Estava muito confiante. A confiança aumentou quando Salles disse-nos que a professora Ada escolheria projeto que perfilhasse a linha da intervenção do Judiciário em políticas públicas. Poderia ser o meu. Tremi. Diante de Salles e Ada, fui perguntado sobre meu texto. Ela tinha a primazia na escolha; após ela feita, Salles apontaria seu orientando do ano. Ao meu lado, os outros dois candidatos, que também foram indagados sobre seus projetos. Ao fim, saímos da sala enquanto os docentes deliberavam. Foram minutos eternos. Esperei olhando pela janela do final do corredor, uma vista sôfrega e melancólica da parte lateral da fachada da sede do Parquet estadual paulista, quase tropeçando na planta que ali ainda costuma repousar.

Quando, afinal, a porta se abriu, saiu uma sorridente professora Ada, dizendo "eu escolhi o Marco Antonio". Aquelas palavras soaram para mim como um ente abstrato, alado, difuso, tanto que nelas não cri. Minha primeira reação foi surpresa, a segunda foi surpreender a professora, dando-lhe um abraço e um beijo. Ela possivelmente não sabia o que aquilo representava para mim. Salles, com seu peculiar bom humor, ainda me sussurrou: "você acabou recebendo um presente". Eu sabia que sim. Era uma segundafeira do final de novembro de 2008. Peguei o elevador e desci para minha aula de Processos Coletivos. Contei aos meus amigos. Eles me disseram que tinham certeza que isso aconteceria. Eu não, por razões evidentes.

Depois disso, fui convidado para monitorar a graduação nas matérias de Interesses Difusos e Coletivos e Processo Civil Aplicado de responsabilidade de Salles. Mesmo fora do PAE, continuei seu monitor. Em 2011, a professora Ada me sugeriu converter o Mestrado para Doutorado Direito, em virtude da natureza do trabalho, uma honraria para poucos. A banca de qualificação fez observação expressa pela conversão. Aconselhei-me. Uns disseram-me como seria bom, outros, que não seria tanto, 
principalmente durante a arguição. Doutorandos diretos são mais vergastados pela banca, diziam. A CPG aprovou o requerimento e, de repente, de mestrando, virei doutorando, subindo um degrau. Fui convidado para ser pesquisador vinculado à Faculdade, professor convidado em certos cursos, conferencista e, honraria para poucos, passei a conduzir alguns seminários na disciplina a cargo daquela que, nessa trajetória, tornou-se minha amiga, a professora Susana Henriques da Costa. De patinho feio da turma, virei assistente de mestrandos, mestres e doutorandos, ainda sem mesmo Doutor ser. Tornei-me professor efetivo de duas faculdades, Business School São Paulo e Fundação Instituto de Administração, duas das mais importantes escolas de negócios. Ano que vem, ou ainda neste, possivelmente darei início ao meu Pós-doutorado na Universidade de Coimbra, onde fui informalmente aceito. Ali, tratarei da liberdade de expressão, tema que me encanta e com o qual lido diuturnamente.

São quase dez anos de jornada desde que me inscrevi em 2005 para concorrer à tão sonhada vaga. Dez anos se passaram desde que saí junto com minha namorada da prova específica, em uma sexta à tarde, e fomos tomar cerveja em um boteco nas cercanias da Faculdade. A namorada de então é, hoje, a luz da minha vida mencionada na Dedicatória.

Daí porque meu primeiro agradecimento é a Deus. Não fosse Ele, essa história não seria possível. Ele quem me dotou de fé. O homem com fé enxerga a vida diferentemente, anda incessantemente, busca, vai além.

Obrigado, meus queridos pais. Seu Sabino saiu da roça de Vila Real, fugido do duro regime de pobreza de Salazar, vindo tentar a sorte no Brasil. Aqui, o portuguesinho de outrora encontrou minha mãe, saída da roça do Sul de Minas Gerais. Ele, industriário que não concluiu a universidade; ela, com o primeiro grau inconcluso. Ambos roceiros que iniciaram cedo seus ofícios e decidiram mudar de vida. Pois esses dois terão seus dois filhos doutores pela USP. Não fossem eles, que abdicaram de jantar fora, ter carro e viajar em prol da educação da prole, minha irmã e eu não atingiríamos tão almejado grau acadêmico. A obstinação de meus pais pela educação fez a diferença, é a eles que devo este doutorado. Meu pai, sei que estas palavras não chegarão a contento para seu bom entendimento... infelizmente... mas não poderia deixar de materializá-las.

Sabem o que quer dizer Luciana?

Eu sou luz.

Quem viveu mais de perto o drama foi ela, minha amada esposa, Luciana. Em 2005, ela fez as provas junto comigo. Aquele foi o ano em que nos conhecemos para, 
depois, casarmos e, agora, sermos presenteados com nosso amor, a pequena Bia, em quem, nos olhos azuis e no sorriso fácil, encontro a paz. A Lu foi entusiasta de meus planos e vítima de meus arroubos mal humorados, finais de semana sem praia ou bar, das minhas noites sem sair, dos meus reclamos e desesperos. Ela sofreu comigo. E, mesmo assim, sempre me apoiou, como se dela mesma se tratasse. Isso é amar. Luciana, luz da minha vida, é a você que agradeço este momento.

Minha querida irmã, você também é parte dessa história, acompanhou tudo, muito obrigado por dividirmos reciprocamente nossas agruras acadêmicas. Ana e Fá, minhas lindas, este seu tio ama vocês.

Devo agradecer aos professores da USP, a quem nutro especial admiração, notadamente minha orientadora, professora Ada, mais os professores Kazuo, Salles e Susana. De Ada só tenho o melhor a falar. De fato, foi Deus quem cruzou nossos caminhos. A honra de ser orientado por alguém como ela me inspira. Ela é doce. Ela magnetiza os olhares e espíritos. Ela é única que conheço cuja fala em congressos de Direito Processual é integralmente ouvida, sem ruídos paralelos, risadas irônicas ou roncos, um temor reverencial motivado sem igual. Kazuo sempre me deu dicas preciosas, todas incorporadas na tese, e sempre foi tenro, embora contundente ao debater comigo. É incrível sua capacidade de perceber o ponto nodal das coisas. Para Salles, meu abraço e apreço. Um grande docente e, sobretudo, uma grande pessoa. Susana também contribuiu muito, com dicas pontuais e seu olhar clínico sobre questões muitas vezes ocultas. São dela bons contrapontos aos pensamentos por mim ostentados, que aguçaram meus sentidos e reverberaram no texto que se apresentará. Salles e Susana, nova geração de grandes processualistas, a continuar a tradição do Largo São Francisco.

Tomara Deus que eu também dela faça parte.

Meus amigos de jornada, meu muito obrigado. Nos bancos acadêmicos fiz bons deles. Citá-los seria injustiça, embora saiba eu do perigo da generalização. Sintam-se vocês abraçados por mim. Sabem vocês quem são.

Meu obrigado, também, aos meus empregadores durante a labuta. Nunca deixei de trabalhar; ao contrário, mudanças profissionais de grande monta se operaram durante o período acadêmico. Ao Koury Lopes Advogados, fantástica banca que honrosamente integrei desde sua fundação até recentemente, cumprimento e agradeço a todos, em especial aos Drs. Pedro Augusto Machado Cortez e Tiago Machado Cortez. O primeiro, homem incrível, pessoa singular, de grandeza inconteste, chegou a ler meus iniciais textos e debatê-los comigo, na certeza que os gênios não precisam dominar o 
assunto para sobre ele flutuar com maestria. Não esquecerei. Tiago, doutor pela USP, foi meu grande ouvido e me rendeu preciosas dicas sobre a academia. Aos dois, e aos amigos do KLA, muito obrigado.

À Rede Globo de Televisão meu igual agradecimento, a quem faço na pessoa do Dr. Gilberto Leifert. Foi Gilberto quem me trouxe do KLA para integrar o rol de executivos dessa que é uma das maiores empresas brasileiras, uma das maiores comunicadoras do mundo. É uma honra enfileirar-me em seus quadros. Gilberto, em particular, ajudou-me muito, não propriamente debatendo a tese, mas, em nossos diálogos e troca de ideias, abasteceu-me do frescor necessário a desenvolver ideias mais práticas que, aqui, foram solidificadas. A ele, meu muito obrigado. De novo, Deus fez nossos caminhos se cruzarem.

Não podem passar em branco meus felinos. Goya sempre esteve comigo, vindo como presente junto com sua original dona, a Lu. Depois, veio Frida, achada na rua, e, enfim, Kilmt (filho do Goya), nossos gatos pintores. Os persas e a vira-lata! Eles sempre me fizeram um afago e subiram no meu colo enquanto estava obcecado pesquisando e escrevendo.

Também não poderia deixar de agradecer aos músicos que tanto me ajudaram, ao longo destes anos, no trabalho de pesquisa e redação. A eles recorri desde logo. Agradeço a todos em nome de Pyotr Ilyich Tchaikovski e Ludwig Van Beethoven: o Quebra-Nozes, do primeiro, e a Sétima e Nona sinfonias, do segundo, foram minha inspiração para dar contornos finais ao texto. E que inspiração.

E o incrível disto tudo é: como é que, por acaso, fui escolhido pela professora Ada?

Por acaso?! 


\section{EPÍGRAFES}

"When citizens or their representatives disagree about what rights we have or what those rights entail, it seems something of an insult to say that this is not something they are to be permitted to sort out by majoritarian processes, but that the issue is to be assigned instead for final determination to a small group of judges".

Jeremy Waldron

“'I care not', says Mr. Dooley, 'who makes th'laws in a nation if I can get out an injunction",.

Donald L. Horowitz 


\section{RESUMO}

Trata-se o presente de estudo analítico e propositivo que circunda em torno do tema do controle jurisdicional de políticas públicas, com destacado vigor no que toca às prestações e ações de saúde a cargo do Poder Público. Analisando o fenômeno da assunção do Judiciário como arena de debate político e atribuição de direitos, ver-se-á que há virtudes e vicissitudes nesse que é caminho irreversível da sociedade moderna. No campo da intervenção judicial na saúde, serão demonstrados os grandes transtornos gerados por uma atividade pouco cautelosa e ainda predominantemente fundada nas premissas processuais do Século XIX, o que gera um desarranjo de contas e estratégias e deflagra uma clara crise entre os Poderes instituídos. Ademais, do modo como sucede hoje, a intervenção judicial em políticas de saúde acaba privilegiando poucos à custa de muitos, quando a saúde é taxativamente direito que deve ser atribuído pelo Estado de maneira isonômica e universal. A partir do diagnóstico das patologias causadas pela desmedida intervenção judicial na saúde, realizada a partir de pesquisa empírica e revisão bibliográfica, esta tese estabelecerá limites que deverão ser observados pelo magistrado, verdadeiras fronteiras que, caso ultrapassadas, agravarão e perpetuarão o problema. Ato contínuo, serão propostas medidas que se prestam a tornar o exercício da judicatura nessa seara mais harmônico com a própria gênese do direito à saúde.

A ideia, assim, é auxiliar magistrados e operadores a tornar a tarefa de sindicar ações e prestações estatais de saúde mais racional, equilibrada, justa e universal, mediante propositura de limites e adoção de instrumentos apropriados, processuais e não processuais.

PALAVRAS-CHAVE: Judiciário. Juiz. Processo. Intervenção. Controle. Saúde. Universalidade. Isonomia. Coletivização. Excessos. Limites. Remédios. Racionalidade. Equilíbrio. Tutela Jurisdicional. 


\section{ABSTRACT}

This work derives from a research upon Brazilian judicial intervention in public policies, focusing in how this intervention works regarding the constitutional duty, drove to the State, of providing health to people. Analyzing the political phenomena of Judiciary as one of the most relevant public discussions arena, this thesis will show that virtues and inconveniences arise from this Brazilian modern society reality. Considering judicial intervention upon public health, the work will explore the great problems issued by a less cautious activity founded - in relevant part - on classic procedural premises of the $19^{\text {th }}$ Century, which causes public accountancy disruption and overwhelms administrative strategies, generating a clear crisis amid instituted Powers. Moreover, as it flows nowadays, judicial intervention upon health public politics privileges few against interests of many, as health is a right of everyone and as indeclinable duty of State under the expression rule of Brazilian Constitution. After diagnose the pathologies caused by immeasurable judicial intervention upon public health, featured both by empirical research and bibliographic revision, this thesis will establish boundaries that might be observed by judges when accomplishing their honorable task, limits that, once overtook, make the problem worst and permanent. Afterwards, some measures will be proposed in order to turn judicial activity in this specific field more harmonic with proper nature of right to health.

Hence, the main idea is to help judges and other agents to turn the judicial task of intervention in public health more rational, balanced, fair and universal by proposing limits and adopting appropriated procedural and no procedural instruments.

PALAVRAS-CHAVE: Judiciary. Judge. Procedure. Intervention. Control. Public health. Universality. Equality. Collectivization. Excesses. Limits. Remedies. Rationality. Balance. Jurisdictional protection. 


\section{TÁBUA DE ABREVIATURAS}

\begin{tabular}{|c|c|}
\hline $\mathrm{ADIN}-$ & Ação direta de inconstitucionalidade \\
\hline $\mathrm{ADPF}-$ & Arguição de descumprimento de preceito fundamental \\
\hline AgRegRE - & Agravo regimental em recurso extraordinário \\
\hline AGU - & Advocacia-Geral da União \\
\hline ANVISA - & Agência Nacional de Vigilância Sanitária \\
\hline APLPP - & $\begin{array}{l}\text { Anteprojeto de Lei que institui o processo especial para controle e } \\
\text { intervenção de políticas públicas pelo Poder Judiciário }\end{array}$ \\
\hline Al. - & Alínea \\
\hline Apel. - & Recurso de apelação \\
\hline Art. - & Artigo \\
\hline Cf. - & Conforme \\
\hline $\mathrm{CF}-$ & Constituição Federal \\
\hline $\mathrm{CNJ}-$ & Conselho Nacional de Justiça \\
\hline $\mathrm{DJ}-$ & Diário de Justiça \\
\hline EMEA - & European Medicines Agency \\
\hline ENFAM - & $\begin{array}{l}\text { Escola Nacional de Formação e Aperfeiçoamento de } \\
\text { Magistrados }\end{array}$ \\
\hline et. al. - & E outros \\
\hline FDA - & Food and Drug Administration \\
\hline i.e. - & Isto é \\
\hline INAMPS - & Instituto Nacional de Assistência Médica e Previdência Social \\
\hline INPS - & Instituto Nacional de Previdência Social \\
\hline IPEA - & Instituto de Pesquisa Econômica Aplicada \\
\hline $\mathrm{HC}-$ & Habeas corpus \\
\hline j. - & Julgado \\
\hline $\mathrm{LDO}-$ & Lei de Diretrizes Orçamentárias \\
\hline $\mathrm{LOA}-$ & Lei Orçamentária Anual \\
\hline Min. - & Ministro \\
\hline $\mathrm{OMS}-$ & Organização Mundial de Saúde \\
\hline $\mathrm{ONU}-$ & Organização das Nações Unidas \\
\hline Par. ún. - & Parágrafo único \\
\hline p. - & Página \\
\hline pp. - & Páginas \\
\hline $\mathrm{PPA}-$ & Plano Plurianual \\
\hline Pet. - & Petição \\
\hline $\mathrm{PIB}-$ & Produto Interno Bruto \\
\hline $\mathrm{RE}-$ & Recurso extraordinário \\
\hline RENAME - & Relação Nacional de Medicamentos Essenciais \\
\hline REsp - & Recurso especial \\
\hline Recl. - & Reclamação \\
\hline Rel. - & Relator \\
\hline SS - & Suspensão de segurança \\
\hline STA - & Suspensão de tutela antecipada \\
\hline STF - & Supremo Tribunal Federal \\
\hline STJ - & Superior Tribunal de Justiça \\
\hline SUDS - & Sistema Único Descentralizado de Saúde \\
\hline SUS - & Sistema Único de Saúde \\
\hline
\end{tabular}


TJSP - $\quad$ Tribunal de Justiça do Estado de São Paulo

V. - Ver

V. - Volume 


\section{SUMÁRIO}

1 INTRODUÇ̃̃

\section{A CRISE NAS FUNCÕES POLÍTICAS DO ESTADO:}

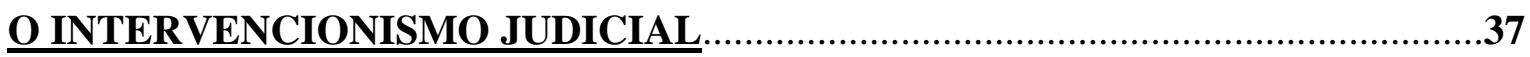

2.1 SITUANDO A DOUTRINA DOS PODERES DO ESTADO.

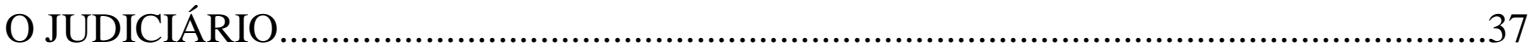

2.1.1 De Aristóteles e de Montesquieu................................................................................37

2.1.2. Do outro lado do Atlântico: a constituição como centro do poder.............................40

2.1.3. O Judiciário segundo o modelo brasileiro. Constitucionalismo no Brasil...............44

2.2 O ALINHAMENTO DO BRASIL COM OS DIREITOS

FUNDAMENTAIS INTERNACIONAIS: O ESTADO PRESTACIONAL........................49

2.2.1 Direitos Fundamentais e a Dignidade da Pessoa Humana...........................................49

2.1.2 Direitos Fundamentais a as ações políticas: políticas públicas.................................55

2.3 O ORÇAMENTO PÚBLICO....................................................................................

2.3.1 Situando o orçamento: brevíssimo escorço histórico....................................................64

2.3.2. A Constituição e as leis orçamentárias brasileiras:o orçamento-programa .............66

2.3.3. Qual a base jurídica do orçamento da saúde?..........................................................75

2.3.4. Ponderações introdutórias sobre a ingerência judicial nas contas públicas.............77 


\subsection{AS FUNÇÕES POLÍTICAS ESTATAIS NA DOTAÇÃO DOS}

SERVIÇOS E PRODUTOS PÚBLICOS OU QUEM TEM

A RESPONSABILIDADE EM DEFINIR A PRIORI POLÍTICAS PÚBLICAS?....

2.4.1 Competência legislativa.

2.4.2 Planos, programas e o Executivo .85

\subsection{AS FALHAS DOS PODERES TRADICIONAIS}

NO EXERCÍCIO DE ALOCAR RECURSOS E POLÍTICAS PÚBLICAS.

O PAPEL CORRETIVO DO PROCESSO CIVIL

2.5.1 Majoritarismo. .92

2.5.2 Public Choice. .103

2.5.3 Intervenção e controle.

3 OS EXCESSOS DA ATUACÃO JURISDICIONAL .116

3.1 PANORAMA ATUAL DO PROBLEMA. 116

\subsection{PROBLEMAS E DIFICULDADES DA}

INTERVENÇÃO JUDICIAL EM POLÍTICAS PÚBLICAS

3.2.1 O orçamento e os custos dos direitos: cobertor curto

3.2.2 A ausência de condições técnicas na alocação de recursos

3.2.3 Individualismo e justiça de misericórdia.

3.2.4 Execução do julgado e dogmas do processo. 
4.1.1 O arcabouço jurídico da saúde no Brasil.

4.1.2 Problemas na saúde

4.1.3 As decisões judiciais a respeito da saúde 160

\subsection{A PROPOSIÇÃO DOS LIMITES À ATUAÇÃO JUDICIAL}

NO TRATO DE POLÍTICAS PÚBLICAS DE SAÚDE.

4.2.1 As peculiaridades do caso da saúde. 176

4.2.1.1 A rede nacional que compõe o Sistema Único de Saúde: a descentralização unificada.

4.2.1.2 A variedade de moléstias que acometem a população.

Novas abordagens terapêuticas e outras variáveis.

4.2.1.3 A particular forma de custeio de um

bem universal como a saúde......

4.2.1.4 $\mathrm{O}$ cunho humanitário do direito à saúde. 
4.2.4 Razoabilidade.

4.2.5 Informações sobre as ações da Administração

4.2.6 Registro prévio da terapia, equipamento de saúde ou medicamento 239

4.2.7 Contemplação de terapias e medicamentos incluídos nas listas. 243

\section{OS REMÉDIOS PARA A INTERVENCÃO}

\section{PATOLÓGICA DO JUDICIÁRIO}

\subsection{A COLETIVIZAÇÃO DAS DEMANDAS E \\ O TRATAMENTO UNIFORME}

5.1.1 Universalização de direitos universais.

A isonomia dos direitos sociais. .252

5.1.2 As ações coletivas no trato da saúde. 266

5.1.3 O caso piloto em demandas repetitivas. 281

5.1.4 O incidente de coletivização 290

5.1.5 A Expansão Coletiva dos Efeitos da Decisão

Manifestada em Ação Puramente Individual .297

5.1.5.1 Dogmas do processo: objeto do feito, limites e autoridade da coisa julgada 298

5.1.5.2 A expansão da autoridade da coisa julgada como medida de isonomia, remédio à patologia individual 
5.1.5.3 Propostas de ferramental: como viabilizar, com razoável segurança, a expansão preconizada?

5.1.6 Formulação adequadamente ampla dos pedidos nas ações coletivas.

5.1.7 O amplo debate entre os Poderes

5.2 A FORMAÇÃO JURÍDICA 330

5.2.1 O ensino de políticas públicas e Direito Sanitário

como tema obrigatório em direito público.

5.2.2 A inclusão dos temas nos concursos públicos e na preparação dos juízes. .336

5.3 A ESPECIALIZAÇÃO DOS MAGISTRADOS

5.3.1 A criação de juízos especializados

5.3.1.1 O Caso da Síndrome de Kanner 341

5.3.1.2 O Caso da vacinação paranaense contra a gripe A

5.3.1.3 Conclusão que emerge da análise casuística: os juízos especializados .354

5.4 ESTATÍSTICAS E INFORMAÇÕES.

5.4.1 Os bancos de dados nacional, estaduais e regionais de processos, inquéritos civis e ajustamentos de conduta. 362

5.4.2 O conhecimento do Judiciário a respeito das ações administrativas. Atuações coordenadas 366 
5.5.1 Experimentalismo e a manobra para a suavização do dogma dos limites objetivos da coisa julgada. 374

5.5.2 O juiz como gerente da execução de medidas relacionadas a políticas públicas .387 


\section{INTRODUÇ̃̃̃}

Um dos temas que, hodiernamente, mais movimenta o universo do Direito é a intervenção do Judiciário na saúde pública. Notícias em jornais e revistas ${ }^{1}$, colóquios entre especialistas ${ }^{2}$, declarações de protagonistas do debate ${ }^{3}$ e, até mesmo, a inclusão e desenvolvimento de matéria praticamente dedicada ao tema e suas variantes no programa de Pós-Graduação em sentido estrito da Faculdade de Direito da Universidade de São Paulo $^{4}$ demonstram o panorama atual do assunto que foi eleito por este pesquisador como merecedor de estudo mais aprofundado 5 .

A grande crítica que se faz a essa espécie de atuação é que judiciar políticas públicas propicia a interferência judicial na harmonia das ações realizadas pela

\footnotetext{
1 "SUS deve atualizar lista de remédio todo o ano", disponível em: <http://www1.folha.uol.com.br/folha/equi librio/noticias/ult263u736201.shtml>, acesso em 12.01.2011, 18:59h; "Indústria usa ações judiciais para lucr ar com medicamentos", disponível em: <http://www.estadao.com.br/estadaodehoje/20100726/not_imp58599 5,0.php>, acesso em 12.01.2011, 19:03h.

${ }^{2}$ Exemplo do Seminário $O$ Controle Jurisdicional de Políticas Públicas, realizado em homenagem aos 10 anos do CEBEPEJ - Centro Brasileiro de Estudos e Pesquisas Judiciárias, em 14 e 15 de abril de 2010, na Faculdade de Direito do Largo São Francisco. Este autor participou como expositor do tema Quando o Judiciário ultrapassa seus limites constitucionais e institucionais: o caso da saúde, influência ao que será aqui escrito e influenciado pelas pesquisas desenvolvidas até aquela oportunidade. Na mesma linha se colocou o I Seminário brasileiro sobre direito à vida e à saúde e seus impactos orçamentário e judicial, organizado pela Faculdade de Direito da Universidade de São Paulo, campus de Ribeirão Preto, de 30 de agosto a 3 de setembro de 2010. Ainda, o APLPP foi objeto de debate na Associação dos Advogados de São Paulo, em colóquio que teve lugar em 19 de junho de 2012. Recentemente, em 30 de agosto de 2013, o tema foi discutido em mesa coordenada por Ada Pellegrini GRINOVER no Instituto dos Advogados de São Paulo (Questões Atuais em Tema de Controle Jurisdicional de Políticas Públicas), ocasião em que este autor compareceu como debatedor, defendendo a primazia da tutela coletiva sobre a individual quando o tema é saúde.

${ }^{3}$ O Presidente do STF em 2013, Min. Joaquim BARBOSA, afirmou, em seminário sobre o assunto, que a judicialização da saúde é um tema superlativo. Segundo ele, "No Brasil, a desigualdade no campo da saúde é tão expressiva, que se tornou imperativo para o Poder Judiciário atuar com bastante rigor e precisão para impedir que o fosso entre os cidadãos se alargue ainda mais." "'Barbosa diz que judicialização da saúde é tema superlativo", em Consultor Jurídico, edição de 3.6.2013, disponível em: <http://www.conjur.com.br/20 13 jun 03/joaquim barbosa judicializacao saude problema superlativo?utm_source=dlvr.it\&utm_medium=fac ebook>, acesso em 5.6.2013, 13:45h).

${ }^{4}$ Intitulada Controle Jurisdicional de Políticas Públicas, ministrada por Ada Pellegrini GRINOVER, Kazuo WATANABE e Susana Henriques da COSTA. Os seminários do I Semestre de 2010 consistiram na análise de jurisprudência acerca da forma como os juízes tutelavam saúde e outros direitos correlatos, como educação, transporte, moradia, direitos de portadores de necessidades especiais, dentre outros; a Disciplina continuou no II Semestre de 2010, em que foram abordados instrumentos processuais aptos ao controle e, no I Semestre de 2012, discutiram-se potenciais técnicas processuais de intervenção, sempre a partir de uma ótica razoável e ponderada.

${ }^{5}$ Justiça seja feita, a discussão a respeito do Judiciário e da imperatividade de suas decisões, pano de fundo do problema apresentado nesta tese, tem permeado o debate jurídico e social há anos. A função judicial moderna teve seus contornos definidos no Século XVIII: ela se mostrou, na sua gênese, mais fraca (como na França pós-absolutista) ou mais forte (como nos Estados Unidos constitucionalista) e, desde então, os juízes e suas decisões não mais pararam de ser questionados. A ordem de indagações sofreu certa alteração após a postura social da Warren Court, nos Estados Unidos, coisa da segunda metade do Século XX para cá. A adoção, pelo Brasil, do modelo norte-americano de revisão judicial explica muito do assunto explorado nesta tese, e merecerá tratamento especial adiante (Itens 2.1.2 e 2.1.3).
} 
Administração com vistas a cumprir a série de direitos a que ela é constitucionalmente obrigada a dispensar à população, como a saúde. A primazia da definição e execução das políticas de saúde, sendo do Legislativo e do Executivo, faz com que principalmente os administradores vejam muito mal a decisão judicial que manda construir hospital, entregar certo medicamento, internar paciente necessitado ou tratar dada doença.

Fosse apenas o preconceito do administrador não haveria maiores consequências e, certamente, não existiria assunto suficiente para ser dar lastro a uma tese, resultado da conclusão de um árduo período protocolar de cinco anos. O problema é muito maior. É teórico e, sobretudo, pragmático.

O modelo tradicional de tripartição de Poderes estatais é, grosso modo, desafiado quando sobrevém decisão judicial que intervenha no que seria, tipicamente, escopo de uma ação executiva pautada proximamente pelo administrador e mediatamente pelo legislador. Afinal e segundo clássica concepção, já muito consagrada e frequentemente invocada pelos opositores do atual papel prático do Judiciário, juízes deveriam servir para resolver controvérsias, de preferência, bipolarizadas, antagônicas e bem definidas, um autêntico jogo de soma zero, de tudo-ou-nada, resumindo sua principal tarefa no pronunciamento do direito e sua titularidade, ordenando providências correlatas e agindo em prol da satisfação desse direito. Ações programadas e planejadas, que envolvem gestão de recursos públicos e controle de uma série de variáveis, seriam objeto de atos da Administração, não do Judiciário. A partir do momento em que juízes declaram o direito e sua titularidade em temas de políticas públicas, determinando ações para a respectiva satisfação, haverá, como corolário, impacto nas medidas executivas já planejadas, ou em fase de planejamento, ou, ainda, que seriam, um dia, programadas e, porque não, mesmo naquelas já em andamento. É nessa seara que o papel do Judiciário, como Poder e instituição, é questionado ${ }^{6}$.

Contudo, o paradigma da Judicial Review adotado pela Constituição nacional estabelece a prerrogativa de o Judiciário controlar todas as ações - privadas ou estatais - que signifiquem solapamento, mitigação ou ignorância de implementação, observância de direitos ou entrega de objetos. Desde que a Constituição decidiu atribuir ao Estado a tarefa de distribuir bens e direitos sociais, qualquer omissão, falha ou

\footnotetext{
${ }^{6}$ Há quem defenda que o Judiciário extrapola seu poder constitucionalmente instituído. Ives Gandra da Silva MARTINS, em artigo publicado na Folha de São Paulo (25 de abril de 2012, no 30.338, p. A3, "Os dois Supremos") e elaborado à luz dos mais recentes pronunciamentos do Supremo Tribunal Federal, defende a competência legislativa de lege lata (artigo 49, XI da Constituição) para que o Congresso anule quaisquer decisões judiciais que invadam sua função legislativa. Segundo o autor, seu receio repousa no avanço de um Poder técnico (o Judiciário) sobre o domínio tí́pico de um Poder político (o Legislativo).
} 
descumprimento desse mister permitirá pronunciamento judicial ${ }^{7}$. É com fundamento nesse paradigma, cujo trigésimo quinto inciso da declaração de direitos do artigo $5^{\circ}$ é o maior expoente ${ }^{8}$, que os juízes se sentem confortáveis em declarar a inconformidade de dada ação estatal com a Constituição, ou declarar o Estado em mora de entregar direitos, condenando-o a expungir os efeitos correlatos, realizando o que é normativamente devido.

Apesar disto, importante questão que se lança a debate é: deveriam os juízes assumir uma veste funcional tão densa quanto aquela modernamente envergada no trato de políticas públicas como a saúde? Corolários desta pergunta seriam tantas outras: ao determinar o modelo de Judicial Review, concebeu o constituinte as consequências de o Judiciário agir como expressão máxima do império da lei ${ }^{9}$ ? Previu ele a sanha dos juízes em, a pretexto de assegurar a observância da norma, intervir em uma engrenagem concatenada pelos outros atores estatais e por eles, magistrados, pouco conhecida? É possível que o que se assiste hoje - o domínio do Judiciário sobre temas sociais - seja prenúncio da falência do modelo estatal moderno, como ele fora originalmente concebido? Será que o constituinte, quando estabeleceu uma série de direitos prestacionais, vislumbrou a possibilidade de transformar o Judiciário em ator político de primeira grandeza? Preconizou o legislador originário a insuficiência de recursos que, afinal, privariam o acesso universal à saúde, por ele mesmo estabelecido, abrindo caminho à intervenção judicial? Achou o constituinte que a simples combinação do conteúdo normativo dos artigos 6 $6^{\circ}, 196$ e 197 da Constituição, por si somente, seria apta a propiciar saúde para $\operatorname{todos}^{10}$ ?

\footnotetext{
${ }^{7}$ Reportagem de $O$ Globo ("Desabrigados de 2008 em Santa Catarina ainda aguardam moradia", edição de 10.1.2012, $\mathrm{n}^{\circ} 28.645$, p. 4) mostra bem a que tipo de adversidade está submetido o cidadão brasileiro. Diante da gravidade dos efeitos das chuvas de verão (que, de resto, são cediças e acontecem religiosamente todos os anos, na mesma época), o jornal apontou que, desde 2008, alguns dos desabrigados do pior alagamento havido em Santa Catarina ainda àquela altura (2012) esperavam por moradia, assim como cento e cinquenta famílias desabrigadas pelos temporais que assolaram Pernambuco no mesmo ano. É esse tipo de demanda que contingencia o Poder Público e, claro, a sociedade, maior prejudicada. A reportagem aponta algumas ações governamentais (i.e., concessão de abrigo provisório, pagamento de aluguel social ou auxílio moradia) que, no caso, revelaram-se precariamente paliativas.

${ }^{8}$ Que obsta exclusão da análise judicial de lesão ou ameaça a direito e consagra o princípio da indeclinabilidade ou inafastabilidade da jurisdição. Sobre o tema, ver CINTRA, Antônio Carlos de Araújo; DINAMARCO, Cândido Rangel; e GRINOVER, Ada Pellegrini. Teoria Geral do Processo. 14a ed. São Paulo: Malheiros Editores, 1998, pp. 137-138.

9 DWORKIN, Ronald. Law's Empire. 1986: Library of Congress Cataloging-in-Publication Data. No Capítulo I desta obra, DWORKIN se propõe a analisar a questão "o que é lei?" e, respondendo porque tal indagação importa, revela que é preciso saber como os juízes decidem casos e porque o processo é tão temido a ponto de HAND - segundo ele, um dos melhores e mais famosos juízes norte-americanos- declarar preferir a tributação e a morte ao processo (p. 1). A ficção de um dos mais brilhantes suspenses já escritos, $O$ Processo, de KAFKA, ilustra bem, a par de ficção ser, o medo de HAND.

${ }^{10} \mathrm{Um}$ dos mais ferrenhos críticos da Constituição, o economista Roberto CAMPOS, chamava o descolamento entre norma e execução da norma de constitucionalite, dizendo o seguinte: “(...) o povo
} 
O estudo dos motivos pelos quais o Judiciário assume esse novo papel - de canalizador dos mais ricos anseios sociais - é objeto das mais variadas ponderações. $\mathrm{O}$ descrédito do Legislativo ao redor do mundo (sobretudo, no Brasil) ${ }^{11}$, o déficit deliberativo em uma inexistente democracia real ${ }^{12}$, exercida de fato pelas pessoas, e a própria definição por eles, os juízes, dessas suas atribuições são alguns dos aspectos que, mais modernamente, explicam o que Tate e Vallinder denominaram a expansão global do Poder Judiciário ${ }^{13}$.

A verdade é que qualquer análise profunda da intervenção judicial em políticas públicas demanda, primeiramente, estudo sobre o papel do Judiciário na sociedade moderna. Os primeiros escritos deste trabalho se dedicarão a examinar como o Judiciário foi originalmente desenhado (quais eram suas funções e qual o alcance de seu poder) e entender porque, ao longo do tempo, os magistrados assumiram atribuições que extrapolam a simples visão liberal da jurisdição. A questão, nesse caso, é definir se, de

percebe que a 'constitucionalite' não lhe melhorou as condições de vida. Aliás, se isso acontecesse, os ingleses estariam perdidos, pois não têm constituição escrita. E os japoneses ainda pior, pois sua constituição foi escrita pelos americanos vitoriosos na guerra. Ante a prosperidade japonesa, chegar-se-ia à bizarra conclusão que a melhor constituição é a escrita pelos inimigos." (CAMPOS, Roberto. O Século Esquisito. Rio de Janeiro: Topbooks, 1990, p. 198).

${ }^{11}$ Uma das explicações encontradas para entender o papel de coadjuvante da República que hoje ocuparia o Legislativo é o domínio sobre ele exercido pelo Executivo, que, nos últimos anos, vem pautando as ações do Congresso Nacional. Retrocedendo a um passado mais próximo, note-se, por exemplo, o uso desmedido do (que deveria ser) o excepcional instrumento das medidas provisórias, o que resultou na tentativa de controle encampada pela Emenda à Constituição n ${ }^{\circ}$ 32/2001 (que modificou o artigo 62 da CF) e que, mesmo assim, não resolveu de todo o problema: recentemente, a votação da Medida Provisória ${ }^{\circ}$ 595, a $M P$ dos Portos, permeada de peculiaridades que não vêm ao caso, mostrou bem o jogo de pressão e trocas que fez com que o Congresso a analisasse e evitasse sua decadência. O Executivo foi bem sucedido e o ato executivo com força de lei foi convertido em lei em 16.5.2013. Sobre o assunto, ver “'Quórum vai ter, tenha fé' diz Renan sobre votação da MP dos Portos", publicado em 16.5.2013 em <http://g1.globo.com/politica/noticia/2013/05/quoru m-vai-ter-tenha-fe-diz-renan-sobre-votacao-de-mp-dos-portos.html>, acesso em 9.6.2013, 10:29h. Também o Presidente do STF ao tempo de apresentação desta tese, Min. Joaquim BARBOSA, constatou o mesmo fenômeno em colóquio por ele aberto, concluindo pela pouca relevância dos atos emanados pelo Congresso, inclusive porque poucas leis aprovadas são de iniciativa dos próprios parlamentares - cerca de $10 \%$ a $15 \%$ (plataforma de vídeo disponível em: <http://g1.globo.com/videos/t/todos-os-videos/v/presidente-do-stf-fazduras-criticas-ao-congresso-nacional/2585353/>, acesso em 9.6.2013, 10:43h).

12 Amy GUTMANN e Dennis THOMPSON assumem existir carência deliberativa no seio da sociedade, o que revela déficit moral e natural discordância quanto à aceitação social das decisões levadas a efeito pela Suprema Corte dos Estados Unidos com base no texto da Constituição (ou seja, decisões dos juízes embasadas nas normas). O engrandecimento do papel judicial, nesse sentido, acentuaria o déficit deliberativo democrático. Para eles, as decisões em um contexto democrático não podem se quedar confinadas às “(...) convenções constitucionais, opiniões da Suprema Corte e suas analogias teoréticas." (Democracy and Disagreement. Harvard: The President and Fellows of Harvard College, 1996, pp. 12-13). Este autor acrescenta que talvez haja um efeito reverso: o deslocamento das discussões da sociedade para o foro judicial pode ocorrer justamente em função da carência deliberativa social. O problema, aí, retroalimentar-se-ia.

${ }^{13}$ TATE, Neal C; VALLINDER, Torbjörn. The Global Expansion of Judicial Power. New York, London: New York University Press, 1995. Para SALLES, a assunção do Judiciário ao posto de definidor de direitos civis nos Estados Unidos durante o Segundo Pós-Guerra ocorreu também porque os juízes assumiram “(...) funções relativas a matérias que outros poderes não haviam querido ou podido solucionar." (SALLES, Carlos Alberto de. Execução Judicial em Matéria Ambiental. São Paulo: Editora RT, 1999, p. 181). 
fato, o Judiciário é foro apropriado para a discussão de políticas públicas, e em que medida $^{14}$.

Serão estudados, também, os mais relevantes pontos a suportar e a infirmar a atuação jurisdicional nesse espinhoso campo, sempre de acordo com as teorias que normalmente se aplicam a essas situações. É neste ponto que se devem realizar dois pequenos esclarecimentos.

Esta pesquisa parte da realidade. Destarte, os capítulos iniciais serão mais descritivos, menos analíticos e quase nada críticos. Eles servirão para concatenar os pensamentos que, ao final, serão desenvolvidos. De fato, o principal objetivo desta tese não é explicar os motivos por detrás da incisiva atuação judicial brasileira de hoje em dia, mas, sim, criticá-la, analisar seus limites e problemas e, bem assim, propor soluções, saídas, alternativas. Este autor considera, para tais fins, que o papel de protagonista da cena política, assumido pelo Judiciário, é irreversível no atual contexto do Estado brasileiro. É preciso aprimorá-lo.

Ademais, esta é uma tese de Processo Civil. Essa sua irremediável e gratificante característica traz ao presente pesquisador o ônus de focar suas principais assertivas no instrumento ou, ainda, no juiz enquanto dirigente do processo e prolator de uma decisão emanada como conclusão da atividade jurisdicional. O estudo do Judiciário no contexto de uma República Democrática pode ser explorado por inúmeras ciências e, mesmo dentro das jurídicas, por várias vertentes; todavia, o direcionamento metodológico, aqui, volta-se ao Processo Civil, ao juiz e às relevantes funções desempenhadas por ambos - instrumento e instrumentador - no contexto das políticas públicas.

O viés pragmático do estudo é, sem dúvida, seu mais importante aspecto. Estivesse encerrado nos muros da academia, o tema não despertaria tanto interesse ou polêmica, sobretudo de estudiosos de diferentes disciplinas como Direito, Sociologia, Educação, Administração, Economia. A questão que se segue à possível resposta positiva a respeito da legitimidade do Judiciário no trato de políticas públicas é se a intervenção judicial é realizada de maneira própria ou imprópria, de acordo ou em desacordo com as funções do Estado, ou, em terminologia que se consagra neste estudo, até pelo recorte que é proposto, de forma saudável ou patológica.

\footnotetext{
${ }^{14}$ Donald L. HOROWITZ (1977) já havia apontado que, nos Estados Unidos, a assunção das Cortes ao papel de definidoras de verdadeiros programas sociais (no campo dos presídios, habitação, educação, segurança) alterou o debate: antes, indagava-se se os juízes deveriam intervir em políticas públicas; depois, passou-se a se perguntar como seria a forma mais adequada de fazê-lo. (HOROWITZ, Donald L. The Courts and Social Policy, Washington D.C.: The Brooking Institution, 1977, p. 18). É um escalonamento que também se observa hoje, no Brasil.
} 
O excesso de demandas que deveriam ser resolvidas pelos Poderes majoritários - o Executivo e o Legislativo -, e não são, abre caminho para que o Judiciário termine por se transformar em importante ator a decidir toda a sorte de temas. Alguns apontam que a inércia de Legislativo e Executivo pode resultar indesejada e, até mesmo, perigosa concentração de poder nas mãos dos juízes ${ }^{15}$. E fato é que o Judiciário, ao longo do tempo, vem se transformando em uma das principais arenas de debate a respeito de questões extremamente relevantes à sociedade ${ }^{16}$.

${ }^{15}$ Em entrevista ao Estado de São Paulo, edição on line de18.4.2009, o então Ministro da Justiça criticou publicamente o excesso de demandas que eram decididas pelo Judiciário em razão da inação do Legislativo e do Executivo. Segundo ele, "Podemos estar perante um fenômeno novo no processo político brasileiro: uma hiperconcentração de poder e legitimidade no Judiciário e um esvaziamento dos demais poderes, que pode ser absolutamente problemático" (em: <http://www.estadao.com.br/estadaodehoje/20090418/not_imp356871 ,0.php>, acesso em 30.12.2010, 11:56h).

${ }^{16}$ Como os casos Raposa Serra do Sol (envolvendo a demarcação de terras indígenas e o conflito com os produtores de arroz do Estado de Roraima - Pet. no 3388/RR, Pleno, Rel. Min. Carlos Ayres BRITTO, j. em 19.3.2009), Anencefalia Fetal (em que foi discutida a possibilidade de antecipação terapêutica do parto de fetos que nasciam sem cérebro, sem que a prática se caracterizasse crime de aborto - ADPF $\mathrm{n}^{\circ} 54$, Pleno, Rel. Min. Marco AURÉLIO, j. em 27.4.2005), Cotas para afro descendentes em universidades públicas (visando a estabelecer um número mínimo de vagas nas instituições de ensino universitárias nacionais para afrodescendentes - ADPF $n^{\circ}$ 186, Pleno, Rel. Min. Ricardo LEWANDOWSKI), dentre outros temas que denotam a consolidação do viés político da arena judicial. Para Flávia PIOVESAN, o julgamento do caso da Anencefalia consolidou “(...) o STF como órgão guardião da Constituição, com a especial vocação de proteger direitos fundamentais." Segundo ela, “As Cortes Constitucionais têm assumido a especial missão de fomentar a cultura e a consciência de direitos e a supremacia constitucional, tendo seus julgados o impacto de transformar legislação em políticas públicas, contribuindo para o avanço na proteção de direitos." ("O resgate dos direitos humanos", em $O$ Globo, no 28.759, edição de 3.5.12, p. 7).

Talvez a sociedade brasileira não tenha dantes evidenciado tamanha concentração de interesses sobre o Judiciário do que no julgamento, pelo STF, da Ação Penal no 470 - o conhecido caso do Mensalão, em que um grupo de pessoas - alguns do principal escalão da República - foi processado por crimes como peculato, corrupção e lavagem de dinheiro em razão de esquema de compra de votos de parlamentares no âmbito federal durante o primeiro governo de Luís Inácio Lula da Silva. Esse processo, que materializou o - por alguns - chamado julgamento da década ou, como para O Globo, "um julgamento para a história", praticamente pautou toda a imprensa durante o mês de agosto de 2012. A TV Justiça, canal especial que, dentre outros programas, exibe ao vivo as sessões do STF, passou do traço (jargão que indica audiência mínima de telespectadores para dado programa) para considerável audiência. Jornais dedicavam capas e sessões inteiras ao assunto. Telejornais se debruçavam sobre o tema, tentando entender os - às vezes dificilmente inteligíveis votos ministeriais. Os Ministros do STF, durante e ao cabo de dito julgamento, tornaram-se, definitivamente, mais conhecidos do cidadão comum do que deputados, senadores e mesmo muitos governadores. Cogitou-se fortemente o nome do Min. Joaquim BARBOSA como presidenciável na corrida de 2014.

A rusga entre Poderes tem diversos episódios. Em 25.4.2013, jornais de todo o País noticiaram a aprovação, pela Comissão de Constituição e Justiça da Câmara dos Deputados, da PEC 33, que veicula uma série de medidas para limitar a eficácia das decisões do STF, notadamente aquelas manifestadas em controle de constitucionalidade na edição de súmulas vinculantes. $O$ Globo deu como manchete: "Câmara dá o $1^{\circ}$ passo para tentar tirar poder do STF” (edição de 25.4.2013, n 29.116, capa e pp. 3-5). Seguiram-se manifestações de alguns Ministros do Supremo, dizendo-se surpresos.

O conflito entre Poderes está presente, também, em nossos vizinhos. A Argentina, por exemplo, promoveu reforma do Judiciário em que propõe o fortalecimento de um órgão de controle externo (o Conselho da Magistratura), a edição de leis que restringem a concessão de medidas emergenciais contra o Estado portenho e a criação de câmaras de cassação, responsáveis por rever decisões de instâncias inferiores. Organizações como a Human Rights Watch enxergaram nessa iniciativa tentativa da Presidente Cristina Kirchner de cooptar o Judiciário. Oposicionistas argentinos, por sua vez, reclamam do que chamam “partidarização do Judiciário” (Folha de São Paulo, edição de 9.2.2013, n 30.717, p. A 17). 
Sem dúvida, hoje, o Judiciário experimenta um momento de consolidação do descolamento daquele seu papel tradicional, bipolar e retrospectivo de resolução de demandas bem definidas, cujos bens em discussão são individual e facilmente passíveis de distribuição, em que se observa a lógica do tudo-ou-nada, papel que cabia muito bem no método oitocentista de emprego do processo. Atualmente, mais que conflitos de égide retributiva, os juízes lidam também com questões eminentemente distributivas, cujos efeitos resultarão na fruição de certos bens objetos da dialética processual por considerável parcela da população.

É, de fato, inquietante o atuar jurisdicional nesse campo, sendo inúmeras e dificultosas as questões que se impõem quando se estuda o tema. Não por menos que a academia há anos sobre ele debate, primeiro, nos Estados Unidos, depois, neste Brasil. O que se percebe da evolução acadêmica, contudo, é que a ordem de indagações vem efetivamente avançando na linha do que se observou na Década de 1970 nos Estados Unidos: antes, os acadêmicos predominantemente procuravam responder se o Judiciário possuía legitimidade para sindicar bens sociais - debate que, afinal, está longe de se pacificar $^{17}$; agora, preocupam-se, mais, em analisar o papel desse Poder nesse Estado de interesses ${ }^{18}$. Esta tese procurará percorrer ambas as linhas, com dedicado foco à segunda.

A relevância do tema é tamanha que, no curso da pesquisa que culmina com a conclusão desta tese, o CEBEPEJ, em iniciativa capitaneada por Ada Pellegrini Grinover

17 É o caso da tese apresentada por Marcos Paulo VERÍSSIMO, defendida neste Departamento ( $A$ Judicialização dos Conflitos de Justiça Distributiva no Brasil: o Processo Judicial no Pós-88, tese de doutoramento apresentada em 2006 no Departamento de Direito Processual da Faculdade de Direito da Universidade de São Paulo). Depositada em janeiro de 2006, seu conteúdo permanece importante e atual, o que demonstra como o assunto ainda suscita dúvidas. É o caso, também, do próprio artigo citado na nota 6, e da observação feita na nota 14. E o papel do Judiciário tem incomodado. Quase que em sintonia, no mesmo dia em que MARTINS publicou o artigo referido, a Comissão de Constituição e Justiça da Câmara aprovou Proposta de Emenda à Constitucional que permitiria ao Congresso sustar decisões provenientes do Judiciário - a já mencionada PEC 33 da nota anterior. A proposta, do Deputado João CAMPOS (PSDB-GO), da frente parlamentar evangélica, colocou-se como reação ao julgamento da ADPF $n^{\circ} 54$, a que aqui já se fez referência e que culminou na impossibilidade prática de condenação dos agentes de antecipações terapêuticas de fetos anencefálicos. Segundo o parlamentar, "Hoje temos um ativismo do Supremo, que está legislando em alguns casos, o que gera insegurança jurídica para o conjunto da sociedade” (O Globo, 26.4.13, $\mathrm{n}^{\circ}$ 28.752, p. 16).

${ }^{18}$ Cinco anos depois da tese de VERÍSSIMO, em janeiro de 2011, Arthur Sanchez BADIN apresentou dissertação de Mestrado com o titulo de Controle Judicial das Políticas Públicas, orientada no Departamento de Direito Econômico, buscando contribuir para o estudo de tal tema a partir do paradigma da Institutional Choice de Neil K. KOMESAR (que também será analisada nesta tese, no Item 2.5.2.). Em 2012, foi depositada, no âmbito do Departamento de Direito do Estado, tese intitulada O Poder Judiciário e o controle do conteúdo das políticas públicas de saúde, de Izaias José de SANTANA, que caminha por linha de pesquisa muito semelhante à ora proposta, embora, neste caso, o ineditismo inerente ao doutorado esteja muito mais ligado ao instrumento e à atuação do juiz no processo do que, propriamente, seu enquadramento no contexto do Estado. No Departamento de Processo, em junho de 2013, Clilton Guimarães dos SANTOS defendeu tese intitulada Tutela jurisdicional aos Direitos Sociais, estudou o fenômeno e procurou estabelecer alguns controles à atuação judicial. São esses, também, alguns dos exemplos de como o tema desta tese e suas claras variações inquietam a academia. 
e Kazuo Watanabe, desenhou um Anteprojeto de Lei que, verbis, “(...) institui processo especial para o controle e intervenção em políticas públicas pelo Poder Judiciário (...)”. Este APLPP já foi objeto de interessantes debates havidos em salas de aula, colóquios e congressos, e toca diretamente ao assunto ora discutido. Por ser, destarte, em grande parte um reflexo do que se debate nesta tese, o APLPP será, por vezes, referido, servindo também como base para provar as proposições que serão lançadas ${ }^{19}$.

Da análise a respeito dos principais problemas apontados pela doutrina, pelos próprios juízes e pelos gestores públicos, escolheu-se metodologicamente estudar o assunto que é, de fato, o mais sensível dentre todos aqueles que implicam em judicialização de políticas públicas: como mencionado no primeiro parágrafo, a saúde. $\mathrm{O}$ exame do sistema de saúde no Brasil já é, de per si, problemático, diante da alta complexidade de gestão dessa pasta. A saúde, apesar de ser exigível do Estado por qualquer um, não chega a todos que precisam de tratamentos, terapias, medicamentos, cirurgias. A demanda é altíssima, os interesses em destaque, múltiplos, o território coberto, vastíssimo e os recursos estatais, limitados. Quando um terceiro agente entra nesse cenário caótico de maneira a desestabilizar algum equilíbrio que ali resta, então essa intervenção merece aprofundamento acadêmico. O terceiro in casu é justamente o juiz, que não é gestor da saúde e que ordena medidas muito sérias sob a simples (mas não falsa) justificativa de que está garantindo a observância da Constituição brasileira no caso concreto.

O cenário de supremacia judicial hoje observado não será substancialmente alterado em longo prazo. Que existem vicissitudes nesse atuar, no entanto, é fora de dúvida. Esta tese parte, justamente, dessas premissas, para apresentar e defender formas e meios de intervenção judicial racional em políticas públicas. É preciso pensar o processo, nesses casos, de forma a que, ao mesmo tempo, ele propicie mais resultados com menos custos (domínio da produtividade) e atenda melhor aos interesses da sociedade, fornecendo soluções mais adequadas (domínio da qualidade) ${ }^{20}$.

É verdade é que, dentro de um embasamento teórico geral, este estudo não se restringirá somente, mas analisará predominantemente as intervenções judiciais na saúde. Por vezes exemplos de outros ricos temas objetos de políticas públicas (i.e., educação, assistência, transporte) serão empregados. Mas do padrão do que atualmente

\footnotetext{
${ }^{19}$ Este autor contribuiu modestamente para as ideias que formaram, com o brilhantismo de seus mencionados escritores, o texto do APLPP.

${ }^{20}$ GALANTER, Marc. "Compared to what: Assessing the quality of dispute processing". Denver University Law Review, v. 66, n 3, 1989, xi-xii.
} 
acontece quando, em uma mesma frase, enlaçam-se os termos Judiciário e saúde, e outros a eles ligados, observa-se, talvez, o que de mais dramático há em termos de intervenção judicial em políticas públicas. O incômodo causado não apenas nos bancos acadêmicos, mas em todas as pessoas que, minimamente, interessam-se sobre o tema possui inúmeras facetas, cada qual a ganhar tratamento específico nesta tese.

Não parece inteligível, por exemplo, um magistrado que se depara com pedido de concessão de determinado medicamento atender ao requerimento ainda que não haja prescrição médica a instruir o feito. Não se faz compreender, igualmente, como a questão do orçamento público, fundamental para o custeio da saúde (e, de resto, de todos os serviços prestados e bens colocados pelo Estado à disposição da sociedade) é altamente negligenciada - quando não é completamente ignorada - da postulação e provação em juízo $^{21}$. Incomoda questão tão multifacetária e complexa quanto a gestão de políticas de saúde ser tratada sem maiores preocupações e por um juiz que, no mais das vezes, conhece em profundidade o Direito, mas é superficialmente dotado de maiores subsídios para gerir e implementar programas governamentais. Talvez, enfim, o que mais cause consternação é o fato de uma pessoa, ao invés de se dirigir à Farmácia Popular ${ }^{22}$, direcionar-se ao edifício do fórum local para obter o medicamento que necessita, enquanto tantos outros, portadores das mesmas deficiências e moléstias que acusam a necessidade de tratamento, caiam na vala comum daqueles que não têm voz e não conseguiram ultrapassar os altamente relevantes óbices que separam sua realidade daquela do foro. Enfim, são estes alguns exemplos que demonstram o quão problemático é o tema central dessa pesquisa e o longo e trabalhoso caminho que deve percorrer aquele que se arvora em discuti-lo.

\footnotetext{
${ }^{21}$ Reportagem da Revista Época é particularmente inquietante. Ela relata a situação de um paciente que possui hemoglobinúria paroxística noturna (HPV) e obteve, do Judiciário, a possibilidade de ser tratado com o medicamento Eculizumab (Sorilis) no Hospital Sírio-Libanês, em São Paulo, ao custo de oitocentos mil reais anuais. O medicamento não cura, mas diminui a degradação de glóbulos vermelhos (patologia), arrefecendo os sintomas. O paciente consegue ter vida normal, mas ao custo de tomar a medicação pelo resto da vida. O SUS dispõe de terapia alternativa - o transplante de medula óssea - que é apto a resolver o problema, contudo ao custo de morbidade considerável (cerca de trinta por cento dos pacientes morre ou fica com graves complicações). O paciente da reportagem resolveu recorrer a um médico especialista no tratamento com o Eculizumab, que indicou uma advogada com invejável experiência no tema, tanto que se permitiu declarar à reportagem que "no caso do Sorilis, não tenho causa perdida”. A mesma reportagem prossegue, levantando que as condenações judiciais do Município de Fortaleza para o fornecimento do Sorilis (mais precisamente, no número de quatro) comprometiam sessenta e sete por cento de todo o montante repassado pelo Estado do Ceará para que Fortaleza comprasse medicamentos de atendimento básico, um evidente sinal de que as coisas não vão bem. A íntegra da notícia está disponível em: <http://revistaepoca.glo bo.com/tempo/noticia/2012/03/o-paciente-de-r-800-mil.html>, acesso em 11.5.12, 13:40h.

${ }^{22}$ A Farmácia Popular é peça essencial na política de acesso a medicamentos adotada pela União. Por meio de postos próprios e da associação com farmácias privadas, o Poder Público disponibiliza aos cidadãos fármacos, ora gratuitos, ora subsidiados, chegando com importante desconto ao usuário. Sobre o programa, ver Manual Básico da Farmácia Popular do Brasil, disponível em: <http://portal.saude.gov.br/por tal/arquivos/pdf/manual_basico_fp1170511.pdf>, acesso em 8.2.2, 13:40h.
} 
O fato é que, verificando-se decisões judiciais que tratam de saúde pública e à luz do que seria normal (ou, antes, equilibrado), de acordo com a base teórica que se apoiará, serão diagnosticados alguns excessos na intervenção jurisdicional nessa específica seara. A apuração de tais excessos dependerá, indubitavelmente, de esclarecimentos sobre o intrincado sistema brasileiro de saúde, o que servirá, ao mesmo tempo, para entender como atua a Administração na implementação desse direito, identificar como o Executivo pode falhar nesse agir e mapear os gargalos da República que desembocam no Judiciário.

A partir da definição dos excessos da intervenção judicial na saúde será possível estabelecer alguns limites que poderiam torná-la apropriada nesses casos. Neste particular, temas já normalmente invocados quando se trata da judicialização de políticas públicas serão retomados e dissecados - caso da reserva do possível, do mínimo existencial e da razoabilidade ${ }^{23}$. Outros serão desenvolvidos especificamente considerando as peculiaridades do caso da saúde - como a necessidade de registro prévio da terapia ou medicamento e a contemplação preferencial nas listas de dispensação obrigatória ${ }^{24}$. A ideia é sistematizar parâmetros que possam ser aplicados indistintamente em todos os casos em que há a postulação judicial de qualquer providência relacionada à saúde.

Com base na cadeia formada entre excessos e limites, serão pensadas algumas providências concretas a tornar a tutela judicial da saúde mais racional e, portanto, equilibrada e apropriada, em termos de isonomia e universalidade. A intenção é apresentar remédios que possam tratar as intervenções judiciais patológicas na saúde. Serão eles instrumentos que, de lege lata ou ferenda, transformariam as decisões judiciais do tema um produto de uma atividade refletida, pensada e organizada por parte do Poder Judiciário, o que, espera-se, seja a grande colaboração deste estudo à comunidade acadêmica.

${ }^{23}$ Capítulo 4, Itens 4.2.2, 4.2.3 e 4.2.4.

${ }^{24}$ Capítulo 4, Itens 4.2 .6 e 4.2.7. 


\section{A CRISE NAS FUNCÕES POLÍTICAS DO ESTADO: O INTERVENCIONISMO JUDICIAL}

\subsection{SITUANDO A DOUTRINA DOS PODERES DO ESTADO. O JUDICIÁRIO}

\subsubsection{De Aristóteles e de Montesquieu}

O modelo político de divisão dos poderes do Estado adotado pela Constituição é o da tradicional atribuição especial de certas prerrogativas e potestades ao Legislativo, ao Executivo e, por fim, ao Judiciário. A Constituição teve tal escolha por tão importante que a ela atribuiu a característica de intangibilidade, insculpida no rol daquelas matérias tidas por imodificáveis ou, ainda, pétreas ${ }^{25}$.

Sabe-se que a ideia não é nova. Claramente ela possui suas vicissitudes, mas revela um modelo razoavelmente bem-sucedido de divisão estatal de poder. Os gregos já apontavam o perigo de se outorgar o poder pleno a apenas um indivíduo. Além desse temor, Aristóteles ainda indicava a dificuldade prática de governabilidade por apenas um único homem, o que demandaria necessariamente sua assessoria por parte de magistrados, a quem incumbiam executar suas determinações ${ }^{26}$. Aristóteles, aliás, foi quem lançou as bases da divisão de poderes como se conhece hoje $\mathrm{e}^{27}$, ao conceber sua segmentação em três linhas diversas: a deliberativa, a executiva e a judiciária. A primeira tinha por escopo deliberar acerca dos negócios do Estado, da promulgação das leis, da guerra e paz e da soberania, pena de morte, banimento e confisco; a segunda era composta dos magistrados

\footnotetext{
${ }^{25} \mathrm{O}$ art. $60, \S^{\circ}$, III da Constituição elege a Separação dos Poderes como parte de seu núcleo imodificável. ${ }^{26}$ ARISTÓTELES. Política. São Paulo: Nova Cultural, 1999. Livro III, 16, p. 248.

27 ARISTÓTELES anota que o Estado é formado por uma coletividade de famílias e, para analisar a sistemática do poder estatal, verificou como funcionava o poder no núcleo familiar. O filósofo expressamente indicou três diferentes partes na administração de uma casa, “(...) correspondente[s] a três governos: a do senhor, despótica (...); a do pai, e uma terceira, que surge do relacionamento conjugal”. Ao senhor incumbia o governo dos escravos e a administração da propriedade; ao pai, o cuidado e educação de seus filhos; e, do relacionamento conjugal, ao homem, o poder sobre a mulher, que é político, como de um estadista, e o poder sobre os filhos, que é real, como de um rei (Política. São Paulo: Nova Cultural, 1999. Livro I, 1-12, pp. 143-165). ARISTÓTELES encontrou registros de divisão de poderes mesmo antes de sua era, quando, ao falar da Constituição de SÓLON, apurou que os avanços obtidos em Atenas por este eram atribuídos a um elemento oligárquico (o Conselho de Areópago), um elemento aristocrático (a escolha de magistrados) e um elemento democrático (o sistema judicial - Política, Livro III, 12, p. 206). Sobre a primazia do ateniense na concepção do que hoje é a separação de poderes, ver DALLARI, Dalmo. Elementos de Teoria Geral do Estado. 20a ed. São Paulo: Saraiva, 1998, pp. 216-217.
} 
antes mencionados que, além de ordenar, também julgavam casos em temas específicos; e, a terceira, dos agentes de jurisdição, que se ocupavam dos julgamentos em geral ${ }^{28}$.

A concepção aristotélica foi sendo estudada, modificada e aplicada ao longo da História ${ }^{29}$ até que surgiu a conformação teórica moderna que mais se aproxima daquilo que é atualmente observado: ela foi montada por Charles-Louis de Secondat, barão de La Brede e de Montesquieu, e reunida na série de livros que, lançada em 1748, ganhou o titulo de L`Espirit des lois, ou $O$ Espírito das Leis.

A complexa obra de Montesquieu é um ensaio sobre as relações de poder que emanam no Estado e na sociedade nele presente. Seria leviano tentar, nesta tese, refletir com a profundidade que se deve suas palavras, até porque não é este o objetivo deste autor. O que essencialmente se tira dali, com efeito, é que o poder do Estado deve ser separado, não condensado em apenas um indivíduo ou ente, de maneira despótica, a bem de formar governo moderado, em que os poderes sejam combinados, regulados, temperados, fazendo-os agir e dando-lhes força para que cada um possa resistir ao outro ${ }^{30}$. Ainda concorde com o filósofo, quando analisava a constituição inglesa, “(...) tudo estaria perdido se o mesmo homem, ou o mesmo corpo dos principais, ou dos nobres, ou do povo exercesse os três poderes: o de fazer leis, o de executar as resoluções públicas e o de julgar crimes ou as querelas entre os particulares"31. Para Montesquieu, o espírito do poder estatal equilibrado (e, assim, desejável) era indissociável de sua separação entre aquele que legisla e o que executa, em primeiro lugar, e ambos daquele que julga.

O pensamento de Montesquieu retumbou como trovão nas sociedades que, naquela época, estavam fartas de tirania, colonialismo e absolutismo. Não por menos a Declaração de Direitos da Virgínia - esta, nos Estados Unidos, em 1776 - estabelecia que o Poder Legislativo e o Poder Executivo deveriam ser distintos e separados da autoridade judiciária $^{32}$. A Declaração dos Direitos do Homem e do Cidadão, de 1789, documento que se seguiu à Revolução Francesa, expôs que "a sociedade em que não esteja assegurada a

\footnotetext{
${ }^{28}$ BARBOSA, Marília Costa. "Revisão da Teoria da Separação dos Poderes do Estado", em Rev. Cient. Fac. Lour. Filho - V. 5, no 1, 2006, pp. 2-3.

29 DALLARI faz interessante sinopse sobre a evolução do pensamento aristotélico, passando por MAQUIAVEL e LOCKE (Elementos..., pp. 216-218).

${ }^{30}$ MONTESQUIEU, O Espírito das Leis, Livro Quinto, Capítulo XIV, p. $32(<\mathrm{http}: / /$ pensamentosnomadas.fi les.wordpress.com/2012/04/montesquieu-o-espirito-das-leis.pdf >, acesso em 9.6.2013, 17:14h). Aí está a raiz dos freios e contrapesos que cada Poder tem a seu dispor para obstar eventuais abusos perpetrados pelo outro e o Estado se vale para equilibrar seu poder.

${ }^{31}$ MONTESQUIEU, O Espírito..., Livro Décimo Primeiro, Capítulo VI, p. 75.

${ }^{32}$ Esta que é consagrada como uma das principais declarações de direitos humanos, assim dispôs, no seu Item V, textualmente: " $V$. That the legislative and executive powers of the state should be separate and distinct from the judicative;"
} 
garantia dos direitos, nem estabelecida a separação de poderes, não têm Constituição "33. Embora congruentes as declarações francesa e norte-americana, o papel dos juízes sob um e outro matiz era bem diferente.

Sobre os juízes, Montesquieu foi categórico: no governo despótico não há lei - o juiz é ele mesmo sua própria regra; no governo monárquico, o juiz segue precisamente a lei, interpretando-a somente quando necessário e na medida para seu bom entendimento; no governo republicano - como, de resto, é o do Brasil dos atuais dias - é da natureza da Constituição que os juízes sigam a letra da lei. "Não há cidadão contra quem se possa interpretar uma lei quando trata de seus bens, de sua honra ou de sua vida", dizia o nobre autor quanto ao Judiciário das repúblicas ${ }^{34}$. Sobre o papel dos magistrados judiciais, o filósofo francês bem expôs seu pensamento: para este, não eram aqueles nada além de meros seres inanimados que pronunciavam as palavras da lei - daí vir a sintomática e difundida expressão la bouche de $l a l o i^{35}$ ao descrever o entendimento de Montesquieu quanto aos juízes. O pensador foi muito duro ao estabelecer as fronteiras do agir judicial: os tais seres inanimados eram incapazes de moderar fosse sua força, fosse seu rigor - claro, porque, afinal, eles se restringiam apenas à tarefa de pronunciar a lei conforme estatuída pelos legisladores.

$\mathrm{Na}$ concepção original da Separação de Poderes que é empregada para explicar como o Estado brasileiro se organiza hoje, os juízes limitavam-se apenas a usar de seu poder para decretar, tão somente, o conteúdo da lei. Ao legislador cumpria elaborar as leis e, ao executor, dar cabo de suas disposições. Montesquieu, claramente positivista, atrelava e pautava a jurisdição à lei, em época em que o papel da Constituição na Europa era simplesmente político.

Qualquer reflexão faz muito mais sentido se for investigado o ambiente em que ela foi formulada e então, manifestada. Montesquieu publicou sua obra em um momento em que a França estava prestes a entrar em ebulição. $O$ barão gaulês era Iluminista - na verdade, um dos expoentes de dada importante corrente filosófica, tendo $O$ Espírito das Leis figurado no Index Librorium Prohibitorum da Igreja Católica ${ }^{36}$. Sua Teoria serviu como inspiração para que ocorresse a revolução que mudou os rumos da História. Naquela época, contudo, Montesquieu ainda vivia sob o regime absolutista de

\footnotetext{
${ }^{33}$ Declaração dos Direitos do Homem e do Cidadão, XVI.

${ }^{34}$ MONTESQUIEU, $O$ Espírito..., Livro Sexto, Capítulo III, p. 38.

${ }^{35}$ No original,"Les juges de la nation ne sont que la bouche qui prononce les paroles de la loi, des êtres inanimés, qui n'en peuvent modérer ni la force ni la rigueur." (MONTESQUIEU, De l'espirit des lois, Paris: Chez Firmin Didot Freres, Libraries, 1838, p. 268).

${ }^{36} \mathrm{Em} 1751$, O Espírito das Leis entrou para a lista negra Eclesiástica.
} 
Luís XV. Concorde com o próprio filósofo, juízes em governos despóticos são simplesmente figurativos, subservientes ao déspota, e não à lei - com o que é razoável afirmar ser este precisamente o retrato judiciário daqueles tempos -, daí desconfiar Montesquieu dos magistrados ${ }^{37}$. Àquela altura, portanto, o barão concebeu o Estado governado por leis, que eram observadas pelos juízes - mas na exata medida de seres inanimados, limitados somente a vocalizar, a declarar a norma preparada pelos legisladores. A Constituição, na França, exercia função subsidiária, já que os franceses entendiam existir poderes e direitos ainda que ausente Constituição - provenientes, a toda evidência, da lei.

A lei - ah, a lei - essa era a diferença para a França de Montesquieu. Resultado da repressão absolutista, no Estado legalista concebido pelo filósofo, juízes eram reles arautos oficiais da lei, e a Constituição servia tão somente para organizar a estrutura estatal. Ninguém ali - muito menos Montesquieu - estava muito preocupado em pensar em Constituição ${ }^{38}$.

$\mathrm{Na}$ verdade, àquela época o papel das constituições estava longe de ser definido, coisa que só ocorreria, na Europa, a partir da Segunda metade do Século XIX, com evolução até a Segunda metade do Século XX. A ausência de uma norma fundamental, aquela que irradiasse sua luz a todo ordenamento normativo da nação, limitava demais a atuação judicial de outrora. Mas isso não era regra no cenário internacional daquele tempo.

2.1.2. Do outro lado do Atlântico: a Constituição como centro do poder

Parece, contudo, que coisa semelhante não ocorria além-mar. Em verdade, os Estados Unidos viviam outra realidade. Era uma Nação que gozava de metodologia

\footnotetext{
${ }^{37}$ Luís XV não conseguiu conter com eficácia os preceitos do Absolutismo como tinha feito seu antecessor, Luís XIV, o Rei-Sol. De fato, "Richelieu e Luís XIV fizeram prevalecer a autoridade absoluta sobre as liberdades públicas porque a nação estava cansada das dissensões que haviam ensangüentado os regimes anteriores. Luís XV desconheceu o espírito de seu tempo; as palavras de liberdade se repetiam por toda a parte: elas repercutiam sob as abóbadas da justiça e saíam da própria boca dos cortesãos. Não seria a mão débil de um monarca desconsiderado que iria sustentar o edifício erigido por Luís, o Grande. A revolução já irrompia na classe alta; ela descerá pouco à pouco à última". Trecho de relato de Hervé de TOCQUEVILLE, constante do Prefácio de François FRUET à edição brasileira de A Democracia na America, de TOCQUEVILLE, Alexis. Livro I - Leis e Costumes. 2a ed. São Paulo: Martins Fontes, 2005 , p. XXIV.

${ }^{38}$ No mesmo sentido, ZANETTI Jr. Hermes. "A Teoria da Separação de Poderes e o estado democrático constitucional: funções de governo e funções de garantia", em GRINOVER, Ada Pellegrini e WATANABE, Kazuo (Coord.) O Controle Jurisdicional de Políticas Públicas. Rio de Janeiro: Forense, 2011, p. 38.
} 
peculiar de colonização, inspirada, em sua porção mais bem-sucedida, na Ética Calvinista, livre de monarcas tirânicos, aristocratas ou legado absolutista - uma antítese da Europa continental.

$\mathrm{Na}$ mesma época em que essa Europa respirava entremeada a tornados revolucionários vindos da França, os Estados Unidos viviam também em revolução, contudo, no âmago, eram bem diversas uma da outra. A Revolução Francesa buscava a ruptura completa com o então modelo político e filosófico, enquanto que a Revolução Americana objetivou unir o País, instalando uma das mais completas e exitosas federações que, de resto, vigora até hoje. Enquanto na França os juízes eram vistos com desconfiança e a mais moderna teoria de outrora restringia seu campo de atuação à simples declaração da lei, nos Estados Unidos o Judiciário possuía longa tradição institucional, sendo crucial no desenvolvimento jurídico e fundamental para o Federalismo que unificou aquele País ${ }^{39}$.

Naquele momento, quando os Estados Unidos tomavam seus contornos constitutivos definitivos, os Federalistas encontraram no Judiciário um Poder fundamental para dar suporte ao Estado Democrático que ansiavam implantar em todo o respectivo território. Foi neste cenário que se definiu a Judicial Review, ou a capacidade dos juízes revisarem normas e atos que, emanados de outros Poderes, violassem a Constituição. A Judicial Review permitiu aos magistrados norte-americanos pronunciarem não exatamente a lei, mas corrigirem distorções em situações em que não bastava a lei, porque incompatível com a Constituição ${ }^{40}$.

\footnotetext{
39 Atribuição oriunda, mesmo, do Common Law, tradição jurídica que principalmente funda o Direito nos precedentes judiciais havidos em casos similares. Assim, "como resultado, os juizes exercem um grande papel na modelação dos direitos norte-americano e britânico." ("The Common Law and Civil Law Traditions". The Robbins Collection. School of Law of Universitiy of California at Berkeley, disponível em: <http://www.law.berkeley.edu/library/robbins/CommonLawCivilLawTraditions.html>, acesso em 10.6.13, $13: 17 \mathrm{~h})$.

${ }^{40} \mathrm{O}$ leading case do controle de constitucionalidade é encontrado no caso Marbury v. Madison (5 U.S. 137, 1803), em que a Suprema Corte dos Estados Unidos declarou inconstitucional a lei que outorgava à ela, Suprema Corte, o poder de conceder writs of mandamus para infirmar atos dos demais Poderes que violassem a Constituição. Um desses writs foi solicitado por William MARBURY para permitir sua titulação como juiz do Distrito de Colúmbia, por efeito da disputa presidencial havida entre Thomas JEFFERSON e John ADAMS (1800), que acabou culminando com a eleição de JEFFERSON. Às vésperas de sua sucessão, ADAMS nomeou uma série de juízes para novos postos de trabalho - os midnight judges -, dentre os quais, MARBURY, que, para assumir, dependia de um documento oficial, expedido pela Presidência - a Comission - na prática, equivalente ao que seria o diploma dos políticos por aqui. Diante da iminente derrota, ADAMS claramente quis, com tal medida, alargar seu espectro de influência, ainda que fora da Presidência. Apesar do estratagema, ADAMS deixou a Presidência sem que a Comission de MARBURY houvesse sido expedida. Quando assumiu, JEFFERSON ordenou a seu secretário de Estado, James MADISON, que não diplomasse MARBURY, o que motivou este último a apresentar writ requerendo que a Suprema Corte anulasse a recusa e o empossasse no cargo. A Corte entendeu, então, que era inconstitucional a lei que autorizava MARBURY a deduzir o writ, por contrariar o Artigo $3^{\circ}$ da Carta dos Estados Unidos.

Nada obstante este ser o caso apontado como divisor de águas e pedra fundante do controle constitucional nos Estados Unidos, há historiadores que indicam ter a Judicial Review raízes mais remotas. William M.
} 
Coube aos Estados Unidos a primazia de elaborar a primeira constituição escrita e posicioná-la precisamente no centro do poder. Barroso entende que ela foi erigida sob as bases das reflexões de Locke, ou seja, como um pacto social de paz e liberdade entre os homens. Continua, asseverando que, nos Estados Unidos, desde a primeira hora, a Constituição foi vista como documento jurídico dotado de supremacia ${ }^{41}$.

Relato extremamente importante sobre as instituições estadunidenses foi realizado por um europeu - que não deixou de se registrar estupefato com as diferenças entre as coisas que ali via e a realidade de sua terra natal. $\mathrm{O}$ historiador francês AlexisCharles-Henri Clérel de Tocqueville, acompanhado de Gustave de Beaumont, embarcou aos Estados Unidos com o discurso de que estudaria as instituições penitenciárias daquele lugar. A ideia era fazer um relatório e empregar o que dali se fizesse útil na França ${ }^{42}$. Em 1831, ambos rumaram à América do Norte.

Anos depois, Tocqueville publicou, em dois volumes, rico relato histórico do funcionamento das instituições norte-americanas: A Democracia na América foi divida

TREANOR, por exemplo, aduz que a Judicial Review era uma prática comum nos tempos que precederam aquele leading case, sendo incorreto afirmar que o controle judicial de constitucionalidade teve origem em Marbury (TREANOR, William Michael. "Judicial Review Before Marbury”, in Stanford Law Review. V. 58, $\mathrm{n}^{\circ} 2$ - November, 2005, pp. 455-562).

Marcos Paulo VERÍSSIMO adverte, com razão, que o caso Marbury deve ser entendido no contexto do Federalismo norte-americano, referendando a ideia que os Federalistas contavam com o Judiciário para operacionalizar seus planos. Os Federalistas - dentre os quais o próprio James MADISON - teorizavam a respeito de um Judiciário independente e imperativo, que tivesse como função aplicar e interpretar a Constituição dos Estados Unidos. Para eles, essa seria a única forma de evitar a tirania em um sistema republicano-democrático-federalista (VERÍSSIMO, Marcos Paulo. A Judicialização dos Conflitos de Justiça Distributiva no Brasil: o Processo Judicial no Pós-88, tese de doutoramento apresentada em 2006 no Departamento de Direito Processual da Faculdade de Direito da Universidade de São Paulo, pp. 31-38).

Muitos anos mais tarde, em United States v. Carolene Products Co. (304 U.S. 144, 1938), a Suprema Corte estabeleceu graus de inconstitucionalidade, proclamando que leis que violassem frontalmente a Constituição (perpetradoras de um facial challenge) poderiam ser, desde logo, anuladas pelo Judiciário. Este caso foi muito importante, também, por sua nota de rodapé no 4 , que, alinhada com o histórico contexto do New Deal, proclamou que, diante de certas circunstâncias, o Estado poderia intervir no domínio econômico, contrariando o precedente formado em 1905 por Lochner v. New York (198 U.S. 45, 1905), igualmente um dos mais relevantes casos de toda a jurisprudência estadunidense. Carolene e Lochner serão novamente referidos nesta tese.

Outro importante precedente - este, mais recente (TVA v. Hill, 437 U.S. 153, 1978), envolveu a proteção de uma espécie ameaçada de peixe (o snail darter) durante a construção de uma represa no rio Little Tennesse. Neste caso, a Warren Court (em referência ao presidente da Suprema Corte da Época, Warren E. BURGER) garantiu a prevalência da Lei de Espécies Ameaçadas, reafirmando seu poder de controlar a constitucionalidade dos atos de governo com base na lei.

41 BARROSO, Luís Roberto. "A americanização do Direito Constitucional e seus paradoxos: teoria e jurisprudência constitucional no mundo contemporâneo", disponível em: <http://www.luisrobertobarroso.co m.br/wp content/themes/LRB/pdf/a_americanizacao_do_direito_constitucional_e_seus_paradoxos.pdf >, aces so em 6.7.2013, 23:00h, pp. 3-4.

${ }^{42}$ Em janeiro de 1835, bem próximo de seu regresso, TOCQUEVILLE confessou em carta a um amigo que o estudo do sistema penitenciário dos Estados Unidos era um grande pretexto para sua jornada: sua pretensão era, de fato, analisar o comportamento da liberdade em um espaço em que a isonomia era valor de primeira grandeza. Àquela época, a França ainda caminhava para a igualdade, com o que TOCQUEVILLE achou interessante partir para a verificação das medidas de liberdade em um cenário isonômico - e, para isso, foi estudar a democracia norte-americana (A Democracia..., Livro I..., pp. XII e XIII). 
no Livro I - Leis e Costumes, de 1835, e no Livro II - Sentimentos e Opiniões, de 1840. Trata-se de retrato fiel do ambiente estadunidense, visto por quem considerava aquele sistema era absolutamente diferente do que se observava na Europa. Trata-se mais, da visão de um historiador, que goza da imparcialidade necessária para ser adotada como fidedigna.

O relato de Tocqueville sobre o Judiciário é altamente interessante. Ele começa justificando dedicar um capítulo inteiro de sua obra a esse corpo institucional diante da força dos juízes no sistema norte-americano. Afirma, categoricamente, que o Judiciário dos Estados Unidos era único, e que não havia questão política naquele local que prescindisse de pronunciamento judicial - daí concluir o historiador consistir o Judiciário uma das primeiras forças políticas daquele País ${ }^{43}$. Embora Tocqueville reconhecesse no juiz norte-americano as três características por ele reputadas como essenciais a um magistrado - agir apenas quando houvesse controvérsia nos autos de um processo; pronunciar-se somente quando ocorressem casos particulares; e atuar estritamente mediante provocação -, a diferença que tornava ímpar o juiz daquele local é que ele tinha imenso poder político. E qual era a razão disso? - indagou Tocqueville. Ele mesmo respondeu: “A causa está neste simples fato: os americanos reconheceram aos juízes o direito de fundar suas decisões na Constituição, em vez de nas leis. Em outras palavras, permitiram-lhes não aplicar leis que lhes parecerem inconstitucionais "44. Tocqueville concluiu, então, que os juízes norte-americanos, porque poderiam invalidar leis ao argumento de sua incompatibilidade constitucional, atuavam como verdadeiros constituintes, já que ao poder deles estava atribuída a última palavra de interpretação da Constituição ${ }^{45}$.

Então, o historiador chega a uma conclusão de suma importância na análise do presente papel do Judiciário brasileiro no controle de políticas públicas, inclusive as de saúde: como, nos Estados Unidos de então, a Constituição dominava tanto os legisladores quanto os cidadãos, sendo ela a primeira das leis e contra a qual não poderia prevalecer lei qualquer, então era absolutamente justo e razoável que os magistrados alhures decidissem com base na Constituição - infirmando, mesmo, atos legislativos emanados pelos representantes do povo ${ }^{46}$. Tocqueville apurou e referendou a Judicial Review dos Estados Unidos. Os juízes, ali, não precisavam afrontar veementemente o Legislativo, causando

\footnotetext{
${ }^{43}$ TOCQUEVILLE, A Democracia ..., Livro I..., p. 111.

${ }^{44}$ TOCQUEVILLE, $A$ Democracia..., Livro I..., pp. 112-113.

${ }^{45}$ TOCQUEVILLE, A Democracia ..., Livro I..., pp. 114-116.

${ }^{46}$ Idem, ibidem.
} 
conflito entre Poderes: bastava apoiar seu pronunciamento na Constituição que, daí, adviria sua legitimidade constitucional - no caso - negativa .

A Judicial Review, portanto, opunha a Constituição norte-americana acima de toda e qualquer norma, ato governamental ou, mesmo, Poderes do Estado, controlandoos e limitando-os exatamente ao quanto constitucionalmente determinado, materializando na norma jurídica de tal envergadura a crença dos Federalistas que o homem já nasce com direitos, precedendo esses direitos o próprio Estado e seus Poderes. Ali, destarte, os juízes agiam como guardiões dos direitos constitucionais. É um inequívoco traço de Constitucionalismo $^{47}$, fundamental para a compreensão do fenômeno estudado nesta sede.

Mais tarde, o Judiciário dos Estados Unidos foi palco de outro surpreendente movimento que o faz aproximar-se ainda mais do que é hoje observado pelos juízes brasileiros na seara das políticas públicas ${ }^{48}$. Por enquanto, as notas relacionadas aos Poderes do Estado servem para mostrar as diferentes concepções de Judiciário observadas na França de Montesquieu e nos Estados Unidos retratado por Tocqueville.

\subsubsection{O Judiciário segundo o modelo brasileiro. Constitucionalismo no Brasil}

No Brasil o Judiciário se fez presente desde a instalação dos portugueses nestas terras. Contudo, abolido o Império, esse Poder assumiu papel descolado da tradição real europeia. Para compreender a dimensão de guardião das normas constitucionais que ostenta o Judiciário de hoje, é preciso desenvolver brevíssimo escorço histórico das Constituições Republicanas e do papel dos juízes no controle jurisdicional de constitucionalidade.

Já sob a égide da Constituição de 1891, juízes federais foram dotados de poder para pronunciar a inconstitucionalidade de leis em casos concretos, anotando-se, aí, o primeiro registro de controle difuso de constitucionalidade neste País. No Brasil,

\footnotetext{
${ }^{47}$ O Constitucionalismo marca a passagem de uma Constituição para o centro do ordenamento jurídico, a partir de onde ela emana efeitos para todas as demais normas, prevalecendo sobre tais. A esse respeito no contexto brasileiro, usando de paradigmas externos, ver BARROSO, Luís Roberto. "O Constitucionalismo Democrático no Brasil: Crônica de um Sucesso Imprevisto", p. 9, disponível em: <http://www.luisrobertobar roso.com.br/wp-content/uploads/2012/12/O-constitucionalismo-democratico-no-Brasil.pdf $\rangle, \quad$ acesso em 10.6.2013, 14:33h.

${ }^{48}$ Ver Itens 5.1.1. e 5.5.
} 
destarte, havia, desde o Século XIX, traços de Judicial Review, claramente uma influência norte-americana $^{49}$. O controle de constitucionalidade pelo Judiciário, portanto, é tradição brasileira desde que o País se tornou República ${ }^{50}$.

A Constituição democrática de 1934 alterou sensivelmente a sistemática do controle de constitucionalidade. Juízes poderiam exercer controle difuso, mas somente pronunciariam a inconstitucionalidade por maioria absoluta dos membros dos tribunais - a cláusula de reserva de plenário. É dessa Constituição a competência - até hoje existente do Senado Federal de atribuir eficácia erga omnes à declaração de inconstitucionalidade manifestada pelo STF em um caso concreto ${ }^{51}$. As alterações promovidas pelo Texto

${ }^{49}$ FILHO, Ives Gandra da Silva Martins. "Evolução Histórica da Estrutura Judiciária Brasileira", em Revista Jurídica da Presidência da República. Brasília: V. 1, no 5 (set/1999), disponível em: <http://www.planalto.go v.br/ccivil_03/revista/Rev_05/evol_historica.htm>, acesso em 10.6.2013, 19:20h. Marcus Vinícius Kiyoshi ONODERA anota a relação direta entre a tradição estadunidense e o controle de constitucionalidade no Brasil. Segundo ele, Rui BARBOSA foi o responsável pela adoção dos Decretos n ${ }^{\circ}$ s 510 e 848 , de 1890 , o último a criar o que seria o Supremo Tribunal Federal ("O controle judicial de políticas públicas por meio do mandado de injunção, ação direta de inconstitucionalidade por omissão e argüição de descumprimento de preceito fundamental. Contornos e Perspectivas, em GRINOVER e WATANABE (Coord.), O Controle..., p. 420) e, o primeiro, a publicar a Constituição dos Estados Unidos do Brazil. O artigo inicial daquele Texto estabelecia que a Nação brasileira adotava, como forma de governo, a República Federativa, um claro traço de idealismo norte-americano. Sobre a inspiração estadunidense que inundou o espírito do Constituinte de 1891, ver, por todos, Paulo BONAVIDES e Paes de ANDRADE (História constitucional do Brasil. $3^{\mathrm{a}}$ ed. Rio de Janeiro: Editora Paz e Terra, 1991, p. 250). Anotam esses autores, todavia, que: “(...) consagrava ela [a Constituição de 1891] a separação de poderes de conformidade com a proposta de Montesquieu - fórmula peculiar, aliás, a todas as Constituições do liberalismo." (p. 250).

${ }^{50}$ Embora, naquela mesma época, o constitucionalismo estivesse surgindo nos países de tradição romanogermânica. Atribui-se a Ferdinand LASSALE a primeira teorização a respeito da força das normas constitucionais e defesa da Constituição, em discurso proferido na Prússia no final do Século XIX. LASSALE entendia que era preciso, mais que uma folha de papel, que a Carta encerrasse normas aptas a materializar uma vontade de constituição, sem a qual não teriam tais regras valor algum - daí, para ele, o caráter político do documento (LASSALE, A Essência da Constituição, $5^{\text {a }}$ ed., Rio de Janeiro: LumenJuris, 2000). Mas foi o alemão Konrad HESSE, já no Século XX, que lançou o consagrado conceito de força normativa da Constituição, assumindo, em contraponto a LASSALE, que as normas constitucionais possuem força própria, que se coloca no topo de um ordenamento jurídico (HESSE, Konrad. A Força Normativa da Constituição (trad. Gilmar Ferreira Mendes). Porto Alegre: Sérgio Antônio Fabris Editor, 1991). Não se pode deixar de citar, nesse enleio, a Teoria Pura do Direito e o simbolismo positivista de Hans KELSEN. Para ele, cujo objetivo foi desenvolver uma teoria jurídica pura, dissociada de toda a ideologia jurídica e de elementos de ciência natural (p. XI), a validade do ordenamento jurídico é explicada por meio do emprego dos conceitos de norma pressuposta e norma posta. Basicamente, KELSEN associava o fundamento de validade de uma norma à necessária dependência da autoridade de outra norma que permitisse àquela primeira efeito vinculante com relação a seus destinatários. A primeira norma é posta, enquanto que a segunda, que dá autoridade à primeira, é pressuposta. Enriquecendo seu pensamento com exemplos, KELSEN entendia que a cadeia de normas integrantes de certo arcabouço jurídico estava definitivamente atrelada a uma norma que pressupunha dar validade a todo o ordenamento. Essa norma única e superior foi por ele conceituada como norma fundamental, que se referia a uma Constituição determinada. KELSEN, então, posicionou a Constituição como fundamento de validade de todo o ordenamento jurídico (Teoria Pura do Direito. $6^{\mathrm{a}}$ ed. São Paulo: Martins Fontes, 1998, pp. 217-308). A combinação entre os estudos de KELSEN e a concepção de HESSE, adotadas no Brasil quanto ao seu texto fundamental, com reflexos em todo o ordenamento jurídico, é de crucial importância para compreender a dimensão do poder Judiciário de hoje. Ver também a respeito BARROSO, “O Constitucionalismo...", p. 5.

${ }^{51}$ FILHO, "Evolução Histórica...". 
Getulista de primeira fase apontavam a tendência de limitação dos poderes jurisdicionais, tendência que se revelou realidade na outorga da Carta do Estado Novo, de 1937.

Aquele Texto atribuía ao Presidente da República o poder de submeter o pronunciamento judicial de inconstitucionalidade à revisão do Parlamento, que poderia revertê-lo por dois terços de votos dos membros da Câmara dos Deputados e do Senado Federal. Não obstante, o próprio Chefe do Executivo poderia não respeitar a decisão judicial de inconstitucionalidade caso ela se revelasse contrária ao interesse nacional, como o autorizava o Decreto-Lei $\mathrm{n}^{\circ} 1.567 / 39$ - esse próprio diploma a cassar uma decisão do STF declarando inconstitucional determinada lei tributária ${ }^{52}$. O caráter despótico da Constituição era claro, sobretudo por esvaziar o controle de suas normas por parte do Poder Judiciário. O Judiciário, em 1937, perdera sua independência e autonomia ${ }^{53}$, o que viria a novamente acontecer no próximo período autoritário que o Brasil ainda sofreria. Vivia-se, ali, tempo ditatorial, com a concentração de poder nas mãos do Presidente, com o que juízes e legisladores não foram poupados.

O advento do Texto de 1946 propiciou a adoção da Emenda nº 16/65, que criou a representação de inconstitucionalidade e, sem previsão de controle difuso, estabeleceu o primeiro instrumento de controle concentrado exercido pelo STF. Nessa mesma época, a Europa ainda não estava certa sobre o efetivo alcance das constituições e, mais, sobre o papel dos juízes em sua observância. Foi nesse contexto que surgiu a teorização de Hesse ${ }^{54}$. No modelo do Segundo Pós-Guerra, aos juízes não se atribuía qualquer atuação relevante na realização in concreto de direitos constitucionais ${ }^{55}$. Enquanto no Brasil o controle difuso já estava contemplado desde o Século XIX, a Europa já se encontrava na metade do Século XX e ainda se discutia o relevo da Constituição e o papel do Judiciário em sua atuação. Daí que qualquer análise de Judicial Review no Brasil, no sentido de os juízes fazerem valer normas constitucionais, deve adotar como paradigma, invariavelmente, o norte-americano ${ }^{56}$.

Em 1968, já na vigência de novo autoritarismo, o famigerado Ato Institucional $\mathrm{n}^{\mathrm{o}} 5$ suspendeu as garantias constitucionais de vitaliciedade e inamovibilidade dos magistrados, atribuindo ao Presidente da República o poder de demitir, remover,

\footnotetext{
${ }^{52}$ FILHO, "Evolução Histórica..."

${ }^{53}$ BONAVIDES e ANDRADE, História Constitucional..., p. 344.

${ }^{54} \mathrm{~V}$. nota 50 .

55 BARROSO, “O Constitucionalismo...", nota 2, p. 5

56 O que não significa que os juízes efetivamente exerciam esse poder, o que passa a ocorrer, inequivocamente, com o advento da atual Constituição.
} 
aposentar ou colocar juízes em disponibilidade ${ }^{57}$ - garantias sem as quais os magistrados não poderiam agir com independência, comprometendo mortalmente a Judicial Review, ainda que estivesse ela formalmente instituída.

O cenário pré-88 era desolador sob o ponto de vista do Constitucionalismo material. Ainda que presentes direitos de primeira grandeza, mesmo sob os auspícios do Autoritarismo, não havia sua observância concreta. Anota-se, por exemplo, que a Carta de 1969 assegurava amplo elenco de liberdades públicas e inúmeros direitos de trabalhadores que não se concretizavam. "Buscava-se, na Constituição, não o caminho, mas o desvio; não a verdade, mas o disfarce" ${ }^{, 58}$. O engodo autoritário embutido na Carta despótica esvaziou o papel do Judiciário como garantidor de direitos ${ }^{59}$.

Mas aí, em 1985, deu-se início à redemocratização para, tempos depois, reunir-se Assembleia Nacional Constituinte e, enfim, em 5 de outubro de 1988, ser promulgada a Constituição hoje vigente. Ela consagra efetivamente o Constitucionalismo, estabelece em seu núcleo intangível a impossibilidade de a lei excluir da apreciação judicial lesão ou ameaça a direito, concentra no Judiciário o poder de análise a posteriori da constitucionalidade de leis e de atos normativos e, claro, estabelece amplo rol de direitos civis, políticos, sociais, econômicos e culturais. A Constituição está no topo da pirâmide jurídica, irradiando seus inexoráveis efeitos sobre os respectivos vértices e área, vinculando os poderes públicos e a sociedade.

A Constituição de 1988 representou o resgate do Constitucionalismo material. As fracassadas experiências anteriores a revelar desconsideração, desrespeito e descumprimento de direitos insculpidos na Constituição resultaram na retumbante doutrina da efetividade, que prega, na essência, normas constitucionais aplicadas direta e imediatamente, dotando-lhes o executor da mais ampla eficácia possível. O Judiciário desempenharia, nesse contexto, papel fundamental: eram os juízes os responsáveis, em caso de falhas ou inobservâncias normativo-constitucionais, por obrigar quem assim o fizesse a dar cabo do conteúdo das normas. Ação e jurisdição passaram a andar lado a lado com a efetivação dos direitos constitucionais. A doutrina da efetividade, segundo Barroso, implicou três relevantes mudanças de paradigma na teoria e na prática do direito constitucional brasileiro: (a) no plano jurídico, capacitou como autossuficientes as normas

\footnotetext{
${ }^{57}$ FILHO, "Evolução Histórica..."

${ }_{58}^{58}$ BARROSO, "O Constitucionalismo...", p. 5.

${ }^{59}$ Nesse sentido, Maria Tereza SADEK explica que: "Durante o regime militar, especialmente depois de 1969, o Judiciário não gozava de independência nem de autonomia. Não se tratava, de fato, de um poder independente." (“Judiciário e arena pública: um olhar a partir da Ciência Política”, em $O$ Controle..., p. 15, nota 18 ).
} 
constitucionais, atribuindo-lhes eficácia plena, direta e imediata; (b) no plano científicodogmático, erigiu o direito constitucional a categoria autônoma, desvencilhando-o apenas do discurso político e ideológico; e (c) no plano institucional, elevou o Judiciário à categoria de executor e guardião dos valores constitucionais ${ }^{60}$.

Sob o aspecto teórico, Barroso assinala, igualmente, três ordens de mudanças promovidas pelo novo Constitucionalismo: (a) a força imperativa das normas constitucionais; (b) a expansão da jurisdição constitucional - com ações diretas de inconstitucionalidade e a fixação do STF como tribunal constitucional -; e (c) as novas maneiras de interpretação constitucional - que abrandam a literalidade da norma e abordam temas como o papel dessas normas, dos princípios e da colisão de direitos, passando-se a se valer da técnica da ponderação como argumento de decisão e de postulação $^{61}$. Esse último aspecto revela empoderamento judicial brasileiro sem precedentes, mas nada além do poder já consagrado de guardião da Constituição ${ }^{62}$.

Não há, a partir de 1988, lei ou ato normativo que possa escapar ao crivo do Judiciário. A Constituição atual alçou esse Poder a um patamar político pouco experimentado até então, mas logicamente oriundo de seus dotes de revisor constitucional. O Judiciário reunia condições de se tornar protagonista da república, muito além do que havia concebido Montesquieu. De fato, se juízes têm o poder de invalidar leis, essas, por sua vez, vigentes após processo legislativo deflagrado e concluído institucionalmente pelos mandatários do povo, políticos em sua essência, então é lógico que tal poder judicial é, sim, igualmente político ${ }^{63}$, mas poder político especial, que não deve responder aos anseios da população, senão obedecer aos preceitos constitucionais. A realidade mostra que, com efeito, a arena política de hoje reserva papel de alta relevância aos juízes. Vive-se no Brasil, afinal, um estado constitucional de direito ${ }^{64}$.

\footnotetext{
${ }^{60}$ BARROSO, “O Constitucionalismo...", p. 6.

${ }^{61}$ BARROSO, “O Constitucionalismo...", pp. 7-8.

${ }^{62}$ É o caso dos pronunciamentos de "interpretação conforme a Constituição" e de "declaração de inconstitucionalidade com ou sem redução de texto”, em que o STF concentra sua análise sobre a interpretação dada a determinada norma.

${ }^{63}$ No mesmo sentido, SADEK (“Judiciário e arena pública...”, em GRINOVER e WATANABE (Coord.), $O$ Controle..., p. 15).

${ }^{64}$ Para Luís Roberto BARROSO, "O estado constitucional de direito desenvolve-se a partir do termino da $2^{a}$ Guerra Mundial e se aprofunda no último quarto do século XX, tendo por característica central a subordinação da legalidade a uma Constituição rígida. A validade das leis já não depende apenas de sua forma de produção, mas também de seu conteúdo com as normas constitucionais. Mais que isso: a Constituição, além de impor limites ao legislador e ao administrador, determina-lhes, também, deveres de atuação. Juízes e tribunais passam a deter ampla competência para invalidar atos legislativos ou administrativos e interpretar criativamente as normas jurídicas à luz da Constituição." (“A americanização do Direito Constitucional e seus paradoxos: teoria e jurisprudência constitucional no mundo
} 
A Constituição de 1988 é parte fundamental da explicação jurídica para o fenômeno da judicialização de direitos sociais, notadamente, o direito à saúde. Primeiro, porque ela exerce supremacia diante de todo o ordenamento jurídico, donde se tira que suas normas gozam de superioridade, impondo-se sobre aquelas ordinárias. Norma constitucional só poderá sucumbir à norma ordinária se esta se apoiar em outra norma constitucional que se mostrar mais adequadamente aplicável no caso concreto. Segundo, porque a Constituição estabelece que a guarda de suas normas e de todo o ordenamento, enfim, caberá ao Judiciário. Terceiro, uma vez que ela disponibilizou robusto ferramental para provocar os juízes nesse mister, com instrumentos específicos - como o mandado de segurança, a ação popular, a ação civil pública, as ações de controle concentrado de constitucionalidade, além do mandado de injunção - e genéricos, como o importante direito de petição. Quarto, a Constituição está recheada de direitos que requerem prestação positiva por parte do Estado, coisa que vai muito além da abstenção de intromissão nas liberdades particulares, demandando o fornecimento público de bens e serviços.

Não é por acaso, destarte, que a Constituição é a base, a fonte e o argumento utilizado por quem busca obter forçadamente saúde contra o Estado. A saúde é direito fundamental do cidadão, daqueles conceituados como sociais, e sua inclusão na Constituição legitima a priori o postulante a lhe exigir cumprimento. Todavia, daí não decorre, necessariamente, estarem os juízes preparados para judiciar saúde. A importância do Judiciário como arena e do processo como ferramenta de decisão de políticas públicas será analisada em momento oportuno. É preciso, antes, falar um pouco sobre como a Constituição tratou os direitos fundamentais, como a mencionada saúde.

\section{$2.2 \mathrm{O}$ ALINHAMENTO DO BRASIL COM OS DIREITOS FUNDAMENTAIS INTERNACIONAIS: O ESTADO PRESTACIONAL}

\subsubsection{Direitos Fundamentais e a Dignidade da Pessoa Humana}

O Poder Constituinte originário escolhe o conteúdo da Constituição. Nessa circunstância, é possível que haja Constituição em um Estado de Polícia? Claro que sim. A 
Alemanha nazista tinha uma Carta, tanto quanto o Brasil do Estado Novo. E a pena de morte, poderia ser permitida? Decerto que sim, uma vez que inúmeros Estados da Federação norte-americana assim agem nos casos preconizados. A tarefa de insculpir em uma Constituição determinada norma é invariavelmente um jogo de opções. Daí constituir tal importante documento jurídico, também, documento essencialmente político ${ }^{65}$.

Ao longo do tempo a sociedade evoluiu na observância e proteção de um rol de direitos sem o qual nem o indivíduo, nem a própria sociedade poderiam viver em paz. A árdua luta que consagrou coisas hoje tidas como simples - como falar ao telefone sem que terceiros ouçam a conversa, ou não permitir o ingresso de quem quer que seja em sua residência, a não ser por ordem judicial, durante o dia, ou em caso de flagrante delito, ou, ainda, não ser preso a não ser que, ao tempo do ilícito, já exista lei criminalizando a conduta e tribunal previamente constituído - converge para a imprescindível previsão de um núcleo de direitos sem o qual não se pode dar segurança, estabilidade e sossego à pessoa e à coletividade. São esses os direitos fundamentais, e a Constituição de 1988 foi cunhada sob seu paradigma, alinhando-se às modernas concepções universais do conteúdo desses direitos.

Alexy observa, sobre os direitos fundamentais, ser possível teorizar sob as mais variadas lentes: pela histórica, procura-se investigar a evolução dos direitos fundamentais (como, por exemplo, o primeiro registro de due process of law na Magna Carta de João-Sem-Terra, em 1215); pela lente filosófica, busca-se esclarecer seus fundamentos (i.e., esses direitos permitem ao homem viver uma vida digna); enfim, pela sociológica, analisa-se o papel dos direitos fundamentais no contexto social (i.e., formam uma sociedade mais justa, harmônica e controlável). Conclui, enfim, que é difícil vislumbrar disciplina no âmbito das ciências humanas que, de alguma maneira, não contribua para o debate a respeito dos direitos fundamentais ${ }^{66}$. Interessa, para esta tese, discutir o que a Constituição entendeu como direitos fundamentais, seu paralelo com o que hoje o mundo compreende como rol mínimo desses direitos e, assim, definir seu alcance, eficácia e imperatividade.

A observância concreta dos direitos fundamentais depende do Estado, de um ou de outro modo. Os direitos civis e políticos servem como limites ao poder estatal,

\footnotetext{
${ }^{65}$ Não por acaso, ao longo da História, algumas Constituições foram mesmo denominadas políticas, como a Constituição Política da Monarquia Portuguesa (1822), a Constitución Política de los Estados Unidos Mexicanos (1917), a Constitución Política de la República de Guatemala (1986), entre outras. O fato de ser política, todavia, não torna a Constituição menos jurídica, como se discutiu em meados dos Séculos XIX e $\mathrm{XX}$.

${ }^{66}$ ALEXY, Robert. Teoria dos Direitos Fundamentais. São Paulo: Malheiros, 2008, p. 31.
} 
norteando as fronteiras da intervenção do Estado na vida privada, tanto quanto aos civis direitos à vida, liberdade, segurança, propriedade e igualdade como no que tange aos direitos de votar e ser votado e demais políticos. Nesse sentido é que são denominados como direitos de liberdade negativa, ou de abstenção, porque envolvem omissão estatal quanto à tutela da vida privada. Já quanto os direitos culturais, econômicos e sociais ${ }^{67}$, esses demandam conduta positiva do Poder Público, uma ação, porque epistemologicamente dependentes do agir estatal. Quando o Estado é compelido a organizar e gerir a previdência social, isso inequivocamente demandará planejamento, contratação de pessoal, abertura de agências, regulamentação, prestação de informações, gestão dos recursos, efetivação de pagamentos, controle de beneficiários, enfim, uma infinidade de atividades que têm de ser providas por aquele que tem o encargo de providenciá-las.

Os direitos fundamentais estão umbilicalmente ligados à noção de direitos humanos. Sob o aspecto do direito natural, são humanos os direitos que cada pessoa goza como característica inerente às próprias vida e vivência. Para os positivistas, claro, humanos são os direitos que norma elege como tal. De um ou de outro modo, trata-se do piso intangível de direitos que a pessoa, apenas em virtude da simples condição de ser humana, titula desde logo. São direitos civis e políticos, já mencionados, de liberdade negativa, que seguram a longa mão do Estado na interação com a vida privada e estabelecem os Standards de participação democrática na distribuição estatal. É o caso, fundamentalmente, de direitos como os do devido processo legal, do contraditório e da ampla defesa, de petição aos órgãos públicos e de propriedade privada. São, também, direitos econômicos, sociais e culturais, que abrangem as relações de emprego e outros temas de igual relevância como o equilíbrio econômico, a tributação comedida, a saúde, a educação, o transporte, o lazer e o desporto adequados. Aí figuram o direito de acesso universal e gratuito às políticas e ações de saúde, o direito à equilibrada política de juros, o

\footnotetext{
${ }^{67}$ Direitos sociais são aqueles que envolvem prestação positiva por parte do Estado. No caso do Brasil, o Estado é constitucionalmente obrigado a prover aos cidadãos saúde, educação, lazer, cultura, habitação, dentre outros (artigo $6^{\circ}$, com especificações a partir do Titulo VIII da Constituição). Nesse sentido, em especial, contextualizando-se com a intervenção judicial a respeito, ver GRINOVER, Ada Pellegrini. "O Controle de Políticas Públicas pelo Judiciário" (O Processo. Estudos \& Pareceres. $2^{\text {a }}$ edição. São Paulo: DPJ Editora, 2007, p. 37, e também, o mesmo articulado, em O Controle..., pp. 127-128). Os direitos sociais são elencados por alguns como direitos humanos de II geração, enquanto que os direitos humanos de I geração são direitos civis e políticos, que revelam ações negativas - ou, antes, de abstenção, regras de não-fazer dirigidas ao Estado (WEIS, Carlos. Direitos Humanos Contemporâneos. São Paulo: Malheiros Editores, 1990). Ressalva-se a crítica à segmentada classificação que faz, dentre outros, Flávia PIOVESAN, por argumentar que essa divisão dos direitos humanos deturpa seu caráter de universalidade (Direitos Humanos e o Direito Constitucional Internacional. $3^{\mathrm{a}}$ ed. São Paulo: Max Limonad, 1997).
} 
direito de autonomia universitária. Da mesma maneira, estão aí os mais modernos direitos de solidariedade, que preparam o mundo para esta e próximas gerações, como os direitos de comunicação e de não-discriminação ${ }^{68}$. São, enfim, os direitos que precisa cada qual para gozar uma vida digna.

A dignidade da vida humana qualifica os direitos fundamentais e os direitos humanos $^{69}$. Não basta viver: há de se viver dignamente ${ }^{70}$. Essa assertiva é de importância determinante. Ela possui conteúdo capaz de diferenciar totalmente o modo como normas jurídicas garantidoras de direitos são interpretadas e efetivadas. Se, por exemplo, a Constituição consagra o direito à segurança, policiais não poderão submeter pessoas à revista vexatória, ainda que sob suspeita do cometimento de infração penal. Eleger o valor dignidade como adjetivo da pessoa, sua vida e seus direitos dota de alcance extensivo as normas veiculadoras de direitos fundamentais, a ensejar uma interpretação ótima, de forma que elas sempre prevalecerão diante de normas que não ostentam essa mesma qualidade ${ }^{71}$.

No Brasil, a dignidade da pessoa humana foi eleita não como direito fundamental em sentido normativo estrito. De fato, o legislador constituinte originário poderia tê-la posicionado como qualidade do caput do artigo $5^{\circ}$, mas não o fez. Como o texto constitucional é político, e o jogo político é um jogo de escolhas, é razoável afirmar que o Constituinte assim não quis. Ele preferiu, na verdade, estabelecer a dignidade da pessoa humana como fundamento do Estado Democrático de Direito Republicano do Brasil $^{72}$. Posicionou um valor tão abstrato quanto a dignidade no patamar mais elevado do texto constitucional. Como fundamento do Estado, a vida humana digna está imune à

\footnotetext{
${ }^{68}$ Como o direito à Paz, à Autodeterminação dos povos, ao Desenvolvimento (Econômico e Social), ao Meio Ambiente. Nesse sentido, v. Constituição, arts. $4^{\circ}$, III, VI e IX e 225.

${ }^{69}$ A moderna encampação do conceito de dignidade às Constituições surgiu na Itália do Segundo PósGuerra, mais precisamente, no art. $3^{\circ}$ da Constituição da República, que estabeleceu deterem todas as pessoas a mesma dignidade social, sendo iguais perante a lei. A Lei Fundamental de Bonn, de 1949, declarou, no art. 1.1, ser intangível a dignidade do homem. A Constituição portuguesa, no art. $1^{\circ}$, estabelece que a República Portuguesa se baseia, dentre outros princípios, na dignidade da pessoa humana. Sobre os demais ordenamentos que positivaram a dignidade da pessoa humana como foco, ver NOBRE Jr., Edilson. "O Direito Brasileiro e a Dignidade da Pessoa Humana", em Revista dos Tribunais, $\mathrm{n}^{\circ} 777$ (julho de 2000), p. 473.

${ }^{70}$ Da dignidade da pessoa humana decorre outra noção, de crucial relevância para este estudo: a necessária observância do mínimo existencial, aquele piso de direitos que o Poder Público deve assegurar ao indivíduo para que ele usufrua, precisamente, de uma vida digna. Sobre o mínimo existencial, ver Item 4.2.3. Sobre a umbilical ligação entre direitos fundamentais, dignidade da pessoa humana e mínimo existencial, confira-se AMARO, Fernanda Pereira. "O serviço público sob a perspectiva da garantia constitucional de direitos humanos fundamentais", em Revista de Direito Constitucional, $\mathrm{n}^{\circ}$ 50, janeiro de 2005, pp. 116-118.

${ }^{71}$ MENDES, Gilmar. "Os Direitos Fundamentais e seus múltiplos significados na ordem constitucional", em Revista Jurídica Virtual, Brasília,V.2, no 13 (junho/1999), disponível em: <http://www.planalto.gov.br/ccivil _03/revista/Rev_14/direitos_fund.htm>, acesso em 17.7.2013, 21:43h. O autor menciona J. J. Gomes CANOTILHO, que assevera que direitos fundamentais devem ser otimamente efetivados.

${ }^{72}$ Art. $1^{\circ}$, III da Constituição.
} 
discussão que tem por fim destacar quais são os direitos fundamentais. Afasta-se, ademais, do debate relacionado ao entrechoque dos vários conteúdos das normas veiculadoras de direitos desse talante. A dignidade da pessoa humana, na verdade, é valor ético dotado de eficácia jurídico-normativa a ser estendido ao conteúdo de todos os direitos, muito além dos fundamentais. Então, os direitos fundamentais só podem ser vistos a partir de uma ótica: a da dignidade da pessoa humana.

A Constituição alinhou-se aos padrões internacionais de direitos humanos ${ }^{73}$. E nem poderia ser diferente: como signatário das principais declarações de direitos - além da Declaração Universal dos Direitos Humanos, do Pacto Internacional dos Direitos Civis e Políticos, do Pacto Internacional dos Direitos Econômicos, Sociais e Culturais, do Pacto de San José da Costa Rica ${ }^{74}$, dentre outras - o Brasil sempre pretendeu se colocar na vanguarda dos direitos humanos internacionais.

De crucial compreensão aos auspícios desta tese são os direitos humanos sociais. São esses, de fato, que despertam maiores debates, não somente pelo fato de seu surgimento ser mais recente do que os já consolidados direitos civis e políticos, mas, também, em razão de exigirem eles ações positivas do Poder Público ${ }^{75}$. Os direitos sociais foram vergastados e infirmados por boa parte da doutrina, que se negava a emprestar-lhes eficácia imediata, ao argumento de que as normas que os validavam consistiam apenas em programas, comandos e mandamentos de obrigação de fazer dirigidos ao Estado, não sendo suficientemente eficazes a ponto de ser exigido seu cumprimento. Essa visão foi superada, não sem esforço ${ }^{76}$, e hoje se tem que as normas de direitos sociais são tão

\footnotetext{
${ }^{73} \mathrm{O}$ espectro internacional dos direitos humanos adveio da necessária implementação de mínimos padrões de direitos a ser observados em todo o mundo e coincide com a própria criação do órgão supranacional necessário à sua guarda e controle, a Organização das Nações Unidas. Nascida no Segundo Pós-Guerra, a ONU surgiu como decorrência lógica da edição da Declaração Universal dos Direitos Humanos (1948), que consolidou a percepção de intolerância a certas atrocidades, ainda que aparentemente revestidas de legalidade e soberania, como as que ocorreram na Alemanha nazista e foram discutidas em Nuremberg.

${ }^{74}$ Incorporados ao ordenamento interno, respectivamente, por meio do Decreto Legislativo $\mathrm{n}^{\circ} 2 / 51$, Decreto Legislativo $n^{\circ}$ 226/91, Decreto $n^{\circ} 591 / 92$ e Decreto ${ }^{\circ}$ 678/92.

${ }^{75}$ Para BOBBIO, “(...) os direitos não nascem todos de uma vez. Nascem quando podem ou devem nascer. Nascem quando o aumento do poder do homem sobre o homem (...) cria novas ameaças à liberdade do indivíduo, ou permite novos remédios para suas indigências: ameaças que são enfrentadas através de demandas de limitações do poder, remédios que são providenciados através da exigência de que o mesmo poder intervenha de modo protetor. Às primeiras, correspondem os direitos de liberdade, ou um não-agir do Estado; aos segundos, os direitos sociais, ou uma ação positiva do Estado. Embora a exigência desses direitos possa estar disposta cronologicamente em diversas fases ou gerações, suas espécies são sempre com relação aos poderes constituídos - apenas duas: ou impedir os malefícios ou obter seus benefícios." (BOBBIO, Norberto. O futuro da democracia. Uma defesa das regras do jogo. $4^{\mathrm{a}}$ ed. São Paulo: Paz e Terra, 1986, p. 6).

${ }^{76}$ A expoente doutrina brasileira da aplicabilidade das normas constitucionais ressoa o magistério de José Afonso da SILVA, em seu Aplicabilidade das Normas Constitucionais ( $5^{\mathrm{a}}$ ed. São Paulo: Editora Malheiros, 2001). Para ele, normas constitucionais possuem eficácia plena (cujo conteúdo possui aplicabilidade imediata
} 
imediatamente exigíveis quanto aquelas relacionadas aos clássicos direitos civis e políticos $^{77}$.

A saúde é consensualmente apontada como direito humano, e a esse respeito não são necessárias maiores ilações. Na verdade, o mundo se preocupa em garantir saúde aos seus habitantes. É notória a sensibilidade supranacional no que refere à saúde das pessoas, tanto que a ONU possui organismo exclusivamente dedicado ao gerenciamento dessa atribuição (a OMS) que, ano após ano, incrementa sua atuação ${ }^{78}$. Esta preocupação é também observada no Brasil, país que escolheu conceder aos seus residentes ou pessoas em trânsito, nacionais ou estrangeiros, ações e serviços de saúde gratuita, igualitária e universalmente.

São inúmeros os direitos fundamentais, muitos deles conflitando entre si mesmo abstratamente. É o caso do direito à propriedade - e suas inequívocas derivações de uso, gozo, disposição, fruição e reivindicação da coisa - e o direito ao sossego, saúde e segurança do prédio vizinho, ou o direito de desapropriação que socorre o Estado. É, também, o caso da liberdade, de um lado, e da segurança da sociedade, representada pela reclusão em caso de crimes apenados com sua privação. Pois quando um magistrado

e direta), contida (em que o conteúdo do preceito constitucional pode ser limitado por lei disciplinadora) e limitada (cuja aplicabilidade depende de regulação legal). No que tange aos direitos sociais, o Judiciário já consagrou que apesar deles primariamente viabilizarem a atuação do administrador e do legislador, na falta dela, poderão comportar escrutínio judicial, já que possuem aplicabilidade imediata. A respeito, consultar o paradigmático RE-AgR n ${ }^{\circ}$ 410.715/SP, Rel. Min. Celso de MELLO, 2 ${ }^{\mathrm{a}}$ T. do STF, j, 21.11.2005.

${ }_{77}$ As normas de conteúdo programático são aquelas que, ainda que previstas no texto constitucional, não teriam aplicabilidade imediata porque dependeriam do planejamento administrativo para respectiva colocação em prática. Exemplo clássico dessa qualidade de normas era referido, pelos defensores da teoria, no artigo $6^{\circ}$ da Constituição, que onera o Estado com o dever de prestar alguns direitos sociais. Indaga este autor como poderia a Constituição consagrar direitos tão importantes de maneira figurativa, quase onírica, sem que deles se extraísse nada mais senão simples promessa, sem a correspondente paga. Nesse sentido e desde logo, vale-se da mesma inquietação que perturbou BOBBIO para externar sua posição a respeito da teoria: "Será que já nos perguntamos alguma vez que normas são essas que não ordenam, proíbem ou permitem hic et nunc, mas ordenam, próbem e permitem num futuro indefinido e sem um prazo de carência claramente delimitado? E, sobretudo, já nos perguntamos que direitos são esses que tais normas definem? Um direito cujo reconhecimento e cuja efetiva proteção são adiados sine die, além de confiados à vontade de sujeitos cuja obrigação de executar o 'programa' é apenas uma obrigação moral ou, no máximo, política, pode ainda ser chamado corretamente de 'direito'?" (BOBBIO, Norberto. A Era dos Direitos. Rio de Janeiro: Campus, 1992. p. 77).

${ }^{78}$ No sítio eletrônico da OMS (<http://www.who.int/en/>) são encontrados fartos exemplos sobre a atuante presença da organização em todo o mundo, ela, que define regras que servem como fonte para a ação política e estratégica de vários países, incluindo-se o Brasil. A OMS não desdenha de seu papel. Ao contrário, segundo ela própria, a crise mundial, que nunca deixou de existir desde a quebra do banco norte-americano Lehman Brothers, demandará uma maior intervenção da ONU, via OMS, para incrementar e assegurar serviços de saúde em países necessitados. Este foi considerado um ponto chave das ações da OMS para 2012 (<http://www.who.int/features/2011/year_review/en/index.html>, acesso em 10.1.2012, 14:15).

Prova da influência da OMS sobre o Estado brasileiro pode ser facilmente obtida no Portal da Saúde, inclusive via notícia de que o governo brasileiro, apoiado em critérios eleitos pela OMS, considera como baixa a frequência de casos de Hepatite B (<http://portalsaude.saude.gov.br/portalsaude/noticia/3890/162/sau de-amplia-faixa-etaria-para-vacinacao-de-hepatite-b.html >, acesso em 10.1.2012, 14:30h). 
ordena forçadamente medida que afeta uma política de saúde, os limites desse direito fundamental - e, também, de outros - são testados. Isso se verá com o apropriado apanhado em momento ulterior ${ }^{79}$.

É bem verdade, deve-se aqui colocar, que a aplicação concreta da norma de abstenção enseja certo grau de dificuldade enquanto que, para a norma de prestação, o correspondente trabalho é muito maior. Essa diferença, por sinal, é essencial para a compreensão dos riscos da ingerência judicial nas políticas públicas de saúde. Mas isso não toca ao grau de eficácia de ambas as normas. Toca, sim, ao modo como os direitos nela colocados são implementados. Aí é o caso de passar a falar sobre políticas públicas.

\subsubsection{Direitos Fundamentais a as ações políticas: políticas públicas}

Porque são fundamentais, os direitos dessa estirpe constituem foco das ações estatais, que devem ser prioritariamente voltadas para sua observância concreta. Há uma eficácia irradiadora dos direitos fundamentais, ou seja, os efeitos da previsão de tais direitos em um dado ordenamento estendem-se a todos os órgãos públicos e, inclusive, aos particulares, marcando as ações da sociedade como um todo ${ }^{80}$. Assim sendo, nada mais natural que o Estado tenha como preocupação nodal lidar com tais direitos, de forma a observá-los e garanti-los o quão perfeitamente possível, senão aceitável e otimamente, como enuncia Canotilho ${ }^{81}$.

A implementação concreta dos direitos fundamentais depende de uma coordenada atuação estatal. Ao conjunto dessas ações, levadas planejadamente a efeito pelo Poder Público com vistas a cumprir esse seu papel constitucional e institucional, pode

\footnotetext{
${ }^{79}$ Quando se tratar do tema da reserva do possível, estudar-se-ão os limites dos direitos fundamentais e, então, ver-se-á mais a respeito do relevante assunto.

${ }^{80} \mathrm{O}$ precedente do conceito de eficácia irradiante dos direitos fundamentais pode ser encontrado na Alemanha, em BVerfGE 39 I (41), uma vez que, "Segundo a jurisprudência reiterada do Tribunal Constitucional Federal, as normas de direitos fundamentais contêm não apenas direitos subjetivos de defesa do indivíduo contra o Estado, elas representam também uma ordem objetiva de valores, que vale como decisão constitucional fundamental para todos os ramos do direito, e que fornece diretrizes e impulsos para a legislação, a Administração e a jurisprudência." Disserta sobre o tema Robert ALEXY (Teoria dos Direitos Fundamentais. São Paulo: Malheiros, 2008, pp. 524-544), apontando três teorias e sugerindo um modelo de três níveis para os efeitos dos direitos fundamentais nas relações privadas.

${ }^{81}$ V. nota 71 .
} 
se denominar políticas públicas. Maria Paula Dallari Bucci qualifica essas ações de acordo com a relevância social e política que elas ostentem ${ }^{82}$.

O Estado possui a incumbência constitucional de regulação e intervenção em diversos campos, como, por exemplo, na Economia, nas Finanças Públicas, na Ciência e Tecnologia, no Mercado Exterior e nos já vistos fundamentais direitos à segurança, à saúde e tantos outros de interesse da sociedade, passando o interesse social a interesse público (nesse caso, o interesse social qualificado pela presença do Estado) ${ }^{83}$. Sempre que o Estado atua em determinado campo visando a cumprir sua missão constitucional, fala-se em política pública - política econômica, política social, política de segurança, política de previdência, e assim por diante. A implementação das políticas públicas representa, destarte, atuação incisiva e estreita do Estado para que sejam atingidos objetivos constitucionais $^{84}$.

O estudo das políticas públicas é caro à Ciência Política ${ }^{85}$. Devido ao grande número de comandos constitucionais que obrigam o Estado, é necessário que se investiguem inúmeros elementos e que se teçam variadas indagações, como, por exemplo, qual política pública é prioritária, como e por meio de qual agente implantá-la de maneira mais eficaz. Frey ensina que, na Ciência Política, os processos de investigação seguem,

\footnotetext{
${ }^{82}$ Trata-se de talvez o mais festejado conceito de políticas públicas, definidas como a “(...) coordenação dos meios à disposição do Estado, harmonizando as atividades estatais e privadas para a realização de objetivos socialmente relevantes e politicamente determinados." (BUCCI, Maria Paula Dallari. "As políticas públicas e o direito administrativo", em Revista Trimestral de Direito Administrativo, v. 13, 1996, pp. 135-136).

${ }^{83}$ Rodolfo de Camargo MANCUSO, ao tratar das diferentes acepções do termo interesse, diferencia o interesse social (aquele que toca à busca do bem comum pela sociedade, à res publica) e o interesse público (aquele que, de alguma maneira, envolve o Estado - Interesses Difusos - Conceito e Legitimação para Agir. $6^{\mathrm{a}}$ edição. São Paulo: Editora RT, pp. 27-35). SALLES assevera que o interesse público não possui uma definição tranqüila, dada a multiplicidade de situações e interesses por ele abarcados. Cita como exemplo o Teorema de Arrow ("Processo Civil de Interesse Público", em Processo Civil e Interesse Público - O processo como instrumento de defesa social. Carlos Alberto de SALLES - org. - São Paulo: Editora RT, 2003, p. 59), que será explicado no Item 2.5.2.

84 Segundo Owen FISS (Um Novo Processo Civil - Estudos Norte-Americanos sobre Jurisdição, Constituição e Sociedade, São Paulo: RT, 2004, p. 25), “A Constituição estabelece a estrutura do Estado, posto que cria órgãos e determina suas respectivas funções e seu inter-relacionamento. Identifica também os valores que informarão e limitarão essa estrutura." Interessante o aspecto observado pelo professor de Yale: sendo a Constituição a norma que institui o Estado, é ela também aquela que estabelece os objetivos a serem por ele perquiridos e os limites a serem observados em sua exaustiva busca.

${ }^{85}$ BUCCI, Maria Paula Dallari, et. al., "Buscando um Conceito de Políticas Públicas para a Concretização dos Direitos Humanos", em Direitos Humanos e Políticas Públicas, São Paulo: Polis, 2001, p. 11. A autora usa uma feliz definição de RONALD DWORKIN a respeito das políticas públicas, qual seja, "A categoria das normas, como produção legislativa, é tradicionalmente definida como associada à generalidade e à abstração. Por outro lado, as políticas públicas atuam de forma complementar, preenchendo os espaços normativos e concretizando os princípios e regras, com vista a objetivos determinados. As políticas, diferentemente das leis, não são gerais e abstratas, mas, ao contrário, são forjadas para a realização de objetivos determinados. Princípios são proposições que descrevem direitos; políticas (policies) são proposições que descrevem objetivos.". No mesmo sentido, da autora, "O Conceito de Políticas Públicas em Direito”, em Políticas Públicas: reflexões sobre o conceito jurídico. São Paulo: Saraiva, 2006.
} 
normalmente, três diferentes espécies de abordagem: (a) a verificação se o governo é um bom governo para propiciar a felicidade dos cidadãos, indagação já constante em Platão e Aristóteles; (b) a análise das forças políticas cruciais que participam do processo decisório; e, enfim (c) quais os resultados produzidos por certas estratégias adotadas pelo sistema político $^{86}$.

Evidentemente, o que fomenta tantas dúvidas a gerar essas três espécies de processos investigatórios é a vasta gama dos campos em que o Estado deve atuar em termos de políticas públicas - e, claro, empregar meios e recursos aptos e suficientes para tal atuação. Essa multiplicidade causa uma crise absolutamente compreensível, já que, sendo escassos os recursos e enorme a demanda, os resultados das políticas públicas não chegam a $\operatorname{todos}^{87}$. Diante disso, as ações a elas voltadas são, normalmente, tomadas no ambiente político, em que as escolhas, sendo da essência da política, são feitas com mais facilidade.

A verdade é que o planejamento da execução de políticas públicas, a cabo do Executivo, pode ser avaliado por meio de sua segmentação em fases sequenciais. Da análise de três estudos, tiram-se cinco fases ou etapas das políticas públicas: (a) a percepção e definição dos problemas; (b) a construção de uma agenda de debates e estratégias de solução dos problemas reconhecidos; (c) a formulação da política a ser empregada; (d) a implementação dessa política, definindo-se prioridade e programando-se a respectiva execução; e, por fim, (e) a avaliação da política, a fim de checar em que medida ela atingiu os resultados almejados ${ }^{88}$. Daí se ver que as políticas públicas envolvem processos estruturados e planejados, desde a raiz até a copa.

Quem define prioritariamente quais serão as políticas públicas do Estado é, precisamente, a Constituição. Daí a clara relação entre Direito e Política. Clune dá contornos ainda mais amplos a essa correlação, ao afirmar que “(...) por definição, toda a lei é política pública, nas quais a vontade da sociedade é expressa por normas

\footnotetext{
${ }^{86}$ FREY, Klaus. Políticas Públicas: Um Debate Conceitual e Reflexões Referentes à Prática da Análise de Políticas Públicas no Brasil. Publicado no sítio da USP (<http://www.usp.br/procam/novosartigosparaaulas), pp. 214-215. Acesso em 19.6.2008, 19:12h.

${ }^{87}$ Esse aspecto cruel da concretização dos direitos fundamentais será tratado com mais vagar nos Itens 5.1 .1$. e 5.1.5.

${ }^{88}$ VIANA, A. L. A. "Enfoques metodológicos em políticas públicas: novos referenciais para os estudos sobre políticas sociais", em CANESQUI, A. M. Ciências Sociais e Saúde. São Paulo: Hucitec/Abrasco, 1997; LINDBLOM, C.E. O Processo da Decisão Política. Brasília: UNB, 1981; e LABRA, M.E. "Análise de política e modos de policy making e intermediações de interesses: uma revisão", em PHISYS Revista de Saúde Coletiva. Rio de Janeiro: 9 (2):1999, p. 131-166.
} 
vinculantes; e toda a política pública é lei, eis que ao menos algum aspecto de sua existência depende das leis e do legislativo" ${ }^{89}$.

O que preocupa por trás das políticas públicas é, justamente, sua estreita relação com os anseios da sociedade. Tome-se exemplo a fim de facilitar a compreensão da afirmação: o artigo 170, VII da Constituição estabelece como princípio geral da atividade econômica a busca do pleno emprego. A União, a fim de executar ações na área do trabalho e dar comando à diretriz constitucional, criou o Ministério do Trabalho, órgão da Administração Pública desconcentrada. Por sua vez, a União também subvenciona uma série de sindicatos e promove inúmeras ações nas áreas profissionais, de quando em vez, inclusive, equilibrando o mercado de trabalho com o uso dos instrumentos cabíveis (como as medidas provisórias, por exemplo).

Fato é que, diante da multiplicidade de interesses envolvidos e da peculiaridade de seu objeto, no trato das políticas públicas não existe uma equação proporcional entre ganhos-e-perdas, custo-e-benefício. Tendo em vista que os bens comuns não são, em tese, passíveis de parcelamento e atribuição individual (ou, antes, são indivisíveis $)^{90}$, não se pode aplicar às políticas públicas o paradigma da oferta-e-demanda, porque sempre será contrário aos ditames constitucionais privilegiar determinado setor da sociedade, em detrimento de outro. Por isso, a provisão de políticas públicas deve ser feita por outros processos que não o de Mercado ${ }^{91}$.

Também em Dworkin é possível encontrar o entendimento de que as políticas públicas merecem tratamento especial pelo Estado. Baseado na idéia de igualdade de consideração, aduz Dworkin que os indivíduos não podem ser responsabilizados pelas circunstâncias a que não deram causa, mas, somente, quando essas circunstâncias derivaram de uma escolha. Nesse sentido, as políticas públicas não são escolhas diretas dos indivíduos, mas, sim, comandos presentes nas normas constitucionais, legais e regulamentares, de forma que, se há desigualdades provocadas pela má-distribuição de objetos sociais, tais devem, de alguma maneira, ser objeto de correção ${ }^{92}$ por meio de algum

${ }^{89}$ CLUNE, Willian, Law and public policy: Map of an area, apud de SALLES, Carlos Alberto de. Processo civil de interesse público: uma nova perspectiva metodológica, em SUNDFELD, Carlos Ari e BUENO, Cássio Scarpinella (orgs.), Direito Processual Público. A Fazenda Pública em Juízo. São Paulo: Malheiros, 2000 , p. 53.

90 ARISTÓTELES já concebia a existência de bens comuns quanto, em A Política, falou nas "coisas partilhadas e os sócios que as partilham". Segundo ele, em um Estado, as pessoas compartilham todas as coisas, ou nada, ou apenas algumas (Livro II, I, pp. 169-170).

${ }^{91}$ SALLES, Processo Civil..., p. 64. No Item 3.2.5. há quadro analítico com as vantagens e desvantagens das várias arenas de decisão de políticas públicas.

92 FERRAZ, Octávio Luiz Motta. "Justiça Distributiva para Formigas e Cigarras", em Revista de Novos Estudos do CEBRAP, no 77, São Paulo (março/2007), pp. 243-253. Citando DWORKIN, FERRAZ explica 
processo. Tudo isso demonstra que a temática envolvendo qualquer política pública é de interesse público.

Especial consideração deste estudo merecem as políticas públicas de direitos fundamentais, notadamente de direitos sociais e, dentro desses, de saúde. Os direitos sociais são o principal exemplo da importância do conteúdo de políticas públicas. A definição se é a comunidade "A" ou a comunidade "B"que receberá o posto de saúde, ou a escola de ensino fundamental, depende de planejamento e, em última análise, do exercício de opções, dentro da margem discricionária de atuação do ente público limitada à necessária proteção do direito almejado.

Dita margem de discricionariedade administrativa no trato das políticas públicas, contudo, pauta-se, a toda evidência, nos princípios próprios da Administração Pública, dentre os quais aquele mais sensível no que tange à definição de planos, metas e programas, um postulado presente desde a concepção até a efetivação, a entrega do direito à sociedade: a eficiência. As escolhas que permeiam o processo de definição e execução de políticas públicas, do início ao fim, têm de encontrar inspiração e limite na eficiência administrativa: por ela, a atuação administrativa - incluída, aí, a prestação de serviços públicos - não deve apenas se ater à legalidade, mas tem de ser dispensada com presteza, perfeição e rendimento funcional ${ }^{93}$. A ausência da plena eficiência terminará por violar direitos cuja discussão será levada ao Judiciário.

No caso dos direitos sociais a questão é ainda mais sensível. Eles, por sua essência, serão sempre objeto de políticas públicas ${ }^{94}$. É que, por demandar ações positivas, um fazer estatal, a prestação de direitos sociais conclama o agente público a agir. Ainda que certa obrigação, originalmente do Estado, seja entregue à exploração privada, aí haverá uma política pública, porque se decidiu desonerar parcialmente o Poder Público da prestação direta de serviços e entrega de bens. Ademais, vários são os casos em que, não obstante tal delegação - como saúde e educação - tem o Estado de manter toda uma estrutura para fiscalizar a atuação privada ${ }^{95}$.

que a igualdade de consideração é a necessidade governamental da consideração do destino de todos sobre os quais pleiteia domínio e dos quais demanda fidelidade.

${ }_{93}^{93}$ MEIRELLES, Hely Lopes. Direito Administrativo Brasileiro. $32^{\text {a }}$ ed. São Paulo: Malheiros, 2006, p. 96.

94 COMPARATO, Fábio Konder. "O Ministério Público na defesa dos direitos econômicos, sociais e culturais”, em GRAU, Eros Roberto et. al.. Estudos de direito constitucional em homenagem a José Afonso da Silva. São Paulo: Malheiros, 2003, p. 249.

${ }^{95}$ Como sucede com a Agência Nacional de Saúde Suplementar, vinculada ao Ministério da Saúde, que tem por objeto o controle dos serviços de saúde prestados por particulares, e com o Ministério da Educação, que regulamenta e acompanha os estabelecimentos privados de ensino. A delegação dos serviços de saúde e educação é constitucional (respectivamente, art. 199 e art. 209 da Constituição). 
Apesar disso, os direitos fundamentais sociais revelam-se claro paradigma de financiamento público: não há direito social que não precise de política pública onerosa aos cofres públicos, ainda que minimamente. De fato, se o núcleo ontológico dos direitos sociais conta com ações positivas capitaneadas pelo Poder Público, então é evidente que tais ações serão pagas a partir do Erário ${ }^{96}$.

Imagine-se, apenas a corroborar a assertiva em apreço, o comprometimento do Tesouro com as políticas de transporte público. O Estado de São Paulo, após atender demanda social pela revogação do aumento da tarifa pelo uso de trens e metrô, anunciou uma série de corte de gastos com vistas a fazer frente ao déficit financeiro que a manutenção das tarifas inevitavelmente implicaria, da ordem de duzentos e dez milhões de reais por ano ${ }^{97}$. Trata-se, no caso, apenas do Estado de São Paulo, com malha ferroviária altamente restrita. É apenas um exemplo, mas que bem ilustra a íntima relação entre prestação de serviços públicos e o Erário.

Dado que a definição de determinada ação governamental, dentro do escopo de uma política pública, passa pela inafastável análise do orçamento, justamente com vistas a verificar se existe rubrica orçamentária prevista e suficiente para custear determinado movimento. O papel que o orçamento desempenha no desenho das políticas públicas é essencial. O tópico seguinte tratará dessa importante variável.

\footnotetext{
${ }^{96}$ Os direitos civis e políticos também demandam gastos públicos, embora alguns deles em nada vulnerem o Erário. Tome-se, como exemplo de gastos, o propalado plebiscito para a reforma política anunciado pelo Governo Federal em meados de 2013, com custos estimados em quinhentos milhões de reais (<http://ultimos egundo.ig.com.br/politica/2013-06-28/gastos-com-plebiscito-sobre-a-reforma-politica-podem-chegar-a-r500-milhoes.html>, acesso em 30.6.2013, 18:14h). Acerca dos custos dos direitos, ver Itens 2.3, 3.2.1 e 4.2.2.

${ }^{97}$ Para fazer frente à despesa, o governador de São Paulo anunciou a venda de um helicóptero, a extinção de dois mil e trinta e seis cargos comissionados, a devolução de quatrocentos e trinta e seis carros alugados, a venda de cento e quarenta e quatro veículos do Estado, a extinção da Secretaria de Desenvolvimento do Metropolitano, um órgão da Administração Pública desconcentrada, e a junção de três autarquias ("Governador de SP diz que irá vender helicóptero e extinguir 2 mil carros", em <http://g1.globo.com/saopaulo/noticia/2013/06/governador-de-sp-diz-que-ira-vender-helicoptero-e-extinguir-2-mil-cargos.html>, acesso em 30.6.2013, 18:04h).
} 


\subsection{O ORÇAMENTO PÚBLICO}

A existência e a operacionalidade do Estado são financiadas por duas receitas básicas, oriundas da exploração de seus bens ${ }^{98}$ e da tributação. Não há dúvida que a segunda fonte é responsável por enorme parte dos dinheiros públicos, que crescem ano a ano $^{99}$. Fato é que o conjunto das receitas financeiras públicas - o Erário - é, sem dúvida, peça fundamental para mantença do Estado como conhecemos hoje. Nesse contexto, o orçamento público exerce papel determinante.

Orçamento público, este mistério. Nós, entusiastas e estudiosos das ciências jurídicas, pouco afeitos aos números, normalmente evitamos lidar com ele, limitando-nos a entender do orçamento o suficiente para tratar de nossas contas particulares, usualmente encetadas na simples, porém fundamental e, por vezes, pragmaticamente tão difícil fórmula dos ativos maiores que os passivos. Isso, contudo, é mero reflexo do instinto que nós, humanistas, temos, em geral, de desprezo aos números. Quem se lança, contudo, no estudo das prestações estatais típicas de um Estado Social não pode deixar de analisar como são materializadas tais prestações, que contam com o imprescindível suporte financeiro do Erário. Até porque, já há algum tempo, o orçamento deixou de ser um compêndio de números para se tornar objeto de preocupação normativa.

Quando o Estado escolheu tratar seus cidadãos com dignidade e respeito, preservando-lhes vida, segurança, propriedade, liberdade, igualdade e, sobretudo, saúde, educação, previdência, assistência, cultura, lazer, desporto, alimentação, entre outros diretos, ele certamente contou com dinheiro para o respectivo financiamento, materializados por bens diretamente fruíveis pelos cidadãos. Um Estado fulcrado no social não pode prescindir de ter suas finanças em ordem.

\footnotetext{
${ }^{98}$ Inclusive aqueles eleitos como tal em virtude da Constituição (i.e., artigo 20).

${ }^{99}$ A carga tributária brasileira chegou a 35,13\% do PIB (<http://g1.globo.com/economia/noticia/2011/03/carg a-tributaria-foi-de-3513-do-pib-em-2010-diz-instituto.html $>$, acesso em 6.3.12, 13:40h), maior que em países desenvolvidos, como os Estados Unidos, em que a carga de tributos equivale a $27 \%$ do PIB. A sanha fiscal no Brasil é tamanha que a Associação Comercial de São Paulo realiza um controle sobre o quanto é recolhido a título de tributos no Brasil, podendo o cidadão saber quanto o Estado recebe de tributos por ano, mês, dia, hora, minuto, segundo e habitante. Os números são assustadores (<http://www.impostometro.com.br/>, acesso em 6.3.12, 13:43h). Os órgãos fiscais comemoram, de tempos em tempos, novos recordes de arrecadação: só em janeiro de 2012 o Brasil ultrapassou a marca de cem bilhões de reais pagos a título de tributos (<http://g1.globo.com/jornal-nacional/noticia/2012/02/brasil-tem-novo-recorde-na-arrecadacao-deimpostos-em-janeiro.html>, acesso em 6.3.12, 13:45h). Em julho de 2013, de acordo com o Impostômetro, alcançou-se a cifra de oitocentos e oitenta e nove bilhões de reais (acesso em 25.7.2013, 13:45h).
} 
De outra parte, os custos de implementação dessa enorme gama de direitos assumem viés particularmente dramático à luz da escassez de recursos. É evidente que, por nossa própria condição humana, as necessidades são infinitas e os recursos, escassos. No caso dos direitos constitucionalmente assegurados pelo Estado, sua vinculação ao Erário é clara - mas eles também são muito maiores do que a soma de todo o numerário público e, aqui, restringe-se a análise ao campo estritamente financeiro. O Erário não basta para custear, como se deve, os direitos constitucionais de que são titulares a sociedade e seus membros. É preciso, pois, aplicar seu produto com eficiência, realizar escolhas muitas vezes trágicas e tentar minorar, tanto o quanto maximamente possível, as parcelas sociais que não receberão os direitos garantidos pela Carta ${ }^{100}$.

Daí a relevância do estudo do orçamento público, principalmente em um cenário de execução de direitos que dependem de políticas públicas ${ }^{101}$.

O desenho orçamentário é atribuição dos poderes majoritários, com amplo destaque ao Executivo, responsável pela efetivação concreta das políticas públicas enlaçadas nas normas. É ele, Executivo, que possui a prerrogativa de elaborar a previsão de despesas para o exercício subsequente, requerendo ao Congresso Nacional, ato contínuo, o respectivo referendo via aprovação das leis orçamentárias ${ }^{102}$, coisa, de resto, de competência exclusiva do Legislativo, nada obstante necessária aprovação dos administradores públicos ${ }^{103}$.

O jogo de poderes relacionados aos dinheiros públicos, na Constituição, é evidente, e ela aponta para a inafastável atribuição legislativa no trato da matéria, seja no que toca à edição de leis orçamentárias (Plano Plurianual, Diretrizes Orçamentárias e Orçamento Anual), seja no que pertine às operações financeiras de que o Estado tome parte, seja com relação ao controle e fiscalização das finanças públicas ${ }^{104}$. Ao Executivo

\footnotetext{
${ }^{100}$ A escassez de recursos merece relevo central nas discussões que circundam esta tese, em que o tema será visto e referenciado por diversas vezes. Aponta-se especial consideração a respeito nos Itens 3.2.1, 4.2.1.3 e 4.2.2 adiante.

${ }^{101}$ Não por menos que o APLPP elege como um dos pilares do processo especial de que trata o equilíbrio orçamentário (Art. $1^{\circ}, \mathrm{VII}$ ). Com toda a razão e em consonância com o espírito da questão, a lei projetada obriga o Poder Público, antes de responder à inicial, a apresentar esclarecimentos relacionados aos pedidos, que, obrigatoriamente, conterão considerações e evidências sobre (artigo $5^{\circ}$ ): (a) recursos financeiros previstos no orçamento para a implementação da política requerida (inciso II); (b) previsão de recursos necessários à implementação ou correção da política pública (inciso III); e (c) em caso de insuficiência de recursos, a possibilidade de sobreposição de verbas (inciso IV).

${ }^{102}$ A competência para elaboração de projeto de Lei de Diretrizes Orçamentárias, Orçamento Anual e Plano Plurianual é do Presidente da República, cf. art. 84, XXXIII da Constituição.

${ }_{103}$ Artigo 48, II da Constituição.

${ }^{104}$ Cf. o já mencionado art. 48, II. O controle e fiscalização contábil e financeira do Erário cabe ao Legislativo, via controle interno (em concomitância com os demais Poderes - art. 70 da Constituição, porque ninguém melhor que os próprios gestores do dinheiro e das necessidades para verificar a respectiva
} 
cabe, apenas, realizar o controle interno das contas, propor o que entende pertinente a título de receitas e despesas e sancionar ou vetar as leis orçamentárias, veto este que tem valor mais simbólico/político do que efetivo, já que pode ser infirmado pelo Congresso. A Constituição foi tão cautelosa que vedou ao Executivo a adoção seja de medida provisória, seja de lei delegada dispondo sobre o tema ${ }^{105}$. Se, pois, a primazia pela definição do que e em que será gasto o recurso público é do Executivo, repousa no Legislativo o papel de grande articulador institucional na definição do destino do produto do Erário. Via de regra, pois, o sistema não deseja que o Executivo, por mais que necessite, por mais que precise fazer frente a uma despesa inesperada, estenda sua mão diretamente ao interior dos cofres do Estado, tomando para si aquilo que não fora antevisto a contento. Se o Executivo possui essa limitação, uma fria análise da letra constitucional conduziria à afirmação de que o Judiciário, muito mais.

A Constituição, basicamente, proibiu terminantemente a eficácia direta de uma sentença judicial sobre as contas públicas, estabelecendo o sistema de pagamentos dessa seara por meio de precatórios. O art. 100 da Carta estatui, claramente, que os pagamentos dar-se-ão cronologicamente, dependendo do momento da apresentação dos precatórios, e à conta dos créditos respectivos. Em outras palavras, determinou a Constituição que as sentenças emanadas dos magistrados que condenem o Estado não produzam seus totais efeitos senão depois de perseguir longos caminhos burocráticos, que teriam por fim evitar uma enxurrada de condenações (despesas) imprevistas, inviabilizando as contas do exercício. Mesmo essas condenações não fogem ao rigor do orçamento ${ }^{106}$. O calvário de quem, hoje, está na fila dos precatórios, mostra como o expediente constitucional foi desvirtuado, implicando severa, ilegítima e inconstitucional restrição de direitos $^{107}$. Por esse lado, o grau de ingerência do Judiciário no budget público é tão frágil

correlação) e externo, por meio do Tribunal de Contas da União, órgão auxiliar do Congresso e responsável por analisar a lisura das contas da União, por sua administração direta ou indireta ou, ainda, empresas públicas ou particulares subvencionadas, de qualquer modo, pelos cofres públicos (arts. 70 e 71 da Constituição).

${ }^{105}$ Respectivamente, arts. $62, \S 1^{\circ}$, inc. I, al. $d$ e $68, \S 1^{\circ}$, III da Constituição.

${ }^{106} \mathrm{O} \$ 5^{\circ}$ do art. 100 da Constituição obriga as entidades condenadas a incluírem, em suas próprias previsões orçamentárias, as verbas necessárias ao pagamento de seus débitos.

${ }^{107} \mathrm{O}$ CNJ divulgou que a principal falha encontrada em inspeção realizada nos tribunais de todo o País é relacionada aos precatórios, especialmente no que toca ao erro de cálculos e desvios. Para isso também serve a Recomendação nº 39/2012 daquele Órgão, para que tribunais aloquem juízes auxiliares das presidências e funcionários de carreira para tratar do tema. O CNJ, inclusive, mandou suspender o pagamento de precatórios em Rondônia, em virtude do potencial desvio de cerca de trezentos e cinquenta e oito milhões de reais do erário (<http://g1.globo.com/politica/noticia/2012/06/suposta-fraude-leva-cnj-suspender-pagamento-deprecatorios-em-ro.html $>$, acesso em 16.6.2012, 20:01h). 
que o Executivo rejeitou a proposta de orçamento do Judiciário para o exercício de 2013, o que aumentou a rusga que já há algum tempo acomete o equilíbrio brasileiro de Poderes ${ }^{108}$.

Questão fundamental quando se trata do financiamento de direitos sociais pelo Estado é: qual o papel exercido pelo Judiciário no controle, interferência e gestão, ainda que indireta, do orçamento, quando determinam os magistrados, via ação judicial, o cumprimento forçado de providências que geram despesa?

Este é o objetivo deste tópico: analisar a natureza do orçamento público, explicar sua complexidade e tenacidade e concluir que é preciso muita técnica, diálogo e entendimento para ensejar qualquer modificação em seu espectro. Este item introdutório servirá para, mais adiante, verificar em que medida o orçamento pode ser controlado por juízes de forma mais racional. A proposta, pois, é realizar justa exposição sobre o papel do orçamento na República Brasileira para, depois, circundar dois ou três importantes aspectos da ingerência judicial nos dinheiros públicos sob o espectro de cumprimento de direitos fundamentais sociais encartados no ordenamento jurídico.

\subsubsection{Situando o orçamento: brevíssimo escorço histórico}

O conceito de Estado é intimamente ligado à ideia de financiamento público. Atribui-se à Magna Carta de João-Sem-Terra a primeira disposição regulamentar

\footnotetext{
${ }^{108}$ A Presidente rejeitou a proposta de reajuste do Judiciário apresentada pelo STF, o que ensejou críticas por parte do então Presidente da Corte, quando de sua saída desse cargo (<http://m.estadao.com.br/noticias/nacio nal,de-saida-da-presidencia-do-stf-peluso-critica-colegas,862207.htm〉, acesso em 7.6.2012, 14:49h). Mais recentemente, o Judiciário influenciou decisivamente a votação do Orçamento da União de 2013. O STF, por meio de decisão monocrática manifestada pelo Min. Luiz FUX, havida em medida apresentada por alguns parlamentares, decidiu que todos os vetos presidenciais pendentes de apreciação pelo Congresso Nacional deveriam ser votados em ordem cronológica, o que motivou o Legislativo Federal a atrasar a votação do Orçamento porque alguns vetos estratégicos não poderiam ser sufragados sem que o Executivo entrasse em acordo com o Legislativo. O pedido dos parlamentares, integrantes de Estados produtores, se deu no contexto da discussão da regulamentação dos royalties do petróleo. Resultado: apesar de a Constituição determinar que o Congresso vote o Orçamento até o dia 22 de dezembro de cada ano, em 19 de fevereiro de 2013 ele ainda não havia sido deliberado. O Congresso, atendendo pedido do Executivo, decidiu aguardar o desfecho do assunto no STF ("Congresso decide esperar STF para votar Orçamento", Folha de São Paulo, 19.2.2013, $n^{\circ} 30.638$, p. A6). O simbolismo por detrás dessa decisão é a demonstração da supremacia judicial vivida hodiernamente. Nesse caso, a Corte Suprema adentrou em questão sensivelmente política e a ela estranha, qual seja, o modo como se deve votar: vetos presidenciais a projetos de lei devem ser colocados em pauta à medida em que eles forem encaminhados ao Congresso, e, não, de acordo com o interesse político em jogo. Essa é uma aguda ingerência do Judiciário nas relações entre Executivo e Legislativo, com inúmeras implicações políticas (a mesma notícia a que se faz referência dá conta da atuação do Advogado-Geral da União e da Ministra das Relações Institucionais, além dos próprios presidentes das Casas Legislativas, para debelar o problema criado). Ao fim e ao cabo, a medida emergencial concedida pelo Relator foi revogada em Plenário (por seis votos a quatro, decidiu-se que o STF não poderia exercer controle prévio de constitucionalidade de leis, divergência liderada pelo Min. Teori ZAVASCKI e ocorrida em 27.2.2013).
} 
no que toca às finanças públicas. Foram mais de seiscentos anos até que, em 1822, o Chanceler do Erário britânico passasse a justificar ao Parlamento os gastos e despesas do Estado frente às receitas a ele afetadas, tudo em razão de uma lei que criava um fundo para gerenciar as atividades financeiras da Grã-Bretanha ${ }^{109}$.

No Brasil, a Constituição de 1824 já outorgava ao Legislativo competência para fixação anual das despesas públicas e repartição da contribuição direta ${ }^{110}$. Naquele contexto em que despontava o Liberalismo, fazia sentido o controle legislativo dos gastos e arrecadações promovidos e geridos pelo Executivo ${ }^{111}$. Àquele tempo, sem dúvida, os orçamentos assumiam as vestes de peças puramente contábeis, informativas, comunicadoras da gestão do Erário, com o que se falar, no ideário da época, em concepção

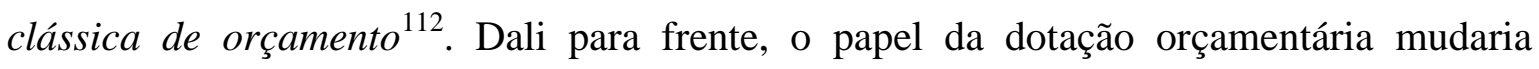
consideravelmente.

Em 1891, a novel Constituição previu que o Legislativo deveria, ano a ano, orçar a receita, fixar a despesa federal e tomar as contas de cada exercício financeiro. Em 1934, a Carta dedicou toda uma Seção ao tema, fixando, no artigo 50, que o orçamento deveria obrigatoriamente incluir todas as receitas, computando-se-lhe tributos, rendas e suprimentos dos fundos e incluindo-se-lhe discriminadamente as despesas e dotações necessárias ao custeio dos serviços públicos. A previsão não se deu ao acaso. O Brasil já começava a incrementar a prestação estatal de serviços à população, rumando para faceta social que, depois, nunca dele se dissociou. Esses serviços demandavam pagamento, preços e custos, sendo de rigor algum planejamento para evitar a bancarrota do Estado.

Foi, de fato, a Constituição de 1934 que mudou a cara do orçamento nacional, nada obstante, com o advento do Estado Novo, os ditames orçamentários terem ficado exclusivamente com o Executivo, ao contrário da tradição anterior e da realidade atual $^{113}$. Relata Conti que em 1938 foi criado o DASP - Departamento Administrativo do Serviço Público, que profissionalizou o orçamento público no País, ensejando sua transformação em instrumento apto a permitir o planejamento de serviços estatais ${ }^{114}$. Os diplomas supervenientes seguiram a mesma toada: o Decreto-lei $\mathrm{n}^{\mathrm{0}} 1.058$, de 1939,

\footnotetext{
${ }^{109}$ CONTI, José Mauricio. A Autonomia Financeira do Poder Judiciário. São Paulo: MP Editora, 2006, p. 57.

${ }^{110}$ Art. 15, X da Constituição de 1824.

${ }^{111}$ SILVA, José Afonso da. Orçamento-Programa no Brasil. São Paulo: Revista dos Tribunais, 1972, p.1.

112 CONTI, A Autonomia..., p. 57.

${ }^{113}$ Histórico a respeito pode ser encontrado em GONTIJO, Valter. "Orçamento Brasil. Evolução Histórica no Brasil”, disponível em: <http://www2.camara.gov.br/atividade legislativa/orcamentobrasil/cidadao/entenda/c ursopo/HistoricoBrasil>, acesso em 8.6.12, 16:13h.

${ }^{114}$ CONTI, A Autonomia..., p. 59.
} 
instituiu o Plano Especial de Obras Públicas e Aparelhamento da Defesa Nacional, que tinha as despesas custeadas por créditos paralelos ao orçamento da União - quebrando-se, assim, a unidade orçamentária. Em 1943, o Plano foi transformado em Plano de Obras e Equipamentos, para, enfim, em 1947 seu financiamento constar no único orçamento válido para a União ${ }^{115}$. Em 1950, surgiu a Lei $\mathrm{n}^{0}$ 1.102, que instituiu o SALTE - Saúde, Alimentação, Transporte e Energia, cujo custeio era provido pela aplicação do percentual de 3\% sobre as rendas da União, com cumprimento para cinco anos (de 1950-1954) ${ }^{116}$.

Em 1964, já na vigência do Regime Militar, editou-se a Lei $n^{0}$ 4.320/64, diploma que passou a regrar normas gerais de direito financeiro para elaboração $e$ controle dos orçamentos e balanços da União, Estados, Municípios e Distrito Federal. Trata-se de extenso e complexo diploma normativo que teve a pretensão, como mencionado em sua ementa, de baixar normas gerais de Direito Financeiro. A Lei, vigente até hoje, é a que prevê a existência dos créditos adicionais, entendidos tais como aquelas autorizações de despesa não computadas ou insuficientemente dotadas na Lei de Orçamento, dividindo-se em Suplementares, Especiais e Extraordinários, vinculados a hipóteses de superávit ou de eventos como guerra e calamidades públicas ${ }^{117}$.

Enfim, sobreveio a Constituição de 1988, que se preocupou sobremaneira com o orçamento público.

2.3.2. A Constituição e as leis orçamentárias brasileiras: o orçamento-programa

Um primado que a Constituição adotou para a feitura dos orçamentos ${ }^{118}$ é o da unidade. Cada ente federado é responsável por legislar concorrentemente sobre seu

\footnotetext{
$115<$ http://www2.camara.gov.br/atividadelegislativa/orcamentobrasil/cidadao/entenda/cursopo/HistoricoBras il>, acesso em 8.6.12, 16:33h.

${ }^{116}$ Promovido por Eurico Gaspar DUTRA, o SALTE tinha por objetivo melhorar a infra-estrutura nacional nas quatro áreas que compunham sua sigla. Foram destinados, do total de vinte e um bilhões e trezentos milhões de cruzeiros, $53,27 \%$ para o transporte, $14,98 \%$ para a energia, $12,83 \%$ para a alimentação e $12,39 \%$ para a saúde (LONGO, Riolando. Avaliação da política energética e da política industrial no Brasil: do plano SALTE ao plano Brasil para Todos. Tese de doutoramento apresentada à Escola Politécnica da Universidade de São Paulo para a obtenção do grau de Doutor em Energia, São Paulo: 2009, p. 51).

117 Arts. 40 e 41. Os créditos adicionais são frequentemente referidos quando se aprofunda a discussão da ingerência do Judiciário nas contas públicas, por meio da exceção da reserva do possível. Ambos os assuntos serão verificados adiante.

${ }^{118} \mathrm{O}$ uso do substantivo orçamento no plural, neste estudo, referir-se-á aos orçamentos dos entese federados, cada qual com o seu próprio no contexto nacional, embora vigore, quanto a cada esfera, a unidade orçamentária.
} 
orçamento, mas a eles não é dado possuir diversas previsões orçamentárias, senão apenas uma. Os benefícios parecem óbvios. Para Fonrouge, a unidade do orçamento: (a) permite apreciar facilmente seu equilíbrio; (b) dificulta a realização de manobras que possam ensejar simulação de receitas ou ocultação de gastos; (c) torna possível conhecer a magnitude orçamentária; (d) evita obscuridades; (e) facilita o controle parlamentar ${ }^{119}$.

A Constituição também preconizou três esferas de deliberação e estabelecimento do orçamento: o Plano Plurianual, a Lei de Diretrizes Orçamentárias e o Orçamento Anual, ou a Lei Orçamentária Anual, designadas, respectivamente, pelas siglas PPA, LDO e LOA. A Constituição sistematizou, sob um mesmo Título, a tributação meio, por excelência, de abastecimento do Erário - e o orçamento, tratado mais minudentemente a partir do artigo 165.

O Plano Plurianual é lei que estatui as diretrizes, objetivos e metas da Administração Pública federal para as despesas de capital e outras delas decorrentes e para as relativas aos programas de duração continuada, ex vi do parágrafo $1^{\circ}$ do artigo 165 da Constituição. Já a Lei de Diretrizes Orçamentárias compreende as metas e prioridades da Administração, incluindo as despesas para o exercício subsequente, servindo como paradigma para a elaboração da Lei Orçamentária Anual, dispondo, inclusive, sobre alterações na política tributária e aplicação das agências financeiras oficiais de fomento ( $2^{\circ}$ do artigo 165 já mencionado). A Lei Orçamentária Anual trata de temas mais corriqueiros, embora não menos importantes, como: (a) orçamento fiscal e fundos dos Poderes da União, além das entidades da Administração direta e indireta; (b) orçamento de investimento das empresas em que a União detenha a maioria das ações com direito a voto; e (c) orçamento da seguridade social, devendo ser acompanhado de demonstrativo regionalizado do efeito, sobre receitas e despesas, de quaisquer subsídios e benefícios de natureza financeira, tributária ou creditícia, tais como isenções, remissões e anistias ${ }^{120}$. O PPA é editado a cada quatro anos (equivalente a uma sessão legislativa), enquanto que LDO e LOA são anualmente editadas (ou cada exercício financeiro).

É no contexto da LOA que o Legislativo se vale de relevante instrumento que pode servir mais concretamente ao atendimento de políticas públicas locais: as Emendas ao Orçamento. Trata-se de proposições dos parlamentares ao Projeto de LOA que usualmente visam a dotar recursos financeiros às bases de apoio eleitoral de cada

\footnotetext{
119 apud de LOCHAGIN, Gabriel Loretto. "A unificação dos orçamentos públicos pela Constituição de 1988”, em CONTI, José Mauricio, e SCAFF, Fernando Facury (coord.). Orçamentos Públicos e Direito Financeiro, São Paulo: Editora Revista dos Tribunais, 2011, p. 197.

${ }^{120} \mathrm{Cf} . \S \S 5^{\circ}$ e $6^{\circ}$ do art. 165 da Constituição.
} 
congressista. Essas Emendas podem ser utilizadas para se construir um hospital, uma escola ou à melhoria do transporte urbano ${ }^{121}$.

A Carta ainda define que os projetos de lei de PPA, de LDO, de LOA e de lei que institui créditos adicionais serão apreciados pelas duas Casas do Congresso Nacional, na forma regimental, e que as emendas parlamentares - representativas daquela fatia do budget público destinada a melhorias nos rincões eleitorais de cada deputado ou senador (que, de resto, assegura reeleições e gera tanta controvérsia, como é cediço) devem guardar congruência com o PPA e com a LDO.

Basicamente, portanto, tem-se que as leis orçamentárias são ordinárias, embora prolixa e inarredavelmente ligadas ao texto constitucional. São elas mais do que normas financeiras: são planos que direcionam as ações estatais, estabelecendo diretrizes ao agir do Estado. O orçamento não é impositivo - vale dizer, o Executivo não está totalmente vinculado ao seu cumprimento, mas as leis respectivas - ao definir o que se pretende alcançar e em que quantidade, quais os programas de duração continuada e o que será preciso para mantê-los - pautam responsavelmente as ações executivas. O PPA tem vigência de quatro anos, daí ser plurianual. "O plano plurianual define o planejamento das atividades governamentais" ${ }^{\prime 22}$. LDO e LOA devem obediência ao PPA sendo, portanto, a ele subservientes.

A Carta proíbe, ainda, com clareza lapidar, a assunção de despesas não previstas nas leis orçamentárias, ou a realização de programas ou projetos nelas não contemplados. Na verdade, o artigo 167 da Constituição elenca um rol de proibições que convergem para a proteção de uma única situação: a insolvência. O cuidado que se verifica, ali, é o impedimento de perda de dinheiro público ou custeio de situações inesperadas, ou, antes, não programadas e planejadas, caso da maioria das decisões judiciais ligadas a políticas públicas. Aqui alguém poderia indagar algo que está no inconsciente coletivo quando estão ligadas, na mesma frase, as expressões orçamento, políticas públicas e Judiciário: mas e os Créditos Suplementares? Eles não servem para cobrir situações inesperadas?

A resposta é não, ou, ao menos, não tão facilmente.

121 Sobre as Emendas ao Orçamento, ver explicação no sítio do Senado Federal, disponível em: <http://www12.senado.gov.br/noticias/entenda-o-assunto/emendas-ao-orcamento, acesso em 28.7.2013, 11:44h>. É nesse contexto que se apresenta a proposta de orçamento impositivo, que esteve em alta no ano de 2013.

122 OLIVEIRA, Regis, apud de BENETON, Marco Antonio Hatem. "O Plano Plurianual, os contratos administrativos e a Teoria do Diálogo das Fontes: os exemplos de elos entre o Direito Financeiro e o Direito Administrativo", em CONTI e SCAFF, Orçamentos..., p. 606. 
Os Créditos Suplementares de que se fala são espécie do gênero Créditos Adicionais, que são - novamente frise-se - as autorizações de despesa não computadas ou insuficientemente dotadas na Lei Orçamentária ${ }^{123}$. Trata-se de válvula de escape para o caso de carência de previsão de alguma rubrica orçamentária ou, mesmo, da dotação correspondente. Claro que esse mecanismo não poderia ser impunemente aplicável, e Créditos Adicionais, com efeito, não podem ser abertos a qualquer tempo e sob qualquer circunstância.

Antes de confirmar essa hipótese, contudo, é preciso conceituar as espécies desse gênero: os Créditos Suplementares são destinados ao reforço da dotação orçamentária - é o caso, portanto, de existência de uma rubrica, mas com recursos insuficientes; os Créditos Especiais se voltam a atender demandas para as quais não haja dotação orçamentária específica - vale dizer, a rubrica não existe ou não foi prevista na lei orçamentária; por fim, os Créditos Extraordinários são destinados a custear despesas urgentes e imprevistas, como guerra, comoção intestina ou calamidade pública ${ }^{124}$. Na sistemática da lei, como se enquadrariam dotações como aquelas que mandam entregar certo medicamento não contemplado no planejamento estatal? Elas poderiam ser entendidas como despesas urgentes e imprevistas e, assim, ser classificadas como Créditos Extraordinários, ou seria mais adequado entendê-las como Créditos Suplementares?

Para ser entendida como Crédito Extraordinário há de se haver urgência e imprevisibilidade na correspondente despesa. Mas em que medida? A lei dá a pista: em situações como guerras, calamidades públicas ou comoções intestinas. Circunstâncias que, efetivamente, ninguém tinha condições de prever com razoável antecedência, mas que, nada obstante, sucederam e demandam urgente remédio. As razões que dariam supedâneo a esse crédito, portanto, não poderiam derivar de escolhas na alocação dos recursos, mas, com efeito, de fatos que escaparam involuntariamente do controle público.

A saúde é uma rubrica orçamentária que deve ser prevista, por expresso mandamento constitucional $^{125}$. Dentro da dotação para a saúde, uma série de afetações nortearão a atividade de irrigação de recursos financeiros por parte da autoridade pública (i.e., tratamentos preventivos, construção de hospitais, entrega de fármacos, cirurgias e internações ${ }^{126}$. A Lei Complementar no 101/2012 - Lei de Responsabilidade Fiscal, que

\footnotetext{
${ }^{123}$ Art. 40 da Lei $n^{\circ} 4.320 / 64$.

${ }^{124}$ Artigo 41 e incisos I, II e III, respectivamente, da Lei ${ }^{\circ} 4.320 / 64$.

${ }^{125}$ Artigo 198, $\S \S 1^{\circ}, 2^{\circ}$ e $3^{\circ}$, regulamentado pela Emenda $n^{\circ}$ 29/2000 e Lei Complementar $n^{\circ} 141 / 2012$.

${ }^{126}$ São as funções e subfunções, tratadas mais adiante, ainda neste item. O artigo $3^{\circ}$ da Lei Complementar $n^{\circ} 141 / 2012$ estabelece doze diferentes paradigmas para consideração pela autoridade de planejamento das
} 
regulamentou o artigo 198 da Constituição, estabeleceu os percentuais de 12\% (doze por cento) para Estados e Distrito Federal, 15\% (quinze por cento) para Municípios e Distrito Federal (percentuais aplicáveis sobre a receita de impostos ali referidos) ${ }^{127}$ e, ao menos, o que fora empenhado no ano anterior, pela União, para aplicação diretamente nos serviços e ações de saúde. $\mathrm{O}$ arcabouço normativo relacionado à dotação orçamentária para a saúde é vasto. O Crédito Especial, então, não se aplica. Assim sendo, parece que uma despesa originalmente não considerada nessa rubrica pode ser entendida como tendo sido insuficientemente prevista em rubrica já existente, e essa insuficiência pode claramente ter sido fruto de escolhas. Parece mais razoável, assim, entender que a figura que mais se aproxima ao custeio de um produto ou serviço de saúde não contemplado no orçamento é a dos Créditos Suplementares.

Esses Créditos Suplementares, entretanto, não podem surgir indistintamente, e a lei confirma a hipótese já aqui lançada. Antes, eles devem ser autorizados por lei e abertos por decreto do Executivo ${ }^{128}$. Demandam, portanto, consenso e aderência manifestada pelos poderes majoritários. Ademais, eles só podem ser autorizados se houver recursos disponíveis ${ }^{129}$. Este ponto é fundamental, porque a lei taxa o que ela entende como recursos disponíveis, e só são eles aqueles oriundos de um superávit inesperado do Erário: ou situação de superávit financeiro, ou de excesso de arrecadação, ou resultantes de anulação de créditos especiais ou do produto de operações de crédito autorizadas ${ }^{130}$. Em suma, Créditos Suplementares, a rigor: (a) dependem de lei e decreto; e (b) só têm lugar quando há recursos financeiros disponíveis, sendo que esses recursos só são considerados como tal se o Estado, em dado exercício, é superavitário. Aqui, também, a regra não foge à rígida lógica do sistema orçamentário: não é, assim, simples ordenar a abertura desse tipo de despesa.

A Constituição e o plantel normativo aplicável são pródigos, destarte, em demonstrar que o orçamento não é mero instrumento contábil, mas peça fundamental dos programas desenhados pelo Poder Público a bem de seu inderrogável ônus de prestar à população uma série de serviços e bens. Daí se falar em orçamento-programa.

ações e políticas de saúde, dentre os quais se enquadram a vigilância epidemiológica e sanitária em saúde, a atenção integral e universal à saúde em todos os níveis de complexidade e o investimento na rede física do SUS.

${ }^{127}$ Daí se explicar porque o Distrito Federal possui dois percentuais diversos: $12 \%$ sobre os impostos típicos dos Estados e 15\% dos impostos típicos de Municípios, ele, Distrito Federal, que é um híbrido em termos de competência tributária (artigo 147, in fine da Constituição).

${ }^{128}$ Art. 42 da Lei ${ }^{\circ}$ 4.320/64.

${ }^{129}$ Art. 43 da Lei $n^{\circ} 4.320 / 64$.

${ }^{130}$ Art. $43, \S 1^{\circ}$, I a IV da Lei n ${ }^{\circ} 4.320 / 64$. 
Existe uma discussão teórica que não pode escapar a este, fundamental para compreender o conceito lançado. Ela toca ao debate que visa a inquirir se as leis orçamentárias são formais, não sendo passíveis de exigibilidade como direito subjetivo, nem vinculando os executores e gestores, ou materiais, com o que assumiriam uma notável relevância no jogo estatal. Essa discussão remonta às origens dos orçamentos públicos e tem como grande expoente os argumentos do positivista prussiano Paul Laband.

Laband via no orçamento não mais do que um amontoado de diretrizes econômico-financeiras que auxiliariam na organização de contas do Estado, amontoado esse que, de jurídico (e, assim, de cogente, imperativo) nada tinha. Para o positivista, o orçamento era lei meramente formal, ou seja, assumia formato de lei, embora não fosse eficaz ao ponto de poder ostentar materialmente tal qualidade. Orçamento, em seu sentir, não passava de um simples plano de gestão financeira ${ }^{131}$. Como, principalmente naquele tempo, o orçamento possuía um viés de consenso entre Poderes, Laband logicamente pensou tratar-se ele de um acordo, que, por isso mesmo, não tinha força de lei em sentido material $^{132}$. A posição de Laband, é bom que se diga, era contraposta igualmente por positivistas de nomeada, embora mais contemporâneos, como Kelsen e Hesse, o que também é totalmente lógico diante das ideias defendidas por ambos.

Estudando com afinco o orçamento e suas indissociáveis implicações tributárias, Francisco Campos esclarece que a ideia propugnada por Laband fazia sentido no contexto alemão do Século XIX, em que a Constituição era vista como um documento político, não jurídico - o que, de resto, já nesta tese paralelamente se tratou ${ }^{133}$. Já ele, Campos, tinha absoluta certeza de que o orçamento é lei material, vinculando o Executivo a segui-lo, sobretudo por sua disposição constitucional. Campos, nesse sentido, estava mais ligado à teoria de força normativa da Constituição, de Hesse - para quem, grosso modo, o fato de uma norma figurar no texto constitucional já a dotava de força jurídica compatível com normas constitucionais ${ }^{134}$ - do que aos fatores reais de poder de que tratava Lassale ${ }^{135}$.

\footnotetext{
${ }^{131}$ LABAND, Paul. Derecho Presupuestario. Tradução: José Zamit. Madrid: Instituto de Estudios Fiscales, 1979, p. 12. Teorizando a respeito do conteúdo e eficácia das leis, Laband apontou o artigo 99 da Constituição prussiana - que, justamente, mencionava a necessidade de fixação anual do orçamento do Estado por meio de lei - como clássico exemplo da exigência de uma lei meramente formal (p. 17).

${ }_{132}$ LABAND, Derecho..., p. 17.

${ }^{133}$ Itens 2.1.2. e 2.1.3. Não se pode, a esse respeito, deixar de referenciar a paradigmática obra já mencionada de Ferdinand LASSALE (A Essência...).

${ }^{134}$ HESSE, A Força Normativa ...

${ }^{135}$ CAMPOS, Francisco. "Orçamento - Natureza Jurídica", em Revista de Direito Administrativo no 71 janeiro/março de 1973, p. 324 e seguintes.
} 
Qual o interesse de discutir o cunho formal ou material da lei orçamentária? Ora, ele parece ser lógico: tratando-se de lei formal, é mais fácil modificar o orçamento, alterar rubricas, alocar verbas e desobedecer ao que ali consta; se, contudo, as contas públicas são objeto de lei material, tal tarefa será mais complicada. O que se discute, assim - e daí a relevância de se definir, a priori, a natureza jurídica das leis orçamentárias - é o seu grau de rigidez, podendo variar do mais tênue (lei formal) ao mais severo (lei material). A discussão, contudo, perde aspectos substanciais de seu sentido quando se considera que, no Brasil, o orçamento consiste verdadeiro planejamento de políticas públicas, de acordo com o determinado pela própria Constituição. Eis aí a proeminência do orçamento-programa.

A noção de orçamento-programa é a de que as leis orçamentárias consistem, a um só tempo, em autênticos veículos de expressão do que foi escolhido como prioridade pelos poderes políticos em termos de efetivação de direitos e guias-mestras para o planejamento de políticas públicas. As leis orçamentárias, assim, possuiriam notável força, não podendo ser objeto de alteração por simples atos da Administração. A expressão orçamento-programa foi consagrada pelo Decreto-lei $n^{0} 200 / 67$, que, em seu artigo 16, deixa clara a respectiva serventia como “(...) roteiro à execução coordenada do programa anual”.

A vinculação do orçamento ao desenho das políticas públicas foi estabelecida na Lei $\mathrm{n}^{\mathrm{o}}$ 4.320/64. Ali, bem em seu artigo $2^{\circ}$, parágrafo $1^{\circ}$, inciso $\mathrm{I}$, o legislador determinou que devessem acompanhar a Lei de Orçamento um sumário das receitas por fontes e das despesas por funções do Governo. Em 1999, a Portaria ${ }^{\circ} 42$, do Ministério do Orçamento e Gestão, definiu o conceito de Função, atrelando-o às despesas que competem ao Poder Público. Dentre as funções está boa parte das ações sociais a cargo do governo - ou seja, as políticas públicas - dentre as quais se destacam desde as funções de Defesa Nacional, Judicial e Essencial à Justiça até Saúde, Trabalho e Educação ${ }^{136}$. Essa Portaria define mais, evidencia o que entende por programa, configurando-o como instrumento de organização da ação governamental visando à concretização dos objetivos pretendidos, sendo mensurados por indicadores estabelecidos no plano plurianual ${ }^{137}$. Eis aí, novamente, a inexorável conexão entre programas e leis orçamentárias como o Plano

\footnotetext{
${ }^{136}$ Cf. art. $1^{\circ}$, par. $1^{\circ}$ da Portaria n ${ }^{\circ} 42 / 99$ e seu Anexo. Neste Anexo, a função Saúde abriga seis subfunções, que revelam claramente as áreas de atuação estratégica do Estado para a efetivação desse direito. São elas atenção básica, assistência hospitalar e ambulatorial, suporte profilático e terapêutico, vigilância sanitária, vigilância epidemiológica e alimentação e nutrição. São esses os seis pilares eleitos pelo próprio Estado como integrantes do núcleo constitucional de tutela à saúde.

${ }^{137}$ Art. $2^{\circ}$, alínea $a$ da Portaria n ${ }^{\circ} 42 / 99$.
} 
Plurianual, que já se tira tanto da Constituição - quando da definição do conteúdo do Plano Plurianual e do mandamento de que planos e programas o seguirão ${ }^{138}$ - quanto da Lei ${ }^{\circ} 4.320 / 64$.

A despeito desses argumentos, há, ainda, teóricos do Direito Financeiro que defendem a ideia da completa desvinculação orçamentária ${ }^{139}$. Nada obstante e com o devido respeito, não é o que parece à luz da própria leitura da Constituição. Fossem as leis orçamentárias meros acordos, sem força legal e não vinculantes, não seria crime de responsabilidade do Chefe do Executivo atentar contra elas ${ }^{140}$; também não se necessitaria de proteção tão gravosa às contas públicas quanto os já mencionados e nefastos precatórios $^{141}$; que dizer, então, da expressa determinação para que planos e programas sigam as regras fixadas no PPA, que congrega as diretrizes, metas e objetivos da Administração Pública federal quanto aos programas de duração continuada ${ }^{142}$ ? Por fim, como sustentar tal tese contra a determinação contida no artigo 167, I do Texto Fundamental, que veda o início de programas ou projetos não incluídos na LOA? Se, enfim, o orçamento fosse um mero balancete, como justificar os mandatórios preceitos de aplicação mínima de percentuais em saúde e educação ${ }^{143}$ ? O orçamento-programa, portanto, é realidade no Brasil, e as leis orçamentárias são peça essencial para a definição de políticas públicas em seu aspecto mais sensível: a disponibilidade e a afetação de $\operatorname{recursos}^{144}$.

\footnotetext{
138 " $\$ 1^{\circ}$ - A lei que instituir o plano plurianual estabelecerá, de forma regionalizada, as diretrizes, objetivos e metas da Administração Pública federal para as despesas de capital e outras delas decorrentes e para as relativas aos programas de duração continuada." $\mathrm{O} \$ 4^{\circ}$ desse mesmo artigo 165 da Constituição determina que os planos e programas governamentais guardarão consonância com o Plano Plurianual.

${ }^{139} \mathrm{Na}$ linha de LABAND e defendendo a ideia de orçamento como plano geral de contas, mesmo dentro do contexto constitucional, v. Ricardo Lobo TORRES (Tratado de Direito Constitucional, Financeiro e Tributário. $2^{\mathrm{a}}$ ed. Rio de Janeiro: Renovar, 2000, vol. 5, p. 76) e Kiyoshi HARADA (Direito Financeiro e Tributário, $15^{\mathrm{a}}$ ed. São Paulo: Atlas, 2006, p. 86).

${ }^{140}$ Art. 85, VI da Constituição.

${ }^{141}$ Art. 100 da Constituição.

${ }^{142}$ Art. 165 da Constituição.

${ }^{143}$ Arts. 198, §2 $2^{\circ}$ e 212 da Constituição, respectivamente.

${ }^{144}$ A esta mesma conclusão chegam, apenas para citar alguns, FARIA, Rodrigo Oliveira de. Natureza Jurídica do Orçamento e Flexibilidade Orçamentária. Dissertação de Mestrado apresentada na Faculdade de Direito da Universidade de São Paulo em 2009, para quem o orçamento hodierno assume o que ele denomina instrumentalização administrativa, pela qual se incorporam na respectiva feitura, execução e avaliação critérios de eficiência, eficácia e efetividade, permitindo sua execução de acordo com critérios objetivos fixados nos planos e programas governamentais; ALMEIDA, Carlos Otávio Ferreira "O planejamento financeiro responsável: boa governança e desenvolvimento no Estado contemporâneo" (em CONTI e SCAFF, Orçamentos, pp. 578-599), para quem os orçamentos contribuem decisivamente para a implementação de direitos humanos, eis o porquê ter o administrador que prestar contas sobre como aplica os dinheiros públicos, responsabilizando-se condignamente a respeito (accountability - pp. 593-596); e FILHO, Sérgio Assoni. "Controle de Constitucionalidade da Lei Orçamentária" (CONTI e SCAFF, Orçamentos, pp. 21-40).
} 
Assumindo, pois, caráter de verdadeiro norte para a programação oficial da implementação de políticas públicas, chega-se a uma delicada conclusão quando da análise de interferências externas nas leis orçamentárias: elas, via de regra, não devem acontecer, e não devem por alguns motivos interessantes: (a) é do Poder Executivo a privativa atribuição do envio, ao Congresso Nacional, dos projetos de lei de PPA, de LDO e de LOA, e é do Congresso a competência, por ambas as Casas, para dispor sobre assuntos orçamentários $^{145}$ - daí se falar que qualquer ingerência que não parta desses atores seja tida por externa. Judiciário e Ministério Público podem dispor de seus próprios orçamentos, mas devem enviá-los para análise por parte do Executivo, que verificará o cabimento das disposições $^{146}$; (b) não serão tolerados gastos ou aumento de despesas em desacordo com as leis orçamentárias, o que demonstra o inequívoco caráter vinculativo do orçamento ${ }^{147}$; (c) a Carta blinda e restringe qualquer movimento abrupto quanto aos orçamentos, instituindo, inclusive, sistemas de controle interno e externo ${ }^{148}$ e vedando expressamente a eficácia automática e plena de condenações judiciais cujo cumprimento esteja amarrado ao Erário $^{149}$; e (d) planos e programas públicos são conjuntos de ações planejadas e coordenadamente executadas para que o Estado cumpra suas funções e metas, encontrando no Erário tutelado por leis orçamentárias o lastro financeiro necessário para executá-las ${ }^{150}$.

É importante explorar o conceito que nem mesmo os Poderes majoritários podem definir o orçamento sem maior responsabilidade. Muito ao contrário. Legisladores e Administradores não podem tomar qualquer decisão que implique desequilíbrio das contas públicas, sob pena, inclusive, de responsabilização criminal. A cada gasto será preciso estudar e demonstrar seu provável impacto financeiro, de acordo com a Lei de Responsabilidade Fiscal. A falta de observância dos ditames legais pode levar o agente público a responder por crime fiscal, nos termos da Lei $n^{\circ} 10.028 / 2000^{151}$. Na Câmara dos

\footnotetext{
${ }^{145}$ Arts. 84, XXIII e 48, II; 166 da Constituição, respectivamente.

${ }^{146}$ Art. 99, $\S \S$ da Constituição, em especial, $\S 4^{\circ}$, que permite que o Executivo modifique as reivindicações do Judiciário constantes em sua proposta orçamentária se ela estiver em desacordo com a LDO, ajustando-as. Quanto ao Ministério Público, ver disposições análogas no art. 127, $\S 3^{\circ}$ a $5^{\circ}$ da Carta.

${ }_{147}$ Art. 167 da Constituição.

148 Art. 71, que prevê o Tribunal de Contas da União para controle externo; art. 74, I, que dispõe sobre o controle interno dos Poderes da República quanto à avaliação de metas e cumprimentos de programas, inclusive presentes no PPA.

${ }^{149}$ Art. 100 da Constituição.

150 BARCELLOS, Ana Paula de. "Constitucionalização das políticas públicas em matéria de direitos fundamentais: o controle político-social e o controle jurídico no espaço democrático", em SARLET, Ingo Wolfgang, e TIMM, Luciano Benetti (coord.). Direitos fundamentais, orçamento e "reserva do possível". Porto Alegre: Livraria do Advogado, 2008, pp. 111-147.

151 SANTA HELENA, Eber Zoehler. Critérios e Procedimentos para Preservação da Objetividade no Exame de Compatibilidade e Adequação Orçamentária e Financeira de Proposições Legislativas. Brasília: Câmara dos Deputados, 2009, p. 3
} 
Deputados, a Comissão de Finanças e Tributação é regimentalmente responsável por dar parecer sobre propostas que importem aumento de despesa ou diminuição de receitas públicas, opinando quanto à respectiva adequação ao PPA, à LDA e à LOA ${ }^{152}$.

Basicamente, a concretização de políticas públicas deve considerar que os recursos para tanto são limitados. Por isso, elas devem ser planejadas e programadas, a fim de racionalizar sua implementação, de forma a torná-las tanto eficazes quanto possível. É preciso, destarte, controlar e ter as rédeas dos dinheiros públicos, o que se dá por meio da estrutura normativa que cerca as questões orçamentárias, além de fixar metas, definindo os meios para atingir os comandos normativos em termos de políticas públicas. Atrelar o Erário ao cumprimento de metas e realizar um básico, porém fundamental exercício de planejamento a longo, médio e curto prazo - correspondente, respectivamente, ao PPA e às LDO e LOA - é fundamental para a racionalização de recursos. Daí que, a priori, qualquer ingerência inesperada no orçamento pode desajustar, deveras, as políticas planejadas e programadas.

2.3.3. Qual a base jurídica do orçamento da saúde?

O tronco das receitas da saúde no Brasil são os dinheiros da seguridade social. Existem outras importantes fontes, como, por exemplo, percentuais das receitas de impostos da União, Distrito Federal, Estados e Municípios, tudo conforme definido no artigo 198 da Constituição. Há, destarte, participação de todos os entes federados para a formação do total de receitas que financiam a saúde, tudo por força da edição da Emenda Constitucional no $29 / 2000$.

Do orçamento da seguridade, a fatia destinada à saúde será proposta pela direção nacional do SUS, participando a previdência e a assistência social, de acordo com as metas definidas na LDO $^{153}$. Outras fontes podem surgir da destinação de doações e donativos, contribuições, alienações patrimoniais e rendimentos de capital, taxas, multas, emolumentos e preços públicos arrecadados no âmbito do SUS. Ações de saneamento básico, que não integram medidas a serem financiadas pelos recursos destinados à saúde,

${ }_{153}^{152}$ Art. 32, X, $h$ do Regimento Interno da Câmara dos Deputados.

${ }^{153}$ Art. 31 da Lei ${ }^{\circ} 8.080 / 90$. 
serão executadas usando recursos tarifários dos entes federados e, em particular, do Sistema Financeiro da Habitação ${ }^{154}$.

Todos os entes federados devem constituir fundos de saúde, cuja falta, no caso dos Municípios, inibirá o repasse de verbas federais e estaduais ${ }^{155}$. Tais repasses, por sinal, são objeto de auditoria promovida pelo Ministério da Saúde a bem de checar se os recursos transmitidos estão sendo aplicados de acordo com os planos e programas desenvolvidos - não se pode perder de vista que o sistema é descentralizado, mas único.

Importante fonte de receita da saúde são aquelas oriundas do destacamento obrigatório da arrecadação tributária. A Emenda Constitucional no 29 de 2000 definiu o dever de aplicação de percentuais mínimos por parte dos entes federados na saúde. Faltava a fixação do percentual aplicável sobre a fonte de receita (esta, sim, contemplada na Emenda), o que aconteceu com a promulgação da Lei Complementar no 141/2012. É ela que define os percentuais mínimos que os entes federados devem aplicar à saúde. A regulamentação da Emenda $n^{\circ} 29$ gerou severas críticas porque a União conseguiu se desonerar de um percentual fixo para afetação de sua receita à pasta da saúde, que era, concorde com o projeto aprovado pelo Senado, de $10 \%$.

Em 2012, a União conseguiu prorrogar a DRU - Desvinculação de Receitas da União, mecanismo que permite ampliar a massa de manobra das receitas federais, permitindo que o Estado afete $20 \%$ ao que julgar mais conveniente, ainda que em desacordo com os percentuais mínimos que deveriam ser aplicados em rubricas como educação, transportes e... saúde. A DRU não seria tão problemática se a lei que regulamentasse a Emenda Constitucional $\mathrm{n}^{\circ} 29$, de 2000, estabelecesse percentual adequado para aplicação, pela União, de receitas na saúde. Não foi isso que aconteceu.

Para a saúde, a LOA de 2013 previu a aplicação de noventa e nove bilhões e duzentos milhões de reais, crescimento de $8,1 \%$ com relação ao orçamento do ano anterior. Para correlacionar, a educação contou com previsão orçamentária de oitenta e um bilhões e duzentos milhões de reais, incremento de $9,4 \%$ quanto a 2012 . O orçamento total previsto foi de dois trilhões e duzentos e setenta e seis bilhões, é dizer, a saúde, em 2013, participou com cerca de $4,3 \%$ do total de receitas estatais do exercício ${ }^{156}$.

\footnotetext{
${ }^{154}$ Art. 32 da Lei $n^{\circ} 8.080 / 90$.

155 Art. $4^{\circ}$ da Lei ${ }^{\circ} 8.142 / 90$.

156 "Saiba como variou o orçamento dos ministérios entre 2012 e 2013", disponível em: http://g1.globo.com/politica/noticia/2013/04/saiba-como-variou-o-orcamento-dos-ministerios-entre-2012-e2013.html, acesso em 9.1.14, 9:00h.
} 
Grosso modo, eis o retrato do desenho orçamentário aplicado diretamente às políticas de saúde no Brasil.

2.3.4. Ponderações introdutórias sobre a ingerência judicial nas contas públicas

No contexto desta tese, decisões judiciais que obrigam o Estado a efetivar direitos, por mais que tenham nobre propósito e estejam de acordo - ao menos, nominalmente - com normas constitucionais, obrigam o Poder Público a gastar em rubricas que não foram planejadas, permitindo a realocação forçada de recursos financeiros, tirando-se de certa despesa para cobrir os efeitos advindos da criação de outra. Isso pode causar importante desarranjo nas contas públicas ${ }^{157}$. A rigor, a Constituição - já se viu - proíbe o aumento de despesa em desacordo com o PPA. Como harmonizar essa vedação com, por exemplo, a liminar que manda custear imprevisto tratamento clínico de milhares de reais por mês?

Para comprovar que as decisões judiciais que não consideram o orçamento impactam sensivelmente no Erário é preciso que alguns dados sejam analisados. Esses dados são, fundamentalmente, ligados à saúde, não somente por conta do escopo desta tese, mas também porque essa é a mais aviltante prestação quando se trata do impacto orçamentário de decisões judiciais.

A preocupação com a ingerência judicial no orçamento público é tamanha que o Estado de São Paulo, por sua Secretaria de Saúde, criou um sistema de cadastramento eletrônico das ações que pleiteiam medidas custeadas pela fatia de dinheiros públicos cabível no orçamento, justificado pelo “(...) volume crescente de demandas [que] vem gerando problemas para o sistema de saúde como um todo, pois, além de

\footnotetext{
${ }^{157}$ Para se ter uma noção da complexidade que envolve o estudo do impacto orçamentário de decisões judiciais, indica-se consultar BITTENCOURT, Fernando Moutinho Ramalho e da GRAÇA, Luis Otávio Barroso. "Decisões judiciais e orçamento público no Brasil: uma aproximação empírica a uma relação emergente", em Direitos Fundamentais, orçamento e "reserva do possível”..., pp. 217-263. Os autores traçam um perfil sobre o impacto financeiro direto que as decisões judiciais causam no orçamento público brasileiro e no endividamento do Estado. Alguns dos dados ali coletados revelam, por exemplo, que os custos estatais diretamente imputáveis à litigância judicial são responsáveis por rubricas ainda superiores que aquelas destinadas aos Ministérios do Transporte e do Meio Ambiente. É claro que esse percentual não considera apenas decisões judiciais que orbitam em torno das políticas públicas, mas certamente o impacto dessas decisões deve constituir boa parte dos dados coletados.
} 
comprometer o orçamento para a saúde, a interferência do Judiciário afeta as políticas

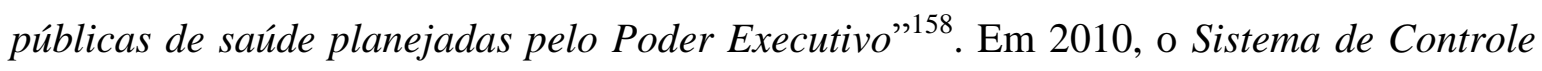
Jurídico registrou uma despesa anual oriunda de processos judiciais de quinhentos e doze milhões, quinhentos e cinquenta mil, setecentos e dezessete reais e setenta e dois centavos, maior do que tudo o que o Estado gastou no ano para tratamentos ambulatoriais em oncologia (trezentos e sessenta e dois milhões, novecentos e trinta e nove mil, cento e três reais e noventa e nove centavos) e nefrologia (trezentos e sessenta e seis milhões, quatro mil, cento e vinte e cinco reais e doze centavos), internações para transplantes de órgãos, tecidos e células (cento e treze milhões, cento e quarenta e um mil, trinta e oito reais e oitenta e seis centavos) e equivalente, grosso modo, aos diagnósticos laboratoriais custeados pelo Poder Público em 2010 (quinhentos e setenta e três milhões, duzentos e noventa e dois mil, trezentos e noventa e seis reais e noventa e dois centavos) ${ }^{159}$.

Ainda no âmbito do Estado de São Paulo, a sensibilidade da intervenção judicial no orçamento é tamanha que motivou uma inédita reunião entre o Governador do Estado e o Presidente da Corte local para debater a respeito. O pano de fundo são as ações judiciais determinando a concessão do medicamento Eculizumab, nome comercial Sorilis, que custam ao Erário oitocentos mil reais por ano para cada paciente ${ }^{160}$. Cálculos da Secretaria de Saúde dão conta que os valores relacionados ao cumprimento de decisões judiciais apenas ligadas a medicamentos seriam suficientes para o Executivo construir um hospital por mês ${ }^{161}$.

Em Minas Gerais, o orçamento conta com uma rubrica específica destinada às sentenças judiciais - trata-se das atividades 7018, em 2009, e 7024, em 2010. Analisando 2009, vê-se que os gastos com o cumprimento de mandamentos judiciais na seara da saúde (trinta e quatro milhões, quatrocentos e cinquenta e quatro mil, novecentos e noventa e cinco reais e cinquenta e um centavos), correspondentes a $0,87 \%$ de toda a despesa da pasta, superaram as despesas com desenvolvimento, produção e entrega de imunobiológicos (trinta e três milhões e cento e noventa e oito mil reais) e com implantação e manutenção da [o programa] Farmácia de Minas (dezenove milhões e

\footnotetext{
${ }^{158}$ CHIEFFI, Ana Luiza; CORREA, Maria Cecília M. M. A.; e FILHO, Michel Naffah. "S-Codes: um novo sistema de informação sobre ações judiciais da Secretaria de Estado da Saúde de São Paulo." Boletim BEPA 7(84) - 2010, p. 18.

${ }^{159}$ CHIEFFI, CORREA, FILHO, “S-Codes... ”, pp. 26-27.

${ }^{160} \mathrm{~V}$. nota 21.

161 <http://geraldoalckminpsdb.blogspot.com.br/2012/06/geraldo-alckmin-vai-justica-contra.html>, acesso em 13.6.2012, 20:04h.
} 
trezentos e quarenta e nove mil reais); em 2010, esse gasto aumentou 78,64\%, perfazendo o total de $1,35 \%$ de toda a despesa com saúde ${ }^{162}$

É claro que diante da escassez de recursos e do rigor orçamentário as receitas previstas para aplicação em políticas públicas deverá ser movimentada. Castro faz conjeturas que, embora não peremptoriamente comprovadas, são perigosamente indiciárias dos efeitos nocivos das decisões judiciais: ele aponta que, para pelo menos cinco programas elaborados pela Secretaria de Saúde de Minas Gerais, experimentou-se sensível diminuição nos recursos aplicados de 2009 para 2010, em que pese ter o orçamento geral da saúde sido incrementado em 10,82\%. A hipótese levantada pelo autor se torna ainda mais plausível quando ele assevera que um único medicamento (Infliximab) foi responsável por consumir $6,86 \%$ de todos os recursos usados para cumprir decisões judiciais ligadas à pasta em Minas Gerais no ano de $2010^{163}$.

As realocações forçadas são a prova do mais nefasto efeito da decisão judicial que Scaff denomina como aditiva ${ }^{164}$ : diante de despesa inesperada, o Executivo é compelido a deslocar verbas originalmente destinadas para cobrir outros gastos, ligados a prestações diversas, porém igualmente debitáveis ao Estado. Assim, as pessoas que se valeriam de prestações já contempladas nos programas vinculados aos orçamentos serão prejudicadas em detrimento àquele que conseguiu ultrapassar os obstáculos que represam uma maior demanda populacional pelos serviços judiciais ${ }^{165}$.

Outra questão que deve ser ponderada é que as decisões judiciais que impõem ônus não previstos ao orçamento contrariam a própria natureza dos dinheiros públicos e da forma como deles dispor, que é a da universalidade. O orçamento contempla, da maneira mais genérica possível, grupos de pessoas; decisões judiciais, sobretudo as individualizadas, privilegiam apenas alguns, precisamente aqueles que ultrapassaram as barreiras que se colocam entre cidadãos e juízes. Esta questão fulcral será mais bem debatida ulteriormente.

\footnotetext{
${ }^{162}$ CASTRO, Sebastião Helvecio Ramos. "Impacto desalocativo no orçamento público estadual em face de Decisões Judiciais". IV Prêmio SOF de Monografias. Belo Horizonte: 2010, pp. 40-43.

${ }^{163}$ CASTRO, "Impacto...", pp. 44-46.

164 SCAFF, Fernando Facury. "Sentenças aditivas, direitos sociais e reserva do possível", em SARLET e TIMM (coord.), Direitos Fundamentais..., pp. 149-172. Ele define como aditiva a decisão “(...) que implica em aumento de custos para o Erário, obrigando-o ao reconhecimento de um direito social não previsto originalmente no orçamento do poder público demandado” (p. 149).

165 Refere-se, aqui, ao fato de que é uma pequena parcela da população que tem conhecimento, disposição e recursos suficientes para pleitear judicialmente direitos contra o Estado, o que causa uma clara distorção entre o que é planejado pelo Estado e quem é efetivamente beneficiado.
} 
A coisa é ainda mais delicada se for considerado que, ao decidir pela entrega de medicamento ou pela inclusão forçada de menor em escola pública de ensino fundamental, ou, ainda, pela concessão de transporte para determinados beneficiários, o juiz decide em bases puramente jurídicas - o que não é tão grave - e lineares - este, sim, o aspecto gravíssimo. O raciocínio meramente jurídico impede o juiz de analisar os impactos econômicos e financeiros de sua decisão, que devem ser irremediavelmente levados em consideração quando se decide qualquer questão que possa impactar em políticas públicas, ainda que os pedidos sejam individuais; o pensamento linear, pior, autoriza o juiz a decidir na seguinte base: jurisdicionado tem direito à vaga em estabelecimento educacional de ensino fundamental, como previsto na Constituição; seu filho, contudo, não está inscrito culpa da Administração, que deveria ter seguido a norma constitucional; como magistrado, devo assegurar direitos, portanto, condenarei o Poder Público a aceitar compulsoriamente o filho do jurisdicionado em suas escolas fundamentais. Ambos os pensamentos - jurídico e linear - retroalimentam-se, porque um é indissociavelmente ligado ao outro ${ }^{166}$.

Agindo assim, sem qualquer conhecimento multidisciplinar e ponderada análise dos impactos de sua decisão, sobretudo em casos individuais, o juiz malfere as políticas públicas. Por isso, o orçamento e as disposições a respeito do Erário - temas relacionados desde a sua disciplina legal quanto à sua elaboração e execução, devem ser de conhecimento obrigatório dos juízes. Ademais, toda a decisão judicial deve considerar de onde saíra verba para seu cumprimento e quem serão os prejudicados.

Parte do problema está posto, portanto: efetivar direitos oponíveis contra o Estado requer ingerência no Erário, que recebe uma rigorosa disciplina constitucional e legal e é peça fundamental no equilíbrio de poderes. Falou-se, aqui, do orçamentoprograma. Mas, para além da questão financeira, quem é que, no desenho institucional de distribuição dos poderes da República, tem a prioridade em estabelecer políticas públicas? Qual é, exatamente, a função de cada Poder nessa seara?

${ }^{166}$ Sobre o que este autor denominou argumento linear, vide Item 4.1.3. 


\subsection{AS FUNÇÕES POLÍTICAS ESTATAIS NA DOTAÇÃO DOS SERVIÇOS E PRODUTOS PÚBLICOS OU QUEM TEM A RESPONSABILIDADE EM DEFINIR $A$ PRIORI POLÍTICAS PÚBLICAS?}

Há razoável consenso no sentido de serem os Poderes majoritários aqueles a quem toca a original incumbência da definição e da execução de políticas públicas. De fato, política é uma atribuição precípua do Legislativo e do Executivo. Ademais, se as políticas públicas são o conjunto de ações coordenadas de que se vale o Estado para cumprir seus objetivos constitucionais e institucionais, será preciso programar, planejar e executar tais ações, gerenciando sua efetivação. A análise das funções de cada Poder leva a entender, basicamente, que a definição preliminar de políticas públicas cabe ao Legislativo, enquanto que a definição secundária, a execução e o gerenciamento são de égide executiva.

\subsubsection{Competência legislativa}

A análise das funções peculiares dos Poderes guarda ao Legislativo o importante papel de definição a priori das políticas públicas. No sistema representativo brasileiro, legisladores são aqueles a quem incumbe baixar leis imperativas, de observância geral e abstrata, capazes de obrigar tanto o particular quanto o administrador e, porque não dizer, o próprio legislador. Vive-se, aqui, um Estado de Direito, em que a primazia na definição de condutas e regulação social é das normas constitucionais e legais, produtos típicos do Legislativo.

Nas etapas das políticas públicas, o Legislativo entraria primordialmente como canalizador da percepção dos problemas, já que representante dos anseios da população (função da qual também não escapa o Executivo, deixe-se claro), e da construção da agenda, estabelecendo o problema e dando-lhe o primeiro tratamento ${ }^{167}$, vale dizer, determinando os objetivos a se alcançar para uma solução adequada.

\footnotetext{
${ }^{167}$ Ver Item 2.4.1.
} 
Ora, as finalidades constitucionais e institucionais do Estado estão definidos no ordenamento jurídico, em que a Constituição e as leis possuem papel de destaque. Se de novo - políticas públicas constituem o conjunto de ações voltadas a cumprir esses objetivos, então não se pode extirpar do Legislativo a primazia em definir quais são elas e em que consistem, já que é esse mesmo Legislativo quem vai definir, em última análise, tanto os objetivos constitucionais quanto os institucionais.

É certo que a Constituição de 1988, em sua redação original, está repleta de comandos que determinam a realização de ações dessa natureza. É igualmente certo que, a despeito daqueles homens reunidos em Assembleia Nacional Constituinte representarem o Poder Constituinte - que, sob a perspectiva positivista que norteou aqueles trabalhos, era inicial, soberano, incondicional, instantâneo, latente, inalienável e especial ${ }^{168}-\mathrm{e}$, por isso mesmo, anterior ao próprio Poder Legislativo - previsto, a propósito, no segundo artigo da Carta -, não se pode extrair daqueles senhores a clara qualidade de legisladores.

Assumindo-se, pois, que a Constituição, em sua redação original, foi realizada por legisladores, e que o texto constitucional estabelece o fundamento das mais variadas políticas públicas, várias a demandar tutela jurisdicional para sua correta observância, então não se há afastar a competência do legislador como primeiro arranjador de políticas públicas.

Com efeito, foi o legislador constituinte originário quem definiu que o Estado garantiria a prestação de educação em estabelecimentos de ensino gratuitos ${ }^{169}$. Também estabeleceu a gratuidade do transporte público aos maiores de sessenta e cinco $\operatorname{anos}^{170}$, bem como a garantia de recebimento de um salário mínimo ao portador de

${ }^{168}$ BULOS, Uadi Lammêgo. Direito Constitucional ao alcance de todos. São Paulo: Saraiva, 2009, pp. 5152. As características do Poder Constituinte de inovação (ele antecede e origina a ordem jurídica do Estado), soberania (é ele independente de qualquer prescrição jurídico-positiva para lhe dar base) e incondicionalidade (não está ele condicionado a qualquer formalidade ou paradigma) revelam um potencial paradoxo: já que ostenta todas essas qualidades, os constituintes se encaixariam em qual classificação? A de constituintes originários? Parece razoável esse entendimento. Mas, na essência, esses constituintes originários, por ostentarem objetivo de criar normas jurídicas fundamentais no ordenamento, em processo que em tudo se assemelha ao legislativo, não podem deixar de ser reputados como legisladores. No caso brasileiro, aliás, a Emenda à Constituição no 26/85 estabeleceu que seriam os congressistas eleitos em 1986 mais vinte e três senadores eleitos em 1982 - aqueles que comporiam a Assembleia Nacional Constituinte. Mais a respeito pode ser visto em OLIVEIRA, Mauro Márcio. Fontes de Informações sobre a Assembléia Nacional Constituinte de 1987. Quais são, onde buscá-las e como usá-las. Brasília: Senado Federal, 1993, pp. 9-12.

Nada obstante, deve este autor fazer menção ao contraponto teórico absolutamente razoável de que mesmo o Poder Constituinte Originário não é, de todo, ilimitado, notadamente no aspecto material: na verdade, pelo menos, ele encontra balizas na ordem jurídica internacional, no que toca aos padrões mínimos de observância de direitos humanos. Nesse sentido, ver STF, ADIN nº 829/DF, Rel. Min. Carlos VELLOSO, j. em 14.4.1993).

${ }^{169}$ Art. 206, IV, Constituição.

${ }^{170}$ Art. 230, §2 , Constituição. 
deficiência ou ao idoso que não consiga meios de prover sua própria subsistência ou contar com o suporte familiar ${ }^{171}$. Decidiu, de igual forma, assegurar acesso universal e igualitário às ações e serviços de saúde ${ }^{172}$ - ponto nodal deste estudo. Foram aqueles senhores, reunidos por cerca de um ano para discutir e consolidar o texto constitucional, os preliminares definidores de políticas públicas constitucionais.

Em termos, aliás, de políticas de saúde, as principais diretrizes foram, mesmo, aquelas promovidas pelo texto constitucional original. O constituinte resolveu proteger a saúde de maneira a evitar que os sabores do jogo governamental alterassem sobremaneira o quadro de tutela desse direito tão relevante, dotando de normatividade constitucional - e, daí, cunhando-o da respectiva rigidez - uma série de dispositivos. São da redação primitiva da Constituição, por exemplo, os comandos de que a saúde: (a) é direito de todos e dever do Estado, ou seja, é o Poder Público quem deve assegurar a fruição, por todos, dos serviços e ações de saúde; (b) será garantida por políticas sociais e econômicas, vale dizer, a prestação de serviços de saúde dependerá de políticas nas áreas social e econômica; (c) que visem à redução do risco de doença e de outros agravos, é dizer, as políticas sociais e econômicas devem ter foco preventivo, almejando reduzir o risco de doenças e seus danos; (d) permitam essas políticas o acesso universal e igualitário às ações e serviços para sua promoção, proteção e recuperação, ou seja, todos têm direito, em igualdade de condições e independente de sua condição econômica, social ou qualquer outra especificidade, às ações e serviços que promovam, previnam ou curem moléstias, tudo a ser fornecido pelo Estado; (e) é de relevância pública; (f) será objeto de uma estrutura única, embora regionalizada e hierarquizada; e (g) será executada por sistema único de saúde ${ }^{173}$.

Mas não apenas o Constituinte Originário estabelece políticas públicas. Há um trabalho produzido no âmbito da Câmara dos Deputados que revela bem a ação do Legislativo na definição de políticas públicas, no caso, de educação, oriundas de normas constitucionais derivadas ou normas legais. De 1995-2007, o estudo aponta que foram mil, quatrocentos e setenta e nove projetos de lei versando sobre o assunto, classificados em financiamento, organização, currículo, criação de escolas, programas suplementares e o residual outros temas. No mesmo período, foram noventa e uma propostas de Emenda à

\footnotetext{
${ }^{171}$ Art. 203, V, Constituição.

172 Art. 196, Constituição.

${ }^{173}$ Arts. 196, 197, 198 e 200 da Constituição. O Item 4.1.1. revelará o arcabouço jurídico da saúde no Brasil, mostrando o tratamento legal e regulamentar que esse direito possui.
} 
Constituição ${ }^{174}$. Tamanho volume de proposições legiferantes apenas no que pertine à educação bem demonstra como é atuante o legislador quando da definição de políticas públicas.

Também não se há olvidar do preponderante papel do Legislativo em seu agir sobre o desenho orçamentário. Se as políticas públicas representam, quanto aos direitos sociais, prestações, ações positivas que demandam custos, a fatia do Erário destinada a fazer frente a cada qual desses custos é relevante - tanto quanto quem as define em última análise, vale dizer, o Legislativo ${ }^{175}$. É nesse sentido que, cabendo a esse Poder exercer tanto a dotação quanto a fiscalização contábil e financeira do Erário, é o Legislativo quem, no fim das contas, viabiliza financeiramente a realização de uma ou outra política pública. Daí se justificar a ideia de orçamento-programa, já tratada, pela qual o próprio arranjo orçamentário revelaria, na raiz, plano de implementação de políticas públicas.

Sucede que nada obstante tais comandos normativos, pode se entender que eles se tratam de diretrizes - principalmente aquelas emanadas da Constituição -, normas que balizarão a feitura de tantas outras ações que, ao fim e ao cabo, entregarão o bem da vida ao cidadão. Se fosse traçado vetor vertical imaginário, na direção de cima para baixo, o ordenamento jurídico (hierarquicamente encabeçado pela $\mathrm{CF}$ ) seria o ponto de partida, e a chegada do vetor, a entrega do bem - no caso, do medicamento, da terapia, do tratamento. No percorrer do vetor imaginário é necessária uma série de outras ações que desencadeiem o resultado buscado, ações essas que também revelam políticas públicas leis, normas, planejamento, execução, entrega, avaliação. O Diagrama I representa a ideia ora exposta.

É dizer, assim, que a CF dá o norte, o restante do ordenamento depura essas diretrizes, mas o efeito final e concreto da norma constitucional depende de muitos outros fatores, todos a serem pautados, precisamente, pelas normas constitucionais aplicáveis.

De fato, o esboço institucional do Estado brasileiro outorga ao Legislativo a primazia na definição de políticas públicas. Há, contudo, outro Poder que se revela tão ou ainda mais - importante que o Legislativo: é aquele responsável por, em algum grau, normatizar, e, plenamente, concretizar, efetivar ou implementar os objetos das mais variadas políticas públicas.

\footnotetext{
${ }^{174}$ MARTINS, Ricardo Chaves de Rezende. O Poder Legislativo e as Políticas Públicas Educacionais no Período 1995-2010. Brasília: Câmara dos Deputados, 2012, pp. 46-47 e 52.

${ }^{175} \mathrm{~V}$. Item 2.4.1.
} 


\section{DIAGRAMA I}

Dinâmica do planejamento-execução de políticas públicas

\section{Constituição Federal}

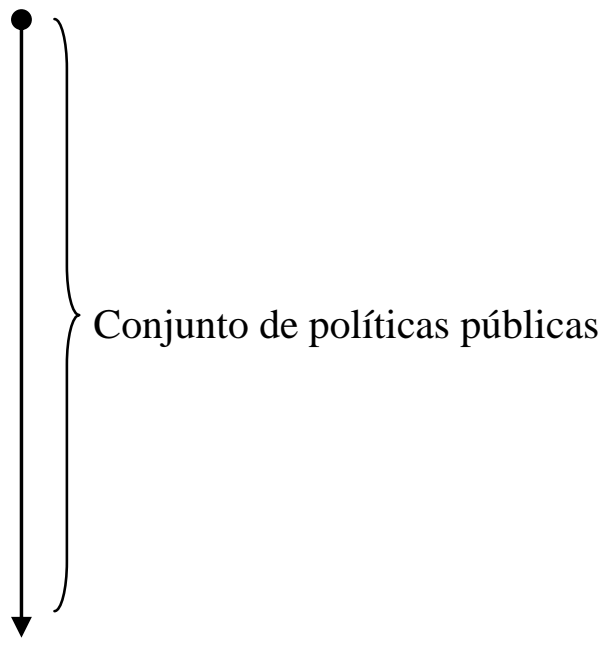

Entrega do bem ou prestação estatal

É, justamente, o Poder responsável por tomar as ações que, a partir das normas constitucionais e legais, efetivará o direito nelas exposto. Trata-se do Executivo.

\subsubsection{Planos, programas e o Executivo}

Se o Legislativo tem a precedência na definição de políticas públicas, não se pode deixar de destacar a relevância do Executivo como regulador - e, assim, também normatizador -, gerente e executor em concreto de tais ações. A análise do Executivo, neste contexto, é essencial, não apenas em função do sistema Presidencialista adotado pelo Brasil, replicado em todas as unidades da Federação, por meio do qual os chefes do Executivo assumem um poder e uma visibilidade incomparável aos atores dos demais Poderes ${ }^{176}$, mas também porque, como responsável direto na prestação de saúde, é o

\footnotetext{
${ }^{176}$ A respeito da preponderância do Executivo sobre o Legislativo, ver BORGES, Arleth Santos. "Papel do Poder Legislativo na produção de políticas públicas no Maranhão", apresentado na II Jornada Internacional de Políticas Públicas, promovida pela Universidade Federal do Maranhão em São Luís entre 23 e 25 de agosto de 2005.
} 
Executivo quem tem maiores e melhores condições de aplicar métodos para tornar mais eficiente a entrega dos direitos encravados em cada política pública. É ele, em última análise, o responsável pela maior parte daquilo que, no Diagrama I, está denominado como conjunto de políticas públicas.

A Constituição estabelece que o direito à saúde será garantido, dentre outros aspectos, com o controle e fiscalização de alimentos e bebidas ${ }^{177}$. Ela, contudo, não diz como. Da mesma forma, a Constituição estatui que os idosos serão gratuitamente transportados nos meios públicos urbanos ${ }^{178}$. Ela não menciona, todavia, de que forma. Não seria, de fato, do talante do Texto ser tão minucioso a ponto de desenhar completamente as políticas públicas nele encartadas. Não haveria linhas suficientes nem papel para impressão, e, afinal, uma Constituição não se presta a esse papel. Por isso que o conjunto de políticas públicas é muito mais complexo do que se poderia pensar da simples leitura dos comandos constitucionais. Para efetiva implementação daquela política cuja gênese se encontra na norma constitucional são necessários programas e planejamento.

O planejamento é da essência das políticas públicas. Não há política pública que exaure seu conteúdo e atinge plenamente seus propósitos sem planejamento. São muitas as variáveis que devem ser consideradas quando se pretende concretizar determinada ação governamental - e, afinal, concretizá-la é tudo o que querem os representantes dos Poderes majoritários prioritariamente por elas responsáveis. Quem define as políticas públicas - e isso não serve apenas ao Executivo; em verdade, aplica-se em cheio ao Legislativo - deve ouvir uma pluralidade de interesses, muitos deles verdadeiramente antagônicos entre si, atendendo a apenas uma réstia, deixando os outros a descoberto. A questão do jogo de interesses no processo majoritário será explorada mais adiante $^{179}$, contudo, por agora, é preciso ter em mente a dificuldade de lidar com tantos anseios diferentes quando se define para quem será destinada fatia do bolo público. $\mathrm{O}$ ponto se torna ainda mais delicado quando se sabe que o Erário é materialmente limitado, porque há um total de receitas que forma o todo dos dinheiros públicos, vale dizer, tanto o idealizador quanto o gestor de políticas públicas ver-se-ão obrigados a escolher quem vai receber o que do Estado ${ }^{180}$. Legisladores e administradores, cada qual à sua medida, devem lidar com essas questões quando do trato da matéria.

\footnotetext{
${ }^{177}$ Art. 200, VI, Constituição.

178 Art. 230, §2º , Constituição.

${ }^{179}$ Itens 2.5 .1 e 2.5 .2 .

${ }^{180}$ Também o tema da escassez será explorado mais amiúde nos Itens 3.2.1 e 4.2.2.
} 
Mas é ao Executivo que toca planejar, implementar e avaliar os efeitos das ações concretas que compõem certa política pública. É o Executivo quem deve dar concretude ao comando legal, detendo até alguma margem de poder regulamentador, mas sempre atendendo ao constitucional primado da legalidade ${ }^{181}$. O Legislativo estabelece que o civilmente identificado, via de regra, não será submetido à identificação criminal $^{182}$; o Executivo, por meio das secretarias de segurança pública ou do Ministério da Justiça, efetivará tal determinação. O legislador determina o confisco de terras em que houver cultivo de substâncias psicotrópicas ${ }^{183}$; o administrador, com autorização judicial, confiscá-las-á; o Legislativo estatui que o Estado promoverá programas de assistência integral à saúde da criança, do adolescente e do jovem, estabelecendo preceitos ${ }^{184}$; é o Executivo quem cumprirá tais preceitos.

Existe clara diferença entre as hipóteses enunciadas, e elas não foram aleatoriamente escolhidas. Há uma gradação nas respectivas concretizações. Para todas elas, é necessário planejamento do Executivo. Contudo, tais são diversas, classificadas de acordo com sua dificuldade.

A primeira situação (vedação à identificação criminal do já civilmente identificado) envolve regulação que vinculará os agentes policiais a não submeterem a pessoa a constrangimento, a reconhecimento datiloscópico ou fotográfico quando apresentar qualquer documento civil autorizado a comprovar sua identificação, salvo em hipótese de prisão ${ }^{185}$. A profundidade do planejamento e dos recursos usados para a efetivação dessa política pode ser tida como baixa. Mais difíceis e dispendiosos são os planos e recursos destinados à identificação civil.

No segundo caso (confisco de terras destinadas ao cultivo de psicotrópicos $^{186}$ ), deverá haver estrutura montada para fiscalizar esse tipo de plantio. $\mathrm{O}$ comando integra a política pública de repúdio do Estado ao consumo de tóxicos. Considerando a extensão do território brasileiro, tal estrutura chega a ser classificada como relevante - serão necessários agentes, veículos, sistema de monitoramento, armamento. Ademais, será preciso usar tempo e recurso de servidores judiciários, já que a decretação do confisco cabe ao juiz. Nada de enormemente sensível, pois o sistema judiciário já vige

\footnotetext{
${ }^{181}$ Sobre o poder regulamentador do Executivo, ver BANDEIRA DE MELLO, Celso Antônio (Curso de Direito Administrativo. 21 a ed. São Paulo: Malheiros, 2006, pp. 333-352). A respeito da legalidade administrativa, ver caput do art. 37 da Constituição.

${ }^{182}$ Art. 5 ${ }^{\circ}$, LVIII da Constituição.

${ }^{183}$ Art. 243 da Constituição.

${ }^{184}$ Art. $227, \S 1^{\circ}$ da Constituição.

${ }^{185}$ A Lei n $^{\circ} 12.037 / 09$ regulamenta tal garantia constitucional.

${ }^{186}$ A Lei no 8.257/91 regulamenta o tema.
} 
normalmente e está preparado para receber uma ação dessa natureza. A concretização dessa política exige claramente preparação do administrador, mas o confisco de glebas dessa natureza não é meta da República. Aqui, embora não como no exemplo anterior, o patamar de planejamento necessário não passa de médio.

No terceiro caso (promoção de assistência integral à saúde da criança, do adolescente e do jovem), o legislador estabeleceu paradigmas. A definição desses parâmetros já indica necessidade de dedicar especial atenção àqueles dois itens muito amplos (destinação de recursos da saúde à assistência materno-juvenil e estabelecimento de ações de inclusão de jovens deficientes físicos e mentais). Dar assistência integral à saúde de crianças, adolescentes e jovens é dizer que o Estado proverá o que for necessário para garantir saúde a esse universo de pessoas. Terá de disponibilizar tratamento preventivo e curativo e estabelecer políticas específicas destinadas ao público-alvo. É dizer, enfim, que crianças, adolescentes e jovens terão dedicação especial do Estado no tema da saúde. É por conta desse comando que o Executivo tem de instalar hospitais ou alas infantis ${ }^{187}$, dispensar gratuitamente drogas que tratam adolescentes ${ }^{188}$, realizar campanhas de vacinação infantil ${ }^{189}$. Imagine-se o hercúleo planejamento que envolve efetivar todos esses misteres. São ações altamente complexas e que não prescindem de concepção adequada, acompanhamento próximo e rigorosa avaliação de resultados. Este tipo de obrigação legislativa possui alto grau de implementação executiva.

Não é por menos. O primeiro caso revelava direito claramente de abstenção, ou de liberdade negativa ou, ainda, de primeira geração. Este último condiz com direito de ação, ou de prestação positiva ou, afinal, de segunda geração. Tal resultado, observado nos raciocínios hipotéticos, é invariavelmente verificado sempre que se pretende efetivar políticas públicas que tenham por conteúdo direitos sociais. Se não houver planejamento antes de se pensar em executar ações relacionadas a políticas públicas, então certamente tal política, porquanto complexa, quedará fracassada ${ }^{190}$.

\footnotetext{
${ }^{187}$ É o caso, por exemplo, do Hospital Infantil Menino Jesus, localizado na Bela Vista, Cidade de São Paulo, mantido pela Municipalidade, v. <http://www.prefeitura.sp.gov.br/cidade/secretarias/saude/hospital_municip al_infantil_menino_jesus/>, acesso em 3.7.2013, 19:35h).

${ }^{18 \overline{8}}$ Como a conhecida pílula do dia seguinte, que objetiva não levar adiante a gravidez indesejada, com incidência relevante na adolescência (<http://drauziovarella.com.br/mulher-2/sus-passa-a-distribuir-pilulado-dia-seguinte-sem-exigir-receita-medica/>, acesso em 3.7.2013, 19:47h)

189 Ver <http://g1.globo.com/distrito-federal/noticia/2013/06/vacinacao-contra-paralisia-infantil-terminanesta-sexta-feira-no-df.html>, acesso em 3.7.2013, 19:50h).

190 "Nota-se que inúmeras políticas públicas resultam fracassadas, certamente em decorrência da falta de planejamento das mesmas, pois geralmente não é feito planejamento ou desenho estratégico para tais políticas. Com isso surge a necessidade de qualificar e inovar os mecanismos de promoção dessas políticas. Para tanto, o gestor público precisa ter cuidado para não cair num imediatismo político, no qual a
} 
Com efeito, sem planejamento estratégico, ações multifacetárias, contínuas e, muitas vezes, realizadas quase que exclusivamente com base na metodologia tentativaerro, em um cenário de limitação de recursos humanos e financeiros, como sucede com as políticas públicas, restariam total ou parcialmente desperdiçadas. Os planos estratégicos servem para que o administrador atue da maneira mais eficiente, como constitucionalmente ordenado. Com muitas variáveis, os planos de políticas públicas são de rigor. E o Executivo é um Poder absolutamente vocacionado para esse mister, já que sua função típica é, de fato, administrar.

Ora, se o agente executivo é normalmente conhecido como administrador, não parece desarrazoado que a ele incumba administrar a política pública, desde sua gênese até a avaliação pós-entrega. É ele o encarregado da gestão administrativa, atividade-fim do Estado que objetiva criar utilidades em favor do corpo social por força direta da atuação estatal ${ }^{191}$. Afinal, a atividade administrativa consiste, em primeiro lugar, em aplicar a norma anteriormente editada ${ }^{192}$, dando-lhe concretude, e, ato contínuo, estabelecendo como, quando, com que recursos e em que prazo a política será executada.

O Executivo, afinal, está organicamente fadado a esse seu destino. Em todos os entes federados, Prefeituras, Estados, Distrito Federal e União se valem de estrutura voltada ao cumprimento da norma de ofício. Atualmente, o Executivo federal conta com nada menos do que quarenta ministérios, mais tantas agências reguladoras, departamentos, conselhos, secretarias especiais ${ }^{193}$, isso sem contar os agentes da Administração Pública descentralizada, em última análise, todos voltados a levar a cabo algum tipo de política pública. O modelo replica-se nos demais entes federados. A estrutura orgânica do Executivo, afinal, tem por justificativa atuar de forma a concretizar os objetivos constitucionais e institucionais do Estado.

elaboração de políticas visa apenas a resultados a curto prazo. É necessário que haja um real conhecimento sobre a realidade e as necessidades sociais, para, a partir delas, elaborar mecanismos de intervenção na realidade, mesmo que os resultados só venham a médio ou a longo prazo. Uma visão meramente imediatista pode comprometer o sucesso de tal política, mas, infelizmente, parece que os governantes têm uma 'cultura de improvisão', adotadas de improviso sem o devido planejamento. Essas políticas estão fadadas ao fracasso na sua grande maioria” (MATUS, Carlos. Adeus, Senhor Presidente. Trad. Luís Felipe Rodrigues Del Riego. São Paulo: Fundap, 1997. p. 38)

${ }^{191}$ SUNDFELD, Carlos Ari. Fundamentos de Direito Público, $3^{\text {a }}$ ed. São Paulo: Malheiros, 1998, p. 80. O autor classifica a prestação de educação, saúde e assistência social como espécies do gênero serviços sociais, que são fruíveis diretamente pela população, revelando ora utilidade, ora comodidade, embora não fornecidos apenas pelo Estado. Segundo ele, ainda, há um caráter mandatório em questão: “A prestação de tais serviços é dever inafastável do Estado, tendo os indivíduos o direito subjetivo de usufruí-los. O objetivo do Constituinte ao outorgar tais competências ao Poder Público não foi o de reservá-las, mas sim o de obrigar a seu exercicio." (p. 81).

${ }^{192}$ SUNDFELD, Fundamentos de Direito Público..., p. 43.

193 <http://www.brasil.gov.br/sobre/o-brasil/estrutura/organizacao-do-governo/print>, acesso em 5.7.2013, $22: 15 h$. 
Além disso, como visto, o planejamento público compreende PPA, LOA e LDO, todas de iniciativa do Poder Executivo, que já as desenha sabendo quais são as diretrizes, objetivos e metas da Administração para os programas de duração continuada ${ }^{194}$, como são as políticas públicas. Antes ainda de saber quanto de dinheiro será necessário para custear ações é necessário conhecer quais são essas ações - e isso é tarefa constitucional do Executivo. É nessa linha que a esse Poder cabe o planejamento tático das ações administrativas, considerando o equilíbrio entre receita e despesa, mais o planejamento operacional ${ }^{195}$.

Para além do campo hipotético, exemplos de programas em áreas relacionadas aos direitos sociais demonstram bem que o desenho e a concretização de políticas públicas não é tarefa fácil. O Programa Saúde da Família, por exemplo, fixa em unidades básicas de saúde equipes multiprofissionais que têm por incumbência o acompanhamento de um número definido de famílias, localizadas em certa área geográfica, protagonizando ações de promoção de saúde, prevenção, recuperação reabilitação de doenças e outros agravos nessa comunidade. Trata-se de eixo do grande programa de Atenção Básica, um dos pilares do SUS ${ }^{196}$.

Verificando-se as informações à disposição do cidadão, é fácil entender porque são os administradores quem devem estar à frente do planejamento de políticas públicas, e por qual razão políticas públicas demandam programação estratégica. O Departamento de Atenção Básica, o DAB, ligado à Secretaria de Atenção à Saúde que, por sua vez, responde ao Ministério da Saúde, é o responsável institucional por operacionalizar tal política, compartilhada por todos os entes da Federação. É o DAB quem orienta e avalia os agentes de Estados, Municípios, Distrito Federal e União. O Programa Saúde da Família desdobra-se em outros tantos, como o Saúde Bucal, os programas de Diabetes e Hipertensão, de Alimentação e Nutrição e, paradigmaticamente, de Gestão e Estratégia e de Avaliação e Acompanhamento ${ }^{197}$. A existência de um programa de gestão e estratégia de acompanhamento e avaliação revela, precisamente, a necessidade de gerência,

\footnotetext{
${ }^{194}$ Art. 165 da Constituição. Ver Itens 2.3.2. e 2.4.2.

195 O planejamento tático, desempenhado pela LDO, consiste no “(...) processo de detalhamento das ações e dos meios necessários para a implementação das ações que levam ao atingimento das metas atribuídas às unidades funcionais de um órgão ou instituição, dentro de um prazo determinado.". O planejamento operacional é entendido como “(..) modalidade de planejamento voltada para assegurar a viabilização dos objetivos e metas dos planos a longo prazo e para a otimização do emprego de recursos num período determinado de tempo." SANCHES, Osvaldo Maldonado, apud de SILVA, Moacir Marques da. "A lógica do planejamento público à luz da Lei de Responsabilidade Fiscal”, em Orçamentos Públicos...”, pp 756 e 759.

$196<$ http://dab.saude.gov.br/atencaobasica.php>, acesso em 9.7.2013, 10:55h.

$197<$ http://dab.saude.gov.br/atencaobasica.php>, acesso em 9.7.2013, 11:22h.
} 
administração e planejamento de uma ação tão densa e vasta quanto essa. A Administração atua dessa forma quanto às políticas públicas: por meio de planos e programas.

Contudo, tanto os administradores como os legisladores compõem Poderes que, por sua essência, devem obediência aos anseios majoritários, ou, quando respondem aos minoritários, assim o fazem em razão da articulação dos grupos que os representam. Esse fenômeno e seus desdobramentos no procedimento de alocação de recursos e definição de ações de políticas públicas é o objeto do próximo tópico.

\subsection{AS FALHAS DOS PODERES TRADICIONAIS NO EXERCÍCIO DE ALOCAR RECURSOS E POLÍTICAS PÚBLICAS. O PAPEL CORRETIVO DO PROCESSO CIVIL}

As decisões tomadas no bojo dos poderes Legislativo e Executivo são inerentemente permeadas por sérias vicissitudes, oriundas mesmo da metodologia como cada qual de seus membros é alçado ao mandato público e, de conseguinte, desempenha seu papel.

São Legislativo e Executivo, destarte, os Poderes estatais encarregados por excelência a prever, planejar, executar e avaliar políticas públicas. Como já se viu, trata-se dos Poderes majoritários, porque seus principais membros são eleitos diretamente e, mais que isso, possuem mandato a prazo certo, vale dizer, apenas se colocam temporariamente em seus postos, sendo cabível reeleição, observando-se, quando houver, certos limites. O fato dos representantes principais do Legislativo e do Executivo serem eleitos faz com que inevitavelmente eles se socorram da política para perpetuar seu poder. Daí seu desejo de atender aos anseios da maioria, de um lado, porque ela lhe garantirá maior votação e visibilidade, e de grupos articulados de interesse, por outro, uma vez que eles podem influenciar decisivamente em uma eleição. E isso pode ter decisivo impacto nas escolhas que são ínsitas ao processo de definição de políticas públicas.

Por isso, e também porque a tarefa de implementar políticas públicas é altamente dificultosa, são observadas falhas e lacunas no empenho de esforços para execução dessas políticas. Para comprovar a existência dessas falhas, serão abordadas duas linhas teóricas aptas a demonstrar a volatilidade dos processos decisórios sociais. Primeiro, verificar-se-á o Majoritarismo; depois, a Public Choice. 


\subsubsection{Majoritarismo}

É fora de dúvida que a deliberação baseada no princípio majoritário consiste na mais tradicional forma de legitimar decisões. É de tempos imemoriais a tomada de decisão com base na vontade da maioria. Já na democracia ateniense todas as pessoas tinham o direito de falar nas assembleias populares (chamadas eclesias) que discutiam assuntos da pólis, por meio do fenômeno conhecido como isegoria, muitas palavras a reforçar certo entendimento majoritário. ${ }^{198}$. Na tradição bárbara, em tempos de paz, os temas de interesse da sociedade eram decididos nas assembleias de guerreiros. Na democracia representativa, o Legislativo delibera respeitando a maioria. Os próprios representantes são investidos em seu poder pela contagem de votos - quem levar a maioria deles é diplomado e passa a representar seus eleitores. Mesmo situações aparentemente paradoxais contam, também, com o majoritarismo: em uma corte, juízes em colegiado decidem majoritariamente. Enfim, a regra da maioria nos é tão natural quanto andar e nos $\operatorname{levantar}^{199}$.

O majoritarismo, por sinal, é da essência da emanação de poder que, criada pelo homem, tem-se como a mais adequada até hoje, a Democracia. No âmbito democrático, decisões são tomadas por maioria. Se a maior parcela dos que decidem resolver seguir algum caminho, aqueles que se colocaram contrariamente terão, grosso modo, de submeter-se a ele, seguindo-o igualmente.

\footnotetext{
198 ARISTÓTELES assim se colocou quando analisou a maioria: "No momento, parece que a resposta mais defensável, talvez a mais verdadeira, seja a de que a maioria, não o melhor, deve ter a supremacia, quando o melhor for a minoria. Pois é possível que a maioria - da qual ninguém, individualmente, é um homem virtuoso -, possa, reunida, ser melhor do que a minoria, não individual, mas coletivamente, do mesmo modo como uma festa para a qual todos contribuem é melhor do que aquela feita às expensas de um único homem. Porque, quando há muitas pessoas, cada qual tem alguma cota de virtude e inteligência; e, quando elas se unem, tornam-se algo parecido a um homem com muitos pares de pés e mãos, além de muitas mentes." (Política. São Paulo: Nova Cultural, 1999. Livro III, 11-47, p. 230). Jeremy WALDRON define o argumento de Aristóteles como a Doutrina da Sabedoria da Multidão, apregoando-lhe o seguinte enunciado: "O povo atuando como um corpo é capaz de tomar decisões melhores reunindo o seu conhecimento, a sua experiência e o seu discernimento do que qualquer subconjunto de pessoas atuando como um corpo e reunindo o conhecimento, a experiência e o discernimento dos membros do subconjunto". WALDRON visivelmente se preocupava com a tensão entre democracia e oligarquia - governo de muitos e de poucos, questão também presente em ARISTÓTELES, estabelecendo, ambos, a primazia da Democracia $(A$ Dignidade da Legislação. São Paulo: Martins Fontes, 2003, pp. 113-117).

${ }^{199}$ Sobre a regra da maioria, ver CAMPILONGO, Celso Fernandes. Direito e Democracia. São Paulo: Ed. Max Limonad, 1997. Segundo o autor: "Legitimar as decisões coletivas e aproximar governantes $e$ governados são objetivos da regra da maioria. Fazer da lei a expressão da 'soberania da maioria' integra o conceito de democracia." A seguir, ele mesmo lança dúvidas sobre essa proposição, indagando: "Mas, se além da noção de Estado, o próprio conceito de Estado de Direito também é relativizado, qual a utilidade da regra da maioria enquanto instrumento de legitimação de decisões políticas?" Op. Cit, p. 114.
} 
Mas nem todas as situações poderiam ser adequadamente resolvidas com a pura aplicação do majoritarismo. Como lidar, por exemplo, com aqueles que dissentem da maioria? E se a maioria for perversa, seus ideários não forem idôneos, confiáveis nem socialmente aceitáveis?

O debate a respeito das tendências majoritárias e minoritárias ${ }^{200}$ na sociedade encontra rico cabedal na consolidação da Federação norte-americana, daí sendo possível extrair as ponderações de James Madison, o mesmo do já mencionado leading case do controle judicial de constitucionalidade Marbury v. Madison. No Federalista $n^{o} 10$, Madison debateu o que ele definiu como medo das maiorias ${ }^{201}$. Para ele, nenhuma outra vantagem de uma união federalista merecia mais discussão e atenção do que sua tendência em obstar e controlar a violência de facções surgidas em seu seio. Madison entendia por facções a união de pessoas, seja a maioria, seja a minoria, movidas por um impulso comum de paixão ou de interesse contrários aos direitos dos outros, ou aos permanentes interesses enleados na comunidade. Muitas pessoas defendendo apaixonadamente suas posições contra o dissenso dos demais gerava inevitáveis problemas.

Madison sustentou haver dois métodos para controlar os problemas causados por facções no regime federalista: um, removendo suas causas; o outro, controlando seus efeitos: no primeiro caso, retirar-se-ia da sociedade a liberdade essencial para o grupamento de facções ou eliminar-se-ia a discordância, fazendo com que todas as pessoas ostentassem os mesmos pensamentos, opiniões, interesses, paixões - o que ele mesmo concluiu ser inviável (no caso da liberdade), impossível (quanto à discordância) e, assim, impassível de ser cogitado. Restou analisar o controle dos efeitos, que poderia ocorrer concorde com o seguinte esquema: se a facção consistisse na minoria, a questão seria resolvida pelo princípio republicano, fazendo-se valer a opinião da maioria; o problema ocorreria, justamente, se a facção representasse a maioria. Nesse caso, Madison sustentava que deveriam ser previstos mecanismos para evitar que essa maioria oprimisse a minoria remanescente. Nascia, aí, o contramajoritarismo ${ }^{202}$.

Antes de se falar no contramajoritarismo, nota-se que a constatação da existência de uma tirania da maioria é ainda mais destacada quando se considera a perigosa

\footnotetext{
${ }^{200}$ As tendências majoritárias e minoritárias serão objeto do item seguinte, 2.5.2.

${ }^{201}$ MADISON, James. "The Utility of the Union as a Safeguard Against Domestic Faction and Inssurection". Daily Advertiser, November 22, 1787.

${ }^{202}$ A esse respeito, ver VERÍSSIMO, Marcos Paulo. A Judicialização dos Conflitos de Justiça Distributiva no Brasil: o Processo Judicial no pós-88. Tese de Doutorado na USP, 2006, pp. 32-34.
} 
e natural tendência de cada indivíduo acompanhar a opinião da turba - e, assim, suas respectivas crenças, pensamentos e ideologias. Logo após a Segunda Guerra, o psicólogo Solomon Asch conduziu experimento em que um mesmo grupo (de sete a nove jovens estudantes) foi submetido a vários e sucessivos questionamentos cujas possíveis respostas eram apresentadas na forma de alternativas. Dentre elas, a escolha correta era óbvia e facilmente verificável ${ }^{203}$. Nos dois primeiros julgamentos, a resposta do grupo foi unânime, todos apontando a evidente assertiva correta; daí para frente, a maioria do grupo sempre apontava uma mesma alternativa - errada, porquanto instruídos a fazê-lo, como parte do experimento, enquanto que o remanescente (dissenter) não concordava e indicava a opção claramente certa. O que o dissenter não sabia é que todos os outros componentes do grupo (a maioria, portanto) foram orientados a não apontar a alternativa certa, mas, sempre, uma das erradas. Essa situação se repetiu até que, algumas vezes depois, o dissenter se sentia embaraçado em apontar a única alternativa certa (e não a que a maioria apontava como tal), hesitando em fazê-lo. A situação foi reproduzida com cento e vinte e três pessoas divididas em grupos e a hipótese foi comprovada: a maioria dos dissenters, ao final, concordava com a maioria, ainda que contrariamente às suas convicções pessoais, que apontavam as respostas, enfim, $\operatorname{corretas}^{204}$.

A prova de que a opinião individual é facilmente influenciável de acordo com as vozes da maioria explica a dificuldade das escolhas do gestor em sua nada fácil tarefa de definir políticas públicas e dividir fatias do bolo orçamentário. Tal dificuldade reflete, na prática, a observância empírica de que haverá pessoas que não serão contempladas pelas políticas implementadas pelos Poderes majoritários. O experimento de Asch, aplicado ao contexto político-público, comprova que o majoritarismo pode se revelar grande ameaça à plena eficiência - ou, se difícil, à eficiência altamente desejável - da

${ }^{203}$ Os estudantes precisavam responder, por exemplo, qual era a linha do segundo cartão que guardava a mesma extensão da única linha desenhada sobre o primeiro, sendo ambos exibidos para exame concomitante, como no exemplo a seguir (em que a resposta é, evidentemente, linha 2):
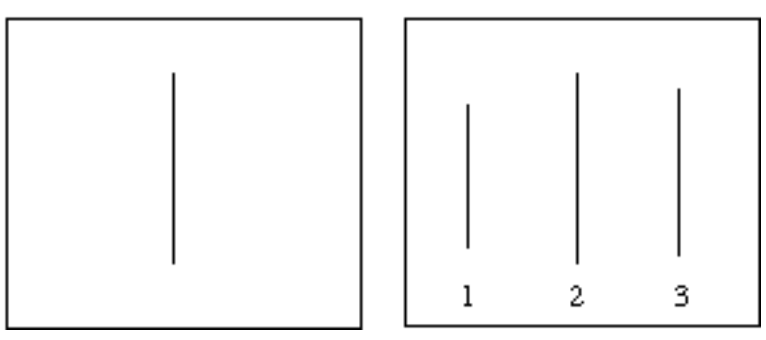

${ }^{204}$ ASCH, Solomon Eliot. "Forming Impressions of Personality", in The Journal of Abnormal and Social Psyhcology, v. 41, 1946, pp. 258-290. 
definição de planos e programas e ulterior execução das políticas constitucionalmente preconizadas, justamente porque a tendência pode não ser a busca pelo eficiente, mas pela vontade majoritária a qualquer preço, o que é altamente delicado em um cenário de escassez de recursos.

Há dúvidas quanto ao majoritarismo expostas pelo próprio Platão: o filósofo criticou o exercício da democracia direta, permitindo-se concluir que as pessoas guerreariam entre si a fim de obter o poder ou sobrepor seus anseios aos demais, ainda que não dominassem exatamente os aspectos relacionados a tais interesses. Esse pensamento corresponde ao argumento do comandante do navio, externado, no diálogo, por Sócrates: nele, o povo seria como marinheiros de um navio que, por não entenderem nada de navegação e sua aspectologia, ficariam discutindo indefinidamente quem seria capaz de comandar a nau, achando-se cada qual mais competente que os outros, sem que isso fosse verdade e ausente desse debate qualquer resultado prático ${ }^{205}$ - a nau não sairia do lugar.

É verdade que o arranjo do Estado em democracia indireta ou representativa, em que os que guiam os rumos da nação são representantes da população total, eleitos democraticamente por meio do voto, diminui, mas não resolve as vicissitudes da maioria. Mesmo os representantes são eleitos, normalmente, pelo esquema majoritário, e considerando seu inevitável interesse pessoal em perpetuar sua estada nos quadros públicos, é palatável concluir que, também aqui, os interesses majoritários é que serão atendidos. Ademais, a existência de grupos sociais que, embora numericamente minoritários, articulam-se de forma mais organizada que os demais, pode forçar a corda legislativa e administrativa para o seu lado, relegando outros legítimos interesses ao ostracismo. Ainda neste item, tratar-se-á da crise da democracia representativa.

Quando, contudo, quem decide é alguém relativamente independente, que, a despeito de suas crenças pessoais (muitas das quais formadas de acordo com o consenso social majoritário, é verdade), não precisa e nem tem por dever responder aos anseios de representados, porquanto não eleito, há clara proposição contramajoritária. Essa é a veste do Judiciário, sua importância e motivo pelo qual sua função no Estado Democrático de Direito é fundamental. Por isso, o papel do Judiciário como vetor contramajoritário é o que de mais importante fazem os juízes no moderno contexto democrático. E aí, muitas vezes, repousa a zona de entrechoque entre aqueles que querem atender a maioria (legisladores e

${ }^{205}$ PLATÃO. A República. Livro VI. São Paulo: Nova Cultural, 1997, pp. 195-196. 
administradores) e aqueles que somente visam a interpretar imperativamente o conteúdo da norma (juízes). A análise casuística comprovará a hipótese.

É certo, como já mencionado, que mesmo grupos menores ou que defendem interesses minoritários podem se articular de forma a ver seu interesse atendido. É o caso, por exemplo, dos deficientes físicos, que conseguiram criar toda uma regulamentação em seu favor, ou dos idosos, ou, mesmo, das crianças e adolescentes, setores da sociedade que não necessariamente estão alinhados com a maioria, mas que encontram defensores dispostos a obter tutela de direitos somente seus. Para esses grupos, o majoritarismo ainda funciona razoavelmente, já que viabiliza o atendimento desses interesses. Existem outros grupos, para quem, contudo, o majoritarismo não resolve, sob qualquer hipótese. São as denominadas Discrete and Insular Minorities, e o caso a ser estudado, neste contexto, é o United States v. Carolene Products Co. (304 U.S. 144, 1938), mais precisamente, sua nota de rodapé $n^{\circ} 4$.

Carolene Products significou a ruptura do paradigma liberal eleito no caso Lochner v. New York (198 U.S. 45, 1905) ${ }^{206}$, este a definir que a lei não poderia infirmar a liberdade contratual no que toca ao exercício da atividade econômica, uma vez que tal liberdade gozava de proteção embasada tanto na Quinta quanto na Décima Quarta Emenda da Constituição norte-americana. Era a tônica do laissez-faire e, então, do Liberalismo ${ }^{207}$. Na nota de rodapé $n^{\circ} 4$ de Carolene Products, já no contexto do New Deal, a Suprema Corte dos Estados Unidos entendeu que o paradigma de Lochner não se estendia aos casos em que a liberdade de contratar, e mesmo a lei, oprimisse certos direitos de participação no processo político, determinadas minorias ou contradissesse liberdades constitucionais. Era o fim da tão criticada Lochner Era e estopim para o movimento pelos direitos civis que, anos depois, mudaria a face da Suprema Corte e, de resto, da sociedade estadunidense.

No terceiro parágrafo da nota de rodapé $\mathrm{n}^{\circ} 4$ de Carolene, Justice Harlam F. Stone, seu redator, fez menção às Discrete and Insular Minorities, grupos minoritários que não conseguiam ver atendidos seus interesses pelo processo democrático tradicional ${ }^{208}$. A

\footnotetext{
${ }^{206}$ Ver Lochner e Carolene na nota 40.

${ }^{207}$ Gergely KLIMA aponta que a Lochner Era não teve início, propriamente, com o caso tão famoso, mas com Allgeyer v. Lousiana (165 U.S. 578 (1897), que igualmente consagrou a prevalência do laissez-faire sobre a lei ("Tradition, Revisionism, and Truth: coming to grips with the 'Lochner Era'," disponível em: <http://lawlib.wlu.edu/lexopus/works/391-1.pdf>, acesso em 6.7.2013, 15:34h, p. 1). A autora se propôs a estudar se, de fato, a Lochner Era existiu, questionando se a Suprema Corte, naquele período, reuniu um bloco sólido de decisões no mesmo sentido do paradigma. Ela concluiu que, embora tivessem sido vários os casos em que o entendimento de Lochner prevaleceu, não é adequado estabelecer o lapso de 1897 a 1937 como a Lochner Era, porque havia, no mesmo interregno, decisões conflitantes com o paradigma (pp. 4-13). 208 "Footnote 4: There may be narrower scope for operation of the presumption of constitutionality when legislation appears on its face to be within a specific prohibition of the Constitution, such as those of the first
} 
partir do conceito e considerando a existência desses grupos sociais, a Suprema Corte entendeu que eles se colocavam sob uma condição especial, e que deixá-los à margem do majoritarismo tradicional, ou da minoria articulada, era prejudicial à democracia como um todo, à cultura democrática. Daí ser necessário o Judiciário que, alheio ao majoritarismo, garantiria aos grupos em condição especial a observância de seus direitos, independentemente do alcance e do volume de sua voz.

A participação do Judiciário e da judicial review no processo democrático foi analisada por John Hart Ely, em obra que se mostrou basilar sobre o tema. Para ele, a nota $\mathrm{n}^{\mathrm{o}} 4$ em Carolene revelou tentativa, que nos anos seguintes mostrou-se concretizada, de estabelecimento do Judiciário como arena de representação - e, assim, de participação - tanto no processo democrático quanto na distribuição de prestações públicas ${ }^{209}$. Ele apontou, ainda, outro aspecto do fenômeno: como os juízes estavam afastados do processo político, então magistrados estariam mais bem preparados para lidar com reclamos de disfunção no processo democrático majoritário ${ }^{210}$, corrigindo virtuais disfunções causadas pelos interesses próprios dos Poderes da maioria.

Além dos problemas já apontados quanto ao majoritarismo puro e simples, há uma crise no majoritarismo representativo, mais especificamente no que toca à legitimidade dos representantes do povo na tomada de decisões e na credibilidade dos eleitos $^{211}$.

ten amendments, which are deemed equally specific when held to be embraced within the Fourteenth. See Stromberg v. California, 283 U. S. 359, 283 U. S. 369-370; Lovell v. Griffin, 303 U. S. 444, 303 U. S. 452.

It is unnecessary to consider now whether legislation which restricts those political processes which can ordinarily be expected to bring about repeal of undesirable legislation is to be subjected to more exacting judicial scrutiny under the general prohibitions of the Fourteenth Amendment than are most other types of legislation. On restrictions upon the right to vote, see Nixon v. Herndon, 273 U. S. 536; Nixon v. Condon, 286 U. S. 73; on restraints upon the dissemination of information, see Near v. Minnesota ex rel. Olson, 283 U. S. 697, 283 U. S. 713-714, 283 U. S. 718-720, 283 U. S. 722; Grosjean v. American Press Co., 297 U. S. 233; Lovell v. Griffin, supra; on interferences with political organizations, see Stromberg v. California, supra, 283 U. S. 369; Fiske v. Kansas, 274 U. S. 380; Whitney v. California, 274 U. S. 357, 274 U. S. $373-$ 378; Herndon v. Lowry, 301 U. S. 242, and see Holmes, J., in Gitlow v. New York, 268 U. S. 652, 268 U. S. 673; as to prohibition of peaceable assembly, see De Jonge v. Oregon, 299 U. S. 353, 299 U. S. 365.

Nor need we enquire whether similar considerations enter into the review of statutes directed at particular religious, Pierce v. Society of Sisters, 268 U. S. 510, or national, Meyer v. Nebraska, 262 U. S. 390; Bartels v. Iowa, 262 U. S. 404; Farrington v. Tokushige, 273 U. S. 284, or racial minorities, Nixon v. Herndon, supra; Nixon v. Condon, supra: whether prejudice against discrete and insular minorities may be a special condition, which tends seriously to curtail the operation of those political processes ordinarily to be relied upon to protect minorities, and which may call for a correspondingly more searching judicial inquiry. Compare 17 U. S. Maryland, 4 Wheat. 316, 17 U. S. 428; South Carolina v. Barnwell Bros., 303 U. S. 177, 303 U. S. 184, $n$ 2, and cases cited."

${ }^{209}$ ELY, John Heart. Democracy and Distrust. A Theory of Judicial Review. Cambridge: Harvard University Press, p. 74.

${ }^{210}$ ELY, Democracy and Distrust..., p. 103.

211 Daniel García DELGADO aponta causas da crise na democracia representativa: (a) sucessivos descumprimentos dos programas eleitorais; (b) corrupção da classe política; (c) declínio de vastos setores 
O Congresso Nacional não é bem visto aos olhos da sociedade. O povo não confia no Legislativo federal. O Índice de Confiança na Justiça - Brasil (ICJ-Brasil), da Fundação Getúlio Vargas, ranking que mede a confiança da população em determinadas instituições e segmentos, aponta o Congresso Nacional como ocupante da penúltima posição, atrás das Forças Armadas, da Igreja Católica e da Imprensa escrita. O Ministério Público ocupa a terceira posição, enquanto que o Judiciário, a oitava (são doze os paradigmas). De acordo com o ranking, a sociedade confia mais em seus vizinhos domiciliares do que no Legislativo ${ }^{212}$.

O Congresso Nacional é duramente criticado por sua inação, desvio de foco dos principais problemas brasileiros ${ }^{213}$ e descolamento de seus eleitores. Já houve declaração expressa de um deputado de que ele não se importava com a opinião pública, já que se reelegeria de toda a forma, o que, afinal, ocorreu no pleito eleitoral sucessivo à declaração ${ }^{214}$.

Não apenas o Legislativo padece de falta de confiabilidade. As demonstrações de insatisfação irrestrita e difusa vistas nas ruas de todo o Brasil, em junho de 2013, não pouparam os representantes do Executivo. Dirigentes de todas as esferas da Federação, além dos próprios legisladores, foram atacados por palavras de ordem proferidas pelos manifestantes. Prédios públicos foram objeto de reclamos: o Congresso Nacional $^{215}$, o Palácio do Itamarati ${ }^{216}$, as sedes da Prefeitura ${ }^{217}$ e do Governo do Estado de

sociais, com a percepção de responsabilidade da classe política pela ampliação da pobreza; (d) complexidade das demandas e baixa especialização técnica para enfrentar desafios das sociedades modernas; (e) crise dos grandes discursos de legitimação das formas de ação política; e (f) influência dos meios de comunicação. Para mais detalhes, ver VALENTE, Manoel Adam Lacayo. "A Dimensão Jurídico-Constitucional na Formulação de Políticas Públicas: uma Perspectiva a ser Explorada”, em Revista de Direito Administrativo $n^{\circ}$ 39. Rio de Janeiro: 2005, pp. 127-129.

212 CUNHA, Luciana Gross; BUENO, Rodrigo de Losso da Silveira; OLIVEIRA, Fabiana Luci de; SAMPAIO, Joelson de Oliveira; RAMOS, Luciana de Oliveira; KLINK, Yuri Campos. Relatório do ICJ Brasil referente ao $1^{\circ}$ Trimestre de 2012, Rio de Janeiro: Direito GV, 2012, p. 24.

${ }^{213}$ De fato, o Congresso abriga projetos de lei como aquele que pretende banir a comercialização de mamadeiras, como suposto incentivo à amamentação materna, ou criminaliza a psicofobia, medo exagerado e incontrolável que acomete patologicamente algumas pessoas, além, mesmo, do famoso projeto de lei da cura gay, que objetivava atacar duas decisões do Conselho Federal da Psicologia, aquela que proibia psicólogos de conduzir tratamentos visando a alterar a opção sexual do paciente, e outra, que vedava conceber e tratar o homossexualismo como doença. São temas que, nem de longe, reputam da relevância de tantos outros ainda à espera do adequado tratamento legislativo, relacionados aos bens mais caros da sociedade, como saúde, educação, assistência. A respeito, ver "Vozes em um mundo distante", em Revista Veja, edição de 10.7.2013, $\mathrm{n}^{\mathrm{o}} 2.329$, pp. 60-61.

214 "Vozes em um mundo...", p. 61.

215 <http://g1.globo.com/bom-dia-brasil/noticia/2013/06/manifestantes-ocupam-cobertura-do-congressonacional-em-brasilia.html>, acesso em 6.7.2013, 20:52h.

$216<\mathrm{http} / /$ g1 .globo.com/distrito-federal/noticia/2013/06/manifestacao-em-brasilia-tem-3-presos-e-mais-de-

120-feridos.html>, acesso em 6.7.2013, 20:50h.

217 <http://www1.folha.uol.com.br/cotidiano/2013/06/1297302-manifestantes-tentam-invadir-a-prefeitura-desp-durante-protesto.shtml>, acesso em 6.7.2013, 20:54h. 
São Paulo ${ }^{218}$, e, assim, por todo o País. São sucessivos os escândalos, desmandos e abusos, tamanhos que a Presidente escolheu designá-los a partir de uma única palavra: malfeitos $^{219}$. Foi, aliás, em função da voz das ruas que o Legislativo federal apressou a deliberação de importantes projetos de lei que, parados há muito, foram votados em tempo recorde ${ }^{220}$.

O sistema eleitoral brasileiro é um caos em que parte considerável do eleitorado mal se lembra em quem votou nas últimas eleições. Se isso é verdade, e é221, esse eleitor evidentemente não se sente representado, até porque, afinal, de quem cobraria ele a realização de alguma política pública de seu agrado? O tema da reforma política não é novo, é sempre lembrado, pouco ou nada se faz a respeito e, quando isso sucede, ocorre de maneira errática ${ }^{222}$.

Não é por acaso, assim, que das portas do Judiciário acabem saindo decisões que impactam severamente na lei ditada pelos Poderes majoritários. Sobre a integração das decisões judiciais à própria lei, Aristóteles tributou à norma legal papel central do ordenamento jurídico, mas afirmou que a realização da Justiça só ocorre com a aplicação equitativa da lei aos casos particulares. Para ele, a decisão concreta pode suprir lacunas legislativas, agindo o aplicador (o juiz, ao que nos importa) como atuaria o legislador se lhe fosse dada oportunidade para tanto ${ }^{223}$. A ascensão judicial é inquestionável. Não, contudo, isentas de críticas.

\footnotetext{
${ }^{218}<\mathrm{http}: / /$ mais.uol.com.br/view/s70pk4i6az2h/manifestacao-segue-para-sede-do-governo-de-sao-paulo04024C1C3372D8A94326?types=A\&>, acesso em 6.7.2013, 20:55h.

${ }^{219}<$ http://www.estadao.com.br/noticias/nacional,na-tv-dilma-diz-que-combatera-malfeitos-semtregua,796255,0.htm>, acesso em 6.7.2013. 21:02h. Durante os primeiros anos de seu governo, Dilma Rousseff demitiu nada menos que seis de seus ministros, todos acusados de corrupção ou malversação de recursos públicos (<http://www1.folha.uol.com.br/poder/1029153-nenhum-dos-ministros-demitidos-pordilma-chegou-a-ser-punido.shtml>, acesso em 6.7.2013, 21:05h). Daí, o termo malfeito se tornou um jargão da dirigente.

${ }^{220}$ Como o caso da PEC n ${ }^{\circ}$ 37/2011, que pretende limitar o poder investigativo do Ministério Público, o projeto de lei que torna hedionda a corrupção e pune vigorosamente empresários que corrompem, a edição da Lei $\mathrm{n}^{\circ} 12.846 / 13$ - alcunhada Lei Anticorrupção, que estabelece a responsabilidade objetiva da pessoa jurídica que praticar certos atos contra a Administração Pública nacional e estrangeira, dentre outros.

$221<\mathrm{http} / / / \mathrm{www} 1$.folha.uol.com.br/poder/837795-pesquisa-indica-que-parte-dos-eleitores-ja-nao-lembra-emquem-votou-nas-

eleicoes.shtml>; <http://www.gazetadopovo.com.br/vidapublica/conteudo.phtml?id=1332668\&tit=357-doscuritibanos-ja-nao-lembram-em-quem-votaram-para-vereador>, acesso em 6.7.2013, 21:14h e 21:16h, respectivamente.

${ }^{222}$ Em junho de 2013, como tentativa de resposta ao clamor das ruas, a Presidente da República anunciou um plebiscito para legitimar uma tão sonhada reforma política. Duramente criticada, inclusive por alegada inabilidade institucional (já que não consultou qualquer um dos outros Poderes - o Legislativo, que convocaria a consulta, e o Judiciário, que a realizaria - e nem mesmo seus pares) e falta de tempo hábil e de oportunidade do plebiscito, pode ser que a reforma política tão desejada não ocorra logo ("Temer derruba plebiscito e, sob pressão, volta atrás", em $O$ Globo, edição de 5.7.2013, n ${ }^{\circ}$ 29.187, Capa e pp. 2-6).

${ }^{223}$ Ver, além da clássica obra citada, excelente ensaio de Eduardo Henrique Raimundo von ADAMOVICH: "A justiça geométrica e o Anteprojeto de Código de Processos Coletivos: Elementos para uma justificativa Histórico Filosófica, ou por uma Visão atual do alcance e da função criadora da jurisdição coletiva", em Direito Processual Coletivo..., pp. 55-65.
} 
Essas críticas são antigas. $\mathrm{Na}$ verdade, existem desde que despontou a Judicial Review ${ }^{224}$. Há uma linha que apoia a Judicial Self-restraint, ou seja, a autocontenção dos poderes do Judiciário, notadamente quanto à interpretação constitucional e penetração em demais assuntos políticos. A teoria entende, fundamentalmente, que o exercício da Judicial Review constitui afronta à vontade da maioria, seja ela direta, seja ela representada pelo Parlamento ${ }^{225}$.

A contínua luta entre os defensores do intervencionismo judicial e aqueles que o repudiam não perdeu fôlego até os dias de hoje, em que os magistrados, de fato, passaram a engrossar as fileiras dos principais atores de políticas públicas. As mais destacadas críticas, sem dúvida, fundamentam-se no majoritarismo. Seguem três comuns indagações, normalmente apresentadas pelos críticos do intervencionismo judicial, que comprovam a tese.

Ora, se as políticas devem refletir a vontade da maioria, como pode um único magistrado, ou poucos deles, atender a quem, ainda que individualmente, requeiralhe algo?

Mais ainda: como os juízes, que decidem isoladamente, encerrados em seus gabinetes, podem adequadamente representar a vontade da maioria?

Se, afinal, os juízes não são eleitos e não devem prestar contas a seus eleitores, como confiar a eles a tarefa de distribuir bens públicos? ${ }^{226}$

Em 1962, Alexander Bickel cravou: “ $A$ 'dificuldade do contramajoritarismo' vem sendo a obsessão central dos estudantes do direito constitucional moderno". A countermajoritarian dificulty, para Bickel, consistia na aparente tensão entre a intervenção judicial e o processo democrático ${ }^{227}$. Este tipo de

\footnotetext{
${ }^{224}$ Barry FRIEDMAN relata que o ambiente que circundava a ascensão de JEFFERSON à presidência dos Estados Unidos era de receio quanto ao papel dos juízes. Menciona o autor citação de 1800, tirada dos anais do Congresso estadunidense, dando conta que os onipotentes juízes desconsideravam e esmagavam as normas da Constituição, rindo do legislador ("The History of the Countermajoritarian Difficulty, Part One: The Road to Judicial Supremacy", in NYU Law Review 333 (1998), p. 53). Trata-se de momento histórico em que a judicial review ainda estava sendo experimentada.

${ }^{225}$ MELLO, Cláudio Ari. Democracia constitucional e direitos fundamentais. Porto Alegre: Livraria do Advogado, 2004, p. 205.

226 Nesse contexto, importante voz destacadamente ouvida em defesa da democracia apoiada no majoritarismo e contra a preponderância judiciária em temas políticos é a de Jeremy WALDRON. Para WALDRON, a participação popular no desenho das instituições sociais, tendo como resultado a encampação da decisão majoritária, é o que ele chama direito dos direitos, ou right of rights. WALDRON insiste em repugnar a revisão judicial dos atos majoritários baseadas na norma (rights-based), assumindo que esse tipo de revisão acaba por expungir o majoritarismo e, assim, a democracia (Law and Disagreement, Oxford University Press, 1999, em especial o Capítulo 11, pp. 232-254, intitulado: Participation: the Right of Rights). Nesse sentido, ver advertência de Luís Roberto BARROSO, em "20 anos da Constituição de 1988: a reconstrução democrática do Brasil”, em Revista do Advogado, nº 99, Setembro de 2008, p. 84.

${ }^{227}$ FRIEDMAN, “The History of...”, pp. 1-2.
} 
receio contaminou, inclusive, os órgãos judiciários. A Suprema Corte norte-americana, na última metade do Século XX, viveu período em que, a par de revelar os verdadeiros valores constitucionais, preocupou-se deveras com os anseios da maioria, constituindo apenas mais um canal de decisão política do que, propriamente, jurídica ${ }^{228}$ e solapando seu cunho contramajoritário. No Brasil, por muito tempo vigorou a tese que o Judiciário não poderia controlar o mérito do ato administrativo, com o que se abriu margem à vitória do majoritarismo puro $^{229}$.

As três indagações serão respondidas com os argumentos lançados ao longo deste texto. Mas, adiante-se desde já, tais dúvidas, se colocam em xeque a função judicial na seara política, são amesquinhadoras da jurisdição e do processo civil. A verdade é que a jurisdição e o processo não podem atuar, apenas, subsidiariamente, mas, antes, devem fazer valer a tutela de qualquer ameaça ou lesão a direito ${ }^{230}$. De fato, se o artigo $3^{\circ}$ da Constituição preconiza como um dos objetivos da República brasileira a construção de uma sociedade livre, justa e solidária, quaisquer políticas que possam comprometer esses ideais são passiveis de correção judicial, se implementadas (portanto, por ação) ou não (nesse caso, por omissão) ${ }^{231}$.

Owen Fiss sustenta que a função do juiz não é falar pela maioria, atendendo seus anseios; é, sobretudo, dar significado aos valores constitucionais, procurando o que é verdadeiro, correto e justo. Para ele, o juiz não é um partícipe dos interesses da política de grupo. Em outras palavras, o majoritarismo está em plano completamente diverso da atividade jurisdicional. É, portanto, um erro confundir os assuntos. Fiss declara, ainda, que equívoco fundamental dos pensamentos baseados na maioria é desprezar, completamente, a vontade minoritária, que, não fosse o Judiciário, poderia ficar completamente desamparada $^{232}$. Volta-se, aí, ao papel contramajoritário do Judiciário.

${ }^{228}$ CHEMIRINSKY, Erwin. "Foreword: the Vanishing Constitution", in Harvard Law Review 43, 71 (1989), p. 61. Refere-se, principalmente, à época da presidência da Corte exercida pelo Justice William REHNQUIST.

229 Sobre o assunto, ver GRINOVER (“O Controle...”, pp. 127-128) e MEDAUAR, Odete. Direito Administrativo Moderno. 14 ed. São Paulo: RT, 2010, p. 406, para quem: “(...) o controle jurisdicional da Administração Pública abrange a apreciação, efetuada pelo Poder Judiciário, sobre atos, processos e contratos administrativos, atividades, operações materiais e mesmo a omissão ou inércia da Administração. Em regra é posteriori, sendo repressivo ou corretivo, desencadeado por provocação”. A posição jurisprudencial a respeito do amplo escopo de penetração judicial no ato administrativo pode ser vista em STJ, RMS nº 24.584/SP, Rel. Min. Napoleão Nunes MAIA FILHO, j. em 9.2.2010, DJ em 8.3.2010.

${ }^{230}$ Artigo $5^{\circ}$, XXXV da Constituição.

${ }^{231}$ COMPARATO, Fábio Konder. "Ensaio sobre o juízo de constitucionalidade de políticas públicas", em Estudos em homenagem a Geraldo Ataliba. São Paulo: Malheiros Editores, 1997, p. 354.

${ }^{232}$ FISS, Um Novo Processo Civil..., pp. 36-37. No mesmo sentido, Willian L. REYNOLDS refuta o uso do argumento majoritário para criticar a atuação ativista do Judiciário. O professor da Universidade de Maryland afirma que esse argumento é inaplicável porque o juiz não decide de acordo com sua vontade, mas, sim, 
Se a atividade jurisdicional no âmbito do controle e da revisão de constitucionalidade acaba anulando ou mitigando o alcance de determinações tomadas pelos poderes majoritários, isso só ocorre, com efeito, reflexamente, como eficácia natural do poder dos magistrados de invalidar atos que violem a constituição. Em um cenário de supremacia constitucional, portanto, em que compete ao Judiciário realizar a fiscalização da compatibilidade de condutas (normativas ou fáticas) que afrontam uma carta de direitos, não parece razoável falar em legitimidade democrática dos juízes. De fato, normas e leis são apenas parte, não o todo do Direito.

O já referido pensamento aristotélico comunga dessa tese, apoiando os defensores do atuar judicial ${ }^{233}$. Em Roma, parcos eram os diplomas legislativos, mas infindáveis eram os direitos ditados pelos intérpretes da Lei. Não raras vezes, a palavra dos pretores era, ulteriormente, transformada em norma. Tomás de Aquino, um dos mais importantes filósofos cristãos, aduzia ser impossível encetar lei que não falhasse no caso concreto. Demais disso, a própria Nona Emenda da Constituição dos Estados Unidos estabelece que os direitos se sobrepõem à própria lei, sendo, deveras, a lei apenas parte do todo que é o Direito ${ }^{234}$.

De fato, juízes não estão tão suscetíveis à ingerência política quanto os demais atores majoritários. Ely entendia que a atividade do juiz deve se fundar na lei e no Direito, e só, não levando em consideração outros elementos extrínsecos, como, segundo ele, “(...) a vontade do Führer ou a consciência revolucionária” (que contaminariam os pensamentos dos legisladores e administradores). Decidindo o juiz com base na norma legal, de maneira reflexa, fá-lo-ia de acordo com a vontade majoritária do povo ${ }^{235}$.

Ademais, não se pode esquecer que o processo civil e o Judiciário são fundamentais peças na correção de falhas perpetradas por Executivo e Legislativo com base nas vicissitudes do majoritarismo. E não apenas: há outra teoria que demonstra que os Poderes Legislativo e Executivo estão propensos a falhar, necessitando mecanismos de correção: trata-se da Public Choice.

conforme determinam as fontes do Direito (entre nós, notadamente, a lei). Nesse diapasão, o campo de atuação judicial seria muito mais restrito que o do legislador. Ademais, juízes não precisam agradar ninguém para obter o seu poder, que vem da imperatividade de suas decisões, sendo que o mesmo não ocorre com o Legislativo (REYNOLDS, Willian L. Judicial Process in a Nutshell. $2^{\text {nd }}$ Edition. Maryland: West Group, 1991, pp. 143-145).

${ }^{233}$ A doutrina que prega a ampla dotação dos juízes para implementar políticas públicas.

234 A Nona Emenda da Constituição norte-americana prenuncia a prevalência do Direito sobre a Lei, reconhecendo - de maneira acertada - que os fatos e fatores sociais são muito mais ricos e férteis que a mente do legislador. Sobre o assunto, ADAMOVICH, “A Justiça Geométrica...”, pp. 60-64.

${ }^{235}$ Apud de CAPPELLETTI, Mauro. Juízes Legisladores? Porto Alegre: Sérgio Antonio Fabris Editor, 1999, p. 102. 


\subsubsection{Public Choice}

A constatação de anomalias nos processos decisórios públicos pode ser encontrada, também, nas ciências econômicas. Uma das linhas mais interessantes nesse contexto repousa na denominada Teoria da Escolha Pública, ou Public Choice, que, grosso modo, defende ser o processo social de tomada de decisões que resultam na formação das normas e definição de políticas públicas permeado por interesses motivados por grupos de pressão organizados, sendo as atitudes levadas a efeito por esses grupos as decisivas para o alcance de determinado resultado - almejado, justamente, por tais organizações $^{236}$.

Aponta-se que importante causa da crise da democracia representativa, vista no item anterior, assenta-se, justamente, na falta de democratização de grupos da sociedade civil que atuam ao lado dos definidores e executores de políticas públicas ${ }^{237}$. Aí estaria indício da parcela de interesse pessoal que moveria certos grupos encarregados de agir incisivamente no núcleo das decisões a respeito de direitos mais relevantes ao interesse público, o que também demonstraria que, na verdade, a democracia não pode ser encerrada somente nas premissas do majoritarismo, sendo informada por elementos muitas vezes ocultos $^{238}$.

Economistas se ocuparam em analisar como os efeitos advindos das normas jurídicas poderiam ser mais eficientes. Nesse contexto, estudos desenvolvidos em países anglo-saxônicos entenderam que o Direito, mais que oriundo do Common Law, provinha do processo político, sujeito a interferências pessoais ${ }^{239}$ e permeado por atos de grupos

\footnotetext{
${ }^{236}$ Para melhor compreensão a respeito da Public Choice, ver MERCURO, Nicholas; MEDEMA, Steven G. Economics and the Law. From Posner to Post-Modernism. Princenton Unversity Press, 1997.

${ }^{237}$ SANTOS, Boaventura de Sousa. Pela Mão de Alice: o social e o político na pós-modernidade. $2^{a}$ ed. São Paulo: Ed. Cortez, 1996, pp. 270-271.

${ }^{238}$ Nesse sentido, mas com reservas, aduz Matthew TAYLOR que os cientistas políticos têm visto o Judiciário como um venue seeking (uma instituição mais favorável procurada pelos atores sociais) para contestar políticas públicas. Assim, os interesses antagônicos envolvidos em determinado assunto de interesse público, frequentemente, são levados ao Judiciário ("O Judiciário e as Políticas Públicas no Brasil”, em Revista de Ciências Sociais, Rio de Janeiro, V. 50, no 2, 2007, p. 234). Sobre o mesmo tema, mas respondendo ao questionamento a respeito da politização judicial, indispensável a análise de TATE e VALLINDER. "Why the expansion...?”, pp. 27-31

${ }^{239}$ Para Jeremy WALDRON, KANT e HOBBES atribuíam ao direito positivo a salvaguarda da sociedade de interesses puramente individuais, ínsitos aos cidadãos, que conduziriam a coletividade, invariavelmente, à luta entre seus próprios membros até que sobreviesse uma força coercitiva externa - justamente, o direito positivo. Em $O$ Leviatã, HOBBES afirmou existir uma guerra de todos contra todos, motivada pela necessidade de cada um fazer valer seus próprios valores e juízos morais, o que, segundo dele, é medida da
} 
articulados que terminavam por exercer pressão sobre o agente público. O sucesso das postulações desses grupos e do atendimento dos interesses do agente andava na contramão da eficiência - daí o interesse da Economia em estudar o fenômeno. A essa inovadora teoria chamou-se Public Choice.

Os motivos pelos quais os economistas debruçaram-se sobre a análise do processo político podem ser explicados pelo Teorema de Arrow ou Teorema da Impossibilidade de Arrow. O economista estadunidense Kenneth J. Arrow pretendia provar, em qualquer situação, a prevalência de interesses individuais sobre os coletivos. Comprovada essa hipótese, Arrow constataria mais um obstáculo para a busca do bem comum na decisão levada a efeito, por exemplo, pelos governantes. Para esse fim, tomou experimentalmente três indivíduos diferentes e, dotando-os de poder de decisão, demonstrou matematicamente que, seguindo a ordem de preferência de cada um, as decisões encontradas diante de um mesmo problema, asseguradas as mesmas informações aos avaliados, foram completamente aleatórias ${ }^{240}$. O Teorema de Arrow é pródigo em demonstrar a impossibilidade de dada decisão contemplar todos os desejos egoísticos daqueles sujeitos nela interessados, ainda que os fatores informativos exógenos se equivalham - na prática, destarte, o Teorema de Arrow mostra que dois agentes públicos, munidos das mesmas informações, podem tomar decisões absolutamente díspares, contrariando eficiência que toda decisão pública deve perquirir ${ }^{241}$.

Foi neste contexto que a Public Choice rendeu a James Buchanan e Warren Nutter, quem lhes deu contornos finais em 1959, o Prêmio Nobel de Economia de 1986. A Teoria é claramente estudada no contexto do Law and Economics, a Escola que analisa o Direito de acordo com o critério de eficiência, fundamento da Economia. Naquela seara, estuda-se como se comporta a regra legal (seja ela emanada de que fonte for: norma, jurisprudência ou outras) em termos de eficiência da aplicação dos escassos recursos nas infinitas necessidades do indivíduo e da sociedade ${ }^{242}$.

própria sobrevivência do indivíduo (WALDRON, Jeremy. A Dignidade da Legislação. $1^{\mathrm{a}}$ ed. São Paulo: Martins Fontes, 2003, pp. 50-54), o que só é suavizado com o adimplemento do contrato social representado, sobremaneira, pela obediência às leis. A guerra de todos contra todos mostra como cada qual é motivado por interesses egoísticos, afinal; mesmo os legisladores, então, são incapazes de agir diferentemente.

240 ARROW, Kenneth J. Social Choice and Individual Values, 1963, $2^{\mathrm{a}}$ ed;; sobre o assunto, no contexto social-jurídico-processual, ver SALLES, Carlos Alberto de. "Processo Civil de Interesse Público", em Processo Civil e Interesse Público - O processo como instrumento de defesa social. Carlos Alberto de SALLES - org. - São Paulo: Editora RT, 2003, p. 59.

241 ARROW, Kenneth J. Law and Market Economy: Reinterpeting the Values of Law and Economics. Cambridge University Press: 2000, p. 101.

${ }^{242}$ MERCURO, MEDEMA, Economics and the Law..., p. 14. 
A Public Choice possui foco específico: a demonstração de que o Estado pode falhar na consecução de seus objetivos, ou o estudo dos fracassos de governo $^{243}$. Esses fracassos seriam justamente motivados por interesses individualmente ligados aos próprios governantes ou a grupos articulados de pressão. Invariavelmente, nesse processo deveriam ser sempre consideradas as seguintes premissas: (a) os políticos agem visando a atingir seu interesse pessoal (objetivando obter sua reeleição e o aumento de seu poder ${ }^{244}$ ), nunca precipuamente o bem comum; e (b) o processo político, ladeado por interesses pessoais, funcionaria como o Mercado, com um sistema de ganhos em razão de trocas e privilegiando a equação custo-benefício $^{245}$.

As preferências pessoais próprias do processo político democrático são decisivas para a tomada de decisões sociais. Do feixe de interesses que possui cada gestor incrustado no seio das instituições do Estado gera-se decisão com escopo coletivo ${ }^{246}$. De fato, não são raras aquelas que, na seara da saúde, são tomadas por poucos ou, apenas, por um gestor (o Ministro da Saúde, o secretário de Estado ou municipal de saúde, os chefes do Executivo). Certamente essas decisões contêm maior ou menor carga de preferências pessoais de seus responsáveis ${ }^{247}$, alimentadas de acordo com outros interesses plantados por grupos articulados, podem distorcer a adequada - ou melhor, a eficiente - distribuição de bens sociais ${ }^{248}$. Adotam-se dois exemplos práticos para melhor ilustrar a hipótese.

\footnotetext{
${ }^{243}$ Por isso que a Public Choice é tomada pelos economistas como um contraponto à Economia do bem estar (Welfare Economics), já que, havendo falhas nos processos decisórios baseados nas máximas de Mercado, o Estado teria de dispor de instrumentos para corrigi-las (PEREIRA, Paulo Trigo. "A Teoria da Escolha Pública (public choice): uma abordagem neo-liberal?”, em Análise Social, vol. XXXIII (141), 1997, p. 3).

${ }^{244}$ Nesse sentido, interessante expor a inquietude de TOCQUEVILLE quanto ao que ele denominou instabilidade democrática, ou seja, o contínuo processo de renovação a que se submetem as legislaturas democráticas - daí ele dizer ser essa instabilidade “(...) um mal inerente ao governo democrático.” (A Democracia... Livro 1, p. 292). Tal instabilidade gera o pernicioso efeito do legislador atuar em prol da perpetuação de seu poder.

245 MERCURO, MEDEMA, pp. 84-97.

${ }^{246}$ Para PEREIRA, a grande contribuição de BUCHANAN e da Public Choice foi, exatamente, a percepção que as decisões institucionais, por maior que seja seu resultado coletivo, são, no fundo, tomadas por indivíduos que possuem toda a sua carga de interesses e percepções próprias ("A Teoria da Escolha Pública...”, p. 6).

${ }^{247}$ O sociólogo John ELSTER realizou, em 2000, estudo (intitulado Local Justice) demonstrando que as instituições que determinam “quem obtém o que, quando e como" não seguem qualquer padrão de justiça distributiva na alocação de recursos, usando, para cada situação, o princípio mais conveniente. ELSTER conclui que os políticos (atores de primeira ordem) pretendem atingir a eficiência geral, enquanto que os técnicos da Administração (atores de segunda ordem) almejam a eficiência local e os indivíduos (atores de terceira ordem) pretendem atender seus interesses individuais ou a justiça. FERRAZ e VIEIRA, ao verificarem o estudo em apreço, concluem não surpreender que o modelo de alocação de recursos, afinal, seja um grande acordo de todos os interesses em jogo, prevalecendo aqueles com maior poder de barganha (FERRAZ, Octávio Luiz Motta e VIEIRA, Fabíola Sulpino. "Direito à saúde, recursos escassos e equidade: os riscos da interpretação judicial dominante" pp. 22-23).

${ }^{248} \mathrm{O}$ axioma básico da linha de pensamento intitulada Teoria Política dos Grupos de Interesse é, justamente, que as ações políticas podem ser explicadas no mais basilar comportamento humano: as pessoas agem em
} 
No Maranhão, o governo local de então instalou, em nove cidades no interior do Estado, novíssimos e modernos hospitais. Reportagem do programa Profissão Repórter, da Rede Globo de Televisão, exibida em 5 de junho de 2012, deu conta que esses hospitais estavam completamente vazios: equipes inteiramente ociosas, equipamentos novos ainda embrulhados, um parto realizado a cada três meses, embora os locais contassem com excelente centros neonatais. A reportagem, com razão, concluiu que os hospitais encontravam-se totalmente vazios pela clara falta de demanda: eles foram alocados em pequenos municípios, alguns dos quais com cerca de cinco mil habitantes. $\mathrm{O}$ que justificaria, então, a adoção de grandes centros onde não havia procura? A resposta dada pela própria imprensa é verossímil: todos os municípios da reportagem tinham ligação com o partido da governadora de então. O ano de 2012 era eleitoral, e o Maranhão foi o Estado que mais inaugurara hospitais: sessenta e cinco, todos pagos pelo governo estadual - quarenta e nove, pelo menos, em municípios da base aliada, o que representou cerca de $75 \%$ do total. A reportagem evidencia mais: em um dos hospitais foi instalado um heliponto, que, até a data da reportagem, só havia sido usado pela governadora por ocasião da inauguração do nosocômio (qual seria a serventia de um heliponto em cidade de cinco mil habitantes - e, pior, em hospital público?); contrapartida, em outra cidade, politicamente desalinhada do comando central e vizinha àquela, o hospital, antigo e superlotado, atendia diariamente centenas de pessoas entre sujeira e acúmulo de materiais de reforma ${ }^{249}$.

É cediço que os hospitais brasileiros têm problemas de organização, estrutura, materiais e não dão cabo da demanda. Esta, contudo, não é a realidade do hospital do Senado Federal, o segundo exemplo das vicissitudes motivadas por interesses pessoais nos processos decisórios: mantido pelo SUS, ele é um dos mais modernos e conceituados hospitais da Capital da República. Os parlamentares podem experimentar quaisquer tratamentos nesse hospital e fora dele, sem limite de reembolso. Tratamentos no exterior, inclusive, também são cobertos. Ademais, clínicas privadas recebem verbas do Senado para atendimento de seus servidores fora mesmo daquele hospital que, por sinal, é subutilizado $^{250}$.

seu próprio proveito (MASHAW, Jerry L. "The Economics of Politics and the Understanding of Public Law, in Chicago-Kent Law Review, v. 65 - 1989- p. 126).

${ }^{249}$ Programa disponível, na íntegra, em: <http://g1.globo.com/profissao-reporter/noticia/2012/06/hospital-nointerior-do-maranhao-tem-mais-funcionarios-do-que-pacientes.html>, acesso em 22.6.2012, 13:14h.

${ }^{250} \mathrm{O}$ hospital do Senado ocupa uma área nobre do Distrito Federal de mais de $2.500 \mathrm{~m}^{2}$, usando mais de cinco milhões de reais por ano para atender menos de cinco mil pessoas por mês. Estudo contratado pelo Senado para apontar meios de gestão mais eficaz de seus recursos, elaborado pela Fundação Getúlio Vargas, 
Estes dois exemplos revelam escolhas: recursos públicos foram desnecessariamente direcionados para cobrir contingências de ordem exclusivamente política, por mais que travestidas de interesse público - robustos hospitais em municípios alinhados com o poder central, de um lado, e paradoxo entre o SUS dos parlamentares e o SUS do cidadão comum. Em um e outro caso, vultosos recursos foram aplicados e aproveitados em favor, precisamente, de quem tinha o poder para destinar seu uso. Tais recursos, nada obstante, são escassos. Os fatos comprovam a teoria ${ }^{251}$.

Arrow e a Public Choice causaram incômodo nos escalões do poder, porque aparentemente tratavam os políticos como uma espécie de chantagistas, que tomavam suas decisões apenas de olho em seus ganhos pessoais, e nunca no interesse público. Mais do que isso: de acordo com a - diga-se - catastrófica constatação da Public Choice, se o processo político é um jogo de cartas marcadas e serve apenas para atendimento de interesses individuais e motivados por grupos de pressão, porque se insistir na democracia? Seria mais útil, então, concentrar os esforços na influência a ser exercida sobre os atores decisórios, a fim de propiciar a concretização de uma política favorável ${ }^{252}$.

Os reflexos jurídicos dos interesses políticos são inequívocos. Se decisões são tomadas no âmbito das instituições estatais justamente com vistas a fazer com que o Estado cumpra com seus deveres constitucionais, normativamente positivados, qualquer decisão que trabalhe, por exemplo, com metas e recursos na seara da saúde terá claro reflexo jurídico. Daí a relevância jurídica do estudo da Public Choice. Richard Posner chegou a afirmar que “(...) a legislação é vendida pelos legisladores e comprada pelos respectivos beneficiários (...) ${ }^{, 253}$, aproximando à mais basilar regra de Mercado o processo de elaboração das leis ${ }^{254}$.

apontou que o serviço médico daquela Casa - da qual faz parte o hospital - deveria ser extinto. Não foi. Em 2012, tal serviço foi alvo de denúncias porque clínicas particulares capitaneadas pelos médicos do Senado recebiam verbas da própria Casa Legislativa para atendimento de servidores. Os médicos, que chegavam a receber quarenta mil reais apenas para atender no hospital, acabavam engordando suas finanças com as verbas públicas repassadas para suas próprias clínicas - ou seja, um serviço subutilizado em hospital próprio ainda recebia verbas extras para propiciar atendimento em clínica privadas ( $<\mathrm{http}: / / \mathrm{www}$.istoe.com.br/reporta gens/256069_MARAJAS+DE+JALECO>, acesso em 27.7.2013, 15:36h).

${ }^{251}$ As próprias Emendas ao Orçamento, referidas no Item 2.3, podem ser malversadas justamente com vistas a beneficiar não a totalidade dos eleitores de determinado parlamentar, mas o grupo que garantirá sua reeleição.

${ }^{252}$ Esta é a visão de uma das correntes da Teoria, defendida pelo já citado ARROW. Neste sentido, v. MASHAW ("The Economics of the Politics...", p. 127).

${ }^{253}$ FARBER, Daniel; FRICKEY, Philip. Law and Public Choice: A Critical Introduction. University of Chicago, 1991, pp. 6-7.

${ }^{254}$ É inevitável aproximar algum aspecto das políticas de saúde com o Mercado, já que boa parte da assistência nessa seara é privada, prestadas por clínicas, hospitais e profissionais que não são mantidos ou congregam a Administração Pública. O histórico da prestação dos serviços públicos de saúde no Brasil bem demonstra tal realidade: desde o princípio o modelo particular foi privilegiado (ver adiante, no Item 4.2.1). É 
Mas a rigidez da Teoria, todavia, era merecedora de temperos e, nesse sentido, destaca-se a obra de Daniel Farber e Philip Frickey. Estes autores apontaram críticas à aplicação jurídica da Public Choice, sendo a maior delas a ignorância de dados empíricos e sustentação que as decisões emanadas dos processos políticos eram destituídas de toda e qualquer ideologia (já que baseadas inteiramente no interesse pessoal de quem decidiria), citando, como exemplo de sua crítica, o malfadado fenômeno do nazismo e estudos feitos pela $A D A$ - Americans for Democratic Action ${ }^{255}$-, que comprovaram o conteúdo ideológico de inúmeras decisões. Na verdade, os autores adicionaram mais um elemento ao caldo de interesses que lastreia qualquer decisão que, entre nós, à guisa exemplificativa, for publicada no diário oficial ou sentida na pele pelas pessoas.

A relevância da Public Choice para a análise dos processos estatais decisórios se dá por ser necessário conhecer em que medida e como atuam os interesses privados no trato da coisa pública, tudo com vistas a tornar as decisões sociais mais eficazes. A Teoria não é imoral: ela apenas constata que a atividade decisória possui variáveis que, normalmente olvidadas, são fundamentais ${ }^{256}$. Mais do que isso: considerando essas variáveis, é possível avaliar quem, dos atores estatais capazes de tomar decisões, é aquele mais adequado ou, antes, o menos vulnerável aos grupos de pressão ou aos interesses individualistas ${ }^{257}$.

No fundo, a Public Choice serve para explicar que a democracia é muito mais complexa do que, simplesmente, o sufrágio ou o majoritarismo, e que algumas decisões são tomadas de maneira arbitrária, porque baseadas em interesses pessoais, principalmente sobre aqueles mais concentrados, em detrimento dos mais dispersos ${ }^{258}$. É

verdade que o Estado estabeleceu um mecanismo regulador da atividade privada nesse campo - a Agência Nacional de Saúde Suplementar - que, por si somente, é incapaz de controlar inteiramente os efeitos mercadológicos da saúde. Para dom Odilo SCHERER, Cardeal Arcebispo de São Paulo, comentando a Campanha da Fraternidade de 2012, "Na medida em que se terceirizam os serviços de saúde, vira comércio, eles acabam sendo submetidos às leis de mercado”, em Folha de São Paulo (edição de 5 de março de 2012, p. A16). Se, em alguma medida, a prestação de serviços de saúde flutua ao sabor do Mercado, é evidente que alguns interesses não serão contemplados e a saúde não será prestada em sua plenitude, como quer a Constituição.

255 <http://www.adaction.org>, acesso em 12.4.2011, 18:33h.

${ }^{256}$ MASHAW, "The Economics of the Politics...", p. 130.

${ }^{257}$ O problema dos interesses privados na tutela da saúde é muito grave. De fato, são eles inúmeros e variados, manifestados por parte de, igualmente, inúmeras e variadas pessoas, que divergem e se mostram decisivas para a definição das políticas respectivas no sistema brasileiro. Apenas como exemplos das vicissitudes que permeiam o atendimento administrativo ao interesse público legítimo no que toca à saúde, ver BARATA, Luís Roberto Barradas e MENDES, José Dínio Vaz. "Uma proposta de política de assistência farmacêutica para o SUS”, em BIACHERIENE, Ana Carla e SANTOS, José Sebastião dos (Org.). Direito à Vida e à Saúde, . São Paulo: Atlas, 2010, pp. 68-69. Mais sobre o tema será exposto, com riqueza de detalhes, nos Itens 4.1.2. e 4.1.3. adiante.

${ }^{258}$ FARBER e FRICKEY, Law and Public Choice..., pp. 3-5. 
esta a base da Interest Group Theory of Politics (Teoria Política dos Grupos de Interesse): o estudo empírico de Farber e Frickey constatou que, no processo legislativo e nas decisões administrativas nos EUA, os interesses mais concentrados prevaleciam sobre os mais $\operatorname{dispersos}^{259}$.

A partir disso, viu-se que a Public Choice servia para estudar a atuação de grupos de pressão no processo decisório e, ao mesmo tempo, a dificuldade de agrupamento diretamente proporcional à difusão dos interesses em jogo (daí se organizarem melhor os grupos com menos interessados, cuja parcela de interesse pessoal é mais aviltante, autêntica releitura da democracia baseada exclusivamente no princípio majoritário) ${ }^{260}$. Como demonstrou Arrow, é matematicamente impossível que uma decisão política atenda a todas as preferências pessoais, daí sendo necessário, tanto quanto possível, que tais decisões sejam eficientes. A Public Choice e sua vertente, a Teoria Política dos Grupos de Interesse, demonstram que essa eficiência pode ser comprometida ora por conta dos anseios dos gestores administrativos, ora em função da articulação de grupos de pressão. Este aspecto revela que, dependendo da concatenação de ações de determinados grupos (observando as tendências majoritárias e minoritárias) ${ }^{261}$, a parcela de interesses da sociedade que será desatendida poderá variar de acordo com motivos artificiais (novamente, os interesses egoísticos dos administradores e dos grupos de pressão). Por isso que a Public Choice consegue explicar falhas nos processos decisórios sociais.

\footnotetext{
${ }^{259}$ Nesse sentido, SALLES, Carlos Alberto de. "Políticas Públicas e a Legitimidade para a Defesa de Interesses Difusos e Coletivos", em Revista de Processo 121 (março de 2005). São Paulo: Editora RT, p. 46. Sobre as vantagens dos minoritários, OSTROM, Elinor. Governing the Commons: The Evolution of Institutions for Collective Action. Cambridge, Cambridge University Press, pp. 6-7. Um dos diagnósticos apontados por Neil K. KOMESAR (Imperfect Alternatives: Choosing Institutions in Law, Economics, and Public Policy. The University of Chicago Press, Ltd., London, 1994), que dá conta das dificuldades de articulação dos grupos mais dispersos, é o free-riding, ou efeito carona, que, em suma, se manifesta quando grande parte do grupo permanece inerte (economizando, assim, seus próprios recursos - como tempo, dinheiro, oportunidade), aguardando a atuação de alguns poucos para, de carona, receberem os futuros e eventuais benefícios. Se os caronas se articulassem melhor, a atuação do grupo seria reforçada. Novamente, mais um efeito do egoísmo ínsito a cada ser humano.

${ }^{260}$ CAMPILONGO, Direito e Democracia..., pp. 29-30. Nesse enleio, não se pode perder de vista que a experiência adquirida pelas articulações dos grupos minoritários funciona, basicamente, de acordo com o conceito de litigância habitual desenvolvido por Marc GALANTER ("Afterword: Explaining Litigation", in Law and Society Review, v. 9, 1975, pp. 347-360). Como os litigantes habituais, os grupos mais bem organizados podem contar com vantagens em relação à maioria dispersa, em termos de: (a) planejamento; (b) economia de escala, porque podem atuar em várias frentes; (c) desenvolvimento de relações informais com as autoridades, dada a habitualidade; (d) diluição dos riscos pelo número de casos; e (e) teste de estratégias. No mesmo diapasão, CAPPELLETTI, Mauro, e GARTH, Bryant. Acces to Justice: The Worldwide Movement to Make Rights Effective. Trad. Ellen Gracie Northfleet (Acesso à Justiça), Porto Alegre, Sérgio Antonio Fabris Editor, reimpressão 2002, pp. 25-26. De igual forma atuam, então, os grupos de pressão.

261 Sobre grupos de interesse, ver SMITH, Rogers M. "Political Jurisprudence, the 'New Institutionalism' and the Future of Public Law”, in American Political Science Review, V. 82, nº 1, March 1988, pp. 89-107.
} 
Uma abordagem diferenciada da Public Choice foi realizada por Neil K. Komesar, que se propôs a examinar cada arena capaz de emanar decisão relevante na sociedade e, verificando sua maior ou menor suscetibilidade a determinados interesses, estabelecer, dentre todas, a mais eficaz. Existindo inúmeros atores imbuídos de poder social decisório, entendeu Komesar ser necessário que se analisasse, para certas definições (como as relacionadas às políticas públicas), quem seria o player que poderia gerar aquela mais eficaz.

De acordo com o autor, apesar da escolha entre os variados objetivos ou valores sociais ser um importante ingrediente para avaliar e entender os efeitos da relação entre o Direito e as políticas públicas, isoladamente essa análise não fornece dados efetivos sobre o que são ou o que deveriam ser tais efeitos. Prossegue afirmando que falta saber quem decide, porque, na medida em que um objetivo social abstrato pode se enquadrar em larga gama de políticas públicas, a consciência a respeito da titularidade do poder de decisão determina sob o espectro de qual política pública tal objetivo será atingido. Esse é o principal aspecto da denominada Institutional Choice, ou Escolha Institucional: é ela que liga os objetivos sociais com seus resultados legais ou em termos de políticas públicas ${ }^{262}$. Para que se saiba qual política pública será a mais provavelmente adotada, é imperioso conhecer quem a decide.

Pois a variação de instituições dotadas de poder de decisão significa ter que escolher, e escolher entre o que é mais conveniente, quem mais atenderia os interesses pessoais e dos grupos de pressão - sejam majoritários ou minoritários ${ }^{263}$ - e qual a arena mais eficiente para perquirir a concretização de determinadas políticas públicas. Com efeito, avaliar quem decide é fundamental para antever o teor da decisão a ser tomada e o que é determinante em um universo de possibilidades, porque aí será possível mapear onde estão e quais os tipos de falhas advindos de cada ator decisório.

Komesar parte de um importante pressuposto: para ele, nunca haverá um player com total eficiência, um agente ou instituição que decida livre de interesses privados ou grupos de pressão. Ele assevera que esta será a maior dificuldade da Institutional Choice como teoria definitiva para estabelecer quais atores decidem certos temas em determinados casos, haja vista que qualquer opção por inúmeras das instituições

\footnotetext{
${ }^{262}$ KOMESAR, Imperfect Alternatives..., pp. 4-5.

${ }^{263}$ KOMESAR assume que também os grupos com interesses mais dispersos têm um lugar ao Sol, podendo influir pesadamente na tomada da decisão estatal. Sua análise leva em consideração a influência que as tendências majoritárias e minoritárias acarretam nos processos decisórios, o que ele chama de modelo de duas forças (two-force model - Imperfect Alternatives..., pp. 53-97). No mesmo sentido, SALLES, "Políticas Públicas"..., pp. 44-47.
} 
estabelecidas sempre envolverá uma "escolha entre alternativas imperfeitas", pois as mazelas, restrições e qualidades dos diversos players levam a crer que, qualquer deles que seja o escolhido, não será o ente perfeito para aquinhoar a decisão esperada ${ }^{264}$.

Tal conclusão e as lições extraídas da Public Choice demonstram a volatilidade de qualquer processo decisório, sobretudo aqueles que envolvem o tema das políticas públicas, ações governamentais implementadas em prol da sociedade segundo direção e mandamento constitucional, que demandam planos, programas, atos continuados e acompanhamento. Essa volatilidade, por vezes, pode significar a tomada de uma decisão inadequada, a resultar na inobservância de um verdadeiro valor constitucional afetado a certa política pública.

Certamente, em temas de políticas públicas e sob o ponto de vista exclusivo da Public e da Institutional Choice há um ator, que se vale de um específico mecanismo capaz de minimizar ${ }^{265}$ os problemas levantados neste item. Trata-se do Judiciário, usando o meio pelo qual usualmente se manifesta: o processo $^{266}$. Se for verdade que os magistrados estão menos suscetíveis às pressões sociais articuladas, tanto porque decidem com base na norma, quanto porque o fazem por meio de um devido processo legal, que requer decisões fundamentadas e públicas, então estará explicado porque o Judiciário é arena tão simpática a entregar políticas públicas.

Mas é bom frisar, desde logo, a concordância com a conclusão de Komesar. Se o processo judicial é uma via de entrega de bens sociais, ele também não é perfeito, possui seus limites e vicissitudes. Antes de demonstrar quais são eles ${ }^{267}$, é tempo de se definir em que termos os juízes podem intervir em políticas públicas.

\footnotetext{
${ }^{264}$ KOMESAR, Imperfect Alternatives..., p. 5.

${ }^{265}$ Minimizar é o termo correto. Como os recursos são escassos a as necessidades infinitas, qualquer que seja a decisão, qualquer que seja o ator, alguém será prejudicado quando se trata de bens públicos. Não se pode perder de vista, nesse sentido, o paradigma econômico de Kaldor-Hicks, segundo o qual será mais eficiente a decisão que, beneficiando o maior número de pessoas, prejudique o menor espectro possível. Sobre KaldorHicks, ver MERCURO e MEDEMA, Law and Public Choice..., além de GOLDBERG, Daniel K. "Controle de Políticas Públicas pelo Judiciário: Welfarismo em um mundo Imperfeito. Capítulo disponíve 1 no website: 〈http://www.ipea.gov.br/sites/000/2/livros/regulacaonobrasil/Arq07_Cap03.pdf〉, acesso em 10.10.2010, 10:00h.

${ }^{266} \mathrm{O}$ que será visto, com mais vagar, no Item 3.2.5. Mas é bom que desde já se frise: embora a grande relevância do processo judicial como vetor da implementação de políticas públicas olvidadas pelos Poderes majoritários repouse no seu método, seu uso desmedido, descontrolado e abusivo pode produzir resultados ainda piores que a própria omissão do Poder Público, tema crucial nesta tese, a ser abordado nos Capítulos 4 e 5 .

${ }^{267}$ No Item 3.2.5 será apresentada tabela em que haverá o cotejo analítico de cinco atores responsáveis por decisões públicas, o Legislativo, o Executivo, o Judiciário, o Mercado e a Sociedade Civil, marcando-se suas vantagens e desvantagens.
} 


\subsubsection{Intervenção e controle}

O processo judicial é poderoso instrumento para correção das falhas inerentes aos procedimentos ordinários de decisão política e social, e isso se dá, como antecipado no item anterior, por uma série de razões, analisando-se o instrumento (processo) e a arena (Judiciário): (a) o processo é legal, vale dizer, ele é definido nas normas constitucionais e legais, sendo competência privativa da União legislar sobre a matéria $^{268}$, ou seja, juízes não podem decidir sem adotar os cânones processuais; (b) o processo é informado pela ampla defesa e pelo contraditório $^{269}$, com o que sempre há a oportunidade de contraposição - nesse caso, do Poder Público, quando demandado a sanar falhas; (c) o processo é, sempre, encerrado por uma decisão motivada, como motivadas são todas as decisões relevantes manifestadas ao longo do processado, o que permite ao jurisdicionado conhecer os motivos de convicção do magistrado; (d) tal decisão sempre se fundamenta em normas, o que evita que o juiz decida com base em preferências ou interesses; e (e) o juiz é o ator institucional dotado da prerrogativa de ordenar aos demais Poderes que cumpram as regras vigentes no Estado Democrático de Direito.

Em um cenário de Estado Constitucional de Direito, em que a Constituição desempenha papel fulcral no ordenamento jurídico e, de conseguinte, na vida das pessoas, aquele que tem a derradeira palavra sobre o verdadeiro conteúdo das normas constitucionais, apta a todos e a qualquer um obrigarem, goza de poder notável, criticável, invejável. No Estado brasileiro, o Judiciário exerce esse papel. No arranjo institucional brasileiro, não fossem os juízes, as falhas nos processos tradicionais de decisão pública não teriam instrumento razoável de correção. A deixar que o próprio procedimento democrático se encarregasse dos problemas, muitos dos direitos em questão não seriam observados.

Em tema de políticas públicas, contudo, dentro da dinâmica constitucional, aos magistrados é reservada a prerrogativa de agir na falha, lacuna ou falta de atuação dos Poderes majoritários, é dizer, ao Judiciário não é dado, a princípio, definir e executar políticas públicas. Nesse tocante, magistrados agem na omissão dos demais Poderes, e não como protagonistas prévios na prestação de bens sociais.

\footnotetext{
${ }^{268}$ Art. 22, I, Constituição.

${ }^{269}$ Art. 5, LV, Constituição.
} 
Isso porque o Judiciário é o guardião do ordenamento jurídico. Se não forem observadas as normas constitucionais, legais e administrativas por parte do Legislativo e do Executivo, então os juízes podem determinar providências concretas que visem a debelar a ação ou omissão inconstitucional ou ilegal. A primazia da definição da Constituição, não obstante, é do Legislativo, da mesma forma como ocorre com as leis. Quem executa os preceitos encartados em ambas as espécies normativas, em termos de políticas públicas, é, usualmente, o Executivo. Já se anotou a prerrogativa desses dois Poderes em assim proceder. Ato contínuo, apenas na sua omissão ou ação antijurídica é que podem agir os juízes, embasados na Constituição e nas leis ${ }^{270}$.

$\mathrm{Na}$ ação antijurídica, o Judiciário atua como uma espécie de legislador negativo, já que infirma e torna ineficaz (inclusive como efeito de declaração de inexistência ou nulidade) o ato normativo legislativo ou administrativo. Isso sucede quando o juiz entende que uma política pública definida em lei não goza de respaldo frente à Constituição, seja por suas normas, seja por seus valores. Na omissão antijurídica, o juiz, baseado igualmente na Constituição, supre tal omissão, muitas vezes determinando providências que equivalham ao cumprimento da norma caso inexistisse a omissão. Neste ponto, aliás, há todo um ferramental específico para que o jurisdicionado possa acessar o Judiciário na busca por seus direitos, como o mandado de injunção e a ação direta de inconstitucionalidade por omissão ${ }^{271}$.

Mesmo o ato que goze de margem de conveniência e oportunidade, o ato discricionário, próprio da Administração, pode ser objeto de escrutínio judicial. Questionava-se a respeito da ingerência dos magistrados no juízo de escolhas do agente público. Por muito tempo, o próprio Judiciário entendeu não ser possível adentrar no mérito administrativo ${ }^{272}$. Acerta, contudo, quem entende que desde 1965 havia autorização legal para que os juízes analisassem o pano de fundo do ato. Quando a lei que instituiu a ação popular estabeleceu como objeto daquele instrumento a anulação de ato lesivo à moralidade administrativa, então abriu as portas para os juízes avaliarem o conteúdo do ato administrativo ${ }^{273}$. E não somente: também no momento em que a mesma lei permitiu

\footnotetext{
${ }^{270}$ A atuação residual ou interventiva do Judiciário pode ser vista em Maria Tereza SADEK, quando ela estabelece que, em tese, não há decisão, quer proferida pelo Executivo, quer aprovada pelo Legislativo, que não seja passível de apreciação judicial (“Judiciário e Arena Pública...," p. 15). O pressuposto da atuação judicial nas políticas públicas, portanto, é a existência de decisão, seja administrativa, seja legislativa. Evidentemente que também a omissão antijurídica permite a intervenção jurisdicional.

${ }^{271}$ Sobre o uso desses dois instrumentos na intervenção jurisdicional em políticas públicas, ver ONODERA (“O Controle Judicial...", pp. 419-432).

${ }^{272}$ Ver nota de rodapé n ${ }^{\circ} 5$ em GRINOVER (“O Controle Judicial...”., p. 126).

273 GRINOVER, “O Controle Judicial...”, p. 127.
} 
ao magistrado anular ato administrativo que padecesse de inexistência de motivos ou de desvio de finalidade $e^{274}$, acertou em cheio os dois mais discricionários elementos do ato próprio da Administração ${ }^{275}$.

Para que o juiz aja, contudo, é preciso existir movimento anterior dos Poderes majoritários, que ou atuam ou se omitem de modo a infligir prejuízos aos direitos do ordenamento. É aí, e só aí, que o juiz - originalmente inerte - poderá exercer seu papel. Uma vez vergastado o direito, pode o magistrado ser acionado e, no mais em diante, o processo seguirá seu rumo até seu desfecho, por impulso oficial, constatando-se ou não a ação ou omissão majoritária danosa e determinando-se medidas práticas para sua correção.

Daí a precisão do conceito do Judiciário interventor em políticas públicas. Essa intervenção, por sinal, dá-se em moldes de controle, já que, sanando inconstitucionalidade ou ilegalidade, a decisão judicial termina por controlar as atuações dos demais Poderes no que toca ao arranjo de políticas públicas. É por isso mesmo que a expressão controle jurisdicional de políticas públicas, ultimamente tão consagrada, é plenamente adequada. De fato, não há maneira de o Judiciário sindicar, na origem, políticas públicas não previstas constitucionalmente, sejam positivadas, sejam oriundas dos fundamentos basais do ordenamento. Trata-se de argumento fulcral para o desenvolvimento da linha adotada nesta tese.

O próprio Judiciário reconheceu que sua atuação se dá em medidas de intervenção. Na celebrada ADPF $n^{0} 45$, o STF entendeu que o papel judicial no que diz respeito a políticas públicas será cabível quando a omissão implicar a não observância de condições mínimas de existência humana, padecendo-lhe razoabilidade, e quando o pedido de intervenção se mostrar razoável ${ }^{276}$. Nesse, que pode ser considerando um leading case da intervenção judicial em políticas públicas no Brasil, o STF fixou a evidente compreensão de que a intromissão dos juízes nas políticas públicas só ocorre, mesmo, caso falhe o plano de competência primária dos Poderes majoritários. É, invariavelmente, forma de controle.

$\mathrm{Na}$ verdade, é este o primeiro limite à atuação jurisdicional nas políticas públicas. Juízes só agem quando Legislativo e Executivo não cumprem suas obrigações

\footnotetext{
${ }^{274}$ Alíneas $d$ e $e$ do art. $2^{\circ}$ da Lei $\mathrm{n}^{\circ} 4.717 / 65$. Dentre os motivos do ato claramente estão abrangidas as escolhas objeto de conveniência e oportunidade. Nesse contexto, se o legislador, expressamente, definiu que se consideram inexistentes os motivos quando o ato estiver destituído de suporte material fático ou se for ele juridicamente inadequado, como argumentar que o juiz não poderia analisar seu mérito? Afinal, verificar se ele é juridicamente adequado é penetrar até a raiz no juízo discricionário do administrador.

275 Sujeito, objeto, forma, motivo e finalidade.

${ }^{276}$ ADPF n ${ }^{\circ}$ 45-9/DF, Rel. Min. Celso de MELLO, DJ em 4.5.2004, j. em 29.4.2004.
} 
constitucionais, seja porque agiram equivocadamente, seja porque pura e simplesmente se omitiram. Em qualquer hipótese, a atitude jurisdicional é corretiva. A questão é que, por uma série de motivos, o Judiciário, mesmo agindo residualmente, termina por assumir papel preponderante na distribuição de bens públicos, como se fosse verdadeiro definidor de políticas públicas na origem. E isso pode acarretar problemas. É o que se verá mais $\operatorname{adiante}^{277}$.

${ }^{277}$ No Item 3.1. 


\section{OS EXCESSOS DA ATUACC̃̃O JURISDICIONAL}

\subsection{PANORAMA ATUAL DO PROBLEMA}

Neste Capítulo serão apontados os mais sensíveis problemas que circundam a tutela jurisdicional de políticas públicas de maneira geral, vale dizer, as questões aqui apresentadas referem-se à distribuição judicial de bens sociais e interferência jurisdicional em políticas públicas. No Capítulo seguinte, estudar-se-ão temas especialmente voltados à saúde.

O Judiciário no Brasil vive um tempo de supremacia. Hoje algumas das principais questões do País são decididas no foro, notadamente, no STF, a principal casa judiciária. Claramente há por aqui, como em outros lugares do mundo, hipótese de superioridade hierárquica das decisões judiciais. As razões para isso ocorrer são inúmeras.

A primeira é clara: em um cenário de Judicial Review como o brasileiro, o Judiciário - e, notadamente, o STF, a Corte Constitucional - assume papel de destacada relevância. Grosso modo, qualquer ação da sociedade ou ato normativo - administrativo ou legal - contrário à Constituição é passível de submissão à análise judicial, que terá por efeito opor-se imperativamente, afastando de maneira definitiva a ação social, o conteúdo dos atos normativos e, ato contínuo, seus efeitos. É decorrência básica de uma Constituição e de um Judiciário reforçados. Este é, na verdade, o principal motivo pelo qual as cortes exercem tarefa tão importante ${ }^{278}$.

A ascensão do Judiciário como arena de debate político e social e do processo como seu veículo também decorre da leniência dos Poderes majoritários ${ }^{279}$ e do

\footnotetext{
278 “'Não importa', diz o Sr. Dooley, 'quem elabora as leis em uma nação se eu puder me valer de uma decisão judicial',' (HOROWITZ, Donald L. The Courts and Social Policy, Washington D.C.: The Brooking Institution, 1977, p. 1). V. Epígrafe.

${ }^{279}$ Uma das mais tormentosas questões levadas à arena política em 2013 foi o marco regulatório da exploração de petróleo no chamado Pré-Sal, sobretudo quanto à repartição, entre Estados, das receitas oriundas de dita exploração (ali chamadas royalties). Em jogo de forças entre Estados produtores (como Rio de Janeiro, Espírito Santo e São Paulo) e outros que assim não se qualificavam, debateu-se ao longo de boa parte daquele ano se aqueles deveriam participar do quinhão de maneira mais contundente que estes. A Presidente da República vetou os dispositivos que, aprovados no Congresso, não privilegiavam os produtores. O Congresso, então, articulou-se para derrubar o veto presidencial quando um grupo de parlamentares que representavam os produtores arguiu, no STF, que o Parlamento deveria, antes de analisar o veto à questão da distribuição dos royalties, avaliar todos os três mil e sessenta vetos presidenciais que, desde 2000, ainda pendiam de exame pelos legisladores. O Min. Luis FUX, então, deferiu medida urgente, impedindo que a votação da questão em tela "furasse a fila" dos demais vetos
} 
desinteresse calculado pelo descolamento de certas questões da arena política ao foro judicial $^{280}$. Com políticas públicas não sucede diferentemente: a tendência é que cada vez mais os juízes se vejam compelidos a tratar de temas que, originalmente, não deveriam lhes dizer respeito, senão para corrigir falhas dos demais Poderes.

Interessante trabalho mostra que pode haver uma transferência estratégica de algumas decisões ao Judiciário: Ran Hirschl teorizou que os processos decisórios são tomados por três elites: as políticas, as econômicas e as judiciais. Analisando o papel das cortes em Canadá, Israel, Nova Zelândia e África do Sul, Hirschl constatou que as elites política e econômica podem transferir uma decisão originalmente sua para os juízes de forma a evitar a erosão de seus respectivos poderes, gerando benefícios a todos. Para as elites judiciais, isso significaria maior poder e prestígio; para as elites econômicas, a garantia de observância da propriedade privada; para as elites políticas, a proteção mais eficaz de suas preferências, sem o desgaste esperado. Resultado óbvio do fenômeno é o aumento do poder judicial, o que motiva o autor a cunhar como representativo o termo Juristocracia ${ }^{281}$.

Tradicionalmente e em função dos diversos limites e freios normativos impostos ao atuar jurisdicional, é correto afirmar que magistrados só intervêm quando são

(<http://oglobo.globo.com/economia/royalties-fux da decisao favoravel produtores votacao de vetos suspensa-7077672>, acesso em 19.12.2012, 20:35h). O interessante dessa decisão não é apenas a comprovação da ingerência do Poder Judiciário em assunto predominantemente político - já que as votações, propostas, vetos e projetos de lei são temas ligados a tal ramo - mas, também, o assustador número de vetos não deliberados desde o ano 2000 - repita-se, três mil e sessenta (O Globo, edição de 19.12.2012, nº 28.989, capa e pp. 31-32). Gustavo BINENBOJM entende que, no caso, não há qualquer intromissão indevida do Judiciário nas coisas do Legislativo, porque, segundo ele, a Constituição é clara quando manda que os vetos sejam analisados em trinta dias e, caso assim não suceda, sejam eles colocados na ordem do dia para votação na sessão imediatamente ulterior ("O Supremo e a agenda legislativa”, em O Globo, edição de 27.2.2013, $\mathrm{n}^{\circ} 29.059$, p. 21). Nada obstante, ao examinar a liminar, o STF, por seis votos a quatro, vergastou a posição do Relator, considerando que ela conflitava com a harmonia e a independência dos Poderes ("STF libera Congresso para votar vetos como quiser”, em Folha de São Paulo, edição de 28.2.2013, nº 30.647, p. A8). Se alguém tem dúvida dos efeitos que o Judiciário opera nos Poderes políticos, este episódio ensina muito. Além do já relatado e da decisão final, que, repita-se, considerou que o STF não deveria se intrometer na questão dos vetos, o próprio Congresso alterou seu Regimento Interno para determinar que vetos presidenciais devam ser analisados em até trinta dias, sob a consequência de trancar a pauta do Legislativo. Essa medida só foi tomada após o debate travado no STF.

${ }^{280}$ Com efeito, é de todo interesse do legislador que temas espinhosos sejam discutidos no Judiciário. O desgaste político da assunção de uma ou outra posição poderia marcar a carreira de deputados, senadores e vereadores de forma perene. Aqui se lança uma indagação: será que a tão alardeada ausência de racionalidade e parametrização de critérios para a dispensação judicial de saúde não atende os próprios interesses da Administração Pública? Será que, diante da escassez de recursos e da infinidade de necessidades, não seria estratégico apagar focos de incêndio pontuais, representados pelas medidas judiciais, contemplando aqueles que conseguem se dirigir ao Judiciário? A tendência, diante das costumeiras reclamações do Executivo sobre a indevida ingerência do Judiciário nas políticas de saúde e relevando o árduo trabalho dos gestores de saúde para levar a todos esse direito, é responder negativamente. Mas fica a inquietação.

${ }^{281}$ HIRSCHL, Ran. Toward Juristocracy: The Origins and Consequences of the New Constitutionalism. Cambridge: Harvard University Press, 2004. 
provocados e quando enxergam, efetivamente, violação a direitos, em termos, como já visto, de intervenção e controle. Tais afrontas, não raras vezes, são fruto da inatividade legislativa e executiva.

Nesse sentido, é emblemática a declaração de um ministro da Suprema Corte brasileira no sentido de que o Congresso vivia um " $f a z$ de conta" e que Legislativo só se firmaria diante da sociedade quando agisse a contento e de modo adequado. Segundo o magistrado, é preciso colocar um fím à "inapetência” do congresso ${ }^{282}$. Quando a sociedade enxerga o Legislativo como ineficaz, como já discorrido, isso tem um peso e um sentido; quando é um ministro do STF a manifestar tal vicissitude, tal soa como um tiro de canhão, sobretudo no delicado momento institucional vivido no Brasil de hoje $\mathrm{e}^{283}$.

Essa supremacia jurisdicional desperta alguns problemas: o primeiro, o poder acusadamente desenfreado dos juízes que decidem sem maiores medos, receios, preocupações e sem o dever de prestação responsável de contas, ou accountability; o segundo, que juízes estão assumindo as vestes dos agentes dos demais Poderes, sem terem, contudo, tino ou preparo para tanto. Ambos os problemas convergem para o risco de decisões judiciais inadequadas, ilimitadas ou, antes, excessivas.

O que será examinado, neste Capítulo, é, justamente, a existência de excessos cometidos por decisões judiciais que sindicam políticas públicas. Será visto que alguns aspectos são indissociáveis das políticas públicas, aspectos esses que não são muito afeitos aos juízes.

\subsection{PROBLEMAS E DIFICULDADES DA INTERVENÇÃO JUDICIAL EM POLÍTICAS PÚBLICAS}

3.2.1 O orçamento e os custos dos direitos: o cobertor curto

O debate da tão controvertida questão de o Judiciário sindicar políticas públicas, notadamente as de saúde, faz muito sentido à luz da escassez. Explica-se:

\footnotetext{
${ }^{282}$ As declarações foram emanadas no contexto do descumprimento, por parte do Congresso, da decisão do Supremo Tribunal Federal que estabelecia prazos para edição de novos critérios para o rateio do Fundo de Participação dos Estados. "Congresso vive 'faz de conta', diz ministro". Folha de São Paulo, edição de 3.1.2013, $\mathrm{n}^{\mathrm{o}} 30.591$, p. A6.

${ }^{283}$ V. nota 16.
} 
imagine-se situação como aquela em que a Constituição determina que todas as crianças tenham o subjetivo direito de inscrição em creches e pré-escolas públicas até os cinco anos de idade $^{284}$. Imagine-se, ato contínuo, que o Executivo atendesse voluntariamente à determinação normativa e absolutamente todas as crianças nessas condições gozassem essa sua prerrogativa: nesse caso, ninguém teria o que reclamar. Se, entretanto, um único infante não fosse contemplado, a violação ao seu direito subjetivo daria causa a uma reclamação ao Judiciário. E não são desconhecidos os inúmeros casos nesse sentido, alguns dos quais trazidos ao escopo desta tese ${ }^{285}$.

A raiz da busca judicial pela tutela desses direitos passa, invariavelmente, pela escassez. Ainda que a ação da Administração Pública no cumprimento dos mandamentos constitucionais fosse irrepreensível sob o ponto de vista estratégico - ou seja, ainda que o administrador não omitisse uma única vírgula na correta aplicação da norma - todos os direitos dessa estirpe seriam atendidos: certamente se imporiam os obstáculos da insuficiência de recursos financeiros. Se há problemas nas escolhas, há, também, o problema da escassez ${ }^{286}$. E é inegável que as normas, mormente as constitucionais, contribuíram decisivamente para a agudez do problema.

A Constituição de 1988 foi ambiciosa: alinhou-se com o que de mais moderno havia em termos de direitos humanos, buscou outorgar ao Estado a dispensa de grande parte dos bens e direitos necessários à vida digna, estabeleceu a obrigatoriedade do Poder Público em cumprir esse seu novel papel, fosse pelos Poderes majoritários, fosse pelos juízes. Mas houve quem se preocupou, durante as discussões que resultaram no Texto, com uma questão inquietante: quem pagaria a conta?

O economista Roberto Campos, que foi Deputado Nacional Constituinte, afirmava, até seus últimos dias, que ninguém havia feito essa pergunta, principalmente aqueles legisladores que encabeçaram a inclusão de direitos na Constituição ${ }^{287}$. Resultado

\footnotetext{
${ }^{284}$ Hipótese do artigo 208 , IV e $§ 1^{\circ}$ da Constituição.

${ }^{285}$ Em junho de 2013, o déficit de vagas em creches no Município de São Paulo chegou a cento e vinte e sete mil e quatrocentas, de acordo com grupo de trabalho formado pelo Ministério Público de São Paulo, Defensoria Pública de São Paulo, organizações não-governamentais e advogados ("Déficit de vagas em creches de São Paulo a 127, mil crianças”, disponível em: <http://educacao.uol.com.br/noticias/2013/08/20/d eficit-de-creches-de-sao-paulo-passa-de-150-mil-vagas-aponta-estudo.htm>, acesso em 15.11.2013, 13:26h). ${ }^{286}$ No já mencionado Leviatã, a guerra de todos contra todos de HOBBES ocorreria, fundamentalmente, em um cenário em que ausente convenção social, já que, sendo escassos os bens, uns lutariam contra os outros para abocanhar a maior parte, senão todos eles.

${ }^{287}$ Cf. dá conta artigo publicado na edição de 19.5 .2013 na Folha de São Paulo (n ${ }^{\circ} 30.727$, p. B9) intitulado "Gargalo tributário".
} 
óbvio desse paradoxo é facilmente observável vinte e cinco anos após sua promulgação ${ }^{288}$. No discurso que fez à Nação em 26 de julho de 1988, o então Presidente, José Sarney, falando sobre a Constituição cuja promulgação se avizinhava, expôs seu medo do potencial desajuste de contas que ela implicaria aos cofres públicos, declarando, textualmente, que as normas ali projetadas deveriam ter tidos seus impactos financeiros previamente depurados, o que não sucedeu ${ }^{289}$.

Sarney não se referiu, especificamente, aos direitos sociais como fontes de despesa, já que, politicamente, isso soaria catastrófico. O Brasil vinha de anos de autoritarismo, sob uma Carta que, a par de recheada de liberdades públicas e alguns direitos prestacionais, não era observada na prática. Mas é óbvio que o então Presidente criticava a conta que seria necessária para pagar tudo o que a Constituição prometia.

288 A realidade está recheada de exemplos nesse sentido, como a proposta para a criação de mais quatro tribunais regionais federais, ao custo de cerca de um bilhão e trezentos milhões de reais, segundo a ONG Contas Abertas (<http://www.contasabertas.com.br/WebSite/Noticias/DetalheNoticias.aspx?Id=1222\&Aspx AutoDetectCookieSupport=1>, acesso em 2.6.2013, 20:00h). Há, todavia, quem aponte para um custo de implantação de quase oito vezes essa quantia ("Há alternativa para verba de novos tribunais", em Folha de São Paulo, edição de 4.6.2013, $\mathrm{n}^{\circ}$ 30.743, p. A15). O Congresso está tendente a aprovar emenda à Constituição que permite a adoção de tal medida, mesmo contra o que conclui o CNJ (<http://g1.globo.com/politica/noticia/2013/04/em-estudo-cnj-diz-que-argumento-para-criacao-de-novos-trfse-fragil.html>, acesso em 2.6.2013, 21:26h), o Presidente do STF (<http://oglobo.globo.com/pais/barbosachama-de-sorrateira-criacao-de-novos-trfs-8060997>, acesso em 2.6.2013, 21:30h) e alguns acadêmicos ("Há alternativa para verba...", p. A15). A adoção dessas novas cortes se faz a pretexto do acesso à Justiça e todos os preceitos constitucionais que o informam (como a razoável duração do processo prevista no inciso LXXVIII do artigo $5^{\circ}$ ). As perguntas que sobram são aquelas arquetípicas: quantos professores de ensino fundamental não seriam contratados com esse valor, ou quantos leitos de hospital não seriam disponibilizados? - indagações que, de resto, têm total correlação com esta tese.

${ }^{289}$ "Como Presidente, eu tenho de visualizar o que é permanente, não o que é transitório. Tenho que enxergar além do meu mandato, e tenho que evitar, na trajetória, que se instalem caminhos inviáveis, inconvenientes ao interesse nacional. Refiro-me, particularmente, à brutal explosão de gastos públicos decorrentes de benefícios desejáveis, que todos nós desejaríamos atender, mas que infelizmente não temos como atender. Como pagar contas astronômicas sem asfixiar os contribuintes, sem inviabilizar nosso crescimento, sem conviver como uma hiperinflação (...). E representa mais ainda, o que é mais grave, uma grande frustração nacional daqueles que pensaram que receberiam os benefícios e que não os vão receber, porque o Estado não terá condições de atendê-los. Quanto aumentaria a despesa pública se fosse promulgado, tal como está, o atual projeto de Constituição? Esta é uma pergunta que eu faço a todos os brasileiros e a todas as brasileiras. Sinceramente, tenho que responder que o valor é incalculável. Não há como estimar imediatamente o impacto da maioria das regras que criam o aumento de gastos. Faltam informações fundamentais que dependem de reações da sociedade aos preceitos, de interpretações múltiplas, ou de dados adicionais relacionados à futura legislação complementar. Mas a avaliação de apenas alguns aspectos mensuráveis basta para demonstrar o desequilíbrio econômico-financeiro a que chegaríamos. Quem pagaria esta conta? O povo. Somente o povo." (apud de BONAVIDES e ANDRADE, História das Constituições..., pp. 912-913). A verdade é que, a despeito da grande indagação presidencial ("Quanto aumentaria a despesa pública se fosse promulgado, tal como está, o atual projeto de Constituição?”), a Constituição foi promulgada exatamente como projetada - sobretudo após a resposta do Presidente da Assembleia Nacional Constituinte, o então Deputado Ulysses Guimarães, dada no dia seguinte (27.7.1988) que, em defesa do projeto e tocando exatamente na questão dos custos levantada por Sarney, ressaltou o vanguardismo da universalidade da seguridade social (abrangendo, aí, direitos como saúde, previdência e assistência), extensível ainda àqueles que nada pudessem contribuir, colocando o Brasil ao lado de outros seis países em que se observava a mesma sistemática (apud de BONAVIDES e ANDRADE, História das Constituições..., p. 917). 
Profetizou, dizendo que, diante da limitação do orçamento, seria necessário criar novas fontes de receita, e logo pensou na tributação. O que o mortificava, contudo, e a tantos outros, era, de fato, a escassez do Erário.

O conceito de escassez é ligado ao de fim. O fim é tema analisável sob as mais diversas óticas, mas, para o que aqui interessa, basta concordar que tudo o que é palpável ou tangível possui fim. Assim é com a vida, com os recursos naturais ${ }^{290}$ e, claro, com os financeiros. Nossas finanças pessoais encontram congruência quando os ativos empatam com os passivos, ou quando há superávit, o que só faz sentido se for considerada a finitude dos valores agregados à nossa receita. Com o Estado não sucede diferente. $\mathrm{O}$ financiamento público encontra limites no total do montante arrecadado que compõe os cofres do governo.

Concepção muito importante para o bom entendimento da questão que ora se coloca é a de custos dos direitos, é dizer, todos os direitos assegurados pelo Estado possuem ônus financeiro ${ }^{291}$. O Estado deve recorrer ao Erário para dar cabo de suas tarefas mais ordinárias ou mais vultosas, desde o bombeiro resgatando o felino da árvore até a abertura de uma estrada de rodagem. Um exemplo que vem a calhar é o custo do Judiciário: no ano de 2010, em São Paulo, os órgãos estaduais arrecadaram das partes apenas $33,6 \%$, cerca de um terço do que gastaram ${ }^{292}$. O restante foi custeado pelo Poder Público. E quanto será que a União gasta para possibilitar que o cidadão brasileiro exerça seu inalienável direito de sufrágio? Pode parecer fácil e pouco dispendioso sair de sua casa no tradicional dia das eleições para escolher seu candidato; mas o fato é que o custo da manutenção democrática representativa no Brasil é alto, e a par dele não vir

\footnotetext{
${ }^{290}$ Basta se imaginar a escassez dos bens que guarnecem o planeta, tão caros à vida humana. A Terra é um sistema fechado, o que significa que o conjunto de recursos naturais hoje disponível estará disponível daqui a cem ou mil anos, podendo ser transformado em outra espécie de matéria, talvez imprestável à vida (LAVOISIER, Lei da Conservação das Massas, publicada em 1760). Se as reservas de petróleo disponíveis forem consumidas inteiramente, este material quedará extinto. De acordo com estudo divulgado pela Royal Society, em 2025 estima-se que cerca de 1,8 bilhão de pessoas viverão em zonas com escassez de água $(O$ Globo, edição de 26.4.12, no 28.752, p. 36).

${ }^{291}$ Sobre o financiamento público de direitos, a obra de Cass SUSTEIN e Stephen HOLMES não pode deixar de ser consultada. $\mathrm{O}$ trabalho de pesquisa e a coleta de dados expostos no livro é enriquecedor e comprovam que muitas contas que ignoramos consomem muito dinheiro do Erário. Um tema extremamente importante - e que, com frequência, é esquecido pelos que estudam políticas públicas e seu controle judicial - é abordado logo no início, quando os autores demonstram como os direitos civis e políticos, ou de liberdade negativa (i.e., propriedade privada, segurança) consomem muitos recursos financeiros do Estado (SUSTEIN, Cass; HOLMES, Stephen. The Cost of Rights: Why Liberty Depends on Taxes. W. W. Norton \& Company. New York: 1999, especialmente pp. 13-16).

${ }^{292}$ LAGRASTA NETO, Caetano; OLIVEIRA NETO, Jaime Martins; e REZENDE FILHO, Durval Augusto. Panorama do Desempenho do Tribunal de Justiça de São Paulo (2003-2010). São Paulo: Letras Jurídicas, 2012, p. 30.
} 
automaticamente às mentes de quem procura os maiores gargalos nas despesas públicas, não pode ser desprezado ${ }^{293}$.

Uma noção que é central neste estudo é a de que um Estado falido é incapaz. de assegurar direitos.

Sustein e Holmes têm um capítulo inteiro de seu mencionado livro analogamente intitulado ao enunciado ora apresentado ${ }^{294}$. Ele, portanto, não é original, mas toma-se a liberdade de usá-lo como inspiração para lançar a ideia. $\mathrm{O}$ enunciado é tão poderoso que é capaz de se explicar por si só.

De fato, um Estado sem dinheiro não pode garantir aos cidadãos uma segurança eficiente. Fosse assim, como o Poder Público arcaria com a respectiva despesa? Da mesma forma ocorreria com a saúde pública: de que maneira seriam mantidos os hospitais municipais, estaduais, distritais e federais? A partir do momento em que se forma consenso em torno da criação do Estado e, ato contínuo, concorda-se os itens que serão guarnecidos por esse Estado, as fontes de receita devem ser previstas. Não por acaso que há uma rigorosa disciplina constitucional das finanças públicas; não por azar que a Carta prevê a criação de tributos em caso de guerra e calamidade pública ${ }^{295}$. De fato, é necessário conhecer a natureza do direito assegurado para investigar seus custos ${ }^{296}$.

Referendando a ideia que inaugurou este item, o Erário é finito. Se os direitos dependem de dinheiro para serem vertidos em bens diretamente fruíveis pela população e esse dinheiro, por sua vez, é limitado, o atendimento à demanda de direitos depende diretamente de sua quantidade (quantos são eles) e qualidade (quais são eles e qual é a sua finalidade).

Alguém poderia argumentar, com toda a razão, que a questão da escassez é anterior à própria intervenção judicial em políticas públicas - o que faria com que sua abordagem estivesse topograficamente desengajada do título deste item, que pressupõe a intervenção jurisdicional. Mas o fato é que a questão da limitação do budget público é, ao mesmo tempo, justificativa e problema quanto à intromissão dos juízes nas atribuições originais dos administradores.

\footnotetext{
${ }^{293}$ SUSTEIN e HOLMES levantaram que, em 1996, nos Estados Unidos, os custos com as eleições foram de trezentos a quatrocentos milhões de dólares, sem considerar os investimentos privados nas campanhas políticas, que, no sistema estadunidense, são bastante consideráveis (The Cost of Rights..., p. 113).

${ }^{294}$ SUSTEIN, HOLMES. The Cost of Rights..., pp. 35-83.

295 Trata-se do imposto extraordinário de guerra (art. 154, II) e dos empréstimos compulsórios em caso de guerra ou iminência ou, ainda, calamidade pública (art. 148, I), todos da Constituição.

${ }^{296}$ SUSTEIN, HOLMES. The Cost of Rights..., p. 37.
} 
A justificativa se dá porque, sendo limitados os recursos, algum destinatário dos bens públicos constitucionalmente atribuídos não poderá usufruir de sua parcela do quinhão. Essa impossibilidade de atendimento a todas as demandas leva o cidadão, invariavelmente, a procurar algum mecanismo que possa garantir seus direitos. Aí entra o Judiciário, na omissão. Se a escassez não é a única faceta da impossibilidade dos Poderes majoritários em alocar recursos, definir e implementar planos e programas, ela é, sem dúvida, determinante, ao menos sob o ponto de vista teórico.

O problema com essa intervenção dos magistrados nas coisas da Administração Pública é o desajuste que suas decisões causam nas respectivas contas. No caso específico dos medicamentos, a doutrina médica, que obviamente tem se preocupado com o tema, já constatou que o acesso do Judiciário consiste uma via alternativa ao SUS, apontando, contudo, que nesse caso não há vinculação orçamentária, o que acaba "consumindo recursos consideráveis e causando dificuldades para garantir aquisição de medicamentos previstos na legislação (...)” e outros definidos pelos gestores públicos ${ }^{297}$. De fato, quando um gestor público realiza escolhas, ele define quem receberá e quem não receberá. Quando o juiz se substitui forçadamente ao gestor, ao albergue de sua constitucional missão de assegurar direitos, ele também faz essas escolhas.

Uma alegoria criada por Octávio Luiz da Motta Ferraz é extremamente feliz, de simplicidade e conteúdo que a permite ser tida como paradigmática. Ferraz, estudioso das políticas de saúde ao redor do mundo e, no Brasil, particularmente, da intervenção judicial nesse campo, cunhou a seguinte hipótese: imagine-se um casal com seus dois filhos dividindo uma única cama em fria noite. O cobertor que os protege não é suficiente para gostosamente sobrar para nenhum deles, mas é precisamente justo para livrar os quatro do frio noturno. Imagine-se, contudo, que um deles se sinta instado a puxar o cobertor para ficar mais confortável: essa decisão certamente fará com que os outros três, ou pelo menos um deles, fique descoberto, em parte ou totalmente, e reste prejudicado. Isso sem contar que, no mínimo, os outros três não gozarão da mesma vantagem.

Ferraz assume que com o orçamento ocorre fenômeno análogo. Sendo o Erário escasso, qualquer processo de tomada de decisão em favor de uns "descobrirá" outros $^{298}$. À teoria ele apregoou a lúdica denominação de Lógica do Cobertor Curto.

\footnotetext{
${ }^{297}$ LOPES, Luciane Cruz (et. al.). "Uso racional de medicamentos antineoplásicos e ações judiciais no Estado de São Paulo", em Revista de Saúde Pública, no 44 (2010), p. 621.

${ }^{298}$ Nesse sentido, destaque-se as declarações do Governador do Estado de São Paulo e do Prefeito do Município de São Paulo quando ambos anunciaram a redução das tarifas de transporte público em 2013: declararam eles que essa medida implicaria corte de investimentos em áreas como infra-estrutura. Houve,
} 
Ferraz sustenta, com razão, que quanto mais pensada, planejada e programada for a disposição dos recursos, mais eficaz ela será, deixando menos pessoas a descoberto. O professor de Warwick destila críticas à posição predominante no Judiciário brasileiro de tratar a saúde como direito subjetivo individual, criando-se a ilusão de que os juízes estão ampliando o acesso aos meios preventivos e curativos quando o que ocorre é exatamente o contrário. Ele argúi que cada decisão judicial fornecendo medicamento, por exemplo, puxa o cobertor para o lado daquele que conseguiu movimentar o Judiciário, deixando à míngua os outros que assim não procederam, nada obstante, em muitos casos, esses outros tivessem sido contemplados pelas políticas originalmente planejadas pelo Executivo, forçadamente modificadas em função do mandamento judicial ${ }^{299}$.

A par da alegoria, quando é ela aplicada ao caso real a situação é ainda mais dramática. Na concessão de direitos, o cobertor (equivalente ao Erário) não é precisamente justo para cobrir a família (no caso, analogia aos sujeitos de direito). Embora matematicamente de difícil comprovação, esta hipótese é confirmada pela análise do atual cenário, em que o Brasil é deficitário em suas contas públicas e, nada obstante, os serviços estatais deixam muito a desejar quanto à abrangência e qualidade. Isso significa de antemão que, no jogo real de alocação de recursos financeiros para realizar direitos, os dinheiros públicos não são suficientes para assegurá-los todos. O cobertor, portanto, já parte de uma situação de descoberta no que toca ao abrigo dos direitos constitucionalmente contemplados.

Ferraz denuncia, ainda, que a respectiva tutela judicial deixa em segundo plano a questão da escassez. Ele reputa a sobreposição de uma inquirição tão relevante à

também, pedido de socorro da Municipalidade ao Governo Federal para que, via desoneração tributária, a redução coubesse no orçamento. Tudo em vão. As medidas em apreço foram tomadas depois de tomar fôlego um dos maiores movimentos populares já vistos no Brasil. No espaço de aproximadamente dez dias, milhares de pessoas foram às ruas expressar sua indignação com a ordem das coisas por aqui. A irresignação pública conjugada parece ter começado, contudo, com um movimento que pedia o retorno das tarifas de transporte público ao que era antes, desencadeado após aumento levado a efeito no início de junho de 2013. Foi uma manifestação como pouco se viu no Brasil que gerou a redução das tarifas em São Paulo (e, de resto, em várias cidades em que medidas de aumento haviam sido tomadas - Folha de São Paulo, edição de 20.6.2013, $n^{\circ}$ 30.759, Capa e pp. C1-C5). As afirmações dos mandatários do Executivo confirmam, pragmaticamente, como ocorre a Lógica do Cobertor Curto: ambos cobriram os interesses dos manifestantes, descobrindo o de outros tantos potencialmente beneficiados pelas obras cujos gastos esses entes federados teriam de cortar. No mesmo sentido e cumprindo a promessa, o prefeito de São Paulo encampou o aumento no Imposto Predial Territorial Urbano - o IPTU - de $20 \%$ a $35 \%$, tudo para o exercício de 2014, e declarou, textualmente, que o incremento se daria para compensar as perdas com o congelamento das tarifas de transporte ("Aumento do IPTU manterá subsídios ao transporte, diz Haddad", disponível em: <http://g1.globo.com/saopaulo/noticia/2013/10/aumento-do-iptu-mantera-subsidios-ao-transporte-diz-haddad.html>, acesso em 15.11.2013, 14:24h).

${ }^{299}$ FERRAZ, Octávio Luiz da Motta. "Direito à saúde, escassez e o Judiciário". Folha de São Paulo, p. A3, em 10 de agosto de 2007. 
crença de que questões financeiras não podem obstaculizar a observância dos bens maiores da saúde e da vida ${ }^{300}$, o que é preocupante.

A despeito do pouco relevo que desperta no Judiciário, o tema da escassez é de fundamental consideração para a aplicação de todo e qualquer recurso estatal, seja por qual player for, inclusive - e principalmente - pelos juízes. Em termos de saúde, a escassez é ainda mais sensível. Mesmo a OMS já reconheceu que o primeiro problema para uma cobertura universal de saúde é a disponibilidade [financeira] do orçamento. Segundo o órgão das Nações Unidas para controle e garantia supranacional do acesso à saúde, "nenhum país, independentemente do grau de riqueza, foi capaz de assegurar que toda a gente tenha acesso imediato a todas as tecnologias e intervenções que podem melhorar a sua saúde ou prolongar a sua vida, ${ }^{301}$. A OMS escancara, em uma única frase, a terrível realidade de um sistema que convive com a universalidade, de um lado, e a escassez, de outro. No âmbito judicial, a celeuma da escassez recebe, usualmente, denominação muito comum a todo aquele que, alguma vez, já tenha lidado com as questões colocadas nesta tese: reserva do possível ${ }^{302}$. Ocorre, como se verá, que poucas são as vezes em que, embora a alegada, a escassez é analisada com toda a robustez técnica que demanda.

A escassez possui classificações: ela pode ser relativa ou ficta, de um lado, e absoluta ou real, de outro. A ideia é instintiva: no campo do Erário, a escassez relativa decorre da concorrência de diversas contas para a mesma receita, o que sucede, por exemplo, quando são concomitantemente destinatárias das fatias do bolo orçamentário saúde, educação, transporte, vestuário, assistência, entre outros. A escassez absoluta deriva da falta irremediável, da ausência total de recursos em função, justamente, de sua limitação real $^{303}$. A noção de escassez absoluta se liga demais ao inconsciente coletivo, tomando-se o exemplo da finitude de recursos da Terra, retromencionada, ou de obras de arte de Leonardo da Vinci, ou, ainda, de tecidos humanos para transplante ${ }^{304}$.

\footnotetext{
${ }^{300}$ FERRAZ e VIEIRA, "Direito à saúde...", p. 4.

${ }^{301}$ OMS, Relatório..., p. XIII.

${ }^{302}$ Sobre este tema, seu desenho como limite à atuação jurisdicional e respectiva aplicação no foro, ver Item 4.2.2 adiante.

${ }^{303}$ FERRAZ e VIEIRA, "Direito à saúde...”, p. 6.

304 John ELSTER usa as obras de arte como exemplo de escassez natural severa, situação em que é impossível aumentar a oferta para atender a demanda, e os tecidos humanos como escassez natural suave, em que tais recursos podem aumentar, mas não em número suficiente para atender a todas as demandas. Esta última classificação parece se assemelhar mais à escassez absoluta dos cofres públicos (apud de SGARBOSSA, Luís Fernando. Crítica à Teoria dos Custos dos Direitos. V. I - Reserva do Possível. Porto Alegre: Sérgio Antonio Fabris Editor, 2010, p. 218).
} 
A escassez ficta ou relativa pode ser transportada para o Erário como as limitações impostas pelas leis orçamentárias que comandam a aplicação de recursos nas mais variadas pastas. Um conhecido limite estabelecido pela norma são os percentuais mínimos aplicáveis na educação ${ }^{305}$ - embora tal piso seja uma garantia para esse específico direito, os percentuais trabalham contra a implementação dos demais, agora em função da escassez absoluta. Um dos mais importantes limites jurídicos é a já mencionada Lei de Responsabilidade Fiscal, que, dentre outros deveres, impõe aos Estados e Distrito Federal a manutenção de certa proporção entre despesa com o funcionalismo e receita - de novo, em função da escassez absoluta.

A esse propósito, o gasto com o pessoal do Executivo demonstra como é grave o problema da escassez. Nos últimos cinco anos, as despesas com o funcionalismo subiram em ritmo preocupante, superior à arrecadação de tributos - em que pesem os constantes recordes a respeito. Em 2012, dois Estados ultrapassaram a marca de 49\% das receitas gastas com seus funcionários, enquanto outros três e o Distrito Federal foram além de $46,55 \%$ da receita ${ }^{306}$. A partir daí, novos postos não podem ser criados, de acordo com vedação imposta pela Lei de Responsabilidade Fiscal.

A União se preocupa deveras com o aumento das despesas. Em 2011, o Executivo federal anunciou a necessidade do encolhimento de cinquenta bilhões de reais em seus dispêndios. Nada obstante, ao cabo do exercício, as despesas foram cortadas em menos da metade dessa conta, e, na maior parte, na rubrica de investimentos ${ }^{307}$. Em um cenário como esse, faz todo o sentido a afirmação de que a escassez cumpre um papel fundamental na disposição do Erário.

Mais dramática do que a escassez jurídica é a absoluta, que é razão de ser da primeira, por sinal. A noção de escassez absoluta - de novo, de que os recursos públicos possuem um limite - dificulta sustentar que as receitas possam ser movimentadas de uma pasta para outra sem que haja sacrifício, inclusive na mesma área, ainda que escassez jurídica não houvesse. A escassez absoluta confirma a Lógica do Cobertor Curto da forma mais drástica.

Com a escassez conclui-se que se o Judiciário não considera o orçamento nas decisões que profere concedendo acesso à saúde, o desajuste nas contas públicas será

\footnotetext{
305 Para a União, nunca menos de dezoito por cento dos impostos de sua competência; para os Estados, Distrito Federal e Municípios, nunca menos de vinte e cinco por cento da receita de seus impostos (Art. 212 da Constituição).

306 “Gasto com pessoal cresce e cria risco para governadores". Folha de São Paulo, edição de 19.3.12, p. A4.

307 “Governo não cumpre corte de gastos como prometido". O Globo, edição de 12.12.11, p. 11.
} 
inevitável. A quantidade de medidas judiciais buscando tal direito é apta a impactar determinantemente o Erário e, de conseguinte, todas as rubricas orçamentárias, planos e programas concebidos - uns mais de perto, outros mais de longe. Quando se fala, por exemplo, em duzentos e quarenta mil processos envolvendo o direito à saúde ${ }^{308}$, mostra-se a magnitude da questão.

O orçamento é, com efeito, ponto nodal a ser considerado nos processos em que políticas públicas são concedidas. Os juízes têm de, peremptoriamente, levar em conta a disponibilidade de recursos e sua distribuição pelos Poderes majoritários em todos os casos em que políticas públicas consistam, direta ou reflexamente, no objeto da ação, porque será preciso, sempre, ponderação, razoabilidade e equilíbrio ${ }^{309}$.

3.2.2 A ausência de condições técnicas na alocação de recursos

Juízes não estão preparados para lidar com o Erário, com a administração ou a definição ou, ainda, a execução de determinada política pública. Eles nunca foram treinados para isso. Ao contrário: muitas vezes, sua pouca predileção aos números e a estratégias e inflexões gerenciais foi causa de cursarem a faculdade de Direito, ao invés, por exemplo, de estudarem Economia ou Administração, ciências sociais aplicadas que flertam com Matemática e o planejamento.

Quando se abordou o tema do orçamento público nesta tese viu-se que entendê-lo e controlá-lo não são tarefas fáceis, sobretudo para um juiz que foi aprovado em concurso de provas e títulos em que não lhe fora direcionada nem mesmo uma única indagação a respeito das contas públicas. Nas provas de ingresso na carreira, seria usual perguntar se o Estado tem o dever de bancar tratamento hospitalar a cidadão que dele precisa, mas não seria nada trivial indagar quanto custaria tal tratamento e, muito menos, quais seriam alternativas para impactar o Erário o quanto menos possível fosse.

\footnotetext{
${ }^{308}$ Levantamento realizado pelo CNJ mapeou, em estimativa de 2010, duzentos e quarenta mil feitos ligados à saúde em trâmite no Judiciário (<http://agenciabrasil.ebc.com.br/noticia/2011-07-07/gastos-do-sus-comacoes-judiciais-passam-de-r-170-mil-para-r-132-milhoes-nos-ultimos-oito-anos >, acesso em 9.3.12, 13:30h). ${ }^{309}$ O APLPP prevê como princípio fundante daquele processo o equilíbrio orçamentário.
} 
Em um cenário em que $99 \%$ dos magistrados não dominam o orçamento de seu próprio tribunal, desconhecendo quanto de recursos possuem à sua disposição ${ }^{310} \mathrm{e}$, evidentemente, qual o valor tirado dos cofres públicos para realizar cada ato em seu cartório, como pressupor terem os juízes capacidade e conhecimento técnico para lidar com orçamentos tão complexos quanto aqueles ligados às políticas públicas? Como sucede hoje, se o juiz não sabe o valor dispendido com sua própria serventia, como avaliará se determinado recurso está alocado de maneira satisfatória para a saúde?

Ora, o exame dos recursos disponíveis se inicia nas leis orçamentárias (PPA, LDO e LOA), passa pela Lei de Responsabilidade Fiscal e termina na minuciosa verificação das contas públicas do ente federado analisado. Pois, nos dias atuais, o juiz não está apto a verificar nem o desenho da política pública, nem a avaliar as peças no tabuleiro do jogo orçamentário.

Daí não ser surpresa que os magistrados não levem em relevo as contas públicas quando proferem decisão estabelecendo a entrega de medicamento ou a inscrição de criança na creche apontada por seus pais. Não se está a falar da reserva do possível como argumento limitador da concessão judicial de políticas públicas, mas da falta de maiores subsídios para se chegar à conclusão que, no caso, há ou não há limitação orçamentária. A reserva do possível simplesmente mencionada - mas não aprofundada em julgados ou artigos acadêmicos como fator de restrição à prestação jurisdicional requerida na espécie, relacionada a bens cuja atribuição de distribuição é do Poder Público, beira a irresponsabilidade. E o grande problema é que, quando mais, tal limite emerge na decisão sem que tenha se concretamente verificado se, de fato, aquela providência almejada pelo jurisdicionado, também cidadão, é financeiramente possível.

Será exigir demais dos magistrados que eles entendam sobre os dinheiros públicos? Talvez. E talvez, também, a questão esteja inadequadamente colocada. Na verdade, antes dela, seria de se indagar em que medida o Erário impacta na decisão judicial que determine a execução de alguma política púbica? Se concluir-se que Erário e políticas públicas são termos e conteúdos indissociáveis, então a resposta à questão é totalmente. Nesse caso, entendendo que os juízes não podem escapar a sindicar políticas públicas, como visto até aqui, então a inevitável conclusão é a de que sim, magistrados devem compreender questões relacionadas ao orçamento público.

310 FALCÃO, Francisco. "Os juízes e a justiça", disponível em: <http://www.cnj.jus.br/atosadministrativos/atos-da-presidencia/433-informacoes-para/imprensa/artigos/13339-os-juizes-e-a-justica>, acesso em 9.7.2013, 16:38h. 
É a falta e o alheamento ao tema que propicia a decisão judicial embasada simplesmente na crença de que saúde não prestada é direito subjetivo descumprido. É muito mais fácil decidir que o jurisdicionado tem direito, e pronto, do que analisar o impacto da sentença nas contas públicas. Isso, contudo, causa severos problemas, principalmente considerando que o cobertor é curto e que essa decisão certamente implicará deixar desatendida uma coletividade de pessoas que verão forçosamente reaplicado aquele numerário originalmente destinado para entregar seus direitos.

\subsubsection{Individualismo e justiça de misericórdia}

A estratégia é insistir no argumento da urgência e sustentar que, sem o remédio, a morte do paciente é iminente. "Sou uma advogada que sai da cadeira. Marco audiências com juízes e desembargadores e explico o caso do paciente pessoalmente." Alguns magistrados se sensibilizam. Outros, não. São minoria. No ano passado, o governo estadual foi obrigado a fornecer o Sorilis a 34 pacientes. Fernanda foi a advogada de 28 deles. ${ }^{311}$

O trecho extraído da reportagem editada por Época revela a grave tendência de o Judiciário decidir demandas por medicamentos e terapias com base em argumentos não jurídicos ou racionais, mas emocionais. Como anotado na Introdução desta pesquisa, o contexto em que este excerto foi extraído é o da obtenção de tratamento que, para um único paciente, consumia do Erário paulista oitocentos mil reais ao ano. A citação revela que a mesma advogada obteve idêntica e custosa terapia para vinte e oito dos trinta e quatro pacientes que recebem o fármaco do Estado de São Paulo. Ele também demonstra o principal argumento utilizado nas postulações da causídica: sustentar que “(...) sem o remédio, a morte do paciente é iminente".

Este autor já ouviu de magistrados que, diante de um pedido individual por certo medicamento, a concessão será sempre medida de rigor, porque, caso contrário, eles, juízes, não conseguiriam se beneficiar do tranquilo sono dos justos. Faz sentido, então, que os pacientes aleguem urgência, risco de morte e contem aos juízes histórias bem tristes em caso de falta do bem judicialmente pleiteado, de forma a lhes sensibilizar e, assim, vencer a luta travada no processo - expressão bem apropriada à concepção oitocentista e bilateral do instrumento.

\footnotetext{
311 <http://revistaepoca.globo.com/tempo/noticia/2012/03/o-paciente-de-r-800-mil.html>, acesso em 11.5.12, $13: 40 \mathrm{~h}$.
} 
De certa forma, não se censuram os juízes. É extremamente difícil lidar com situação em que a vida digna de alguém está em suas mãos. Antes de serem magistrados, indivíduos por sob a toga são humanos. Daí a facilidade de entender a emoção presente, ainda que velada ou caladamente, em boa parte das decisões judiciais ligadas à saúde. Mas o argumento emocional não é justificativa hábil a explicar ou fundamentar as decisões em casos individuais, sobretudo sob o viés técnico. E, com efeito, a justiça de misericórdia é um grave problema da concessão judicial de acesso à saúde.

A feliz expressão justiça de misericórdia foi cunhada por José Reinaldo Lima Lopes justamente para tratar da distorção causada por decisões judiciais que, mais que razões jurídicas ou de boa técnica, levam em conta os apelos do demandante. O professor desta Faculdade apontou que esse tipo de expediente tem fértil lugar nas ações individuais, em que certa pessoa, isoladamente, dirige-se ao magistrado para obter o tratamento que pretende ${ }^{312}$.

Ele tem razão. Olhar nos olhos do jurisdicionado, ou de seu advogado, produz impacto severo. Ademais, decidir na base singular faz com o que o juiz, inconscientemente, assuma a posição de que sua decisão não reverberará tanto no Erário afinal, se é um absurdo a quantidade de tributos que pagamos ${ }^{313}$, então o Erário deve ser muito bem fornido de recursos (!). Parece uma estratégia infalível promover medida judicial individual pedindo providência de saúde. Afinal de contas, trata-se apenas de discutir dinheiro público versus vida digna.

Um contraponto ao referido efeito desse tipo de ação individual seria o emprego da tutela coletiva para obter, do Judiciário, a entrega de saúde. A questão é que em casos individuais não existe a abstração própria da tutela coletiva: nesta, há um claro distanciamento entre a discussão judicial e quem por ela se interessa. Nem juiz, nem o próprio Ministério Público têm exata noção de quem a medida beneficiará, sobretudo nas categorias de direito coletivo, em que a titularidade ainda não foi determinada, e difuso, que, por natureza, não possui titular específico.

\footnotetext{
${ }^{312}$ LOPES, Direitos Sociais... Introdução.

313 A carga tributária brasileira bateu recorde em 2012, chegando a quase $37 \%$ do Produto Interno Bruto ("Carga tributária bate recorde e atinge 36,27\% do PIB em 2012, diz estudo", em <http://g1.globo.com/economia/seu-dinheiro/noticia/2013/03/carga-tributaria-bate-recorde-e-atinge-3627-dopib-em-2012-diz-estudo.html>, acesso em 15.11.2013, 14:53h), figurando como uma das maiores participações mundiais. Dentre os trinta países com maior arrecadação tributária, o Brasil apresentou a pior correlação entre exações pagas e serviços prestados pelo Estado (AMARAL, Gilberto Luiz, AMARAL, Letícia Mary Fernandes do, OLENIKE, João Eloi. Cálculo do IRBES (Índice de Retorno de Bem Estar à Sociedade) - Estudo sobre a Carga Tributária/PIB $\times$ IDH. Curitiba: Instituto Brasileiro de Planejamento Tributário, abril de 2013, disponível em: <https://www.ibpt.org.br/img/uploads/novelty/estudo/787/ESTUDO FINALSOBRECARGATRIBUTARIAPIBXIDHIRBESMARCO2013.pdf>, acesso em 15.11.2013, 15:01h).
} 
O contrário ocorre com a ação individual. Nos casos de saúde, não raras vezes o magistrado é achacado pela parte, que quer promover um encontro com ele para explicar os motivos de seu recurso ao Judiciário. Se assim sucede, a emoção é inevitável. Se não, o advogado se encarregará de carregar sentimentalismo a favor de seu cliente. Nada de errado com isso, ambos - parte e advogado - fazem seu papel. O problema é que o magistrado é tomado pelo remorso e pela culpa. Ele, o juiz, invadido por nobres sentimentos de justiça e - como disse Lopes - misericórdia, acabará cegado e terminará, destarte, por não levar em conta a pluralidade de aspectos que toda e qualquer decisão judicial em termos de saúde deveria considerar. Ou, ainda que leve, o juiz não pretenderá carregar a culpa e o remorso de ter debitado em seu currículo morte ou vida menos digna do postulante, aspectos que os advogados fazem questão de exagerar.

A confirmação do fenômeno repousa na verificação empírica do insucesso das ações coletivas que buscam obter medicamentos. Em pesquisa realizada no Tribunal de Justiça de São Paulo no universo de postulações de medicamentos para tratamento da AIDS, verificou-se que, das decisões concessivas, 93\% consideravam a saúde direito individual, contra 5\% que a tinham como direito coletivo; já nos casos de não concessão, o percentual dos magistrados que entendia ser a saúde um bem coletivo subia a $53 \%{ }^{314}$. A análise prova que quando a saúde é considerada um bem individual, o sucesso é certo; quando ela é tida como direito coletivo, a maior probabilidade é a de fracasso ${ }^{315}$.

Será, contudo, que este é um problema somente da saúde? Outros direitos, tais como a educação, sofreriam do mesmo mal? Não há qualquer base teórica para sustentar tal dúvida, já que saúde e educação são ontologicamente ligados pela raiz. Estudo empírico focado em decisões judiciais em primeiro e segundo graus, considerando o tema educação, também aponta para a identidade de conclusões: das setenta e cinco ações civis públicas analisadas, todas transitadas em julgado, o êxito apurado foi baixíssimo, ao passo que providências semelhantes foram asseguradas em ações individuais $^{316}$. A apresentação da questão de forma segmentada, além de não evidenciar ao juiz um problema estrutural e edificante que ele normalmente não quer resolver, aparenta

\footnotetext{
${ }^{314}$ DURAN FERREIRA, Camila. O Judiciário e as Políticas de Saúde no Brasil: o Caso AIDS, vencedor do Prêmio IPEA 40 anos, p. 25.

${ }^{315}$ Sobre o uso adaptado da ação civil pública para benefício de titular ou titulares determinados, ver resultado de pesquisa no Item 4.1.3.

316 MARINHO, Carolina Martins. Justiciabilidade dos direitos sociais: análise de julgados do direito à educação sob o enfoque da capacidade institucional. Dissertação de Mestrado apresentada ao Departamento de Teoria Geral e Filosofia do Direito da Faculdade de Direito da Universidade de São Paulo, São Paulo, 2009 , pp. 9 e 16.
} 
ser de fácil solução (i.e., a inscrição de uma criança na pré-escola versus a matrícula de todas as crianças em idade para tanto) e, portanto, mais palatável a ser judiciada ${ }^{317}$.

É correto, ainda neste contexto, falar-se em graus de sensibilidade do direito discutido. Pensando objetivamente, é possível dividir direitos mais e menos passíveis de misericórdia. Essa parametrização - como o tema deste item, afinal - está ligada aos sentimentos despertados no - e, portanto, à sensibilidade do - magistrado no momento do recebimento do pedido. O requerimento de medicamento oncológico é percebido de maneira diferente do reclamo por habitação; o pedido de transplante custeado pelo Estado é tratado diversamente do pleito por vagas em creches na Zona Sul de São Paulo. Os casos envolvendo saúde são normalmente mais urgentes e mais sensíveis do que as demais políticas públicas, porque se tem a ideia que eles se ligam diretamente à vida digna da pessoa ${ }^{318}$. A natureza do direito discutido é fundamental para determinar a sensibilidade com que ele é tratado no foro. E a saúde sai na frente ${ }^{319}$.

De fato, via de regra, ações a postular saúde, sobretudo as individuais, são o cenário propício para a misericórdia judicial. Já houve, inclusive, declaração proveniente do STF que resume bem o problema: no âmbito da discussão se, no caso, o Poder Público deveria ser obrigado a fornecer certo fármaco, um dos mais brilhantes magistrados do Colegiado disparou: "quem salva uma vida, salva toda a humanidade 320 ". As indagações que desde já se lançam são: que vida seria essa? A do autor? Ou a dos outros tantos que, nas mesmas condições, não lançaram mão de semelhante medida? Evidentemente que o Ministro se referiu à vida do postulante. Mas o que preocupa são os que não puderam ou podem se valer de expediente análogo, ainda que, de igual forma, fizessem jus à mesma medida.

O maior grau de abstração, característica própria da ação coletiva, faz com que juízes se sintam mais à vontade para racionalizar sobre o objeto postulado, e, daí, levarem em consideração argumentos como escassez, eficácia e segurança do medicamento, ponderabilidade, razoabilidade, mínimo existencial e outros paradigmas

\footnotetext{
${ }^{317}$ MARINHO, Justiciabilidade..., p. 106

${ }^{318} \mathrm{~V}$. Item 4.2.3.

319 A doutrina fala em densidade normativa dos direitos sociais, explicando, por exemplo, que o fato da norma prever o pleno emprego não significa que o Estado deva assegurar empregabilidade completa. É o que permite a alguns argumentar que um sem-teto não poderia ingressar em juízo pedindo o social direito à moradia, mas poderia pedir a inclusão de seu filho em escola fundamental. A esse respeito, v. SUNSTEIN, Cass R. The Second Bill of Rights: FDR's Unfinished Revolution and Why we Need it More than Ever. Nova York: Basic Books, 2004 p. 210.

${ }^{320}$ AgReg na STA n ${ }^{\circ}$ 223/PE, Rel. Min. Ellen GRACIE, j. em 14.4.2008. As palavras foram proferidas pelo notável decano da Corte, Min. Celso de MELLO, um dos expoentes da imperatividade dos direitos sociais.
} 
que, mais adiante, apontar-se-ão como limites à adjudicação de bens ligados à saúde pública em qualquer suporte material (individual ou coletivo).

Com efeito, quando a postulação assume viés de direito transindividual, o juiz compreende melhor o impacto orçamentário que sua decisão poderá causar. Imaginese ação civil pública requerendo a entrega de medicamentos para tuberculose para todos os pacientes do Estado do Amazonas, por exemplo: certamente, ali, o magistrado indagaria o cabimento orçamentário de uma procedência. Arriscar-se-ia dizer que haveria, nesse caso, grande possibilidade de indeferimento, fruto da falta de informações que levaria o juiz a pensar que aquela providência estampada no pedido seria incompatível com as finanças públicas - isso sem contar o argumento da Separação dos Poderes, que viria acoplado. Não haveria, nesse caso, escoramento em qualquer dado de realidade por parte do magistrado, mas, apenas, fundamentação lastreada na noção geral de que algumas pessoas podem ser atendidas, mas não todas, porque então o Erário se revelaria incapaz de suprir essas necessidades.

Ainda valendo-se do exemplo do fornecimento de medicamentos para os tuberculosos do Amazonas, imagine-se ação individual em que se pleiteasse a mesma providência. Nesse caso o juiz possivelmente não pensaria no impacto financeiro de uma decisão concessiva; ele refletiria e concluiria, afinal, que apenas uma pessoa - o autor seria beneficiada com a criação da imprevista despesa necessária para cumprimento da decisão judicial que obrigaria o Poder Público a tratá-lo. Seriam amplamente ignorados todos os demais aspectos ligados ao tema, sobretudo e, mais dramaticamente, a necessidade de acesso universal às políticas de saúde.

A mecânica pela qual a pretensão em obter saúde é realizada em casos individuais não funciona. Trata-se do emprego de um método inadequado para sindicar justiça distributiva, porquanto fundado em lógica moldada sob as bases do Liberalismo, em que direitos sociais não existiam. É o tratamento subjetivo puro de direitos que são predominantemente metaindividuais. O individualismo ligado à postulação judicial de saúde possui muitas vicissitudes, e, nesse sentido, estimula a perversa justiça de misericórdia. De nada valerá este estudo e os debates em torno do problema aqui tratado se os juízes continuarem decidindo com base em sentimentos, emoções e sensações que acabam deturpando a real celeuma em torno da judicialização da saúde e de políticas públicas em geral. Nesse sentido, a justiça de misericórdia é a banalização da importante 
discussão que envolve o assunto. $\mathrm{O}$ individualismo, destarte, é um grave aspecto da patologia, e as soluções que serão apontadas levarão em conta esse sensível problema ${ }^{321}$.

\subsubsection{Execução do julgado e dogmas do processo}

O processo civil é regido por vários postulados, alguns dos quais assumem a forma de verdadeiros dogmas ${ }^{322}$. Esses dogmas foram cunhados sob as bases clássicas do processo, que pressupunham litigância com objeto bem definido, bipolarizada, retrospectiva e fundada na lógica do tudo-ou-nada ${ }^{323}$. Dentro dessas bases os dogmas, não se nega, fazem sentido: assim é que a coisa julgada só imobiliza os efeitos da sentença entre as partes da causa (claro, porque o objeto em discussão era de interesse comum e antagônico daquelas partes, então elas obviamente não poderiam replicar a mesma ação noutra oportunidade); de igual forma, somente estaria legitimado a requerer determinado objeto quem com ele tivesse alguma relação jurídica, oponível a outro com idêntica qualidade $^{324}$; também nesse grupo se encontra a extinção terminativa do processo porque seu autor não escolheu a via adequada.

Quem duvida que estes três aspectos exemplificados - na ordem, limites subjetivos da coisa julgada, legitimidade de parte e interesse processual - não consistam ou, pelo menos, consistiam, na sua concepção original - verdades processuais insofismáveis? Para obter a resposta, basta cogitar do seguinte exemplo: em determinada ação de cobrança movida entre A e B, sobrevém sentença obrigando B não somente a pagar A, mas, também, C, que nunca participou do feito. Muitos perguntariam: "como?" para, logo a seguir, vaticinarem: "impossivel!".

Desafiar dogmas é sempre tarefa duplamente hercúlea: primeiro, porque uma multidão de vozes se levantará contra o desafiante, em defesa do dogma, ainda que a multidão sequer conheça suas bases de defesa; depois, o desafiante terá que sustentar, com veemência e profundidade, os fundamentos de sua irresignação quanto ao enunciado

\footnotetext{
${ }^{321}$ Sobre a prevalência da tutela coletiva no caso da saúde, inclusive de acordo com a gênese desse direito social, ver Item 5.1 .

322 Os dogmas são pontos eleitos por doutrina, religião, ideologia ou organização, considerados inquestionáveis e indubitáveis. Sendo assim, os dogmas são os pilares da respectiva ideologia, impassíveis de desafio. Uma sua característica que, infelizmente, é recorrente é que, pela falta do dissenso, eles acabam perdendo seu significado com o passar do tempo.

${ }^{323}$ V. CHAYES, Abraham. "The Role of the Judge in Public Law Litigation", in Harvard Law Review V. 89, $1281,1284,1288-89$.

${ }^{324}$ DINAMARCO, Instituições de Direito Processual Civil. 5a ed., São Paulo: Malheiros Editores, 2006, p. 306.
} 
atacado. Mas o ataque aos dogmas, assim como a livre oposição a ideias, é da essência humana e faz parte tanto da liberdade de expressão quanto da democracia. Na nossa essência repousa o dissenso, que estará sempre pronto a se manifestar.

Mas o fato é que pode parecer quase impossível que tais paradigmas, tão condizentes com o método de resolução de conflitos privados em que se consolidou o processo, pareçam impassíveis de contestação. Contudo, não é o que se observa na prática: mesmo no âmbito privado, o rigorismo dos dogmas foi desafiado. E vem sucumbindo.

A escola processual do Largo São Francisco demonstra a vocação para sua grandiosidade por possuir mais do que professores, pensadores, que conseguem revolucionar o modo de ser do processo. Dentre os inúmeros exemplos que podem ser creditados à Velha Academia no bojo do processo (de onde se tiram os estudos que levaram à adoção da parte instrumental do $\mathrm{CDC}$, o desenvolvimento da tutela da litigância de menor complexidade e acesso à Justiça, o próprio CPC de 1973 e, atualmente, o novo CPC e boa parte da revisão processual do CDC) destaque-se a contribuição capitaneada por Dinamarco e desenvolvida por Bedaque, consistente na interpretação que, hoje, é fundamental para o processo: a doutrina da instrumentalidade ${ }^{325}$. Se pudesse ser explicada em poucas linhas, diríamos que ela prega a interpretação das normas entendendo o processo não como um fim em si mesmo, mas como meio, privilegiando, assim, o direito material, desde que com razoável segurança.

A partir daí, a instrumentalidade relativiza uma série de dogmas do processo, muitos dos quais remontam à época em que o Direito de Processo objetivou, com sucesso, descolar-se do direito material para ser objeto de análise autônoma, separada, independente $^{326}$. Enxergando o processo como simples instrumento, as regras que, outrora, serviram para lhe conferir peculiar importância (muitas vezes, artificial), hoje, em que se busca justiça efetiva, podem ser casuisticamente derrogadas.

\footnotetext{
325 Sobre o tema, imprescindível consultar DINAMARCO, Cândido Rangel. A Instrumentalidade do Processo, $3^{a}$ edição. São Paulo: Malheiros, 1993. No mesmo sentido, OLIVEIRA, Carlos Alberto Alvaro. Do Formalismo no Processo Civil. Proposta de um formalismo-valorativo. $4^{\mathrm{a}}$ ed. São Paulo: Saraiva, 2010; e BEDAQUE, José Roberto dos Santos. Efetividade do Processo e Técnica Processual. São Paulo: Malheiros, 2006.

${ }^{326}$ DINAMARCO, Fundamentos do Processo Civil Moderno, $4^{\mathrm{a}}$ ed., Tomo I, São Paulo: Malheiros, 2001, Capítulo I. BEDAQUE sustenta, por exemplo, ser plenamente válida sentença que julgou improcedente os pedidos em ação em que não houve a regular citação do demandado. Analisando a situação sob o ponto de vista da teoria das nulidades, BEDAQUE entende que se não houve prejuízo ao réu, o ato (no caso, a sentença) deve ser aproveitado (Efetividade...), o que significa a supressão (pelo menos, nessa hipótese) do velho entendimento de que a falta ou irregularidade da citação constitui o mais grave vício processual, insanável e permanente.
} 
A riquíssima doutrina, contudo, não ocupará mais linhas desta tese, ainda que extremamente serviente para seus auspícios. A raiz da teoria está no inconformismo da rigidez com o que algumas regras técnicas eram - e ainda são - aplicadas pelos magistrados. Ela não somente demonstra a superação do modelo antigo, fundado em formalismos exagerados, e prega a adoção de um novo, fulcrado na funcionalidade do processo: a instrumentalidade comprova como alguns anacrônicos dogmas processuais não se sustentam na sociedade brasileira de hoje.

Existem dogmas cuja observância é particularmente preocupante nos processos judiciais que pretendem obter ações de políticas públicas e, nesse sentido, a dinâmica instrumentalista consiste em importante vetor para apontar as mazelas das regras que ventilam tais enunciados. De fato, se para o processo clássico, individual e tendo por objetivo a obtenção de fins privados, a instrumentalidade já demonstrou que certas regras não podem se aplicar com o mesmo vigor - e rigor -, com mais razão ainda alguns dogmas do processo devem ser suavizados no plano das políticas públicas, a bem de conferir ao instrumento toda a efetividade que dele se pretende extrair.

Um deles é aquele que estabelece que a decisão do juiz deva corresponder exatamente ao que foi precisamente pedido pela parte, o que se denomina adstrição ou congruência $^{327}$. Na verdade, a adstrição é parte do bem desenhado mecanismo que entrega exclusivamente às partes o controle da definição do objeto do processo, limitando a atuação de ofício do magistrado. Nesse mesmo sentido, operam outros dois grandes fundamentos do processo, a inércia e o princípio dispositivo, o primeiro a vedar ao juiz adoção, ao seu alvedrio, de decisões sem que esteja estabelecido processo, ou, mesmo, de o magistrado deflagrá-lo sponte própria, e o segundo a impedir o juiz de determinar a feitura de certas provas não requeridas pelas partes.

Esse bem desenhado mecanismo funciona adequadamente no cenário Chayeseniano de litigância bipolar e retrospectiva - de novo - em que as partes são definidas, o objeto, facilmente atribuível e em que vigora a lógica do jogo de soma zero (se o autor perde, o réu ganha, e vice-e-versa). Contudo, a adstrição e seus corolários consistem em importantes óbices quando os juízes passam a sindicar políticas públicas. É que, como visto, elas demandam planejamento, programação e certo grau de variação

\footnotetext{
${ }^{327}$ O princípio da congruência ou adstrição revela a necessidade do magistrado se ater apenas e tão somente ao que foi requerido nos pedidos iniciais. É corolário dos princípios da demanda e da inércia da jurisdição. Se desrespeitado, pode ter como consequência a prolação de uma sentença extra, ultra ou citra petita, com sua anulação, no primeiro caso, e redução ou ampliação de seu escopo a fim de se adequar ao pedido, nos dois últimos. Nesse sentido, ver GRINOVER, Ada Pellegrini, FERNANDES, Antonio Scarance e GOMES FILHO, Antonio Magalhães. As Nulidades no Processo Penal. São Paulo, RT, 6 Edição, 1998, p. 219.
} 
dependendo de seus resultados, tudo o que escapa à tradicional adstrição. É aí que está o problema: o juiz, no panorama processual brasileiro, deve atender exatamente ao que fora almejado pelo autor, mesmo que não seja o mais adequado para responder ao pleito formulado.

Frequentemente, os pedidos deduzidos em sede de ações que requerem bens dispensados pelo Estado - sobretudo as individuais, em que um cidadão, isoladamente ou em litisconsórcio, pretende obter do Poder Público determinada providência - não encerram, em si, a magnitude de uma política pública de saúde, embora, muitas vezes, essas demandas - notadamente quando múltiplas - tenham o condão de influenciar decisivamente política pública já delineada.

Um dos maiores problemas hodiernos é o claro paradoxo enfrentado pelos juízes. Se, de um lado, verifica-se que o Judiciário é, mesmo, chamado a intervir decisivamente em dada política pública, muitas vezes substituindo o gestor competente, consistindo essa em uma inexorável tendência, por outro ele, juiz, deve pronunciar-se de acordo - e precisamente de acordo - com os pedidos deduzidos na inicial, seguindo o binômio inércia-adstrição. Com efeito, já se viu que as políticas públicas são complexas: elas exigem escolhas que devem ser eficientes, demandam conhecimento técnico e profundo e o estabelecimento de metas e sistemas periódicos de avaliação. Pedidos deduzidos em inicial normalmente não contêm diretrizes que permitam o desenvolvimento correto de determinada política pública. Muitas vezes sequer tais requerimentos levam em conta sua dimensão - seja por desconhecimento, seja por estratégia. E o juiz tem o dever legal de a eles se ater, uma completa incompatibilidade com a veste de gestor subsidiário de políticas públicas que, adjetamente, o magistrado termina por assumir.

Respondendo exatamente ao pedido do autor, não importando sua qualidade, o juiz obviamente determina a sorte do atendimento (antes, da execução) da pretensão. Claro, pois a execução também deve corresponder exatamente ao quanto disposto no título, já que nulla executio sine titulo, que deve ser líquido, ou seja, definir precisamente o objeto a ser executado. O problema está sinalizado: se o juiz atender um pedido inadequado, insuficiente ou, de qualquer maneira, mal formulado, sentenciado em seus exatos moldes, a política pública correspondente também será inadequada, insuficiente e mal formulada. O magistrado, todavia, por mais que conheça e seja hábil definidor de políticas públicas, coloca-se de mãos atadas, porque nada pode fazer além ou diferentemente do quanto estritamente pleiteado pelo autor. 
Nos processos coletivos é recorrente o problema que advém da adstrição quanto a pedidos mal deduzidos. A questão é, de fato, inquietante: o que fazer se um dos representantes adequados propõe ação coletiva e deduz pedidos malfeitos julgados procedentes, diante tanto da adstrição quanto da imunização dos efeitos da sentença pela autoridade da coisa julgada, se os efeitos dessa sentença operarão erga omnes por força legal? Imagine-se, por exemplo, a hipótese da associação que promove ação civil pública pleiteando indenização de determinada empresa que poluiu o meio ambiente, quando, na verdade, em questões ambientais sempre será mais adequado o pedido de recomposição da área atingida, quando possível ${ }^{328}$ : caso passe em julgado sentença de condenação indenizatória, certamente o melhor interesse da coletividade não foi atingido. Claro que o sistema contempla válvulas de escape - como, por exemplo, a participação do Parquet como custos legis, ou a ampla interpretação do objeto coletivo - mas, mesmo assim, pode ocorrer do pedido inadequado quedar-se imunizado e indiscutível.

Este é, invariavelmente, exemplo das mazelas causadas por sistema processual pensado sob uma lógica e aplicável, na prática, a outra completamente diferente. Correlacionando-se, também é sensível a questão do dever do magistrado de executar exatamente o que consta no título, porque, afinal, foi aquele objeto que se consolidou com o término de todos os recursos processuais possíveis e é sobre ele que deve repousar a ação do Estado para entregar ao vencedor o bem judicialmente almejado.

Mas os objetos tratados nesta tese são complexos, variáveis e cuja execução demanda medidas contínuas e, destarte, protraídas no tempo. Elas exigem programas e planejamento, muitas vezes sob o método tentativa-erro, porque certas circunstâncias são simplesmente impassíveis de previsão hermética - e, como se verá, a saúde é um bem com particular tendência à imprevisibilidade. Pois a atual sistemática da execução judicial de sentenças requer total previsibilidade. Há dissonância aí.

De fato, sob a ótica do processo civil clássico, se o objeto é ilíquido, liquida-se. Se ele é deduzido em ação coletiva, cenário que mais se aproxima à litigância de políticas públicas, não há qualquer diferença: o juiz tem obrigação de prolatar sentença líquida ou passível de liquidação. Não há a menor possibilidade de, durante a execução da sentença, alterar-se seu objeto, modificando-se o respectivo dispositivo. Isso, nos dias de hoje, implicaria violação à adstrição e aos limites objetivos da coisa julgada. O fato é que, na sistemática atual, se uma decisão que determina a criação de dez mil leitos em

\footnotetext{
${ }^{328}$ SALLES, Execução...
} 
determinado Município se mostrar, durante a execução, insatisfatória, ela terá que ser cumprida até o fim, ou, quando menos, qualquer modificação no seu conteúdo deverá ser objeto de nova medida judicial $^{329}$.

Todas essas características contribuem para que o Judiciário seja, nas felizes palavras de Veríssimo, um formulador errático de políticas públicas ${ }^{330}$. Mas essa realidade precisa mudar. A propósito, esta tese procura, justamente, formular propostas para uma atuação judicial racional no trato de políticas públicas. Mais adiante, quando os remédios forem tratados, serão indicadas medidas que podem amenizar o problema da obediência cega aos dogmas processuais aqui apontados.

\subsubsection{Vantagens e Desvantagens do Judiciário como arena pública}

Depois da verificação de alguns problemas próprios do Judiciário, tira-se, de logo, ser ele não a melhor, mas, inegavelmente, uma das principais arenas de decisão para políticas públicas. Como as outras, possui vantagens e desvantagens. A Tabela I expõe os principais foros de decisão do processo político-jurídico-social, apontando suas relevantes benesses e desvantagens, a bem de demonstrar o argumento de Komesar já anteriormente explorado - que inexiste um agente perfeito para garantir decisão de impactos públicos. Além dos já analisados Poderes da República, dois outros players - o Mercado e a Sociedade Civil - também consistirão variáveis de análise.

\footnotetext{
${ }^{329}$ José Reinaldo Lima LOPES aponta a coisa julgada como um dos limites do Poder Judiciário ao trabalhar com temas distributivos como as políticas públicas. Baseado em sua teoria e analisando-se o discurso encartado no Item 3.2.1 da obra (Direitos Sociais - Teoria e Prática. São Paulo: Ed. Método, pp. 132-138), vê-se o inconformismo do autor com a imposição desses limites, inclusive de ordem espacial. São dele as seguintes inquirições: "num Estado Federal como o Brasil, a interpretação dada por um tribunal estadual a uma lei federal pode ultrapassar as fronteiras do seu Estado? Qual o seu impacto?” (p. 134).

${ }^{330}$ VERÍSSIMO, A Judicialização..., p. 16. VERÍSSIMO indica as principais dificuldades enfrentadas pelo Judiciário nessa sua cada vez mais difundida função, que são "a incapacidade de pensar em termos de preferências, a incapacidade de lidar com a barganha em plano coletivo (não se transacionam direitos indisponíveis, como aqueles de natureza coletiva ou os que envolvam as políticas do Estado, diz o cânone), a necessidade de transformar pontos de vista parciais em direitos que precisam ou não ser titulados por quem os afirma, em um jogo de tudo ou nada, a necessidade de adstrição ao caso concreto e a correlativa impossibilidade de extrapolá-lo ou ampliá-lo de sorte a contemplar outras necessidades sociais e, enfim, a incapacidade de gerir a própria agenda e de determinar as próprias soluções fazem do Judiciário, ao fim e ao cabo, um péssimo alocador de recursos." p. 17.
} 
TABELA I

Decisões que envolvem ou circundam políticas públicas por Arena

\begin{tabular}{|c|c|c|}
\hline & Vantagens & Desvantagens \\
\hline \begin{tabular}{|l} 
Legislativo \\
\end{tabular} & $\begin{array}{l}\text { - Está acostumado a definir, em } \\
\text { primeiro lugar, políticas } \\
\text { públicas. } \\
\text { - Elabora as leis orçamentárias, } \\
\text { discutindo seus meandros. } \\
\text { - Consulta sua base de apoio } \\
\text { eleitoral para destinação de } \\
\text { emendas ao orçamento. } \\
\text { - Está presente no dia a dia da } \\
\text { população, mediante escala } \\
\text { federativa. } \\
\text { - Tem na essência o viés político } \\
\text { necessário para o sopesamento e } \\
\text { exercício de escolhas. } \\
\text { - É espaço democrático e foro de } \\
\text { ouvida das vozes de seus } \\
\text { representados. }\end{array}$ & $\begin{array}{l}\text { - Está sujeito a grupos } \\
\text { articulados de pressão. } \\
\text { - Decide de acordo com suas } \\
\text { preferências pessoais ou } \\
\text { visando à reeleição ou, ainda, o } \\
\text { aumento de poder. } \\
\text { - Não toma isoladamente } \\
\text { decisões que revertam, na } \\
\text { prática, na entrega de bens } \\
\text { sociais. } \\
\text { - No modelo institucional de } \\
\text { Estado brasileiro, submete-se } \\
\text { ao Executivo, perdendo pouco a } \\
\text { pouco seu poder. } \\
\text { - Tolhe a efetiva participação de } \\
\text { seus representados no processo } \\
\text { democrático. }\end{array}$ \\
\hline \begin{tabular}{|l|} 
Executivo \\
\end{tabular} & $\begin{array}{l}\text { - É o responsável institucional } \\
\text { por realizar ações de políticas } \\
\text { públicas, executando-as na } \\
\text { prática. } \\
\text { - Define a proposta dos } \\
\text { orçamentos públicos, elegendo } \\
\text { prioridades. } \\
\text { - É formado por gestores e } \\
\text { administradores, que planejam e } \\
\text { programam ações de políticas } \\
\text { públicas. } \\
\text { - Considera a imensa variedade } \\
\text { de questões a serem arranjadas } \\
\text { no desenho de politicas } \\
\text { públicas. } \\
\text { - Vale-se de estrutura } \\
\text { desconcentrada e } \\
\text { descentralizada de atuacão, }\end{array}$ & $\begin{array}{l}\text { - Como o Legislativo, está } \\
\text { submetido a grupos de pressão e } \\
\text { a decisões motivadas pelo } \\
\text { desejo de perpetuação ou } \\
\text { aumento de poder ou, ainda, } \\
\text { interesse pessoal. } \\
\text { - Elabora planos e programas que } \\
\text { não são executados } \\
\text { integralmente na prática. } \\
\text { - A alternância de poder faz com } \\
\text { que muitos programas de média } \\
\text { e longa duração sejam } \\
\text { abandonados, quando não } \\
\text { revertidos na nova gestão. } \\
\text { - A estrutura hierárquica é pouco } \\
\text { conhecida e intrincada, de } \\
\text { forma que não se sabe, ao certo, } \\
\text { a quem pedir a revisão de certa }\end{array}$ \\
\hline
\end{tabular}




\begin{tabular}{|c|c|c|}
\hline & $\begin{array}{l}\text { capilarizando as decisões e seu } \\
\text { controle. } \\
\text { - Estabelece mecanismos de } \\
\text { diálogo com a sociedade, } \\
\text { fazendo-se presente no dia a dia } \\
\text { da população. }\end{array}$ & $\begin{array}{l}\text { decisão. } \\
\text { - Faltam rotinas, práticas e } \\
\text { procedimentos. }\end{array}$ \\
\hline Judiciário & $\begin{array}{l}\text { - Age contramajoritariamente, } \\
\text { baseando-se na Constituição, na } \\
\text { lei e em atos normativos. } \\
\text { - É o responsável institucional } \\
\text { por corrigir falhas nos processos } \\
\text { políticos tradicionais. } \\
\text { - Seus membros possuem } \\
\text { garantias com vistas à } \\
\text { necessária imparcialidade. } \\
\text { - Não se submete a ingerências de } \\
\text { ordem política, grupos de } \\
\text { pressão e interesse pessoal no } \\
\text { mesmo grau dos demais } \\
\text { Poderes. } \\
\text { - Atua no bojo de um processo } \\
\text { legal, do qual não pode se } \\
\text { desviar. } \\
\text { - Possui instâncias bem definidas } \\
\text { de revisão de decisões. } \\
\text { publicadas. }\end{array}$ & 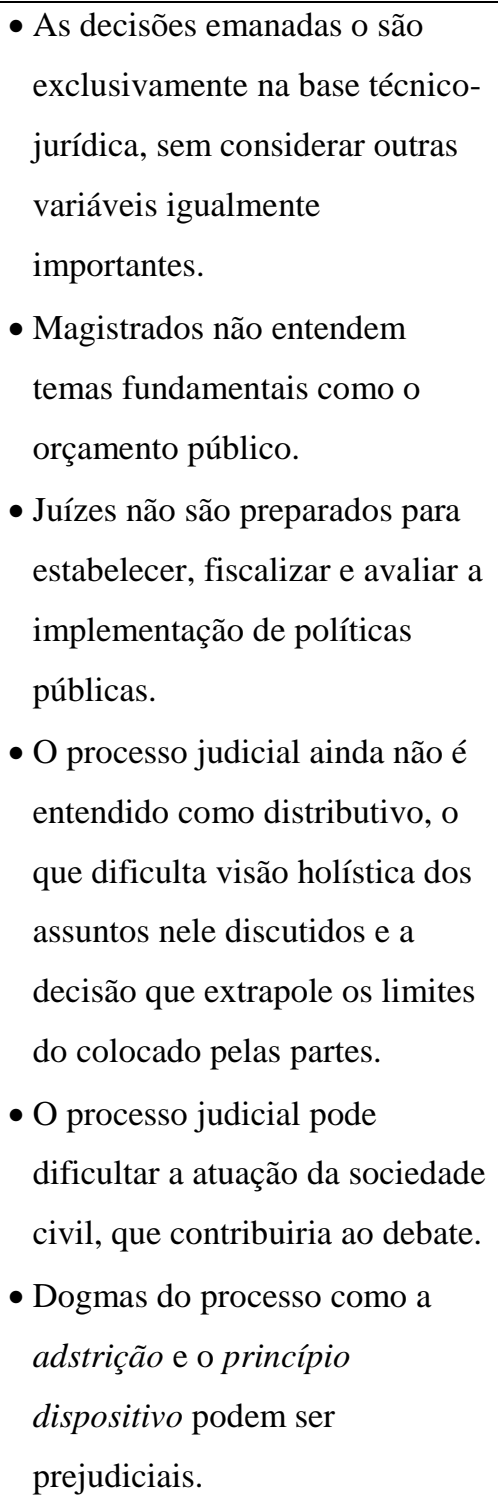 \\
\hline Mercado & $\begin{array}{l}\text { - Emana as decisões mais rápidas } \\
\text { e sensíveis pela sociedade. } \\
\text { - Atua buscando a máxima } \\
\text { eficiência, descartando } \\
\text { rapidamente medidas } \\
\text { ineficientes. } \\
\text { - Toma decisões com base } \\
\text { econômica e utilitarista. } \\
\text { - Responde imediatamente às }\end{array}$ & $\begin{array}{l}\text { - Não está preparado para lidar } \\
\text { com questões difusas e } \\
\text { indivisíveis, que independem de } \\
\text { fundamentação à base de trocas. } \\
\text { - Está exclusivamente } \\
\text { preocupado com o aspecto } \\
\text { econômico, desprezando a } \\
\text { proteção de direitos a não ser } \\
\text { que eles revertam em ganhos }\end{array}$ \\
\hline
\end{tabular}




\begin{tabular}{|c|c|c|}
\hline & intervenções do Poder Público. & $\begin{array}{l}\text { financeiros. } \\
\text { • Não é capaz de se autorregular } \\
\text { na inteireza, dependendo da } \\
\text { intervenção do Estado. } \\
\text { • Não possui pleno poder } \\
\text { coercitivo. }\end{array}$ \\
\hline Sociedade Civil & $\begin{array}{l}\text { - Dinamiza as necessidades da } \\
\text { população, que surgem em seu } \\
\text { seio. } \\
\text { - Articula-se de forma a levar ao } \\
\text { Estado vozes que poderiam } \\
\text { nunca ser ouvidas. } \\
\text { - Consegue formar inúmeros } \\
\text { grupos, cada qual defendendo } \\
\text { uma ou mais diferentes } \\
\text { bandeiras, cobrindo boa parte } \\
\text { dos direitos à disposição. } \\
\text { - Consiste em fundamental } \\
\text { instrumento de fiscalização do } \\
\text { Poder Público e do Mercado. } \\
\text { - É capaz de mobilizar-se e agir } \\
\text { incisivamente na execução de } \\
\text { políticas públicas. }\end{array}$ & $\begin{array}{l}\text { - Incapaz de tomar decisões mais } \\
\text { impactantes. } \\
\text { - Sua atuação, em temas mais } \\
\text { sensíveis, está sujeita à } \\
\text { regulação do Poder Público, } \\
\text { ficando restrita à pressão sobre } \\
\text { os Poderes majoritários e à } \\
\text { possibilidade de demandar o } \\
\text { Judiciário. } \\
\text { - Os grupos tendem a defender } \\
\text { seus próprios interesses, muitos } \\
\text { deles colocando-se contra } \\
\text { interesses titulados por demais } \\
\text { pessoas. } \\
\text { - Alguns desses interesses podem } \\
\text { até, conflitar com direitos } \\
\text { fundamentais. }\end{array}$ \\
\hline
\end{tabular}

A Tabela I apresenta os principais pontos e contrapontos das arenas de decisão indicadas, mostrando, como havido em Komesar, que nenhuma delas é perfeita a sindicar políticas públicas, nem mesmo o processo judicial. Neste Capítulo, viram-se alguns excessos cometidos pelos juízes no tema aqui estudado, que estão intimamente ligados às desvantagens do processo judicial como locus de decisão sobre políticas de saúde. O trabalho desta pesquisa é apresentar propostas para minorar as desvantagens, na tentativa de tornar o processo judicial mais adequado para sindicar esse tipo de bem social. No Capítulo seguinte, tratar-se-á especificamente da denominada "judicialização da saúde”, procurando estabelecer limites à decisão judicial que veicular tema ligado a esse fundamental direito. 


\section{O CASO DA SAÚDE E OS LIMITES À ATUACÃ̃O JUDICIAL}

Chega-se, enfim, ao amadurecimento necessário à análise da atuação judicial na interferência em políticas de saúde. Faltam, ainda, algumas noções a serem fixadas neste Capítulo, sobretudo em seu primeiro subtítulo, em que será estabelecido o regime normativo do SUS e evidenciadas as principais ações e planos elaborados e executados pelos Poderes majoritários na saúde.

Já estão expostos e compreendidos os motivos que explicam a interferência judicial em políticas públicas, é verdade, mas não em sua inteireza. Algumas dessas razões aplicam-se exclusivamente à distribuição de saúde - daí a necessidade de, antes, analisarse o arcabouço normativo que suporta esse direito, até porque é nas normas que se fiarão tanto o legislador e o administrador quanto o próprio juiz que se deparar com um pedido dessa classe. Do estudo das normas relacionadas à saúde é que se verificará, também, a dificuldade da execução de certas decisões judiciais, além da atual inaptidão técnica que envergam os magistrados ao conceder postulações dessa natureza.

Neste capítulo serão objeto de depuração algumas das milhares de decisões judiciais afetas ao tema da saúde, buscando-se isolar seus principais fundamentos e as respectivas dificuldades de materialização. A seguir, verificar-se-á especialmente o papel do STF, que nos últimos anos mostrou-se especialmente preocupado com o problema. Constatar-se-á como a Corte Suprema evoluiu no trato do tema, partindo de uma fundamentação de tudo-ou-nada para uma argumentação muito mais técnica e condizente com as peculiaridades do direito à saúde - embora seus ecos ainda sejam incipientemente ouvidos pelos demais magistrados.

Então, seguir-se-á a primeira parte propositiva desta tese, parcial contribuição original, consistente nos limites a serem observados pelos magistrados no trato judicial das políticas públicas de saúde.

\subsection{A DISPENSAÇÃO JUDICIAL DE SAÚDE}

De fato, a Constituição Federal de 1988 encampou um dos mais audaciosos planos de inclusão social jamais visto em todo o mundo: ela proclamou ser a saúde um 
direito de todos, direito social a que os mais avançados ordenamentos consagradores de direitos humanos ao redor do globo conferiam a qualidade de intangibilidade, posto ser ele fundamental $^{331}$. Determinou mais: é dever do Estado assegurar a observância desse direito, via adoção de políticas que tenham por fim prover o acesso universal e igualitário aos serviços de saúde. Este compêndio mandamental, capitulado no artigo 196 da Constituição, garante que todas as pessoas - independentemente de classe, cor, religião, etnia, crenças e ideologias - possam indiscriminadamente receber saúde por meio do Poder Público. Além disso, a Carta também fixa o dever do Estado atuar tanto na prevenção (a redução do risco de doença e de outros agravos a que alude o mencionado artigo) quanto na proteção, recuperação e promoção de saúde.

Nem sempre foi assim. Aliás, o panorama pré-Constituição era bem diferente. Com efeito, a atuação estatal no trato da saúde, no Brasil, pode ser dividida em dois momentos: antes e depois da Constituição Cidadã ${ }^{332}$. Antes, havia extrema instabilidade quanto à efetiva obrigação de guarida pública da saúde da população. Duas são as constatações mais importantes desse período: (a) os atos do Estado eram voltados muito mais ao monitoramento e erradicação de endemias, abrangendo ações de vacinação, controle e saneamento básico; e (b) o sistema privado de saúde foi concebido, montado e executado, ocupando importantes espaços deixados abertos pelo Estado.

O esquema de saúde estatal deficitário, que, até meados da Década de 1970, era tocado conjuntamente com a previdência social, foi permeado de aspectos que tornavam sua operabilidade altamente questionável. O fato de prestar saúde apenas àqueles que efetivamente contribuíam para a previdência causava severo incômodo, sobretudo em um país desigual e com relevantes índices de desemprego como o Brasil. O tratamento da

\footnotetext{
${ }^{331}$ Esta não é a realidade observada em diversos países do mundo. Nos Estados Unidos, recentemente foi estabelecido o dever de colaboração com um sistema público de saúde, obrigando as pessoas a adquirir seguro-saúde, porque, até então, quem não o possuía não era atendido nos hospitais (essa questão, a propósito, foi desafiada na Suprema Corte daquele País que, por apertada maioria - cinco a quatro - julgou a constitucionalidade da medida). Na Tailândia, a única obrigatoriedade do Estado é a de atender pessoas em situação emergencial. Na Inglaterra, todos são passíveis de atendimento pelo National Health Service, mas apenas após rigoroso credenciamento que envolve questões relacionadas à potencial incapacidade financeira da pessoa para custear tratamento privado. Uma vez inscrito, o tratamento é gratuito, inclusive quanto aos medicamentos necessários. A prestação de saúde na Inglaterra é reputada como inspiradora do SUS. Sobre a universidade da seguridade social, aí compreendida a saúde, ver discurso do Deputado Ulysses Guimarães na nota 288.

${ }^{332}$ Não se olvide que a preocupação do Poder Público com a saúde data de tempos mais remotos. Consta que em 1521, Dom Manuel nomeou Cirurgião-Mor do Reino e, por volta de 1550, havia encarregados da saúde do povo, principalmente na verificação da qualidade dos alimentos, que eram destruídos ao se constatar sua inadequação. As atribuições observadas na Metrópole eram obviamente estendidas ao Brasil-Colônia. A informação é prestada por mais um dos tantos órgãos governamentais encarregados da saúde, a Fundação Nacional de Saúde (<http://www.funasa.gov.br/internet/museuCronHis.asp〉, acesso em 19.1.2012, 14:17h).
} 
desgastante situação veio justamente com a Constituição, que contemplou proposta, já realizada em 1986, de prestação universal de saúde.

Então não é nada por acaso que o artigo 196 da Constituição determina que o Estado atue de maneira a cobrir a saúde da universalidade de pessoas sob seu albergue. Essa exigência, ao revés, foi pensada, debatida, aprovada e consolidada no texto da Constituição. A interpretação histórica, neste caso, é extremamente importante para que fique claro que a Carta de 88 não almeja nem nunca almejou tirar de uns para dar a outros, mas, sim, atender a todos. O fornecimento de bens e serviços ligados à saúde, no Brasil, tem que ser, sob qualquer ótica, analisado com essa lente: a da universalidade. Trata-se de escolha constitucional que não pode ser olvidada.

Mas não é tarefa fácil cumprir o mister constitucional nesse campo. Mais adiante, serão analisadas algumas características específicas que fazem da saúde um campo extremamente arenoso para a definição de qualquer projeto. Além da variedade e mutabilidade das moléstias que acometem a população, do caráter de maior ou menor incidência, da dimensão do território brasileiro e das diferenças regionais encontradas, ainda há o problema dos altos custos dos tratamentos e fármacos, que transformam o acesso à saúde um problema mundial ${ }^{333}$.

Neste Capítulo será estudada a estrutura normativa de algumas ações políticas que dão lastro à norma constitucional, a bem de demonstrar quão intenso e complexo é o cenário que se coloca ao alvedrio do Judiciário.

\subsubsection{O arcabouço jurídico da saúde no Brasil}

É extremamente complexa a estrutura jurídica da saúde no País, sobretudo pelo fato de o tema consistir competência comum entre União, Estados, Distrito Federal e

\footnotetext{
${ }^{333}$ Em 2010 e como já noticiado nesta tese, a OMS intitulou seu Relatório Mundial de Saúde demonstrado a preocupação com o financiamento do sistema (Financiamento dos Sistemas de Saúde: o caminho para a cobertura universal). Octávio FERRAZ também sinaliza, objetivamente, as dificuldades enfrentadas pelo alto custo da saúde: falando a respeito da polêmica da quebra de patente, pelo governo brasileiro, do Efavirenz, remédio usado no tratamento da AIDS, o articulista revela que “(...) o alto custo da saúde e a consequente necessidade de racionamento nessa área [é um problema mundial]. Certa ou errada a decisão política, o fato é que o preço de medicamentos (influenciado pelo regime de patentes) tem claro impacto na capacidade de qualquer sistema de saúde de atender às necessidades da população." ("Direito à saúde, escassez e o Judiciário". Folha de São Paulo, p. A3, em 10 de agosto de 2007).
} 
Municípios, tanto quanto aos cuidados concretos necessários ${ }^{334}$ como quanto à legislação ${ }^{335}$. E não poderia ser diferente. A descentralização é da essência dos serviços de saúde e também deveria ser refletida, como foi, na competência legiferante. Em um país continental como o Brasil, em que no Norte há malária e, no Sul, gripe, há políticas gerais assim como existem políticas específicas e pontuais, regionalizadas ${ }^{336}$.

O resultado, em termos legislativos, é emaranhado de leis, portarias, instruções normativas e decretos que tratam sobre o assunto saúde. Seria esforço hercúleo e pouco inteligente mapear toda a capilarizada estrutura normativa da pasta no Brasil. Proceder assim seria ultrapassar o escopo da pesquisa. Para os fins a que ela presta, é preciso, somente, que se entenda: (a) o que determina a Constituição; e (b) como funciona o SUS. Com base apenas nestes dados é possível traçar um panorama geral apto a demonstrar que, de fato, não é tarefa fácil entender sequer as mazelas normativas da saúde.

\subsubsection{Constituição}

O legislador constituinte não negligenciou o tema da saúde. A tese mais provável, aliás, é a de que os artigos que abordam tal temática, ao fim e ao cabo, representaram contundente resposta ao que se via, até então, depois de décadas de reclamos, desserviço e uma insistente e irritante postura estatal de não se preocupar deveras com a saúde de sua população ${ }^{337}$. De fato, a partir de 1988, a saúde se tornou um direito duplamente qualificado pela universalidade ${ }^{338}$, o que significa que qualquer pessoa passava a poder usufruir dos bens dispensados pelo Estado nesse contexto, independente se efetivamente contribuiu ou não para a seguridade. Ademais, a fruição desses bens deve-se dar, também, e em função de dois mandamentos constitucionais, de maneira igualitária ${ }^{339}$, garantindo-se a todos, destarte, acesso aos mesmos bens.

\footnotetext{
${ }^{334}$ Art. 23, II da Constituição.

${ }^{335}$ Art. 24, XII da Constituição.

${ }^{336}$ Compete aos Municípios, com apoio técnico e financeiro dos Estados e da União, prestar os serviços de atendimento à saúde da população, concorde com o inciso VII do artigo 30 da Constituição.

${ }^{337}$ Cf. Item 4.2.1.

${ }^{338}$ O artigo 194, I da Constituição estabelece a universalidade como objetivo da seguridade social (que compreende a saúde); o artigo196 estipula que as ações de saúde serão universais.

$339 \mathrm{Na}$ Constituição, o artigo 194, II garante uniformidade e equivalência dos serviços e ações urbanas à população urbana e rural; o artigo 196 torna obrigatório o tratamento igualitário na dispensação de políticas de saúde.
} 
O audacioso plano referido no item anterior possui propósitos muito nobres, é engenhoso, vale-se de uma mecânica com alto potencial de manejo e alinha o Brasil com o que de mais moderno há em termos de consenso ao direito humano fundamental à saúde $^{340}$. De acordo com a Constituição, o Poder Público é o responsável tanto por executar um plano preventivo de combate ao tabagismo (cediça causa das mais variadas moléstias) ${ }^{341}$ quanto por vacinar a população ${ }^{342}$, passando por viabilizar internações, consultas, entrega de medicamentos e terapias ${ }^{343}$. O dever estatal advém tanto da força normativa que assume o direito à saúde, eleito como direito social fundamental, quanto das claras diretivas apontadas no artigo 196 do Documento: a necessidade de promoção e proteção às atuações preventivas - com a redução do risco de doenças e agravos - e curativas - com a recuperação dos afetados.

O tamanho do território e as moléstias regionais típicas de cada local refletiram no constituinte o mandamento de congregar as ações e políticas de saúde em um sistema único e hierarquizado, nada obstante planejá-las e executá-las de forma regional. Apesar da multiplicidade das normas e das próprias ações de saúde, presentes em todo o território nacional, a Constituição preservou uma unidade, ou direção única, em cada esfera de governo ${ }^{344}$. É neste fundamento constitucional que se apoia o Sistema Único de Saúde, o SUS, instrumento responsável por executar as políticas de saúde no Brasil.

A própria Constituição tratou de fixar as mais importantes atribuições do SUS, um exemplo clássico do legislador constituinte como definidor de políticas públicas (no caso, de saúde). O SUS deve controlar procedimentos, produtos e substâncias de interesse para a saúde, participando da produção de medicamentos, equipamentos, imunobiológicos, hemoderivados e outros insumos, além de aplicar em suas ações desenvolvimento científico e tecnológico correlato. É dele, bem assim, a vigilância

\footnotetext{
${ }^{340}$ A OMS considera que o Brasil, na Década de 2000, avançou grandemente para concretizar a cobertura universal de saúde (Relatório..., xiii-xiv).

${ }^{341}$ O Estado adota o Programa de Controle ao Tabagismo no Brasil, executado pelo INCA - Instituto Nacional do Câncer. Trata-se de estratégia traçada a partir da adesão, pelo Brasil, à Convenção-Quadro para $o$ Controle do Tabaco, delineada e debatida no âmbito da OMS e trazida ao direito interno pelo Decreto $\mathrm{n}^{\mathrm{o}} 5.658 / 2006$.

$342<$ http://www2.planalto.gov.br/imprensa/noticias-de-governo/saude-oferece-duas-novas-vacinas-paracriancas-a-partir-do-2o-semestre>, acesso em 19.1.2012, 13:40h. É interessante notar que esta notícia, que trata de vacinação infantil, foi extraída do sítio eletrônico do Planalto, e, não, do sítio eletrônico do Ministério da Saúde (que também reproduzia a notícia no mesmo momento, em <http://portalsaude.saude.gov.br/portalsaude/index.cfm>).

${ }^{343}$ Em janeiro de 2012, o governo brasileiro decidiu custear as cirurgias de troca das próteses mamárias de silicone das marcas PIP e Rofill, que empregaram, na composição do material, silicone industrial, inadequado para uso humano (<http://g1.globo.com/bom-dia-brasil/noticia/2012/01/sus-vai-trocar-de-gracaproteses-de-silicone-rompidas-ou-deformadas.html〉, acesso em 13.1.12, 20:55h). Vê-se que mesmo no caso de origem estética de problemas o Poder Público atua em prol dos prejudicados.

${ }^{344}$ Art. 198, caput e inciso I, Constituição.
} 
sanitária, epidemiológica e de saúde do trabalhador, bem como a fiscalização e inspeção de alimentos, com o controle de seu teor nutricional, compreendendo bebidas e águas para o consumo humano. Também deve o SUS ordenar a formação dos agentes de saúde, participar da formulação política e da execução das ações de saneamento básico, controlar e fiscalizar produção, transporte, guarda e utilização de substâncias e produtos psicoativos, tóxicos e radioativos, colaborando na proteção ao meio ambiente, inclusive o do trabalho $^{345}$. Sem dúvida são muitas, e variadas, as atribuições constitucionais do SUS. Não se pode negar que todas elas são de alta relevância tanto para a saúde da população quanto para os serviços prestados pelo Estado, e que cada uma delas demanda uma espécie de política pública diferente ${ }^{346}$.

Preservando a estrutura já enraizada no País, o constituinte admitiu a exploração econômica dos serviços de saúde, considerando-os, contudo, de relevância pública, abrindo o desejável flanco do controle, pelo Estado, da iniciativa privada que se arvorasse a atuar na área ${ }^{347}$. Do que se observa hoje em dia fica clara a dinâmica pragmática da norma constitucional: quem pode não se vale da estrutura estatal quando o tema é saúde; ao revés, os seguros-saúde, hospitais, laboratórios, médicos, enfermeiros, farmacêuticos, terapeutas, psicólogos privados e tantos outros especialistas e trabalhadores que poderiam ter suas denominações incluídas nesta lista vivem pródigo momento. A União mantém controle sobre essa estrutura disseminada e enraizada no cotidiano por meio da Agência Nacional de Saúde Suplementar. Mas o fato é que se parte da prestação dos serviços de saúde não tivesse sido entregue à iniciativa privada, os problemas observados no SUS seriam inegavelmente maiores. E é fato, de igual maneira, serviços e ações de saúde prestados pelo particular estão terminantemente proibidos de contar com subvenções públicas $^{348}$. Daí, e também porque só atendem a seus clientes contratados e segurados, não

\footnotetext{
${ }^{345}$ Art. 200, incisos I a VIII, Constituição.

${ }^{346}$ De fato, o controle de alimentos e bebidas esbarra na política de prevenção aos agravos de saúde, já que alguns desses produtos podem causar problemas e danos às pessoas, sobretudo aqueles que contenham em sua composição substância nociva. O controle dos alimentos está a cargo da ANVISA, no plano federal, e aos órgãos de vigilância sanitária de Estados e Municípios. À ANVISA compete o registro, o controle de informações e riscos, a inspeção e, ainda, o estabelecimento de normas e padrões. No sítio eletrônico da Agência vê-se a gama de temas correlacionados ao controle dos alimentos e bebidas, cada qual a ensejar uma política própria. Mesmo os alimentos servidos e consumidos em restaurantes são objeto da preocupação estatal (<http://portal.anvisa.gov.br/wps/content/Anvisa+Portal/Anvisa/Inicio/Alimentos>, acesso em 14.7.20 13, 11:38h). Da mesma forma, equipamentos de radioterapia precisam ser controlados, já que usam componentes atômicos. Quanto ao saneamento básico, é fora de dúvida que o SUS deve estar na linha de frente de suas definições, porque conta em suas fileiras com médicos sanitaristas, além do que o saneamento básico elide uma série de doenças clássicas dos grotões do Brasil, como a teníase, a esquistossomose, entre outras.

${ }^{347}$ Arts. 197, parte final, e 199 da Constituição.

${ }^{348}$ Art. $199, \S 2^{\circ}$ da Constituição .
} 
se aplicar aos planos de seguro-saúde, equipamentos, profissionais, hospitais, laboratórios ou qualquer outro suporte particular o problema ora estudado, a não ser quando estiverem eles atendendo em substituição ao Estado e, portanto, integrados à política do SUS ${ }^{349}$.

Na Seção dedicada especialmente à saúde, a Constituição define sua forma de custeio. Estabelece que o SUS será financiado com recursos da seguridade social, arrecadados mediante as contribuições definidas no artigo 195, mais receitas dos entes federados e aplicação mínima de recursos. A importância da aplicação do percentual mínimo exigido constitucionalmente nas ações de saúde é revelada pelo advento da Emenda à Constituição $n^{0}$ 29/2000, que elegeu tal aplicação como um dos denominados princípios sensíveis que, presentes no artigo 34, VII, da Constituição, autorizam a intervenção da União nos Estados e Distrito Federal em caso de descumprimento. Também o artigo 35, III, por força da mesma emenda, permite o paralelismo, com a intervenção dos Estados em seus Municípios em idêntica hipótese.

Dogmaticamente, a Constituição estabelece as mais importantes definições a respeito da prestação de serviços de saúde. É o caso, por exemplo, da obrigação de o Poder Público dispensar assistência à saúde ao educando do ensino básico, o que está textualmente incluído no dever do Estado de prestar educação ao povo ${ }^{350}$. À criança, ao adolescente e ao jovem, o Estado promoverá programas de assistência integral à saúde, com destaque à saúde materno-infantil e aos portadores de deficiência física, sensorial ou mental $^{351}$.

É evidente, contudo, e já se advertiu a respeito, que o conjunto de políticas públicas necessárias à implementação do comando constitucional é muito mais complexo, amplo e denso do que está constitucionalmente escrito ${ }^{352}$. A CF estabelece as diretrizes, mas não os meios como elas serão observadas no caso concreto.

\subsubsection{O SUS e seus órgãos}

Dentro da estrutura da Administração Pública desconcentrada, o executor das mais relevantes políticas nacionais de saúde é o ministério que ganha seu nome. É ele o

\footnotetext{
${ }^{349}$ Nos locais em que não possui estrutura própria, o SUS contrata hospitais e laboratórios particulares para prestar o serviço público de saúde, integrando-se à rede do SUS e estando, pois, submetidos a seus princípios e diretrizes (<http://portal.saude.gov.br/portal/saude/Gestor/area.cfm?id_area=378>, acesso em 14.7.2013, $15: 49 \mathrm{~h})$.

${ }^{350}$ Art. 208, VII da Constituição.

${ }^{351}$ Art. 227, $\$ 1^{\circ}$, incisos I e II da Constituição.

${ }^{352}$ Ver Item 2.4. e Diagrama I, nesse mesmo item.
} 
responsável por definir a Política Nacional de Saúde e, mais, por coordenar e fiscalizar o SUS. Sob o guarda-chuva do Ministério da Saúde estão as principais políticas desse direito observadas no território, ainda que os demais entes federados tenham ampla competência para definir suas próprias, dependendo da demanda local.

O desenho descentralizado, mas apontado em uma única direção, permite que o SUS funcione de maneira congruente, porém respeitando as diferenças inerentes a um território com a dimensão do brasileiro. O Poder Público julga que essa estratégia é capaz de fomentar a prestação dos serviços de saúde de maneira mais eficaz, porque permite ao gestor que esteja mais próximo dos reclamos da população ${ }^{353}$. A ideia é criar pequenos e médios centros de decisão - representados por Municípios, Estados e Distrito Federal - que gravitam em torno de um organismo central - a União - para dar conta da demanda e manter o controle das ações. Em tese, a estrutura poderia evitar - ou, senão, mitigar - desperdícios, corrupção e ações ineficazes.

O entendimento adequado do SUS passa pela verificação de sua lei orgânica, a Lei $n^{0} 8.080 / 90$. Ela cria um órgão consultivo denominado Conselho Nacional de Saúde, integrado por representantes do Ministério da Saúde, de outros ministérios, demais órgãos de interesse e entidades representativas da sociedade civil ${ }^{354}$. Também são criadas diversas comissões, como a permanente, responsável pela integração entre os serviços de saúde a instituições de ensino superior, e as intergestores bipartite e tripartite, verdadeiros foro de negociação entre gestores quanto a aspectos operacionais, financeiros e administrativos do SUS, além de definição de diretrizes e organização de ações integradas de saúde em âmbito nacional, regional e intermunicipal ${ }^{355}$.

Estudo promovido pelo Ministério da Saúde dá bem a conta da burocracia por detrás da administração estatal da saúde no Brasil. O Ministro da Saúde conta com quatro órgãos - o Gabinete, a Secretaria-Executiva, o Departamento Nacional de Auditoria do SUS e a Consultoria Jurídica. Órgãos específicos do respectivo Ministério são a Secretaria de Gestão do Trabalho e da Educação na Saúde, a Secretaria de Ciência, Tecnologia e Insumos Estratégicos, a Secretaria de Gestão Participativa e a Secretaria de Vigilância em Saúde. Os órgãos colegiados do Ministério são o Conselho Nacional de Saúde e o Conselho Nacional de Saúde Suplementar. No âmbito da Administração Pública descentralizada, há, ainda, as autarquias (ANVISA e Agência Nacional de Saúde

\footnotetext{
$353<$ http://portal.saude.gov.br/portal/saude/Gestor/area.cfm?id_area=378>, acesso em 14.7.2013, 16:06h.

${ }^{354}$ Art. 12 da Lei ${ }^{\circ} 8.080 / 90$.

${ }^{355}$ Respectivamente, arts. 14 e $14-\mathrm{A}$ da Lei ${ }^{\mathrm{o}} 8.080 / 90$.
} 
Suplementar), as fundações (Fundação Oswaldo Cruz e Fundação Nacional de Saúde) e as sociedades de economia mista (Hospital Nossa Senhora da Conceição S.A., Hospital Fêmina S.A. e Hospital Cristo Redentor S.A.) - e isso, somente no que toca à Administração Pública federal ${ }^{356}$.

Existem dois conselhos, um representando os Estados (o CONASS, Conselho Nacional de Secretários de Saúde), outro, os Municípios (CONASEMS, Conselho Nacional de Secretarias Municipais de Saúde), estabelecidos como competentes para tratar de matérias relacionadas à saúde, tendo suas atividades custeadas pelo Fundo Nacional de Saúde ${ }^{357}$.

É em sua Lei Orgânica que o artigo $4^{\circ}$ define o que é o SUS: um conjunto de ações e serviços de saúde prestados por órgãos e instituições públicas dos entes federados, pertencentes à Administração Pública direta, indireta e fundacional. Para a lei, portanto, ações e serviços é que constituem o SUS, e não as instituições e pessoas que os prestam. Sabe-se, contudo, que tal conceito é impróprio, vez que o sistema é formado também por seu instrumental, a saber, as instituições e pessoas.

Além das atribuições constitucionais examinadas no item anterior, o SUS possui inúmeras outras, das quais duas têm relevante destaque para os estudos aqui desenvolvidos: a primeira, a execução de ações de assistência terapêutica e integral, inclusive farmacêutica; a segunda, a formulação de uma política de medicamentos ${ }^{358}$. Esses dois comandos constituem, mais especificamente, a obrigatoriedade do Poder Público prover ao povo fármacos, terapias e tratamentos.

A lei estatui algumas competências que são comuns entre os entes federados, dentre as quais se destaca a organização da saúde e seu controle orçamentário $^{359}$. Outras são exclusivas da direção nacional do SUS, outras ainda, de sua direção estadual. A rede é hierarquicamente montada e integrada por uma série de órgãos e gestores. Tratar de saúde em grau municipal significa dizer que são ao menos cinco mil, quinhentas e sessenta seis secretarias e corpos diretivos de saúde, isso sem contar as demais secretarias estaduais, os órgãos municipais, estaduais e federais. Explicar todo o sistema consumiria muitas linhas para um assunto que não é central. É preciso, apenas, demonstrar que há estrutura pública criada e dedicada integralmente ao desenho, controle e

\footnotetext{
356 MINISTÉRIO DA SAÚDE, Secretaria de Vigilância em Saúde. Manual de Direito Sanitário com Enfoque na Vigilância em Saúde. Brasília: Ministério da Saúde, 2006. pp. 61-62.

${ }^{357}$ Criado pela Lei n ${ }^{\circ} 8.142 / 90$, o Fundo Nacional de Saúde é o gestor financeiro federal do SUS.

${ }^{358}$ Arts. $6^{\circ}, \mathrm{I}, d$ e VI, respectivamente, da Lei $n^{\circ} 8.080 / 90$.

${ }^{359}$ Art. 15, II da Lei n ${ }^{\circ} 8.080 / 90$.
} 
execução das políticas de saúde, representada pelo SUS, todas com suas atribuições, todas a trabalhar em prol da saúde.

Juízes em geral desconhecem a estrutura do SUS e, a toda a evidência, as atribuições de cada órgão. Ora, mas eles precisariam conhecer tudo a respeito da saúde? Parece que a resposta é não. Mas o magistrado que decide questões de saúde tem de, ao menos, possuir graus de cognição a respeito do SUS, exatamente para saber: (a) que existem planos, programas e ações encetados por esses inúmeros órgãos; (b) em alguma medida, que há órgãos específicos para tratar da vigilância farmacológica, da epidemiológica, da medicina curativa e outros, o que é fundamental para dissociar do pedido judicial de saúde a perniciosa imagem de que o Poder Público deve, a qualquer custo, providenciar o quanto requerido, sempre; e (c) novamente, em alguma medida, em que consistem as atribuições desses órgãos, o que possibilitará a ele, juiz, investigar se a Administração Pública já não executou, ou está em fase de execução ou de planejamento, a ação de saúde judicialmente postulada.

Do universo das ações de saúde uma modalidade desperta maior interesse, uma vez que diretamente relacionada ao problema que é central neste estudo: a assistência farmacêutica, com a distribuição de medicamentos. Ela será tratada em momento oportuno e quando for estudada a casuística judicial da matéria. Por ora, evidenciados de maneira sumária tanto o suporte constitucional quanto aspectos do SUS, é tempo de se penetrar nos problemas na saúde.

\subsubsection{Problemas na saúde}

Este é, talvez, o item mais facilmente inteligível desta tese. São de conhecimento geral, estão no inconsciente coletivo e são experimentados na pele por parte da sociedade os problemas, mazelas e incapacidades que assolam a saúde no Brasil. Não obstante o louvável e intenso esforço estatal, estruturado no bojo de uma rede entrelaçada e integrada, conforme já exposto antes, a saúde no País ainda é um problema ${ }^{360}$. Esta não é

\footnotetext{
${ }^{360}$ Em pesquisa de opinião organizada pelo Datafolha e divulgada em 30.6.2013 no Fantástico, a população apontou a saúde como a principal transtorno do país, ultrapassando itens como segurança, educação, desemprego e corrup̧̧ão. Para $48 \%$ dos entrevistados, o sistema de saúde é problemático (também disponível em: <http://m.g1.globo.com/politica/noticia/2013/06/para-48-dos-entrevistados-saude-e-maior-problema-dopais.html?hash=3>, acesso em 14.7.2013, 18:06h).
} 
uma tese sobre a saúde, por óbvio, e até em função disso que se passará longe de investigar proficuamente os motivos da ineficiência do sistema. Todavia, para ajudar a entender porque o Judiciário é diuturnamente conclamado a intervir nas políticas correspondentes, é fundamental que sejam perfunctoriamente demonstradas as vicissitudes da saúde no País.

As maiores demandas da população convergem para o fornecimento de medicamentos ${ }^{361}$. O Poder Público possui intrincado e complexo programa de distribuição gratuita de fármacos ${ }^{362}$. Basicamente, de acordo com a política de assistência farmacêutica a que está obrigado o Estado, a Administração Pública adquire medicamentos e os coloca à disposição da população. São milhões de reais gastos todos os meses para a aquisição de medicamentos previamente definidos pelos governos. É muito dinheiro envolvido. Nada obstante essa preocupação, entre $15 \%$ e $20 \%$ dos brasileiros não têm acesso a qualquer tipo de medicamento, $50 \%$ dos pacientes que precisam de determinado fármaco não têm condições financeiras para adquiri-lo, nas farmácias privadas, $15 \%$ da população mais rica compra $48 \%$ dos medicamentos, e $51 \%$ da população mais pobre, apenas $16 \%$, um déficit de uso de fármacos entre os mais necessitados ${ }^{363}$.

O problema do custeio da saúde desponta como relevante nos quatro cantos do mundo. Já se fez referência ao trabalho feito pela OMS em 2010, que demonstra a complexidade de se lidar com o desejo de uma cobertura universal tendo um orçamento visivelmente limitado, sobretudo em questões custosas, como são, via de regra, questões de saúde $^{364}$. A OMS elenca uma série de variáveis que, na sua concepção, devem ser inevitavelmente consideradas quando a o tema for o financiamento da saúde.

Trata-se de questões altamente intrincadas, que demandam conhecimento específico e, certamente, uma afetação especial e dedicada por meio de quem for aplicar as recomendações respectivas. O conhecimento não se restringe, apenas, ao domínio dos temas orçamentários, mas exige do gestor desenvoltura no trato das peculiaridades do sistema de saúde. O documento da OMS é extenso e de denso conteúdo, mas um exemplo que dele se pode tirar no que toca às questões relacionadas à definição e financiamento da saúde são os passos estratégicos indicados para a progressão do ideal de acesso universal.

\footnotetext{
${ }^{361}$ O Item 4.2.1.3 se vale de dados organizados pela OMS e pelo Ministério da Saúde a demonstrar a magnitude da demanda por medicamentos, fenômeno mundial.

362 Item 4.2.1.

363 DEPRÁ, Aline Scaramussa e SOARES, Jussara Calmon Reis de Souza. "Ligações perigosas: indústria farmacêutica, associações de pacientes e as batalhas judiciais por acesso a medicamentos”, em Physis Revista de Saúde Coletiva, Rio de Janeiro, 22 [1], 2012, p. 312.

364 A escassez foi tratada 3.2.1. O Relatório da OMS será recorrentemente citado como exemplo do tratamento dispensado pelas autoridades de saúde quanto às complexas questões do acesso universal a tão caro direito.
} 
A Ação 1 consiste na definição, pelo Estado, do que significa cobertura universal naquele seu território. Estar-se-ia, no Brasil, no campo da interpretação constitucional. A questão é fundamental, deveras: o primeiro passo de qualquer ação humana para se alcançar um objetivo é definir seus limites. A Ação 2 mapeia quanto desse objetivo já está implementado no recorte temporal da aplicação da estratégia. Aqui, também o prazo da estratégia foi definido. A Ação 3 identifica as fontes de custeio e o budget a ser aplicado, além de sua evolução com o passar do tempo e a verificação dos gastos despendidos em cada rubrica. A Ação 4 destaca os obstáculos à cobertura universal, enquanto as Ações 5 e 6 definem e implementam estratégias para remoção desses entraves. Por fim, a Ação 7 demanda reflexão sobre o progresso do determinado país rumo a uma cobertura universal $^{365}$. Deste breve exemplo, rasamente analisado, vê-se quão complexa é a tarefa do administrador com vistas a assegurar a universalidade de acesso à saúde.

Usando a estratégia da OMS, este item se direciona à análise do que podem ser classificados como entraves à cobertura universal de saúde no Brasil. Daí ser ele denominado problemas na saúde.

Quanto mais complexa é tal tarefa, maior a probabilidade de erros e advento de lacunas. Com a saúde está longe de ser diferente. Evidentemente que existem problemas nesse campo, e de toda a sorte: desde uma decisão equivocada, embasada em informações insuficientes, até eventos imprevistos, que poderiam ter seus efeitos minorados houvesse uma antevisão técnica e experimentada por parte da Administração. Para o Banco Mundial, por exemplo, maior do que a falta de recursos, a saúde no Brasil esbarra no problema da eficiência, ou melhor, a falta dela ${ }^{366}$.

Mas há outra ordem de problemas muito mais graves e que, em nosso País, estão longe de ser raros. São os crimes. Ações criminosas que, no campo da saúde, prejudicam sobremaneira o sistema. Para ilustrar, tome-se o caso da fraude ocorrida na dispensação do tratamento da psoríase.

\footnotetext{
${ }^{365}$ OMS, Relatório..., p. XXIII.

${ }^{366}$ No apagar das luzes de 2013 o Banco Mundial divulgou relatório fazendo balanço dos vinte anos do SUS e concluiu que o sistema não funciona adequadamente mais por desorganização do que por falta de dinheiro. Citou como exemplo a precária eficiência do sistema hospitalar: mais da metade dos hospitais brasileiros são pequenas unidades, com menos de cinquenta leitos, enquanto que a literatura internacional aponta que, para ser eficiente, um nosocômio deve ter, pelo menos, cem leitos. Mesmo assim, leitos e salas cirúrgicas estão subutilizados, com taxa de ocupação média de $45 \%$ (contra 70-75\% da média mundial). As salas de cirurgia, a seu turno, estão desocupadas em $85 \%$ do tempo. Ao mesmo tempo, os grandes hospitais de referência estão superlotados ("Falta mais eficiência ao SUS do que verba, afirma estudo", em Folha de São Paulo, edição de 9.12.13, nº 30.931, Capa e pp. C1 e C3).
} 
A psoríase é doença epitelial altamente incômoda, sob o ponto de vista funcional e estético, que demanda cuidados permanentes. O tratamento, em regra, é realizado com medicamentos de alto custo, alguns dos quais são dispensados pelo Estado. Para que se tenha ideia do impacto orçamentário dos medicamentos que tratam essa moléstia, a Agência Câmara concluiu que, em 2010, os dois primeiros lugares que encabeçavam a lista dos cinco medicamentos de maior relevância financeira para o Ministério da Saúde eram ocupados por fármacos para o tratamento da psoríase $^{367}$.

Em 2008, foram detidas nove pessoas acusadas de lesar o Estado de São Paulo em um esquema de fraude que envolvia pedido judicial de medicamentos para psoríase. A Associação dos Portadores de Vitiligo e Psoríase do Estado de São Paulo foi acusada de engendrar-se em esquema que contava com médicos, advogados e laboratórios para obter decisões que obrigavam o Estado a fornecer a certos pacientes medicamentos que não estavam contemplados pelas listas obrigatórias do SUS. O paciente se dirigia àquela Associação e era atendido por médico que receitava o fármaco de determinados laboratórios - sempre os mesmos, fora das listas públicas, mas aparentemente tão ou mais eficientes do que aqueles por elas contemplados. Então, munido da prescrição, o paciente movia medida judicial e conseguia a droga, uma autêntica fraude não apenas à licitação, mas, principalmente, aos demais estudos que antecedem a compra de medicamentos ${ }^{368}$. No caso, verificou-se que três autores de ações judiciais sequer tinham a doença. O Estado de São Paulo foi obrigado a gastar duzentos milhões de reais em 2007 para atender decisões judiciais que, como no caso colocado, obrigavam-no a conceder fármacos fora das listas oficiais $^{369}$.

Outro estudo empírico apontou que as prescrições para remédios antineoplásticos de apenas cinco médicos resultaram em gastos de sete milhões de reais, em apenas dois anos, contra a Fazenda do Estado de São Paulo. A mesma pesquisa levantou que um único médico foi responsável por quase $40 \%$ das prescrições do remédio Erlotinibe, enquanto que um mesmo advogado subscreveu os pedidos que acarretaram na

\footnotetext{
${ }^{367}$ Em 2010 foram gastos nada menos do que cerca de trezentos e oitenta e cinco milhões de reais apenas para a compra do Adalimumabe 40mg e do Infliximabe 100mg (<http://www2.camara.gov.br/agencia/noticias /SAUDE/192120-MEDICAMENTOS-MAIS-CAROS-FORNECIDOS-PELO-SUS.html>, acesso em 9.3.12, $13: 44 \mathrm{~h})$.

368 <http://fantastico.globo.com/Jornalismo/FANT/0,MUL777176-5605,00>, acesso em 9.3.12, 14:15h.

${ }^{369} \mathrm{http}: / /$ ias2.epharmatecnologia.com.br/sa/sec/newsdtl_dtl?p_informa=20403>, acessos em 9.3.12, 14:17h.
} 
propositura de $70 \%$ das ações envolvendo o fármaco Cetuximabe ${ }^{370}$. Colucci e Westin descobriram, a propósito, que nove entidades brasileiras de defesa dos direitos de pacientes eram financiadas por laboratórios privados ${ }^{371}$. Estudos em volta do globo apontam como existem estreitas e inconvenientes (para a sociedade) relações entre associações representativas de adoentados e a indústria farmacêutica ${ }^{372}$. Ligações como essas podem subverter toda a necessária eficiência que se deve ter como marca preponderante de uma política universal executada com óbvia limitação de recursos, agravando o quadro.

As fraudes envolvendo medicamentos comprados com dinheiro público são extremadas. Em fevereiro de 2012, foi desbaratada quadrilha que atuava em São Paulo e no Rio de Janeiro e cujo propósito era desviar medicamentos de oncologia de alto custo dos estoques públicos, revendendo-os com deságio para farmácias e distribuidoras. Medicamentos comprados pelo Estado por oito mil reais eram desviados e alienados a particulares por mil e oitocentos reais. O Ministro da Saúde comemorou a prisão dos envolvidos, reputando a ação como fundamental para evitar o desperdício de recursos da $\operatorname{pasta}^{373}$.

Além dos conluios, grave problema é o desperdício gerado por medicamentos estragados. O Conselho Federal de Farmácia estima que, todos os anos, cerca de um bilhão de reais destinados ao SUS sejam desperdiçados em medicamentos. Em 2007, aproximadamente trinta e quatro mil pessoas apresentaram intoxicação medicamentosa, muitos em virtude do consumo de fármacos vencidos e imprestáveis ${ }^{374}$. Não é novidade, no Brasil, que os recursos públicos pereçam com o tempo. O grande problema é a aplicação inócua desses recursos que, escassos, não serão aproveitados por quem deles necessita.

E ainda há mais. Que dizer de médicos que recebem do sistema público por consultas que não realizam? O já mencionado Programa de Saúde da Família, da União, registrou falhas gravíssimas, envolvendo tanto médicos que trabalhavam muito menos do que declaravam para o SUS, quanto prefeituras que registravam profissionais que não

\footnotetext{
${ }^{370}$ LOPES, "Uso racional...", p. 622.

${ }^{371}$ COLLUCCI, Cláudia e WESTIN, Ricardo. "Indústria Farmacêutica financia ONGs". Folha de São Paulo, 18.5.2005, p. C1.

${ }^{372}$ DEPRÁ e SOARES, “Ligações perigosas...”, pp. 320-322.

$373<$ http://g1.globo.com/sao-paulo/noticia/2012/02/operacao-contra-desvio-de-remedios-prende-12-em-sp-e-no-rio.html $>$, acesso em 9.3.12, 20:10h.

$374<$ http://www.ecodebate.com.br/2010/04/26/r-1-bi-em-remedios-no-lixo-falhas-na-compra-e-noarmazenamento-levam-a-desperdicio-de-medicamento-no-pais/>, acesso em 9.3.12, 20:22h.
} 
atendiam em seus hospitais apenas para receber os repasses federais ${ }^{375}$. A OMS estimou, em 2010, que cerca de 10\% a 25\% dos recursos aplicados em saúde são desperdiçados por fraude e corrupção ao redor do mundo. Apenas nos países tidos por desenvolvidos, o prejuízo alcança a marca de doze a vinte e três bilhões de dólares por ano ${ }^{376}$.

O Fantástico teve acesso a informações de mais de vinte mil suspeitas de fraudes ocorridas no SUS entre 2008 e 2013, consubstanciadas em fichas médicas que continham erros grosseiros. Dentre os casos mais acintosos, em Salvador, um homem deu a luz; em Rio Bonito, um senhor morreu duas vezes; em Maricá, uma mulher tirou a próstata; em São Paulo, um rapaz bem vivo foi anotado como morto. Essas fraudes foram encontradas nas Autorizações de Internação Hospitalar - AIH, documentos emitidos por clinicas particulares e hospitais públicos para cobrar do SUS os gastos com paciente internado. De acordo com o Datasus, banco de dados do sistema, em 2012 foram gastos mais de onze bilhões apenas com AIH. Os auditores do Datasus suspeitam de fraude em, pelo menos, $30 \%$ desses casos, ou seja, foram cerca de três bilhões e trezentos milhões desviados $^{377}$.

Estes são agudos exemplos não somente das dificuldades da distribuição de saúde no Brasil, mas, também, de como o processo pode ter seu fim último amplamente desvirtuado, a ponto de servir como instrumento para concretizar - ou, pelo menos, desconfiar-se da adoção de - estratagemas contra o interesse público, assunto que será abordado no momento oportuno.

É claro que os recursos mobilizados para o atendimento das demandas surgidas em função de joguetes, fraude e corrupção geram passivo intangível na distribuição de serviços de saúde. Se algum dinheiro é gasto para cobrir despesas de tal ordem, sobretudo em razão de realocações forçadas, alguém se quedará desatendido na outra ponta, com o agravante da injustiça, ilicitude e contrariedade à ética da causa do desatendimento $^{378}$. Todos esses exemplos demonstram que o Brasil está longe de cumprir a

\footnotetext{
375 Apurou-se casos de médicos que "trabalhavam" dezoito horas por dia. Um deles declarou trabalhar vinte e quatro horas diárias. Outra médica estava registrada em hospital em que não pisava havia seis anos (<http://www.gazetadopovo.com.br/vidaecidadania/conteudo.phtml?tl=1\&id=1215642\&tit=Cadastr o-permite-fraude-na-Saude>, acesso em 9.3.12, 20:54h)

${ }^{376}$ OMS, Relatório..., pp. 73-74.

377 <http://g1.globo.com/fantastico/noticia/2013/09/sus-cobrou-por-parto-em-homem-e-operacao-de-prostataem-mulher.html>, acesso em 15.11.2013, 17:27.

${ }^{378}$ Esta mesma lógica foi observada por Luiz FUX quando declinou seu voto no julgamento da Ação Penal $\mathrm{n}^{\circ} 470$ (Rel. Min. Joaquim BARBOSA) - caso Mensalão. Segundo ele, “(...) a cada desvio de dinheiro público, mais uma criança passa fome, mais uma localidade fica sem saneamento, mais um hospital, sem leitos. Estamos falando de dinheiro público, destinado à segurança, à saúde e à educação”, em $O$ Globo n 28.876, de 28.8.2012, coluna de Merval PEREIRA, p. 4.
} 
obrigação constitucional de prover saúde a todos, igualitariamente ${ }^{379}$. Omissões sempre ocorrerão, sobretudo em função das vicissitudes apontadas. Onde houver lacunas, haverá espaço à intervenção judicial.

E o resultado desses percalços é amplamente visto na situação do atendimento hospitalar-ambulatorial. $O$ Globo analisou os quatro mais importantes hospitais de emergências do município do Rio de Janeiro a cargo do SUS - Salgado Filho, Lourenço Jorge, Souza Aguiar e Miguel Couto. A reportagem constatou falta de profissionais de saúde, demora excessiva na marcação de consultas, necessidade do internado em aguardar vaga nos centros cirúrgicos. Uma pessoa teve que passar por três hospitais em cinco horas, sem atendimento. As condições de asseio eram precárias. Cirurgias demoravam três meses para ser marcadas. O Ministério da Saúde admite que, na rede federal de atendimento presente naquele município, faltam nada menos do que quatrocentos médicos ${ }^{380}$. E estamos falando do Rio de Janeiro.

A situação atual não é aliviada em termos financeiros, o que a torna ainda mais grave, principalmente após a prorrogação da DRU ${ }^{381}$.

Talvez em função dos fatos por trás destes exemplos que o Ministério da Saúde decidiu avaliar a prestação dos serviços sob sua tutela nos milhares de Municípios brasileiros, criando, recentemente, o IDSUS (Índice de Desempenho do SUS). O IDSUS é consolidado pela União a partir de dados informados por cada município, levando-se em conta, basicamente, o índice de acessos, que mede a qualidade dos atendimentos, e o índice de efetividade, que averigua se o serviço é integralmente prestado. O Diagrama II demonstra a metodologia de aferição do IDSUS.

\footnotetext{
${ }^{379} \mathrm{~A}$ OMS chegou à mesma conclusão. No Relatório em que o órgão supranacional trata da delicada questão do financiamento da saúde, ela elenca dez causas de ineficácia na aplicação de recursos para uma cobertura universal. A nona causa é intitulada como fugas nos sistemas de saúde: desperdício, corrupção e fraude (p. 67).

${ }^{380}$ Edição de 7.3.12, p. 3. Na edição de 11.12.13, O Globo denunciou que a Defensoria Pública da União constatou que cerca de doze mil e quinhentas pessoas estavam à espera por cirurgia nos hospitais federais do Rio de Janeiro. Setecentos e trinta delas eram crianças. Havia pessoas que estavam há sete anos da fila de espera ( $n^{\circ} 29.346$, chamada de Capa e p. 14).

${ }^{381}$ V. Item 2.3.
} 


\section{DIAGRAMA II ${ }^{382}$}

\section{Explicação do cálculo do IDSUS}

\section{Saiba o que é e como é calculado o novo indicador de saúde}

\author{
O que é o índice? \\ O Índice de Desempenho de \\ Saúde (IDSUS) é uma forma de \\ avaliaçăo criada pelo governo para \\ verificar, a cada três anos, 0 \\ desempenho do atendimento de \\ saúde nos municipios brasileiros
}

\section{Que aspectos são levados em conta?}

- Com o indice de acesso, o ministério quer verificar a qualidade do acesso ao SUS

- Com o indice de efetividade, se o serviço é prestado em sua totalidade. Juntos, os indices compōem uma nota final
Como as cidades são avaliadas?

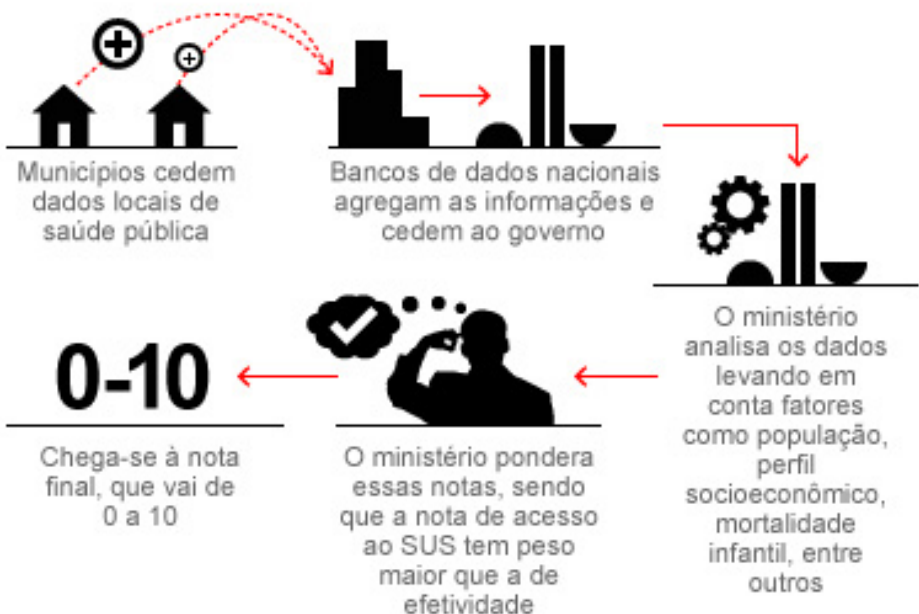

O IDSUS revelou, não sem espanto, que a nota dada à saúde pública no Brasil é de 5,4 (2012). Apenas 1,9\% dos brasileiros recebem serviços adequados de saúde, com nota igual ou acima de $7,0^{383}$. O que é espantoso é que se trata de um índice formado a partir de dados captados pelo próprio Poder Público. São os Municípios que preenchem fichas encaminhadas a bancos de dados consolidados e analisados pelo Ministério da Saúde (Diagrama I), o que, evidentemente, desafia a confiabilidade plena ${ }^{384}$. Não seria desarrazoado supor, em um país como o Brasil, que esse índice, se obtido por mecanismos isentos, fosse revelador de avaliação ainda inferior, tanto que, no dia seguinte à divulgação da nota, a imprensa se fez presente em alguns dos Municípios mais bem avaliados e, perguntando aos usuários do serviço - a população, esta, sim, legitimada a ranquear a saúde por ela recebida - sua satisfação a respeito, verificou que a realidade se mostrava

\footnotetext{
$382<$ <ttp://g1.globo.com/ciencia-e-saude/noticia/2012/03/de-0-10-indice-do-governo-da-nota-54-saudepublica-no-brasil.html>, acesso em 1.3.2012, 20:05h.

383 "SUS só é bom para $2 \%$ dos brasileiros, diz ministério", em $O$ Globo, chamada de Capa da edição de 2.3.12. O Rio de Janeiro, capital, objeto de análise pela reportagem do jornal publicada em 7.3.12, foi a pior capital avaliada: sua nota foi 4,33 .

${ }^{384}$ Como os próprios técnicos do Ministério da Saúde avaliaram, "Não é de interesse do município, por exemplo, aparecer mal em um ranking de seu grupo na próxima avaliação por não preencher corretamente os protocolos com, por exemplo, a quantidade de atendimentos realizados."
} 
bem diversa, consistindo em mais do mesmo: esperas, em média, de três horas para atendimento, falta de leitos, fila de pessoas no chão de hospitais, alagamentos em locais de atendimento, consultas nos corredores, enfim, situações que um paciente chegou a caracterizar como "cenário de guerra" 385 .

O IDSUS corrobora a preocupação do Poder Público com a saúde, o que é extremamente positivo. Contudo, ele igualmente revela que há muito a ser feito. A União aduz que o IDSUS não poderia ser inferior a 7,0, embora o levantamento mostre haver Municípios em que ele é de $2,5^{386}$. O Índice ainda não considera outros serviços de incumbência estatal nessa seara, como a assistência farmacológica (que envolve a distribuição de medicamentos), uma das facetas mais visíveis da ineficiência dos serviços públicos.

É, precisamente, neste problemático cenário que se constitui o espaço propício para a atuação judicial nas políticas de saúde. Não fossem os juízes, certas demandas dessa população tão negligenciada jamais seriam ouvidas. A depender da vontade da maioria, os pacientes atendidos em macas nos corredores de um pequeno hospital no interior do Ceará não veriam a luz representada pela simples observância de direitos que a Constituição lhes assegura: a vida digna, o atendimento médico de qualidade, a política de saúde decente. É correto afirmar que se a saúde funcionasse adequadamente, quedaria sensivelmente diminuído o espaço para intervenção judicial. Este Capítulo demonstra que é precisamente o contrário que ocorre: deficiência administrativa explícita, interferência judicial excessiva.

4.1.3 As decisões judiciais a respeito da saúde

Os processos judiciais estudados nesta tese não se voltam propriamente à inação do Poder Público em delinear planos e estratégias preventivas de combate a doenças e males, mas, sim, à omissão administrativa em adotar providências materializáveis diretamente experimentadas pela população. Não há quem postule judicialmente a definição de um plano para o combate à obesidade infantil, mas o foro está repleto de casos

\footnotetext{
385 <http://g1.globo.com/brasil/noticia/2012/03/pacientes-do-sus-relatam-problemas-mesmo-em-cidadesbem-avaliadas.html>, acesso em 2.3.12, 13:50h.

${ }^{386}$ Trata-se de Pilão Arcado, na Bahia.
} 
em que o jurisdicionado requer do Estado o medicamento, a vacina, a internação ou a cirurgia. No máximo, pleiteia-se a construção de um hospital ou requer-se que a Administração apresente um plano de atendimento da demanda (coisa, deveras, mais avançada no que toca às políticas públicas ${ }^{387}$ ). É possível, assim, definir de antemão o objeto da análise, que repousa justamente sobre medidas concretamente aproveitadas pela população, passíveis de identificação. Assim sucede, por exemplo, com o fármaco necessário ao tratamento de asma e a cirurgia de hérnia inguinal. A definição dessa realidade é fundamental para o entendimento do fenômeno ora estudado.

Com efeito, quem chega ao foro normalmente não faz um planejamento sobre como será sua vida dali a cinco anos e postula uma providência preventiva, embora, em tese, assim pudesse proceder, desde que demonstrado o interesse para tanto. Quando a pessoa se dirige ao juiz no caso particularmente estudado, ela já precisa ou do medicamento, ou da cirurgia, ou do transplante - isso, claro, no mais das vezes. Se a ação judicial tem por pano de fundo uma questão preventiva, a fruição de determinado bem usado na prevenção é imediata (como ocorre, por exemplo, em casos de vacinação), o que dota os processos judiciais de saúde de uma característica muito própria: a urgência ${ }^{388}$.

A urgência quase que ínsita às medidas judiciais que buscam providências de saúde faz toda a diferença no resultado desses procedimentos, sobretudo quando estão em jogo tutelas emergenciais. A urgência torna a misericórdia de que já se falou premente, e o resultado é que, no mais das vezes, o jurisdicionado sai do foro com a ordem que necessita. Daí, a sentença confirmatória de uma crível ordem liminar torna-se muito mais fácil. Não fosse essa a mecânica hoje observada, não haveria uma crise na concessão judicial de saúde, nem, talvez, uma tese de doutoramento abordando o tema.

Para além da questão emergencial, é preciso investigar quais são as alegações que comovem os magistrados a ponto de fazê-los obrigar o Poder Público a atender a providência de saúde perquirida. Há um aprofundamento do debate, capitaneado,

\footnotetext{
${ }^{387}$ Como ocorreu no caso da ação civil pública proposta em face da União em que a Defensoria pretendeu obrigar a Ré a apresentar, em sessenta dias da concessão de ordem liminar, cronograma completo para realização das cirurgias atrasadas nos hospitais públicos federais do Rio de Janeiro, com atendimento prioritário a idosos, adolescentes e crianças, além das situações mais gravosas, tudo a ser realizado em prazo máximo de dois anos. A ação também requereu que a União realize concurso público para suprir a carência de profissionais nos hospitais. É uma linha mais racional do que, simplesmente, obter mandamento judicial determinado a realização imediata de cirurgias. Mesmo assim, será que a União foi consultada antes? Será que a Defensoria procurou entrar em consenso com a União? ( $O$ Globo, "Hospitais federais..., p. 14).

${ }^{388}$ Sobre graus de sensibilidade no campo da saúde com relação ao argumento emocional de magistrados, ver Item 3.2.3 retro.
} 
é verdade, pelo STF, e é possível separar os diferentes tipos de decisão judicial no que toca à saúde.

Quando se chegou à conclusão de que direitos sociais como a saúde poderiam ser objeto de dialética e escrutínio judicial, as decisões preocupavam-se, ainda, em afirmar como o Judiciário era capaz de render a solução buscada pelo jurisdicionado. Daí que o pensamento revelado nas decisões era, de certa forma, simples e direto, calcado na ótica do direito subjetivo, hipoteticamente representado pela seguinte construção: se o Estado deve prover saúde, o jurisdicionado precisa dela e não a tem, eu, juiz, devo determinar ao Poder Público que supra essa omissão, permitindo a adoção de providências no caso concreto que equivalham ao adimplemento, porque, afinal, a dignidade da vida humana não pode ser soçobrada em virtude de qualquer óbice alegado. Denominar-se-á esse modelo de articulação de argumento linear ${ }^{389}$. O argumento linear pode ser facilmente isolado na decisão da Petição no $1.246 / \mathrm{SC}$, de relatoria do Min. Celso de Mello, do STF ${ }^{390}$, havida em 1997.

Embora o precedente do STF date de quase dezoito anos, recentes decisões do Tribunal de Justiça de São Paulo andam no mesmo sentido ${ }^{391}$. O exame dos arestos

\footnotetext{
${ }^{389}$ Interessante artigo procurou isolar os grandes argumentos do discurso encetado nas ações judiciais em que se pleiteiam medicamentos. Silvia Badim MARQUES e Sueli Gandolfi DALLARI analisaram medidas judiciais que, de 1997 a 2004, requeriam assistência farmacêutica. Constataram que os discursos dos juízes foram responsáveis pela condenação do Estado em 96,4\% dos casos estudados, e que eles se baseavam em alguns argumentos que obedeciam à determinada lógica compassada. $\mathrm{O}$ exame também isolou os principais argumentos dos autores e dos réus desses processos, todos encontrando repouso na lógica linear ora apresentada. ("Garantia do direito social à assistência farmacêutica no Estado de São Paulo", em Revista de Saúde Pública $\mathrm{n}^{\circ} 41$ (2007), pp. 101-107).

${ }^{390}$ É do voto: "Entre proteger a inviolabilidade do direito à vida, que se qualifica como direito subjetivo inalienável assegurado pela própria Constituição da República (art. $5^{\circ}$, caput), ou fazer prevalecer, contra essa prerrogativa fundamental, um interesse financeiro e secundário do Estado, entendo - uma vez. configurado esse dilema - que razões de ordem ético-jurídica impõem ao julgador uma só e possível opção: o respeito indeclinável à vida." No caso, o óbice apresentado pelo Estado foi a exceção de reserva do possível. É bem verdade, conforme relata o julgado, que tratava-se de situação limítrofe, em que a falta do medicamento poderia acarretar a morte da menor postulante. Mas não se considerou, diante da dignidade da vida humana e da delicadeza da situação, a defesa do Estado, por pior que ela tivesse sido deduzida (Pet. $\mathrm{n}^{\circ}$ 1.246-1/SC, Rel. Min. Celso de MELLO, DJ em 13.2.1997).

${ }^{391}$ São elas: (a) "APELAÇÃO FORNECIMENTO DE MEDICAMENTO. Ação de concessão e manutenção permanente de medicamento. Sentença que julgou a demanda procedente, por entender que o Município tem o dever de prover a saúde de todos, com fundamento nos artigos 196 e seguintes da CF. Direito constitucional à saúde. Dever do Poder Público em fornecer medicamento àqueles que necessitam. Responsabilidade solidária dos entes públicos, nos termos do art. 23, II, da CF. Preliminar de ilegitimidade passiva ad causam rejeitada. Denunciação da lide. Inadmissibilidade. Não cabe a denunciação da lide ou chamamento ao processo na ação que visa ao fornecimento de medicamentos ou insumos (Súmula 29 desta Corte) - Preliminar rejeitada - Necessidade e eficácia demonstradas - Hipossuficiência da paciente comprovada - Sentença de procedência mantida - Recursos improvidos." (Apel. $\mathrm{n}^{\circ}$ 000338155.2009.8.26.0663, Rel. Paulo Barcellos GATTI, 4a Câmara de Direito Público, j. em 24.6.2013); (b) "APELAÇÃO FORNECIMENTO DE MEDICAMENTO. Ação de concessão e manutenção permanente de medicamento. Sentença que julgou a demanda procedente, por entender que o Município tem o dever de prover a saúde de todos, com fundamento nos artigos 196 e seguintes da CF. Direito constitucional à saúde
} 
manifestados em junho de 2013 pelo TJSP é bem elucidativo. Nota-se que: (a) todas decidiram recursos ou remessas necessárias oriundas de sentenças de procedência dos pedidos, ou decisões emergenciais, concedendo-se, em primeiro grau, as providências de saúde dos postulantes - ou seja, os acórdãos confirmaram tais sentenças e decisões; (b) mesmo tendo o Estado lançado mão de argumentos mais ou menos importantes (como a impossibilidade financeira e a falta do medicamento requerido nas listas obrigatórias ${ }^{392}$, no primeiro caso, e ilegitimidade passiva para a causa, no segundo), a Corte ignorou tais exceções; e (c) há clara tendência à repetição de argumentos, sendo muitos os julgamentos

Dever do Poder Público em fornecer medicamento àqueles que necessitam Responsabilidade solidária dos entes públicos, nos termos do art. 23, II, da CF. Preliminar de ilegitimidade passiva ad causam rejeitada. Denunciação da lide. Inadmissibilidade. Não cabe a denunciação da lide ou chamamento ao processo na ação que visa ao fornecimento de medicamentos ou insumos (Súmula 29 desta Corte) - Preliminar rejeitada - Necessidade e eficácia demonstradas - Hipossuficiência da paciente comprovada - Sentença de procedência mantida - Recursos improvidos." (Apel. $\mathrm{n}^{\circ}$ 0031161-83.2011.8.26.0053, Rel. Paulo Barcellos GATTI, 4" Câmara de Direito Público, j. em 6.7.2013); (c) "Apelação. Fornecimento de fraldas descartáveis, lenços umedecidos e cadeira de rodas adaptada para portadores de paralisia cerebral. Admissibilidade. Artigo 196 da Constituição Federal. Direito constitucional à saúde. Dever do Poder Público em fornecer medicamento àqueles que necessitam. Responsabilidade solidária dos entes públicos, nos termos do art. 23 , II, da CF. Necessidade e eficácia demonstradas. Ausência de comprovação de pedido administrativo. Desnecessidade. Incidência do princípio da inafastabilidade da jurisdição, previsto no artigo $5^{\circ} \mathrm{XXXV} d a$ Constituição Federal - Sentença mantida - Recurso não provido." (Apel. no 0017293-60.2010.8.26.0348, Rel. Paulo Barcellos GATTI, 4ª Câmara de Direito Público, j. em 24.6.2013); (d) "Obrigação de fazer Fornecimento de medicamentos. $O$ fato de o remédio não constar de listagem e ser prescrito por médico da rede particular é absolutamente irrelevante - Admissibilidade - Configurada responsabilidade do Município e do Estado - Providências burocráticas não elidem a obrigação (arts. 6º 196 e 203, IV, da CF/88 e art. 219 da Carta Paulista). Recursos improvidos." (Apel. no 9000296-06.2010.8.26.0037, Rel. Marrey UINT, $3^{\text {a }}$ Câmara de Direito Público, j. em 25.6.2013); (e) "Ação de rito ordinário - Obrigação de Fazer Fornecimento de medicamento - Afastadas as preliminares de falta de interesse de agir, ilegitimidade passiva e chamamento ao processo - Dever do Estado de prestar atendimento integral à saúde (art. 198, II, da CF). Tutela constitucional do direito à vida (artigo 196 da CF) Procedência da ação - Recurso Improvido." (Apel. n ${ }^{\circ}$ 0004751-80.2011.8.26.0572, Rel. Burza NETO, 12a Câmara de Direito Público, j. em 6.7.2013) - e, exatamente no mesmo sentido, alterando-se apenas o medicamento ou providência, do mesmo Relator, Câmara e data de julgamento: (f) Apel. 0006237-30.2011.8.26.0272; (g) Apel. 001929176.2012.8.26.0224; (h) Apel. 0028063-56.2012.8.26.0053; (i) 0012890-69.2012.8.26.0286; (j) Apel. 0025164-85.2012.8.26.0053; (k) Apel. 0000003-88.2013.8.26.0554; (l) Apel. 0001236-85.2012.8.26.0189; (m) Apel. 0050171-56.2009.8.26.0224; (n) Apel. 0001893-78.2011.8.26.0248; (o) Reexame Necessário $\mathrm{n}^{\circ}$ 0002132-79.2012.8.26.0076; (p) Reexame Necessário no 0003383-51.2012.8.26.0394; (q) Reexame Necessário $n^{\circ}$ 0001632-19.2011.8.26.0441. Como este, foram diversos os relatores que agiram do mesmo modo na amostra estudada, vale dizer, julgando em uma mesma sessão inúmeros casos relacionados à saúde, alternando-se, apenas, a medida ou medicamento buscado, mas sempre os concedendo com base no direito à saúde e na dignidade da vida humana.

${ }^{392}$ Foi, inclusive, manifestado o entendimento que a presença do produto nas listas obrigatórias faz parte de "providências burocráticas" que "não elidem a obrigação" (Apel. 0007640-67.2011.8.26.0358, Rel. Marrey UINT, $3^{a}$ Câmara de Direito Público, j. em 25.6.2013). Esse mesmo Relator entendeu que a falta do medicamento na listagem era "absolutamente irrelevante" (v. item "d" na nota anterior). Na mesma linha, Apel. n ${ }^{\circ}$ 0032062-42.2012.8.26.0562, Rel. Cristina COTROFE, 8 ${ }^{\mathrm{a}}$ Câmara de Direito Público, j. em 26.6.2013. Outro julgamento expôs pensamento interessante, embora as conclusões desta tese andem em sentido contrário: entendeu que a falta de contemplação do medicamento na listagem obrigatória não trazia qualquer consequência ao administrador caso ele fosse obrigado a adquiri-lo, pois se trataria de uma clara hipótese de dispensa de licitação (Apel. nº 0014453-97.2010.8.26.0309, Rel. Jarbas GOMES, $8^{\text {a }}$ Câmara de Direito Público, j. em 19.6.2013). 
praticamente idênticos, revelando pouca flexibilidade do órgão judicial na análise casuística $^{393}$.

A pesquisa usou como amostra os julgamentos do TJSP obtidos a partir de investigação em seu sítio eletrônico ${ }^{394}$ empregando-se o argumento "medicamento $e$ dignidade da pessoa humana". O resultado retornou dezoito mil, trezentos e noventa e cinco mil julgamentos. Percebeu-se, contudo, que alguns casos envolviam planos privados de saúde, o que invariavelmente contaminou a amostra. Usou-se, então, o argumento "medicamento e dignidade da pessoa humana e Estado e Poder Público", com o retorno de dezessete mil, duzentos e onze ocorrências. Para junho de 2013, foram duzentos e cinquenta e oito os julgamentos, e percebeu-se que, ainda com o filtro, escapavam outros assuntos que não condiziam com a pesquisa. Apartando tais julgamentos, além de outros que lidavam apenas com questões processuais, chegou-se ao número de duzentos e quarenta acórdãos de mérito. Desse universo, apenas um aresto não concedeu o medicamento pleiteado. Os outros duzentos e trinta e nove acórdãos entenderam que a vida é um bem maior, sobrepondo-se a qualquer defesa que pudesse ser articulada pelo Poder Público. Em termos porcentuais, 99,59\% dos julgamentos analisados se valeram do que este autor chama de argumento linear. O Gráfico I demonstra o resultado alcançado.

\section{GRÁFICO I}

Resultado em decisões do TJSP

embasadas no argumento linear em junho de 2013

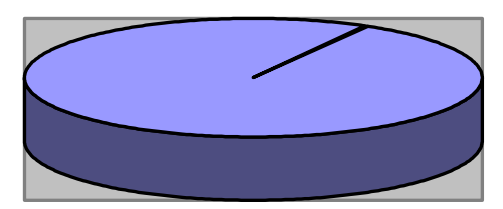

$\square$ Decisões concessivas (argumento linear - 99,59\%)

$\square$ Decisões não concessivas $(0,41 \%)$

O Fluxograma I demonstra a lógica do argumento linear, observado na quase totalidade dos julgamentos componentes da amostra:

\footnotetext{
${ }^{393}$ V. observação final na nota 390.

$394<$ https://esaj.tjsp.jus.br/cjsg/resultadoCompleta.do>, acesso em 15.7.2013, 6:10h.
} 


\section{FLUXOGRAMA I}

Lógica do argumento linear
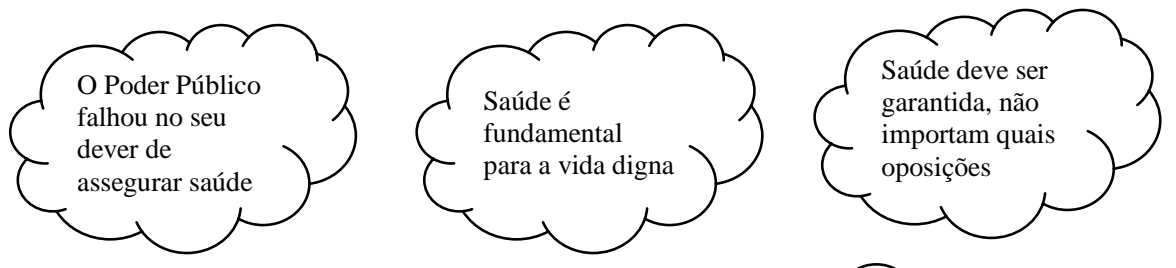

premissa A
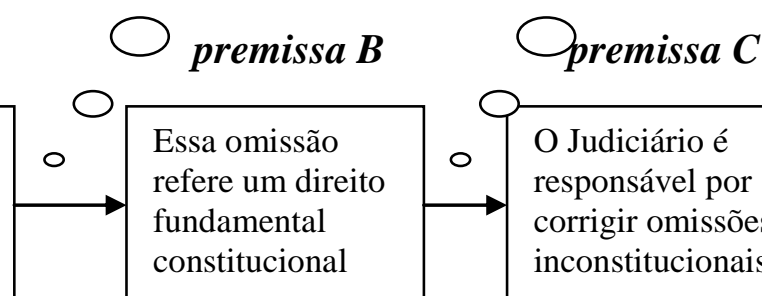

conclusão

\begin{tabular}{|c|c|c|c|c|c|c|}
\hline $\begin{array}{l}\text { Há uma omissão } \\
\text { executiva na } \\
\text { consecução da } \\
\text { política de saúde }\end{array}$ & 0 & $\begin{array}{l}\text { Essa omissão } \\
\text { refere um direito } \\
\text { fundamental } \\
\text { constitucional }\end{array}$ & 0 & $\begin{array}{l}\text { O Judiciário é } \\
\text { responsável por } \\
\text { corrigir omissões } \\
\text { inconstitucionais }\end{array}$ & 0 & $\begin{array}{l}\text { O Executivo é } \\
\text { condenado a } \\
\text { sanar a omissão }\end{array}$ \\
\hline
\end{tabular}

Nas hipóteses de concessão, o argumento linear é sedutor: ele, Judiciário, é o guardião da Constituição, podendo lançar mão, se provocado, dos meios possíveis a garantir sua efetividade. O Poder Público, por sua vez, é o responsável pela concretização dos direitos assegurados na Carta. Já o jurisdicionado tem direito subjetivo à saúde. Quando o Poder Público falha, o Judiciário deve corrigir e suprir a omissão, sobretudo no que toca aos direitos fundamentais, dentre os quais um dos mais sensíveis, crucial para uma vida digna, a saúde. Daí a conclusão automática de ser condenada a Administração ${ }^{395}$.

\footnotetext{
${ }^{395}$ Em colóquio realizado em 19.7.2012 na sede da ANER - Associação Nacional dos Editores de Revistas, em São Paulo, a Min. Carmen LÚCIA, do STF (embora, na ocasião, estivesse na qualidade de então Presidente do Tribunal Superior Eleitoral, já que o debate girava em torno do papel da Imprensa nas eleições que, naquele momento, aproximavam-se), ao se referir às conquistas da sociedade brasileira depois da Constituição de 88, usou exemplo que toca diretamente a esta tese. Segundo ela, antes da Carta era impensável que um cidadão que não fosse atendido pelo sistema público de saúde obtivesse o procurado atendimento, o que não ocorre hoje, em que as pessoas nessas condições podem obter liminares em menos de seis horas e uma internação pode ocorrer ainda antes do esperado. Prossegue - e aí, sim, de forma muito interessante - dizendo que o juiz primeiro dá a liminar para que o Estado, depois, procure quem vai pagar a conta. Jocosamente, asseverou que, de vez em quando, governadores reclamam um pouco, com o que ela responde dizendo que se esse político cumprisse o que está constitucionalmente determinado, o magistrado da vez não precisaria ter intervindo. Continuou, contando que a pergunta do governador que se seguiria seria algo do tipo: "e de onde eu tirarei dinheiro para isso?", com o que Ministra responderia algo como: "das verbas de publicidade, por exemplo". O pensamento da magistrada, ocupante de uma das onze mais elevadas cadeiras da carreira judicial, bem revela como pensam, via de regra, os juízes: confirmando o raciocínio diagramado, o argumento é linear e, sem maiores preocupações, os juízes concedem a medida pleiteada para que, depois, o Estado veja como vai pagar. Ainda mais temerário é o pensamento de que as verbas a serem realocadas para cumprir a prestação jurisdicional serão de áreas sem nenhuma identidade direta com a saúde, como a publicidade, quando, na verdade, o administrador provavelmente realocará da rubrica da própria saúde o montante necessário ao adimplemento da obrigação judicial.
} 
$\mathrm{O}$ argumento linear se apoia, e muito, na primeira parte do que Dworkin chama de rescue principle. Nesse entender, vida e saúde seriam, como já asseverava René Descartes, os principais de todos os demais bens: todo o resto seria de menor importância, devendo ser sacrificados em virtude dos outros dois. Dworkin aponta que isso é um erro ${ }^{396}$, sobretudo por uma profunda simplificação do que cada um considera como principal em sua vida.

Deveras, o argumento linear é pernicioso. Ele simplesmente desconsidera toda a extensa teorização que entremeia o tema, as densas discussões e, porque não dizer, os pontos igualmente relevantes levantados por aqueles que, como este autor, pensam que o Judiciário, ainda que ator de primeira grandeza na sindicância de bens típicos de políticas públicas, não está preparado nem atua considerando a multiplicidade de aspectos ínsita ao assunto. O uso do argumento linear na quase totalidade dos casos julgados em junho de 2013 pelo Tribunal de Justiça e São Paulo é a prova do acerto da hipótese.

O problema do argumento linear é que ele pesa na mão ao entender que saúde é um direito subjetivo. Não é tão simples, já se viu e mais se verá porque.

Um único julgamento da amostra deu provimento ao recurso do Poder Público aduzindo que houve cerceamento de defesa da sentença que não permitiu ao demandado fazer prova das políticas públicas que estava empenhando para fazer frente às necessidades das pessoas com problemas análogos ao exposto na inicial ${ }^{397}$. Trata-se do único julgado dentre as centenas de outros que decidiram apenas com base no argumento linear. O acórdão ora colacionado - que teve voto vencido, mostrando a resistência dos magistrados à linha nele insculpida - entra em acordo com um dos remédios encontrados por este pesquisador contra as decisões judiciais patológicas, a ser oportunamente verificado. Este julgamento, contudo, é uma gota no oceano de decisões judiciais que ainda decidem saúde com base no argumento linear.

Mas não apenas nos tribunais locais, representados, aqui, pelo TJSP, grassa a tese da concessão judicial de providências de saúde independentemente de quaisquer limites. Um retrato da atualidade e força do problema debatido nessa pesquisa pode ser tirado da análise de um caso, a suspensão de liminar e sentença ("SLS") n 1.570/RS ${ }^{398}$.

\footnotetext{
${ }^{396}$ DWORKIN, Ronald. Sovereign Virtue: The Theory and Practice of Equality. London: Harvard University Press, 2000, pp. 309-310.

397 Apel. $n^{\circ}$ 0011175-43.2012.8.26.0269, Rel. José Luiz Gavião de ALMEIDA, 3ª Câmara de Direito Público, j. em 21.5.2013. Tal entendimento não revela uma predisposição do Relator a adotá-lo indistintamente, tanto que já decidiu com base no argumento linear (Apel. $\mathrm{n}^{\circ}$ 0000667-91.2012.8.26.0219, j. em 30.4.2013).

${ }^{398}$ Decisão do Min. Ari PARGENDLER, Presidente, em 9.5.12.
} 
Em ação individual promovida por paciente que pretendia a concessão de um fármaco ao custo de quase quarenta e dois mil reais, o Judiciário chegou ao extremo de, diante de reiterados descumprimentos por parte do Executivo da decisão que concedeu o pedido, determinar o bloqueio das contas da AGU para fazer frente à despesa, ficando aquele valor à disposição do autor.

O Ministro Ari Pargendler, responsável, no STJ, pela confirmação da decisão já prolatada nas instâncias ordinárias, asseverou que, tendo em vista os reiterados descumprimentos de ordem para a entrega do medicamento requerido, solução outra não havia senão afetar uma determinada conta da União - no caso, a conta da AGU - para não tornar a decisão judicial inócua. A decisão faz menção, inclusive, à tentativa de bloqueio de fundos nas contas do Ministério da Saúde e do Fundo Nacional de Saúde, que, surpreendentemente, estavam zeradas. O presidente do STJ reconheceu o extremismo de sua decisão, mas admitiu que não deixaria de zelar pelos direitos do jurisdicionado e era de se observar a força da decisão judicial. Considerou, por fim, que a solução seria outra caso a União apresentasse alternativas de cumprimento do julgado ou induzisse o Ministério da Saúde a cumpri-lo.

Esta decisão é paradigmática ${ }^{399}$.

Primeiro diante de algo que surpreendeu mesmo o Ministro: como as contas bancárias do Ministério da Saúde não possuem um único tostão? É difícil imaginar que, em maio de 2012 - ou seja, no primeiro semestre de um ano fiscal - a conta de um ministério tão importante estivesse sem fundos. Uma de duas: ou o sistema judiciário de bloqueio agiu equivocadamente ou o Ministério estava manobrando para evitar, precisamente, o drástico bloqueio de suas contas. Essa segunda hipótese deve ter colaborado para o Ministro-juiz tomar a decisão. Mas não só: se verdadeira, ela confirma a panaceia que se tornou a judicialização da saúde no Brasil, efeito da gravidade que circunda o tema.

Com efeito, se um órgão público tem que se valer de manobras típicas de inadimplentes contumazes, que dilapidam ou mascaram seu patrimônio para frustrar e fraudar a execução, então a situação, definitivamente, é crítica e caótica. É o caso de apontar duas prováveis causas para esse comportamento hipotético: a primeira, a adoção de comportamento defensivo por parte da Administração para evitar os sucessivos bloqueios

\footnotetext{
399 Já é jurisprudência consolidada no STJ que o bloqueio de contas do Poder Público para fazer frente ao custeio judicial de medicamentos é viável. O entendimento foi, enfim, referendado em julgamento de recurso repetitivo, tornando-se, assim, de aplicação compulsória pelos demais órgãos judiciários (REsp $\mathrm{n}^{\mathrm{o}}$ 1.069.810/RS, $1^{\text {a }}$ Seção. Rel. Min. Napoleão Nunes Maia FILHO, DJ em 6.11.2013). O inusitado da decisão tida por paradigmática é que ela determinou o bloqueio das contas da AGU, responsável pela representação judicial em defesa da União.
} 
judiciais de seu numerário - ou claras incisões do Judiciário nas contas do Executivo. Tal seria muito grave, beirando a malícia; a outra, existiriam situações em que as contas do Poder Público ficam sem saldo, o que seria normal. Das duas, a mais plausível é a primeira causa.

Não seria de admirar que a Administração reagisse com as armas que tem contra a ingerência judicial em suas contas. O raciocínio é elementar: se eu, administrador, frequentemente sou incomodado com bloqueios bancários e se eu, administrador, tenho o poder para dispor dos dinheiros públicos, movimentado-os pontualmente, porque não adotar um estratagema para tornar inócua a ordem de congelamento de ativos em minhas contas? A ideia goza de certa lógica. Como também de lógica goza a ação daquele gestor que, sabendo que, todo o ano, "x" por cento de seu orçamento da saúde é voltado para cumprimento de decisões judiciais, já deixa reservado montante equivalente aos tais " $\mathrm{x}$ " por cento, como se fosse uma reserva de mercado ou uma provisão para devedores duvidosos $^{400}$. Qual o claro resultado dessa ação? Evidente: a implementação dos programas de governo ficaria " $x$ " por cento comprometida, mais omissões seriam observadas, mais direitos, violados. Se assim fosse, ficaria difícil censurar a decisão analisada, a não ser pelo fato que mais pessoas procurariam o conforto do foro judicial, e o problema tratado neste estudo aumentaria sensivelmente.

Ademais, a decisão merece ser estudada porque ela determinou o bloqueio incidente sobre uma conta específica que nada tinha que ver com a despesa - bloqueou recursos da defesa judicial da União em seus três Poderes, inclusive o Judiciário, frise-se para cobrir despesas na saúde. Estaria o Judiciário preocupado com o cobertor curto da saúde, tirando verbas de uma conta "menos" importante para fazer valer um direito fundamental, ou a decisão se deu em retaliação ao desdém manifestado pelo Executivo, descumprindo sistematicamente o comando judicial?

Outras interessantes decisões, bem recentes, parecem se sensibilizar com as questões levantadas nesta tese e andar contra o argumento linear. Investigando um pouco mais a fundo, todavia, mesmo elas se embasam no demonstrado argumento, ainda que a providência ordenada não seja de fruição imediata por quem dela se aproveita e tenha sido emanada em ação que, adiante, será defendida como o mais apropriado suporte por meio do qual deve o Judiciário sindicar políticas públicas de saúde. É o caso que ora se verifica.

\footnotetext{
${ }^{400}$ A provisão para devedores duvidosos é noção contábil que, grosso modo, indica a conta de ativos que, pelo alto risco de inadimplemento, devem ser contabilizados com reservas. O nome diz tudo.
} 
No Espírito Santo, sentença em ação coletiva julgou procedente pedido realizado pela Defensoria Pública e ordenou o Estado a construir um hospital exclusivamente para tratamento de dependentes químicos. De acordo com o magistrado, o pedido não poderia ser imediatamente atendido, já que a edificação do dito hospital, com seu necessário início de operação, demandaria tempo. Concedeu, então, prazo de dois anos para a entrega do nosocômio à população ${ }^{401}$.

A decisão começou bem. Primeiro, foi exarada nos autos de ação civil pública. Depois, ordenou a adoção de medida que beneficiaria toda uma coletividade, a saber, o grupo de dependentes químicos presentes em Vitória. Antes disso, indeferiu a tutela antecipatória pleiteada, determinando, primeiramente, a ouvida do Estado, certificando-se de dar oportunidade ao Poder Público para demonstrar quais as políticas públicas que ele estava providenciando para aquele dado grupo. Mas acabou incidindo em alguns equívocos.

O primeiro foi indeferir o pedido de audiência pública ao argumento que estava claro o problema da dependência química e a falta do respectivo tratamento, e que, no caso, havia determinação constitucional para garantir saúde à população. Afinal prossegue a sentença - audiências públicas servem para discutir amplamente problemas sociais, e, naquela hipótese, a Constituição já resolvia o assunto - eis, aí, o pernicioso argumento linear. É evidente, como se viu a verá nesta tese, que qualquer questão relacionada a políticas públicas demanda debate e a busca para a solução de reclamos sociais. Nesse contexto, quanto mais diálogo, melhor. E o que é mais notável? É que tal requerimento foi deduzido por ninguém menos que a Defensoria Pública, a autora da ação.

O segundo equívoco foi estabelecer, sem a menor base técnica, o prazo de dois anos, ou vinte e quatro meses, para a construção do hospital. Da sentença não se observa qualquer dado que indique que um hospital para tratamento de dependentes químicos demorasse dois anos para ser posto em funcionamento. Não se sabe se o Poder Público possuía um terreno onde pudesse construí-lo. Não se sabe se tinha um projeto. Não se sabe, enfim, quem seriam as empresas contratadas para erigir o hospital, e nem se o procedimento licitatório de rigor seria iniciado a contento. $\mathrm{O}$ que dizer, então, do concurso para contratação de servidores? Todas essas variáveis foram ignoradas pela sentença.

\footnotetext{
${ }^{401}$ Autos no 024.09.013938-7, 2 ${ }^{\text {a }}$ Vara da Fazenda Pública de Vitória, Espírito Santo. Sentença de 2.7.2012 e disponível em: <http://s.conjur.com.br/dl/sentenca-acp-crack-hospital.pdf〉, acesso em 28.7.2013, 18:17h. Sobre o assunto, ver: <http://www.conjur.com.br/2012-jul-11/espirito-santo-construir-hospitaldependentesquimicos-2014>, acesso na mesma data, 18:40h.
} 
Mais, ainda: a sentença apenas aparentemente ordenou medida protraída no tempo, de modo a permitir planejamento e programação. Ela, na verdade, estabeleceu dispêndio imediato, haja vista que seu dispositivo fez contar o prazo de dois anos a partir da respectiva intimação - e tinha pronta eficácia, como é próprio das sentenças em ações coletivas. De novo, recursos teriam de ser deslocados para realizar o certame licitatório, pagar o preço do contrato, ainda que em parte, contratar novos servidores, tudo a mobilizar imediatamente dinheiros públicos para dar cabo da decisão. A pretexto de permitir planejamento, a sentença implicou desajuste. E assim o fez em função do terceiro equívoco: relegar a reserva do possível a segundo plano, muito aquém da linearidade de seu argumento.

No Pará, medida análoga foi ordenada pelo Tribunal de Justiça, a não ser que, ali, o hospital a ser construído em dois anos se prestava ao atendimento maternoinfantil. Naquele caso, o Relator estabeleceu a necessidade de se providenciar licitação para as obras, além da realização de concurso público para contratação dos respectivos servidores. Ora, provavelmente os dois anos serviriam apenas para a realização dessas medidas administrativas ${ }^{402}$.

Qualquer que seja o cenário, constata-se indesejável desarmonia, praticamente um embate entre Poderes, em prejuízo ao jurisdicionado (que não tinha obtido seu tratamento por vias normais, tampouco pelo Judiciário), ao equilíbrio entre os Poderes e à dignidade da justiça. Verifica-se, assim, que esta tese é oportuna e atual, porque, do retrato hodierno das decisões na seara da saúde, é preciso desenhar limites e propor soluções - ou, antes, remédios.

\subsubsection{O papel do Supremo Tribunal Federal}

No atual estado da arte da jurisprudência a respeito de saúde destaca-se o fundamental papel desempenhado pelo STF. Ao longo dos anos, nota-se uma evolução na dialética envolvendo juízes e fornecimento forçado de ações e providências de saúde na mais alta Corte da República. Pode-se destacar, claramente, três momentos na jurisprudência do STF nesse tocante: um incipiente, em que a Corte discutia se o Judiciário

\footnotetext{
$402<$ http://g1.globo.com/pa/para/noticia/2013/06/jutica-obriga-construcao-de-hospital-materno-infantil-nopara.html>, acesso em 28.7.2013, 18:46h.
} 
poderia sindicar políticas públicas (e se direitos sociais eram sindicáveis, duas faces da mesma moeda); um momento de amadurecimento, em que, ultrapassada a primeira questão, o STF passou a conceder medidas de saúde com base no argumento linear; e, enfim, um terceiro momento, em que a Suprema Corte compreendeu que o argumento linear não bastava, e que questões de saúde eram muito mais complexas e multifacetárias do que a aplicação pura, simples e combinada dos artigos 6º, 196 e 197 da Constituição.

$\mathrm{Na}$ maior parte dos julgados da primeira e segunda fase, as questões inerentes a cada uma delas acabavam surgindo, pois se é eficaz e sindicável o direito social, solução outra não haveria senão, reconhecida a violação, concedê-lo. Eis a advertência. A diferença da primeira para a segunda fase é a intensidade dos argumentos usados em uma e outra, sendo que as fronteiras temporais de ambas são difusas.

A respeito da primeira fase merece consideração o AgRegRe $\mathrm{n}^{\mathrm{o}} 271.286 / \mathrm{RS}^{403}$. Nesse recurso, em que se discutia o fornecimento de medicamentos para tratamento da infecção pelo vírus HIV, a Corte entendeu que o direito à saúde encartado na Constituição é público e subjetivo e que o cunho programático do artigo 196 da CF não poderia transformá-lo em promessa constitucional inconsequente, sob pena de o Poder Público fraudar as justas expectativas nele depositadas pela população, substituindo de maneira irresponsável seu inderrogável dever em gesto de contrário ao que determina a norma constitucional. Nesse caso, o STF referendou que o artigo 196 da CF, embora tendo conteúdo programático, configurava direito público subjetivo do jurisdicionado, com a lógica consequência de ser imediatamente exigível, dotando-se o comando, assim, da plena efetividade que dele razoavelmente se espera.

Como paradigma da segunda fase do STF, tome-se o RE $n^{\circ} 247.900 / R^{404}$. Embora cronologicamente anterior ao expoente anotado da primeira fase, nesse extraordinário, de 1999, foi prolatada decisão monocrática negando provimento ao recurso que se insurgia contra decisão do Tribunal de Justiça do Rio Grande do Sul que mandou o Poder Público entregar medicamentos para o tratamento da AIDS de um grupo de portadores da moléstia. O Estado, no extraordinário, alegou, dentre outras matérias, que não poderia atender individualmente os postulantes judiciais, quando existia toda uma coletividade à míngua do recebimento de tais medicamentos, e pugnou não haver prévia fonte de custeio para fazer frente à decisão judicial, o que seria imprescindível. De acordo com o Relator, o artigo 196 da CF era automática e imediatamente aplicável, e o custeio de

\footnotetext{
${ }^{403}$ Rel. Min. Celso de MELLO, j. em 12.9.2000, DJ em 24.11.2000.

${ }^{404}$ Rel. Min. Marco AURÉLIO, j. em 20.9.1999, DJ em 27.10.99.
} 
medidas com educação, saúde e segurança pública deveria sair das receitas obtidas com os impostos pagos pelos contribuintes, com o que não se haveria falar em falta de fontes de custeio. Segundo o Ministro, o objetivo maior do próprio Estado era o de assegurar o conforto de uma vida gregária apta a garantir a dignidade do homem. Em outras palavras, o STF assegurava, ali, a providência de saúde com base no que estabelece a Constituição, pouco importando os obstáculos deduzidos pelo Estado na defesa de sua posição.

Chegou-se, enfim, à terceira fase, representada pela $\mathrm{SS} \mathrm{n} \mathrm{n}^{\circ} 3.073 / \mathrm{RN}$, de $2007^{405}$. O incidente em apreço chegou às mãos da presidência da Corte em face de decisão liminar concedida pelo Tribunal de Justiça do Estado do Rio Grande do Norte, que determinou o fornecimento, pelo Estado, do medicamento Rituximabe para tratamento de câncer no impetrante. O STF entendeu que havia lesão à ordem pública na decisão vergastada, dado que ordens judiciais como aquela prejudicavam o já tão abalado sistema público de saúde. Entendeu mais, que a norma constitucional privilegiava o atendimento coletivo ao individual, e que as políticas públicas regionais de saúde visavam, justamente, a fornecer tão importante direito de forma racional. Atender o pedido do impetrante, para o STF, seria desatender as necessidades de tantos outros que, como ele, não lançaram mão de medida judicial. No caso concreto, a Corte verificou que o medicamento não constava nas listas obrigatórias do SUS, e temia um efeito multiplicador caso fossem propostas ações por quem se sentisse no direito de obter o mesmo tratamento.

A partir daí foram inúmeras as decisões que acabaram negando o requerimento de fornecimento de medicamentos, com base nos mesmos argumentos da paradigmática SS n ${ }^{\circ} 3.073 / R N$. Não obstante, esse entendimento da Presidência recebeu críticas $^{406}$, tendo, em outra oportunidade, sendo ele revertido no Plenário por cinco votos a um (a dissenter foi, justamente, a Presidente, que manteve a posição original) ${ }^{407}$ e deflagrou um movimento que, mais tarde, revelou-se decisivo para o trato mais racional da judicialização da saúde pela Suprema Corte brasileira.

Sob a presidência do Ministro Gilmar Mendes, o STF convocou audiência pública em que se discutiria a judicialização da saúde. Em 5 de março de 2009, o Presidente despachou convocando o colóquio, justificando-o diante dos inúmeros pedidos

\footnotetext{
${ }^{405}$ Rel. Min. Ellen GRACIE, j. em 9.2.2007, DJ em 14.12.2007.

406 "[...] É tempo de perceber-se noção comezinha: em Direito, especialmente o instrumental, o meio justifica o fim e não o inverso, sob pena de ter-se o descalabro, a babel. [...] Paga-se um preço por viver em um Estado de Direito - e é módico, estando ao alcance de todos -, o respeito irrestrito à Constituição Federal e às normas abstratas com ela compatíveis. Esse arcabouço a todos, indistintamente, submete. Descabe potencializar, em detrimento dela, o pragmatismo, mesmo porque não falta criatividade, não faltam “bem-intencionados.” (MS 28627, Rel. Min. Celso de MELLO, j. em 20.02.2010, DJ em 01.03.2010).

${ }^{407}$ AgReg na STA no 223/PE, j. em 14.4.2008.
} 
de suspensão de segurança e de tutela antecipada em trâmite na Presidência versando sobre lesão à ordem pública alegadamente provocada por decisões judiciais concessivas de medicamentos e terapias, além do claro interesse público que permeava o tema. Definindo os assuntos a serem debatidos (que demonstram como o STF bem cercou algumas das questões mais sensíveis) ${ }^{408}$ e apontando quem deveria ser ouvido, o despacho foi publicado e se seguiu a realização do colóquio.

Os dados colhidos na audiência auxiliaram o STF a estabelecer critérios para que os magistrados lidassem com pedidos judiciais por saúde. Esses critérios foram, afinal, fixados em decisão manifestada na STA n ${ }^{\circ} 175 / \mathrm{CE}^{409}$.

O Presidente do STF considerou que a intervenção judicial no domínio das políticas públicas de saúde não derivava, na maior parte dos casos, de omissão absoluta do Poder Público, mas de descumprimento das políticas já existentes. Todavia, as decisões judiciais relativas à matéria eram, muitas vezes, contrastantes com as políticas previstas e executadas, e iam além das forças do orçamento. Por isso era necessário racionalizar o acesso judicial à saúde. Era a admissão, pela mais alta Corte do Brasil, que o argumento linear não era válido para sindicar racionalmente e judicialmente políticas de saúde.

Prosseguiu, dizendo que se existente no SUS a política almejada pela parte, então haverá direito público subjetivo de obtenção. Se, contudo, inexistente tal política, seria necessário investigar se tal derivava de omissão legislativa ou administrativa, de uma decisão administrativa de não fornecimento ou, ainda, de vedação legal. No último caso se enquadrariam os medicamentos e terapias experimentais, ou seja, ainda não registrados na ANVISA, que não podem ser disponibilizados em mercado por força do comando do artigo 12 da Lei $n^{\circ}$ 6.360/76. Esses, para o Ministro, eram inaptos a ser sindicados por decisão judicial, salvo em casos excepcionais que permitissem a dispensa de registro, previstos na Lei $\mathrm{n}^{\circ}$ 9.782/99.

Em continuação, um segundo aspecto a ser considerado no escrutínio judicial é a investigação dos motivos que levaram a Administração Pública a não conceder

\footnotetext{
${ }^{408}$ Foram definidos os seguintes tópicos de debate: a) responsabilidade dos entes da Federação em matéria de direito à saúde; b) obrigação do Estado de fornecer prestação de saúde prescrita por médico não pertencente ao quadro do SUS ou sem que o pedido tenha sido feito previamente à Administração Pública; c) obrigação do Estado de custear prestações de saúde não abrangidas pelas políticas públicas existentes; d) obrigação do Estado de disponibilizar medicamentos ou tratamentos experimentais não registrados na ANVISA ou não aconselhados pelos protocolos clínicos do SUS; e) obrigação do Estado de fornecer medicamento não licitado e não previsto nas listas do SUS; e f) fraudes no Sistema Único de Saúde. O documento está disponível no sítio eletrônico do STF, em <http://www.stf.jus.br/portal/cms/verTexto.asp?servico=processoA udienciaPublicaSaude>, acesso em 16.7.2013, 20:33h.

409 J. em 18.9.2009.
} 
a medida postulada, com a conseguinte constatação - ou não - de sua idoneidade. Em linhas gerais, o tratamento dispensado pelo SUS sempre deverá ser privilegiado, porque fruto de análises prévias e gestão balizada pela natural escassez dos recursos públicos, o que impediria que cada um buscasse a providência que melhor lhe aprouvesse. A restrição não seria tão rígida, frisou, a ponto de impedir que o Judiciário - e mesmo a Administração - fugisse casuisticamente ao tratamento amealhado a partir do SUS, caso não ficasse constatada eficácia.

Por fim, o Ministro exortou aos magistrados e operadores do foro que esses critérios fossem bem discutidos caso a caso, para evitar a padronização de iniciais, defesas, sentenças e decisões, considerando-se enfim o inequívoco aspecto peculiar de cada postulante ou grupo de postulantes. Com base nesses paradigmas, denegou a suspensão de tutela antecipada, mantendo o tratamento à jurisdicionada que impetrara o writ. Tais parâmetros foram, depois, replicados em outros julgamentos, ora deferindo a suspensão, ora indeferindo-a, para conceder ou não as medidas de saúde pleiteadas ${ }^{410}$.

Ato contínuo e na qualidade de Presidente do CNJ, Gilmar Mendes formou um grupo de trabalho que teria por escopo sistematizar os achados daqueles debates e transformá-los em orientações aos magistrados. Assim foi que o CNJ editou a Recomendação $n^{\circ} 31 / 2010$, ato com uma série de diretrizes preferencialmente observáveis pelos juízes quando colocados diante de postulação por medidas de saúde, diretrizes que seguiram os cânones estabelecidos na decisão paradigma. $\mathrm{O}$ ato não tem imperatividade, mas é de grande valia em termos de orientação. Seu conteúdo, porquanto, muitas vezes, parelho ao que este autor encontrou como medidas remediais, será mencionado no decorrer deste texto.

Por essa sumária revisão histórica do posicionamento do STF em casos de saúde é que se verifica o importante papel da Corte, que se predispôs de forma pioneira a chamar a sociedade e o Poder Público para discutir a tormentosa questão, tirando, dali, parâmetros para pautar a análise judicial. Esses parâmetros são importantes, mas, infelizmente, não são suficientes. É importante que outros limites sejam estabelecidos, e é com os olhos nessa preocupação que a tese passa a se desenvolver.

410 (a) STA no 244/PR, j. em 19.9.2009, DJ em 24.4.2009; (b) SS n ${ }^{\circ}$ 3989/PI, j. em 7.4.2010, DJ em 15.4.2010; (c) STA no 283/PR, j. em 7.4.2010, DJ em 15.4.2010; (d) $S S n^{\circ} 3.962 / S E$, j. em 7.4.2010, DJ em 15.4.2010; (e) $S S n^{\circ}$ 4.045/CE, j. em 7.4.2010, DJ em 15.4.2010; (f) $S T A n^{\circ} 334 / S C$, j. em 16.4.2010, DJ em 26.4.2010; (g) STA no 434/BA, j. em 16.4.2010, DJ em 26.4.2010; (h) STA no 421/PE, j. em 20.4.2010, DJ em 30.4.2010; (i) SL no 256/TO, j. em 20.4.2010, DJ em 30.4.2010; (j) STA no 424/SC, j. em 20.4.2010, DJ em 30.4.2010; (k) STA nº 260/SC, j. em 20.4.2010, DJ em 30.4.2010. 


\subsection{A PROPOSIÇÃO DOS LIMITES À ATUAÇÃO JUDICIAL NO TRATO DE POLÍTICAS PÚBLICAS DE SAÚDE}

Diante do extenso quadro até aqui exposto, tendo sido constatados alguns perigosos excessos na atuação jurisdicional em tema de políticas públicas de saúde, é hora de se conjeturar a propositura de determinados limites que a judicatura deveria observar nesse seu mister.

A discussão a respeito da imposição de limites à atividade jurisdicional não é nova e, na verdade, é objeto de extensos estudos, inclusive em Filosofia e Teoria Geral do Direito. Os aspectos que foram abordados até então, frequentemente evocados por quem pondera a intervenção judicial em assuntos políticos, demonstram como a questão é delicada e merece reflexão mais profunda ${ }^{411}$.

Elegeu-se, como recorte metodológico, a análise da saúde porque esse é, sem dúvida, o mais agudo e sensível assunto com que se depara o juiz ao exercer seu típico ofício. Como evidenciado, a cognição judicial sobre problemas relacionados à saúde sempre é ligada à dignidade da pessoa humana, isso quando, nos casos mais graves, não encerra uma questão sobre vida e morte. A sensibilidade do tema faz, muitas vezes, com que a atividade judicial ultrapasse seus limites, seja porque os magistrados decidem muito mais pela emoção do que pela razão, seja porque, mesmo embasados na razão, não conseguem enxergar o alcance de uma decisão sobre saúde, sobretudo sendo ela proferida em ação individual. A decisão em casos que envolvem saúde se reveste normalmente de urgência e sensibilidade que, normalmente, os demais bens ligados a ações políticas não possuem $^{412}$.

\footnotetext{
${ }^{411}$ Neste contexto, cite-se o celebrado artigo de Lon L. FULLER ("The Forms and Limits of Adjudication", in Harvard Law Review 92, 1978, pp. 353-398). FULLER concordava que a atividade jurisdicional tinha como finalidade a ordenação social, mas assumia que os juízes não ostentavam a capacidade de exercer tarefas policêntricas, ou seja, que envolvessem inúmeros aspectos diversos de forma que a decisão a respeito de um deles afetaria os demais. Seria, mais ou menos, uma defesa da incompetência das cortes para implementar políticas públicas.

${ }^{412}$ Várias são as decisões em que os juízes, ao explicar porque o legislador constituinte originário elegeu como direito fundamental a saúde, sustentam que a ausência ou precariedade de meios para sua salvaguarda significa uma minoração à dignidade da pessoa humana que, antes de direito positivo constitucional, é regra de convivência social de primeira grandeza. Se, de um lado, é certo que não há como se negar essa conclusão - instintiva, até - de outro é impossível dissociá-la de algum conteúdo emocional, que termina por repercutir na decisão judicial, como já se analisou.
} 
A apresentação já realizada sobre as decisões judiciais que versam sobre o tema, somada à recente preocupação do Supremo Tribunal Federal e à aspectologia acerca da justiça de misericórdia impõem um estudo mais apurado sobre os limites às decisões, sentenças e acórdãos que disciplinam as políticas aplicadas na área da saúde.

É preciso, contudo e a título de introdução ao tema, que sejam apontadas as particularidades que tornam a jurisdição da saúde um assunto tão problemático e delicado.

4.2.1 As peculiaridades do caso da saúde

De todos os direitos sociais, talvez a saúde seja aquele mais complexo. Não se nega a dificuldade de planejamento, definição de metas e implantação de medidas relacionadas à educação, ou, mesmo, à moradia, mas, de fato, a saúde é, de todos, o mais problemático desses direitos. Hoje, quando se pensa em saúde, a imagem que vem imediatamente à nossa mente é a de um hospital, de uma pessoa internada e de médicos vestidos de branco; se ao vocábulo saúde se juntar, na mesma frase, processo, juiz, judiciário ou judicial, então a imagem se transmudará em medicamentos, postos de saúde e filas intermináveis, mas, também, de uma trilha mais rápida para obter o que se pretende. Só isso seria suficiente para demonstrar a dificuldade em lidar com o tema.

Mas o que dizer, então, das demais áreas sanitárias que absolutamente não vêm ao nosso pensamento quando com ele lidamos? O que falar das áreas humanísticas voltadas à saúde, como a Psicologia, a Psicanálise, a Terapia Ocupacional? Como essas especialidades são providas pela rede pública? O que discutir a respeito dos tratamentos odontológicos? Já teria alguém procurado um dentista da rede pública, esse ser desconhecido e imaginário $?^{413}$

Medicamentos, tratamentos, terapias, consultas, internações, medicina preventiva, vacinação, diversas especialidades médicas. Lidar com saúde não é fácil; ao contrário, a dificuldade que lhe é ínsita torna esse campo ainda mais propenso a observar falhas nos processos decisórios, sejam eles os tradicionais, tocados pelos Poderes majoritários, seja o judicial vanguardista. Este item se ocupa em apontar algumas peculiaridades que tornam da saúde um dos bens de maior dificuldade executiva.

413 Um panorama crítico a respeito pode ser tirado da leitura de "Dentistas, convênio, governo e desdentados", em Folha de São Paulo, edição de 22.5.12, p. A3. 
Certos aspectos podem ser eleitos como determinantes para que o assunto da intervenção judicial na saúde seja tratado com destaque: (a) a intrincada estrutura normativa que disciplina esse direito; (b) a quantidade, o grau de incidência, a diversidade e a imprevisibilidade de moléstias e problemas que podem afligir uma população; (c) as particularidades da dotação orçamentária; e (d) o próprio caráter humanitário e emergencial que, normalmente, envolve toda e qualquer questão relativa à saúde.

4.2.1.1 A rede nacional que compõe o Sistema Único de Saúde: a descentralização unificada

Nos Itens 4.1.1 e 4.2.1 se expôs, ainda que de maneira sumária, como a rede de saúde no Brasil é intrincada. A despeito de se constituir sobre a pedra angular de um sistema único, as dimensões continentais do Brasil não permitiriam a centralização restrita dos serviços e ações no campo em destaque. De fato, era preciso que não apenas a União, mas, também, os demais entes federados participassem ativamente nos programas, planos e políticas de saúde, seguindo-se o modelo federal de Estado eleito pela constituinte. Existe, no caso da saúde, uma descentralização unificada: Há único tronco e, a partir dele, inúmeras são as ramificações. Esta estrutura, no todo considerada, é o SUS; suas ramificações são os diversos órgãos dispostos e alojados nos Estados, Distrito Federal e Municípios. A estrutura unificada do SUS é singular: nenhuma outra política pública conta com um sistema único ${ }^{414}$, ainda que, como se verá, ele esconda uma complicada descentralização.

Evidentemente que tal descentralização pressupõe a distribuição de competências e recursos para os mais variados órgãos do sistema unificado (ou único). Sem dúvida que o posto de saúde de localidade isolada no Amazonas precisa receber medicamentos e possuir estrutura própria para o atendimento da população a ele atrelada. Necessita, nesse passo, de um chefe, aquele que definirá o funcionamento do posto de saúde, que, por sua vez, responderá a outro chefe mais graduado, este com estreito contato com agentes responsáveis por traçar as diretrizes das políticas públicas de saúde (diretores, secretários, prefeitos, governadores, agentes reguladores, ministros, Presidente). Enfim, é

${ }^{414}$ Como efeito da unicidade do sistema é que existe a COMARE - Comissão Técnica e Multidisciplinar de Atualização da Relação Nacional de Medicamentos Essenciais, da qual se tratará oportunamente, em que participam gestores tanto dos estados quanto dos municípios. 
preciso existir um plano pré-estabelecido ou, pelo menos, algumas regras ou costumes ${ }^{415}$ que definam os recursos recebidos e o modo de agir do indigitado posto de saúde. Assim se dá tanto com outro posto de saúde na periferia de grande cidade como com hospital de ponta que seja mantido por recursos públicos.

A partir deste exemplo se verifica que a unificação do sistema pode, em um primeiro e superficial momento, obscurecer a verdadeira burocracia dos inúmeros órgãos e agentes de saúde em todo o Brasil. Há chefes dos chefes dos chefes, que reportam ao secretário, que responde ao governador, que depende de recursos captados e das diretrizes estabelecidas pela União. Quem será o competente por decidir a respeito dos vários temas envoltos nessa seara? Quem decide a compra de um medicamento para o posto? E quem decide a criação desse mesmo posto? Quem estabelece quais serão os cargos e funções daqueles que atuam nas políticas de saúde? São, indubitavelmente, muitos questionamentos, informações que devem ser dominadas por aquele que determina, em maior ou menor grau, as políticas de saúde - inclusive, quando for o caso e em alguma medida, o juiz. Efeito automático da questão burocrático-estrutural é a problemática orçamentária na alocação de recursos.

Já foi verificado que os direitos têm custos: eles não nascem em árvores ${ }^{416}$. Isso faz do estudo dos recursos disponíveis para o Estado (e sua respectiva afetação ou distribuição) matéria de primeira grandeza na análise das políticas públicas exercidas por qualquer Poder. No caso da estrutura da saúde, é preciso avaliar quem, dentre os entes federados, é o responsável por captar e distribuir recursos para cada ação desempenhada pela estrutura descentralizada. Somente após este exame seria possível, a priori, definir com propriedade contra quem demandar determinada prática ou dispensação de medicamento $^{417}$.

O grande problema da descentralização unificada é o completo desconhecimento de seu funcionamento por parte do Judiciário, principalmente no que toca aos recursos disponíveis e os responsáveis por alocá-los. Contra quem se demanda o

\footnotetext{
${ }^{415}$ O que em tudo contraria a imposição normativa constitucional sobre os serviços públicos, que, como toda a qualquer atividade da Administração Pública, devem se ater à legalidade em sentido estrito (artigo 37, caput da Constituição).

${ }^{416} \mathrm{Na}$ didática expressão empregada por Flávio GALDINO em Introdução à Teoria dos Custos dos Direitos - Direitos não nascem em árvores. Rio de Janeiro: Lumen Juris, 2005.

${ }^{417}$ Não se pretende infirmar a competência constitucional concorrente dos entes federados no que toca às políticas e ações de saúde, mas, sim, demonstrar a necessidade de que se entenda como funciona a repartição de competências quanto aos recursos disponíveis e sua distribuição. Políticas públicas envolvem custos e se o juiz, em seu atuar contemporâneo, decide a respeito desses temas, é necessário que, igualmente, ele entenda o assunto.
} 
provimento de medicamentos para colocá-los nas prateleiras da farmácia do hospital público com vistas ao atendimento da população? Quem definirá quantos serão os pediatras concursados que atenderão aqui ou ali? A quem, dentro da estrutura unificada, cumpre definir a implantação de unidade de terapia intensiva em um hospital de base? Para os próprios agentes da saúde é difícil responder a essas perguntas. Para o Judiciário é, sem dúvida, uma tarefa heroica e, por vezes, negligenciada.

A complicada rede da saúde e seu desconhecimento pelo público em geral e, porque não afirmar, pelo Judiciário - faz com que floresçam alegações no sentido de certo ente federativo constituir parte ilegítima para figurar no pólo passivo de processos que discutem acesso à saúde, em vista de não ser ele o responsável, dentro do SUS, pelo atendimento ao que demandado na inicial. Mas o Judiciário já expôs seu juízo sobre essa situação. O STF entendeu, justamente, que por ser a saúde direito social de primeira grandeza, faceta da dignidade da pessoa humana, além de, pela própria Constituição, ser dispensado por meio de uma estrutura única, os entes federados - todos eles - são corresponsáveis por seu provimento à população, podendo ser demandados em juízo, isoladamente ou em conjunto ${ }^{418}$.

Aparentemente a solução judicial se revela mais adequada, certamente sob a perspectiva positivista. Todavia, o desconhecimento acerca da estrutura da saúde pode causar problemas, principalmente de ingerência do Judiciário em campos genuinamente governamentais. Imagine-se determinada ação proposta em face de dado município pleiteando-se um tratamento excepcional, que envolve a dispensação de medicamentos de alto custo e posologia contínua, muitas vezes por toda a vida. Se o município for o de São Paulo, o impacto será menor, sem dúvida, embora não desprezível, mas se o município condisser com uma pequena cidade no interior de Minas Gerais, o custo financeiro dessa decisão terá monta considerável.

O desconhecimento judicial e geral a respeito da repartição de competências e receitas em matéria de orçamento afetado à saúde, além da falta de informações sobre a já explicada estrutura da saúde no País, gera instabilidade que torna a tarefa do juiz nesse campo ainda mais delicada e passível de inadequação. Daí a necessidade de se considerarem esses dados na formação dos limites ora propostos.

\footnotetext{
${ }^{418}$ O artigo 23, II da Constituição outorga como competência comum aos entes federados o zelo pela saúde. O artigo 198, $\S 1^{\circ}$ da Constituição determina que o custeio da saúde se dê, além de por outras fontes, pelo orçamento da seguridade social da União, estados, Distrito Federal e municípios. Sobre o reconhecimento do STF sobre o assunto, ver RE n 195192, Rel. Min. Marco AURÉLIO, DJ em 31. 3.2000.
} 
4.2.1.2 A variedade de moléstias que acometem a população. Novas abordagens terapêuticas e outras variáveis

A partir do momento em que a espécie humana habitou o planeta surgiram moléstias. Vírus, bactérias, fungos, mau desenvolvimento celular, enfim, o organismo humano sempre teve que se deparar com agentes que desafiavam seu bom desenvolvimento. A história da ocupação humana na Terra, desde que ela é relatada, é também marcada pelo efeito de doenças que dizimaram populações inteiras. Assim ocorreu com a peste no Século XIV, com o cólera no Século XVIII, e, mais recentemente, com o HIV, o câncer e o Alzheimer, três dos mais relevantes males modernos. Não há limites para o surgimento de doenças: a história demonstra que ainda que algumas delas sejam erradicadas (exemplos da varíola e da catapora), outras aparecem para ocupar seu espaço, seja fruto do desenvolvimento do próprio agente causador da doença, seja pelo contato humano com áreas antes inexploradas e suas respectivas fauna e flora ${ }^{419}$.

Ao mesmo tempo em que são diagnosticadas as moléstias, surge quem seja capaz de estudar meios para seu tratamento. Nesse campo, o estudo e a análise das doenças, de certa forma, garante a própria continuidade da raça humana. Com efeito, a nós não nos é dado saber o que seria da humanidade se o cólera não tivesse sido controlado, ou, mesmo, não a tivesse sido a gripe espanhola. Os métodos e meios de manutenção da saúde têm mantido os homens mais longevos: hoje, vive-se mais do que no início do século passado. É extremamente interessante, destarte, dedicar-se ao estudo e tratamento de doenças. Os cientistas modernos possuem muito mais recursos que Alexander Fleming ${ }^{420}$, e o resultado disso são os contínuos anúncios de descobertas na área da saúde e lançamento de terapias e tratamentos inovadores.

O efeito correspondente é que não poucas são vezes em que existe mais de um medicamento ou terapia apta a tratar determinada doença. Ano após ano, determinado método pode ser lançado em substituição a outro, ou é possível haver terapia que aprimore aquela anteriormente indicada, ou, ainda, simplesmente coexistirem dois ou mais medicamentos que tratam com a mesma eficácia e segurança certa doença, diferenciandose, apenas, o laboratório fabricante.

\footnotetext{
${ }^{419}$ Exemplo disso, além do próprio HIV, é o Ebola, ambos atribuidamente originados de primatas africanos. ${ }^{420} \mathrm{O}$ criador da penicilina.
} 
A Associação Médica Canadense elegeu, em 2007, cinco critérios que podem explicar a maior acessibilidade a medicamentos hoje também vista no Brasil: (a) mudança de tamanho, estrutura e distribuição da população; idade, sexo e etnia das pessoas; surgimento de novas moléstias; (b) maior acessibilidade aos serviços e mecanismos de saúde; (c) novos medicamentos, drogas que substituem cirurgias, terapias para doenças até então impassíveis de tratamento, avanço da medicina diagnóstica; (d) desenvolvimento de novos fármacos, trabalho da indústria em sua promoção; e (e) mudança nos padrões de prescrição de medicamentos, aderência ao tratamento e comportamento de consumidores $^{421}$. Para a OMS, o processo de constante mutação das políticas de saúde ocorre pela evolução dos padrões de doenças, fluxo e refluxo de recursos e desenvolvimento ou arrefecimento de certas instituições ${ }^{422}$.

Enfim, são inúmeras as variáveis com que têm que lidar os médicos. Essas mesmas variáveis devem ser consideradas pelos gestores da saúde, sobretudo levando-se em conta as diretrizes da PNM, principalmente de otimização de recursos em face da multiplicidade de tratamentos disponíveis: o comando exposto na Política faz com que o gestor a todo o tempo aprimore seu conhecer a respeito das inovações e da eficácia na seara medicamentosa, de modo a escolher, para tratamento da população, o medicamento ou terapia de eficácia adequada cujo custo seja o mais baixo ${ }^{423}$.

De fato, diante da escassez de recursos, é recomendável que se aplique à risca a determinação da PNM: havendo mais de uma opção para o tratamento de determinada moléstia, com eficácia e segurança idênticas ou análogas, o gestor público deve optar por aquela menos custosa (sob o ponto de vista econômico). Trata-se de uma questão de gestão inteligente da coisa pública, representada pela conhecida equação do melhor custo-benefício $^{424}$, tipicamente de mercado.

Quando se elege o juiz como ator apto a decidir questões relacionadas à saúde, é preciso que também ele conheça temas ligados ao custo-benefício de medicamentos e tratamentos, tudo para que sua decisão, mais eficaz, cause menor impacto nas contas públicas e não deixe direitos alheios a descoberto. O problema é que os juízes

\footnotetext{
${ }^{421}$ Canadian Medical Association Journal, junho de 2007, p. 176.

422 OMS, Relatório..., p. XXIII.

${ }^{423}$ Segundo a PNM, "Para assegurar o acesso da população a medicamentos seguros, eficazes e de qualidade, ao menor custo possível, os gestores do SUS, nas três esferas de Governo, atuando em estreita parceria, deverão concentrar esforços no sentido de que o conjunto das ações direcionadas para o alcance deste propósito estejam balizadas pelas diretrizes a seguir explicitadas”. Seguem, aí, as ações adotadas pela PNM como necessárias à dispensação racional de saúde, como, por exemplo, a elaboração da RENAME.

${ }^{424}$ É possível traçar um paralelo, neste caso, com o modelo econômico de eficiência de Kaldor-Hicks (v. nota 265).
} 
desconhecem os meandros do mundo dos medicamentos e da saúde. Alguns deles não sabem, até, que existem medicamentos diferentes para tratamento da mesma doença com a mesma eficácia e segurança.

Um sinal do problema acarretado pelo apontado desconhecimento ocorre quando o jurisdicionado postula do Estado o fornecimento gratuito de algum medicamento por ele eleito como o indicado, sem mencionar que na Relação Nacional de Medicamentos Essenciais, por exemplo, esteja contemplado outro fármaco que trate seu problema da mesma maneira daquele judicialmente requerido - este, não previsto nas listas de dispensação obrigatória e, pelas razões já mencionadas, provavelmente obtenível por preço muito maior. O juiz, sem saber a realidade, concede liminarmente o medicamento pleiteado, forçando a Administração a provê-lo ao postulante, não obstante, frise-se, estar disponível nos postos de saúde da comarca fármaco idêntico, mas com outra denominação $^{425}$.

A variedade de terapias e tratamentos, aliada ao desconhecimento do Judiciário a esse respeito, pode dar causa a uma decisão judicial nociva ao interesse público, porque acaba modificando política pública já existente sem que haja motivo para tanto. Decisão como essa acaba por infirmar o árduo trabalho da Administração Pública na apuração do medicamento que deverá ser dispensado gratuitamente à população, trabalho esse, sobretudo, técnico e baseado em evidências. No exemplo apontado, o juiz simplesmente desconsideraria o empenho administrativo e concederia o medicamento ao requerente da medida judicial, ordenando despesa não prevista no orçamento. Haveria, na hipótese, verdadeira alteração da política existente, porque o juiz elegeria medicamento para ser dispensado à determinada pessoa ainda que existente fármaco semelhante disponível no SUS.

O desenvolvimento da Medicina e das técnicas curativas é invariavelmente mais rápido do que a burocracia estatal na eleição de medicamentos para dispensação pelo Estado. Se hoje um fármaco para o tratamento da asma é previsto nas listas, amanhã ele já poderá ser ultrapassado por outro que trate a doença com alguma vantagem. Nesse caso, o medicamento listado pode não revelar o tratamento mais eficaz e seguro dentre as alternativas do mercado. Aí se poderia cogitar de intervenção judicial para, controlando os critérios escolhidos pelo legislador (o direito de farmácia aliado à saúde e dignidade da

\footnotetext{
${ }^{425} \mathrm{O}$ reconhecimento da falta de conhecimento por parte do magistrado a respeito de informações clínicas de pacientes em demandas judiciais quedou expresso na Recomendação CNJ no 31/2010. Nela, há a orientação no sentido de que os juízes exijam a descrição da moléstia com base no CID - Cadastro Internacional de Doenças, além de prescrição médica apontando denominação genérica ou princípio ativo (Item I.b.1).
} 
pessoa humana) e pela Administração (concessão de medicamento seguro, eficaz e de custo razoável), fornecer o remédio mais desenvolvido, verdadeiramente aprimorando ou revisando as listas de dispensação obrigatória.

Mas como proceder dessa maneira sem extirpar o poder administrativo de estabelecer políticas em termos de medicamentos? Sim, porque ainda não é o ideal obter certo fármaco em virtude de decisão judicial, mesmo que a decisão seja irrepreensível sob o ponto de vista técnico e jurídico. De fato, quantos serão aqueles que, por inúmeros motivos, não foram capazes de levar seus reclamos ao Judiciário e, assim, não terão direito à obtenção do medicamento mais eficaz e seguro que não está nas listas, em que pese outro jurisdicionado conseguir obtê-lo? As políticas de saúde devem ser universais, de forma que mesmo a decisão que concede o medicamento postulado, sem qualquer medida ou consideração suplementar, ultrapassa os limites do poder jurisdicional de intervenção em políticas públicas.

4.2.1.3 A particular forma de custeio de um bem universal como a saúde

Tomando por paralelo as palavras já colocadas a respeito da diversidade de moléstias e tratamentos que surgem dia após dia, é preciso descolar o direito à saúde dos demais direitos sociais e fundamentais, agora sob a perspectiva de seu custeio.

É certo, como já abordado, que todos os direitos têm seu respectivo custo. Mesmo os direitos civis e políticos, ou de liberdade negativa, custam aos cofres do Estado. Dotar a polícia de meios hábeis à realização da segurança ostensiva e investigação repressiva certamente não custa pouco em um país como o Brasil. Nesse sentido, concorda-se inteiramente com Sustein e Holmes ${ }^{426}$. É um grande erro imaginar que apenas os bens oriundos dos direitos de prestação demandam recursos públicos. O que é necessário esclarecer, entretanto, é que, em termos de fonte de custeio, não se pode colocar em uma vala comum os direitos civis e políticos e aqueles denominados econômicos, culturais e sociais. Mesmo dentro dessa última categoria, merecem diferenciação alguns direitos que devem levar em consideração, para fins de análise acerca de seus custos, suas particularidades. Trata-se, precisamente, do caso da saúde.

${ }^{426}$ HOLMES e SUSTEIN (The Cost of Rights..., pp. 13-16). GALDINO (Introdução..., pp. 215 e ss.). 
Uma coisa é a análise do custeio dos direitos civis e políticos. Para eles não existe contrapartida do cidadão diretamente aferível. De fato, os custos envolvendo o resgate do gato preso em uma árvore pelo corpo de bombeiros não se diferenciam tanto dos custos imputados ao socorro da senhora entrevada no primeiro andar de um edifício. Da mesma forma sucede com o policiamento ostensivo afetado a determinado evento público, cujos custos praticamente não variam caso se verifique ou não qualquer ocorrência (de vulto modesto, por suposto). Há um custo geral das ações de segurança, como há um custo geral para o funcionamento do Judiciário, não existindo, grosso modo, relação direta entre o bem usufruído e o custo imputável a cada qual que dele usufruiu ${ }^{427}$.

No caso dos direitos sociais, essa contrapartida é muito mais evidente. Com efeito, cada aluno devidamente matriculado no ensino público fundamental pode ter a si atribuído determinado custo (equivalente à mensalidade ou anualidade). Cada idoso que se vale gratuitamente do transporte público também reverte em cifras a fruição desse seu direito. Em matéria de saúde, o sinalagma é ainda mais perceptível, porque as características individuais têm um cunho todo especial: de fato, cada indivíduo poderá desenvolver determinada doença; a mesma moléstia pode ser experimentada em graus diversos por cada um, isso, dependendo de idade, sexo, condição social, ou características do próprio organismo ${ }^{428}$. São infinitas as possibilidades de ocorrência de problemas relacionados à saúde, de forma a ser extremamente complicada a tarefa de planejar a distribuição estatal dessa prestação.

Pode parecer mais fácil mensurar quanto custa internar uma pessoa em unidade de terapia intensiva, embora, em matéria de saúde, nunca se saiba o que pode acontecer. De fato, um procedimento cirúrgico que, em um primeiro momento, mostra-se simples e consolidado na prática médica pode evoluir para um quadro grave. Uma biópsia endomiocárdica é capaz de evoluir para um estado de coma vigil, com internação por tempo indefinido ${ }^{429}$. Ciente dessa variabilidade, o STJ já editou súmula declarando abusiva cláusula que, em contrato de seguro-saúde, limita no tempo a internação hospitalar do

\footnotetext{
${ }^{427}$ Nesse sentido, v. LOPES, José Reinaldo de. "Em torno da `reserva do possível', em SARLET e TIMM, (coord.). Direitos Fundamentais..., pp. 175-177.

${ }^{428}$ ARISTÓTELES já declarava que a saúde sofre variação de intensidade de pessoa para pessoa, uma vez que ela não seria constituída pela mesma proporção de elementos em todas os seres, muito menos por uma mesma proporção em uma pessoa sempre (Ética a Nicômaco. Brasília: UnB, 1999, p. 266).

${ }^{429}$ A casuística do INCOR - Instituto do Coração da Faculdade de Medicina da USP mostra que de seiscentas e noventa e cinco biópsias realizadas em determinado interregno foram observadas cinco complicações $(0,7 \%)$ nenhuma fatal, e, todas com resolução sem necessidade de intervenção (JATENE, Adib D. et. al. "Biopsia Endomiocárdica do Ventrículo Direito - 9 anos (1978 a 1987)" em Arquivos Brasileiros de Cardiologia n $\mathrm{n}^{\mathrm{O}}$ 49,1987, pp. 147-149). Mesmo neste consagrado procedimento, portanto, pode haver grave complicação.
} 
paciente, porque sua legalidade se chocaria com a própria essência do contrato. É o claro reconhecimento do Judiciário da incerteza que cerca a prestação de saúde que, embora manifestada no âmbito privado, aplica-se, neste caso, inteiramente ao contexto da dispensação de saúde pelo Poder Público ${ }^{430}$.

Se essa dificuldade é observada no caso de uma pessoa, imagine-se o trabalho e o grau de incerteza ao se tentar mensurar quantos serão os que se valerão de determinada prestação sanitária em certo espaço de tempo. Este é um exemplo simples que demonstra o quão complexa é a tarefa de se aprovar um orçamento para o custeio da saúde, ou definir quais tratamentos e medicamentos são os mais indicados. Certamente o trabalho envolverá a coleta e a análise de dados estatísticos, além de estudos técnicos que avaliem a possibilidade de novas e inesperadas demandas, como, por exemplo, o surgimento de uma epidemia. Já se verificou o extenso trabalho envolvido na elaboração das listas de dispensação obrigatória de medicamentos, tema que será retomado ainda neste capítulo. Já se tratou, inclusive neste tópico, da rede normativa e executiva que tem como incumbência concretizar a obrigação constitucional de acesso universal, integral e igualitário à saúde. De todas essas características, talvez a universalidade seja a mais problemática.

Universalidade. Ela não foi incluída no artigo 196 da Constituição por acaso. Trata-se de contundente resposta à política de saúde em vigor até então, como já evidenciado nesta tese. Até meados da Década de 1960, o grande serviço de saúde prestado pelo Estado era o de vigilância epidemiológica e imunização, como já relatado. As incumbências do Ministério da Saúde foram definidas pelo Decreto-Lei n²00, de 1967, e consistiam, basicamente, na prevenção, controle de medicamentos e estudos clínicos. A política curativa de saúde estava sob o encargo da previdência. A dicotomia saúdeprevidência ficou ainda mais evidente com a instituição do Sistema Nacional de Saúde, que estabelecia o funcionamento dos serviços públicos e privados na área, além de consolidar a política preventiva a cargo da pasta da saúde e a curativa a cargo da

\footnotetext{
${ }^{430}$ Súmula 302. Segundo Sérgio CAVALIERI FILHO, “(...) se a doença tem cobertura contratual outra cláusula não pode limitar os dias de internação; isto não importa mera limitação do risco, vale dizer, limitação da obrigação, mas limitação da própria responsabilidade do segurador, e, por via de consequência, restrição da obrigação fundamental inerente ao contrato. Uma coisa é a doença não ter cobertura, caso em que o segurador não assumiu nenhuma obrigação a seu respeito (não assumiu seu risco), e outra coisa, bem diferente, é a doença ter cobertura e, a partir de um determinado momento, deixa de têla. Na realidade, afigura-se abusivo impor tempo de cura para uma doença coberta pelo seguro. Complicações de todos os tipos podem surgir, pré e pós-operatórias, inclusive infecção hospitalar, ampliando compulsoriamente o tempo de internação. Pretender livrar-se o segurador dessas consequências não é limitar o seu risco, porque o risco foi assumido quando se deu cobertura para a doença, e o sinistro até já ocorreu. O que se pretende, na realidade, com essa cláusula, é limitar a responsabilidade do segurador decorrente de uma obrigação regularmente assumida, e isso a torna inválida." (Programa de Responsabilidade Civil, $9^{a}$ ed., rev. e amp., Atlas: São Paulo, 2010, p. 455).
} 
previdência. A medicina curativa era subsidiada pelas contribuições dos trabalhadores ao antigo INPS - Instituto Nacional da Previdência Social. Logo depois, a institucionalização do modelo previdência-saúde foi formalmente reconhecida pela reversão do INPS no INAMPS - Instituto Nacional de Assistência Médica e Previdência Social.

Poucos recursos eram destinados ao Ministério da Saúde, o que logo revelou uma opção política pela medicina curativa - mais cara -, custeada em parte pelos trabalhadores. O problema de se atrelar o maior montante à previdência social é cristalino: a pasta atendia a inúmeras demandas - como ocorre até hoje, era também a responsável pelo pagamento de benefícios previdenciários, desde acidentes de trabalho a aposentadorias - e não raras vezes os recursos tinham que ser remanejados. Na época de retração econômica pós-milagre econômico, o Brasil passou por maus bocados em termos de saúde, ainda que o INAMPS tenha divulgado dados que apontassem o aumento do cumprimento da demanda - tanto pública quanto privada ${ }^{431}$. Aqueles que contribuíam à previdência eram retribuídos com serviços de saúde ainda - muito - piores do que os de hoje; os que não contribuíam simplesmente não eram atendidos ${ }^{432}$.

A rede privada de saúde crescia vertiginosamente sob o modelo anterior a 1988. A democratização, de um lado, e os movimentos internacionais, de outro, proporcionaram o clamor por mudanças profundas na sistemática da saúde. Foi nessa época que se criaram o CONASS e o CONASEMS ${ }^{433}$. Em 1986 ocorreu um encontro que definiu as bases constitucionais do acesso à saúde no Brasil: a VIII Conferência Nacional de Saúde, que lançou o SUDS - Sistema Único Descentralizado de Saúde, o precursor do SUS.

\footnotetext{
${ }^{431}$ Segundo dados do INPS/INAMPS, de 1971 a 1977 o número de consultas médicas na rede pública (dentre serviços próprios, contratados e conveniados) passou de quarenta e quarto mil, seiscentos e noventa e duas a cento e trinta e quarto mil, quatrocentas e dezessete - mais do que triplicando, portanto. Também aumentou o número de internações naquele interregno: de duas mil, novecentas e trinta e duas a seis mil, oitocentas e três. Chama atenção a quantidade de internações em hospitais próprios: apenas duzentas e dezesseis (OLIVEIRA, Jaime A. de Araújo e TEIXEIRA, Sônia M. F. (Im)previência social: 60 anos de história da Previdência no Brasil. Petrópolis: Vozes, 1989).

${ }^{432}$ Note-se que, em certa medida, contemplar com bens públicos aqueles que fazem parte da PEA (população economicamente ativa) vai contra o princípio da diferença, de RAWLS, segundo o qual só se admitem desigualdades econômicas sociais se elas servirem para privilegiar os menos favorecidos (RAWLS, John. A Theory of Justice. London: Harvard University Press, 1971, pp. 60-61). Diferentemente dessa ideia se posiciona Ronald DWORKIN, para quem, em Taking Rights Seriously (London: Harvard University Press, 1977), o mérito (i.e., de quem contribuiu para a previdência) deveria ser privilegiado (i.e., em detrimento de quem não contribuiu). As ideias desses dois filósofos voltarão a ser exploradas nesta tese.

${ }^{433}$ Conselho Nacional de Secretários de Saúde e Conselho Municipal de Secretários de Saúde, respectivamente. De acordo com o já mencionado, sua função é representar Estados e Municípios no SUS, além de proporcionar apoio técnico às secretarias de saúde. Como se verá no momento oportuno, ambos esses conselhos possuem papeis fundamentais na confecção das listas obrigatórias de dispensação gratuita de medicamentos.
} 
O pilar do SUS sempre foi assegurar que o Estado provenha saúde a qualquer um, independentemente de sua efetiva contribuição para o custeio, em todas as suas variáveis. O projeto foi, de fato, encampado, encartado na Constituição e se transformou em um dos mais importantes paradigmas de proteção de direitos humanos fundamentais. O Brasil escolhia garantir a seus cidadãos - a todos eles, sem que houvesse condição qualquer pré-estabelecida - a fruição de todos os bens de saúde - preventivos ou curativos. A universalidade estava sacramentada: ela levou ao SUS e ao Estado brasileiro a cidadania, pura e simples, como elemento norteador das políticas de saúde ${ }^{434}$.

Resultado claro da herança pré-constitucional aqui relatada é que, ainda no atual texto constitucional, a saúde está sob o guarda-chuva da seguridade social, embora afastada da previdência ${ }^{435}$. O primeiro dos objetivos gerais do regime de seguridade social no Brasil é, justamente, a universalidade da cobertura e do atendimento ${ }^{436}$. Só com a previsão geral a saúde já gozaria do atendimento universal, mas o legislador constitucional quis asseverar essa sua novel qualidade: fez questão de textualizar, no artigo 196, a universalidade.

É preciso, aqui, esclarecer, na linha do evidenciado no Item 4.1.1.2, que o Estado não trata, sozinho, da saúde da sociedade. A maior parte dos cuidados com saúde é custeada pela iniciativa privada. Cerca de $55 \%$ do valor dedicado à saúde na parcela do PIB cabem à ela. Este montante pode ser aproveitado por quarenta e seis milhões de conveniados. Já o remanescente $-45 \%$ do gasto nacional com saúde - volta-se ao atendimento potencial de cento e noventa milhões de brasileiros ${ }^{437}$. Diz-se potencial porque quem usufrui dos convênios privados normalmente não usa os benefícios do SUS em sua plenitude, embora os reembolsos dos planos particulares ao sistema público sejam da ordem de oitenta e três milhões de reais, de acordo com dados de $2011^{438}$. Recentemente, o Poder Público anunciou uma iniciativa que pode injetar ainda mais recursos na saúde, aumentando o reembolso vindo dos particulares: agora, quem possuir convênio médico terá que se cadastrar no SUS, de forma que, quando esses conveniados se valerem da estrutura pública de saúde, o SUS poderá pleitear o ressarcimento

\footnotetext{
${ }^{434}$ FERRAZ e VIEIRA, "Direito à saúde...", p. 21.

${ }^{435}$ A saúde é tratada na Seção II do Capítulo II do Título VIII da Constituição; a previdência é disciplinada na Seção subseqüente desse mesmo Capítulo e Título, a Seção III.

${ }^{436}$ Cf. Art. 194, Par. ún., I da Constituição.

437 "Só no Brasil há saúde gratuita e universal, mas gasto privado é maior", disponível em: <http://www.carta maior.com.br/templates/materiaMostrar.cfm?materia_id=18512>, acesso em 15.5.12, 14:13h.

438 "Só no Brasil...".
} 
correspondente $^{439}$. Trata-se, sem dúvida, de empenho para uma disposição mais consciente dos dinheiros públicos.

Evidentemente, a universalidade só faz sentido se fundada na premissa de que todos são iguais, uma igualdade de respeito e consideração, ou seja, na elaboração das políticas de saúde, todos devem ser respeitados e considerados ${ }^{440}$. É óbvio: só se assim acontecer é que a universalidade será observada. Não é possível, destarte, privilegiar uns ou alguns. Esta é a pedra constitucional fundamental do provimento de saúde pelo Estado brasileiro.

Mas essa mesma bela pedra fundamental gera uma celeuma que só pode ser compreendida se for assumida a escassez de recursos. Com efeito, como assegurar acesso igualitário a todos se os recursos públicos são limitados?

Por isso que a confecção do orçamento, no caso da saúde, é particularmente peculiar e dificultosa, de forma que qualquer ingerência nesse campo deveria ser precedida de árduo estudo e discussão, pelo menos, idealmente. Daí se vê o porquê qualquer determinação judicial que determine custeio imprevisto de medicamento ou tratamento se faz ainda mais delicada: em matéria de saúde, uma decisão desse grau pode implicar desajuste nas contas da Administração Pública, de forma a penalizar aqueles para quem, originalmente e após denso e extenso estudo e debate, a rubrica orçamentária fora destinada.

Estas palavras são importantes para entender como, na saúde, o custeio é tema que não pode ser, nunca, negligenciado; ao contrário: uma das propostas defendidas é que o juiz, ao decidir questões de saúde, mesmo na concessão de medicamento para o tratamento de um resfriado, deva inquirir se o Estado é capaz de suportar aquela despesa. Mas é preciso mais, é necessário conhecer, ao menos um pouco, alguns dados acerca do custeio da saúde em nosso País. A pergunta que pretende ser respondida nesta ordem de indagações é se no caso da saúde há, mesmo, escassez de recursos, ou se é possível atender a todas as demandas nesse campo.

O Brasil não possui rigoroso controle das contas da saúde, de forma a apontar, com certeza, a totalidade de gastos despendidos sob essa rubrica em determinado

\footnotetext{
439 "Usuário de plano de saúde terá número do Cartão do SUS", em <http://veja.abril.com.br/noticia/saude/us uario-de-plano-de-saude-tera-numero-do-cartao-sus>, acesso em 15.5.12, 14:19h. Em entrevista dada à Folha de São Paulo (edição de 5.6.2013, $\mathrm{n}^{\circ}$ 30.744, p. C10), o ex-Presidente da Agência Nacional de Saúde Suplementar declarou que o SUS recuperou cerca de cento e sessenta e seis milhões de reais das seguradoras privadas de saúde em dois anos e meio. Ele entende expressivo o montante recuperado, maior do que o ressarcido nos dez anos anteriores, e reputa o sucesso à mudança do procedimento respectivo pela Agência ("ANS apertou cobrança a planos, diz ex-chefe").

${ }^{440}$ Idem, p. 21.
} 
exercício. O que há são estimativas, das quais a mais famosa é a organizada pela OMS, mas que deve ser analisada com alguma desconfiança por potencialmente não refletir fidedignamente as quantias aplicadas na área ${ }^{441}$.

Contudo, é importante o documento editado pela OMS em 2010, porque revela como a escassez preocupa em um mundo em que o ideal de saúde universal é uma diretriz das Nações Unidas. Seu próprio título é emblemático: Financiamento dos Sistemas de Saúde: o caminho para a cobertura universal. Com efeito, o estudo do órgão é ferramental para que se entenda que, de fato, o tema da limitação das reservas do Poder Público é extremamente relevante e não pode ser deixado de lado em qualquer discussão que envolva dispensação de saúde. Ele parte da premissa de que os recursos são escassos e sua aplicação sempre pode ser mais eficaz, de forma a fazer com que os serviços respectivos de saúde cheguem a mais gente - aproximando-se do desejo de universalidade - com maior qualidade ${ }^{442}$. Trata-se de meta eleita pela OMS desde 2005: fazer com que as pessoas possam se valer dos serviços de saúde sem sacrifício financeiro ${ }^{443}$.

A OMS aponta três principais obstáculos à cobertura universal: o primeiro, que nenhum país, por mais rico, foi até hoje capaz de assegurar que todas as pessoas tivessem acesso aos meios de melhoria de sua saúde ou prolongamento de sua vida; o segundo, a necessidade de algum pagamento pelos serviços de saúde, ainda que as pessoas tenham seguro-saúde (no Brasil, as coberturas dos planos consistem em automático exemplo de tal barreira); o último, a ineficácia da aplicação dos recursos. A OMS estima que se $20 \%$ a $40 \%$ dos recursos de saúde sejam desperdiçados. E faz questão de alertar que esta é uma estimativa conservadora ${ }^{444}$. A fórmula da OMS para a cobertura universal com os meios financeiros existentes ou plausíveis inclui duas iniciativas básicas: melhorar a arrecadação de recursos, tornando-a mais eficaz e austera e criando novas fontes, além de aplicá-los de forma mais eficaz. O Órgão esclarece que a segunda iniciativa é ainda mais importante que a primeira ${ }^{445}$.

\footnotetext{
${ }^{441}$ PIOLA, Sérgio Francisco. "Tendências do financiamento da Saúde", em Debates GV Saúde, Volume 2 II Semestre, 2006, p. 12.

${ }^{442}$ OMS, Relatório... A mensagem da Diretora-Geral da OMS que encarta o estudo não poderia ser mais clara e referenda de que a escassez é muito mais do que vã alegação do Poder Público: "Num tempo de dinheiro escasso, o meu conselho aos países é este: antes de cortarmos nas despesas em saúde, procuremos primeiro as oportunidades para aumentar a eficiência. Todos os sistemas de saúde, em toda a parte, podem fazer melhor uso dos seus recursos, seja por melhores práticas de aprovisionamento, um uso mais generalizado de produtos genéricos, melhores incentivos aos prestadores, ou mecanismos financeiros e administrativos mais fluidos.", p. vi.

${ }^{443}$ Resolução 58.33 da Assembleia Mundial da Saúde de 2005.

${ }^{444}$ OMS, Relatório..., p. xiii.

445 OMS, Relatório..., p. xix.
} 
O uso racional dos recursos à disposição é o principal mote da OMS para a cobertura universal. Baseada na racionalidade, a agência isola as principais causas de ineficiência: a primeira é a necessidade de eliminação de despesas desnecessárias com medicamentos, com o pagamento, pelo Poder Público, do preço justo pelo medicamento, embasado nos preços de referência internacional (para saber se o que um país paga é compatível do que se cobra em outro). Outras são: (a) o uso de medicamentos de qualidade inferior; (b) o uso inapropriado ou ineficiente de fármacos; (c) excesso de uso ou de oferta de procedimentos e meios de diagnósticos; (d) estrutura de pessoal inapropriada, dispendiosa e imotivada; (e) admissões hospitalares e internações inadequadas; (f) baixo uso das instalações disponíveis; (g) erros médicos; (h) qualidade inferior dos serviços; (i) desperdício, corrupção e fraude; e (j) estratégias inapropriadas e ineficientes ${ }^{446}$. O que a OMS indica, indiscutivelmente, é que é preciso melhorar os procedimentos, porque os recursos são, de fato, limitados.

No Brasil, o financiamento e a transferência de recursos federais para as ações e serviços de saúde são regulados pela Portaria MS nº 204/GM, de 29 de janeiro de 2007, editada pelo Ministério da Saúde. Ela estabeleceu cinco blocos de custeio, intimamente ligados à própria gestão do sistema: (a) atenção básica, que tem os recursos para financiamento transferidos mensalmente, de maneira regular e automática, a partir do fundo nacional de saúde aos fundos de saúde do Distrito Federal e dos municípios, além de recursos variáveis para o custeio de estratégias (como, i.e., saúde da família e saúde bucal); (b) atenção de média e alta complexidade ambulatorial e hospitalar, que também possui transferência mensal de recursos; (c) vigilância em saúde, que recebe recursos de acordo com a demanda; (d) assistência farmacêutica, que se vale de três diferentes contas ou componentes (componentes básico e estratégico da assistência farmacêutica e componente de medicamentos de dispensação excepcional, custeados mensalmente); e (e) gestão do SUS, que envolve ações de planejamento, orçamento, programação, monitoramento, regulação, auditoria - enfim, gestão propriamente dita do sistema, com custeio de acordo com as ações desenvolvidas.

Essa norma (Portaria MS no 204/GM/2007) fornece uma ideia do quão complexo é o desenho do orçamento específico para as ações de saúde. Tomando-se o emblemático bloco de financiamento de assistência farmacêutica (que envolve a dispensação de medicamentos pelo Estado) tem-se noção do problema. O componente

${ }^{446}$ OMS, Relatório..., p. 67. 
básico da assistência farmacêutica, destinado a custear tratamento de agravos e programas de saúde específicos, é composto de uma parte financeira fixa e outra variável. A fixa consiste em um valor per capita transferido para estados, municípios e Distrito Federal, definido por Comissões Intergestores Bipartites, órgãos estaduais formados por administradores de saúde; a variável também revela valores per capita, mas para a implementação de políticas específicas, como as de hipertensão e diabetes, rinite e asma, saúde mental, saúde da mulher, alimentação e nutrição e combate ao tabagismo.

O componente estratégico da assistência farmacêutica é destinado ao controle de endemias, programa DST/AIDS, sangue e hemoderivados e imunobiológicos. O componente de medicamentos de dispensação excepcional ${ }^{447}$ depende de deliberação em Comissão Intergestores Tripartite - formada por representantes de todas as esferas da Federação -, mais aprovação prévia em comissão estadual que ateste a efetiva necessidade e entrega do medicamento. O repasse será, assim, por demanda, e o cálculo para fins de provisão orçamentária se fará com base na média trimestral das autorizações.

Sem dúvida, o mais sensível caso de intervenção judicial em políticas de saúde é o da distribuição forçada de medicamentos. De 2005 a 2010, estima-se que os gastos da União com decisões judiciais mandando prover medicamentos de alto custo dispararam, aumentando, no período, mais de 5.000\%. O dispêndio do Ministério da Saúde com apenas essa espécie de fármacos representou, em 2010, 1,8\% ${ }^{448}$. O Estado de São Paulo, em 2011, gastou cerca de cinquenta e sete milhões de reais por mês para cobrir as decisões judiciais e administrativas dos vinte e cinco mil casos em andamento ${ }^{449}$. Em 2010, o Ministro da Saúde declarou que o Poder Público gastou com medicamentos concedidos judicialmente cento e trinta e dois milhões de reais, enquanto que, em 2003, a cifra correspondente era cento e setenta mil reais ${ }^{450}$. Reportagem já citada neste texto mostra que, em 2005, a União destinou dois milhões e quatrocentos mil reais para atender três centenas de ordens judiciais de concessão de medicamentos; em 2010, o dispêndio pulou para duzentos e quarenta e três milhões de reais, isso, para dar conta de cerca de sete mil

\footnotetext{
${ }^{447}$ Os medicamentos excepcionais são aqueles de alto custo e que devem ser utilizados por longo período da vida dos pacientes, como é o caso dos medicamentos para tratamento do Alzheimer e das doenças manifestadas por erros inatos do metabolismo.

448 "Gasto do governo com remédios via ação judicial cresce 5.000\% em 6 anos", disponível em: <http://www.estadao.com.br/noticias/impresso,gasto-do-governo-com-remedios-via-acao-judicial-cresce5000-em-6-anos,711740,0.htm>, acesso em 8.3.12, 22:14h.

449 "Gasto do governo...".

450 “Gastos do SUS com ações judiciais passam de R\$ 170 mil para R\$ 132 milhões nos últimos oito anos”, disponível em: <http://agenciabrasil.ebc.com.br/noticia/2011-07-07/gastos-do-sus-com-acoes-judiciaispassam-de-r-170-mil-para-r-132-milhoes-nos-ultimos-oito-anos>, acesso em 9.3.12, 13:30h.
} 
processos judiciais $^{451}$. Em 2012 foi noticiado um verdadeiro recorde: o SUS gastou cerca de trezentos e quarenta milhões de reais, de janeiro a outubro, para dar cabo de decisões judiciais mandando entregar fármacos, equipamentos e insumos, um incremento de mais de $20 \%$ do valor gasto durante o ano inteiro de 2011, que, por sua vez, havia crescido $90 \%$ do montante pago em $2010^{452}$.

$\mathrm{Na}$ verdade, a reação judicial às vicissitudes do processo político ordinário é oriunda, no campo dos fármacos, do próprio impacto que esses medicamentos causam nas contas da saúde. No mundo todo aumentam, ano a ano, os gastos com remédios, dentre públicos e privados. No Canadá, esses gastos cresceram 11\% em 2005; no Reino Unido, o aumento calculado entre 2001 e 2002 foi de $10 \%{ }^{453}$. De 1980 a 1999, os valores registrados como pagamentos pela aquisição de medicamentos aumentaram vinte e quatro vezes, de cinco bilhões de dólares para cento e vinte bilhões de dólares em todo o mundo $^{454}$. Os gastos com fármacos superam, e muito, o que é investido na conta geral da saúde. É o que ficou constatado no Brasil: enquanto o Ministério da Saúde apontou um incremento de 9,6\% nos valores aplicados nos serviços gerais de saúde de 2002 a 2006, os valores pagos em medicamentos subiram $123,9 \%$ no mesmo interregno ${ }^{455}$.

Apesar do dever de atendimento universal às demandas, dos limites e pisos orçamentários, da participação da saúde no PIB do País, como visto, as famílias ainda gastam mais com medicamentos do que o governo ${ }^{456}$ - e, mesmo assim, há um manifesto déficit estatal no fornecimento de fármacos.

Não é por menos que no Brasil, país em que o direito à saúde é universal e deve ser distribuído de maneira isonômica e gratuita, o acesso a medicamentos esteja na ordem do dia. Com a faceta judicial não ocorre diversamente. A particular forma de custeio da saúde revela que alocar recursos limitados em seara recheada de variáveis, em grande parte, instáveis, é tarefa dificultosa até aos mais tarimbados gestores. Que dirá aos juízes, que não possuem, salvo esforço pessoal e individual, menor preparo para lidar com tais dilemas.

451 “O paciente de R\$800 mil”, disponível em: <http://revistaepoca.globo.com/tempo/noticia/2012/03/opaciente-de-r-800-mil.html>, acesso em 11.5.12, 13:40h.

452 "SUS tem despesa recorde com ações judiciais", disponível em: <http://www1.folha.uol.com.br/cotidiano/ 1199942-sus-tem-despesa-recorde-com-acoes-judiciais.shtml>, acesso em 15.7.2013, 6:55h.

${ }^{453}$ MENDES, Andréa Cristina Rosa e VIEIRA, Fabíola Sulpino. Evolução dos Gastos do Ministério da Saúde com Medicamentos. Ministério da Saúde: Brasília, 2007, p. 5.

${ }^{454}$ VIEIRA, Fabíola Sulpino e ZUCCHI, Paola. "Distorções causadas pelas ações judiciais à política de medicamentos no Brasil". Revista de Saúde Pública no 41 (2007), p. 215.

${ }^{455}$ MENDES e VIEIRA, Evolução dos Gastos..., p. 3.

${ }^{456}$ O IBGE aponta que em 2009 a população gastou, diretamente, cerca de dez vezes mais o total que o Estado investiu na mesma rubrica naquele mesmo ano (DEPRÁ e SOARES, "Ligações perigosas...", p. 312). 
Por isso, como se verá, este Item é passagem obrigatória para que se mensurem, corretamente, alguns temas ainda a serem abordados nesta tese: o debate a respeito da reserva do possível ganha especial relevo no trato da intervenção judicial na saúde. Mesmo o mínimo existencial e a proporcionalidade possuem, em alguma medida, certo cuidado com as questões relativas ao custeio dos serviços sociais. Por último, o despreparo dos magistrados e, regra geral, dos players do jogo processual em tratar bens e serviços de saúde. Com os olhos neste item é que tais temas serão retomados em momento oportuno.

\subsubsection{O cunho humanitário do direito à saúde}

Uma das características que mais marcam a postulação judicial de saúde é inerente a esse próprio direito: trata-se de seu caráter humanitário e emergencial. Nenhum outro direito social ou individual possui expressão tão nevrálgica quanto a saúde. De fato, a manutenção da saúde está umbilicalmente ligada a uma vida digna. Salvo exceções patológicas, não há caso de jurisdicionado que requeira determinada medicação por mero capricho. Sempre a postulação judicial é a resposta a uma verdadeira necessidade e não raras são vezes em que essa necessidade significa a vida ou a morte do postulante, independentemente de exagero das partes e causídicos.

O receptor dessa necessidade, nos casos de intervenção judicial na saúde, é o juiz. É ele quem enfrentará, frente a frente, o pedido daquele que demanda certa medicação capaz de assegurar a manutenção de uma vida adequada. A decisão, nesses casos, é encarada pelo juiz como uma responsabilidade sua, pessoal, e questiona o magistrado o que ocorrerá com o postulante caso a providência por ele requerida não lhe seja concedida. Um campo fértil dessa espécie de ocorrência são as ações individuais com pedidos emergenciais. Elas são particularmente cruéis para o magistrado, que acaba por vezes exercendo a justiça de misericórdia de que já se tratou.

$\mathrm{Na}$ educação, outra seara extremamente preocupante em tema de políticas públicas e normalmente invocada no debate, não se vê situação semelhante. Mesmo os casos mais lancinantes, como a matrícula de certa criança em creche, ou a concessão emergencial do direito de se submeter à avaliação bimestral, não se igualam à situação do jurisdicionado que está no leito do hospital à espera de medida que o permita ser 
transplantado à custa do Estado, ou à circunstância da pessoa que precisa da administração de determinado medicamento excepcional, sob pena da falta acarretar danos permanentes ao organismo.

Essas hipóteses são graves e urgentes, não havendo outra saída ao magistrado senão, diante de pressupostos mínimos de cabimento, conceder a medida pleiteada. No mais das vezes, o juiz não desejará assumir a carga emocional de não ter atendido o pleito do jurisdicionado, temendo que o pior lhe aconteça. Essas situações tornam da saúde um campo propício para ocorrerem decisões que contrariam toda a lógica da intervenção jurisdicional em políticas públicas: com efeito, com base na urgência e inaudita altera parte, o juiz pode dar uma ordem que não considera minimamente os planos e programas da Administração, o orçamento público e, evidentemente, aquele cidadão que não teve meios de pedir judicialmente providência semelhante, embora igualmente necessitado ${ }^{457}$.

Haverá, contudo, saídas para tal quadro? Quer dizer, em situações em que verdadeiramente a providência judiciária seja cabível - seja pela inação dos Poderes majoritários, seja pela cooptação política, seja porque tal medida atendia ao interesse minoritário do eleitorado articulado, ou, ainda, estando perfeitamente adequada a política de saúde programada -, em ocasiões em que, de fato, o postulante necessite da medida almejada, o juiz não poderá ordenar o quanto requerido? Ora, evidentemente que sim, já que o Judiciário, como sustentado, é o último recurso a quem a sociedade pode recorrer, devendo ele, Judiciário, responder aos anseios sociais sempre que tal providência se conforme à ordem jurídica vigente.

Mas é preciso que sejam diferenciados os casos e, ainda assim, ocorra a observância de determinados parâmetros que devem nortear a atividade judicial. Pontuadas as peculiaridades da saúde, características que tornam a administração (e, claro, a judicialização) desse direito tão problemática, é hora de se estabelecer os limites: (a) a reserva do financeiramente possível; (b) o mínimo existencial; (c) a razoabilidade; (d) as informações amplas e acessíveis sobre as ações administrativas no campo da saúde; (e) o registro prévio de terapias, equipamentos ou medicamentos no órgão competente; e (f) a

\footnotetext{
${ }^{457}$ Quem aponta o problema da cognição sumária no trato da saúde é André Castro CARVALHO. Para ele, o uso desenfreado de instrumentos processuais dessa espécie termina por, anomalamente, implicar a adoção de medidas que frequentemente contêm impacto orçamentário sem a devida discussão exauriente que seria de rigor ("O Impacto Orçamentário da Atuação do Poder Judiciário", em AMARAL Jr., José Levi Mello do (coord.). Estado de Direito e Ativismo Judicial. São Paulo: Quartier Latin, 2010, em especial pp. 13-14 e 3940).
} 
preferência pelo provimento de medicamentos e terapias contemplados nas listas estatais de dispensação obrigatória.

O que passa a se propor, é bom que se frise, são mais que meros limites; são, sim, parâmetros para uma atividade jurisdicional mais racional e responsável no acesso à saúde. Não se pretende, aqui, sustentar que tais parâmetros são imperativos, estanques e inderrogáveis, como se a atividade jurisdicional deles não pudesse escapar. Vezes haverá que nem mesmo o mais ponderado dos magistrados conseguirá repousar as reflexões sugeridas nas linhas seguintes sobre o caso que se coloca à sua colação. De toda forma, espera-se que, via de regra, sejam observadas e refletidas as colocações postas adiante.

Inicie-se com aquele que é o mais consabido dos temas invocados quando se fala em intervenção judicial em políticas de saúde: a reserva do possível.

\subsubsection{Reserva do financeiramente possível}

A reserva do possível é questão que recorrentemente vem alegada pelo Poder Público em sede de defesa ${ }^{458}$. Trata-se de exceção ligada à disponibilidade (fática ou técnica ${ }^{459}$ de recursos para o cumprimento das providências pleiteadas em Juízo. A ideia, basicamente, é a de que não existe a possibilidade de que todas as prestações a que está obrigado o Estado sejam cumpridas, por pura falta de dinheiro para tanto. É, destarte, tema ligado à escassez de bens e arrimado na concepção de que todos os direitos têm seus custos $^{460}$.

A preocupação da intromissão judicial nas finanças públicas não é nova e está consagrada na Constituição: a previsão dos precatórios judiciais e toda a sua sistemática nada mais revela senão a intersecção entre decisão judicial e orçamento ${ }^{461}$, como, aliás, já se apresentou nesta tese. Com as políticas públicas não sucede diferentemente.

\footnotetext{
${ }^{458}$ Esta também é a constatação de GRINOVER (“O Controle”..., p. 20).

${ }^{459} \mathrm{O}$ direito de crédito é técnico porque não necessariamente devem existir, fisicamente, cem por cento de suas representações, no caso mais costumeiro, a moeda. Isso significa que se o Estado, por exemplo, tem em seu caixa um milhão de reais, não necessariamente possui ele essa quantia em cédulas físicas. Nesse sentido ver LOPES ("Em torno da reserva do possível"..., pp. 179-180).

${ }^{460}$ HOLMES e SUSTEIN (The Cost of Rights..., pp. 13-16); GALDINO (Introdução à Teoria ..., pp. $215 \mathrm{e}$ SS.).

${ }^{466}$ SALLES, Execução judicial..., p. 267.
} 
De fato, é bem palatável o conceito de que, ao mesmo tempo em que as necessidades (ou, antes, as possíveis demandas oriundas do cumprimento de obrigações estatais) são infinitas, os recursos são escassos. Parece elementar a ideia de limitação financeira do que o Estado pode dispor, daí a recorrente defesa da Fazenda no sentido de que não tem possibilidade de cumprir eventual ordem que outorgue ao jurisdicionado o bem da vida por ele almejado. É exatamente esse o pano de fundo da já mencionada Lógica do Cobertor Curto. Com efeito, a reserva do possível é intuitivamente um dos mais importantes aspectos a serem considerados na dispensação judicial de saúde (e de políticas públicas em geral). Tal aspecto encontra fundamento, inclusive, em algumas vertentes mais concretas da própria Teoria dos Direitos Fundamentais.

Em 1978, Guido Calabresi e Philip Bobbitt publicaram uma obra em que ambos analisavam questões relacionadas à implementação dos itens típicos do welfarismo à luz de questões práticas ligadas às políticas públicas. Os autores, em visão geral, concluíram que os recursos disponíveis para aplicação em políticas públicas eram insuficientes para atendimento de toda a demanda, o que fazia com que o responsável pela alocação dos escassos recursos estivesse fadado a proceder a escolhas trágicas, porque sempre alguém ficaria à míngua da política eleita, deixando de receber aquilo que lhe seria devido $^{462}$. A teoria de Bobbitt e Calabresi ornou o voto do Min. Celso de Mello no julgamento da STA $n^{\circ} 175-A g R / C E$, que, entendendo haver dilema entre a prestação do direito à saúde, de um lado, e a alocação dramática de escassos recursos ${ }^{463}$, de outro, deveria prevalecer a primeira ${ }^{464}$.

\footnotetext{
${ }^{462}$ CALABRESI, Guido e BOBBIT, Philip. Tragic Choices - The conflicts society confront in the allocation of tragically scarce resources. New York and London: W. W. Norton \& Company, 1978. Os autores dividiam as escolhas em dois aspectos: o de primeira ordem, que examinava quanto dos escassos recursos seriam aplicados em determinada rubrica (i.e., quanto será usado para a compra de seringas descartáveis); e o de segunda ordem, que definia quem seriam as pessoas beneficiadas (i.e., os moradores da cidade de São José dos Campos, em São Paulo).

${ }^{463}$ A OMS, em sua realística análise, conclui que no caminho para a cobertura universal será impossível não se realizar escolhas difíceis (Relatório..., p. 96).

464 "Essa relação dilemática, que se instaura na presente causa, conduz os Juízes deste Supremo Tribunal a proferir decisão que se projeta no contexto das denominadas "escolhas trágicas" (GUIDO CALABRESI e PHILIP BOBBITT, "Tragic Choices", 1978, W. W. Norton \& Company), que nada mais exprimem senão o estado de tensão dialética entre a necessidade estatal de tornar concretas e reais as ações e prestações de saúde em favor das pessoas, de um lado, e as dificuldades governamentais de viabilizar a alocação de recursos financeiros, sempre tão dramaticamente escassos, de outro. Mas, como precedentemente acentuado, a missão institucional desta Suprema Corte, como guardiã da superioridade da Constituição da República, impõe, aos seus Juízes, o compromisso de fazer prevalecer os direitos fundamentais da pessoa, dentre os quais avultam, por sua inegável precedência, o direito à vida e o direito à saúde". Esse voto, sob o ponto de vista analítico, é um dos mais importantes paradigmas judiciários da intervenção daquele Poder nas políticas de saúde.
} 
Que os direitos fundamentais são conquista da humanidade não há dúvida. Que uma das maiores importâncias da jurisdição é a defesa desses direitos é assertiva que também não necessita maiores ilações. O grande problema é essa defesa cega, sob o aparentemente lógico argumento de que, porquanto fundamentais, eles não podem ter seu alcance limitado ou restrito. Não é raro que a saúde seja tida como um direito que não possui esteios, sendo irrelevante potencial falta de recursos financeiros.

O fato é que qualquer direito fundamental pode sofrer restrições. Algumas delas, inclusive, gozam de proteção constitucional. Tome-se, por exemplo, o direito à vida, que ninguém questiona ser fundamental: ele pode ser relativizado em caso de guerra declarada $^{465}$. Também a privacidade é um direito dos mais importantes, basilar do sistema democrático - mas pode da mesma forma ser relativizada em caso de estado de sítio, tanto quanto a liberdade ${ }^{466}$. São alguns os exemplos nesse sentido que a Constituição outorga, além de outros, delineados no Item 2.2.

Sofistiquemos um pouco mais os paradigmas. O que ocorreria caso se entrechocassem direitos fundamentais, como - no clássico exemplo - o conflito entre a liberdade de expressão e a honra de alguém? No caso concreto algum dos direitos sucumbiria. Em outras palavras, a observância fática de um direito fundamental não seria verificada.

Alexy referenda teoricamente a existência de fronteiras aos direitos fundamentais, mostrando serem sustentadas na doutrina as teorias externa e interna desses direitos. Para a teoria externa, o direito fundamental possui determinado conteúdo, que pode vir a ser restringindo por um fator que a ele seja alheio. A teoria interna, por sua vez, prega que não se podem impor restrições aos direitos fundamentais, mas eles possuem limites, que definem seu próprio conteúdo. Trata-se, pois, de limites ou restrições imanentes $^{467}$.

Alexy, com razão, defende o cabimento da teoria externa, tomando, para isso, o exemplo da restrição da liberdade dos motociclistas em face da obrigatoriedade de uso de capacete. Se o direito de liberdade fosse abstratamente considerado em uma posição definitiva - para ele, impune a qualquer óbice -, nenhum elemento externo poderia obrigar os motoristas de motos usarem a proteção. Se, ao contrário, o conteúdo do direito

${ }^{465}$ Art. $5^{\circ}$, XLVII, $a$, parte final da Constituição.

${ }^{466}$ Art. 139, I, III, IV e V da Constituição.

${ }^{467}$ ALEXY, Robert. Teoria dos Direitos Fundamentais. São Paulo: Malheiros, 2008, pp. 277-279. Quanto à teoria interna, José Joaquim Gomes CANOTILHO destaca ser ela informada por uma cláusula de comunidade, vale dizer, os direitos fundamentais seriam limitado por limites éticos e da ordem social (Direito Constitucional..., p. 1.280) 
fundamental é tomado prima facie - vale dizer, como um comando que admite contornos de agentes externos, permitindo, portanto, a verificação de seu conteúdo e alcance no caso concreto - a hipótese da obrigatoriedade do uso do capacete é plenamente explicável. A Teoria dos Princípios de Alexy, então, se justifica à luz da teoria externa de restrição aos direitos fundamentais. Daí ser tangível a ponderação que o professor alemão defende valer quando os direitos dessa estirpe colidem ${ }^{468}$. As restrições, de acordo com ele, podem ser diretamente constitucionais (como o caso da pena de morte em caso de guerra declarada) ou indiretamente constitucionais, quando elas derivam de norma infraconstitucional, mas mediante autorização da Constituição (como no caso dos requisitos e hipóteses para a quebra do sigilo telemático $)^{469}$. A teoria demonstra que o direito à saúde pode sofrer restrições - inclusive, e porque não, de égide orçamentária ${ }^{470}$.

Não sem razão, a questão da escassez sempre é levantada por aqueles que apontam a inadequação do processo como meio de adjudicar políticas públicas, porque os juízes desconhecem questões orçamentárias, as ações executivas engendradas e, não tendo noção de como alocar ou mover recursos, também não poderiam atuar em ações relacionadas a esse tipo de bem ${ }^{471}$.

Apesar da importância do tema, ele constantemente é arguido de maneira inadequada pelos poderes públicos quando instados a se defenderem da alegação de omissão na entrega de bens sociais. O grande problema é que, da forma débil como tão relevante ponto é abordado nas defesas da Fazenda, no mais das vezes os juízes absolutamente desconsideram toda a complexidade e importância que lhe está por detrás. Antes de desenvolver este aspecto, alguns esclarecimentos preliminares devem ser tecidos.

\footnotetext{
${ }^{468}$ ALEXY, Teoria..., pp. 278-279.

${ }^{469}$ ALEXY, Teoria..., pp. 286-295.

${ }^{470}$ SGARBOSSA (Crítica à teoria..., pp. 273) afirma que tanto as limitações jurídicas do orçamento (aquelas relacionadas à escassez relativa), impostas por leis que pregam a austeridade fiscal ou para a observância de outros direitos, quanto as limitações fáticas (ligadas à escassez absoluta) consistem em restrições aos direitos fundamentais. Releva, contudo, o perigo de banalização do uso da constatação, apontando que, na tarefa de sua aplicação concreta, sempre devem ser observados alguns parâmetros: (i) para a limitação jurídica: (i.a) proibição do excesso: qualquer lei restritiva de direitos, liberdades e garantias deve ser adequada (apropriada), necessária (exigível) e proporcional (em justa medida); (i.b) proibição de proteção deficiente, que obriga a observância suficiente de direitos, típica daqueles de prestação positiva; (i.c) proteção do núcleo essencial: o núcleo essencial dos direitos fundamentais deve ser sempre preservado, a fim de evitar sua aniquilação; (i.d) proibição de retrocesso: os direitos fundamentais conquistados jamais poderão ser mitigados ou ter tolhida sua eficácia jurídica ou material; (i.e) mínimo existencial e dignidade da pessoa humana: todos devem ter efetivados os mínimos direitos necessários a uma vida digna (pp. 274-312); (ii) para a limitação fática: (ii.a) princípio da progressividade: os governos devem progressivamente destinar fatia de seus recursos para a implementação de direitos sociais, tal como previsto no Pacto Internacional dos Direitos Econômicos, Sociais e Culturais (PIDESC); (ii.b) princípio da aplicação do máximo dos recursos disponíveis; (ii.c) indivisibilidade e independência dos direitos humanos, segundo o qual os direitos humanos devem ser analisados integralmente, sem fracionamento (pp. 314-340).

${ }^{471}$ v. HOROWITZ (Courts and Social..., p. 257); VERÍSSIMO (A Judicialização..., p.77).
} 
Aplicar a ideia da reserva do possível ao campo da saúde possui uma pecha que, com alguma frequência, reverbera sobre os mais variados julgamentos. De fato, à primeira vista pode parecer mesquinharia tratar dos dinheiros públicos quando se fala do bem-estar, da subsistência e da dignidade da vida de uma pessoa. Pode, com efeito, soar antipático negar acesso farmacológico sob o fundamento de que o Estado não tem dinheiro $^{472}$. Muitas decisões judiciais perfilharam nesse sentido, alegando que direitos fundamentais não poderiam se submeter a questões menores como o orçamento público ${ }^{473}$. A tarefa, ao longo deste item, será, precisamente, mostrar como o orçamento é fundamental no trato estatal - inclusive judicial - da saúde.

Neste ponto, outra ressalva há de ser feita: a reserva do possível não pode ser usada como um paradigma isolado, independente e dissociado dos outros propostos neste estudo. Sua fria e inconsequente aplicação pode, sim, revelar um perigo, aliás, frequentemente invocado por aqueles que recusam sobrepor a reserva do possível aos direitos fundamentais. $\mathrm{O}$ grande perigo da exceção da reserva do possível é transformar o Estado em um grande gerente empresarial, trocando a concretização de direitos mandatórios pela efetiva implementação daqueles que representem maior utilidade versus menor dispêndio, ou seja, tais quais mais bem se amoldem à lógica do custo-benefício.

Este autor é consciente da dificuldade de defesa da tese de que é preciso sempre questionar se o Estado tem reservas financeiras para implementar determinado direito, sobretudo em função da antipatia que tal limite ora proposto goza, por parte, inclusive, dos próprios juízes. Longe de ser banal, a hipótese da reserva do financeiramente possível é complexa e não pode servir como supedâneo da aplicação puramente econômica. Um argumento, ora desenvolvido, demonstrará o perigo do utilitarismo financeiro exagerado aplicado ao contexto dos direitos sociais, de onde se tira, destarte, todo o cuidado que a argumentação da reserva do possível deve guardar. Esse argumento, calcado em um exemplo, mostrará, a um só tempo: (a) que a lógica do custo-benefício não pode ser oponível a todas as situações; e (b) como o debate sobre a priorização de direitos só se justifica à luz da escassez, mola-motriz da reserva do possível. Convenciona-se denominá-lo argumento do encarcerado.

\footnotetext{
${ }^{472}$ Mesma advertência feita por FERRAZ e VIEIRA, com a diferença que os autores apontam, também com razão, que a tradição de desídia e negligência com os serviços públicos do Estado brasileiro tomam de desconfiança qualquer alegação que aponte a insuficiência de recursos (FERRAZ, VIEIRA. "Direito à saúde...", p. 8.

${ }^{473}$ Foi o que concluiu o Tribunal de Justiça do Rio Grande do Norte na concessão a um paciente do medicamento oncológico Devacizumab ("Direito à vida se sobrepõe às questões de orçamento", disponível em: <http://tj-rn.jusbrasil.com.br/noticias/2467271/direito-a-vida-se-sobrepoe-as-questoes-de-orcamento>, acesso em 14.5.12, 13:31h).
} 
Se a lógica do custo-benefício fosse levada às últimas circunstâncias, os presidiários no Brasil seriam ainda mais tolhidos de direitos em sua lamentável situação e, isso, em virtude da cega aplicação da reserva do possível.

De fato, são cediças a negligência e a leniência geral - do Estado, da sociedade e das pessoas individualmente consideradas - com o sistema carcerário brasileiro. Os indivíduos encarcerados, seja em regime de prisão cautelar, seja por condenação definitiva, são esquecidos ${ }^{474}$, apagados, extirpados do convívio social, lembrados apenas quando se rebelam ou quando, em franca demonstração das falhas do sistema, praticam no isolamento ações bandidas, ou as ordenam aos comparsas em liberdade. Longe de pretender, aqui, discutir a teoria da pena e os motivos que levaram as sociedades a sempre fustigar os criminosos (o que é certamente explicável por Psicanálise, Filosofia, Antropologia, Sociologia e, claro, pelo próprio Direito), fato é que as subhumanas condições as quais são submetidos os presos no Brasil são incontestes. E lamentáveis $^{475}$.

Nada obstante - e até mesmo por efeito da repulsa que os presos geram -, causou furor levantamento dando conta que encarcerados do sistema federal de presídios custam ao Erário três vezes mais que estudantes de escolas públicas de segundo grau. Esse mesmo levantamento concluiu que, ainda nos presídios dos Estados, o custo por pessoa ali mantida supera o valor aplicado individualmente na educação de base ${ }^{476}$. Vozes se levantaram apontando um nocivo contrassenso entre esses dados. Mesmo o propósito da comparação já soa enviesado: diante da inquestionável limitação de recursos financeiros, parece terrível que se gaste mais com encarceramento do que com educação, sobretudo quando o Brasil ocupa o nada honroso terceiro posto mundial da chamada taxa de

\footnotetext{
${ }^{474}$ Levantamento feito pelo CNJ em 2009 acusou que cerca de um terço da população carcerária brasileira estava indevidamente presa, ou porque sua pena já estava cumprida, ou porque eles não deveriam estar nessa condição. Este é um dado empírico que demonstra, sem maiores ilações, como os presos são tratados no Brasil (obtido em: <http://g1.globo.com/Noticias/Brasil/0,MUL1004668-5598,00.html>, acesso em 22.2.12, $12: 37 \mathrm{~h})$.

${ }^{475}$ Editorial da Folha de São Paulo (23.2.12, p. A2, "Prisões Lotadas") anuncia que apenas no Estado de São Paulo - o maior do Brasil - há um déficit de oitenta e três mil vagas, ou seja, há oitenta e três mil presos mais do que o limite comportado pelas penitenciárias paulistas. O mesmo editorial dá conta que o CNJ, ato contínuo ao levantamento mencionado na nota anterior, acabou liberando vinte e um mil presos indevidamente encarcerados. Dias antes, em 21.2.12, a manchete do jornal foi "Presos superam em $81 \%$ número de vagas em SP". Mas é um erro atribuir apenas à superlotação a degradação completa dos presos no País. Fato é que a cadeia nada regenera, educa, engrandece ou dignifica seus hóspedes - muito ao contrário. $\mathrm{O}$ preso é retirado de circulação, trancafiado e abandonado à sua própria sorte.

476 "Brasil gasta com presos quase triplo do custo com aluno", disponível em: <http://oglobo.globo.com/educ acao/brasil-gasta-com-presos-quase-triplo-do-custo-por-aluno-3283167>, acesso em 22.2.12, 12:45h.
} 
encarceramento $^{477}$, e o penúltimo lugar no ranking de qualidade da educação ${ }^{478}$. É sedutor o pensamento de que as crianças e jovens, com um futuro a percorrer, tenham a seu dispor mais recursos educativos, ainda que em sacrifício daqueles considerados párias.

A análise do problema sob a pura lente da reserva do possível faria com que, certamente, fosse ele solucionado com a realocação dos recursos aplicados no sistema prisional para a educação de base, de forma a equilibrar a equação ou, ainda - claro -, fazer com que as verbas educacionais ultrapassassem os custos com presidiários. Se o Erário não basta para dar a todos os direitos que a norma lhes assegura, é preciso eleger prioridades - de novo, a questão das escolhas - e, no presente caso, soa razoável que se privilegie quem constrói à custa de quem destrói.

O nó que surgiria a partir dessa saída é que os presos teriam piorada sua já deplorável situação, o que seria inadmissível, diante, inclusive, de questões humanitárias evidentes. Os encarcerados também têm direito à vida digna, e a Constituição não fez distinção sobre quem não goza desse direito ou quem dele abre mão. Deslocar verbas do sistema prisional para aplicar na educação ao simples entendimento de que uma situação é mais socialmente valiosa que outra é levar ao extremo a reserva do possível, exacerbando sobremaneira a dramaticidade de tão trágica escolha.

O argumento do encarcerado - é dizer, nem mesmo o mais desprezado dos seres pode ser deixado para trás, porque a ele também é assegurada a constitucional vida digna -, portanto, consiste em sustentar que ainda a mais nefasta situação fática em função dos mais fustigados e polêmicos direitos humanos justifica, isoladamente, a movimentação de recursos à luz exclusivamente do binômio custo-benefício.

A ressalva feita aqui, portanto, e demonstrada pelo argumento do encarcerado, é que a escassez, sozinha, não resolve os problemas da entrega de bens e direitos pelo Poder Público: de fato, o argumento do encarcerado pressupõe não a realocação de recursos dos presos para a educação a pretexto da melhora do segundo tema, mas, sim, aplicação mais eficaz ou realocação até determinado limite: o mínimo. Daí que outros parâmetros - sobretudo, o mínimo existencial e a razoabilidade, que serão oportunamente estudados - devem guiar o gestor de políticas públicas em sua árdua tarefa

\footnotetext{
${ }^{477}$ Editorial "Cadeia de Resultados" e artigo "Dilema Carcerário", publicados na Folha de São Paulo de 28.3.2012, p. A2.

${ }^{478}$ Em 2012, o Brasil ocupou o $39^{\circ}$ lugar de 40 países analisados quanto às habilidades cognitivas e realizações educacionais dos alunos do $5^{\circ}$ ao $9^{\circ}$ ano do ensino fundamental ("Ranking de qualidade da educação coloca Brasil em penúltimo lugar”, disponível em: <http://g1.globo.com/educacao/noticia/2012/11/ ranking-de-qualidade-da-educacao-coloca-brasil-em-penultimo-lugar.html >, acesso em 16.11.2013, 10:47h).
} 
de escolher como aplicar o Erário. O mesmo deve se impor ao juiz, quando substituir o gestor nessa seara.

Sim, porque a ardorosa questão da intervenção jurisdicional em políticas públicas, notadamente, as de saúde, também não se resolve com o simplório e isolado fundamento de que basta realocar recursos de rubricas como publicidade ou funcionalismo para cobrir os dispêndios sanitários.

Depois da advertência, volta-se ao encadeamento lógico deste item.

A expressão reserva do possível (Voberhalt des Möglichen) foi desenhada pelo Tribunal Constitucional Alemão no contexto do Segundo Pós-Guerra. O caso paradigma envolvia debate a respeito da possibilidade de adjudicação de vagas em instituições universitárias. O Tribunal entendeu, naquele caso, que não se daria essa possibilidade preponderantemente diante da escassez de recursos, e que, havendo tal limitação, não era de se privilegiar uns poucos cidadãos (i.e., aqueles que tiveram a oportunidade de levar ao Judiciário sua irresignação) em detrimento de outros, o que violaria a universalidade dos direitos sociais ${ }^{479}$. É evidente, como adverte Krell, que as realidades - e diversidades - sócio-econômicas de Brasil e Alemanha fazem com que os modelos emprestados do país tedesco devam ser analisados com ressalvas ${ }^{480}$. A questão dos limites orçamentários e dos recursos do Estado pode, sem embargo, ser estudada no Brasil independentemente de sua origem.

O julgamento paradigma denota a possibilidade de extração da íntima correlação que a escassez tem com a distributividade e a universalidade imanente aos direitos sociais, correlação que, na verdade, se dá por um paradoxo: se todos têm direito de acesso e políticas públicas que sejam universais e igualitárias (sobretudo em termos de saúde, por conta de sua gênese e da expressa estipulação constitucional consubstanciada no artigo 196 da Constituição) e sendo escassos os recursos, então, na verdade, nem todos serão plenamente atendidos de forma universal e igualitária quanto a todos os serviços e bens que devem ser providos pelo Estado. Assumir esse paradoxo é, em última análise, entender que, mesmo que atuem perfeitamente e em condições ideais, sempre haverá

\footnotetext{
479 Segundo a decisão em apreço (BVerfGE 33: 303-333), "fazer com que os recursos públicos só limitadamente disponíveis beneficiem apenas uma parte privilegiada da população, preterindo-se outros importantes interesses da coletividade, afrontaria justamente o mandamento de justiça social, que é concretizado no princípio da igualdade (SCWABE, Jürgen (Org.) Cinquenta Anos de Jurisprudência do Tribunal Constitucional Federal Alemão. Trad. Leonardo Martins. Montevideo: Fundação Konrad Adenauer, 2005, pp. 633/634).

${ }^{480}$ KRELL, Andreas. "Realização dos direitos fundamentais sociais mediante controle judicial da prestação dos serviços públicos básicos (uma visão comparativa)", em Revista de Informação Legislativa, ano 36, nº144 out/dez, Brasília: 1999, p. 244-247.
} 
omissão dos Poderes majoritários na efetivação de políticas públicas, o que equivale a igualmente dizer que frequentemente haverá espaço para a intervenção jurisdicional nesse campo. Em última análise, é dizer que até mesmo o mandamento judicial ordenando ao Poder Público realizar despesa para assegurar direitos pode se revelar imprestável.

O paradoxo ainda revela a responsabilidade com que os juízes têm que tratar suas decisões a respeito de políticas públicas. Pressupondo-se que o juiz só poderia outorgar ao jurisdicionado recurso disponível (ou possível), constitui-se o ponto levantado verdadeira restrição ao poder jurisdicional de adjudicar. Essa restrição, por sua vez, constitui dado essencial da correta distribuição de recursos, porque força o juiz a decidir com a consciência de que, ao mesmo tempo em que provê um direito a um postulante e, como tal, dispõe a respeito de recursos estatais, retira de outros tantos cidadãos o mesmo recurso, que seria, fatalmente, utilizado para a concretização de outros direitos ${ }^{481}$.

É preciso que se faça um importante esclarecimento: toda a discussão a respeito da aplicação da cláusula da reserva do possível se faz assumindo situações em que, de fato, o Estado não disponha de recursos financeiros para adjudicar ao jurisdicionado o direito postulado. Se esses recursos existem e há omissão estatal que permita a intervenção judicial em assuntos típicos dos Poderes majoritários, então jamais se haveria falar em reserva do possível. É verdade que é muito difícil imaginar um Estado esgotado sob o ponto de vista financeiro, sobretudo pelos mecanismos - inclusive, internacionais - de financiamento público ${ }^{482}$. Mas é igualmente verídico ser um erro conceber o Estado infalível quanto aos seus recursos. Por isso, a exceção da reserva do possível deve ser estudada e considerada. Aí é muito importante separar a escassez real e inescapável, oriunda da simples falta de recursos nos cofres públicos, daquela originada por escolhas do administrador, que, ao invés de aplicar em uma conta ligada, por exemplo, ao fundamental direito à saúde, designa recursos para outra rubrica qualquer, como, por exemplo, o pagamento de juros da dívida pública. Há tratamentos diversos para essas hipóteses que, por uma questão de desenvolvimento, serão estudados no capítulo destinado ao mínimo existencial.

É inevitável, com base no que aqui já foi discutido, que a questão a respeito da distribuição dos bens sociais tenha como pano de fundo o debate acerca dos recursos

\footnotetext{
${ }^{481}$ Ao mesmo tempo em que o juiz deve redobrar sua carga de responsabilidade, o administrador deve quadruplicar a sua respectiva, já que, sabedor das limitações do orçamento, deverá se esmerar ao máximo para garantir uma ótima alocação dos parcos recursos. Essa é a faceta da máxima eficiência na aplicação de recursos, que será oportunamente tratada.

${ }^{482}$ Cujo exemplo mais soberbo é o FMI - Fundo Monetário Internacional.
} 
que permitem a fruição desses bens. Se a conta da saúde goza de verba "x"para a compra de quantidade "y" de certa categoria de medicamentos, é preciso saber que há motivos para tanto. É necessário conceber que assim se deu com base em planejamento, fruto de estrutura única e, contudo, complexa. É de se ter em mente que essa estrutura se encarregou de montar um plano de acordo com os recursos que lhes foram disponibilizados por quem responsável (o que torna extremamente importante a competência para a alocação de recursos, o que, de resto, foi visto neste estudo). É fundamental que se tenha a exata noção, diante desse cenário, que a limitação de recursos torna muito mais complexa a tarefa de decidir como serão eles aplicados ${ }^{483}$, mormente para o Judiciário hodierno, que carece de conhecimentos técnicos para aprofundar tão importante debate.

O tema é relevante porque os recursos são escassos e as necessidades - ou os direitos fundamentais - infinitas. Mais: a escassez faz com que os direitos fundamentais, muitas vezes, contraponham-se no mesmo plano sem necessariamente possuírem qualquer interconexão. É o caso da escolha entre dispor recursos para a construção de uma escola ou de um viaduto em bairros diferentes. A escassez implica escolhas que, invariavelmente, resultam algum sacrifício ${ }^{484}$.

A importância das reservas financeiras na dotação das políticas de saúde em juízo pode ser observada com o uso da Teoria dos $\operatorname{Jogos}^{485}$, sobretudo sob o prisma de um clássico problema apresentado nesse âmbito, o Dilema do Prisioneiro ${ }^{486}$. Na tutela individual da saúde, se um jurisdicionado recorrer ao Judiciário para obter o medicamento, ele o receberá se os demais em situação análoga não propuserem suas próprias ações, a que todos têm direito; se isso ocorrer, todavia, receberá quem conseguir primeiro a tutela, até a exaustão de recursos, porque todos agiram visando a atingir seu próprio interesse. Mas,

\footnotetext{
483 "Not a single right valued by Americans can be reliably enforced if the Treasury is empty. All rights are protected only to a degree, and this degree depends partly on the decisions about how to allocate the scarce public resources". Este excerto é tirado do Capítulo em que SUSTEIN e HOLMES apresentam a inexorabilidade das trocas (tradeoffs) em matéria de direitos, porque, sendo escassos os recursos, sempre a opção pelo atendimento a uma obrigação implicará o desatendimento a outra. The Cost of Rights..., p. 121.

${ }^{484}$ CALABRESI e BOBBIT. Tragic Choices...

485 A Teoria dos Jogos, para a Economia, parte da premissa que, em um contexto de múltiplos interesses em jogo, os atores (ou, antes, jogadores) atuam estrategicamente para obter um retorno que lhe seja mais vantajoso (apud de CARVALHO, "O Impacto Orçamentário...”, p. 23).

${ }^{486}$ No Dilema do Prisioneiro, está em jogo a conquista da liberdade entre dois prisioneiros. A vitória (liberdade) é conquistada se um prisioneiro trair o outro, delatando-o, sem que haja ação recíproca, com o que aquele que não delatou perde (e é condenado a 5 anos de reclusão). Se ambos os prisioneiros atuarem em conjunto (assumindo ambos a responsabilidade), apesar de não conquistarem a liberdade, receberão uma pena branda (6 meses de reclusão); se eles atuarem competitivamente (ou seja, os dois delatam), a pena de ambos será mais severa (10 anos de reclusão). O dilema é: atuará o prisioneiro cooperando com seu colega ou se arriscará o traindo (e esperando a cooperação desse outro prisioneiro) em busca do melhor resultado? Ver, a propósito, Stanford Encyclopedia of Philosophy, disponível em: <http://plato.stanford.edu/entries/pris oner-dilemma/>, acesso em 19.12.2010, 19:11h.
} 
nessa hipótese, muitos seriam prejudicados, e mesmo quem saiu na frente correria riscos de não obter o quanto postulou, porque os bens disponíveis não bastam a todos. É o que, ainda no campo da Teoria dos Jogos e do Dilema apresentado, convencionou-se chamar de $A$ Tragédia dos Comuns $^{487}$. Na cena atual brasileira e com a série de medidas judiciais individuais pleiteando o acesso a políticas de saúde, aplica-se a Tragédia dos Comuns, ou seja, recebe quem chega primeiro, até o limite ou a exaustão dos recursos coletivos disponíveis. Acabando os recursos, todos perdem. Cada qual atua individualmente, sem se preocupar com a ação dos demais jogadores (como se, para o Dilema, fosse o prisioneiro traidor), muitos deles, inclusive, assumindo o risco de sua atuação inviabilizar as vantagens (ou, no caso examinado, o direito à saúde) dos demais. Quando os jurisdicionados agem individualmente, o risco orçamentário é potencializado justamente em função da limitação dos recursos ${ }^{488}$.

Parece instintiva a limitação à judicialização da política imposta pela cláusula da reserva do possível. Todavia, há quem defenda que ela não constitui este óbice ora desenhado, e grande parte desse pensamento deriva da forma inábil como o Estado ventila esse argumento em sede de exceção. Fundamentalmente, a doutrina da inaplicabilidade da reserva do possível aos direitos prestacionais - notadamente, a saúde possui três ordens de fundamentos.

O primeiro e mais respeitável é aquele que sustenta não haver limitação de recursos para os direitos fundamentais. Sendo os direitos fundamentais expressão máxima dos bens a que cada indivíduo faz jus, e incluindo-se como fundamentais direitos que têm que ser prestados pelo Estado, então o orçamento e as finanças públicas devem necessariamente prever a contemplação desses direitos pela população, sob pena de tornar letra vazia as conquistas que, depois de muita luta, vieram encartadas na Constituição sob a forma de direitos, o que significaria verdadeiro retrocesso em termos de direitos fundamentais sociais. Seria mais ou menos uma questão de prioridades na aplicação de recursos: os direitos fundamentais deveriam ser, sempre, prioritários, e partindo do pressuposto que há gastos estatais, diga-se assim, supérfluos, as receitas deveriam ser

\footnotetext{
${ }^{487} \mathrm{Na}$ Tragédia dos Comuns, empregada para a análise estratégica de casos que envolvam muitos jogadores - como, precisamente, a busca do Judiciário para a concessão de medicamentos - os jogadores preferem usar os recursos comuns aos seus próprios - ou, na formulação original, os pastos comuns. Se os pastos comuns se exaurissem, este seria o sinal de que o limite dos recursos disponíveis fora ultrapassado. Stanford Encyclopedia... Terminologia análoga é empregada por CALABRESI e BOBBIT, em Tragic Choices... Transportando-se ao caso da saúde, tem-se que existe uma irresistível vontade em cada qual agir em seu próprio prol, consumindo desordenadamente as reservas financeiras do Estado, sendo que, no extremo, tais reservas seriam extintas.

${ }^{488}$ CARVALHO, "O Impacto orçamentário...", pp. 23-26.
} 
realocadas dessas rubricas não tão relevantes para aquelas que constituiriam um dos próprios fins do Estado, o bem-estar de todos. Em suma, a inclusão dos direitos sociais como fundamentais ${ }^{489}$ levaria à bancarrota o argumento da reserva do possível ${ }^{490}$.

O segundo argumento é que a lei orçamentária não é vinculativa, vale dizer, é possível a realocação de recursos sem que isso, de per si, viole a Constituição. Ademais, sempre as leis orçamentárias prevêem a possibilidade de abertura de Créditos Suplementares, Especiais e Extraordinários, espécies do gênero Créditos Adicionais, que a lei que regulamenta a feitura de orçamentos e balanços estabelece como aqueles destinados a cobrir despesas não computadas ou insuficientemente dotadas na lei do orçamento ${ }^{491}$. Com isso, seria possível sempre cobrir a ordenação de despesas ainda que não previstas no orçamento público - bastaria a criação de um Crédito Especial para cobrir a despesa ${ }^{492}$. A ideia, basicamente, é a de que sempre existe uma reserva, um local de onde extrair os recursos necessários para pagar determinada conta.

O terceiro argumento é que a reserva do possível é uma exceção de natureza econômica, com o que sobrepô-la aos direitos fundamentais como a saúde, que são categorias jurídicas, seria um grande erro.

Quanto ao primeiro argumento pela inaplicabilidade da cláusula, não é incomum, em um país como o Brasil, que ele seja extremamente sedutor, a par de absolutamente técnico. Com efeito, aqui, onde a quantidade de denúncias de malversação de recursos públicos e corrupção nos altos escalões governamentais ${ }^{493}$ não coloca em dúvida a forma como os dinheiros públicos vêm sendo aplicados, ou, basicamente, o fato

\footnotetext{
${ }^{489}$ Ver, nesse sentido, ALEXY, pp. 499/511; PIOVESAN, Flávia. Temas de Direitos Humanos. São Paulo: Max Limonad, 1998. Reflexo dessa posição se encontra em BISSI, Rythielle de Medeiros ("Reserva do Possível: Instrumento Inconstitucional Mitigador dos Direitos Fundamentais Sociais". Revista Olhar Científico - Faculdades Associadas de Ariquemes, v. 1, n 1, jan/jul 2010), de onde se tira, na p. 81, que, "Não se pode admitir hoje, o retrocesso social, pois seria deixar no esquecimento anos de lutas pela igualdade, pelo reconhecimento da condição humana e dos direitos a ela inerentes, escapando ao poder público e ao legislador a responsabilidade social e admitindo a liberdade de escolha nas decisões, ainda que claramente desrespeitassem a vontade do Constituinte originário no Estado Democrático de Direito." Sobre o problema da discussão a respeito da categorização dos direitos sociais como fundamentais, ver TORRES, Ricardo Lobo (“O Mínimo Existencial, os Direitos Sociais e os Desafios de Natureza Orçamentária”, em Direitos Fundamentais..., pp. 69-74), para quem os direitos sociais não são fundamentais, mas meramente aqueles que compõem o mínimo existencial.

${ }^{490}$ É o entendimento do Min. Celso de MELLO na já mencionada ADPF n ${ }^{\circ} 45$.

${ }^{491}$ Artigo 40 da Lei $n^{\circ}$ 4.320/64. Segundo o artigo 41 do diploma em questão, os créditos podem ser: a) Suplementares, quando destinados ao reforço de uma dotação já existente; b) Especiais, quando a dotação não foi prevista no orçamento; e c) Extraordinários, para cobrir despesas urgentes e imprevistas, como guerras, comoções intestinas e calamidades públicas. Mais sobre este tema está exposto no Item 2.3.2.

${ }_{492}$ Cf. artigo 41, II da Lei $n^{\circ} 4.320 / 64$.

${ }^{493}$ Apenas a titulo ilustrativo é a reportagem de capa de Veja edição 2.182 (ano 43, no 37 - 15.7.2010) que revela denúncia de direcionamento em licitações por obra de funcionários do alto escalão da Casa Civil da Presidência da República.
} 
de aparentemente inexistir sentido lógico para o mesmo Estado que corrompe alegar não possuir recursos para implementar direitos fundamentais, autêntico venire contra factum proprium $^{494}$. Mas é preciso que o calor que envolve o tema não obscureça a clareza de algumas ponderações que se fazem necessárias.

A reserva do possível, frise-se preliminarmente, não implica retrocesso, e assim alegar é desconhecer o uso adequado desta exceção. A própria proibição de retrocesso, conceito fundamental em matéria de direitos humanos, revela que as leis e a sociedades não podem infirmar, suprimir ou restringir direitos fundamentais, normalmente frutos de significativa conquista ${ }^{495}$. É aqui que entra o já estudado argumento do encarcerado. De fato, a escassez não serve para tolher direitos, mas para racionalizar sua entrega. O significado prático da reserva do possível, que possui reflexos jurídicos, é a impossibilidade de alocação forçada de uma despesa não prevista em prejuízo de uma determinada rubrica já planejada. Ao "puxar o cobertor”, a decisão judicial poderá deixar desatendidos direitos, eventualmente, frutos de luta muito maior e mais heroica do que aqueles que a decisão veio atender. Dessa forma, a inobservância dos limites orçamentários consubstanciada na cláusula da reserva do possível teria catastrófico e, assim, indesejável efeito reverso de implicar retrocesso de uma série de direitos fundamentais, a pretexto do atendimento a outros. A decisão judicial que pensa no orçamento, sob esse viés, não é somente permitida: ela é necessária, justamente porque visa a preservar a incolumidade de direitos já contemplados no orçamento ${ }^{496}$. Retrocesso é acreditar fazer um bem, reconhecendo e tomando providências para o cumprimento de dado direito, ignorando que tal providência prejudicará o outro.

Existe mais um aspecto que legitima o debate da reserva do possível quanto a direitos fundamentais. Refere-se à universalidade. Por excelência e como sua característica inerente, os direitos fundamentais - que são igualmente qualificados como direitos humanos - são universais, isto é, devem ser distribuídos uti universi, ou seja, toda

\footnotetext{
${ }^{494}$ A teoria do non venire contra factum proprium (ou proibição ao comportamento contraditório) é uma das modernas teorias aplicáveis no âmbito das relações civis e integra o restrito rol daqueles rótulos que se propõem a estudar o comportamento das partes e, a partir deles, criar, derrogar ou modificar obrigações. A respeito do assunto, ver SCHREIBER, Anderson. A Proibição do Comportamento Contraditório: Tutela da confiança e venire contra factum proprium. Rio de Janeiro: Renovar, 2005.

495 CANOTILHO fala em proibição de retrocesso do núcleo essencial dos direitos humanos. CANOTILHO, José Joaquim Gomes. Dignidade da Pessoa Humana e Direitos Fundamentais na Constituição Federal de 1988. Porto Alegre: Livraria do Advogado, 2001, p. 81.

${ }^{496}$ É com o que também concorda SALLES. Para ele, “(...) medidas judiciais de intervenção em entidades públicas mostram-se juridicamente viáveis, desde que respeitem os limites da clausura orçamentária e não substituam o Executivo naquelas funções que lhes são próprias, relacionadas à vontade política do Estado." (Execução Judicial..., p. 296).
} 
a coletividade humana pode exercer essa espécie de direitos, que devem ser promovidos e protegidos nacional e internacionalmente ${ }^{497}$. Já se viu, na análise do artigo 196 da Constituição, que o direito à saúde tem positivada sua característica de universalidade, assim como a igualdade e a equidade ${ }^{498}$. Da mesma forma estatui o artigo $7^{\circ}$ da Lei $\mathrm{n}^{\mathrm{o}} 8.080 / 90$, a Lei do SUS, o artigo 15 da Lei $\mathrm{n}^{\circ}$ 10.741/03, o Estatuto do Idoso, o artigo $3^{\circ}$, II da Lei Complementar $n^{\circ} 141 / 12$ e os diplomas internacionais que tratam da matéria ${ }^{499}$. A já tratada universalidade, como característica ínsita aos direitos humanos fundamentais e, assim, ao direito à saúde, voltará à tona mais profundamente nos capítulos adiantes, oportunidade em que se estudará o efeito das ações individuais que buscam a tutela jurídica da saúde. Por enquanto, o que basta saber é que o direito à saúde, tanto quanto os demais direitos humanos fundamentais, é universal, não podendo o Estado ou os particulares tolherem quem quer que seja da fruição desses direitos.

No que toca especificamente às políticas exercidas na área da saúde, há outra exigência imposta pela norma que dá à reserva do possível importância de primeira grandeza no trato da distribuição de bens nessa seara: é a obrigação de acesso igualitário às ações e serviços para a promoção da saúde, além da proteção e recuperação dos pacientes. A junção do dever de igualdade com a característica de universalidade revela que, para a norma constitucional, a distribuição estatal da saúde no Brasil necessita, tanto quanto possível, ser realizada para todos, e igualmente. É evidente que, como já observado anteriormente, cada indivíduo possui suas próprias características, o que, em tema de saúde, é aviltante. Por isso que, aqui, essa igualdade é material, consubstanciada na proibição de privilégios para alguns em detrimento dos demais ${ }^{500}$. Este pensamento, afinal,

${ }^{497}$ WEIS, Direitos Humanos..., pp. 113-114. Importante revelar a posição de BOBBIO no sentido de que a universalidade só ocorre quanto aos direitos de liberdades negativas, e não os sociais (p. 116). RAWLS incorpora em sua teoria a ideia da universalidade ao tratar da distribuição equitativa e a todos de bens primários (bens básicos para qualquer pessoa independentemente de seus anseios pessoais), dentre os quais, além das liberdades básicas (como a liberdade de expressão e de religião), inclui-se a saúde (Theory of Justice...), ideia que é bem explicada em Justice as Fairness: a Restatement (2001, edited by Erin Kelly, Harvard College). Segundo ele, diante das desigualdades sociais, dois princípios de justiça devem ser observados. O primeiro, a que RAWLS outorga mais importância do que o segundo, é resumido na seguinte proposição: "cada pessoa tem o mesmo direito irrevogável a um esquema plenamente adequado de liberdades básicas iguais que seja compatível com o mesmo esquema de liberdade para todos.", o que traz, em si, a noção de universalidade quanto ao que ele denomina como liberdades básicas (p. 60). Mais sobre a Teoria está em 5.1.1.

498 Consenso na doutrina especializada. Nesse sentido, ver SANTANA, José Lima. "O princípio constitucional da eficiência e o Sistema Único de Saúde (SUS)”, em Direito à Vida e à Saúde ..., pp. 42/59.

499 Além da Carta das Nações deixar clara a adoção universal dos direitos humanos, o artigo 12, $d$ do PIDESC estabelece o dever dos Estados signatários - dentre os quais, o Brasil - assegurarem a todos (ou seja, universalmente) assistência médica em caso de necessidade.

${ }^{500}$ A igualdade não é uma característica que a doutrina reputa inerente aos direitos humanos: ela é um próprio direito humano, sendo, destarte, de alcance desejável, sobretudo quanto às ações exercidas pelo Estado. Sobre a promoção da igualdade, ver PIOVESAN, Flávia e SATO, Priscila Kei. "Implementação do 
é tão importante que chega a estar positivado no artigo $7^{\circ}$, IV, da Lei $n^{\circ} 8.080 / 90-$ como se viu, a Lei Orgânica do Sistema Único de Saúde ${ }^{501}$.

Partindo, pois, do instintivo pressuposto de que o orçamento - antes, as reservas financeiras públicas são limitadas -, como conciliar o atendimento igualitário e universal das demandas sociais com a limitação de ordem material que se impõe? A resposta para a qual se encaminha o raciocínio mais apropriado é a de que os dois assuntos são inconciliáveis. Com efeito, o fato de o orçamento ser limitado impede que todas as demandas sejam atendidas como determina a Constituição em seu artigo 196. Sempre faltará recurso para que aquele determinado cidadão goze plenamente de seu direito à saúde, tanto ele quanto seu compatriota, seja seu amigo, vizinho ou morador de alguma região longínqua dentro do território nacional. De fato, "nunca haverá ocasião em que esses direitos serão completamente protegidos ${ }^{, 502}$. Sob o ponto de vista dos direitos fundamentais - dentre os quais se inclui o direto à saúde -, destarte, a discussão a respeito da reserva do possível é mandatória.

Isso não quer dizer, é necessário referendar, que a concessão de saúde pelo Poder Público seja mera promessa utópica, inconsequente, abstrata e incapaz de ser concretizada $^{503}$; significa, muito ao contrário, que devem ser adotados mecanismos que tenham o condão de fazer a melhor saúde chegar ao maior número possível de cidadãos. $\mathrm{O}$ sistema é claro ao imputar ao Estado a obrigatoriedade de dispensar atendimento universal e igualitário, curativo e preventivo, e seria perniciosa idiossincrasia estatal usar da potencial impossibilidade fática de atendimento a todos nos mesmos moldes para se imiscuir de seu inalienável dever.

Quanto à ideia de que a lei orçamentária não é vinculativa e, por isso, é possível a realocação de recursos para cobrir as despesas judiciais, ela é falsa. A existência da previsão de Créditos Adicionais na lei não justifica a fática e material limitação de recursos. A própria Lei $n^{\circ}$ 4.320/64 estabelece textualmente, no artigo 43, que a abertura

Direito à Igualdade", em Temas de Direitos Humanos..., pp. 191/196, aqui, com ênfase às ações afirmativas em políticas raciais.

${ }^{501}$ Segundo o Min. Gilmar MENDES, “O princípio do acesso igualitário e universal reforça a responsabilidade solidária dos entes da federação, garantindo, inclusive, a igualdade da assistência à saúde, sem preconceitos ou privilégios de qualquer espécie' (art. 7º IV, da Lei 8.080/90).” (STA n 278/AL, j. em 22 de outubro de 2008).

502 SUSTEIN e HOLMES (The Cost of Rights..., p. 119), dizendo que o fato de todo e qualquer direito ter custo os torna open-ended, ou seja, sempre haverá algum espaço em que eles não serão protegidos.

${ }^{503}$ FERRAZ chama atenção ao mesmo paradoxo, criticando aqueles que entendem que, porque a saúde deve ser integral e prestada isonomicamente a todos, havendo escassez, então ocorreria paradoxo intransponível que transformaria da norma constitucional promessa frustrada. Sobre os riscos dessa perniciosa interpretação para o SUS como ele é hoje, abordando a questão judicial, ver "De quem é o SUS?" (FERRAZ, Octávio Luiz da Motta, em Folha de São Paulo, edição de 20.12.2007, p. A3). 
de créditos suplementares e especiais depende da existência de recursos disponíveis para ocorrer a despesa e será precedida de exposição justificativa, o que, depois, foi elevado ao grau constitucional pelo artigo $166, \mathrm{~V}$ da Constituição. O alcance dessa restrição é ainda maior do que a mera leitura da lei ordinária pode parecer. Por recursos disponíveis se entendem apenas aqueles decorrentes de: (a) superávit financeiro do exercício anterior; (b) excesso de arrecadação; (c) anulação de dotações orçamentárias existentes ou créditos especiais; e (d) o produto de operações de crédito autorizadas. Todas essas rubricas podem ser enquadradas como créditos inesperados, caso se assuma que todos eles derivam de situações que geram lucro para o Estado. Então, basicamente, créditos suplementares e especiais só serão abertos se houver recursos disponíveis, entendidos tais como os advindos de alguma situação em que o Estado obteve lucro ${ }^{504}$. Claramente essa determinação, além de, como mencionado, ser mais restritiva do que parece - porque não é todo e qualquer recurso que dá origem a um crédito adicional, mas somente aquele fruto de receitas inesperadas - revela a importância da reserva do possível.

Mesmo a lei que estabelece o modo de feitura das leis orçamentárias estabelece a interdependência entre Créditos Adicionais e recursos disponíveis. Evidentemente que, diante de uma demanda imprevista de saúde em determinado exercício, poderia o Estado abrir Crédito Especial para seu respectivo atendimento, desde que havendo recursos disponíveis. Mas esse fato nada tem a ver com a potencial inaplicabilidade da exceção da reserva do financeiramente possível; ao contrário, a análise ora realizada só demonstra que o orçamento continua limitado 505 .

No que toca, enfim, à terceira exceção, apregoando ser a reserva do possível uma questão econômica, não jurídica, a falha fulminante desta teoria é que ela não considera que o suporte fático da reserva do possível é o orçamento público, ou as reservas detidas pelo Estado, coisas que, de resto, também são jurídicas. Ora, a Constituição define o ente competente e a forma como serão elaborados os orçamentos públicos ${ }^{506}$. As normas infraconstitucionais estabelecem como deve ser realizado o orçamento ${ }^{507}$. Por fim, anualmente, normas são editadas em todas as esferas federativas dispondo sobre o orçamento $^{508}$. Há faculdades de Direito que possuem a cadeira de Direito Financeiro ${ }^{509}$, ou,

\footnotetext{
${ }^{504} \mathrm{~V}$. Itens 2.3 .2 e 2.3.4.

${ }^{505} \mathrm{~V}$. Itens 2.3.2. e 2.3.4.

${ }^{506}$ Artigos 24, II; 48, II; 74, I; 84, XXIII; 100, §5º 165, III, 166, dentre outros, da Constituição.

${ }^{507}$ A já mencionada Lei no $4.320 / 64$.

${ }^{508}$ Como é o caso do Titulo V da Constituição do Estado de São Paulo e da Seção II, Capítulo VI, Titulo IV da Lei Orgânica do Município de São Paulo.

${ }^{509}$ Como a Faculdade de Direito da Universidade do Estado do Rio de Janeiro.
} 
então, Direito Econômico ${ }^{510}$. Como, então, considerar a questão do orçamento e seu aspecto, a reserva do possível, como temas não jurídicos? A necessidade de disciplina imperativa e de disposição regulamentar sobre como lidar com os dinheiros públicos torna máxime de dúvidas a necessidade de juridicidade do orçamento. Ademais, se todos os direitos possuem custos, é óbvio que a questão econômico-financeira deve ser objeto de exame nas atribuições de direitos. Nesse sentido, o argumento falha em sua essência, e remonta mais ao entendimento de Laband já tratado no item apropriado ${ }^{511}$.

Apesar dos contrapontos levantados por aqueles que defendem a impossibilidade de dedução da cláusula da reserva do possível pelo Estado em sede de defesa em ações judiciais que intervêm em políticas públicas de saúde, as limitações fáticas ou técnicas dos recursos são realidades que não podem ser, simplesmente, ignoradas em qualquer debate a respeito da distribuição de bens sociais. A impressão que o Estado é superavitário e que, por mais que existam limitações momentâneas, dinheiro surgirá de forma a fazer frente às despesas impostas pelo Judiciário - porque, afinal, o Estado "não pode falir" - acaba contaminando a correta percepção a respeito dos apertados recursos públicos. A tradição de imputar ao Estado o dever da realização de algumas ações que, na verdade, poderiam perfeitamente ser buscadas pelos indivíduos ou pela sociedade civil organizada é parte do mito da não limitação dos recursos ${ }^{512}$. Este pensamento, contudo, é falacioso.

A saúde, no Brasil, como todo e qualquer direito fundamental, encontra, sim, limitação pelos escassos recursos ${ }^{513}$. Um Estado que não possua recursos não é capaz de assegurar direitos, porque direitos têm custos. Se garantir o direito de propriedade é um dos objetivos do Estado, ele tem que investir em segurança pública; se outro objetivo é inscrever todas as crianças em creches e escolas primárias, investimento haverá nessa área, também; se, por sua vez, é o direito de autor de obra intelectual que é objeto de tutela, da mesma forma essa proteção demandará atuação estatal. A dimensão dos custos que determinado direito acarretará às contas públicas deriva diretamente das decisões adotadas

\footnotetext{
${ }^{510}$ Como a Faculdade de Direito da Universidade de São Paulo.

${ }^{511} \mathrm{~V}$. Item 2.3.1.

${ }^{512}$ LOPES ("Em torno da...", p. 178).

${ }^{513}$ Ver o artigo de FERRAZ, Octávio Luiz da Motta, e VIEIRA, Fabiola Sulpino. "Direito à Saúde, Políticas Públicas e Desigualdades Sociais no Brasil: Equidade como princípio fundamental”, trabalho apresentado na Faculdade de Direito da Universidade de São Paulo em 2007 e submetido à revista Dados em maio de 2008. Segundo os autores, em conclusão desse estudo que considera e avalia dados empiricamente obtidos, "Procuramos demonstrar, nesse trabalho interdisciplinar, que uma interpretação adequada do direito à saúde deve estar centrada no princípio da eqüidade, entendido como igualdade de acesso a serviços e ações de saúde necessariamente limitados por recursos escassos." Há outras conclusões que derivam desse raciocínio, ligadas à individualização de direitos universais e que serão abordadas no momento oportuno.
} 
pelo legislador ou, muitas vezes, pelo juiz. Nesse sentido, mesmo a decisão em Roe v. Wade $^{514}$, um dos mais importantes casos da Suprema Corte norte-americana cuja discussão, em síntese, envolvia a temática do aborto em um caso individual, gerou grande debate a respeito do alcance da decisão, i.e., se o Estado seria obrigado a custear serviços médicos especializados nessa seara, inclusive com acompanhamento psicológico, coisa que só foi dirimida depois, em Maber v. Roe $e^{515}$, em que a Suprema Corte determinou que a decisão primitiva não obrigava o Estado a elevar seus custos na área, porque o que ela assegurava era o direito de exercício, pela gestante, do direito de abortar, passando, dali para frente, a arcar com os ônus de sua escolha. No final, o debate teve como ponto fundamental, e que não foi deixado de lado pela Corte, a questão dos custos ${ }^{516}$.

$\mathrm{Na}$ verdade, o limite imposto pelo orçamento é inescapável e a decisão judicial que não considera a escassez de recursos (ou a reserva do possível) - quando ela efetivamente existe, frise-se - chega a ser irresponsável. Como já asseverado, a leviana crença do Estado superpoderoso e infalível (no sentido econômico-financeiro) acaba fazendo com que, sobretudo os juízes - que lidam com o dia-a-dia da distribuição de recursos, embora desconheçam os orçamentos públicos -, não levem em conta as limitações do orçamento, o que, além de perigoso quando há recursos (porque implicam realocações forçadas dos recursos, deixando a descoberto tantos outros direitos), revela-se inútil quando eles não existem ${ }^{517}$.

Para se referendar tal conclusão, imagine-se o que poderia fazer o juiz para superar a limitação fática dos recursos estatais. Pense-se no juiz que, no caso concreto, ordena ao Estado que promova determinado tratamento médico, em que pese, na verdade e estando devidamente provado, padecer o ente estatal, naquele caso, de falta de recursos suficientes para cumprir a decisão. Volta-se à indagação: como seria capar de atuar o magistrado nessa hipótese? Poderia ele determinar ao Estado que criasse uma fonte de

\footnotetext{
514410 U.S. 113 (1973).

515432 U.S. $464,474$.

${ }^{516}$ SUSTEIN e HOLMES, The Cost of Rights..., pp. 35-36.

${ }^{517}$ A decisão judicial não pode ser vã. Decisão meramente declaratória, quando a providência postulada não é essa, é inútil e se revela anti-econômica, porque movimentou a máquina judicial, além dos advogados e partes envolvidas, tudo permeado por custos.

GALDINO (Introdução à Teoria...), como epíteto de seu estudo, revela sua intenção de criticar aqueles que insistem em ignorar a realidade, pugnando pelo cumprimento de direitos irrealizáveis (p. 345). LOPES ("Em torno...") estabelece uma interessante correspondência entre a impossibilidade de condenar o Estado a entregar determinado bem a um postulante por conta da falta de recursos e a obrigação impossível, instituto clássico de direito civil que estabelece ser ela nula, como nulo é o objeto juridicamente impossível (Código Civil, artigo 104, II): não havendo recursos a custear a obrigação, ela é inexigível, porquanto impossível (pp. 178-182).
} 
receita para cobrir aquela específica despesa? A resposta parece ser negativa, e, isso, por diversos motivos.

O juiz não poderia determinar a criação de uma fonte de receita além daquelas já previstas na Constituição ou, quando o caso, nas leis. Nem mesmo o legislador pode apresentar um simples projeto de lei sem, antes, expor os motivos e detalhes a respeito de seu custeio e respectivas fontes. Também o administrador é obrigado a seguir tais ditames ${ }^{518}$. Não parece haver outra solução para a obtenção de recursos quando eles não existem senão com a instituição de um tributo, que, no caso, somente poderia ser uma contribuição social ${ }^{519}$. Acontece que somente lei, e lei complementar, pode criar essa espécie tributária, de acordo com expressa regra estabelecida no artigo $195, \S^{\circ}$ da Constituição ${ }^{520}$. O juiz não pode agir assim. Ao mesmo tempo em que a Lei Maior obriga ao Estado a distribuição de bens públicos, ela determina o modo e a forma como serão criados os tributos. Esses modo e forma não incluem, definitivamente, a decisão judicial.

Alguém poderia argumentar que, havendo conflitos entre normas constitucionais, a questão deveria ser resolvida casuisticamente, sendo que haveria a prevalência ao atendimento do mínimo existencial, já que ele toca à manutenção da vida digna. Assim, a decisão poderia estabelecer a criação de tributo. O argumento é interessante, mas equivocado. É que ao mesmo tempo em que ao indivíduo é garantido o mínimo existencial, a ele é assegurado não ser desapropriado ${ }^{521}$ de seu patrimônio sem a observância de inúmeras garantias. A tributação - pagamento compulsório ao Estado embasado na ocorrência de um fato gerador cuja hipótese de incidência está na lei ou na Constituição - é uma forma de ingerência na propriedade. Ninguém duvida que uma tributação além do limite razoável configura violação brutal ao direito de propriedade dos indivíduos. A Constituição chama isso de confisco, e o veda terminantemente, este que se

\footnotetext{
518 A Lei Complementar $n^{\circ}$ 101/2000 (Lei de Responsabilidade Fiscal) determina, em seu artigo 16, que qualquer ação governamental que acarrete aumento de despesa seja obrigatoriamente justificada. Também a Lei de Diretrizes Orçamentárias de 2012, no artigo 88, estabeleceu que qualquer projeto de lei que implicasse diminuição de receita ou aumento de despesa da União devia estar acompanhado de estimativa dos efeitos respectivos no exercício em que entrar em vigor e nos dois subsequentes, detalhando a memória de cálculo e correspondente compensação, para fins de adequação orçamentária e financeira e compatibilidade constitucional e legal.

${ }^{519}$ Nenhuma das outras espécies tributárias - impostos, taxas, contribuições de melhoria, de intervenção no domínio econômico, parafiscais e empréstimos compulsórios - possuem natureza jurídica apta a afetar os recursos obtidos com sua arrecadação a determinada despesa - como a saúde, por exemplo. Somente contribuições sociais têm esse viés. Tome-se o caso, por exemplo, da extinta CPMF (Contribuição Provisória sobre Movimentação Financeira), a que a Constituição expressamente destinava as receitas arrecadadas à saúde (Cf. artigo 74, par. $3^{\circ}$ do ADCT).

${ }^{520}$ Que remete à restrição do artigo 154, I da Carta, a determinar que impostos que não aqueles constitucionalmente previstos só poderão ser adotados mediante Lei Complementar.

${ }^{521}$ Expressão empregada não no sentido jurídico, mas geral.
} 
constitui princípio geral de Direito Tributário ${ }^{522}$ - também, e porque não, um direito fundamental $^{523}$. Ademais, soaria absurdo outorgar ao magistrado a capacidade legislativa tributária, um acinte que não pode sobreviver nem nas mentes mais criativas.

Jamais poderia o juiz determinar a criação de tributos para cobrir despesas que ultrapassem os limites dos recursos disponíveis, principalmente porque a coletividade tem o direito a uma apropriação moderada de seus bens para custear o Estado, não podendo ser arbitrariamente tolhida desse direito que, por proteger a propriedade, é, tanto quanto o direito à saúde, fundamental. A solução do problema da insuficiência de recursos não se resolve com a criação de mais fontes de receita; ela se resolve, em parte, definitivamente, com uma correta e eficiente alocação dos recursos disponíveis.

Que a reserva do possível é um limite à distribuição judicial de saúde parece razoável, e certamente muitos administradores públicos respiram aliviados quando a academia se pronuncia nesse sentido. Evidentemente, a contrapartida é extremamente alta. Sem dúvida, a escassez de recursos e a possibilidade, destarte, de arguição da reserva do possível como defesa responsável trazem aos gestores públicos, ao menos, dois deveres, o primeiro, de ordem processual, o segundo, relacionado ao próprio modo de ser da administração de recursos públicos: o primeiro condiz, como mencionado no parágrafo antecedente, com o dever do Estado de estruturar muito bem e provar sua alegação de inexistência de recursos públicos (o que, no fundo, envolve verdadeira prestação responsável de contas, autêntico accountability); o segundo, com o dever dos gestores de aplicar, da maneira mais eficiente possível, os recursos que estão à sua disposição.

O que não é razoável, como exposto no início deste tópico, é a alegação lacônica, destituída de provas e, assim, irresponsável de insuficiência de recursos, como se esta defesa fosse uma verdadeira negativa geral do Estado ${ }^{524}$. Já adverte Ada que o Estado, quando alega em defesa a reserva do possível, deve provar que seus recursos são

${ }^{522}$ Artigo 150, IV da Constituição. Sobre a vedação ao confisco, ver CARRAZZA, Roque Antonio. Curso de Direito Constitucional Tributário. $19^{\mathrm{a}}$ ed. São Paulo: Malheiros, 2003, p. 89.

${ }_{523}$ Analisando o problema dos gastos com saúde dos Estados Unidos, DWORKIN indica que eles são absolutamente irracionais. Assumindo que se as próprias pessoas custeassem seus dispêndios médicos elas procurariam economizar e, daí, gastar menos, o mesmo não ocorre quando alguém a elas banca a mesma providência (na hipótese analisada, os seguros-saúde e o Estado, que concedia incentivos fiscais aos valores pagos a tal título). Segundo o filósofo, a irracionalidade advinha do fato de que o sistema realizava escolhas para as pessoas que elas mesmas não fariam se tivessem poder para tanto, o que aumentava a despesa que, depois, seria cobrada dessas mesmas pessoas (Sovereign Virtue..., pp. 310-311). A multiplicidade de medidas judicias tratando de saúde também tem esse efeito, porque ao dar para alguns - os que propuseram ações - a sociedade inteira será impactada, e aqueles que não se valeram dos processos poderão nem receber a contrapartida que lhes é constitucionalmente devida.

${ }^{524}$ A defesa por negativa geral é exclusiva do curador especial (nomeado em caso de revelia), do advogado dativo e do representante do Ministério Público, figuras que não se submetem ao ônus da impugnação especificada dos fatos (artigo 302, Par. único do CPC). 
insuficientes, isso por aplicação do artigo $6^{\circ}$, VIII do CDC e da doutrina da carga dinâmica da prova, que ensina que as rígidas distribuições de ônus da prova devem ser reorientadas de forma a onerar com a produção da prova aquela parte que tem mais condições para tanto ${ }^{525}$. Com razão a professora, embora pareça que a questão se resolva na aplicação da regra ordinária de distribuição dos ônus da prova, preconizada no artigo 333 do CPC: com efeito, quando o Estado contesta alegando insuficiência de recursos, ele impõe um fato impeditivo da pretensão do autor. Se o jurisdicionado busca a obtenção de um medicamento com base em seu constitucional direito de obter saúde, o Estado responde alegando que não possui recursos para atendimento àquela demanda específica, ou seja, impõe um impedimento à pretensão do autor. Verdade é que, seja por um prisma (inversão ou carga dinâmica do onus probandi) ou por outro (aplicação da regra ordinária de distribuição do ônus da prova), o resultado é análogo: à Administração Pública, em defesa, compete não somente argumentar detalhadamente que não possui recursos para cumprimento do que requer o autor (de per si ou em substituição processual), mas, também, deve provar a circunstância ${ }^{526}$.

Ora, mas a prova da insuficiência de recursos parece ser extremamente técnica, muito mais complexa do que mera conta aritmética simples. A dificuldade de produção da prova, contudo, não exonera o Estado desse seu ônus. Na verdade, ele, Estado, deve estar estruturado para ter tamanho controle de suas contas e gastos que comprovar a insuficiência de recursos em juízo seja tarefa não tão complicada. E não basta que o Estado leve aos autos números e mais números, documentos e mais documentos, e confie toda a análise a uma prova técnica que haveria por vir. É preciso algo mais: não somente que o ente estatal oferte ao juízo informações inteligíveis, mas, também que os magistrados tenham formação e sejam especialistas em questões do orçamento, já que eles que lidarão com o tema e serão aqueles que, no fim, decidirão pela condenação ou não do Estado na obrigação postulada.

Além dos aspectos processuais que calham ao tema, também a alegação vazia de insuficiência de recursos significa absoluto e reprovável desprezo ao dever de transparência da Administração Pública. Com efeito, o jurisdicionado e todos aqueles que

\footnotetext{
${ }^{525}$ GRINOVER, “O Controle...", p. 20.

${ }^{526}$ Assim também pensa o Supremo Tribunal Federal, mencionando-se as já referidas ADPF no 45 e a STA n ${ }^{\circ}$ 278-6, Rel. Min. Gilmar MENDES (j. em 22.10.2008), esta, com assunto que envolvia o custeio, pelo Estado do Alagoas, do medicamento Mebthera (Rituximabe), para tratamento de leucemia. $\mathrm{O}$ tratamento estava orçado em cento e sessenta e dois mil, setecentos e sete reais e um dos motivos pelos quais foi indeferido o pedido do Estado do Alagoas foi o fato de ele não ter comprovado a alegada lesão à ordem econômica oriunda da decisão que pretendia ver suspensa.
} 
tiverem acesso aos autos (e, claro, às alegações e contra-alegações) têm o direito de saber como o Estado está gastando os dinheiros públicos e, nesse sentido, toda a maneira de revelar dados correspondentes a esse direito é verdadeira obrigação do Estado, débito indelével que o Poder Público tem com o seu contribuinte. Se não houver comprovação do saldo zero ou insuficiente em suas reservas, de maneira clara e cabal, a exceção da reserva do possível não poderá ser admitida pelo magistrado.

Outro efeito da escassez e que condiz não apenas com a intervenção judicial nas políticas públicas é considerar o dever do administrador de alocar recursos da maneira mais eficiente possível. Se existe um núcleo de direitos que são inerentes à própria condição e moderna concepção de humanidade, se o Estado é incumbindo constitucional e internacionalmente de implementar esse núcleo, e, ainda, considerando que esses direitos têm custos, esse mesmo Estado deve administrar seus escassos recursos da melhor maneira possível, a fim de compreender o maior número de direitos e abranger a maior quantidade de pessoas. A alocação de recursos deve ser, sobretudo, eficiente, cobrindo o maior número de sujeitos e direitos, com prestações de qualidade ${ }^{527}$, o que só é possível após extensa e profícua análise das diversas opções disponíveis em termos de prestações e recursos (o que, evidentemente, demanda planos, programas e planejamento $)^{528}$. Por isso, a alocação eficiente também está sujeita a controle jurisdicional: se ela não for eficaz (i.e., é adquirido um medicamento de alto custo para tratar moléstia cujo tratamento análogo pode ser conduzido por um medicamento mais barato) então haverá a possibilidade de intervenção, porque aí terá ocorrido falha ${ }^{529}$.

Se a reserva do possível é um limitador ao controle jurisdicional de políticas públicas, inclusiva na seara da saúde, essa área, a propósito, é pródiga em fornecer exemplos de como é necessário que outro parâmetro seja observado: o mínimo existencial.

\footnotetext{
${ }^{527}$ Eficiência que é princípio da Administração Pública, de acordo com o caput do artigo 37 da Constituição.

${ }^{528}$ Eis o porque, como discutido, o Poder Judiciário não pode ser entendido como o mais eficiente ator a distribuir bens objetos de políticas públicas.

${ }^{529}$ Ana Paula de BARCELLOS elege quatro espécies de controle jurisdicional sobre políticas públicas: (a) controle de fixação de metas e prioridades e do resultado final esperado das políticas públicas; (b) controle da quantidade de recursos a ser investida; (c) controle de alcance ou não das metas fixadas pelo Poder Público; e (d) controle de eficiência mínima na aplicação de recursos públicos. É este último aspecto que toma peculiar relevância quando se fala nas limitações impostas pela reserva do possível ("Constitucionalização das políticas públicas em matéria de direitos fundamentais: o controle político-social e o controle jurídico no espaço democrático", em Direitos Fundamentais..., pp. 128-138).
} 


\subsubsection{Mínimo existencial}

A ideia do mínimo existencial foi cunhada, de novo, na Alemanha do Segundo Pós-Guerra, precisamente no âmbito da mesma dialética que envolveu a reserva do possível. Atribui-se a Otto Bachof, no início da Década de 1950, a conceituação a respeito do dever do Estado em estabelecer as garantias necessárias à existência digna do indivíduo. O suporte jurídico desse conceito era encontrado no artigo $1^{\circ}$, inciso I da Lei Fundamental da Alemanha, que estabelecia o princípio da dignidade da pessoa humana. Bachof entendeu que uma vida digna não seria observada apenas com a garantia de liberdade e não intervenção do Estado na vida privada, mas, também, com a aplicação de recursos materiais por parte do Poder Público. Um ano após tal formulação, o Tribunal Constitucional Alemão julgou caso concreto que culminou no entendimento de que sujeito fazia jus a auxílio material por parte do Estado, para a ele propiciar a manutenção de suas condições de existência ${ }^{530}$. De lá para cá, o Tribunal Constitucional Alemão tem referendado o entendimento aposto no paradigma ${ }^{531}$, e a doutrina tedesca outorga ao mínimo existencial o status de essência do Estado Social de Direito, objetivo precípuo a ser almejado $^{532}$. O mínimo existencial, assim, pode ser conceituado como um núcleo intangível de direitos assegurados pelo Estado, necessários para o exercício da vida humana digna ${ }^{533}$.

\footnotetext{
${ }^{530}$ SARLET, Ingo Wolfgang; FIGUEIREDO, Mariana Filchtiner. "Reserva do possível, mínimo existencial e direito à saúde: algumas aproximações", em SARLET, Ingo W. e TIMM, Luciano B. (org.). Direitos Fundamentais, Orçamento e `Reserva do Possível', Porto Alegre: Livraria do Advogado Editora, 2008, pp. 19-20. O paradigma mencionado é a decisão em BVerwGE 1, 159 (161 e ss.), de 24 de junho de 1954. O artigo $1^{\circ}$, I da Lei Fundamental Alemã consagra textualmente o dever do Estado de respeitar a dignidade da pessoa humana. Sobre a dignidade da pessoa humana, inclusive com análise comparada, ver extensa e rica nota de rodapé (nota 375) de PIOVESAN e VIEIRA (“A Força Normativa...” pp. 359-360).

${ }^{531}$ BVerfGE 78, 104. É importante, neste contexto, pontuar o que ALEXY teoriza a respeito da jurisprudência do Tribunal Constitucional Alemão e o mínimo existencial (Teoria..., pp. 435-440). Para ele, existem três paradigmas que devem ser anotados: a decisão de 1951 sobre assistência social; a primeira decisão sobre numerus clausus e a decisão a respeito do ensino superior integrado na Baixa Saxônia. Assinala ALEXY que a decisão de 1951 foi, concomitantemente, cautelosa e ambígua, porque ao mesmo tempo em que o Tribunal interpretou que o artigo $1^{\circ}, \S 1^{\circ}$ da Lei Fundamental Alemã não garantia o direito do indivíduo a ter um auxílio material automático por parte do Estado, ele outorgava ao sujeito, em caso de omissão estatal, uma pretensão por serviços que assegurassem uma vida digna (BVerfGE 1, 97 - 104-105). Apenas em 1975 o Tribunal se posicionou claramente no sentido de que a assistência aos necessitados é um claro dever do Estado Social, e que "a comunidade estatal tem que lhes garantir no mínimo as condições para uma existência humana digna" (BVerfGE 40, 121 - 133).

${ }_{533}^{532}$ SARLET e FIGUEIREDO, "Reserva do possível...", p. 20.

${ }^{533}$ V. GRINOVER (“O Controle...", p. 15). ALEXY fala em um programa minimalista de direitos fundamentais, que objetiva conferir ao indivíduo o domínio de um espaço vital e de um status social mínimos (Teoria..., p. 502).
} 
O mínimo existencial se configura relevante dentro do contexto das escolhas à disposição dos gestores públicos e, claro, do juiz ${ }^{534}$. Essas escolhas podem dar-se dentre diversos direitos disponíveis (i.e., entre prover ao sujeito o que vestir ou o que comer, em que e como trabalhar ou em que se educar) ou dentro de um mesmo direito (o sujeito se satisfaz com arroz tipo A ou tipo B, na mesma medida). Como visto, políticas públicas envolvem escolhas. A oportunidade de poder escolher é que confere ao mínimo existencial a relevância que se pretende a ele atribuir nesta tese. É o mínimo existencial a compor o núcleo fundamental do argumento do encarcerado já estudado ${ }^{535}$ : é porque os presos já se encontram em condições deploráveis que qualquer tentativa em reaplicar verbas que garantem seu sustento, ainda que para alimentação dos mais nobres propósitos, como a educação, deveria ser negada.

Uma primeira, instintiva inquirição condiz com a demarcação do conteúdo do rol de direitos que compõem o mínimo existencial. Evidentemente que a pergunta é pertinente, haja vista o cunho aberto ou conceitual que envolve o nome mínimo existencial, sendo ela, inclusive, importante para definir como o mínimo existencial pode servir de baliza para o juiz ao decidir a respeito de políticas públicas, sobretudo no que toca à saúde.

Mas é preciso que, antes, seja colocado limite à discussão. É necessário definir o que é mínimo, sem dúvida, mas não se pretende alongar o debate para, por exemplo, assumir que os atributos necessários para que determinada pessoa viva dignamente variem de indivíduo para indivíduo, tempo para tempo, local para local, condição para condição. Questões econômicas, bélicas e catastróficas, de maneira geral, podem frustrar qualquer tentativa preliminar de definir um mínimo existencial abstrato. Hoje o mínimo direito à vida digna é entendido como a prerrogativa de qualquer um de bem se alimentar (dentre tantos outros aspectos); amanhã, diante de escassez mundial de alimentos, a alimentação digna se amoldará às novas circunstâncias fáticas. Hoje a mínima

\footnotetext{
${ }^{534}$ Não por acaso que o APLPP prevê, no projetado artigo $6^{\circ}$, a possibilidade de antecipação de tutela se o pedido envolver mínimo existencial "(...) assegurado em norma constitucional de forma perfeita $e$ acabada". Kazuo WATANABE, um dos pródigos idealizadores do projeto, cita o direito dos maiores de sessenta e cinco anos de transporte gratuito nos meios coletivos urbanos (art. 230, $\$ 2^{\circ}$ da CF). A partir do exemplo é fácil apreender que sempre que a Constituição não dê margem à grandes questões de interpretação sobre o conteúdo de direitos essenciais, o magistrado poderá conceder o direito de forma precária. A mesma coisa ocorre, por paralelo, com o mandamento do art. $2^{\circ}$ da Lei $n^{\circ} 12.732 / 2012$, que ordena que o SUS providencie o primeiro tratamento ao portador de neoplasia maligna em até sessenta dias contados da data em que o diagnóstico for apurado em laudo patológico, ou com a Lei $\mathrm{n}^{\circ}$ 11.347/06, que estabelece o dever do Poder Público de fornecer gratuitamente fármacos para tratamento de diabetes. Nesses casos, fica difícil tolher o juiz de, havendo paciente diagnosticado, não ordenar seu tratamento no prazo e na forma cristalinamente estabelecidos pelas normas legais.

${ }^{535} \mathrm{~V}$. Item 4.2.3.
} 
saúde envolve internação em quarto de hospital público; amanhã, feridos em combate, catástrofe ou por conta de uma situação de guerra terão de ser atendidos em corredores hospitalares, tendas ou campos abertos.

Destarte, é extremamente delicada a tarefa de compor um núcleo duro do mínimo existencial, integrado por direitos que, objetivamente, deveriam figurar no rol daqueles que são imprescindíveis à vida digna. O exame do mínimo existencial, assim, é inegavelmente casuístico: usá-lo como limite objetivo às intervenções jurisdicionais em políticas públicas serve para que fique clara a ideia de que não integrarão o núcleo desses direitos as prestações que excedam aquelas estritamente necessárias para que o sujeito de direitos possa viver dignamente ${ }^{536}$.

Mas fato é que, não obstante o casuísmo, é induvidoso que, em situações normais, o mínimo existencial é ponto de partida. Não fosse assim, a ONU não poderia estabelecer um patamar básico dos direitos humanos que ela considera universais - e, sem dúvida, mesmo para o mais selvagem cidadão ocidental, a mutilação de órgãos e partes do corpo observadas em certos países seria censurada, repelida e exemplarmente punida. Então, ainda que impossível definir preliminar e abstratamente em que consista o mínimo existencial, há, claramente, standards que norteiam a proteção conferida pelos ordenamentos jurídicos. E é inequívoco que nesses standards figura o direito à saúde mas não a toda e qualquer saúde: à saúde essencial ${ }^{537}$.

\footnotetext{
${ }^{536}$ Daí se desconfiar da definição apriorística do conteúdo do mínimo existencial, concordando, contudo, que exista um contemporâneo ponto de partida em situações normais. Mas ligar o mínimo existencial à vida digna apresenta dificuldades - precisamente porque ao atrelar o mínimo ao subjetivo conceito de dignidade, qualificando a simples vida, importa assumir que, para certas comunidades, educação fará parte do piso, mas, para outras, a cultura será mais importante. À vida digna do livre-docente, por exemplo, pode importar mais o desporto que a educação. O mínimo existencial, em função de sua variabilidade de local para local, pessoas para pessoas, culturas para culturas, deve ser composto por aqueles bens que, para a pessoa, consistam no piso para sua vida digna. - embora aqueles direitos relacionados às básicas necessidades do indivíduo - pelo menos, saúde e alimentação básicas - esses, sim, sejam invariáveis. Mas esses dois direitos - saúde e alimentação básicas - não estão, simplesmente, ligados ao direito à vida sem a qualidade de ser ela digna? Para Ricardo Lobo TORRES, o mínimo existencial remete à noção de direitos ostentados por um indivíduo que lhe assegurem o pleno exercício da liberdade (Os Direitos Humanos e a Tributação: imunidades e isonomia. Rio de Janeiro: Renovar, 1998, pp. 128-129). Ana Paula de BARCELLOS aponta o mínimo integrado por educação fundamental, saúde básica, assistência em caso de necessidade e acesso à justiça ( $A$ eficácia jurídica dos princípios constitucionais. Rio de Janeiro: Renovar, 2002, p. 305). Luís Roberto BARROSO aposta no tripé saúde, educação e moradia, imprescindíveis à subsistência física e ao desfrute de outros direitos (Curso de Direito Constitucional Contemporâneo. São Paulo: Saraiva, 2009, p. 253). Então, e para os fins a que se propõe este estudo, se existe definição a priori dos direitos componentes do mínimo existencial, invariavelmente, a saúde está dentre eles.

537 ALEXY entende que a moradia simples, a educação fundamental, média e profissionalizante e um patamar mínimo de assistência médica conformam o núcleo do mínimo existencial (Teoria..., p. 512). Ricardo Lobo TORRES equipara, de certo modo, o mínimo existencial aos direitos fundamentais sociais ("O mínimo existencial...," p. 86).
} 
O uso do adjetivo induvidoso no parágrafo anterior não é à toa. Parece clara a importância que a saúde tem para o jurisdicionado. Ninguém que se coloca em situação de necessidade quanto a uma terapia ou tratamento está tranquilo, sobretudo se sabedor da existência de meios para tanto que deveriam ser providos pelo Estado ${ }^{538}$. A vida doente é perturbadora, e isso é induvidoso. Daí a saúde essencial - e só a essencial - figurar em todo e qualquer proposição de conteúdo de mínimo existencial ${ }^{539}$.

No que toca à saúde, o estabelecimento do que é mínimo pode não sofrer tantas variações quanto outras espécies de direitos assegurados por ações políticas estatais. Para o camponês que mora na fria região Sul do Brasil, o direito ao vestuário mínimo é diferente daquele que contempla o caboclo da região Centro-oeste, em que o clima normalmente é quente. Da mesma forma, o lazer de quem vive em uma metrópole como São Paulo é diverso do que pretende quem mora em uma pequena cidade no interior. No caso da saúde não é exatamente assim. É certo que há doenças típicas do clima tropical úmido do Norte, e outras mais restritas ao Sul. Afora essas, as moléstias e problemas possuem dinâmica operacional muito semelhante, ainda que diferentes os sujeitos. Se determinada pessoa sofre de acidente vascular encefálico no Sul, outra pessoa acometida pela mesma doença no Norte, dentro de uma mesma faixa etária, será tratada de maneira semelhante. Não há, assim, tantas indefinições na dispensação do conteúdo que goza o direito à saúde dentro do conceito de mínimo existencial.

Mas é claro que pode haver técnicas mais avançadas que outras já existentes no combate e prevenção de doenças. Há vacinas neonatais ministradas em clínicas particulares que, a despeito de prevenirem as mesmas moléstias dessa fase - como diarreia, difteria, coqueluche, pneumonia, tétano -, possuem menor incidência de reação do que aquelas prestadas pelo SUS, porque usam vírus mortos ou são acelulares, qualidade não presentes na rede pública. É fácil, aí, notar que o mínimo condiz com as vacinas dispensadas nos postos de saúde, já que a eficácia da imunização é semelhante.

É verdade que o conceito de mínimo existencial surgiu para marcar deveres do Estado, como obrigações e prestações a que ele, Estado, estava afetado a prover ao indivíduo para que este pudesse usufruir, na plenitude, de uma vida digna. No caso da intervenção jurisdicional em políticas públicas e os parâmetros dessa jurisdicionalidade,

\footnotetext{
${ }^{538}$ A OMS empresta à saúde a característica de mantença da paz e da segurança (Constituição da OMS, 1946, preâmbulo, item $c$ ).

${ }^{539}$ De fato, com o que, de maneira geral, concorda-se é que a saúde integra o núcleo do mínimo existencial. $\mathrm{Na}$ doutrina, observe-se SARLET ('Reserva do Possível..., pp. 38-53); no Judiciário, ver STJ, REsp $\mathrm{n}^{\mathrm{o}}$ 1.185.474/SC. $2^{\mathrm{a}}$ T. Rel. Min. Humberto MARTINS, j. em 20.4.2010.
} 
essa abordagem pode mudar de matiz e, assim, constituir um referencial confiável ao controle jurisdicional de políticas públicas. Explique-se.

$\mathrm{Na}$ origem, o mínimo existencial era visto a partir do Estado para o indivíduo, ou seja, consistia núcleo de direitos que o Poder Público tinha que proteger, lançando mão dos meios para tanto. Para os fins desta tese, o que se propõe é a visão do mínimo existencial a partir do indivíduo para o Estado, ou seja, em tema de bens sociais medicamentos, inclusive - só deve ser dispensado ao jurisdicionado aquilo que é minimamente necessário para garantir a dignidade de sua vida. É o que se pode chamar de visão bifronte ou negativa do mínimo existencial: ao postulante só pode ser entregue o estritamente suficiente para que se atinjam os resultados por ele pretendidos. Nenhum excesso ou, mais didaticamente, luxo deverá ser judicialmente provido ${ }^{540}$. O Diagrama III demonstra a dicotomia entre os dois conceitos.

\section{DIAGRAMA III}

Visão brifonte ou negativa do mínimo existencial

\begin{tabular}{|c|c|c|}
\hline $\begin{array}{l}\text { Mínimo Existencial } \\
\text { (Visão positiva) }\end{array}$ & obriga & \multirow{2}{*}{ ESTADO } \\
\hline & & \\
\hline \multirow{2}{*}{$\begin{array}{l}\text { Mínimo Existencial } \\
\text { (Visão negativa) }\end{array}$} & limita & \multirow{2}{*}{$\begin{array}{c}\text { INDIVÍDUO } \\
\text { ou GRUPO }\end{array}$} \\
\hline & & \\
\hline
\end{tabular}

Vê-se que enquanto o mínimo existencial consiste no núcleo duro de direitos que o Estado é obrigado a prover ao indivíduo, também o indivíduo não pode pedir além do necessário a sua vida digna, limitando-se ao mínimo existencial. É a visão negativa, ou bifronte do conceito.

\footnotetext{
${ }^{540}$ Pode parecer um contrassenso usar o mínimo existencial não como garantidor, mas como baliza a direitos. Mas esse contrassenso é apenas aparente: falar neste tema dentro do contexto ora apresentado serve, na verdade, para assegurar direitos. Com efeito, se o que o juiz prover ao postulante for o mínimo para garantir sua vida com dignidade, mais seguramente ele estará realizando justiça distributiva, aplicando racionalmente critérios que levem, tanto quanto possível, à equidade na distribuição de saúde. O mínimo existencial bifronte, frise-se, não é negar a existência ou a relevância do instituto, mas, sim, conceituar didaticamente o parâmetro que deve ser observado pelos magistrados em sua nobre e dificultosa tarefa de entregar saúde aos jurisdicionados. De fato, nenhum excesso ou, mais didaticamente, luxo deverá ser judicialmente provido.
} 
O mínimo existencial sob o viés negativo serve para limitar as ambições do indivíduo, garantindo-lhe um piso para sua vivência digna (e, assim, negando aquilo que ultrapasse esse piso), ao mesmo tempo em que orienta o magistrado quando confrontado com tal situação. A observância do mínimo existencial em seu cunho bifronte impede que o juiz, por exemplo, forneça o tratamento mais custoso que está referido na inicial, havendo à disposição terapia análoga e comprovadamente menos onerosa aos cofres públicos. A ideia de mínimo existencial sob o espeque negativo está intimamente ligada, assim, à necessária eficiência na alocação de recursos e ao respeito à universalidade e igualdade que caracterizam os direitos fundamentais, notadamente o direito à saúde.

Quando se assume que o jurisdicionado tem o direito à postulação do que é mínimo para garantir a dignidade de sua vida, assume-se que o Estado gastará o mínimo possível para assegurar o serviço a que faz jus o postulante. Considerando-se a limitação do orçamento a que já se fez alusão e os altos custos dos direitos, sobretudo os sociais, a aplicação dos mínimos recursos possíveis significa, em um cenário ideal e em contrapartida, mais dinheiro para a cobertura de outras demandas, ou, em outras palavras, para a garantia de demais direitos. Gastar menos, assegurando o mínimo, enseja possibilidade racional de aplicação mais eficiente de recursos, ou obtenção dos melhores resultados, considerando a equação custo-benefício.

No momento em que o juiz provê ao jurisdicionado o que é o mínimo, ele também auxilia uma distribuição mais igualitária e universal dos bens sociais. Se todos os que procuram o Judiciário para que ele atue na omissão dos Poderes majoritários obtiverem o mínimo necessário para a dignidade de sua vida, haverá critério objetivo de distribuição de direitos, ou seja, será dispensado tratamento isonômico aos jurisdicionados. Ademais, diante de suas limitações, o Estado não pode ser obrigado a atender aos pleitos de toda e qualquer ordem, não obstante estar constitucionalmente obrigado a prestar certa gama de direitos. O mínimo existencial bifronte, assim, constitui um parâmetro mais justo e seguro para a observância do juiz no trato de sua intervenção em políticas públicas.

Destarte, nenhum magistrado deve levar em consideração o mínimo existencial apenas como conceito apto a condenar o Estado, mas, também, como limitador aos auspícios do indivíduo por direitos além da conta.

Daí se tem a importância da atividade investigativa do juiz, que deve conhecer, por exemplo, quais são os medicamentos e tratamentos disponibilizados pelo SUS, priorizando-se sua distribuição. Se os medicamentos e terapias não estiverem nas listas públicas, será necessário inquirir se o remédio postulado é o único que cumpre o 
tratamento da moléstia que reclama o autor e, não sendo, qual seria o mais econômico. É claro que o mínimo existencial não pode ser um cheque em branco para que o juiz, a todo o custo, outorgue ao postulante o medicamento e a terapia mais baratos, senão os mais eficazes, ou seja, devem tratar o doente de maneira eficiente, com o menor custo.

A cláusula do mínimo existencial pode implicar, à primeira vista, uma contradição em termos com as limitações atinentes à reserva do financeiramente possível. Ora, ao mesmo tempo em que ao indivíduo é assegurado o direito à obtenção de um núcleo mínimo, um piso de direitos, tudo com vistas à conservação de uma vida humana digna, como garantir que a totalidade de pessoas obterá esses direitos básicos se o Erário padece de limitações? É dizer, como assegurar que a totalidade de pessoas possuirá atendimento digno em hospitais e postos de saúde, além de acesso aos medicamentos que necessita, sem que isso conflite com as restrições de natureza orçamentária?

A contradição não sobrevive ao fato de que o cenário real revela a escassez de bens e a infinidade de necessidades. Quanto mais demandas forem atendidas de maneira enxuta (ou seja, dispensado o, como já colocado, luxo), mais recursos restarão para cobrir outras demandas. A observância do mínimo existencial revela uma gestão mais inteligente dos recursos públicos - independentemente do ator a determinar despesa.

Note-se que apesar de ambos - mínimo existencial e reserva do possível servirem como parâmetros à atividade do juiz como interventor em políticas públicas, é preciso examinar o momento em que eles se entrechocam na análise judiciária. Diante de caso em que o indivíduo postula o mínimo para sua existência com dignidade e, mesmo assim, o Estado não possui recursos, como deveria o magistrado se portar?

Há posições que defendem que o mínimo existencial não se submete à limitação da reserva do financeiramente possível. Para Ricardo Lobo Torres, o mínimo existencial independe, sequer, de maiores conjeturas legislativas para ser provido, porque os direitos nele encetados emanam da própria Constituição, o que por si somente garantiria sua pronta judicialização. Nesse sentido, a exceção orçamentária não seria oponível aos direitos integrantes da família do mínimo existencial ${ }^{541}$. Da mesma forma se colocou o Ministro Celso de Mello na ADPF $n^{\circ} 45^{542}$, que já ecoou no $\mathrm{STJ}^{543}$.

${ }^{541}$ LOBO TORRES, “O Mínimo Existencial...”, pp. 80-84. Nesse sentido, ver entendimento do Ministro
Celso de MELLO na PET n $1.246-1 /$ SC. Para ele, o interesse financeiro do Estado perece diante dos direitos
sociais fundamentais. O caso específico envolvia pedido de tratamento da postulante em uma clínica norte-
americana no valor de cento e sessenta e três mil dólares.
542 Verdade seja dita, o Min. Celso de MELLO também se posicionou no sentido de que as limitações de
recursos são contingências reais e o intérprete da norma jamais poderá ignorá-las. Segundo ele, essa
limitação deverá ser levada em conta sempre que algum bem exigível do Estado possa sê-lo judicialmente 
Existem, em contrapartida, aqueles que defendem que a reserva do financeiramente possível sempre será oponível, inclusive para direitos integrantes do mínimo existencial. Sustentam que não há como superar a fática barreira da insuficiência de recursos, e que a inobservância dos limites dos recursos disponíveis pode levar a decisões inexequíveis, justamente pela ausência desses recursos ${ }^{544}$. Esta posição é bastante interessante e, por isso, aqui se deve realizar uma pequena digressão a respeito da escassez que advém de escolhas do administrador e a escassez oriunda da real e efetiva insuficiência de recursos.

Que os recursos são parcos é cediço: eles serão sempre limitados. Existe essa escassez, diga-se, natural, ligada à insuficiência de meios aptos a cobrir todas as

(AgReg no RE no 410.715-SP, $2^{\mathrm{a}}$ T, DJU em 03.02.06). É o reconhecimento de que a reserva do possível constitui, sim, certo limite à prestação jurisdicional de bens fornecidos pelo Estado.

543 “CRECHE. RESERVA DO POSSÍVEL. TESE ABSTRATA. A tese da reserva do possível (Der Vorbehalt des Möglichen) assenta-se na idéia romana de que a obrigação impossível não pode ser exigida (impossibilium nulla obligatio est). Por tal motivo, não se considera a insuficiência de recursos orçamentários como mera falácia. Todavia, observa-se que a reserva do possível está vinculada à escassez, que pode ser compreendida como desigualdade. Bens escassos não podem ser usufruídos por todos e, justamente por isso, sua distribuição faz-se mediante regras que pressupõem o direito igual ao bem e a impossibilidade do uso igual e simultâneo. Essa escassez, muitas vezes, é resultado de escolha, de decisão: quando não há recursos suficientes, a decisão do administrador de investir em determinada área implica escassez de outra que não foi contemplada. Por esse motivo, em um primeiro momento, a reserva do possível não pode ser oposta à efetivação dos direitos fundamentais, já que não cabe ao administrador público preteri-la, visto que não é opção do governante, não é resultado de juízo discricionário, nem pode ser encarada como tema que depende unicamente da vontade política. Nem mesmo a vontade da maioria pode tratar tais direitos como secundários. Isso porque a democracia é, além dessa vontade, a realização dos direitos fundamentais. Portanto, aqueles direitos que estão intimamente ligados à dignidade humana não podem ser limitados em razão da escassez, quando ela é fruto das escolhas do administrador. Não é por outra razão que se afirma não ser a reserva do possível oponível à realização do mínimo existencial. Seu conteúdo, que não se resume ao mínimo vital, abrange também as condições socioculturais que assegurem ao indivíduo um mínimo de inserção na vida social. Sendo assim, não fica difícil perceber que, entre os direitos considerados prioritários, encontra-se o direito à educação. No espaço público (no qual todos são, in abstrato, iguais e cuja diferenciação dá-se mais em razão da capacidade para a ação e discurso do que em virtude de atributos biológicos), local em que são travadas as relações comerciais, profissionais e trabalhistas, além de exercida a cidadania, a ausência de educação, de conhecimento, em regra, relega o indivíduo a posições subalternas, torna-o dependente das forças físicas para continuar a sobreviver, ainda assim, em condições precárias. Eis a razão pela qual os arts. 227 da CF/1988 e $4^{o}$ da Lei n. 8.069/1990 dispõem que a educação deve ser tratada pelo Estado com absoluta prioridade. No mesmo sentido, o art. 54, $I V$, do ECA prescreve que é dever do Estado assegurar às crianças de zero a seis anos de idade o atendimento em creche e pré-escola. Portanto, na hipótese, o pleito do MP encontra respaldo legal e jurisprudencial. Porém é preciso ressalvar a hipótese de que, mesmo com a alocação dos recursos no atendimento do mínimo existencial, persista a carência orçamentária para atender a todas as demandas. Nesse caso, a escassez não seria fruto da escolha de atividades não prioritárias, mas sim da real insuficiência orçamentária. Em situações limítrofes como essa, não há como o Poder Judiciário imiscuir-se nos planos governamentais, pois eles, dentro do que é possível, estão de acordo com a CF/1988, não havendo omissão injustificável. Todavia, a real insuficiência de recursos deve ser demonstrada pelo Poder Público, não sendo admitido que a tese seja utilizada como uma desculpa genérica para a omissão estatal no campo da efetivação dos direitos fundamentais, principalmente os de cunho social. Dessarte, no caso dos autos, em que não há essa demonstração, impõe-se negar provimento ao especial do município. Precedentes citados do STF: AgRg no RE 410.715-SP, DJ 3/2/2006; do STJ: REsp 1.041.197-MS, DJe 16/9/2009; REsp 764.085-PR, DJe 10/12/2009, e REsp 511.645-SP, DJe 27/8/2009." REsp 1.185.474-SC, Rel. Min. Humberto MARTINS, julgado em 20.4.2010.

${ }^{544}$ GALDINO, Introdução à Teoria..., pp. 345-349. 
necessidades humanas ${ }^{545}$. A escassez, todavia, também pode ser artificial, oriunda de escolhas realizadas por aquele que é o responsável pela alocação de recursos. Diante das inúmeras opções (antes, necessidades) que se impõem, o administrador escolhe por atender uma ou umas delas, deixando outras desamparadas, aplicando o dinheiro para a execução de suas escolhas. É preciso diferenciar essas situações. Sim, porque se a violação a direito integrante do mínimo existencial é originada da omissão administrativa motivada por escolhas discricionárias, então a reserva do possível não pode se contrapor à efetivação desse direito, vale dizer, não se deverá evocar a insuficiência de recursos quando ela provier de decisão administrativa.

Este entendimento é derivado de uma construção lógica bastante simples: se a Constituição estabelece a dignidade de cada um e de todas as pessoas humanas como meta a ser atingida pelo Estado e estando essa dignidade assegurada pela observância de um núcleo mínimo de direitos, todos os recursos devem ser prioritariamente voltados para a outorga desses direitos às pessoas. É dizer, o administrador está vinculado ao cumprimento do comando constitucional, ou seja, ele não goza de irrestrito espaço para tecer um juízo de conveniência e oportunidade para escolher em que posto aplicar os recursos públicos. Se exerceu escolha e tornou mais escasso o recurso para o atendimento, por exemplo, da mínima demanda de saúde, então o recurso terá que ser devolvido para cobrir essa necessidade. É nesse sentido que deve atuar o juiz, mas sempre assegurando o mínimo ao jurisdicionado ${ }^{546}$.

Assim, e lastreado nas lições antes apresentadas, quando for fática a limitação financeira, o mínimo existencial sucumbirá à reserva daquilo que for possível; quando, contudo, a limitação for jurídica, o mínimo existencial haverá de prevalecer em regra, salvo circunstâncias em que o Poder Público efetivamente demonstrar que aquela omissão atacada pelo jurisdicionado não decorreu de escolhas desconsideradoras dos direitos fundamentais.

Solução outra deverá ser tomada pelo juiz quando comprovadamente inexistirem recursos de quaisquer ordens para o atendimento da demanda, ainda que relacionada a direitos integrantes do mínimo existencial. Todos os direitos têm custos.

\footnotetext{
${ }^{545}$ Como o caso da escassez de água já mencionado.

${ }^{546} \mathrm{O}$ importante arrazoado do Min. Humberto MARTINS em recurso especial que tratava de pedido de acesso à creche a menores de zero a seis anos no município de Criciúma faz um objetivo apanhado sobre a espinhosa inter-relação entre mínimo existencial e a reserva do possível. Segundo o magistrado, não pode ser oposta a exceção da reserva do possível quando, por escolha do administrador, os direitos ligados ao mínimo existencial (como a educação, no exemplo do acórdão) forem preteridos. Ele ressalva que quando a escassez não se originar do processo de escolhas políticas, no entanto, não há como o Judiciário intervir nos planos e programas do Executivo (REsp n ${ }^{\circ}$ 1.185.474-SC, $2^{\mathrm{a}} \mathrm{T}$, j. em 20.4.2010).
} 
Inexistindo meio fático de custeá-los, o Estado não poderá provê-los, nem mesmo a saúde. O mínimo existencial, nesse contexto, demanda atendimento prioritário, vale dizer, dentre todos os direitos garantidos pelo Estado, primeiramente devem ser providos aqueles que constituem o piso para a fruição de uma vida digna.

O mínimo existencial de viés negativo é baliza para o juiz dispensar políticas públicas. Isso não significa, contudo, que a pretexto do atendimento ao mínimo existencial o juiz deva passar impunemente por sobre as limitações fáticas do orçamento. Evidentemente que este não é o panorama ideal, em que cada qual teria acesso completo aos bens necessários para sua existência digna. Mas, de novo e como advertido no item anterior, esta não é uma questão de criação de novas fontes de custeio, e, sim, de aplicação mais eficiente daqueles recursos já existentes.

$\mathrm{Na}$ verdade, se os magistrados seguirem o parâmetro do mínimo existencial em todos os casos, aproximando-se, assim e como observado, de uma distribuição de saúde mais universal e igualitária, proibindo-se, logo, os excessos por parte do jurisdicionado, possivelmente haverá mais recursos financeiros para cobrir a demanda.

É preciso esclarecer que não se quer defender, neste estudo, que a reserva do possível é aplicável em todas as situações e que, por isso, deverá a decisão judicial sempre contemplar o medicamento ou terapia menos custosa aos cofres públicos. Como já explicado, só haverá idoneidade na defesa da reserva do possível quando, de fato e comprovadamente, inexistirem ou forem insuficientes os recursos para o atendimento à demanda do jurisdicionado, e se a medida pleiteada for dissonante com a outra eleita pelo Poder Público como passível de entrega. Em todas as outras situações, o mínimo existencial deverá prevalecer, assegurando-se ao indivíduo a fruição de sua vida com dignidade.

E igualmente necessário entender ser falaciosa a conclusão de que o mínimo é sempre o mais barato. Na verdade, o que é mínimo é, de um lado, o que é menos custoso ao Erário e, de outro, o quanto efetivamente necessário à vida digna do cidadão. Pode ser que um medicamento de altíssimo custo constitua o mínimo existencial do demandante. Pode ser que um caríssimo transplante signifique o atendimento ao piso de saúde da pessoa. O mínimo existencial bifronte, é bom que se frise, não limita o juiz de forma a que ele negue todo e qualquer tratamento de alto custo. Ele serve, somente, para evitar excessos na provisão jurisdicional de políticas públicas - notadamente, de saúde.

Agora o debate está maduro para que se lancem algumas luzes sobre as inquirições que deve o magistrado tecer quando se deparar com um pedido judicial de 
fornecimento de certo medicamento ou terapia. Assumindo, como proposto, que o mínimo existencial constitui limite à intervenção judicial em políticas públicas e considerando os fundamentos dessa conclusão, seguem estas proposições: (a) o juiz deve sempre inquirir se a postulação se amolda ao conceito de mínimo existencial, sob seu viés negativo, ou seja, da perspectiva do que o indivíduo realmente necessita do Estado e dele faz jus; (b) havendo duas formas de medicamento ou terapia para o tratamento da mesma demanda, o juiz deve optar pela menos custosa ao Erário, desde que sua segurança e eficácia sejam equivalentes. Nesse sentido, as listas de dispensação obrigatória de medicamentos são importante suporte ao magistrado, porque elas gozam de presunção relativa de incluir em seu bojo medicamentos e tratamentos mais seguros e eficazes; (c) o juiz precisará analisar casuisticamente o que pode ser considerado como saúde básica, evitando, assim, prover ao jurisdicionado postulações que exorbitem ao mínimo necessário para sua sobrevivência ${ }^{547}$; e (d) o juiz não poderá deixar de atender à demanda do postulante, ao argumento de inobservância do mínimo existencial, pelo simples e matemático fato da providência postulada ser altamente custosa, caso em que, não havendo alternativa que se conforme como o proposto em (a) e atendidos os demais requisitos e limites, deverá ela ser concedida. Essas linhas-mestras podem ajudar o magistrado a exercer um efetivo controle sobre o mínimo existencial, limitando sua intervenção a um patamar seguro e concorde com a intervenção em questões de políticas públicas.

\subsubsection{Razoabilidade}

A decisão judicial em políticas públicas lida com direitos fundamentais. A gama de vetores que apontam em direção contrária a tal mister faz da respectiva atividade do juiz uma tarefa delicada. De um lado, o jurisdicionado tem direito de obter saúde do Estado; de outro, o Poder Público não pode privilegiar apenas indivíduo ou grupo de pessoas, mas deve atender a todos. A uma, há várias formas e espécies de bens que podem ser providos em atendimento a certo direito, alguns mais interessantes ao jurisdicionado

${ }^{547}$ É comum a propositura de ações que extrapolam o comando constitucional. Luiz Roberto Barradas BARATA, Secretário de Saúde do Estado de São Paulo de 2003 até julho de 2010, esclareceu que, além de medicamentos, o Estado via-se obrigado a entregar aos jurisdicionados iogurte, requeijão cremoso, queijo fresco, adoçante, leite desnatado, mel e, até, xampu ("Regulamentar é o melhor caminho - É positivo que o Estado seja obrigado por decisão judicial a fornecer certos medicamentos", em Folha de São Paulo, p. A2, edição de 17.3.2007). 
que outros; a duas, apenas o mínimo existencial deve ser garantido, diante da escassez e do dever de tratamento igual e universal. As políticas públicas têm em si, ínsitas, conflitos de interesses que se resumem em choques de direitos fundamentais.

O adimplemento estatal da obrigação constitucional de prover saúde possui inúmeras facetas. De fato, existe enorme gama de medicamentos e terapias, de produtos que, por mais variados que sejam, acabam por atender as necessidades alheias. Não é dado ao jurisdicionado, contudo e a pretexto de postular bens estatais a que ele tem direito, requerer a tutela judicial que lhe propicie atender o que é mais conveniente. Deve o postulante, sim, obter o que parece ser mais equilibrado diante das circunstâncias. As duas facetas expostas neste item demandam a observância de mais um paradigma na dotação judicial de bens públicos: a razoabilidade.

A razoabilidade, para os fins a que se propõe este estudo, pode ser entendida e estudada em termos de proporcionalidade. Aristóteles ensinava, de maneira simples e contundente, que a proporcionalidade é um meio termo, no sentido de que, em uma relação bilateral e antagônica, tanto o excesso quanto a falta revelariam injustiça ${ }^{548}$. A proporcionalidade, assim, seria o justo equilíbrio entre os meios empregados e os fins a serem alcançados ${ }^{549}$. O que é proporcional é o que é equilibrado. Razoável é, da mesma forma, o que não é excessivo. Esta é a ideia central, o ponto nevrálgico de toda a doutrina da proporcionalidade - ou, como referido neste subtítulo, da razoabilidade ${ }^{550}$.

A proporcionalidade é princípio conhecido de direito público, notadamente na seara administrativa ${ }^{551}$. Paulo Bonavides defende que a proporcionalidade advém da isonomia, para ele conceito fundante do Estado Democrático de Direito ${ }^{552}$. Isso demonstra

\footnotetext{
548 ARISTÓTELES, Ética a Nicômaco..., pp. 93, 96 e 101. Também Karl LARENZ estabeleceu a relação entre justiça, proporcionalidade e antagonismo de interesses, ou interesses reciprocamente contrapostos (Metodologia da ciência do direito. Lisboa: Fundação Calouste Gulbekian, 1997, p. 63).

549 GRINOVER, Ada Pellegrini. "Princípio da Proporcionalidade. Coisa julgada e justa indenização", em $O$ Processo-Estudos e Pareceres, $2^{\mathrm{a}}$ ed., São Paulo: Editora DPJ, 2009, p. 61.

${ }^{550}$ Chama-se a atenção, aqui, à advertência feita por Ada Pellegrini GRINOVER no sentido de que, embora haja conceituações diferentes entre razoabilidade (que seria gênero do qual a proporcionalidade seria espécie, ou, ainda, seria o aspecto casuístico da abstrata proporcionalidade), o que deve se tirar de ambos os institutos é que eles medem o equilíbrio nas relações entre duas pessoas ou entes ou pessoas e entes ("Princípio da Proporcionalidade...", p. 61). A autora, em artigo que se tornou verdadeiro clássico sobre o tema da intervenção do Judiciário em políticas públicas, resumiu a interação entre proporcionalidade e razoabilidade como sendo a segunda uma medida de aplicação da primeira (“O Controle...”, p. 43).

${ }^{551}$ Luís Roberto BARROSO entendeu, em estudo a respeito da possibilidade de o Estado controlar preços, que a razoabilidade serve como esteio para o controle da discricionariedade legislativa e administrativa ("A Ordem Econômica Constitucional e os Limites à Atuação Estatal no Controle de Preços", em Revista Diálogo Jurídico, Salvador, CAJ - Centro de Atualização Jurídica, no 14, junho/agosto de 2002, p. 21, disponível em: <http://www.direitopublico.com.br>, acesso em 14.8.2013, 14:33h) . O que ora se defende nesta tese é que ela deve nortear também os trabalhos do juiz ao sindicar políticas públicas de saúde.

${ }^{552}$ BONAVIDES, Paulo. Curso de Direito Constitucional, $25^{\text {a }}$ ed. São Paulo: Malheiros, 2010, pp. 396-397.
} 
porque, na ordem jurídica positiva, a proporcionalidade é princípio que orienta toda e qualquer ação dos agentes públicos, como esteira não apenas do mandamento constitucional, mas da expressa previsão normativa ${ }^{553}$. Mesmo a menor ação proveniente de um agente do Estado deve ser proporcional, isso como forma de evitar favorecimentos e arbitrariedades em prejuízo de alguns e benefícios de outros. A proporcionalidade deve ser observada pelos Três Poderes e, assim, serve como parâmetro para a atuação administrativa responsável e constitucionalmente ligada ${ }^{554}$. A gênese da proporcionalidade - como limite aos abusos da Administração - guarda íntima relação com a eleição da razoabilidade como critério que deve obstar eventuais excessos judiciais na intervenção em políticas públicas.

No âmbito dos direitos fundamentais, o justo equilíbrio pode encontrar duas balizas: uma é a proibição do excesso, no sentido de que não serão toleradas medidas que ultrapassem o que é razoável, o que é ponderado; a outra, a vedação à proteção insuficiente, ou seja, a adoção de determinada providência jamais poderá representar o não atingir de um mínimo patamar de proteção conferido pelos direitos fundamentais. São balizas que se situam em dois extremos, no piso (a vedação à proteção insuficiente) e no teto (proibição de excesso). É dentro desta margem que o magistrado deve atuar para realizar a análise da razoabilidade, como, aliás, vem reconhecendo o próprio Supremo Tribunal Federal ${ }^{555}$.

O estudo da proporcionalidade ganhou substância quando os técnicos começaram a tratar da colisão de direitos. Nesse sentido é preciso fazer referência aos estudos de Alexy a respeito dos direitos fundamentais e da Teoria dos Princípios. Esse professor alemão diferencia, em primeiro lugar, regras e princípios. Assim, embora ambos possam ser formulados a partir de expressões deônticas básicas de dever, proibição e permissão, os princípios são normas que ordenam a realização de alguma ação ou omissão

\footnotetext{
${ }^{553}$ Está implícito no caput do artigo 37 da Constituição e é expresso no Artigo $2^{\circ}$ da Lei no 9.784/99. Sobre o assunto, ver BANDEIRA DE MELLO (Curso..., pp. 107-108) e MEIRELLES, Hely Lopes (Direito Administrativo Brasileiro. 32a ed. São Paulo: Malheiros Editores, 2006, pp. 92-94).

${ }^{554}$ A doutrina entende que a proporcionalidade deriva de uma série de comandos constitucionais, dos quais o principal é o devido processo legal substantivo. Nesse sentido, ver CASTRO, Carlos Roberto Siqueira. $O$ Devido Processo Legal e os Princípios da Razoabilidade e da Proporcionalidade. $5^{\mathrm{a}}$ edição. Rio de Janeiro: Forense, 2010, em especial o Capítulo V. Como bem relata o autor, esta linha também foi seguida pelo Supremo Tribunal Federal (MC em ADIN no 1.407/DF, Rel. Min. Sepúlveda PERTENCE, j. em 7.3.1996).

${ }_{555}$ De acordo com o ministro Gilmar MENDES, então Presidente da Corte, "Como tenho analisado em estudos doutrinários, os direitos fundamentais não contêm apenas uma proibição de intervenção (Eingriffsverbote), expressando também um postulado de proteção (Schutzgebote). Haveria, assim, para utilizar uma expressão de Canaris, não apenas uma proibição de excesso (Übermassverbot), mas também uma proibição de proteção insuficiente (Untermassverbot) (Claus-Wilhelm Canaris, Grundrechtswirkungen um Verhältnismässigkeitsprinzip in der richterlichen Anwendung und Fortbildung des Privatsrechts, JuS, 1989, p. 161).” (STA 278-6/AL, j. em 22.10.2008).
} 
da melhor maneira possível, dentro das possibilidades fáticas e jurídicas. Os princípios podem ser observados em sua plenitude - e aí estarão otimizados, ou seja, terão atingido o grau máximo de imperatividade - ou apenas parcialmente. O que se busca na observância de um princípio, contudo, é a plenitude. Por isso Alexy os qualifica como mandados de otimização. Já as regras são normas que devem ser sempre satisfeitas ou não satisfeitas, repercutindo no caso concreto exatamente naquilo que ela contém, nem mais, nem menos $^{556}$.

As regras, dada essa sua característica hermética, conflitam. Se tal sucede, o impasse se resolve pela simples eleição daquela mais apropriada para ser aplicada no caso concreto e o descarte da outra conflitante, seja pela inserção de uma cláusula de exceção ou por meio de uma declaração de invalidade, que redundarão em impossibilidades jurídica e fática. Os princípios não conflitam; eles colidem e, para a solução da celeuma, um dos princípios terá que ceder, sem que, contudo, haja qualquer cláusula de exceção ou declaração de invalidade do princípio cedente. Apenas se elegerá o princípio mais apropriado para o caso diante das circunstâncias, sem exclusão do outro. Se os mesmos princípios colidirem, mas as circunstâncias se alterarem, o princípio que, no primeiro caso, cedeu poderá prevalecer na nova situação. A análise a respeito da colisão entre princípios é, pois, casuística e demanda o que Alexy denomina sopesamento de princípios: tomandose ambos os princípios colidentes - que, abstratamente, estão no mesmo plano - verificase, no caso concreto, qual deles terá maior peso. Não existe uma determinação anterior que determine que certo princípio tenha prevalência sobre outro: a verificação sempre se dará no plano concreto, na análise do caso posto, em que o intérprete - o juiz, em exemplo muito conveniente - verificará qual princípio se sobressai em face de outro ${ }^{557}$. É essa verificação que consiste no sopesamento de princípios.

A doutrina da proporcionalidade estabelece três ordens de indagações para a análise a respeito do equilíbrio de uma determinada medida, ou, de acordo com Alexy, três máximas $^{558}$, e sempre que aquele que decide se colocar diante de um caso concreto, elas devem ser consideradas. Imagine-se determinada demanda pelo custeio estatal de um medicamento e aplique-se a metodologia de Alexy. Primeiro, o juiz deve se perguntar se o meio eleito pelo postulante é adequado para os fins por ele almejados; depois, deve ele procurar saber se aquele provimento é necessário, ou seja, se o jurisdicionado precisa

\footnotetext{
${ }_{556}$ ALEXY, Teoria ..., pp. 85-91.

557 ALEXY, Teoria..., pp. 91-99.

${ }^{558}$ ALEXY, Teoria..., pp. 116-120.
} 
mesmo lançar mão da medida judicial para obter o medicamento procurado. Por fim, o magistrado deve verificar se a solução procurada é proporcional, é dizer, se ela é equilibrada sob o ponto de vista dos interesses antagônicos presentes ${ }^{559}$, coisa que ele fará com o sopesamento de valores. Daí a íntima ligação entre os princípios e a proporcionalidade, aspecto que será abordado mais adiante.

No caso específico da postulação judicial de saúde, adequada para atingir o fim de obter saúde, parece, em primeiro plano, que a medida normalmente será ${ }^{560}$. A adequação, neste caso, decorreria da autorização constitucional outorgada pelo inciso XXXV do artigo $5^{\circ}$. Sempre que se colocar diante de uma situação de necessidade de tutela jurisdicional, o jurisdicionado poderá lançar mão de toda e qualquer medida apta a lhe garantir o acesso do bem da vida buscado. Para o exame da proporcionalidade, contudo, o meio de tutela jurídica pouco importa, pelo menos na análise da adequação ${ }^{561}$.

A análise da necessidade é um pouco mais delicada. Neste caso, é de se inquirir se a medida postulada é, de fato, necessária. No caso da intervenção judicial em políticas públicas a necessidade apresenta faceta muito interessante. Por exemplo, não é necessária a medida judicial que pretenda a entrega de um medicamento que pode ser obtido regularmente nos postos de saúde e hospitais do SUS. Não é igualmente necessário o provimento jurisdicional que determina a internação do jurisdicionado em hospital da rede privada, com o pagamento custeado pelo Estado, quando o hospital público provê a mesma espécie de tratamento. A atividade investigativa do magistrado na análise do que é ou não necessário é um importante paradigma para aferir se a providência pretendida pelo postulante - e, de conseguinte, a eventual decisão judicial que, com ela, deve guardar congruência - é proporcional e razoável.

Talvez o exame a respeito da proporcionalidade em sentido estrito seja o mais delicado dentre todos os paradigmas informativos da proporcionalidade. É na análise desta máxima que se situa o sopesamento, o mesmo que Alexy atribuiu como necessário para resolver, em caso de colisão de princípios, qual deles deverá preponderar no caso concreto. Parece, dessas lições e de tudo aquilo que se mostrou nesta tese, que sempre haverá de se ponderar para resolver qualquer demanda relacionada à intervenção

\footnotetext{
${ }^{559}$ CANOTILHO, J. J. Gomes. Direito Constitucional e Teoria da Constituição. $3^{\mathrm{a}}$ ed., Coimbra, Almedina, pp. 264-265.

${ }^{560}$ Salvo, evidentemente, pedidos impertinentes como xampu e vitaminas.

${ }^{561}$ Ressalve-se que, no momento oportuno, esta tese revelará que, em matéria de saúde, normalmente mais adequada será a ação coletiva.
} 
jurisdicional em políticas públicas ${ }^{562}$, afinal, direitos sociais sempre colidem entre si. Tal embate pode vir à tona da maneira mais variável possível, abrangendo direitos de uma mesma natureza ou não.

Assim sucede em todos os casos em que o juiz atende a demanda de determinado postulante à obtenção de certo medicamento. Aí sempre estará implícito o sopesamento entre dois princípios básicos: o primeiro condiz com a universalidade de acesso à saúde; o outro, com a escassez de recursos ${ }^{563}$.

Sempre o atendimento da demanda exemplificada implicará o desatendimento a alguma outra, notadamente na área da saúde, porque, afinal, a prestação alcançada não será universal - antes, será apenas direcionada àqueles que ultrapassaram todos os óbices que têm que enfrentar quem consegue acesso ao Judiciário - embora os direitos sociais sejam ontologicamente universais. É preciso, então, no caso concreto, examinar se a medida, ao mesmo tempo, não é excessiva de forma a prejudicar uma série de outros indivíduos e em que grau de prejuízo, e se ela representa o patamar mínimo para $\mathrm{o}$ atendimento adequado do direito postulado.

Além disso, como já abordado, os recursos estatais são limitados, o que significa que a entrega de um bem ao indivíduo, pelo Estado, em tese implicará o não atendimento de outra pretensão legítima de indivíduo ou grupo diversos. Isto já se dá quando um agente político escolhe em que área e como aplicar recursos, e sucede com ainda mais agudez quando quem exerce esse jogo de escolhas é o juiz. Ao determinar o gasto com um tratamento hospitalar de longo prazo, o magistrado poderá conduzir à realocação forçada de recursos que originalmente estavam afetados a outra rubrica orçamentária, como, por exemplo, à construção de casas populares. O primeiro passo para que o juiz adote a razoabilidade e a ponderação como parâmetros decisórios em tema de políticas públicas é a sua consciência de que situações como aquela exemplificada neste parágrafo não são puramente teóricas ou retóricas.

Quando diante de uma postulação judicial de saúde, o exame da razoabilidade deve necessariamente levar em conta se o Estado tem condições de arcar com a demanda não apenas daquele que figura no pólo ativo da medida judicial, mas, também, a todas as demais pessoas que se encontram em situação análoga, ainda que não

\footnotetext{
${ }^{562}$ Segundo ALEXY, ao patamar dos princípios pertencem todos aqueles que sejam relevantes para a tomada de decisões a respeito de direitos fundamentais. Não por acaso o professor faz específica referência à íntima relação entre os princípios e os direitos fundamentais, concluindo que as colisões entre uns e outros sempre serão resolvidas por sopesamento (Teoria..., p. 212).

${ }^{563}$ Sobre a proporcionalidade como técnica apta a fazer ceder um princípio constitucional ante outro, ver GRINOVER, "Princípio da proporcionalidade...", em especial pp. 58-72.
} 
tenham lançado mão de qualquer ação para buscar a tutela de seus direitos. Esta fórmula revelaria, com efeito, um aspecto da proibição de excesso, no sentido de que aqueles que estão nas mesmas condições poderão ser atendidos pelo ente público. Evidentemente que essa checagem deve ser precedida de informações a respeito das políticas adotadas pelo Estado, bem como dos recursos disponíveis para atendimento a determinadas necessidades ${ }^{564}$. E, como no caso da exceção da reserva do possível, compete ao Poder Público o ônus de, em juízo, demonstrar não possuir condições de arcar com as demandas de pessoas que, como o postulante do caso concreto, sejam portadores das mesmas necessidades.

\subsubsection{Informações sobre as ações da Administração}

Todos os limites ora propostos já vinham sendo em alguma medida contemplados pela doutrina ${ }^{565}$ e observados em julgados. Agora é hora de analisar outros parâmetros, alguns dos quais especificamente ligados ao tema da judicialização da saúde. O que se sugere neste item é um limite que deflui automaticamente dos três paradigmas anteriormente expostos - reserva do possível, mínimo existencial e razoabilidade. Em todos esses casos, viu-se que o juiz, em seu novo e atual papel, é instado a se ausentar por alguns momentos da fria realidade processual clássica e iniciar uma tarefa investigativa, fruto mesmo da intrincada relação entre Poderes que a intervenção judicial em políticas públicas impõe. É preciso, assim, que os juízes possuam, ao decidir, o maior número e a melhor qualidade de informações a respeito das políticas e ações executivas adotadas pela Administração ${ }^{566}$.

\footnotetext{
564 O Ministro Gilmar MENDES entendeu que a ponderação dos princípios colidentes demanda a compatibilização dos critérios de justiça comutativa (próprios das decisões judiciais clássicas) e justiça distributiva (mais afetos ao novo modelo de litigância pública) que determinam, segundo ele, a elaboração de políticas públicas (STA 278-6/AL, j. em 22.10.2008).

565 GRINOVER, “O Controle...”.

${ }^{566}$ O APLPP percebe o déficit de informação que acomete os magistrados, de maneira geral, ao decidir sobre políticas públicas, e preconiza uma fase preliminar, vale dizer, uma fase inicial do processo especial em que ficará mais claro o objeto perquirido pelo autor. Nessa fase preliminar (cf. art. $5^{\circ}$ projetado), a Administração Pública, pelo órgão que ocupar o pólo passivo do processo, terá sessenta dias, no mínimo, e cento e vinte, no máximo, para apresentar o planejamento e a execução de políticas públicas relacionadas ao pedido, justamente para se verificar, de antemão, se a ação judicial é mesmo necessária e em que medida o pedido do autor é cabível em sua plenitude. $\mathrm{O}$ artigo $7^{\circ}$ projetado, por sua vez, estabelece as sanções em caso de não prestação de informações e como deve agir o magistrado caso sejam elas inadequadas ou insuficientes.
} 
De maneira geral, o Brasil sofre demais com a ausência de dados, números e estatísticas. Estudiosos do Judiciário e militantes do dia-a-dia do foro conhecem bem este problema. Apenas após o advento da Emenda Constitucional n 45/2004, com a criação do Conselho Nacional de Justiça, algum controle estatístico das ações judiciais passou a ser realizado $^{567}$. De maneira geral, contudo, ainda faltam informações, aspecto que é decisivo - sob o ponto de vista negativo - para a interação entre Judiciário, Executivo e Legislativo, o que, como visto, é da essência do controle jurisdicional de políticas públicas ${ }^{568}$.

Existe uma tentativa do CNJ de monitorar, reunir e compreender os dados relacionados às ações judiciais que postulam medicamentos, o que foi instituído com a Portaria CNJ no 91/2010 569 . Sem dúvida este é um importante aspecto a ser considerado. Com efeito, é preciso saber em que medida o Judiciário vem sendo conclamado a intervir nas políticas de saúde, até para medir objetivamente a debilidade das ações dos Poderes majoritários no trato do tema ${ }^{570}$. Mas a análise desta forma se dá sobre o resultado da intervenção jurisdicional, o que é de eficiência relativa quando o que se pretende é uma intervenção mais racional do Judiciário nas políticas de saúde. O que o Judiciário precisa, além de medir como e quanto os juízes distribuem ações de saúde, é saber quais são as ações tomadas pelos Poderes majoritários para cumprir esse seu ônus constitucional.

O mesmo CNJ, por meio da Recomendação $n^{\circ} 31 / 2010$, exortou os magistrados a ouvirem os gestores públicos antes de decidirem medidas urgentes a respeito de saúde. Nesse ato consta, ainda, a orientação para que os juízes visitem os conselhos de saúde, dispensários de medicamentos e hospitais oncológicos, tudo a fim de verificar, como se de inspeção judicial se tratasse, o funcionamento dessas instituições na prática, obtendo, assim, informações que facilitariam muito agir racional na matéria.

O processo judicial que trata de políticas públicas é insofismavelmente dialógico. Ele é instrumento para que os destinatários das ações de saúde, educação e

\footnotetext{
${ }^{567} \mathrm{O}$ artigo 103-A, $\$ 4^{\circ}$, VI da Constituição obriga o CNJ a semestralmente elaborar um relatório estatístico sobre os processos e sentenças prolatadas. É possível consultar alguns desses relatórios em <http://www.cnj.jus.br>.

568 Recentemente foi editada a Lei de Acesso à Informação (Lei $\mathrm{n}^{\circ}$ 12.527/2011), já referida, que, basicamente, obriga os órgãos públicos a divulgarem todas as informações que não sejam, de alguma excepcional forma, classificadas como sigilosas, o que não deve ser o caso de nenhum dado ligado à saúde. Essa lei pode ser importante vetor para a organização de dados e compilação de documentos, início de qualquer procedimento de divulgação.

${ }_{569}<$ http://www.cnj.jus.br/index.php?option=com_content\&view=article\&id=11083:portaria-no-93-de-17de-maio-de-2010\&catid=58:portarias-da-presidia\&Itemid=511>, acesso em 15.10.10, 17:11h.

${ }^{570}$ O Fórum Nacional do Judiciário para a Saúde, instituído pelo CNJ para especialmente tratar da matéria, é o órgão encarregado por obter e organizar dados relacionados às ações judiciais correlatas (<http://www.cnj.jus.br/noticias/cnj/14986:acoes-contra-planos-de-saude-serao-monitoradas-pelo-cnj〉, acesso em 12.7.12, 20:35h).
} 
demais direitos incluídos no rol apropriado reivindiquem tais bens daquele que diretamente os destina - o Estado. Nesse processo, em que o que está em jogo é a distribuição de bens sociais, há uma chance única de diálogo, manifestado, porque não, pelo exercício do contraditório caso a caso. O jurisdicionado e o magistrado podem ter, nos autos, acesso a informações que não teriam caso não se fizesse presente a autoridade judicial. Os dados de planos e programas públicos de implementação do direito discutido são da essência do processo judicial que pretende sindicar políticas públicas.

Concluiu-se, aqui, que a intervenção judicial ora tratada deve ter lugar quando a Administração Pública não atua. O arcabouço jurídico na seara da saúde é tão complexo e a rede administrativa tão intrincada, com inúmeras ramificações, competências e esferas de atuação, que não se pode dizer que Executivo e Legislativo sejam inertes neste campo. Evidentemente, como visto, há omissões, algumas decorrentes de falhas, outras da simples impossibilidade de atender, na plenitude, as necessidades da população. É aí que o juiz deve agir. Para o exame da omissão no caso concreto, o magistrado pode se valer de duas opções, uma mais fácil e menos adequada à delicadeza dos direitos que estão em questão, e outra mais complexa e racional: a primeira é presumir que sempre que há uma postulação judicial por serviços de saúde exista omissão dos Poderes majoritários - lógica do argumento linear estudado linhas antes; a segunda é concretamente verificar se essa omissão existe, o que demanda do juiz o conhecimento das medidas e políticas da Administração Pública. A conclusão a que se chega é que a atuação judicial na saúde deve ser muito mais racional e profunda do que partir, meramente, de uma presunção.

Imagine-se exemplo que poderia facilmente representar um caso concreto: jurisdicionado propõe ação visando a obter um medicamento para o tratamento de bronquite. $\mathrm{O}$ medicamento por ele postulado, contudo, estará à sua disposição nos postos de saúde na semana subsequente à propositura da medida. O juiz, não sabendo dessa circunstância, ordena a aquisição do medicamento. Pode-se tomar outro exemplo: jurisdicionado pede a internação em hospital particular para a realização de uma cirurgia, alegando que o Poder Público não dispõe de leitos nem de tecnologia para a realização da intervenção médica. O que o magistrado não sabe - e, talvez, nem o jurisdicionado - é que já há dois meses o Estado é dotado de todo o aparato para realizar imediatamente dada cirurgia. Em ambos os casos, a medida judicial era desnecessária, e a consequência é a movimentação da máquina judiciária sem necessidade. As hipóteses apresentadas são passíveis de ocorrência no cenário judicial de hoje? Completamente. E, isso, devido, em 
grande parte, à absoluta falta de diálogo dos juízes com o Estado nas ações que buscam direitos sociais.

Exemplo de maior gravidade, contudo, seria a concessão de um medicamento que não é contemplado pelas listas de dispensação obrigatória, em que pese nas listas haver outro fármaco que trate da mesma moléstia, mas muito mais barato. O juiz, sem essa informação, obriga o Estado a comprar o medicamento indicado na inicial. Imagine-se se essa providência é adotada no cenário de uma ação coletiva, em que o impacto financeiro será invariavelmente maior. Neste caso, além da medida judicial ser desnecessária, ela revelaria um exemplo não somente de má-gestão administrativa, mas, também, de contrariedade à proporcionalidade já observada, um dos pilares da Política Nacional de Medicamentos, que é a aquisição de fármacos seguros e eficazes e de menor custo se comparados com outros em posição análogas.

É a ausência de informações e de diálogo entre os Poderes que permite que algumas decisões judiciais obriguem o Estado a comprar e dispensar a autores de medidas judiciais medicamentos que se encontram disponíveis no SUS, um agudo exemplo da panaceia que se verifica em parte dos processos judiciais que veiculam saúde à população $^{571}$.

A falta de informações a respeito das ações da Administração no campo da saúde torna a decisão judicial a respeito, de certa maneira, irresponsável. Já se observou, empiricamente, que a maioria dos juízes não conhece as políticas públicas que são chamados a corrigir ${ }^{572}$. Ora, como adequar o que não se sabe estar equivocado? Um diálogo maior entre os Poderes, de modo a dotar o Judiciário de plenas informações a respeito das ações executivas tomadas, mais do que desejável, é imprescindível para a tutela racional das políticas de saúde. Somente o conhecimento a respeito da atuação do

\footnotetext{
${ }^{571}$ Estudo demonstrou que $52 \%$ dos medicamentos solicitados aos juízes em ações contra o Estado do Rio de Janeiro (no ano de 2005) se encontravam inscritos na RENAME (BORGES, Danielle da Costa Leite; UGÁ, Maria Alícia Dominguez. "Conflitos e impasses da judicialização na obtenção de medicamentos: as decisões de $1^{a}$ instância instância nas ações individuais contra o Estado do Rio de Janeiro". Brasil. 2005. Cadernos Saúde Pública, Rio de Janeiro. 26(1):59-69. jan. 2010, p. 62); em São Paulo, a pesquisa que estudou as ações judiciais propostas contra o Município de janeiro a dezembro de 2005 apontou que eram $62 \%$ os processos em que o medicamento perquirido fazia parte das listas do SUS (VIEIRA e ZUCCHI, "Distorções causadas...”, p. 219).

${ }^{572}$ A falta de informação dos juízes a respeito das ações do Estado não é novidade. Em pesquisa empírica realizada sobre acórdãos prolatados pelo Tribunal de Justiça de São Paulo quanto aos medicamentos componentes do coquetel antirretroviral da AIDS, verificou-se que nenhum dos cento e quarenta e quatro acórdãos analisados demonstrou conhecer as ações do Executivo nesse campo (DURAN FERREIRA, Camila. O Judiciário e as Políticas de Saúde no Brasil: o Caso AIDS, vencedor do Prêmio IPEA 40 anos, pp. 23-24).
} 
Estado na seara da saúde outorga ao juiz legitimação política para intervir nos assuntos da Administração.

O tradicional alheamento do Judiciário quanto a questões políticas não tem mais lugar dentro da moderna concepção da atuação judicial, ora analisada. Os Poderes ou Funções do Estado devem conversar entre si, sobretudo quando convergem para o mesmo ideal constitucionalmente determinado: o atendimento às demandas de saúde. Os atores envolvidos no processo judicial - o autor, o Estado e o juiz - têm de debater, não apenas por petições, mas por encontros, reuniões e audiências públicas, para que as informações a respeito do objeto do processo sejam todas expostas, como se fosse o discovery norteamericano $^{573}$. Os dispositivos que podem autorizar o juiz na realização desses colóquios são os artigos 342 e 599, I do Código de Processo Civil, a autorizar o magistrado, a qualquer tempo, no processo ou na fase de execução, convocar o comparecimento das partes para tratar de fatos relacionados à causa. De lege lata, é possível, com base nestes dispositivos, permitir que o juiz convoque audiências públicas para a manifestação das partes antes de decidir qualquer tema afeto a políticas públicas ${ }^{574}$.

A magistratura tem percebido a dificuldade de judiciar sem ter as corretas informações. Audiência pública conduzida pela mais alta Corte do país rendeu ao Judiciário uma série de informações que, no fim, revelaram ser muito importantes nas decisões ulteriores em tema de saúde, como já tratado ${ }^{575}$. O ponto de partida foi dado e, sem dúvida, essa iniciativa só comprova a relevância do conhecimento do Judiciário a respeito das informações técnicas ligadas à saúde, incluindo-se, aí, ações realizadas pelos Poderes majoritários, orçamento destinado à determinada ação, discussões a respeito de medidas que favoreçam a maior parte da população, dentre outros aspectos fulcrais para uma boa dispensação de saúde ${ }^{576}$.

\footnotetext{
573 Sobre o Discovery, ver ANDRIGHI, Fátima Nancy. "Estrutura e Dinâmica do Poder Judiciário NorteAmericano: aspectos de composição judicial e extrajudicial de litígios", disponível em: 〈http://bdjur.stj.gov.br/xmlui/bitstream/handle/2011/1538/Estrutura_Dinâmica_Poder.pdf?sequence=4>, acesso em 13.6.2010, 20:20h.

574 Existem modelos consagrados de processo dialógico que terminam por pacificar, como ilustra WATANABE, Kazuo. "Cultura da sentença e cultura da pacificação", em Estudos em Homenagem à Ada Pellegrini Grinover. São Paulo: DPJ Editora, 2005, p. 688.

575 A discussão a respeito da medicina baseada em evidências e os protocolos clínicos e diretrizes terapêuticas revela como o STF tem se preocupado em avaliar temas até então desconhecidos dos juízes, nada obstantes essenciais para uma tutela racional da saúde pública (STAs $n^{\circ} 171,211$ e 278/2010; SSs ${ }^{\circ}$ 3724, 2944, 2361, 3345 e 3355/2010; e SL no 47/2010, Rel. Min. Gilmar MENDES, j. em 17.3.2010).

${ }^{576}$ Remeta-se o leitor ao Item 4.1.3., em que está exposta tímida, porém vanguardista posição do TJSP em requerer a apresentação de informações por parte do Poder Público demandado antes de conceder a tutela emergencial pleiteada, estabelecendo um saudável contraditório nas ações relacionadas à obtenção de saúde.
} 
Tanto quanto a análise das contas da Administração no que toca à política pública pleiteada nos autos, para fins de verificação da reserva do possível, como, também, no exame do aspecto bifronte do mínimo existencial, saber as informações do Poder Público acerca da providência almejada concretamente toca à cognição do magistrado que, mais do que nunca, tem de ser plena e exauriente. Dessas informações dependerá a lógica atividade do magistrado tendente a verificar se a demanda tem ou não fundamento, com o resultado de procedência ou improcedência dos pedidos ${ }^{577}$. Isso equivale dizer que em quaisquer ações em que se busque providência de saúde, tal providência somente poderá ser concedida liminarmente em casos de grave risco de perecimento do direito, de maneira altamente excepcional. É preciso, antes de decidir pedidos emergenciais e sempre que possível, que o Poder Público seja ouvido. Somente assim o magistrado terá elementos para aferir se o pleito reúne ou não condições de ser atendido, sabedor, dentre outros aspectos, de quais ações estão sendo tomadas pela Administração com relação ao objeto do processo $^{578}$.

Existe um modelo de decisão judicial que causa menor impacto nas contas e ações públicas e, assim, revela uma espécie de mínima intervenção judicial. É a decisão em que o juiz, verificando que o Poder Público se omitiu em contemplar certa categoria de pessoas pela não inclusão de seu tratamento nas listas obrigatórias, convence-se de que aquele tratamento é adequado e, assim, ordena sua inclusão nas listas, para que os gestores possam planejar sua aquisição e distribuição posterior. Neste tipo de decisão, o magistrado não bloqueia contas do Estado, não manda fornecer imediatamente o medicamento, não causa qualquer desarranjo nas antecedentemente planejadas ações estatais. O juiz, neste caso, passa a realizar, também, o planejamento, ou, ao menos, sua decisão é vetor para o plano a ser delineado. A determinação judicial, aqui, tem caráter prospectivo, e é uma das melhores decisões que pode o juiz tomar, porque não somente atende aos postulantes judiciais, mas a todos aqueles que se encontrem em situação idêntica, atendendo à universalidade. Sobre este tipo de pronunciamento judicial voltar-se-á a tratar mais adiante.

\footnotetext{
${ }^{577}$ Kazuo WATANABE ensina que a cognição no processo é, basicamente, ato de inteligência, dado que consiste em dar valor às questões fáticas e jurídicas apresentadas pelas partes, tendo por resultado o alicerce da decisão (Da Cognição no Processo Civil, $2^{\mathrm{a}}$ ed., Campinas: Bookseller, 2000, pp. 58/59). No mesmo sentido, Giuseppe CHIOVENDA (Instituzioni di..., p. 217) e DINAMARCO, Cândido Rangel (Fundamentos do Processo..., p. 243).

${ }^{578}$ Nesse sentido, andou bem o item I.b.3 da Resolução CNJ n ${ }^{\circ}$ 31/2010, que exorta os magistrados a, antes de concederem medidas liminares em ações judiciais de saúde, darem ouvida aos gestores.
} 
O fato é que uma espécie de decisão prospectiva como essa só seria viável se o magistrado estivesse plenamente informado dos mais relevantes aspectos a respeito do que a Administração vem executando em termos de contemplação daquele grupo postulante e daquele fármaco postulado: o juiz precisaria conhecer as listas, as discussões que antecedem sua redação final, as técnicas debatidas pelos especialistas que elegem medicamentos para que nelas se afigurem, os motivos pelos quais aquele medicamento não foi incluído nas listas, dentre outros dados. Sem essas informações seria impossível determinar a inclusão de um medicamento nas listas, ainda que, como me parece, esta seja a melhor decisão que se possa tomar ${ }^{579}$.

O Judiciário precisa se aproximar mais, como vêm fazendo o STF e o $\mathrm{CNJ}^{580}$, além da recente audiência levada a efeito pelo Tribunal de Justiça de São Paulo ${ }^{581}$. À Administração só interessa abrir aos juízes seus dados e informações, trabalhando em conjunto com eles para um atendimento mais inteligente da demanda por saúde. As informações trocadas de modo adequado no processo judicial - isso como regra, jamais como exceção - são importante caminho para a tutela judicial racional. Sem informações suficientes, o juiz, via de regra, não pode decidir, sob pena de vulnerar, ainda que potencialmente, a série de princípios tão debatida nesta sede. A não ser que a situação fática se mostre emergencial (e, ainda assim, em um segundo momento o juiz terá que se informar), o magistrado não pode se escusar de conhecer as ações administrativas. $\mathrm{O}$ diálogo entre Poderes, nesse sentido, é um paradigma que deve nortear a decisão judicial relacionada à saúde.

4.2.6 Registro prévio da terapia, equipamento de saúde ou medicamento

Na busca por limites à intervenção jurisdicional no trato da saúde, é hora de se propor a observância de um parâmetro mais técnico e afeito às questões próprias desse

\footnotetext{
${ }^{579}$ De certa forma, o APLPP prevê mecanismo que pode ser útil e corrobora o entendimento dos estudiosos a respeito da necessidade que ora se aponta. Com efeito, o artigo $5^{\circ}$, que trata da fase preliminar à instauração do processo especial de políticas públicas, manda o Poder Público informar o planejamento e a execução existentes para a implementação da política pública respectiva e documentos que comprovem como se dará a execução, em caso de eventual atendimento do pedido, inclusive orçamentário-financeira.

${ }^{580}$ Ver, nesse sentido, itens 5.1.3 e 5.4.2 infra. A troca de informações entre Judiciário e Administração é, ao mesmo tempo, limite e remédio à desmedida atuação judicial em políticas públicas. Sem o diálogo entre os Poderes, qualquer decisão pode ser temerária.

581 <http://www.estadao.com.br/noticias/vidae,tj-sp-promove-audiencia-publica-sobre-a-falta-de-vagas-naeducacao-infantil,1065603,0.htm>, acesso em 30.9.2013, 18:51h. Sobre a audiência, ver mais detalhes em 5.1.7.
} 
direito social, notadamente considerando seu caráter curativo: a necessidade de que o equipamento médico, ou mais sensivelmente, o medicamento ou terapia postulado possuam licença prévia de comercialização ou realização, ou seja, registro no órgão competente.

Algumas decisões judiciais já asseguraram ao postulante o direito de obter tratamento fora do Brasil, ou, ainda, o provimento de um medicamento que só é encontrado no exterior ${ }^{582}$. Outras, ainda, consideram que a ausência de registro e o cunho experimental do medicamento não são motivos para que o Estado não seja condenado a entregá-los ${ }^{583}$. Essas situações são, por vezes, questionadas pela parte da doutrina que tende a restringir os poderes judiciais no trato de políticas públicas, notadamente pelos altos custos que, normalmente, envolvem tais iniciativas. O próprio STF, como consequência da audiência pública sobre saúde, considerou que apenas medicamentos e terapias registrados, via de regra, podem ser objeto de decisão judicial, o que reverberou em decisões judiciais e foi inscrito na Recomendação CNJ nº 31/2010. Há, neste contexto, alegação que não pode ser desdenhada de que, ausente registro no Brasil, não poderia o juiz autorizar o fornecimento estatal de dado medicamento ou terapia. De fato, este parece ser um razoável paradigma a se levar em conta.

A Lei $n^{\circ}$ 6.360/76, que trata da vigilância sanitária sobre medicamentos e outros produtos, demanda, em seu artigo 12, caput, que qualquer terapia ou medicamento, para ser dispensado à população brasileira, deve, antes do fornecimento, comprovar sua eficácia e segurança. É a medicina baseada em evidências. O medicamento ou terapia é

\footnotetext{
${ }^{582}$ REsp no 353.147/DF, $2^{\text {a }}$ T., Rel. Min. Franciulli NETO, DJ em 18.8.2003. No especial, o STJ determinou o custeio do tratamento do postulante em Cuba com relação à doença retinose pigmentar. Outras decisões, contudo, reviram esse entendimento, entendendo pela primazia da Portaria MS no 763/1994, que veda o pagamento, pelo SUS, de tratamento médico no exterior (EDcl nos EDcl nos EDcl no AgRg no REsp $\mathrm{n}^{\mathrm{o}}$ 1.028.835/DF, $1^{\mathrm{a}}$ Turma, Rel. Min. Luiz FUX, DJ em 2.3.2010). Mas a matéria está longe de ser pacificada. Em julgado em que a questão foi exaustivamente debatida, o STF entendeu por obrigar o Estado a custear um tratamento ocular disponível apenas - de novo - em Cuba. O Relator, Min. Menezes DIREITO, votava contra a tese, mas o Tribunal entendeu por acompanhar a orientação do Min. Marco Aurélio MELLO, que se tornou o Relator para o acórdão (RE 368.564/DF, Rel. Min. Menezes DIREITO, Rel. para o acórdão Min. Marco AURÉLIO, $1^{\mathrm{a}}$ T., DJ em 10.8.11).

583 "OBRIGAÇÃO DE FAZER Pretensão de compelir o Poder Público ao fornecimento de medicamento à pessoa portadora de neovascularização de coróide (CID H 35.3) Prescrição do medicamento Avastin. Conversão do Julgamento em diligência. Prova pericial que demonstra a adequação do remédio à patologia da apelada. Impossibilidade de substituição da droga por outra com a mesma eficácia. Inexistência de tratamento alternativo. Caráter experimental do tratamento não reconhecido. Ausência de registro na ANVISA que não constitui requisito à dispensação do medicamento. Dever da Administração Pública em fornecer atendimento integral à saúde. Incidência do disposto nos artigos 196 e 198, inciso II, da CF. Competência comum a todos os entes federativos. Súmula 37 do TJSP. Possibilidade de interferência do Poder Judiciário para cumprimento de normas legais em vigor. Recurso não provido." (TJSP. Apel. $n^{\circ}$ 0017410-56.2009.8.26.0196. Rel. Des. Manoel RIBEIRO, 8 a Câmara de Direito Público, j. em 26.6.2013). Essa decisão, de mais de três anos depois da Recomendação CNJ no 31/2010, mostra como há um longo percurso a ser percorrido até a racionalização da distribuição judicial de saúde.
} 
eficaz quando alcança os resultados a que se propõe, combatendo os sintomas ou tratando a moléstia; é seguro quando não impõe risco ao usuário. A conjugação desses dois pressupostos torna a fórmula apta a ser colocada em mercado. Prossegue a lei, determinando que o registro no órgão competente confere ao medicamento ou terapia a possibilidade de dispensação e comercialização, já que, estando registrado, terá sua eficácia e segurança previamente comprovadas.

O grande avanço, decorrente do aprimoramento do conhecimento a respeito da farmacoterapia que qualquer gestor do SUS deve dominar, deu-se com a edição da Lei $\mathrm{n}^{\mathrm{o}}$ 12.401/11. Ali estão estampadas as diretrizes para a incorporação de medicamentos e procedimentos pelo sistema público de saúde, celebrando a primazia dos protocolos clínicos e diretrizes terapêuticas, estudos técnicos a respeito das peculiaridades de cada tratamento, e, na ausência, o uso das relações nacionais, estaduais e municipais de medicamentos, que levam em consideração a segurança e a eficácia do fármaco, além de fatores econômicos a ele relacionados. O artigo 19-T da Lei estabelece o que ora interessa: a vedação ao reembolso, pelo SUS, de produtos ou procedimentos experimentais e que não estejam registrados no órgão sanitário. Na prática, essa disposição é corolário do dever de dispensação de remédios e tratamentos somente após registro.

O registro dos medicamentos, terapias e equipamentos de saúde é realizado, no Brasil, pela ANVISA, nos moldes do que sucede em outros países. Também nos Estados Unidos, o FDA exerce um rigoroso controle sobre os fármacos e terapias, assim como o EMEA europeu e o Pharmaceuticals and Medicals Devices Agency do Japão. Ali, como aqui, exige-se prova de segurança e eficácia do produto oferecido. De fato, parece ser imprescindível que antes que um fármaco ou dado tratamento sejam colocados no mercado eles tenham se mostrado seguros e eficazes: um medicamento inócuo é imprestável e acabará fazendo com que o usuário sobre ele deposite falsas esperanças, o que, dependendo do caso, certamente pode ser muito cruel; um tratamento de alto risco ou cujos riscos superem desproporcionalmente os benefícios também não pode ser referendado. Na verdade, a comprovação desses dois requisitos se dá depois da realização de uma série de complexos procedimentos averiguados pelos órgãos sanitários.

Apenas medicamentos e terapias registrados podem ser dispensados. Somente depois do registro é que há a sua inclusão nas listas de dispensação obrigatória. A complexidade e o grau de exigência que antecedem o registro do fármaco militam duplamente a favor da Administração quando de sua tarefa de prover assistência farmacêutica aos administrados: primeiro, porque atestam que os medicamentos ou 
terapias a ser dispensados cumprem a missão constitucional relacionada à saúde; segundo, porque evitam ações arbitrárias daqueles que confeccionam as listas já mencionadas. $\mathrm{O}$ atesto de segurança e eficácia de um fármaco não é apenas garantia ao cidadão de obter da atuação estatal resultados práticos, mas, também, é segurança de melhor gestão dos parcos recursos públicos, que não serão empenhados em campanhas que podem não levar a resultado algum.

É preciso, diante do cunho altamente complexo do direito à saúde, que o magistrado se cerque de todos os cuidados necessários para atender a requerimentos que visem a obter medicamentos e terapias que sejam seguros e eficazes. Terapias e medicamentos cujos resultados prometidos não possuam qualquer comprovação científica (que normalmente se dá por meio de estudos clínicos cujos dados coletados são publicados normalmente em respeitosas revistas) não podem ser dispensados pelo Judiciário, não apenas por conta de violação das ações dos Poderes majoritários de forma a desequilibrar o jogo institucional (a uma, porque contraria a Lei que demanda a análise da segurança e da eficácia do medicamento ou terapia para sua dispensação, seja privada, seja pública, e a duas, por contrariar a PNM, que segue a linha legal), mas, também, porque toda e qualquer decisão a respeito desse tema, como já visto e discutido, implica em desalojamento de outros tantos jurisdicionados, de forma que não há como empreender esforços principalmente, os judiciários - para prover aquilo que não passa, aos olhos da ciência e das autoridades competentes, de mera conjetura.

Evidentemente que o cunho burocrático do Estado $^{584}$ pode tolher o jurisdicionado de determinado tratamento que, por razões procedimentais, ainda não foi registrado ${ }^{585}$. Nesses casos e em caráter especialíssimo, o juiz poderá atender ao pleito do

584 Owen FISS faz uma análise sobre como a burocracia pode ser negativa às instituições. Ao avaliar o
Judiciário norte-americano, FISS usa de dois modelos - de Max WEBER e de Hannah ARENDT - para
analisar sobre qual deles deveria ser estudado o Judiciário alhures, concluindo pelo modelo de ARENDT - da
norma por ninguém, ou seja, o burocrata se limita a seguir ordens, sem tentar entender sua pertinência. O que
se depreende do texto é que é um perigo que, pela extensa burocratização, as instituições não sejam capazes
de executar suas ações (Um Novo Processo Civil..., pp. 213-243).
585 Reportagem do Consultor Jurídico evidenciou bem o problema da demora do registro de produtos de
saúde no Brasil. Segundo pesquisa do IPEA realizada em 2010, o tempo médio de registro de medicamento
genérico na ANVISA era de seiscentos e cinco dias (a amostragem estudou trezentos e vinte e três
procedimentos). A delonga dá causa a um sem número de medidas judiciais, apresentadas pela indústria
farmacêutica, para que seu pedido de registro seja apreciado imediatamente (de novo, o Judiciário sendo
acionado para intervir no processo tipicamente executivo). De acordo com a notícia - e é curioso tal paralelo,
sobretudo no contexto desta tese - alguns juízes estavam denegando pedidos emergenciais desse talante
porque as liminares tiveram o pernicioso efeito de criar outra fila de registro, fazendo com que as empresas
que lançassem mão da ação judicial ultrapassassem a ordem cronológica da análise dos pedidos - fenômeno
análogo aos jurisdicionados que se dirigem aos magistrados a fim de conseguir seu tratamento de saúde,
transporte especial ou vaga na escola. Diante desses fatos imputáveis à burocracia estatal, o Ministério da
Saúde anunciou que, dali em breve, diminuiria em $40 \%$ o tempo médio de registro de medicamentos - não se 
postulante, desde que, por outros meios, fique comprovada a segurança e eficácia do medicamento ou terapia. Um exemplo que pode ser usado para ilustrar a hipótese ocorre com fármacos ou tratamentos que, a par de ainda não possuírem registro na ANVISA, foram registrados em outros países, sobretudo se for o caso dos já mencionados FDA, EMEA e congênere japonês. Esses reputados órgãos possuem requisitos rigorosos para a comprovação dos requisitos de registro da terapia ou medicamento, tanto que, algumas vezes, a própria ANVISA usa da aprovação estrangeira para justificar o registro em território nacional.

Se, não obstante a ausência de registro na ANVISA, FDA, EMEA ou outro organismo confiável já tenham reconhecido a eficácia e a segurança do medicamento ou tratamento, o juiz pode, diante de grave quadro apresentado pelo postulante e, sobretudo, se comprovado que o fármaco já se encontra em fase de registro na ANVISA, prover o bem por ele buscado (atendidos os demais requisitos exigidos e ora apresentados). Evidentemente que quanto mais próximo do registro na ANVISA o medicamento estiver, mais subsídios terá o juiz para atender aos anseios do jurisdicionado.

Por isso que nem sempre é irreal a ordem judicial que manda que o jurisdicionado se trate no exterior ou receba medicamento já comercializado alhures: se ambos contarem com o atesto das autoridades locais a respeito de sua segurança e eficácia (que, no fim, é o que realmente releva nesses casos), o problema não resvala tanto no campo da ausência de registro na ANVISA, mas ele pode infirmar outros paradigmas, como, por exemplo, a reserva do possível, o mínimo existencial bifronte e a razoabilidade.

$\mathrm{O}$ tema não fugiu à análise pelo STF, ainda não rendida: recurso extraordinário em que este tema houve tal debate foi declarado de repercussão geral. Pelos precedentes já apresentados pelo Tribunal, é muito provável que os ministros caminhem pela linha sustentada nesta tese ${ }^{586}$.

Fato é que, diante da comprovada segurança e eficácia que goza o medicamento ou tratamento registrado na ANVISA, o juiz deve sempre se indagar se a postulação que lhe é dirigida atende esse requisito, caso em que, não sendo assim, apenas

sabe se equipamentos como próteses, seringas e tomógrafos também se beneficiariam ("Registrar remédio na Anvisa vira batalha judicial", Conjur, edição de 2.4.2013, disponível em: <http://www.conjur.com.br/2013abr-02/industria-justica-acelerar-registro-remedios-anvisa>, acesso em 17.6.2013, 13:43h).

586 "SAÚDE - MEDICAMENTO - FALTA DE REGISTRO NA AGÊNCIA NACIONAL DE VIGILÂNCIA SANITÁRIA - AUSÊNCIA DO DIREITO ASSENTADA NA ORIGEM - RECURSO EXTRAORDINÁRIO REPERCUSSÃO GERAL - CONFIGURAÇÃO. Possui repercussão geral a controvérsia acerca da obrigatoriedade, ou não, de o Estado, ante o direito à saúde constitucionalmente garantido, fornecer medicamento não registrado na Agência Nacional de Vigilância Sanitária - ANVISA”. (RE 657.718RG/MG, Pleno, Rel. Min. Marco AURÉLIO, DJ em 9.3.12). 
muito excepcionalmente poderá ser provida. Da mesma forma, o juiz deve privilegiar, em seu ofício, a adjudicação de terapias e medicamentos que, já estudados pelos órgãos competentes, mostraram-se a priori os mais adequados ao tratamento desta ou daquela moléstia. É este assunto que será tratado no tópico seguinte.

4.2.6 Contemplação de terapias e medicamentos incluídos nas listas

Segundo a OMS, um dos mecanismos mais eficientes eleitos por técnicos para que um Estado que tenha escolhido prover saúde a seus cidadãos (atuando, assim, na vanguarda dos direitos humanos) cumpra escrupulosamente esse dever é a elaboração de listas de medicamentos e terapias de dispensação obrigatórias a toda e qualquer pessoa ${ }^{587}$. O Brasil se alinhou a essa diretriz e a PNM também prevê a listagem de fármacos e procedimentos que devem necessariamente ser cobertos pelo SUS ${ }^{588}$.

As listas em apreço, realmente, coadunam-se com a distribuição mais equilibrada, racional e universal de saúde. Sem dúvida, elas são precedidas de amplo debate entre inúmeros órgãos técnicos que discutem todos os múltiplos aspectos que resultam na eleição de um remédio ou terapia como aqueles que o Estado escolheu como indicados para o tratamento de dada necessidade. Para a elaboração da RENAME, a lista de medicamentos essenciais ${ }^{589}$ editada pela União ${ }^{590}$, um árduo trabalho é desenvolvido antes que o fármaco seja incluído na lista. Primeiro, há um mapeamento sobre quais os males que vêm acometendo a população: nesse contexto, existem, desde problemas de alta incidência (i.e., diabetes, cefaleia), até doenças epidêmicas e pandêmicas (como foi o caso da gripe A, que obrigou o Estado a adotar meios para evitar o alastramento da pandemia,

\footnotetext{
${ }^{587}$ Desde 1977, a OMS elabora uma lista modelo de medicamentos essenciais (http://www.who.int/medicines /publications/essentialmedicines/en/, acesso em 6.11.2010, 23:06h). Na 16 a edição da lista modelo, o órgão deixa claro tudo o que se sustentou aqui: as listas contemplam medicamentos seguros e eficazes de me nor custo. Segundo a OMS, "The core list presents a list of minimum medicine needs for a basic healthcare $s$ ystem, listing the most efficacious, safe and cost effective medicines for priority conditions. Priority condition $s$ are selected on the basis of current and estimated future public health relevance, and potential for safe and cost effective treatment." (<http://www.who.int/selection_medicines/committees/expert/17/WEB_unedited_1 6th_LIST.pdf>, acesso em 6.11.2010, 23:14h).

${ }_{588}$ Cf. Política Nacional de Medicamentos.

589 De acordo com a OMS, essencial é o medicamento que trata as moléstias de maior incidência populacional com eficácia e segurança.

${ }^{590}$ Cf. estatuído na Política Nacional de Medicamentos, Estados e Municípios também podem organizar suas próprias listas, desde que guardem congruência com a RENAME. É o caso da REMUME, a Relação Municipal de Medicamentos Essenciais de São Paulo.
} 
via aquisição de vacinas especiais). Depois, analisa-se como se pode tratar determinada moléstia: sendo vários os fármacos, será eleito aquele que, seguro, eficaz e estando previamente registrado na ANVISA, for o mais economicamente interessante. Enfim, a lista é revista periodicamente e qualquer interessado pode provocar o órgão executivo respectivo para questionar qualquer ponto nela presente (ou ausente). A RENAME é atualizada a cada dois anos.

O órgão executivo da RENAME é a COMARE, Comissão Técnica e Multidisciplinar de Atualização da Relação Nacional de Medicamentos Essenciais, formada por cinco órgãos do Ministério da Saúde, oito outros órgãos especializados (dentre os quais a ANVISA, o CONASS e o CONASEMS) e oito representantes das mais renomadas universidades brasileiras ${ }^{591}$. Para publicar a edição de 2010 da RENAME, a COMARE se reuniu nada menos do que dezessete vezes, desde 2008, com trezentas e quarenta horas de trabalho, chegando a uma série de alterações na listagem, dentre as quais se colocam exclusões e inclusões de medicamentos. O trabalho da COMARE é embasado em dados objetivos coletados a partir da medicina baseada em evidências, ou seja, medicamentos são incluídos ou excluídos da RENAME dependendo de dados técnicos e científicos a respeito de seus efetivos efeitos, ou de evidências que ele produza os efeitos benéficos a que se propõe.

Como se mencionou, dentre as diretrizes da RENAME está sua revisão periódica, que é realizada tanto pelas reuniões da COMARE quanto, e inclusive, pela possibilidade de qualquer interessado requerer administrativamente a providência ${ }^{592}$, pedido este que é decidido pela COMARE. Essa é uma forma que foge ao controle jurisdicional do que está ou não está incluído na listagem, provocando um foro apropriado, porquanto técnico - a COMARE, próprio órgão do Executivo - a refletir, repensar e motivar suas decisões a respeito da RENAME.

Já os medicamentos excepcionais são caso à parte dentro do mesmo cenário. Excepcionais são os fármacos que tratam doenças de baixa incidência, tratamento contínuo e de alto custo ${ }^{593}$. Alguns excepcionais são conhecidos como drogas-órfãs,

\footnotetext{
${ }^{591}$ Maiores informações disponíveis em: <http://www.portalsaude.gov.br/portal/profissional/área.ccfm?id_ar ea=1337> e <http://www.saude.gov.br/medicamentos>. Neste último, a propósito, está à disposição a última edição da RENAME ( $8^{\mathrm{a}}$ edição, datada de 2012).

592 Artigo 26, parágrafo único da Portaria COMARE no $1 / 2008$.

593 Esta equação é de uma simplicidade quase pueril. Os investimentos da indústria farmacêutica no desenvolvimento dos excepcionais são tão ou mais vultosos que aqueles aplicados aos medicamentos essenciais. A diferença, justamente, é quanto ao público consumidor: se, no segundo caso, os investimentos podem ser repartidos entre uma maior quantidade de pessoas, o mesmo não sucede no primeiro caso. Daí o
} 
justamente porque, tendo em vista seu alto custo de desenvolvimento e o desequilíbrio quanto ao contingente de pacientes, não interessa à indústria farmacêutica reivindicar a paternidade da droga. Alguns países, como os Estados Unidos, conferem àqueles que se esmeram no desenvolvimento de drogas-órfãs benefícios e isenções, de forma a estimular a aplicação da ótica de mercado também nesses casos (de novo, em que, a priori, há um amplo desequilíbrio na relação custo-benefício). O Ministério da Saúde editou, em 2006, a Portaria MS no 2.577, inserindo na PNM o Componente de Medicamentos de Dispensação Excepcional. Entender esses basilares pontos a respeito dos excepcionais permitirá compreender porque a atuação jurisdicional é indispensável na seara da saúde.

Evidentemente que as listas representam uma previsão, um planejamento do Executivo, com a consequente aplicação de recursos para a compra de medicamentos. No caso das relações, os remédios são comprados anteriormente e colocados à disposição dos pacientes. Há, inclusive, a possibilidade de negociação de valores para a compra, o que é adequadamente razoável. As listas são facetas do planejamento a que alude a Constituição e a cujo respeito já se tratou neste estudo. Não por menos que a própria apresentação da RENAME dá conta ser ela instrumento que racionaliza as ações no âmbito da assistência farmacêutica e medida indispensável para o uso adequado de medicamentos no contexto do SUS ${ }^{594}$. Uso racional, em outras palavras, ou seja, dependente de planejamento, de cobertura mais eficaz com menor dispêndio de recursos.

Imagine-se, contudo, a postulação judicial de determinado fármaco embasado em receita médica, sem que a inicial e os documentos tragam ao magistrado qualquer informação a respeito das listas de dispensação obrigatória. Imaginemos o pior: o julgador sequer sabe da existência dessas listas obrigatórias, desconsiderando por completo as ações e planos do Poder Executivo. Uma decisão como tal vai de encontro a toda a lógica sistêmica ora defendida, porque, a um só tempo, joga cinzas sobre as atribuições naturais dos Poderes, ignora o caráter distributivo de uma decisão dessa espécie e solapa o inafastável fato de ser o direito à saúde universal ${ }^{595}$.

alto custo dos medicamentos excepcionais, o que os torna especialmente peculiares para um Estado que, como o brasileiro, escolheu se responsabilizar pela dispensação de medicamentos.

594 <http://portal.saude.gov.br/portal/arquivos/pdf/rename2010.pdf>, acesso em 4 de junho de 2010, 20:23h.

595 Segundo Eduardo APPIO, "O direito à saúde, embora previsto constitucionalmente dentro do rol dos direitos fundamentais, é via de regra dependente de comando legal que delimitará a amplitude da atuação da Administração na formulação de políticas na área da saúde. Por essa razão, em que pese a imediata aplicabilidade dos direitos sociais, o autor irá identificar um conflito entre o direito à vida daquele que tenta socorre-se do Judiciário para ver cumprido direito subjetivo que lhe assiste e o direito à vida de uma coletividade que carece do orçamento público." (Controle Judicial das Políticas Públicas, $1^{\text {a }}$ ed., Curitiba: Juruá, 2008, pp. 184-189). 
Medidas como o bloqueio imediato de numerário das contas do Estado 596 causam sensível impacto nas ações governamentais, com o surgimento invariável da equação mencionada no início deste estudo, e que nos ensina que sempre que são retirados recursos de um local para aplicá-los em outro, alguém não experimentará sua fatia no bolo, já que, afinal, o cobertor é curto. Ignorar as listas é entregar ao povo uma decisão judicial desequilibrada, indesejável e, de conseguinte, contrária ao objeto do direito, que é universal.

De certa forma, a inclusão do medicamento nas listas poderia, salvo as anomalias próprias do processo político, ser entendida como a consagração do mínimo existencial: escolhendo os fármacos e terapias que representem melhores ou iguais resultados com menor custo e igual ou melhores eficácia e segurança, a autoridade administrativa elege aquilo que se compreende como o mínimo para que o jurisdicionado mantenha sua saúde íntegra e qualificada. A observância do conteúdo das listas em apreço parece coadunar com o mínimo existencial, podendo consistir em um parâmetro concreto a nortear a decisão judicial.

É preciso, pois, equilíbrio. Por isso que em toda e qualquer demanda que envolva a postulação judicial de saúde, em suas múltiplas facetas, o juiz deve ser informado a respeito do conteúdo das listas. Se a moléstia for de alta incidência, o postulante deve instruir a inicial com a prova de que o medicamento está incluído na RENAME; se a doença for rara ou daquelas que exigem tratamento custoso e contínuo, a relação dos medicamentos excepcionais deverá ser exibida. Se o medicamento estiver contemplado nas listas e apenas não estiver à disposição do jurisdicionado na forma e no tempo como ele precisa, então a medida almejada deve ser deferida.

Existem, todavia, dois aspectos a serem abordados nesta sustentação: o primeiro é relacionado ao pedido de fármaco não contemplado nas listas; o segundo, relativo à possível cooptação de interesses que envolvem a elaboração das relações.

É palatável que magistrados se deparem com pedidos de fornecimento de fármacos não incluído nas listagens de dispensação obrigatória do SUS. Com efeito, os elaboradores das relações não são capazes de cobrir a totalidade de situações que podem

\footnotetext{
596 SCAFF, "Sentenças Aditivas...". Nesse artigo, chama-se a atenção para uma recente discussão do Tribunal Constitucional Italiano a respeito do tema, considerando o $\$ 4^{\circ}$ do art. 81 daquele diploma, que determina não ser admissível despesa pública se não for indicada a respectiva fonte. Na mesma linha, entre nós, o artigo 167 da Constituição. Indica o autor, todavia, que na Itália foi decidido que as decisões emanadas do Judiciário não se enquadram na dada previsão (pp. 88-89). Como já noticiado, o STJ já sedimentou o entendimento de que tal bloqueio é possível, inclusive tendo sido a questão objeto de recurso repetitivo (REsp n ${ }^{\circ} 1.069 .810 / R S, 1^{a}$ Seção, Rel. Min. Napoleão Nunes Maia FILHO, DJ em 6.11.2013).
} 
levar o jurisdicionado a postular algum bem necessário à mantença de sua saúde. Nem todos os fármacos disponíveis no mercado poderão ser, eventualmente, avaliados. O Judiciário deve prever e lidar com situações como estas. Nada obstante, o juiz não pode escapar de inquirir os motivos pelos quais o medicamento não está contemplado nas $\operatorname{listas}^{597}$. Se, diante de uma situação como esta, perceber o magistrado que, a despeito do fármaco não estar contemplado nas listas, seu fornecimento no caso concreto atende a todos os demais paradigmas propostos (i.e., reserva do possível, razoabilidade, mínimo existencial bifronte, registro prévio e conhecimento sobre as ações administrativas), então deverá atender ao postulado.

Não se procura, aqui, estabelecer a vinculação do magistrado ao quanto colocado na lista, até porque sustentar esta hipótese seria militar contra tudo o que já neste estudo se argumentou. O que se propõe é que em toda e qualquer postulação judicial envolvendo saúde o juiz deva questionar aspectos relacionados às listas estatais de dispensação obrigatória. Se, sabedor de importantes informações sobre o medicamento postulado e sua ausência das listas, convencer-se o juiz em atender o pleito, deverá fazê-lo. As listas não são vinculativas, mas parâmetro para uma judicialização da saúde mais racional e universal. A tutela jurisdicional equilibrada da saúde deve passar pela análise das relações.

Esta construção abre espaço para mais um importante aspecto relacionado ao tema, que é a possibilidade do juiz, munido de dados para tanto, ordenar a revisão das listas, podendo até determinar a inclusão de certo medicamento nas relações para os próximos exercícios, o que, com efeito, retiraria o impacto econômico imediato da decisão judicial que ordene a compra do fármaco. Evidentemente que a revisão das listas pressupõe um intenso e extenso debate entre a Administração, o Ministério Público e órgãos técnicos que permitam ao magistrado chegar à conclusão de que a inclusão daquele remédio atende a todos os requisitos estabelecidos na Constituição e na PNM. É essa a decisão prospectiva

\footnotetext{
${ }^{597}$ Análise de caso proposta no âmbito da Escola de Direito da Fundação Getúlio Vargas constatou que, no caso do tratamento da diabetes, pacientes e alguns médicos discordam dos fármacos abrangidos nas listas e, destarte, fornecidos pelo SUS. Segundo eles, as chamadas insulinas análogas seriam mais eficazes e resultariam menos efeitos colaterais que as tradicionalmente dispensadas pela Administração, o que motivou a dedução de pedidos judiciais de concessão de tais medicamentos. O Poder Público, de sua feita, alega que a única vantagem das insulinas análogas é a comodidade dos pacientes, ao custo cerca de treze vezes superior ao quantum do tratamento tradicional. Neste estudo, verificou-se, como parece ser regra, que as ações individuais se mostraram mais exitosas que as coletivas (FRANCO, Denise, PIRES, Natália, Terrazas, Fernanda, VILLELA, Mariana e WANG, Daniel. "Judiciário e fornecimento de insulinas análogas pelo sistema público de saúde: direitos, ciência e políticas públicas". Casoteca Direito GV - Produção de Casos 2011, disponível em: <http://direitogv.fgv.br/sites/direitogv.fgv.br/files/insulinas_analogas__nota_de_ensino .pdf $>$, acesso em 1.8.2013, 22:13h).
} 
a que já se referiu, produzindo seus efeitos práticos no futuro, o que, por isso mesmo, permitindo o planejamento adequado das ações da Administração e o conseguinte equacionamento de recursos.

Ato contínuo à revisão das listas é o fato que essa possibilidade vem ao encontro do silogismo que não se pode açodar do Judiciário o poder de corrigir as inúmeras anomalias que envolvem a elaboração das políticas de saúde. A verdade inescapável é que a inclusão de determinado medicamento nas listas de dispensação obrigatória interessa a muita gente. Esses interesses podem redundar na cooptação de determinados agentes administrativos que, por fim, definem quais medicamentos entram e saem das listas. É verdade que, em sua maioria, os componentes dos órgãos responsáveis por essa definição são técnicos; contudo, a realidade é que esses técnicos respondem, sempre, a uma autoridade inegavelmente motivada por interesses políticos ${ }^{598}$, além deles próprios ostentarem seus ínsitos anseios.

Por isso é não se pode tirar do Judiciário a prerrogativa de eliminar a lesão ou ameaça a direito oriunda da ausência da inclusão de um dado medicamento nas listas, ou de um tratamento como sendo de fornecimento gratuito pelo Estado. De novo: não se pode ignorar que o Judiciário tenha, em princípio, papel subsidiário ao Executivo, ou seja, ele deve atuar - sempre, em princípio - onde a omissão Executiva lesione direitos do jurisdicionado $^{599}$. Mas é preciso, antes disso, examinar as listas. A análise das listas, por tudo o que elas representam - planejamento, racionalidade, distributividade $\mathrm{e}$ universalidade - deve ser encargo a ser suportado por cada juiz quando frente a frente com um caso que postule saúde.

Estão propostos, pois, seis limites à intervenção jurisdicional em políticas públicas de saúde. A seguir, respaldadas nesses parâmetros, serão realizadas asserções concretas para evitar que a decisão judicial se dê de maneira patológica e, destarte, problemática. Passe-se, pois, a apresentar os remédios para evitar distorções nas decisões judiciais relacionadas à saúde.

\footnotetext{
${ }^{598}$ Aqui é necessário remissão à leitura dos aspectos relacionados à Public Choice, colocados no Item 2.5.2.

${ }^{599}$ Sempre respeitando as ponderações de FISS.
} 


\section{OS REMÉDIOS PARA A INTERVENCẼ̃O PATOLÓGICA DO JUDICIÁRIO}

Os limites estudados no Capítulo anterior fornecem parâmetros para a atividade jurisdicional de provimento de ações na área da saúde. Esses limites, todavia, por si somente, não são suficientes para que o atuar judicial nesse mister seja dispensado equitativamente. É preciso mais: o magistrado deve se valer de alguns mecanismos que, encampados pela lei e pelos próprios magistrados, funcionem justamente no sentido proposto neste estudo, de modo a evitar a atividade jurisdicional lesiva e atentatória ao interesse público constitucional.

Não se duvida que o cenário enfrentado hoje em dia pela sociedade, em termos de intervenção judicial em políticas públicas, é deveras problemático. Os aspectos negativos das decisões judiciais que, por exemplo, determinam providências a serem tomadas na seara da saúde (i.e., alocação forçada de recursos, míngua de direitos, desconsideração do planejamento administrativo) permitem que a essa plêiade de decisões se isole a característica de patológicas: elas não representam o efetivo papel do Judiciário no trato de políticas públicas de saúde, porquanto desprovidas de maior reflexão e adequado debate, ao mesmo tempo em que são multiplicadas em todas as instâncias e tribunais, sendo, não raramente, repetidas em julgados ${ }^{600}$. A rigor, patológica é toda a decisão judicial que, intervindo nas políticas de saúde, despreza os macroaspectos relacionados ao tema.

As decisões patológicas devem ser evitadas pelo uso do que ora se convenciona intitular remédios $^{601}$. A analogia médica (ainda mais oportuna - ou, quem

\footnotetext{
${ }^{600}$ Pesquisas exploradas nesta tese já concluíram a aversão dos juízes à obtenção de informações e ao exercício do papel de definidores de novas estruturas políticas. No estudo analisando as decisões judiciais relacionadas ao coquetel da AIDS, o número de arestos do Tribunal de Justiça de São Paulo que não levavam em consideração as ações já tomadas pela Administração na área da saúde (DURAN FERREIRA, pp. 23-24); no caso da educação, a autora definiu que, "Nas situações em que os interesses protegidos estavam mais dispersos, abordados como efetivos interesses coletivos, o Judiciário teve mais dificuldades para atuar no conflito, pois estes solicitavam reformas estruturais mais complexas que exigiam não só informação técnica e especializada, mas também um conhecimento mais amplo, da política educacional como um todo, e não apenas do conflito fragmentado que foi apresentado ao Judiciário." (MARINHO, Justiciabilidade..., p. 106). Também na pesquisa inédita ora apresentada (Item 4.1.3) viu-se que apenas um julgado, que representou menos de $0,5 \%$ da amostra analisada, requereu maiores informações a respeito dos programas da Administração.

${ }^{601} \mathrm{O}$ uso do termo remédio em Direito não é novo. A doutrina constitucionalista entende os remédios constitucionais como as medidas judiciais aptas à concretização dos direitos fundamentais (i.e., habeas corpus, habeas data, mandado de injunção, mandado de segurança, ação popular - SILVA, José Afonso.
} 
sabe ao menos, curiosa) é didática: patologias se tratam com remédios. Em outras palavras, decisões judiciais patológicas devem ser evitadas pelo emprego de algumas medidas remediais propostas justamente com esse fim.

Quando se assume a assertiva de que o juiz decide usando razoabilidade e levando em consideração o mínimo existencial bifronte e o conteúdo das listas de dispensação obrigatória, procura-se estabelecer linhas orientadoras do provimento judicial, adotadas pelo próprio magistrado. O que se verá referir-se-á à apresentação e defesa do emprego de ferramentas viabilizadoras de uma jurisdição da saúde mais condizente com a natureza desse direito e sua previsão constitucional. A essas ferramentas é que ora se apregoa o uso do termo remédios.

Baseando-se nessa concepção, é possível dizer que, partindo da inteligência julgadora, os limites atuam de dentro para fora (eles partem da mente intelectiva do juiz, que os exterioriza em sua decisão), enquanto que os remédios têm seu campo de incidência de fora para dentro (são mecanismos que, contemplados pela lei ou resultantes de sua interpretação, vinculariam ou representariam possibilidade de sua adoção pelo juiz). Os limites se projetam e se estabelecem na decisão judicial; os remédios são observados anteriormente à sua prolação, consistindo prevenção à atividade judicial indesejada. Os remédios servem, na verdade, como método facilitador para que os limites sejam observados. Ambos agem em conjunto. E é salutar que assim seja.

Um magistrado que conheça o suficiente a respeito do orçamento, das finanças estatais e dos múltiplos aspectos que envolvem políticas públicas é desejável e, assim, propõe-se, como limite, que seja mandatória a análise econômica de decisão como a estudada. Antes disso, é preciso, logicamente, que o magistrado seja formado nessa seara. De igual forma, a sentença prolatada em ação coletiva em que se discute o fornecimento de medicamentos é melhor, em termos qualitativos e quantitativos, do que aquela emanada em um processo individual. Este é o limite proposto. Precedentemente, entretanto, o sistema normativo deve preconizar métodos de coletivização de demandas. Limites e remédios são verso e reverso de uma mesma moeda, indissociavelmente presentes no uso racional da capacidade e função judicial.

Os remédios foram pensados a partir de dois grandes eixos, ligados logicamente aos maiores problemas enfrentados pela sociedade quanto a decisões judiciais

Direito Constitucional..., pp. 442 e ss.). No presente estudo, como explicado, a palavra remédio mais se assemelha com o emprego médico do termo, já que são estudadas medidas para mitigação ou eliminação da atividade jurisdicional patológica em casos de políticas de saúde, como já qualificado. 
que veiculam políticas públicas. O primeiro é a ausência de informações e diálogo entre os Poderes; o segundo, a falta de preparo do aparato judicial (incluindo-se, aí, os instrumentos normativos empregados nos dias atuais) para lidar com essa estirpe de questões.

A pretensão é teorizar inúmeros mecanismos para a tutela judicial racional e equilibrada da saúde, de modo a, agindo concorrentemente, evitar-se, de todas as maneiras, a decisão patológica. Os remédios apresentados, embora apliquem-se, mormente, no processo judicial, são aptos a funcionar ao mesmo tempo, tanto quanto isoladamente - e, mesmo assim, tornando mais equilibrado o controle jurisdicional de políticas públicas de saúde.

Calcado nos ideais de justiça já estudados, a proposta parte de algumas premissas, todas decorrentes ou já trabalhadas na tese: a primeira, que direitos sociais são universais - logo, cabem a todos, sendo inconstitucional impor, de qualquer maneira, diferenciação quanto à sua prestação, salvo situações pessoais inerentes às diferenças entre pessoas; a segunda, que a realidade de hoje revela situação insustentável, de privilégio indevido aos que acessam o Judiciário; a terceira e derradeira, que é necessário, diante das premissas anteriores e considerando o importante papel dos juízes na sindicância de políticas públicas, que se racionalize tal sindicância. É sobre os remédios que, doravante, esta tese se debruçará.

\subsection{A COLETIVIZAÇÃO DAS DEMANDAS E O TRATAMENTO UNIFORME}

5.1.1 Universalização de direitos universais ${ }^{602}$. A isonomia dos direitos sociais

O aparente pleonasmo do título deste Item não foi descuido deste autor. Direitos universais como a saúde, a despeito dessa sua característica, são, não raras vezes, tratados como se fossem estanques, independentes e facilmente atribuíveis a um determinado titular. Que grave equívoco.

${ }^{602} \mathrm{O}$ tema da universalidade, essencial para o estudo da distribuição estatal de saúde, é reiteradamente referido nesta tese (v. Itens 4.2.1.3 e 5.5.1.1). 
Refere-se, especificamente, ao tratamento, pelo Judiciário, de questões de saúde como se simples direitos subjetivos fossem, desconsiderando, por completo, a verdadeira gênese desse direito e causando graves prejuízos à sua disposição pública ${ }^{603}$.

O ideal de universalidade exposto na Constituição não é uma característica inerente à condição de saúde do indivíduo, mas, sim, ao direito à saúde. Como já demonstrado e sustentado, linhas antes, a escolha realizada pelo constituinte originário foi resposta a anseios da população que viam no regime vigente até 1988 um mar de excluídos, o que andava na contramão, inclusive, dos direitos humanos internacionais. De fato, a universalização do acesso é uma das mais importantes diretivas da OMS, que tem se preocupado, nos últimos anos, em estudar mecanismos que garantam que mais pessoas tenham possibilidade de se valer das benesses da saúde estatal com o mesmo dispêndio de recursos $^{604}$.

Repita-se que a universalidade materializada pelo SUS faz da política brasileira de acesso à saúde um dos maiores programas mundiais de inclusão social: depois da Constituição, mesmo aqueles que não contribuíam para o fundo de previdência poderiam se valer dos serviços sanitários - tanto quanto os que contribuíam ${ }^{605}$.

Direitos sociais são universais na sua essência ${ }^{606}$. Por universais entendemse direitos que todos titulam. Quando se cogita de direitos sociais universais, fala-se de prestações que oneram o Estado em favor de todos e, não apenas, de alguns. A ideia de universalidade está diretamente conectada à noção de proibição de contemplação de uns, mas não de outros, quanto à mesma ação estatal - conclusão que, aliás, facilmente se depreende do quanto foi até aqui explorado ${ }^{607}$. De alguma forma, tal conceito está enraizado no princípio da isonomia, porque impede que somente uns recebam bens públicos.

\footnotetext{
${ }^{603}$ Estudo realizado pela Advocacia-Geral da União aponta como uma das causas da falta de noção da dimensão dos desarranjos causados pela intervenção judicial na saúde o fato das ações estarem divididas entre as Justiças (Federal e Estadual) e as várias Regiões e Estados, cada qual como se um universo autônomo e independente fosse, particularizando se a questão (Intervenção judicial na saúde pública. Panora ma no âmbito da Justiça Federal e Apontamentos na seara das Justiças Estaduais. Brasília: Advocacia.Geral da União, Introdução, disponível em: 〈http://portalsaude.saude.gov.br/portalsaude/arquivos/Panorama.pdf〉, acesso em 15.7.2013, 7:43h).

${ }^{604}$ A mensagem de abertura da Diretora-Geral deixa claro o intento da OMS em seu Relatório (2010): "Como indica o subtitulo, coloca-se firmemente a ênfase no caminho para a cobertura universal, um objectivo actualmente no centro dos debates sobre prestação de serviços de saúde".

${ }^{605}$ FERRAZ e VIEIRA, "Direito à Saúde...," p. 21.

${ }^{606}$ RAWLS, Justice as Fairness...; LOPES, José Reinaldo Lima. Direitos Sociais - Teoria e Prática. São Paulo: Método, pp. 132-138.

${ }^{607} \mathrm{O}$ art. $1^{\circ}$, VI do APLPP estabelece a universalidade como princípio do controle judicial de políticas públicas.
} 
A igualdade em sentido puro, contudo, significa outra coisa, um pouco mais particular. O dever de igualdade dirigido ao Estado demanda tratamento igualitário quando do fornecimento de seus serviços e bens. Seria possível que certo direito, embora universal, não fosse prestado de maneira isonômica, como se veria no hipotético caso de concessão, pela Administração Pública, de moradia para duas pessoas desabrigadas, quando uma tivesse à sua disposição abrigo público com quarto individual, chuveiro quente e roupas limpas todos os dias e a outra fosse albergado em instituição cujos aposentos fossem coletivos e o banho, frio: ambas estariam alentadas pelo Estado, embora não de forma semelhante. O aspecto universal do direito social de assistência estaria atendido, ainda que ao sacrifício da isonomia. Acesso universal significa acesso de todos, enquanto que acesso igual é o acesso aos mesmos bens quanto às características, qualidades e quantidades ${ }^{608}$. Em tema de direitos sociais, a isonomia tanto constitui fundamento de existência da universalidade quanto seu próprio limitador.

O fato é que, quanto aos direitos sociais, tal dicotomia não pode existir: ao contrário, admitir uma disparidade entre a universalidade e a igualdade é dizer que uns podem obter mais e melhor do que outros, o que, a um só tempo, contrariaria o conteúdo político-ideológico da isonomia que dá sustentação à sua positivação ${ }^{609}$, imporia perigo de tratamento desigual a situações análogas e revelaria desajuste social que levaria à sociedade a um nocivo inconformismo. O núcleo dos direitos sociais, destarte, é permeado tanto pela universalidade quanto pela isonomia ${ }^{610}$.

Não foi por acaso que o constituinte declarou, textualmente, a universalidade e a isonomia de um dos mais sensíveis direitos sociais, a saúde: existe, no artigo 196 da Constituição, a dupla garantia de universalidade, quando se coloca ser a saúde um direito de todos, assegurável via acesso universal, além da isonomia, quando se determina ser igualitário tal acesso ${ }^{611}$. A educação, de acordo com o artigo 205 da Carta,

\footnotetext{
${ }^{608}$ De novo, aqui, adverte-se que, obviamente, deve-se respeitar as particularidades inerentes a cada qual. Neste sentido, KELSEN, Hans. Teoria Pura do Direito, apud de BANDEIRA DE MELLO, Celso Antônio. Conteúdo Jurídico do Princípio da Igualdade. $3^{\mathrm{a}}$ ed. São Paulo: Malheiros, 2010, p. 11.

609 Justamente, o dever da norma (e, claro, da Administração Pública, por decorrência lógico-jurídica) de dispensar tratamento equânime às pessoas (BANDEIRA DE MELLO, O Conteúdo..., pp. 9-10).

${ }^{610} \mathrm{O}$ problema da desigualdade é algo quase arquetípico, pertencente ao inconsciente coletivo e que permeia a sociedade desde tempos imemoriais. Ele se observa em J. J. ROUSSEAU (Discurso sobre a origem da desigualdade e, mesmo, Do Contrato Social, em que ROUSSEAU imputa a origem da desigualdade à propriedade) e em I. KANT (Metafísica dos Costumes). Sobre os dois, FLEISCHACKER, Samuel. Uma breve história da justiça distributiva. São Paulo: Martins Fontes, 2006, pp. 81-90/99-110.

${ }^{611} \mathrm{O}$ que já foi debatido nesta tese demonstra que a saúde, além de revelar um dos mais sensíveis problemas quanto à intervenção jurisdicional em políticas públicas, é, sem dúvida, talvez o mais complexo dos direitos sociais, porque uma vida saudável não prescinde do uso de tantos outros bens vindos de prestações como alimentação, educação, assistência, lazer, moradia, transporte, saneamento básico e condicionantes como o
} 
também é direito de todos (universalidade) e o acesso e permanência na escola deve se dar em igualdade de condições ${ }^{612}$. Da mesma forma, o Estado garantirá a todos o exercício dos direitos culturais e acesso às fontes de cultura, tanto quanto é direito de cada um o exercício de práticas desportivas ${ }^{613}$. A universalidade e a isonomia dos direitos prestacionais já deixa o campo da teorização para serem alçadas ao império das normas positivas.

Entretanto, não é o que se observa na prática judicial de distribuição de saúde.

Algo que sempre incomodou e incomoda este autor, como estudioso do controle jurisdicional de políticas públicas, é a diferenciação, recorrente nessa seara, havida entre aqueles que postulam judicialmente - e, geralmente, conseguem o que buscam - e outros tantos - a maioria - incapazes de manejar instrumentos de efetivação de seus direitos, como o processo judicial. O dado mais terrível dessa dicotomia é que, no terreno das políticas públicas, normalmente, encontram-se na mesma situação fática tanto aquele que consegue se valer do Judiciário quanto os outros que, por inúmeros motivos, não ultrapassam os obstáculos de acesso que os separam dos ouvidos do Estado. $\mathrm{O}$ resultado evidente é que os primeiros terão grandes chances de ver seus interesses atendidos, enquanto que os segundos certamente permanecerão sob a inércia estatal que, no mais das vezes, caracteriza o direito de obter prestações públicas.

É extremamente difícil conceber uma sociedade cunhada sob o lastro básico da isonomia ${ }^{614}$, dado fundamental de qualquer regime democrático, a conviver com a dura realidade observada nos dias atuais. Das grandes discussões que gravitam em torno do controle judicial de atos administrativos - i.e., Separação de Poderes, legitimidade democrática do Judiciário, capacidade técnica dos juízes sindicarem prestações sociais nenhuma gera mais transtornos, pelo menos, para este autor ${ }^{615}$, do que a manifesta falta de

meio ambiente equilibrado e o trabalho digno. A saúde é um direito que integra o bem estar físico, social e mental. Nesse sentido, andou muito bem o artigo $3^{\circ}$ da Lei $n^{\circ} 8.080 / 90$, que instituiu o SUS. Ainda, o reconhecimento constitucional do meio ambiente equilibrado como essencial à sadia qualidade de vida está no caput do artigo 225 da Constituição.

${ }_{613}$ Artigo 206, I da Constituição.

${ }^{613}$ Artigos 215 e 217 da Constituição, respectivamente.

${ }^{614}$ A igualdade está presente no Preâmbulo da Constituição, tida, ali, como valor supremo da sociedade brasileira. Os dados de isonomia permeiam toda a Carta, mas, principalmente, seus artigos mais críticos e principiológicos, que são os primeiros. De fato, vê-se a igualdade presente textualmente nos incisos III e IV do artigo $3^{\circ}$, no inciso $\mathrm{V}$ do artigo $4^{\circ}$ e, mais sensivelmente, no caput do artigo $5^{\circ}$ e em diversos dos direitos e garantias ali preconizados.

${ }^{615}$ Em conferência realizada pelo CEBEPEJ na data de 3 de outubro de 2011, nesta Faculdade, Virgílio Afonso da SILVA confidenciou à plateia que o assomava incômodo semelhante. Segundo ele, era 
tratamento igualitário hoje observada entre os que alcançam e não alcançam o Judiciário. Alude-se, especialmente, às ações individuais que buscam, do Estado, vagas em escolas, fornecimento de medicamentos e próteses, transporte especial, acessibilidade, assistência de qualquer espécie e todas as medidas congêneres. Mas a ênfase, aqui, é sobre a tutela judicial do direito à saúde.

A situação exposta se torna ainda mais dramática se forem considerados os custos das prestações postuladas, que não são poucos, em contraposição às limitações orçamentárias $^{616}$. Aquele que consegue obter a prestação a todos devida via manejo de ação judicial impõe ao Erário, muitas vezes, ônus imprevisto - e já foi vista, aqui, a inequívoca responsabilidade do Estado por não prever tal despesa, já que concernente a direito constitucionalmente assegurado -, fazendo com que o Poder Público seja obrigado a alocar receitas para situações - mal ou bem - inesperadas, deixando outras necessidades, afetadas àquele numerário forçosamente deslocado, descobertas ${ }^{617}$. Na prática, isso significa que sempre que decisão judicial assegurar a efetividade de direito via prestação estatal, outras tantas pessoas ficarão à míngua, porque dinheiro suficiente não bastará para garantir a todos o que a Constituição determina ser-lhes devido.

Igualmente delicada é a consideração que, usualmente, aqueles que ultrapassam os custos que separam a situação de inércia de cada um da postulação judicial - custos econômicos, de informação, técnicos ou de compreensão - não figuram na parcela mais necessitada da população ${ }^{618}$. Normalmente, quem se vale do Judiciário para obter determinada providência estatal pertence às classes mais abastadas, capazes de entender que, para garantir seus direitos, será preciso se valer de ação judicial, contratar advogado de preferência, um bom advogado ${ }^{619}$ - comparecer ao fórum, conversar com o magistrado

extremamente problemático contemplar que situações idênticas fossem diferenciadas pela simples provocação do Judiciário de alguns, beneficiando-os.

${ }^{616}$ Sobre os custos dos direitos, em perspectiva extremamente realista, que também leva em conta alguns direitos normalmente negligenciados nesse debate (os direitos de abstenção ou negativos ou de primeira geração), ver Item 3.2.1.

${ }^{617}$ É a Lógica do Cobertor Curto, já tratada (Item 3.2.1.) cunhada para revelar como as ações judiciais que buscam prestações sociais possuem a cruel tônica de deixar outras tantas prestações análogas sem cumprimento, diante dos instintivos limites orçamentários (FERRAZ, Octávio Luiz da Motta. "Direito à Saúde, Escassez e o Judiciário". Artigo publicado no sítio da Folha de São Paulo - http://www.folha.com.br, em 10 de agosto de 2007).

${ }^{618}$ No já mencionado colóquio realizado pelo CEBEPEJ, em 3 de outubro de 2011, Luís Roberto BARROSO apontou pesquisa que demonstrou que a Defensoria da Bahia, em Salvador, era profundamente ineficiente porque ela se localizava em um dos bairros mais abastados da cidade, em que, inclusive, não havia transporte público. Este é um exemplo das barreiras concretas que separam o jurisdicionado do fórum.

619 À semelhante conclusão chegam VIEIRA e ZUCCHI quando, pesquisando as ações movidas contra o município de São Paulo em 2005 pleiteando medicamentos, apuraram que 54\% delas eram patrocinadas por advogados particulares ("Distorções causadas...", p. 220). 
e com promotores, sendo o caso, dentre outras providências. A realidade é que, em um país como o Brasil, a parcela mais pobre da população não tem adequado acesso à justiça ${ }^{620}$.

A OMS já concluiu que as pessoas mais ricas têm mais acesso aos serviços de saúde, ainda que públicos. Ela indica estudo que analisou que, na Austrália, os mais pobres tinham $52 \%$ menos probabilidades de realizar uma angiografia do que os mais ricos. Também faz referência a uma série de fontes que apontam tal tendência ao redor do planeta $^{621}$.

A verdade é que a dura realidade ora estampada, tolerada negligentemente pela sociedade, jurisprudência e alguma parcela da doutrina ${ }^{622}$, não pode sobreviver à evolução que representa o paradigma da universalidade de direitos sociais. A modernidade da atual sociedade democrática brasileira, que, de um lado, possui uma Constituição das mais belas do mundo, exemplo de garantia de direitos, a bem de formar uma sociedade harmônica, justa e igualitária, e, de outro, convive faticamente com a profunda depressão revelada nas mazelas sociais, não pode mais viver tranquila com a desigualdade promovida por aqueles que levam vantagem em qualquer aspecto, mesmo o judicial.

Claramente se coloca, aqui, mais um paradoxo: ao mesmo tempo em que é fundamental que se observe tratamento isonômico a todos, em termos de direitos sociais, como dotar esses direitos da qualidade necessária a fazê-los justiciáveis, no jargão típico de quem estuda a discussão judicial desses direitos? Em outras palavras, como qualificar como subjetivos direitos que devem ser dispensados igualmente a toda a sociedade, permitindo que uma única pessoa consiga um bem que, em tese, devesse ser entregue a

\footnotetext{
${ }^{620}$ Estatística levada a efeito pelo CNJ aponta que a incidência processos em que se discute o direito à saúde é maior nos Estados do Sul e Sudeste - os mais ricos da nação - do que nas outras localidades: Estados dessas regiões concentram nada menos do que $80 \%$ do total dessas ações ( $<$ http://saudefloripa33pj.wordpress .com/2011/04/28/processos-na-area-de-saude-passam-de-240-mil/>, acesso em 21.11.11, 13:15h). Outras pesquisas apontam a concentração da postulação judicial por (poucos) advogados privados: estudo realizado em 2006 no Estado de São Paulo indicou que 97,2\% dos advogados que atuavam em causas postulando medicamentos eram particulares, ou seja, alguém os pagava, considerando que o fornecimento de medicamentos não gera a hipótese de percentual sobre o êxito de eventual condenação pecuniária (simplesmente porque não há condenação em dinheiro) e que os honorários judiciais, nestes casos, não são vultosos (regra do artigo 20, §4 do CPC), tudo em CHIEFFI e BARATA, “Ações judiciais ...”, pp. 421-429. ${ }^{621}$ OMS, Relatório..., p. 85.

${ }^{622}$ Felizmente, a doutrina tem se preocupado com tal situação. Apenas para sumariamente citar, rememore-se SALLES, Carlos Alberto de. "Coisa julgada e extensão dos efeitos da sentença em matéria de direitos sociais constitucionais”, em GOZZOLI, Maria Clara; CIANCI, Mirna; CALMON, Petrônio e QUARTIERI, Rita. Em defesa de um novo sistema de processos coletivos. Estudos em homenagem à Ada Pellegrini Grinover. São Paulo: Saraiva, 2010, pp. 143-158; LOPES, José Reinaldo Lima. Direitos Sociais - Teoria e Prática. São Paulo: Método, pp. 132-138, e "Direito subjetivo e direitos sociais: o dilema do Judiciário no estado social de direito," em FARIA, José Eduardo de (Coord.) Direitos humanos, sociais e justiça. $1^{a}$ ed. São Paulo: Malheiros, 2205, pp. 113-143); COMPARATO, Fábio Konder. "Ensaio sobre o juízo de constitucionalidade de políticas públicas", em Revista dos Tribunais n ${ }^{\circ} 737$ (março de 1997), pp. 11-22; Virgílio Afonso da SILVA, no colóquio já referido (nota 615).
} 
todos que se encontrassem na sua mesma condição? Este paradoxo, sem dúvida, motivou a defesa da impossibilidade de dispensação judicial de bens fornecidos pelo Estado, tanto quanto inspirou o constituinte a incluir a expressa qualidade de direito subjetivo ao acesso ao ensino obrigatório e gratuito ${ }^{623}$. Mas o fato é que, com o atuar judicial que é vivenciado hoje, não há mais dúvidas de que direitos sociais estão, de fato e, com efeito, sendo tratados, sob qualquer hipótese, como subjetivos.

Isso não configura problema por si só: afinal, não fossem consideradas prestações prontamente exigíveis, direitos sociais poderiam jamais ser implementados, o que revelaria manifesta inconstitucionalidade e claro problema de inefetividade da norma. A celeuma surge com o mau uso da prerrogativa de exigibilidade autônoma e independente de certa prestação estatal em juízo. Esse mau uso tem íntima relação, de um lado, com o fato dos direitos sociais serem entendidos por subjetivos, e, de outro, com as limitações fáticas das reservas financeiras do Estado.

Com efeito, há uma crise muito séria ao se entender a existência e o custeio, pelo Estado, de direitos que devam ser dispensados a todos e de forma igualitária. As limitações reais dos recursos presentes nos cofres públicos impõem indesejável, porém inexorável limites à universalidade e, claro, à isonomia. Uma coisa é determinar que o Estado e as pessoas não interceptarão comunicações umas das outras; outra, bem diversa, é estabelecer o acesso gratuito aos meios de transporte aos de certa idade. O envelhecimento da população, nesse caso, será determinante à despesa do Estado para fazer frente a esse seu dever. No limite, receitas terão que ser realocadas de outras pastas, ou novas fontes de custeio deverão ser criadas, pois os dinheiros públicos são limitados ${ }^{624}$.

A verdade é que a Constituição do Brasil previu uma série de custosas prestações a serem outorgadas a seus concidadãos; na prática, o pesado fardo oriundo da observância desses direitos acaba gerando a caótica situação vista todos os dias: médicos do SUS em greve, tratamentos que não chegam a todos, escolas impassíveis de frequência, transporte em situações indignas ${ }^{625}$. Tem-se a prova que o Estado não consegue, hodiernamente, dar a todos aquilo que a Constituição lhe manda. A despeito de essa deficiência poder ser imputada à incompetência, à inoperância e à corrupção, ela

\footnotetext{
${ }^{623}$ Artigo 208, $\S 1^{\mathrm{o}}$ da Constituição.

${ }^{624} \mathrm{Cf}$. Itens 4.2.1 e 5.2.2, em que se abordam a escassez e a reserva do financeiramente possível.

${ }^{625}$ Como exemplo, a reportagem de $O$ Globo que denuncia verba da saúde sendo utilizada para a construção de pistas de skate e academias de ginástica (edição de 11.10.2011, Segundo Caderno, pp. 23-24). Da mesma forma, foi amplamente divulgada a paralisação dos médicos do SUS por 24 horas, em protesto contra sua remuneração. Uma análise crítica do desleixo com o sistema de saúde que motivou a paralisação foi feita por Ricardo NOBLAT e está disponível em: <http://oglobo.globo.com/pais/noblat/posts/2011/10/26/a-greve-dosmedicos-do-sus-editorial-413320.asp>, acesso em 19.11.11, 20:57h.
} 
certamente é composta pela falta de receita, que não comporta todos os compromissos entregues ao gerenciamento do Estado.

Considerando, pois, os paradigmas de que direitos sociais, como a saúde: (a) são universais, isto é, todos têm a prerrogativa de obtê-los; (b) quando deduzidos em juízo, por vezes, colocam-se indivisíveis ou incindíveis; (c) devem ser prestados igualitariamente, respeitando-se, claro, as diferenças ínsitas a cada pessoa; e (d) tais direitos demandam custeio estatal a partir de reservas que são limitadas, a medida judicial que, individualmente, postula certo direito social como subjetivo, requerendo ao juiz que outorgue seu uso àquele postulante, e somente a ele, é, ao mesmo tempo, violadora da essência do direito que persegue e disfuncional.

A ação individual, em termos de políticas públicas que versam direitos sociais, viola a essência desses direitos porque não observa a necessária universalidade: de fato, como já mencionado no intróito deste escrito, nem todos conseguem deduzir em juízo seus anseios, nem todos são aptos a ultrapassar as custosas barreiras que se colocam desde o íntimo da pessoa até o carimbo do protocolo do fórum ou a distribuição eletrônica com certificação digital. Este é um problema de acesso à justiça que, invariavelmente, existe e, no Brasil, ainda é mais cruel, porque é a parcela mais rica da população que tem acesso ao Judiciário $^{626}$.

A questão dos custos é fundamental para entender a disfunção causada pelas ações individuais que veiculam pretensões relacionadas a direitos garantidos pelo Estado. Mesmo em metrópoles como São Paulo, boa parte das pessoas não sabe explicar qual a serventia de um juiz. Muitos sequer conhecem seus direitos ${ }^{627}$. Numerosos são aqueles que pensam que entre eles e um advogado existe uma barreira intelectual e financeira intransponível, que de per si os inibe a buscar réstia do que entendam ser seu direito ${ }^{628}$. Aí reside importante aspecto da questão: se os direitos que nos preocupam nesta tese são universais e devem ser dispensados de maneira igualitária, a parcela dos titulares dos bens

\footnotetext{
${ }^{626}$ Conforme já relatado (nota 620) e na fala de BARROSO (nota 618).

${ }^{627}$ Ver KOMESAR e SADEK na nota 681.

${ }^{628}$ Aqui vale reproduzir, textualmente, as palavras de Ada Pellegrini GRINOVER: “(...) a deficiência de informação completa e correta, a ausência de conscientização de enorme parcela da sociedade, o desconhecimento dos canais de acesso à justiça, a distância existente entre o povo e o Poder Judiciário, tudo a constituir gravíssimos entraves para a intervenção de terceiros, individualmente interessados, nos processo coletivos, e mais ainda para seu comparecimento a juízo visando à exclusão da futura coisa julgada." (Código de Defesa do Consumidor..., p. 907). O mesmo pensamento da professora para explicar a necessidade de representatividade nas ações coletivas serve para ilustrar as dificuldades que os jurisdicionados possuem na busca por seus direitos. Também SALLES, ao estudar o acesso específico da população à tutela ambiental, coloca como entraves uma série de custos relacionados à tutela do meio ambiente, como, por exemplo, os custos com aptidão técnica e relacionados à complexidade do objeto (Execução judicial...).
} 
correspondentes que não consegue se dirigir ao Judiciário, pelas mais variadas razões, quedar-se-á desassistida, à míngua das políticas que asseguram seus direitos. Daí ser inevitável a primazia da tutela coletiva sobre a individual, porque é a medida transindividual que propicia tutela mais racional do bem essencialmente coletivo, seja durante seu processamento, seja, inequivocamente, na respectiva decisão.

Além dessa questão, a ação individual também está mais apta a ser antiisonômica porque a decisão judicial é controlada pelo pedido realizado na inicial, ou seja, é o próprio postulante quem vai definir o que é bom para ele, e, não, partir de política programada para atender eficazmente e de forma isonômica todas as pessoas nas mesmas condições (coisa que, a rigor, é feita pelas ações estabelecidas pela Administração Pública). A inércia da jurisdição e o princípio dispositivo permitem esse tipo de comportamento. São comuns, por exemplo e como já demonstrado, pedidos de concessão de medicamentos que não estão incluídos nas listas de dispensação obrigatória do SUS e que possuem os mesmos princípios ativos de outros que lá se encontram, ou porque, simplesmente, determinada providência é mais conveniente ao autor ${ }^{629}$. De fato, se todos devem merecer tratamento igual, não é possível que haja o prevalecimento de anseios pessoais materializados em um pedido individual ${ }^{630}$ sem que ocorra justificativa adequada $^{631}$.

Tal impossibilidade é ainda mais relevante se for levado em conta que decisões judiciais manifestadas em casos individuais sempre se dão em detrimento de outros, o que acontece porque o Erário é limitado e todas as vezes que se procede a uma alocação forçada, tipicamente oriunda de uma decisão judicial condenatória (ainda que provisória), retira-se dinheiro de uma rubrica para fazer frente ao cumprimento do preceito judicial $^{632}$. Por isso que a medida individual é disfuncional: sob os propósitos do constitucional e intangível direito de ação, ela leva a situações que, longe de beneficiar, prejudicam deveras a população, gerando anomalias que deturpam o verdadeiro significado das normas constitucionais que garantem prestações sociais, sobretudo quando verificadas

\footnotetext{
${ }^{629}$ Foi o que sucedeu em ação individual em que jurisdicionada pediu, contra o Estado da Bahia, o fornecimento da bomba de insulina Accu-Check. O pedido foi tido por improcedente porque o tratamento da moléstia prescindia da providência. Em seu parecer, o Ministério Público asseverou que o direito à saúde constitucionalmente garantido não permite o atendimento individualizado e isolado aos anseios de cada qual, enquanto outros na mesma situação recebem o tratamento padronizado pelo SUS (<http://pgeba.jusbrasil.com.br/noticias/1502850/decisao-judicial-promove-seguranca-juridica-do-sus $>$, acesso em 2.11.11, 18:00h).

${ }^{630}$ BARCELLOS, A Eficácia ..., p. 280.

${ }^{631}$ ADIN no 3.305-DF, Rel. Min. Eros GRAU, j. em 13.9.2006. A Corte revela que a violação à isonomia, ocorrida quando ausente justificativa adequada para tanto, resulta em medida arbitrária.

${ }^{632}$ V. Itens 4.1.3. e 4.2.1.3..
} 
ocorrências de manipulação dolosa de ações judiciais para beneficiar interesses $\operatorname{privados}^{633}$.

E há mais: ao se colocar diante de uma medida individual que postula acesso do autor ao transporte público especial, a ação é tratada como se versasse um problema isolado, pontual e específico, e, não, como providência tipicamente peculiar às políticas públicas. O juiz decidiria tal ação, então, como se declarasse resolução contratual de instrumento celebrado entre duas pessoas ou condenasse ao pagamento de certa obrigação por quantia, não se dando conta da dimensão coletiva que essa sua decisão poderia ter. A medida individual obscurece a macroanálise do problema, a verificação consequencialista da decisão e permite que o magistrado decida mais com base na emoção do que na razão (ou na técnica jurídica) ${ }^{634}$.

Os fura-filas das medidas judiciais individuais em casos de políticas envolvendo direitos sociais devem ser coibidos, como medida de isonomia, universalidade e funcionalidade do Estado. O problema é que esta realidade, no caso da saúde, já se tornou um vício: os jurisdicionados preferem ir ao Judiciário a se dirigir aos postos de saúde. Em muitos casos, como comentado, medidas judiciais pleiteiam medicamentos já incluídos nas listas do SUS ${ }^{635}$. Por mais que faltem esses medicamentos, certamente houve circunstâncias em que o postulante preferiu ingressar diretamente em juízo ao invés de, primeiro, procurar obter administrativamente o fármaco. Em outros casos - pasme-se ações judiciais são instruídas sem receita médica ou sem o total de prescrições necessárias

\footnotetext{
${ }^{633}$ V. CHIEFFI e BARATA (“Ações Judiciais...”, p. 421).

${ }^{634}$ É o que acontece nos casos de medicamentos, em que o juiz se imagina negando o direito do postulante de ter saúde, decidindo em moldes da chamada justiça de misericórdia de José Reinaldo Lima LOPES (Direitos Sociais - Teoria e Prática. São Paulo: Método, pp. 132-138). Luiz Roberto BARROSO concorda com a tese. Segundo ele, “(...) O juiz, por vocação e treinamento, normalmente está preparado para realizada a justiça do caso concreto, a microjustiça. Ele nem sempre dispõe das informações, do tempo e mesmo do conhecimento para avaliar o impacto de determinadas decisões, proferidas em processos individuais, sobre a realidade de um segmento econômico ou sobre a prestação de um serviço público. Tampouco é passível de responsabilização política por escolhas desastradas. Exemplo emblemático nessa matéria tem sido o setor da saúde. Ao lado de intervenções necessárias e meritórias, tem havido uma profusão de decisões extravagantes ou emocionais em matéria de medicamentos e terapias, que põem em risco a própria continuidade das políticas públicas de saúde, desorganizando a atividade administrativa e comprometendo a alocação dos escassos recursos públicos. " BARROSO, neste único excerto, aborda os mais sérios aspectos da intervenção judicial em políticas de saúde, apontando para a anomalia da ação individual que requer terapias e medicamentos. Tais aspectos são: a) a deficiente formação dos magistrados para lidar com a questão; b) a falta de informações sobre as ações do Executivo; c) carência de estrutura judicial para tratar esse tipo de demanda; d) deturpação do verdadeiro impacto da decisão em função dela se dar em caso individual; e) falta de responsabilização dos magistrados por escolhas equivocadas; f) decisões emocionais em tema de saúde; e g) desmedida intervenção judicial, prejudicial às ações dos Poderes majoritários, sobretudo, do Executivo. Ele, enfim, arremata: "Em suma: o Judiciário quase sempre pode, mas nem sempre deve interferir." ("Judicialização, Ativismo Judicial e Legitimidade Democrática", em Constituição \& Ativismo ..., pp. 287-288).

${ }^{635}$ BORGES e UGÁ, "Conflitos e impasses...", p. 62.
} 
para a verificação do cabimento do tratamento ${ }^{636}$. E há mais: em estudo analítico, constatou-se que 59,3\% das prescrições médicas que acompanhavam as iniciais não satisfaziam o critério de legibilidade exigido - ou seja, o juiz possivelmente nem entendeu o que estava escrito no receituário, guiando-se exclusivamente pela inicial, que é normalmente redigida em computador e, por isso, legível - com a diferença é que sua redação se dá pelo parcial causídico. Ainda, verificou-se que das quinze prescrições originadas do SUS, apenas 6,7\% indicavam seu fármaco pelo nome genérico, conforme exigido pela Lei $n^{\circ} 9.787 / 99^{637}$, o que pode sugerir o direcionamento a certos laboratórios que tiveram o nome comercial de seus medicamentos prescritos, já que o uso de tal expediente é apto a levar o juiz a determinar a compra daquele específico remédio, e, não, em havendo, do equivalente.

O incômodo referido parágrafos antes, relacionado ao uso das ações individuais para tratamento de temas universais como a saúde, tem a ver com a ideia de Justiça, e aí invoquem-se os conceitos de igualdade de oportunidade, de Rawls, e igualdade de consideração, de Dworkin, para aclarar melhor a celeuma.

Rawls entendia esse seu postulado como um de seus dois princípios de justiça. Para ele, e já se viu, as pessoas devem ostentar e usufruir de seus direitos exatamente na mesma extensão umas das outras (primeiro princípio), sendo que desigualdades sociais e econômicas só seriam toleradas se, ao mesmo tempo, significassem vantagens extensíveis a todas as pessoas e todas essas pessoas possuíssem as mesmas oportunidades de acesso aos bens públicos (segundo princípio). Com isso, de acordo com Rawls, a distributividade de bens seria mais justa ${ }^{638}$.

A Teoria mostra quão problemática é a obtenção de bens relacionados a políticas públicas pela via das ações individuais. Se o déficit de informações a respeito da movimentação da máquina judicial, o desinteresse em litigar ou, simplesmente, a questão econômica impedem os titulares de direito de se dirigir aos magistrados, então não houve igualdade de oportunidade e, assim, quem ultrapassou todos os obstáculos obteve bem à revelia do ideal de Justiça.

\footnotetext{
${ }^{636}$ FIGUEIREDO, Tatiana Aragão. Análise dos medicamentos fornecidos por mandado judicial na Comarca do Rio de Janeiro: a aplicação de evidências científicas no processo de tomada de decisão. Dissertação de Mestrado defendido na Escola Nacional de Saúde Pública Sérgio Arouca, março de 2010, p. 36.

${ }^{637}$ SANT'ANA, J.M.B., apud de FIGUEIREDO, Análise dos medicamentos..., p. 35.

${ }^{638}$ RAWLS, A Theory of Justice ..., pp. 60-61. Os dois princípios já foram mencionados nas notas 452 e 497 retro.
} 
Já Dworkin entende que o ideal de igualdade não prescinde do direito de a todos garantirem-se iguais oportunidades, recursos ou ônus ${ }^{639}$. Se as pessoas se colocaram em posições desiguais por fruto de suas escolhas individuais, partindo elas de uma mesma posição quanto aos recursos disponíveis (ideia de igualdade de recursos) ${ }^{640}$, assume Dworkin que não haverá injustiça ${ }^{641}$. A crise ocorre quando parcela da população é absolutamente desconsiderada na distribuição de bens, com o que sua posição de fragilidade quanto à repartição do bolo não foi fruto de suas escolhas, mas the fora imposta. Nessa hipótese, não ocorreria a igualdade de consideração preconizada por Dworkin, caracterizando-se a injustiça.

Seja por uma, seja por outra teoria de justiça vê-se o problema criado pela ação individual que requer do Estado concessão de medicamento para tratamento de uma moléstia que atinja mais pessoas, estas que não serão tratadas porque não acionaram o Judiciário, fosse por qual razão fosse. É impossível determinar, na população brasileira, quem se coloca em posição deficitária na busca pelos provimentos judiciais por escolha própria ou imposição social, porque, em nosso País, a marca é a desigualdade - o que faz com que a igualdade de consideração seja considerada suspeita $^{642}$. Mas fato é que a julgar os custos do processo, os valores de honorários, a tecnicidade do Direito e a ausência de sérias políticas de acesso à justiça, é possível afirmar que grande parte da população brasileira, sobretudo a parcela mais carente, não está habilitada a buscar o Judiciário, ou seja, ela não foi igualmente considerada, a ela não foi prestada a mesma oportunidade dada ao autor de uma ação.

Não se trata, aqui, de adotar a precipitada posição de ser o Judiciário um pernicioso gestor da igualdade, mas, sim, de demonstrar os perigos de certas decisões

\footnotetext{
${ }^{639}$ DWORKIN, Taking Rights Seriously.... 227.

${ }^{640}$ A ideia de igualdade de recursos coloca DWORKIN no panteão dos modernos jusfilósofos. Terminou, enfim, por se dissociar da perigosa interpretação de outras teorias (como, a propósito, a de RAWLS) de que o Estado era o exclusivo culpado pelas desigualdades do povo. De fato, a assunção da posição de que os menos favorecidos, sob qualquer hipótese, devem obter para si recursos dos mais ricos sempre foi tida por esquerdista e, então, rechaçada pelos filósofos liberais. Quando DWORKIN estabelece que a igualdade de recursos deve ocorrer no momento em que as escolhas de cada qual são realizadas (e não de acordo com o bem-estar adquirido por cada um pela correta aplicação ou não dos recursos), ele invariavelmente coloca ônus sobre as opções exercidas pelos indivíduos. Sendo os mesmos os recursos disponíveis para as pessoas, a desigualdade observada no futuro não é relevante, a não ser que fruto de circunstâncias impostas ao indivíduo (como ocorreria, i.e., se certa pessoa passasse a ostentar certa deficiência física). Uma belíssima sinopse sobre o pensamento do filósofo britânico pode ser encontrado em FERRAZ "Justiça Distributiva ...,", pp. 243-253.

${ }^{641}$ DWORKIN, Sovereign Virtue ..., pp. 65 e ss.

${ }^{642}$ DWORKIN sustenta que em um Estado marcantemente desigual, a igualdade de consideração é suspeita (Taking Rights Seriously..., p. IX). É precisamente o caso do Brasil.
} 
judiciais para os propósitos da justiça, sobretudo aquelas que sindicam bens universais e dispensáveis em igual grau a toda a sociedade.

Deve-se lembrar, ainda, que o direito a qualquer ação ou prestação estatal de saúde - seja internação, obtenção de medicamento, realização de tratamento ou transplante, inclusão de fármaco em lista, dentre outras - é fundamentalmente coletivo, valendo tanto para o que se chamou essencialmente coletivo, quanto para o denominado acidentalmente coletivo. $\mathrm{Na}$ primeira hipótese, porque a necessidade de tratamento coletivo - e, não, individual - advém da própria natureza do direito apresentado em juízo, definido pelo objeto da demanda: se esse objeto for indivisível ou incindivel, os efeitos lógico e prático da decisão serão sua extensão a todos que desse direito se aproveitam; na segunda ocasião, porque os direitos pertencentes a indivíduos, normalmente condizentes com saúde e exercidos contra o Estado, são homogêneos e comuns, ou seja, as questões coletivas prevalecem sobre as individuais ${ }^{643}$.

A realidade torna ainda mais acintosa a necessidade de esvaziar as ações judiciais individuais que buscam bens sociais, que só devem ser admitidas em casos muito especiais. É imperioso notar que mesmo o APLPP, que celebra a primazia da tutela coletiva de políticas públicas sobre a individual, só as tolera em casos de violação ao mínimo existencial do indivíduo ou quando a norma constitucional for sobremaneira clara que não suscite qualquer dúvida, sendo razoável o pedido e desarrazoada a conduta administrativa propugnadora da violação alegada. Ainda assim, o juiz deverá notificar os legitimados à propositura da ação coletiva para, sendo o caso, proporem tal ação.

Àqueles que julgam que tal proposição vilipendia o conteúdo do inciso XXXV do artigo $5^{\circ}$ da Constituição, responda-se afirmando que também essa norma há de ser interpretada, e a interpretação da indeclinabilidade da jurisdição que mais coaduna com o juízo de políticas públicas de saúde é aquela que clama pela tutela universal e racional, o que, de resto, só se atinge com a tutela coletiva do tema.

É preciso, assim, que sejam propostas alternativas para afastar o problema. Concomitantemente, não se pode extirpar do jurisdicionado o poder de se dirigir ao Judiciário na busca pela solução a um problema que o aflige, e cuja solução o direito lhe assegura. É tempo, apenas, de racionalizar o acesso ao Judiciário, de forma a que a patologia não se torne a regra, como se vê hoje.

${ }^{643}$ Em paralelo à Rule 23 (b) 3 das Federal Rules of Civil Procedure, cf. já anotado. 
As ações coletivas (evidentemente, aquelas que buscam obter ações do Estado que atinjam todas as pessoas nas mesmas condições de necessidade) contribuem fortemente para a isonomia e o acesso universal. Se o correspondente pedido tiver o condão de abranger toda uma coletividade, vale dizer, todos os que se encontrem em posição semelhante, então universalidade e isonomia serão observadas. O problema é que o só manejo das ações coletivas como hoje contempla o sistema é insuficiente, já que elas não são isoladamente capazes de evitar que alguém proponha sua ação individual; antes, convivem perfeitamente bem ações coletivas e individuais ${ }^{644}$.

O que se pretende concluir com este arrazoado é que a partir da universalidade, da isonomia e das duas teorias de justiça expostas, é possível afirmar que a própria raiz do direito à saúde, universal e isonômico em sua essência, leva toda e qualquer pretensão exercida contra o Estado a ostentar certo núcleo, em maior ou menor grau, transindividual.

De fato, não existe mal que acometa apenas uma ou duas pessoas: mesmo doenças raras vitimam centenas de indivíduos no mundo. Determinado paciente da Doença de Gaucher ostentará exatamente as mesmas características de outro paciente, até o limite de suas respectivas individualidades. Serão ambos tratados com semelhante medicamento, e não só eles, mas todos os doentes de Gaucher ${ }^{645}$. Havendo dever do Poder Público fornecer o tratamento adequado e ocorrendo omissão respectiva, todos os pacientes da moléstia serão prejudicados, e, daí, todos eles terão o isonômico e parelho direito de buscar do Estado aquilo que lhes falta. Se a dose para o primeiro é de uma ampola por dia e, para o segundo, de duas, esta é uma questão que não infirma a predominância dos temas coletivos sobre os individuais. Daí tratar-se de direito consideravelmente coletivo.

Com efeito, qualquer pretensão de saúde tem em si componente coletivo, mesmo aquele mais ordinário direito do jurisdicionado obter o medicamento que, previsto nas listagens do SUS, não está disponível no posto de saúde: como ele, todos os demais pacientes que precisam da droga também não serão providos, com o que não se há falar de direito à saúde puramente individual sob a ótica da justiça e da equidade ${ }^{646}$. Daí as

\footnotetext{
${ }^{644}$ A relação entre demandas individuais e coletivas é regrada pelo artigo 103 do CDC.

${ }^{645}$ A Doença de Gaucher é uma anomalia rara que se enquadra na classificação dos erros inatos do metabolismo. Mesmo sendo poucos os pacientes. No Brasil, estima-se serem cerca de quinhentos, enquanto que, no mundo, incluindo esse número, são cinco mil portadores (<http://www.doencadegaucher.com.br/paci entes/conheca_doenca_de_gaucher/o-quanto-e-comum-a-doenca-de-gaucher〉, acesso em 29.9.2013, 16:17h).

${ }^{646}$ Ada Pellegrini GRINOVER classifica as ações judiciais pleiteando saúde em ações coletivas, individuais, individuais com efeitos coletivos e pseudoindividuais. Ada sistematiza as ações, destarte, conforme seu resultado e respectivos efeitos, isolados de acordo com o objeto da causa. Segundo ela, as ações coletivas
} 
pretensões relacionadas à saúde encaixarem-se perfeitamente, em menor ou maior grau, no que Barbosa Moreira, com a maestria que sempre lhe foi própria, convencionou denominar direitos acidentalmente e essencialmente coletivos ${ }^{647}$.

\subsubsection{As ações coletivas no trato da saúde}

A teoria das ações coletivas casa perfeitamente com a hipótese ora estudada. Já que a saúde é direito universal, ou seja, direito que, traduzido em prestações estatais, deve ser entregue indistintamente a todos, a decisão que abranger maior número de pessoas em semelhante situação (por exemplo, pessoas portadoras do vírus da gripe A) será a que mais atende não apenas ao comando constitucional, mas, propriamente, ao âmago do direito à saúde. Essa hipótese assenta nas ações coletivas o modo adequado pelo qual o juiz entrega aos jurisdicionados frações de políticas públicas de saúde ${ }^{648}$. Se confirmada essa hipótese, a coletivização - ou, ao menos, o tratamento uniforme - de demandas ligadas ao tema pode constituir importante remédio para decisões judiciais ditas patológicas.

A razão de se pensar na adoção do modelo coletivo de proteção do direito à saúde possui uma causa preponderante e um pernicioso sintoma que, oriundo da

pleiteiam providências transindividuais, como a aprovação de um novo medicamento e sua inclusão nas listas de dispensação obrigatória; nas causas individuais, simples direito subjetivo é almejado, como, por exemplo, aquele que requer transplante ou internação; as causas individuais com efeitos coletivos são aquelas em que a ação proposta é individual, mas sua decisão atingirá toda a coletividade, como é o caso de eventual medida judicial em que autor pede a revisão de cláusula de seguro saúde, decisão que, favorável, poderia ser aproveitada por toda a coletividade; e, por fim, as pseudoinviduais são causas que surgem individuais, mas com objetivo incindível, claramente multilateral e assemelhadas ao litisconsórcio passivo unitário, já que a decisão dada na causa invariavelmente atingiria toda a coletividade, precisamente, em função do objeto. Exemplo é o da ação que, individual, obtém ordem para inclusão de determinado medicamento que interessa ao autor nas listagens do SUS. Neste caso, todas as pessoas precisadas do mesmo fármaco seriam beneficiadas, tendo a decisão inequívoco efeito erga omnes. "A Coisa Julgada no Litisconsórcio Passivo Unitário. O Exemplo de Ações Coletivas e Individuais no Campo da Saúde”, no prelo. Sobre as ações pseudoindividuais, ver nota que revela o parecer de Kazuo WATANABE a seguir.

647 BARBOSA MOREIRA, José Carlos. Temas de Direito Processual-Terceira Série. Rio de Janeiro: Saraiva, p. 193.

${ }^{648}$ Há quem discorde, ao argumento de que: “(...) esses entendimentos [de primazia das ações coletivas sobre as individuais] conduzem a uma incorreta primazia do coletivismo sobre o individualismo, o que redundaria no massacre das opções individuais em prol da coletividade." (LAGE, Lívia Regina Savergnini Bissoli. "Políticas públicas como programas e ações para o atingimento dos objetivos sociais do Estado", em $O$ Controle Jurisdicional..., pp. 157-158). O que vê nesta tese é que o ora autor parte de bases muito diferentes para concluir que, de fato, o modelo que mais se apropria às peculiaridades dos direitos sociais é, mesmo, o coletivo. Não é necessário temer a intervenção excessiva do Estado na coisa individual, até porque, no caso estudado, o bem em jogo é inequivocamente público, embora de fruição muitas vezes individualizada. 
individualização, deve ser debelado. A causa é encontrada, justamente, no direito material, cuja regra é a do provimento universal (e também integral e igual) de saúde a todas as pessoas do Estado brasileiro ${ }^{649}$. O sintoma negativo é representado pelo fato de que, na tutela individual, só consegue acesso à providência pleiteada aquele que ultrapassa as barreiras (econômicas, informativas, culturais) que o leva ao Fórum, enquanto que a pessoa que, em condição análoga, não enfrenta tais óbices, não será contemplada pelo processo ${ }^{650}$, contrariando, destarte, a própria universalidade.

O objeto tutelado pelas ações coletivas possui, por sua própria natureza, interesse social que condiz com alguns dos valores que a sociedade reputa como mais elevados, assim eleitos ${ }^{651}$ pela mesma sociedade ${ }^{652}$. São temas como meio ambiente, consumidor, idoso, criança e adolescente, cultura, saúde, lazer, educação, entre outros. A indivisibilidade do objeto e a universalidade dos direitos coletivos (rectius, essencialmente coletivos) explica a típica assertiva que tais direitos pertencem, ao mesmo tempo, a todos e a ninguém ${ }^{653}$, porque, a despeito de todos os titularem, não podem ser fracionados, com parcela atribuída a cada qual, tendo de ser, necessariamente, objeto de tutela única que contemple a todos da maneira mais isonômica possível. Daí a relevância dos direitos metaindividuais para o interesse público ${ }^{654}$. Trata-se de direitos que, quando apresentados individualmente em juízo, são objeto das malfadadas ações pseudoindividuais ${ }^{655}$, e

${ }^{649}$ É do que trata o artigo 196 da Constituição e artigo $7^{\circ}$, I da Lei no ${ }^{\circ} 8.080 / 90$.

${ }^{650}$ Existe uma crítica muito severa ao uso distorcido das ações individuais que pleiteiam medicamentos. Apoiados em notícias a respeito, muitos estudiosos denunciam o uso direcionado da via judicial por advogados oportunistas. Sobre o assunto, ver BARATA e MENDES, pp. 60-78. Também estudo estatístico muito interessante se propôs a analisar a influência da indústria farmacêutica nas ações individuais que pleiteiam medicamentos. As autoras partiram da hipótese de que as medidas judiciais servem de reserva de mercado para os fabricantes de fármacos, que estimulam a litigância para que o Estado seja obrigado a adquirir e distribuir seus produtos. Destaca-se, no estudo, o impressionante número de que, no ano de 2006, $35 \%$ das ações que requeriam o fornecimento de medicamentos contra o Estado de São Paulo foram patrocinadas por apenas $1 \%$ de todos os advogados que militaram em todas as causas (CHIEFFI e BARATA, "Ações judiciais...", pp. 421-429).

${ }^{651}$ Sobre as escolhas sociais e respectiva responsabilidade pelo atendimento a tais escolhas, rememore-se DWORKIN na nota 640.

${ }^{652}$ MANCUSO, Rodolfo de Camargo. Interesses Difusos, $6^{\text {a }}$ edição. São Paulo: Editora Revista dos Tribunais, 2004, p. 29; YEAZEL, Stephen C. "Collective Litigation as Collective Action". University of Illinois Law Review, v. 1989, pp. 43-68; VERÍSSIMO, Marcos Paulo. A Judicialização ..., p. 234.

${ }^{653}$ Nesse sentido, VIGORITTI, Vincenzo. Interessi Colettivi e Processo - La Legitimazioni ad Agire, Milano, Giuffré, 1979. Também CAPPELLETTI e GARTH. Access to Justice..., pp. $26-28$.

${ }^{654} \mathrm{O}$ tratamento especial do direito coletivo pode ser visto em Owen FISS (Um Novo Processo Civil..., p. 90), quando o autor estabelece aspectos fundamentais do processo por ele chamado estrutural e sua diferença para o processo tradicional. Para FISS, o remédio judicial tradicional decorre necessariamente de uma violação, e esse remédio guarda quase que uma correspondência necessária com tal violação. No processo estrutural isso nunca acontece: o remédio pode ser adotado de inúmeras maneiras. Por isso, conclui o professor que: "A medida judicial estrutural é indubitavelmente instrumental".

${ }^{655}$ A expressão deriva do conceito de demandas pseudocoletivas de Luiz Paulo da Silva Araújo Filho, cunhado para tratar de fenômeno inverso ao ora apresentado (WATANABE, Kazuo, et. al.. Código de Defesa do Consumidor comentado pelos Autores do Anteprojeto. $9^{\mathrm{a}}$ ed. Rio de Janeiro: Forense Universitária, 2007, 
malfadadas porque lançam ao magistrado argumentos de direito puramente subjetivo para albergar questões indivisíveis ${ }^{656}$.

Tecnicamente, direitos objetos de ações coletivas ou são transindividuais em sua gênese, ou o são por conveniência político-legislativa. Na primeira hipótese encontram-se os direitos intitulados coletivos (em sentido estrito) e difusos, aqueles a que Barbosa Moreira denominou essencialmente coletivos; na segunda, estão os que o professor encontrou por bem chamar de acidentalmente coletivos ${ }^{657}$. Os essencialmente coletivos assim são classificados em função de sua característica-mestre, que é o cunho incindível, ou seja, a natureza indivisível que ostentam. Diferem um do outro em função da determinação de sujeitos e da ligação entre esses sujeitos, ou com a parte contrária, por relação jurídica antecedente (no caso dos coletivos em sentido estrito) - para os difusos, a ligação se dá por circunstâncias fáticas e seus titulares são sempre indeterminados. A marca de ambos, contudo, é da indivisibilidade do objeto, com o que não há individualidade - “A quem pertence o ar que respiro?”, já indagou, com maestria, Mauro Cappelletti ${ }^{658}$, demonstrando que bens essencialmente coletivos não podem ser individual e isoladamente apropriados. No caso dos individuais homogêneos, os direitos em tela serão singulares, mas contendo núcleo predominantemente comum, apto a reuni-los em torno de uma única tutela para, então, particularização haver. Na categoria dos acidentalmente coletivos, é correto afirmar que os direitos nascem singulares, coletivizam-se por força normativa e, depois, voltam a se particularizar quando da entrega do bem da vida ao final objetivado $^{659}$.

pp. 798-799). Aqui, como visto, são pseudoinviduais aquelas ações que se apresentam como fundadas em direito subjetivo singular, mas tratam de remédio em todo subjetivamente plúrimo (GRINOVER na nota 646). Adiante, em nota, ver conceito WATANABE a respeito.

${ }^{656}$ Kazuo WATANABE, em parecer analítico da multiplicidade de processos individuais propostos sob o auspício de discutir a assinatura básica de telefonia (que gerou mais de cento e trinta mil feitos individuais apenas no Estado de São Paulo, uma série de conflitos de competência, muito tempo e recursos gastos pelos jurisdicionados, advogados, juízes e serventuários), assume a existência de direitos incindíveis, que não poderiam, a priori, ser individualmente sindicados. A hipótese estudada pelo celebrado professor repousa, justamente, na impossibilidade de propositura de ações individuais buscando uma solução que deveria ser uniforme a todos - no caso, o questionamento acerca de uma obrigação imposta contra quem consumisse serviços de telefonia. Seriam ações pseudoindividuais. O raciocínio de WATANABE é de extrema importância para a defesa das providências eleitas e expostas nas linhas seguintes, porque, de fato, existem direitos que - sob os paradigmas da proporcionalidade e razoabilidade, não poderiam ser individualmente judicados (WATANABE, Kazuo. "Parecer no tocante à natureza jurídica da tarifa de assinatura telefônica". São Paulo, 3.8.04). O mesmo entendimento é explanado pelo auto em "Relação entre demanda coletiva e demandas individuais", em GRINOVER, MENDES, WATANABE, Direito Processual Coletivo..., pp. 158160.

${ }^{657}$ BARBOSA MOREIRA, Temas..., p. 193.

${ }^{658}$ CAPPELLETTI, Mauro. "Formações sociais e interesses coletivos diante da justiça civil", em Revista de Processo, Ano II, n ${ }^{\circ}$ 5, Jan/Mar, 1977, p. 135.

${ }^{659}$ Os três incisos do art. 81 do CDC conceituam-se essas três espécies de direitos coletivos. 
A indivisibilidade do objeto dos direitos essencialmente coletivos deveria fazer com que a solução dada na controvérsia quanto a eles surgida sucedesse de maneira uniforme, equânime, isonômica, de modo que ao pertencente do grupo socorresse o mesmo direito garantido a todos os demais membros. Daí a melhor doutrina, com acerto, equiparar sua legitimidade multisubjetiva à hipótese de litisconsórcio facultativo unitário ${ }^{660}$. Nos direitos essencialmente coletivos, destarte, conclusão outra não há senão admitir que uma mesma solução judicial seja aquinhoada a todos os titulares do direito em questão, opondose, de conseguinte, erga omnes.

Exemplo clássico de situação incindível que comportaria litisconsórcio facultativo unitário é o da ação de dissolução de assembleia de sociedade empresária: todos os sócios têm o autônomo direito de se insurgir contra o colóquio, seja qual seja a natureza do motivo, mas os efeitos de eventual anulação atingirão invariavelmente, e de maneira uniforme, a esfera jurídica dos demais (porque, anulada a assembleia, anular-se-iam, na hipótese de estudo, todos os seus efeitos). Trata-se de objeto incindível cuja inteligência a respeito atingirá inclusive a quem não figurou como parte na ação respectiva ${ }^{661}$. Nestes casos, a solução dada pelo processo é predominantemente marcada em função do objeto pretendido.

Tratando-se de direitos acidentalmente coletivos, a lei encontrou saída para evitar o pernicioso efeito de lidar com sem-número de demandas de mesmo núcleo (medida antieconômica e altamente suscetível ao indesejado risco de julgados contraditórios), cuidando de agrupá-las em uma única ação para receberem tutela coletiva em um primeiro momento e, depois, quando da liquidação do julgado, tornarem a individualizar-se, agora em estágio muito mais avançado e propício à efetiva guarida. A norma tratou - em mais uma das felizes matrizes cunhadas por Kazuo Watanabe - de

${ }^{660}$ GRINOVER, Ada Pellegrini. "Coisa Julgada Erga Omnes, Secundum Eventum Litis e Secundum Probationem", em Revista de Processo n 126, São Paulo: Editora Revista dos Tribunais, 2005, pp. 3-5; MENDES, Aluísio Gonçalves de Castro. Ações Coletivas no Direito Comparado e Nacional, $3^{\mathrm{a}}$ ed., São Paulo: Editora Revista dos Tribunais, 2012, p. 211.

${ }^{661}$ GRINOVER, “Coisa Julgada Erga Omnes...”, p. 3-5. Cândido Rangel DINAMARCO exemplifica com a absurda ação anulatória de matrimônio promovida pelo Parquet que considerasse válido o casamento do marido e nulo o da esposa (ora, o mesmo casamento). Seria a ocasião de conflito prático, e não puramente lógico: o primeiro o sistema não admite, enquanto que, o segundo, tolera (Litisconsórcio, São Paulo: Editora RT, 1986, pp. 88-89). No mesmo sentido, BARBOSA MOREIRA, José Carlos. Litisconsórcio Unitário. Rio de Janeiro: Forense, 1972, pp. 26-27. A respeito da natureza e dos efeitos da sentença que julga impugnação de deliberações em assembleia de sociedades por capital, ver PEREIRA, Guilherme Setoguti Julio. Conteúdo do Provimento e Limites Objetivos e Subjetivos do Provimento e da Coisa Julgada na Impugnação de Decisões de Assembleias de Sociedades por Ações. Dissertação de Mestrado da área de Direito Processual, apresentada em 2013 e orientada por Flávio Luiz YARSHELL. Sobre a autoridade da coisa julgada em casos de objeto indivisível, ver Item 5.1.5. 
buscar a molecularização dos conflitos, em detrimento à sua observância atomizada $^{662}$. $\mathrm{O}$ fato é que, sejam acidentalmente, sejam essencialmente coletivos, os direitos dessa estirpe vieram a atender a nova necessidade de tutela da justiça, oriunda da dimensão social desses interesses, espalhados e informais, à guarda de pretensões coletivas, sinteticamente referíveis à qualidade de vida ${ }^{663}$.

É fácil, então, posicionar a tutela da saúde no campo da jurisdição coletiva. É que ali, excepcionalmente - e em hipóteses cerebrinas, diga-se - o direito em questão não poderá ser classificado como difuso, coletivo ou individual homogêneo. Apenas um único pedido singular, de patologia que acometa uma ou duas pessoas, é que potencialmente não se enquadraria como coletivo. O difícil é categorizar, no caso concreto, de qual hipótese se trataria ${ }^{664}$. Fie-se naqueles exemplos que Ada Pellegrini Grinover definiu como suporte das ações coletivas, individuais com efeitos coletivos e pseudoindividuais, mas permita-se, aqui, realizar exercício de casuísmo a bem de ilustrar a ideia.

Considere-se medida judicial que, promovida por jurisdicionado, intente obter a prioridade na tramitação do registro de determinado medicamento no órgão sanitário, fármaco da qual ele necessita e tem comprovada eficácia no exterior, mas que, por conta da burocracia estatal, não é capaz de adquirir. Se for o pedido julgado procedente (ou, mais concretamente, a medida urgente deferida) e o medicamento, logo, registrado, acarretará o aproveitamento a todos os outros portadores do mesmo mal. Aqui se trata claramente de medida pseudoindividual, porque a natureza de seu objeto é indissociavelmente coletiva. Na verdade, o direto em questão é genuinamente difuso, mas erradamente tratado como individual.

Pense-se, agora, em ação que peça a construção de nosocômio em dado Município para atendimento de certo cidadão que possui câncer. Se o juiz entender procedente o pedido, todos os demais portadores desse mal naquele local, e até em lugares vizinhos, serão atendidos. Este é claro exemplo de ação individual que versa sobre direito difuso.

No último exemplo, jurisdicionado precisa ser tratado de hipertensão. Ausentes medicamentos listados na RENAME dos postos de saúde, propõe ação e, ali,

\footnotetext{
${ }^{662}$ WATANABE, Kazuo, et. al.. Código de Defesa do Consumidor comentado pelos Autores do Anteprojeto. $9^{\mathrm{a}}$ ed. Rio de Janeiro: Forense Universitária, 2007, p. 797.

${ }^{663}$ GRINOVER, Ada Pellegrini. "Significado social, político e jurídico da tutela dos interesses difusos", em A marcha do processo, Rio de Janeiro: Forense Universitária 2000, pp. 17-23.

${ }^{664}$ Advertência já feita por WATANABE (Código de Defesa ..., p. 798).
} 
obtém medida emergencial obrigando o Poder Público a disponibilizar tais medicamentos imediatamente nos postos. Assim, todos aqueles sujeitos indeterminados que necessitarem desse fármaco serão beneficiados. De novo, não se trata de ação puramente individual, embora assim travestida: é medida cujo escopo é claramente coletivo em sentido estrito.

Se, valendo-se deste mesmo exemplo, o pedido for outro - de entrega do medicamento - então, havendo mais pessoas na mesma situação (hipertensos), o direito discutido será individual homogêneo.

Não se passa ao largo da problemática caracterização do direito individual homogêneo. No trato da saúde, a tutela coletiva se mostrará mais efetiva quando as questões comuns prevalecerem sobre as puramente individuais. Essa, por sinal, é uma máxima da ação coletiva relacionada a direitos individuais homogêneos, inspirada na class action for damages das Federal Rules of Civil Procedure norte-americanas. A Rule 23 (b) 3 estabelece que será admitida (rectius, certificada) a class action em que questões comuns à classe se sobreponham às individuais. A outra máxima condiz com a class action se mostrar meio mais eficaz de obtenção do bem da vida pelo postulante ${ }^{665}$. Respeitadas as diferenças de regime, também no Brasil, a necessidade de prevalência da comunhão sobre a singularidade de profusões é necessária para que haja tutela genuinamente coletiva, ainda que acidental. E essa prevalência pode ser avaliada de acordo com a origem comum, ou a causa que fez surgir a pretensão.

Ada Pellegrini Grinover entende que quanto mais próxima a causa, mais se enquadrará o direito na categoria de individual homogêneo. Exemplifica com a queda de um avião: todas as vítimas estarão invariavelmente ligadas por um conjunto de circunstâncias comuns que ensejará tratamento coletivo. Se o caso, ainda de acordo com ela, for de indenização pelo uso de produto nocivo, então as circunstâncias pessoais soçobrarão às coletivas, revelando-se inexistente a comunhão de causas apta a dotar o direito - ou direitos - de tratamento coletivo. Seria a situação de ação coletiva que pede reparação de danos aos fumantes pelos males do consumo de tabaco ${ }^{666}$.

\footnotetext{
${ }^{665}$ Foi o que sucedeu no caso Castano v. American Tobacco Company (84 F.3d 734 - 5th Cir., 1996). A Corte de Apelação do $5^{\circ}$ Circuito reviu decisão de primeiro grau que certificou como class action ação que pleiteava indenização para todos os dependentes de nicotina dos Estados Unidos. No caso, a Corte entendeu a prevalência das circunstâncias individuais sobre as comuns - porque, com acerto, ter-se-ia que ali demonstrar - e provar - quantos cigarros determinado cidadão fumou, qual a marca, qual o mal - ou males - que lhe acometeu, por quanto tempo havia fumado, dentre outras questões. Segundo Charles Alan WRIGHT, o juiz JONES, que negou certificação à class action, teria criado um Frankenstein se houvesse referendado a decisão de primeiro grau (apud de PINKERTON, Michael H. "Castano v. American Tobacco Company: America's Nicotine Plaintiffs Have No Class", em Lousiana Law Review, nº 58 - 1998, p. 647).

${ }^{666}$ Apud de WATANABE, Código de Defesa do Consumidor..., p. 825.
} 
A tutela da saúde enseja maiores cautelas, mas o que se propõe neste estudo é que o juiz sempre enxergue pedido como tal postulado contra o Estado como sendo presumidamente coletivo. Ainda que a questão, de plano, seja apresentada como individual, o magistrado deve verificar se, no fim, ela não releva a tantas outras pessoas em condições análogas. Existem no tema dois dados igualmente fundamentais e que respaldam esta proposição: a de que todos têm direito à saúde da forma mais igual possível e a de que os recursos para financiá-la são limitados. Nessa linha, dificilmente haverá ação puramente individual, ainda que ela se mostre recheada de questões particulares. $\mathrm{O}$ direito à prestação estatal de saúde é marcadamente coletivo, como ressaltado.

Em contrapartida, não é possível expungir do mundo jurídico a medida individual. Por isso que ela deve ser excepcionalmente aceita, e somente em casos que envolvam aprioristicamente o mínimo existencial ou, nos termos do artigo 26 do APLPP, aqueles cujo bem da vida for assegurado em norma constitucional de maneira completa e acabada, mas desde que o pedido seja razoável e a conduta da Administração, desarrazoada ${ }^{667}$.

Nessa hipótese projetada - abrangendo, é bom que se frise, questão genuinamente individual, e não coletiva - parece razoável admitir medida individual. Note-se que alguns freios seriam impostos pela norma: a (a) necessidade de o direito dizer respeito ao mínimo existencial do postulante ou de constar em norma constitucional de maneira perfeita e acabada (ou seja, que não demande maiores ilações, algo próximo à classificação de norma de eficácia plena de José Afonso da Silva ${ }^{668}$ ); (b) razoabilidade do pedido, que não pode ser abusivo e deve se orientar pelos parâmetros constantes nesta tese; e (c) desarrazoabilidade da ação da Administração, medida de salvaguarda do próprio Poder Público, que, claro, se falhar de maneira contundente, será forçado a sanar a falha. Interessante notar que, mesmo nessa hipótese, e com acerto, o APLPP estabelece, no artigo 27, que o magistrado notificará o Parquet e outros legitimados para, querendo, propor ação coletiva com o fito de corrigir omissões relacionadas às políticas públicas relacionadas ao objeto individual - ou seja, ali também se reconhece o fundo coletivo de ações que, em matéria de políticas públicas, apresentam-se ao magistrado como individuais.

\footnotetext{
${ }^{667}$ Seria o exemplo do medicamento listado indisponível que, se falta nos postos de saúde, é por presumível desídia do Poder Público.

${ }^{668}$ SILVA, Aplicabilidade das normas... V. nota 76.
} 
Via de regra, destarte, será coletiva a ação que versar a respeito de políticas públicas de saúde ${ }^{669}$, porque o instrumento para veicular pretensões transindividuais, essencial ou acidentalmente, são as ações coletivas, não as individuais ${ }^{670}$.

Nesse sentido, é do contexto afirmar que a tutela do direito coletivo merece capítulo à parte na processualística, principalmente diante da peculiaridade de seu objeto e das inúmeras formas pelas quais ele pode ser assegurado a seus titulares. A regra que vigora nesse caso, com notável incidência no campo ambiental, é a da reparação in natura do dano, com a conferência de tutela específica que, da melhor forma possível, permita a restauração da situação ao status quo ante ${ }^{671}$, assegurando-se a máxima coincidência possível entre o direito e sua realização ${ }^{672}$.

Essa correlação entre a máxima coincidência da decisão outorgada em ação coletiva e o direito titulado por quem lhe aproveita é crucial para entender como o processo coletivo é importante instrumento de trato das políticas públicas, apesar de suas limitações. Partindo dessa premissa, pode-se concluir, com certo grau de fidelidade, que a decisão judicial proferida em ação coletiva equivalerá à própria ação estatal que, por via do Poder Executivo, estaria incumbida de concretizar tal política. Nas ações coletivas, tutela efetiva $^{673}$ será, não apenas, aquela que beneficia direta e imediatamente os membros do grupo, classe ou categoria, mas, mais ainda, aquela que atua de maneira prospectiva e distributiva, outorgando-se aos titulares do direito aquilo, e precisamente aquilo, que o processo lhes deve proporcionar ${ }^{674}$.

Daí já é possível estabelecer o que pode parecer, à primeira vista, uma contradição em termos. Já se tratou, linhas antes, dos dogmas da congruência e da inércia e das severas implicações de ordem, sobretudo, prática que eles trazem ao controle

\footnotetext{
${ }^{669}$ Não por acaso o art. $2^{\circ}$, caput do APLPP celebra a primazia das ações coletivas no que toca a controle judicial de políticas públicas.

${ }^{670}$ Kazuo WATANABE crava que se ações individuais veicularem a mesma pretensão de uma ação coletiva ou de outra individual, serão elas inadmissíveis, por gerar um claro bis in idem que potencializa os riscos de conflito prático de sentenças, obstados por institutos como a litispendência e a coisa julgada (Código de Defesa do Consumidor..., p. 800).

${ }^{671}$ SALLES, Execução Judicial..., p. 315 e "Execução Específica e Ação Civil Pública" em MILARÉ, Édis (coord.). A Ação Civil Pública Após 20 Anos. São Paulo: Editora RT, 2005, pp. 86-87. Nesse sentido, o $\$ 1^{\circ}$ do artigo 84 do Código de Defesa do Consumidor deve ser interpretado com reservas, haja vista que o CDC pode ser considerado microssistema de proteção a interesses difusos e coletivos. Ali está dito ser opção do autor a conversão da obrigação em perdas e danos. No caso de interesses individuais homogêneos, a determinação legal poderia ocorrer na plenitude; todavia, não é o que parece no caso dos interesses difusos e coletivos, em que se deve priorizar a tutela específica ainda que o autor peça sua conversão em perdas e danos, dado o interesse público que permeia a matéria.

${ }^{672}$ WATANABE, Kazuo, et. al.. Código de Defesa do Consumidor..., p. 862.

${ }^{673}$ Sobre o tema efetividade da tutela jurisdicional, confira-se o Item 3.2.4.

${ }^{674}$ CHIOVENDA, Giuseppe. Instituzioni di Diritto Processuale Civile. Trad. Paolo Capitaneo (Instituições de Direito Processual Civil), 2a ed., Campinas, Bookseller, 2002.
} 
jurisdicional de políticas públicas. Eis o aparente paradoxo: se, de um lado, a sentença judicial deve assegurar a máxima coincidência entre o bem almejado e a providência ordenada, se essa mesma sentença deve corresponder exatamente ao quanto pedido (congruência), e se, em questões de políticas públicas, os pedidos normalmente são deficientes, porquanto incapazes de prever todas as situações passíveis de tutela, como podem ser realizados pedidos de intervenção judicial em políticas públicas e a decisão subsequente atender, na plenitude, a multiplicidade de interesses envolvidos?

A grande questão é que ao materializar sua pretensão deduzindo os pedidos na inicial, o autor, muitas vezes, ignora os melhores métodos e soluções para a tutela do quanto ele pretende ver protegido. É o caso dos bens tipicamente sindicados por ações de políticas públicas. A dificuldade, multidisciplinariedade, imprevisibilidade e complexidade de certos direitos fazem com que o autor, muitas vezes, não consiga representar, no pedido, o que realmente almeja. Não por menos que as associações são acompanhadas de perto pelo Parquet nas ações coletivas, nem por menos que a doutrina avalizada prega a necessidade de flexibilização da rigidez da estabilização da demanda e da interpretação estrita dos pedidos nas ações coletivas ${ }^{675}$.

Quando, pois, alude-se à Chiovenda para confirmar a serventia da tutela jurisdicional, refere-se à tutela jurisdicional mais adequada, que, em certos casos, não necessariamente corresponde ao quanto estritamente requerido. Por isso que, nesses especiais casos, a ideia Chiovendiana permite a suavização da imutabilidade (rectius, estabilização) das causas de pedir e pedidos.

Não se pode esquecer que algumas decisões manifestadas em processos formalmente individuais são aptas, em certo grau, a ter alcance coletivo muito grande, ainda que não seja o caso de medida pseudoindividual. Seria o caso das ações que geram efeito colateral coletivo. Por vezes, a reiteração de medidas análogas requerendo certo fármaco e a respectiva coleção de decisões no mesmo sentido implicam na inclusão desse medicamento nas listas de dispensação gratuita, o que vem a beneficiar não apenas os

\footnotetext{
${ }^{675}$ Como também a jurisprudência. O Min. Teori ZAVASCKI, hoje, no STF, exarou dois importantes julgados enquanto ministro do STJ considerando que a tutela coletiva é tão flexível a ponto de ser modificada da forma que for necessária a garantir a efetiva e adequada tutela dos direitos metaindividuais tipicamente por ela sindicados. Trata-se do REsp n ${ }^{\circ}$ 592.693/MT, j. em 7.8.07, e do REsp no 801.005/SP, j. em 20.3.07. A alteração legislativa correspondente está perto de ocorrer. No projeto de modernização do CDC (o Projeto de Lei do Senado ${ }^{\circ} 282$ é o que trata da alteração da parte processual do diploma consumerista), foi entregue relatório com proposta de inclusão do art. 90 -A, em que o $\S 4^{\circ}$ enuncia que o juiz poderá permitir que o autor altere o pedido ou causa de pedir até o momento da prolação da sentença, desde que realizada com boa-fé, não importe prejuízo à parte contrária e seja observado o necessário contraditório, facultada a produção de prova complementar.
} 
autores das ações, mas todos os pacientes que necessitam da medicação, não a podendo adquirir onerosamente ${ }^{676}$. Essas são ações individuais - muito possivelmente, individuais homogêneas - que possuem certo side-effect coletivo, consistindo elas, adjetivamente, também importante instrumento de tutela judicial da saúde. Mas, sem engano, mesmo aqui essas pretensões poderiam ter sido coletivamente agrupadas, tanto quanto deveria ser objeto de ação coletiva a ação cuja pretensão é de revisão das listas de dispensação obrigatória, ou de inclusão de dado medicamento nelas não indicado.

Observou-se, antes, que existem inúmeras variáveis capazes de influir decisivamente na execução de políticas públicas (os interesses pessoais dos tomadores de decisão, a qualidade institucional dessas pessoas, a ação de grupos de pressão, a atuação das tendências minoritárias e majoritárias, a escassez de recursos). Viu-se, também, que por conta de tais variáveis, muitos serão os interesses não atendidos pelos atores que deveriam possuir a primazia do controle, fiscalização e concretização das políticas públicas. Nesse ponto, diversos são os que elegem o processo civil como meio adequado para a correção das imperfeições típicas do processo político ${ }^{677}$. Seria, de acordo com o que sustenta essa corrente teórica, o que ocorreria no manejo, justamente, das ações coletivas, como teria sucedido no caso Brown vs. Board of Education, decidido pela Suprema Corte norte-americana ${ }^{678}$.

\footnotetext{
${ }^{676}$ É o que ocorreu no caso das ações individuais propostas para obtenção do coquetel de medicamentos para controle da AIDS. A multiplicidade de medidas manejadas para esse mister e as várias sentenças garantido acesso aos medicamentos resultaram na edição da Lei $\mathrm{n}^{\circ}$ 9.313/96, que dispõe sobre o fornecimento gratuito de remédios para tratamento do HIV. Sobre tal constatação, ver importante trabalho de Flávia PIOVESAN ("Justiciabilidade dos Direitos Sociais e Econômicos: Desafios e Perspectivas", em SILVA, Roberto B. Dias (Org.). Direito Constitucional - temas atuais - homenagem à Professora Leda Pereira da Mota. São Paulo: Método, 2007, v. , p. 59-74).

${ }_{677}^{67}$ SALLES, Execução Judicial..., pp. 95-99. VALENTE, A Dimensão..., p. 136.

678347 U.S. 483 (1954) e 349 U.S. 294 (1955). Brown exigiu do Judiciário norte-americano, na Década de 1950, o fim do sistema dual de ensino no país, em algumas localidades em que havia escolas para negros e escolas para brancos. Usando do argumento da igualdade, Brown requereu que brancos e negros pudessem dividir as salas de aula, importantíssimo passo na luta contra a segregação racial. Brown acabou se sagrando vencedor, o que implicou profunda modificação no sistema educacional de todos os Estados Unidos, já que eram necessários novos critérios para a escolha de alunos e construção de escolas, substituição de parte do corpo docente, reformulação da grade curricular, revisão do sistema de transportes de alunos, entre outros aspectos (FISS, Um Novo Processo Civil..., p. 28). Essa decisão judicial obtida em Brown implicou, além da primazia da igualdade, a implementação de nova política pública direta de educação, e, indireta, de privilégio às famílias, aos alunos e a toda a sociedade. Sobre Brown, ver mais no Item 5.5.

Hoje, a tutela coletiva nos países do Common Law é uma realidade. Por ocasião do XIII Congresso Mundial de Direito Processual, ocorrido em Salvador de 16 a 22 de setembro de 2007, Linda MULLENIX foi a relatora do General Report para os países do Common Law, em que ocorreu profundo trabalho de investigação sobre os métodos coletivos de resolução de conflitos nos países daquela família. O relatório completo está publicado em Os Processos Coletivos nos Países de Civil Law e Common Law (GRINOVER, Ada Pellegrini; MULLENIX, Linda e WATANABE, Kazuo. São Paulo: Editora RT, 302008, pp. 253-297).
} 
As ações coletivas defendem os interesses daqueles grupos sociais mais dispersos ou daqueles que, de outra forma, não conseguiriam ter seu "dia na corte "679. De fato, alguns anseios de membros de certo grupo podem jamais aflorar, seja porque os custos com o processo são altos ${ }^{680}$, como a inviabilizar a tutela de direito de expressão econômica ínfima, seja porque falta à parcela do grupo aptidão técnica para a defesa de seus interesses, seja, simplesmente, em razão do desconhecimento sobre o que ocorre, ou o direito, ou a mera necessidade de adoção de política pública que os favoreça ${ }^{681}$ (e a decisão em uma ação coletiva que contemple todo esse grupo poderá ser aproveitada, inclusive, pelos membros dormentes - um típico caso de free riding ${ }^{682}$ positivo). Nesse sentido, as ações coletivas são crucial ferramenta de acesso à justiça.

A clássica obra homônima de Cappelletti e Garth teceu algumas importantes proposições para a caracterização do amplo acesso, sendo a justiça uma das mais sagradas prerrogativas do homem - enquanto ser humano e social - e da própria sociedade. Das proposições, conhecidas por Ondas Renovatórias, concluem os autores que as ações coletivas são relevante meio de amplo acesso à justiça, principalmente pelo enfoque da Representação dos Interesses Difusos, a Segunda Onda ${ }^{683}$.

Adotando a linha proposta pelos autores, ação individual que procura obter medida ligada à saúde não é a melhor saída na tutela desse tipo de interesse, e, isso,

\footnotetext{
${ }^{679}$ FISS, Um Novo Processo Civil..., pp. 205-208. A expressão dia na corte é largamente usada por FISS quando se refere ao direito de representação dos membros do grupo nas class action, importante tema quando se trata das class action for damages do direito norte-americano (Federal Rules of Civil Procedure, Rule 23 (b)(3). Menciona FISS decisão no caso Martin vs. Wilkis (490 U.S. 755 (1989), em que o Presidente da Suprema Corte da época, Juiz REHNQUIST, proclamou o direito de ampla participação no processo, sob pena do não participante não poder ter seu direito determinado pela Corte (se não participou do feito). Esse problema tem derivação do sistema vinculante do Opt-Out, adotado pelos EUA no trato específico dessas class action, em que a decisão vincula a todos os membros da classe. O dia na corte é diretamente correlacionado ao contraditório. A todo esse respeito, FISS sentencia: "Acredito que o que a Constituição garante não é o direito de participação, mas o que chamarei de direito de representação: não 'um dia na corte', mas o direito à representação adequada de interesses." (p. 215). Efetivamente, a regra legal que hoje vigora nos EUA é a da representação adequada, mas com a melhor notificação possível dos membros da classe, diante das circunstâncias.

${ }^{680}$ CAPPELlETTI e GARTH, Access to Justice..., pp. 15-21. No mesmo sentido, SALLES, "Políticas Públicas...", pp. 40-41.

681 Para KOMESAR, os grupos mais dormentes são aqueles cujos membros sequer reconhecem a necessidade de uma ação política (Imperfect Alternatives..., p. 71). Sobre esse aspecto, aplicado ao contexto brasileiro e afirmando ser baixa a taxa de litigiosidade em nosso País, confira-se Maria Teresa SADEK:, para quem “(...) as razões para isso são inúmeras, indo desde a descrença na lei e nas instituições até a banalização da violência. (...) Por outro lado, ainda que em menor grau que no passado, é baixa a conscientização da população tanto sobre seus direitos, como sobre os canais institucionais disponíveis para a solução de seus litígios" (SADEK, Maria Teresa (org). Acesso à Justiça, Fundação Konrad Adenauer, São Paulo, 2001, p. 7).

${ }^{682}$ KOMESAR, Imperfect Alternatives..., p. 69.

${ }^{683}$ Access to Justice..., pp. 49-67. A Primeira Onda (Assistência Judiciária para os Pobres) e a Terceira Onda (Acesso à Representação em Juízo a uma Concepção Mais Ampla de Acesso à Justiça. Um Novo Enfoque de Acesso à Justiça) também emprestam importante papel para as ações coletivas.
} 
porque, assim, o acesso ao Judiciário não é propriamente desonerado, sob o ponto de vista financeiro, e porque nem todas as pessoas têm informações suficientes sobre como movimentar essa máquina. Os custos relacionados à tutela judicial impõem óbices que não podem ser negligenciados pelos estudiosos do processo e do atuar judicial no Estado Democrático de Direito, justamente, a um, o fato de o processo ser extremamente caro (custos financeiros), e, a outro, os custos de informação ${ }^{684}$. Pode-se concluir que muitos direitos não são atendidos por conta das barreiras à movimentação judicial. Neste sentido, aqueles que conseguem transpor os obstáculos, por suportarem os custos do processo, saem em vantagem ${ }^{685}$. Esse modelo poderia muito bem servir de molde se a lide fosse privada e bilateral, mas ele absolutamente não condiz com a tutela da saúde, em que o objeto é universal ${ }^{686}$.

Tome-se o seguinte exemplo: portador de Cirrose Hepática contrata advogado e apresenta medida judicial postulando a entrega do medicamento. A providência é concedida, sem qualquer indagação a respeito de quantas seriam as outras pessoas que, também acometidas pelo mesmo mal, necessitariam do fármaco adequado, em que pese todas elas, pela Constituição, possuírem igual direito ao tratamento condizente. A decisão em ação como essa é duplamente perigosa: primeiro, porque a questão, tratada de forma puramente individual, normalmente ignora os impactos econômicos coletivos (como, por exemplo, a alocação forçada de recursos); depois, porque privilegia aquele que ultrapassou os custos do processo, em detrimento ao que não o fez. Parece que o trato coletivo de questão como esta vai ao encontro de tudo o que foi visto até então. Mas aqui é necessário que se faça pontual advertência.

Apesar de a saúde ser, sem dúvida, questão também política, nem todas as pretensões que envolvem o tema possuem imediato impacto extraprocessual, vale dizer, uma experimentação de efeitos que ultrapassa prontamente os limites subjetivos da causa.

\footnotetext{
${ }^{684}$ Evidentemente que a Constituição e a lei preveem mecanismos de minoração dos custos do processo, com a instituição da Defensoria Pública e a isenção das custas judiciais aos comprovadamente pobres. Contudo, muitos são aqueles que sequer sabem existir Defensoria, ou que podem processar estando exonerados de custos. Sobre a questão dos custos do processo, ver SALLES, Execução Judicial...

${ }^{685}$ Sobre a análise dos jurisdicionados que "furam a fila" nos direitos sociais pela procura ao Judiciário, ver a questão relacionada ao Dilema do Prisioneiro mencionada no Capítulo dedicado à reserva do possível e em CARVALHO (“O Impacto...”, pp. 24-27).

${ }^{686}$ A Folha de São Paulo noticiou estudo realizado por Octávio Luiz da Motta FERRAZ dando conta que os cinco Estados mais ricos da federação brasileira concentram 75\% (setenta e cinco por cento) das ações individuais que buscam da União medicamentos, enquanto que esses cinco Estados concentram apenas $45 \%$ (quarenta e cinco por cento) da população. Para Octávio, “A judicialização garante a poucos, aos que têm acesso mais fácil ao Judiciário, benefícios que o Estado não pode dar a toda a população, já que os recursos são necessariamente escassos." (“Ações por remédios caros favorecem ricos, diz estudo", disponível em: <http://www1.folha.uol.com.br/cotidiano/772062-acoes-por-remedios-caros-favorecem-ricos-dizestudo.shtml>, acesso em 12.12.2011, 18:55h).
} 
Pedido de internação para o tratamento de patologia pontual em que sobressaiam as particularidades do paciente pode nada ter de transindividual quando analisado, embora, como visto, qualquer demanda de saúde tenha conotação mediatamente coletiva. A decisão em ação como essa não precisa ser tratada coletivamente a priori, muito embora mesmo a decidir essa demanda o magistrado deva observar os freios apresentados nesta tese.

Outras demandas, contudo, são e serão, clara e imediatamente, coletivas seja essencial, seja acidentalmente. Qualquer causa em que se pleiteie a concessão de medicamentos transcenderá o espectro individual do feito, porque sempre haverá pessoas que necessitarão daquele mesmo medicamento (aliás, possivelmente não existirá medicamento se a patologia não possuir incidência populacional que a justifique - dai ser cerebrina a hipótese de o núcleo coletivo sucumbir ao individual) ${ }^{687}$. A análise do cabimento ou não do trato coletivo das questões ligadas à saúde deve se dar ope iudici ${ }^{688}$, embora se arrisque afirmar que, quase na totalidade dos casos, a vexatia questio será, efetivamente, coletiva.

Ada Pellegrini Grinover, ao estudar a relevância social das ações coletivas, assevera que a tutela de interesses transindividuais e de conflitos de massa invariavelmente passa pelo contexto do acesso à justiça ${ }^{689}$. Também o assunto é posto como um dos princípios da tutela jurisdicional coletiva, na letra a do artigo $2^{\circ}$ do antigo Anteprojeto do Código Brasileiro de Processos Coletivos ${ }^{690}$, e - variação de um mesmo tema - não se há de olvidar da preocupação ao acesso garantida no núcleo constitucional intangível do artigo $5^{\circ}$, LXXIII, ampliada pelo artigo 87 do CDC e igualmente prevista na Lei $\mathrm{n}^{\mathrm{o}} 7.347 / 85^{691}$. Nesse sentido, importante precedente norte-americano no que toca ao tema é o caso Eisen vs. Carlise \& Jacqueline ${ }^{692}$.

\footnotetext{
${ }^{687}$ Mesmo no caso das já tratadas drogas-órfãs, a incidência populacional, ainda que baixíssima, justifica o estudo e a produção de medicamentos para o seu tratamento.

${ }^{688}$ É precisamente nesse sentido que anda o projeto de revisão do CDC. No art. 90-D projetado, o inciso I estabelece como dever do juiz decidir, não alcançada conciliação e apresentada defesa, se a ação tem condições de prosseguir como se coletiva fosse.

689 GRINOVER, Ada Pellegrini. "Direito Processual Coletivo", em Direito Processual Coletivo e o Anteprojeto de Código Brasileiro de Processos Coletivos, coord. Ada Pellegrini GRINOVER, Aluisio Gonçalves de Castro MENDES e Kazuo WATANABE. São Paulo: Editora RT, 2008, p. 12.

${ }^{690}$ Disponível do sítio do Instituto Brasileiro de Direito Processual (<http://www.direitoprocessual.org.br>, acesso em 3.1.2010, 14:47h).

${ }^{691} \mathrm{Na}$ Constituição, o artigo em apreço isenta o autor popular de custas e sucumbência, salvo comprovada má-fé. No CDC, a disposição destacada determina que, nas ações coletivas não haverá adiantamento de custas, emolumentos, honorários periciais ou outras despesas, o que é igualmente observado na Lei da Ação Civil Pública.

692417 U.S. 156 (1974). O caso Eisen envolveu tutela de prejuízos e indenizações devidas a pequenos investidores por conta de um esquema de fixação de preços entre corretores da bolsa de valores na negociação de Odd-lots. No caso em comento, o prejuízo individualmente considerado, por diminuto, tornaria inviável o manejo de ação individual para buscar a respectiva indenização. A reunião dos interesses
} 
Mais ainda: dada a volatilidade dos processos decisórios a respeito de políticas públicas, existe forte posição doutrinária que dá conta de que as ações judiciais são, por vezes, a única solução cabível para a tutela de certos interesses. Nesse tocante, o processo é, inequivocamente, instrumento de defesa social. No caso da saúde, porém, só têm relação com políticas públicas decisões judiciais manifestadas ou nas ações coletivas, ou na massa de ações individuais que, por sua reiteração, impliquem um importante sideeffect coletivo $^{693}$ - mas que deveriam ter sido coletivamente reunidas. Por isso que, diante de ação individual em que se discuta o direito à saúde e que, assim, possa repercutir na esfera jurídica de indeterminadas pessoas, inclusive de multiplicidade de ações versando sobre objeto análogo (hipótese em que o direito será provavelmente difuso, coletivo ou individual homogêneo), é de se adotarem mecanismos que tendam ao: (a) tratamento uniforme da questão; e (b) emprego de técnicas de coletivização.

Há mais duas características que tornam a tutela coletiva quase necessária nos casos de judicialização da saúde: são as constitucionais universalidade e isonomia dessa prestação, que coincidem com as mesmas qualidades, típicas dos direitos sociais ${ }^{694}$.

Quando o Judiciário é chamado a agir nessas hipóteses, deve fazê-lo seguindo a linha da norma constitucional que exige universalidade e isonomia, ou seja, que demanda ações estatais dispensadas a todos, universalmente, e de forma igualitária. Pessoas que se colocam na mesma situação (i.e., possuam problemas renais atacados por determinado fármaco) devem ser tratadas da mesma maneira. Vale dizer: a decisão judicial deve, tanto quanto possível, atingir a todos que dela possam se beneficiar, como forma de atender ao dogma constitucional. A ação individual não é adequadamente capaz de assim

desses pequenos investidores (que poderiam ser classificados como individuais homogêneos entre nós Artigo 81, III do CDC) e, principalmente, do tratamento coletivo da indenização devida a cada um, tornou o montante cobrado palatável para ser tratado em uma class action, inegável dado de acesso à justiça. No fim, contudo, a ação não prosperou, porque os custos com a notificação dos prejudicados tornava economicamente inviável a continuidade do processo. Eisen tornou-se paradigma de como alguns antigos preceitos do processo civil - como a notificação pessoal e inequivocamente levada a efeito do interessado podem inviabilizar as benesses da tutela coletiva - naquele caso, alcançadas pela efetiva reparação dos danos causados por parte dos corretores de valores mobiliários aos pequenos investidores.

${ }^{693}$ Sobre o assunto, ver FERREIRA, Éder. "As ações individuais no controle judicial de políticas públicas”, em $O$ Controle Jurisdicional..., pp. 333-352.

694 “(...) o princípio [da universalidade da jurisdição] assume dimensão distinta no processo coletivo, pois é por intermédio deste que as massas têm a oportunidade de submeter aos tribunais as novas causas, que pelo processo individual não tinham sequer como chegar à justiça. O tratamento coletivo desses interesses $e$ direitos comunitários é que efetivamente abre as portas à universalidade da jurisdição". GRINOVER, Ada Pellegrini. "Direito Processual Coletivo", em Tutela Coletiva: 20 anos da Lei da Ação civil Pública e do Fundo de Defesa de Direitos Difusos. 15 anos do Código de Defesa do Consumidor. São Paulo: Atlas, 2006, p. 304. 
atuar $^{695}$, senão por acidente, se ela versar objeto incindível ou se sua reiteração gerar mudança na política pública vigente. Todavia, a ação coletiva tem todos os predicados para atingir a coletividade, porque isso, aliás, é de sua gênese. Ela, enfim, serve precipuamente para isso.

Evidentemente que em função dos limites impostos mesmo às ações coletivas $^{696}$, a decisão manifestada no bojo do processo com essa característica poderá não atingir todas as pessoas que se colocam em uma mesma situação. Mas há de se preferir uma tutela coletiva da coisa pública que é a saúde. A tutela jurisdicional metaindividual é a melhor maneira de o Judiciário atuar nessa seara. Seja difuso, coletivo ou individual homogêneo, o direito à saúde sempre gozará de parcela coletiva de relevo, tornando sua discussão apta a receber tratamento coletivo.

A coletivização da tutela judicial da saúde abre espaço, também, para um controle mais democrático da coisa pública. Já se mencionou, e não é novidade, o uso distorcido das ações judiciais que postulam a concessão de fármacos, motivadas muito mais por advogados que atendem seus próprios interesses do que ao dos jurisdicionados ${ }^{697}$. A ação coletiva moraliza esse uso destemperado do acesso à justiça. Constituindo veículo de participação muito mais ampla e com atuação ativa do Ministério Público, seja como parte, seja como custos legis, a coletivização da disciplina judicial de postulação de saúde é forma, além de equilibrada, mais proba de se lidar com os recursos públicos que, nesses casos, são alocados pelo Poder Judiciário.

Além da coletivização, que atende, a um só tempo, às exigências de universalidade e igualdade, é preciso também se preservar a uniformidade de julgamentos em casos em que houver multiplicidade de demandas versando sobre um mesmo objeto. $\mathrm{O}$ risco de decisões contraditórias, nesse caso, é agravado pelo fato da saúde dever ser

\footnotetext{
${ }^{695}$ A não ser que à decisão judicial sejam emprestadas qualidades que a tornem oponível contra todos os que lhe aproveitam. Sobre o assunto, ver Item logo mais adiante, que traz a proposta de expansão dos efeitos da coisa julgada manifestada no processo individual.

${ }^{696}$ Como é o caso do malfadado artigo 16 da Lei $\mathrm{n}^{\circ} 7.347 / 85$, com a redação que lhe foi dada pela Lei n ${ }^{\circ}$ 9.494/97, a estabelecer, com técnica altamente questionável, que a sentença das ações civis públicas fará coisa julgada erga omnes nos limites da competência territorial do órgão prolator. Sobre essa problemática, ver LIEBMAN, Enrico Tullio. Eficácia e Autoridade da Sentença. $2^{\mathrm{a}}$ edição. Rio de Janeiro: Revista Forense, 1981; GRINOVER, Ada Pellegrini. Código de Defesa do Consumidor..., pp. 939-944; VIGLIAR, José Marcelo Menezes. "A Lei 9.494, de 10 de setembro de 1997, e a nova disciplina da coisa julgada nas ações coletivas: inconstitucionalidade", em Revista dos Tribunais $\mathrm{n}^{\circ} 745$ (novembro de 1997, 86ªno), pp. 67-72.

${ }^{697}$ V. CHIEFFI e BARATA (“Ações Judiciais...”) apontando que 35\% das ações foram patrocinadas por 1\% dos advogados que atuaram em todas as causas (nota 643) e reportagem da revista Época (mencionada nas notas 20 e 298).
} 
dispensada de maneira isonômica. Daí é de se propor, mesmo, técnica de agrupamento de ações individuais que versem sobre objeto comum.

Não basta, contudo, que exista este embasamento teórico. Ele, por si só, não fará com que os jurisdicionados prefiram a tutela coletiva à individual. Também o lastro teórico não permitirá ao juiz indeferir a inicial da ação individual que pleiteia tratamento médico a que todos na mesma situação fariam jus. É necessário que sejam desenhados instrumentos que permitam ao magistrado, deparando-se com caso individual, transmudálo em coletivo, ou permitir a uniformização dos pronunciamentos. Com base nestas premissas, a seguir serão propostos três modelos para sua concretização. Comece-se pelo mecanismo de uniformização, que pode ser entendido como técnica coletiva em sentido lato, porquanto busca a isonomia.

5.1.3 O caso piloto em demandas repetitivas

Um dos efeitos oriundos da multiplicidade de interesses relacionados às políticas públicas, especialmente as de saúde, ou seja, o fato de que muitas pessoas se colocam, inúmeras vezes, exatamente na mesma situação (i.e., possuem Alzheimer, mas não conseguem obter do Estado o medicamento excepcional respectivo), é a possibilidade de propositura de inúmeras ações individuais que tratam precisamente do mesmo tema ${ }^{698}$.

Suponha-se a seguinte situação fictícia: absolutamente todas as pessoas que necessitam de internação para tratamento de insuficiência renal decidem, cada qual, valerse de sua ação individual para pedir ao juiz competente tal providência contra o Estado. São propostas milhares de ações em todo o Brasil, algumas com pedido de concessão de tutela emergencial, outras não, algumas com requerimentos tidos por procedentes, outras com procedência parcial, outras, ainda, com total improcedência dos reclamos inaugurais, isso sem falar no tempo de tramitação e solução de cada processo. A autonomia da parte, consistente, neste exemplo, na hipótese de propositura isolada de uma ação, pode levar a resultados díspares e, inclusive, contraditórios entre si. Há, aí, problemas de tratamento diferenciado em hipóteses análogas, quase idênticas (coisa que deriva da universalidade e

698 Como ocorreu no caso já mencionado das medidas judiciais que pretendiam obter o coquetel antirretroviral da AIDS (DURAN FERREIRA, O Caso Aids..., pp. 24-25) e naquelas pretendo conseguir vagas em escolas públicas (MARINHO, Justiciabilidade..., pp. 9 e 16) além da pesquisa inédita produzida nesta tese (Item 4.1.3). 
que, a propósito, já foi tratada) e, claro, de absoluta insegurança jurídica oriunda das variadas formas de tratamento de uma mesma questão - isso sem falar do óbvio defeito de analisar direito coletivo sob o viés individual.

Se o direito tratado for incindível, não há se falar em ação individual como via mais escorreita, já que é a ação coletiva quem tem tônus para lidar com a situação. Ações nominadas como individuais que tratam direitos indivisíveis não são individuais, e, aí, a solução deverá ser a coletivização. Já a hipótese de trato individual da questão acidentalmente coletiva, com impactos negativos para a segurança das relações jurídicas, apesar de tolerada, não é desejada, inclusive, pela legislação de regência. O uso de instrumentos tendentes a tornar decisões judiciais aplicáveis a um mesmo problema abrange tanto institutos mais antigos (como a uniformização de jurisprudência ou os embargos de divergência), como aqueles mais recentes, oriundos das últimas reformas (e aí se incluem da súmula vinculante ao recurso especial repetitivo, passando pela súmula impeditiva de recursos, repercussão geral em recurso extraordinário e pela improcedência liminar dos pedidos) ${ }^{699}$. Por sinal, o recurso especial repetitivo abriu as portas, na legislação, para que se adote o remédio que ora será proposto sem tanto escândalo. Em verdade, a tendência atual nesse sentido é claramente reflexo dos estudos mais aprofundados a respeito dos benefícios do sistema do Common Law e da força dos precedentes, relevantes justamente quando se trata de segurança jurídica advinda das decisões judiciais $^{700}$.

O que se propõe como um dos remédios à tutela jurisdicional de políticas públicas, precipuamente as de saúde, é a adoção, mediante reforma legislativa pontual, da mecânica do caso piloto.

A ideia em si não é inédita, seja alhures, seja aqui. Países como Alemanha $^{701}$, Áustria ${ }^{702}$, Dinamarca ${ }^{703}$, Noruega $^{704}$ e Espanha já adotam a solução de

${ }^{699}$ Com uma profícua análise dos instrumentos que revelam a adoção da tendência ora apontada, ver GRINOVER, Ada Pellegrini. “O Tratamento dos Processos Repetitivos”, em O Processo..., pp. 27-35.

${ }^{700}$ Nesse sentido, já posicionou-se este autor em "O Precedente jurisdicional vinculante e sua força no Brasil”, na Revista Dialética de Direito Processual no 85 (abril-2010), pp. 51-72.

701 A respeito, ver RALF-THOMAS Wittmann. "Il 'contenzioso di massa' in Germania", in Giorgetti ALESSANDRO e Valerio VALLEFUOCO, Il Contenzioso di massa in Italia, in Europa e nel mondo, Milão, Giuffrè, 2008, p. 178.

${ }^{702}$ A Áustria possui o test-case, ou Musterprozess, aplicável ao contexto de relações consumeristas de massa, por meio do qual um dos legalmente legitimados apresenta um único processo abrangendo todos os danos (GRINOVER, MULLENIX, WATANABE. Os Processos Coletivos..., pp. 152-153).

${ }^{703} \mathrm{Na}$ Dinamarca, o pilot case propicia, dentre múltiplas causas, a escolha de uma ou algumas representativas da controvérsia. Nos eternite cases (UfR 2002.249H), dois dentre oitocentos e cinquenta processos discutindo os danos provocados pelo uso de asbesto nos telhados de casas foram escolhidos e 
aplicar, em casos repetitivos, a resposta encontrada em processos com objetos idênticos e eleitos como modelos, o que se chama caso piloto, caso teste ou processo mestre. É interessante checar a disciplina estrangeira da matéria, e para isso foram pinçados dois exemplos: o alemão e o espanhol.

$\mathrm{Na}$ Alemanha há a figura do Kapitalanleger-Musterverfahrensgezets $(K a p M u G)^{705}$, um procedimento modelo cuja decisão serve para todos os demais feitos em que as partes estejam em idêntica situação, embora a ação não seja a mesma. Essa foi a saída germânica para contornar o problema criado nos anos de 1999 e 2000 pela divulgação falsa de dados nos prospectos da Deutsche Telekom AG, deturpando o valor das ações da empresa e prejudicando cerca dezessete mil investidores. Foram propostas em torno de duas mil e quinhentas ações judiciais relacionadas ao tema, que seriam totalmente julgadas apenas em 2015, de acordo com cálculos dos próprios tribunais alemães ${ }^{706}$. O procedimento modelo para o mercado de capitais, assim, teve a finalidade de tratar uniformemente a mesma questão de direito, com grande aproximação das respectivas matérias de fato. Ali, o KapMuG é instaurado em primeiro grau por meio de, ao menos, dez pedidos de partes (autores ou réus), em decisão irrecorrível, e remetido ao tribunal do respectivo local, ou, mesmo, ao Tribunal Superior Federal, caso várias sejam as unidades federadas envolvidas. Os feitos individuais são automaticamente sobrestados, é eleito um representante pelos investidores ${ }^{707}$ - o master plaintiff, outro pelo demandado, e as demais questões são dirimidas pelo tribunal em que se processa o KapMuG. Foi desenvolvido sistema eletrônico de informações, de modo a dar a maior publicidade possível em torno do $K a p M u G$ e seus aspectos. A solução do procedimento modelo é automaticamente aplicada a todos os casos versando sobre a mesma questão, concorde com o $n^{\circ} 1$ da Seção

enviados como casos-pilotos para análise pela Suprema Corte (GRINOVER, MULLENIX, WATANABE. Os Processos Coletivos..., pp. 142-143).

${ }^{704} \mathrm{Na}$ Noruega, as pilot actions são causas no âmbito de direitos coletivos também isoladas e analisadas separadamente, com conclusões que podem, de acordo com Tore SCHEI, facilitar soluções fora da corte (GRINOVER, MULLENIX, WATANABE. Os Processos Coletivos..., pp. 62-63).

${ }^{705}$ GRINOVER, "O tratamento...", p. 31.

${ }^{706}$ De acordo com Burkhard HESS, relator da Alemanha para o relatório geral dos processos coletivos nos países de Civil Law, o KapMuG, encampado no Master Proceedings Act de novembro de 2005, foi a rápida resposta do legislador à previsão dada pelo juiz da corte distrital de Frankfurt de que seriam necessários quinze anos para julgar todos os casos propostos contra a Deutsche Telekom AG. Ele também aponta uma clara inspiração nas class actions norte-americanas na adoção do remédio (GRINOVER, MULLENIX, WATANABE, Os processos coletivos..., pp. 147-149).

${ }^{707}$ Semelhantemente ao US Private Securities Litigation Reform Act 1995, é escolhido como representante o investidor que estiver pleiteando a maior soma, dado que, presumidamente, ele quem terá o maior interesse no desfecho favorável e, assim, liderará de melhor forma o KapMuG (Evaluation of the effectiveness and efficiency of collective redress mechanisms in the European Union - country report Germany. European Comission, 2008, pp. 6-8, disponível em: <http://ec.europa.eu/consumers/redress_cons/de-country-reportfinal.pdf >, acesso em 30.9.2013, 15:48h). 
16, na III Parte da Lei que prevê esse instrumento ${ }^{708}$. O que se vê, a propósito, é que a saída apresentada nos projetos de Código de Processo Civil e Código de Defesa do Consumidor, entre nós, é muito inspirada no remédio alemão, mas há diferenças, sobretudo quanto à restrição do objeto.

O KapMuG nasceu como procedimento experimental e com prazo de validade: $1^{\circ}$ de novembro de 2010. Contudo, a experiência, embora tortuosa, motivou a continuidade da ferramenta. Em 2012, о КарМиG foi objeto de intensa discussão acadêmica, chegando-se à conclusão de que esse instrumento não deveria, apenas, restringir-se aos conflitos do mercado de capitais, mas, sim, ser aplicado a todo o contencioso de massa. O Ministério da Justiça recusou a proposta, alegando que seria necessária maior experiência procedimental antes de estender o KapMuG para todo e qualquer conflito de massa. A reforma no $K a p M u G$ também previu, de forma inédita na Alemanha, a possibilidade de acordo vinculante para todos os litigantes a não ser que eles, quando notificados, exercessem direito de Opt-out $^{709}$.

$\mathrm{Na}$ Espanha, o pleito-testigo ou recurso-test foi também inspirado na solução alemã. Previsto na Ley de La Jurisdicción Administrativa (LJCA, 29/1998), seu propósito foi acelerar a solução de demandas com pedidos idênticos, oriundas de direito massificado, estendendo-se os efeitos obrigacionais da sentença dada em um caso a todos os demais que contivessem objeto análogo. O tribunal escolhe um ou alguns dentre os vários recursos veiculando o mesmo pedido, suspendendo os demais feitos, e a sentença que sobrevier, la "sentencia-testigo", pode ser aplicada em todos os feitos ${ }^{710}$. A grande diferença - e causa de certo fracasso da medida - é que, julgado o pleito-testigo ou recurso-test, o titular da ação individual poderá optar por estender a ela os efeitos daquele caso piloto, ou desistir de sua ação, ou, enfim - e aí mora o problema - continuar com a ação individual ${ }^{711}$. A Espanha não conseguiu abandonar totalmente a sedução do individualismo.

\footnotetext{
${ }^{708}$ BUNDERSMINISTERIUM DER JUSTIZ, “The German 'Capital Market Model Case Act”, disponível em: <http://www.clglaw.eu/cmsimages/Publications/German\%20Capital\%20Markets\%20Case.pdf>, acesso em 30.9.2013, 15:02h.

${ }^{709}$ BUNDERSMINISTERIUM DER JUSTIZ "Reform of German Model Proceedings Act planned”, disponí vel em: <http://globalclassactions.stanford.edu/sites/default/files/documents/Reform\%20of\%20German\%20 Model\%20Proceedings\%20Act\%20planned.pdf >, acesso em 30.9.2013, 15:26h.

${ }^{710}$ GRINOVER, MULLENIX, WATANABE. O Processo Coletivo..., p. 162.

${ }^{711}$ RIBEIRO, Cristina Hamdar. "A Lei dos Recursos Repetitivos e os Princípios do Direito Processual Civil Brasileiro", em Revista Eletrônica de Direito Processual - REDP, V. V. Rio de Janeiro: Universidade Estadual do Rio de Janeiro, pp. 629/630, disponível em: <http://www.redp.com.br/arquivos/redp_5a_edicao. pdf>, acesso em 30.9.2013, 16:20h (pp. 614-691).
} 
A legislação projetada também segue a linha de tratamento isonômico de questões iguais $^{712}$. O Projeto do novo Código de Processo Civil, atento à massificação do direito e aos empíricos sinais de que grande parte dos processos levados a julgamento se refere a causas análogas ou, no jargão da lei e dos especialistas, repetitivas, prevê a possibilidade de, semelhantemente ao que, hoje, ocorre com os recursos especiais repetitivos $^{713}$, sobrestar o julgamento de todos os processos análogos que não um, apenas, que servirá de julgamento e paradigma a ser aplicável a todos os outros $\operatorname{casos}^{714}$. Na hipótese do codex, será admissível o incidente de resolução de demandas repetitivas quando houver efetiva ou potencial repetição de processos que contenham controvérsia sobre a mesma questão de direito material ou processual ${ }^{715}$. Os valores ali protegidos são, textualmente, a isonomia e a segurança jurídica, ou seja, o legislador está efetivamente preocupado em dar tratamento idêntico (ou análogo) a questões idênticas (ou análogas).

Percebe-se, de antemão, que a multiplicidade de demandas pode envolver repetição de questões individuais, individuais homogêneas, coletivas ou difusas. O caso piloto serve para as ações individuais e individuais homogêneas, enquanto que o remédio para os direitos coletivos é outro, e será tratado adiante: o incidente de coletivização.

Tal caso piloto não revela técnica de coletivização, é bom se frisar, mas de uniformização de julgamentos. Essa confusão foi desfeita pelo legislador projetista do novo CPC, já que, na versão original, chamava-se incidente de coletivização mecanismo em todo compatível com o caso piloto. No Substitutivo da Câmara dos Deputados, o mal entendido foi desfeito e, então, a técnica passou a ser denominada incidente de resolução de demandas repetitivas ${ }^{716}$, enquanto que a coletivização propriamente dita foi tratada no capítulo intitulado Da conversão da ação individual em coletiva ${ }^{717}$.

\footnotetext{
${ }^{712}$ A exposição de motivos do Anteprojeto do novo Código de Processo Civil estabelece, ao fundamentar a criação do Incidente de Resolução de Demandas Repetitivas, que a inspiração para esse instrumento proveio do direito alemão, em que a decisão gera um modelo para expressiva resolução de processos em que as partes estejam na mesma situação, mesmo não se tratando dos mesmos autor e réu. Segundo os expositores, “(...) $o$ incidente de resolução de demandas repetitivas é admissível quando identificada, em primeiro grau, controvérsia com potencial de gerar multiplicação expressiva de demandas e o correlato risco da coexistênc ia de decisões conflitantes". (Disponível em <http://www.senado.gov.br/senado/novocpc/pdf/Anteprojeto.pd $\mathrm{f}>$, acesso em 19.12.2010, 20:24h).

${ }^{713}$ Cf. artigo $543-\mathrm{C}$ do CPC.

${ }^{714}$ A questão da resolução das causas repetitivas é tida como uma das grandes e esperadas novidades da legislação projetada (Revista Veja, edição no 2.196 - 22 de dezembro de 2010 - pp. 118-121).

${ }^{715}$ Artigo 988 do Substitutivo da Câmara dos Deputados.

${ }^{716}$ Arts. 998 a 1000 do Substitutivo da Câmara dos Deputados.

${ }^{717}$ Art. 334 do Substitutivo da Câmara dos Deputados. Sobre a alteração da atécnica denominação, ver entrevista de Bruno DANTAS ao Consultor Jurídico ("Lei de Recursos Repetitivos pode se tornar obsoleta"), disponível em: 〈http://www.conjur.com.br/2010-mai-02/entrevista-bruno-dantas-integrantes-comissao-cpc>, acesso em 12.12.13, 7:43h).
} 
O incidente de resolução de demandas repetitivas tem a boa pretensão de se tornar instrumento de uniformização de questões múltiplas - como geralmente ocorre na tutela da saúde - tanto que, nele, o Ministério Público sempre intervirá e, em caso de abandono por disjuntivo titular - circunstância que não exime a análise de mérito -, poderá assumir sua titularidade. Também o pedido de instauração do incidente será apresentado pelas partes ou pelos tradicionalmente legitimados à propositura de ações coletivas - o Parquet, as associações, a pessoa jurídica de direito público e a Defensoria Pública. A instauração do caso piloto gozará de ampla publicidade dada pelo CNJ que, afinal, deve consolidar banco de dados alimentado pelos tribunais. A abrangência da decisão está afetada à competência territorial do respectivo tribunal (atecnicamente denominada, na norma, de área de jurisdição do respectivo tribunal, erro já observado, criticado e infirmado pelo Judiciário quanto ao artigo 16 da Lei $\left.n^{\circ} 7.347 / 85\right)$ e dela cabe, conforme for, recursos especial e/ou extraordinário. Enquanto desenrola-se o incidente, ações que tramitam no mesmo território do tribunal serão suspensas por até um ano, prazo em que também o incidente deverá ser julgado, preferindo a todos os demais feitos (incluindo, então, recursos), salvo habeas corpus e medidas relacionadas ao réu preso. E o mais interessante: os casos futuros que tratem de idêntica questão de direito submeter-se-ão ao decidido no caso piloto.

O Anteprojeto de revisão do Código de Defesa do Consumidor contempla medida semelhante. Nota-se, destarte, a preocupação do legislador com a multiplicidade de feitos, fenômeno típico da massificação do Direito ${ }^{718}$.

O caso piloto envolve repetição, é dizer, multiplicidade de demandas já alocadas no Judiciário tratando da mesma questão, tal qual sucede em temas que motivam a massificação de feitos. A própria massificação de processos legitima seu trato múltiplo, sejam os direitos difusos, coletivos ou individuais homogêneos ${ }^{719}$. Nessa hipótese, o juiz, de ofício, a parte, o Ministério Público, a Defensoria, uma associação que goze de pertinência temática ou mesmo um amicus curiae poderia, informando a respeito da existência de multiplicidade de processos discutindo mesmo tema, solicitar a eleição de um feito como o caso piloto, enquanto que os demais permaneceriam sobrestados à espera do respectivo resultado. Se favorável aos postulantes, todos se aproveitariam da decisão; se

\footnotetext{
${ }^{718}$ A nova redação do CDC que se avizinha preconiza, inclusive, a reunião de feitos em sede administrativa, quando permite ao órgão administrativo que profira uma única decisão aplicável ao conjunto de reclamações, sempre que elas forem “individuais de natureza repetitiva” (art. 55, §6 $6^{\circ}$ II).

${ }^{719}$ Sobre a repetição de causas envolvendo direitos coletivos em sentido estrito, ver item subsequente, sobre o incidente de coletivização.
} 
desfavorável, todos os demais processos seriam extintos, a não ser que o indivíduo demonstrasse ser seu caso diferente do paradigma.

Havendo concomitância entre ações individuais e coletivas (claro, na hipótese delas todas tratarem a respeito do mesmo objeto), o caso piloto deve ser, preferencialmente, a ação coletiva. Nesse sentido, afinal, não se diverge do que já decidiu o STJ ao tratar da análoga hipótese do recurso especial repetitivo ${ }^{720}$. Ademais, o processo a ser escolhido deve ser o mais bem aparelhado, em termos de alegações, provas e dimensão do objeto discutido. Essa decisão cabe ao relator de eventual recurso, mediante provocação das partes interessadas. A escolha dependeria, ainda e invariavelmente, de sistemas bem alimentados de coleta, análise e cruzamento de dados. O Ministério Público, quando não for autor do pedido, deve opinar necessariamente sobre o acerto da escolha. Seria a escolhida ou a ação coletiva, ou a individual mais bem aparelhada em termos de alegações e provas. Uma vez eleita, seria acompanhada de perto pelo Parquet, que assumiria sua titularidade em caso de abandono ou pedido de desistência.

Não seria necessária a eleição de mais casos além de um único, a ser selecionado no juízo em que se instaurou a questão incidente ${ }^{721}$, mas não obstando que sejam outros poucos os casos escolhidos. Ali, naquele feito, seriam discutidas todas as questões que o juiz e as partes têm que enfrentar quando se fala na dispensação judicial da saúde: a reserva do possível, a análise do mínimo existencial e da razoabilidade, a verificação das ações tomadas, já a propósito, pela Administração. A prova seria toda produzida nessa sede. Poderiam ocorrer debates públicos, inclusive quanto às necessidades da população versus a questão orçamentária, tudo em um único processo de cuja decisão se aproveitariam ou prejudicariam os demais feitos.

\footnotetext{
${ }^{720}$ REsp n ${ }^{\mathrm{o}}$ 1.110.549/RS, 2 ${ }^{\mathrm{a}}$ Seção, Rel. Min. Sidnei BENETTI, DJ em 14.12.2009. Discutia-se, nesse recurso, a possibilidade de suspensão forçada das ações individuais para julgamento de uma ação coletiva, todas versando sobre as "trombadas" dos planos econômicos adotados pela União na Década de 1980, mesmo diante da previsão de coexistência pacífica entre ações individuais e coletivas posta no artigo 104 do CDC. O pensamento vencedor foi singular: basicamente, o Relator sustentou, com fundamento no artigo 543-C do CPC, que a suspensão dos feitos individuais seria medida de economia processual, já que, caso procedentes os pedidos deduzidos na ação coletiva, os autores individuais poderiam executá-los (transporte in utilibus preconizado no artigo 104 do CDC), ou seus pedidos poderiam ser liminarmente rejeitados com base no artigo 285-A do CPC. O Relator, assim, elegeu um microssistema de recursos repetitivos, aplicando a suspensão forçada às ações individuais. Segundo ele: "Na identificação da macro-lide multitudinária, devese considerar apenas o capítulo principal substancial do processo coletivo", um evidente prestígio ao tratamento coletivo de questões transindividuais.

Nota-se, contudo, não ter sido a questão tão tranquila. O Min. Honildo Amaral de Mello CASTRO, convocado, divergiu do Relator para celebrar a autonomia da vontade representada pelo direito de postular individualmente, apoiado no sistema já mencionado, fundado no artigo 104 do diploma consumerista.

${ }^{721}$ Que deveria ser, como se sugerirá, um juiz especialista em análise de questões de políticas públicas.
} 
Os debates públicos, aliás, estão entre os atos mais relevantes do juízo de políticas públicas. O juiz deve estar informado para atuar nesse mister, para, por ocasião do julgamento, munir-se de todas as informações de parte a parte, refletindo a respeito e, então, decidindo de forma segura, plena e exauriente. Os atores envolvidos no processo judicial - o autor, o Estado e o juiz - devem debater, não apenas por petições, mas por encontros, reuniões e audiências públicas, para que as informações a respeito do objeto do processo fossem todas expostas, como se fora - de novo - inspirado no discovery norteamericano $^{722}$. Os dispositivos que podem autorizar o juiz na realização desses colóquios são os artigos 342 e 599, I do Código de Processo Civil, que o autorizam, a qualquer tempo no processo ou na fase de execução, convocar o comparecimento das partes para tratar de fatos relacionados à causa. De lege lata, é possível, com base nestes dispositivos, permitir que o juiz convoque audiências públicas para a manifestação das partes antes de decidir qualquer tema afeto a políticas públicas, o que deve acontecer, para maximizar a eficiência processual, no âmbito de uma ação coletiva ${ }^{723}$.

Por sua própria natureza, a ação coletiva é mais indicada à dialética dos grandes temas. Ela é o instrumento que melhor congrega os múltiplos interesses relacionados ao direito material discutido. Modelo de participação social pelo processo ${ }^{724}$, as ações coletivas permitem o amplo engajamento da sociedade e ampliam o diálogo sobre os temas que lhes são mais caros. Isso não significa, contudo, que patologias não possam existir mesmo nas ações coletivas (aliás, há exemplos no Item 4.1.3, que demonstram justamente problemas), mas o uso racional desses mecanismos contribui, indubitavelmente, para a racionalidade da judicialização de políticas públicas.

Nesse sentido, de curial importância é a coleta de dados a respeito das ações individuais e coletivas já existentes. O juiz, na distribuição, recebendo a inicial da ação individual e vislumbrando a possibilidade de se tratar de um tema que ultrapasse os limites subjetivos do processo, seria instado a consultar os cadastros nacional, estadual e regional de ações que envolvem políticas públicas, instrumento que será oportunamente tratado

\footnotetext{
722 Sobre o Discovery, ver ANDRIGHI, "Estrutura e Dinâmica...”..

${ }^{723}$ Novamente calha mencionar a legislação projetada do CDC, que, no artigo 90-J, outorga ao magistrado o poder de convocar, a todo o tempo e grau de jurisdição, audiências públicas para ouvida de especialistas e membros da sociedade. $\mathrm{O}$ texto a ser votado ainda explica que essas audiências servirão, precisamente, para aprofundar a cognição judicial.

${ }^{724}$ No sentido de que ao abarcar múltiplos interesses, inclusive alguns de titularidade indeterminada e objeto indivisível, as ações coletivas permitem que a atenção do Estado, via Poder Judiciário, volte-se a pessoas cujos interesses jamais seriam perquiridos pelos métodos ordinários (administrativos ou judiciais). A participação pelo processo, inclusive, é um dos postulados básicos da teoria da tutela coletiva, e seria positivada no artigo $2^{\circ}, c$ do Anteprojeto de Código Brasileiro de Processos Coletivos. A concepção está na linha do que FISS consagra como direito de representação.
} 
(Item 5.4.1) e, checando a existência de ação ou ações cadastradas, determinaria as providências para eleição do caso piloto ${ }^{725}$.

O pedido de eleição da ação individual ou coletiva em caso piloto poderia também partir dos legitimados à propositura da ação metaindividual, bem como das partes interessadas, que municiariam o magistrado de argumentos para que ele pudesse determinar qual seria o caso a seguir como modelo.

Proposta de procedimento para concretização do caso piloto, de conseguinte, é a que segue: diante de qualquer demanda cujo objeto identificado disser respeito a políticas públicas, direitos tipicamente por elas tratados ou, ainda, aqueles que, por sua natureza, envolvam multiplicidade de processos em tramitação no foro, e havendo tal multiplicidade, as partes, o Parquet, a Defensoria, a pessoa jurídica de direito público e associações que ingressem no feito ou participem como amici curiae, juiz ou relator de recurso intermediário, de ofício, poderão indicar aquele caso como piloto, suspendendo-se todas as demais ações já propostas ou a propor, bem como os prazos prescricionais eventualmente observados. A decretação do caso como piloto será tomada pelo relator de eventual recurso, cabendo, dela, irresignação à turma considerada como juiz natural. Daí o caso piloto seria conduzido em primeiro grau, e direcionado ao juízo especializado em políticas públicas, prevenindo-o. Se a multiplicidade de ações ou o objeto questionado condisser questão que ultrapasse a competência territorial do tribunal, então será o STJ o responsável por escolher e qualificar tal caso como piloto. De qualquer modo, a decisão do relator deverá ser tomada em até sessenta dias da entrada do incidente e passará a constar dos cadastros de registros de ações de políticas públicas. As decisões manifestadas no caso piloto valerão para todos os processos suspensos, precluindo decisões análogas e constituindo coisa julgada oponível como exceção em novos casos e podendo ser executadas por seus destinatários, individual ou coletivamente.

$\mathrm{Na}$ já tratada hipótese de abrangência do objeto que ultrapasse Estado ou região, o STJ escolherá um juízo especializado em políticas públicas para processar o caso piloto, que, eletronicamente, participará outros juízos análogos, um em cada Estado ou região, também escolhidos pelo STJ, para facilitar a postulação e o acesso a informações.

\footnotetext{
${ }^{725} \mathrm{Na}$ verdade, este é mais um caso de relação entre demandas, já contemplado, de lege lata, no Código de Defesa do Consumidor, artigo 104. O próprio Anteprojeto do Código Brasileiro de Processos Coletivos também previa mecanismo nesse sentido, tanto quanto ao texto que dele adveio, o projeto de (nova) Lei de Ação Civil Pública (artigos 34 a 37), disponível em: 〈http://www.camara.gov.br/sileg/integras/651669.pdf〉, acesso em 20.12.2010, 22:30h. Da mesma forma, o projeto de CDC contempla a criação, manutenção e alimentação de cadastros não apenas de processos coletivos, mas de inquéritos civis e compromissos de ajustamento de conduta (arts. 104-B e 104-C).
} 
O caso piloto tramitará normalmente, sem prazo definido, gozando, contudo, de prioridade perante os demais feitos, com a exceção daqueles relacionados a habeas corpus e réu preso. No juízo especializado em políticas públicas, ele preferirá as demais ações. As medidas urgentes atendentes a cada indivíduo deverão ser solicitadas ao juiz competente para o julgamento do caso piloto. O processo seguirá como caso piloto até decisão definitiva contra a qual não caiba mais recurso.

Como adiantado, em caso de procedência do pedido, sendo ele individual homogêneo, passar-se-á à liquidação. Se, contudo, for improcedente o pedido, somente o indivíduo que provar que seu caso não guarda semelhança com os motivos e com o dispositivo da decisão do caso piloto poderá continuar com seu processo.

\subsubsection{O incidente de coletivização}

Passando, pois, à propositura de instrumentos de coletivização stricto sensu, é tempo, para transformar questão coletiva tratada individualmente em questão coletiva tratada coletivamente, de estudar o que se poderia denominar incidente de coletivização.

Questões de saúde são, normalmente, massificadas que, assim, devem ser tratadas de forma coletiva. Por isso, o que se sugere é que, estando diante de ação individual em que o autor requeira alguma providência que envolva a adjudicação de bens na seara da saúde (o que pode se aplicar para qualquer política pública, afinal), o juiz deva sempre inquirir a respeito da possibilidade de transformar aquela questão individual - que, no fundo, também é metaindividual - em formalmente coletiva.

No incidente de coletivização, o juiz, deparando-se com caso envolvendo saúde (e não apenas: a solução seria aplicada sempre que o direito em tela fosse daqueles universais e marcadamente coletivos em sentido estrito), seria obrigado a, preliminarmente, tomar providências para coletivizar a questão. Mas que providências seriam essas?

Diante de demanda individual pleiteando direitos sociais - como, por exemplo, o acesso a medicamento não disponível nos postos de saúde - que possa, a toda a evidência, gerar contingência coletiva, o juiz oficiaria o Ministério Público e demais 
legitimados para a propositura da necessária ação coletiva o que, afinal, mesmo hoje deveria ser feito, isso, com fundamento no artigo $6^{\circ}$ da Lei $n^{\circ} 7.347 / 85$ : o juiz, como servidor público, tem o dever de municiar o Ministério Público de informações que constituam o objeto de uma clara e evidente ação civil pública. Essa é medida que assegura que os direitos sejam tutelados da maneira coletiva como devem, distribuindo-se de modo mais igualitário os bens sociais. O problema é que tal previsão legislativa, embora existente, não é utilizada para esses fins. Os magistrados normalmente não conseguem enxergar a repercussão coletiva de uma demanda que nasce formalmente individual.

Deve-se frisar que objetos difusos e coletivos envolvendo saúde podem muito bem constituir pedidos de única ou de multiplicidade de demandas que se apresentam como individuais. Aí é o caso de coletivizar o assunto, vale dizer, transformar essa ação ou ações individuais em coletivas, por força natural de seu objeto. Entre nós, o Anteprojeto do Código Brasileiro de Processos Coletivos já estabelecia, em seu artigo $8^{\circ}$, que a multiplicidade de processos individuais correndo contra o mesmo demandado, com identidade de fundamento jurídico, daria ensejo a uma notificação ao Parquet e a outros legitimados para que propusessem uma ação coletiva a respeito. Era uma ideia ousada, nada obstante correta, e bastante condizente com a relevância das tutelas metaindividuais, solução pensada a partir do direito material para o processo, e não o inverso. Também o artigo 139, X do Substitutivo do CPC da Câmara dos Deputados outorga ao juiz essa possibilidade. O que se propõe, aqui, segue a mesma vertente, com a vantagem é que mesmo uma única ação pode ser transformada em coletiva - desde que, ali, o magistrado identifique direito coletivo em sentido estrito.

A primeira ação a ser tomada na nova ordem do juízo sobre políticas públicas seria a ampla ciência à população e aos poderes públicos a respeito da propositura da ação e de seu objeto, para que, a uma, aqueles jurisdicionados que estivessem na mesma situação pudessem ingressar no feito e, a duas, a Administração fosse capaz de verificar, em seus próprios cadastros ou de acordo com seus dados e estudos, a demanda pela ação ou prestação de saúde ${ }^{726}$. A ciência seria realizada da maneira mais ampla possível, com a publicação em periódicos, em sítios na internet (inclusive dos tribunais e dos órgãos de saúde) e por inclusão da mídia eletrônica e televisiva ${ }^{727}$. Com ou sem o ingresso dos

\footnotetext{
${ }^{726} \mathrm{O}$ artigo $2^{\circ}$, o do Anteprojeto de Código Brasileiro de Processos Coletivos previa como princípio do processo coletivo a ampla divulgação da demanda $e$ dos atos processuais, em evidente corolário à necessidade de ampla participação e contemplação das medidas tomadas nesse tipo de processo.

${ }^{727}$ Claro que os custos relacionados a essa proposta preocupam. Seria preciso - e natural, até - que o Estado absorvesse esses custos. Ora, se é do interesse dele, Estado, que sejam cumpridos os objetivos constitucionais
} 
interessados no feito, a ação passaria de individual para coletiva, contando, aí, com o auxílio de representantes adequados - do Ministério Público, da Defensoria ou de um órgão de classe ou associação, a serem, nestes últimos dois casos, certificados pelo juiz ${ }^{728}$ - que passariam, então, à condução do processo, podendo contar com o auxílio do autor da ação individual em que o incidente foi instaurado ${ }^{729}$. A decisão proferida nessa nova ação seria aplicável a todos os que informaram estar na mesma situação, independente de processos instaurados em seu nome, que se incumbiriam de atuar incisivamente no feito, habilitando-se na vindoura execução do julgado, o que, de resto, já acontece no sistema de ações coletivas de lege lata ${ }^{730}$.

As mais incisivas alterações ocorreriam na primeira fase do processo individual, ou, mais especificamente, assim que fosse ele proposto. O sucesso da proposta teria íntima relação com a criação de juízos especializados em tratar questões relacionadas

ligados, por exemplo, à saúde, e considerando a necessidade de distribuir universalmente tais direitos, é do completo interesse do Estado que mais pessoas sejam abrangidas nos reclamos - e pelas respostas - judiciais. Sobre o uso dos fundos como o FDD, ver Item 5.5.1.2. adiante.

O fluid recovery, mecanismo norte-americano criado no âmbito das class actions, recebe condenações estabelecidas nessa espécie de ação e serve, dentre outras coisas, para o pagamento dos pesados custos envolvidos em class actions. Sobre o fluid recovery em sua versão estrangeira original, ver KARMEL, Philip E. e PADEN, Peter R. "Fluid Recovery in Class Action Litigation", in New York Law Journal, December 26, 2006 edition.

No Brasil, a Lei no 9.008/95 disciplina o FDD - Fundo de Defesa dos Direitos Difusos, que recebe o produto de multas e indenizações de titularidade indeterminada, além de doações e rendimentos, e os aplica na recomposição dos bens metaindividuais lesados. Não seria um absurdo pensar em atribuir ao FDD missão de financiar as providências que oneram o projetado incidente de coletivização. Sobre o FDD, ver Balanço Social 2007/2008, disponível em: <http://portal.mj.gov.br/cfdd/data/Pages/MJ038B8D53PTBRNN.htm>, acesso em 20.12.2010, 23:18h.

${ }^{728}$ A representação adequada é uma construção do direito norte americano, presente na Rule 23 das Federal Rules of Civil Procedure. Ali, as class action contam, no pólo ativo, com um representante da classe, categoria ou grupo que, segundo a lei e atendendo a diversos critérios (i.e., histórico do representante na defesa dos direitos tais como aqueles em discussão, capacidade econômica de conduzir o processo), é certificado pelo juiz como um representante adequado da classe substituída. Nos Estados Unidos, como as class action vinculam a todos que não exercem o direito de Opt-Out, o cuidado com a eleição do representante adequado é redobrado e feito casuisticamente, como mencionado, pelo magistrado. Alhures, ele pode até ser uma pessoa natural.

No Brasil, o Código Brasileiro de Processos Coletivos procurou emprestar a representatividade adequada para ampliar não apenas o controle jurisdicional sobre o autor da ação coletiva, mas, também, ampliar o rígido esquema de legitimidade ativa presente na Lei de Ação Civil Pública e no Código de Defesa do Consumidor (GRINOVER, MENDES e WATANABE. Direito Processual Coletivo..., pp. 450/451).

${ }^{729}$ A solução de outorgar ao autor a concordância com a conversão não parece ser a mais apropriada, principalmente considerando haver situações em que o autor não queira ver seu pleito coletivizado (i.e., possibilidade de transação para recebimento de um medicamento, por exemplo, eventualmente não contemplada na demanda coletiva pelas claras limitações impostas em função da potencial indisponibilidade do objeto). Neste caso, a autonomia da vontade materializada na ação individual sucumbiria à necessidade de atendimento aos pressupostos da universalidade e indivisibilidade.

${ }^{730}$ Evidentemente que as pessoas que formalmente não ingressarem no feito não poderão se aproveitar das benesses da sentença coletiva, muito embora, fundado nos princípios relacionados à distribuição da saúde e já debatidos neste texto, o ideal seria que fossem contemplados todos aqueles em situação idêntica, mesmo a despeito da ausência de ingresso formal no processo. 
a políticas públicas, que, de resto, são muito peculiares ${ }^{731}$. Demanda pleiteando a inclusão de criança em creche mantida pelo Poder Público teria que ser deduzida nesses órgãos. Pedido de internação para a realização de uma cirurgia nos hospitais do SUS, de igual forma, seria apresentado nesses juízos. Embora, excepcionalmente, ficasse constatado que a decisão daquele feito seria individual, a concentração e o direcionamento racionalizado viabilizaria o controle de tal espécie de causas e, de conseguinte, maximizaria a eficácia do incidente de coletivização.

Aliada à proposição de juízos especializados anda a já mencionada ideia da criação de cadastro ou de uma relação nacional, estadual e regional de ações coletivas. Este é fator determinante para a extração de efeitos contundentes do incidente de coletivização. Tal instrumento viabilizaria o juiz a, de seu próprio gabinete, consultar quais são os processos que, eventualmente em curso, discutiriam a mesma questão que lhe fora submetida nos autos que estão ali, defronte do magistrado. Mas é o distribuidor que terá a primordial função de fazer a primeira triagem. Os cadastros merecerão um capítulo à parte nesse estudo ${ }^{732}$.

Ao receber o processo individual em que a questão tratada fosse potencialmente coletiva, o distribuidor, de imediato, consultaria os cadastros existentes e, checando a existência de discussão semelhante, enviaria o feito ao juízo especializado em políticas públicas. Expediria o magistrado, ato contínuo, pedidos de informação às autoridades responsáveis pela execução das políticas para avaliar a demanda do mesmo objeto presente na ação ${ }^{733}$. Analisando-se tratar o caso, de fato, de questão coletiva e já existindo demanda dessa espécie em curso, determinaria o compulsório sobrestamento da ação individual e a habilitação do demandante na ação coletiva; se inexistisse demanda transindividual, provocaria a instauração dela, oficiando os órgãos e entidades já aludidos - Ministério Público ${ }^{734}$, Defensoria, associações civis - para a propositura da ação coletiva

\footnotetext{
${ }^{731}$ Ideia que será tratada oportunamente, no Item 5.3.1, inclusive à luz de dois casos paradigmáticos.

${ }^{732} \mathrm{~V}$. Item 5.4.1.

${ }^{733}$ A interessante solução dada pelo artigo 26 do APLPP merece destaque - ali, menciona-se que o juiz, diante de latente relevância social e ouvido o Ministério Público, poderá converter a ação individual em coletiva, sempre que: (a) o bem discutido seja universal e indivisível, afetando, a um só tempo, o indivíduo e a coletividade; ou (b) a situação jurídica faça impor a adoção de uma solução uniforme, como medida de isonomia. A primeira hipótese versa sobre questões como o direito ao fornecimento de medicamentos e terapias; a segunda, aquelas tipicamente classificáveis como individuais homogêneas.

${ }^{734}$ O Parquet possui o dever constitucional de zelar e promover as medidas necessárias a garantir que os poderes públicos cumpram os direitos assegurados na Constituição, tais como educação, saúde, alimentação, lazer, vestuário, assistência, moradia, transporte. Esta é a pura inteligência do inciso II do artigo 129 da Constituição. Sinaliza nesse sentido, dizendo ser essa uma função esquecida pelo Ministério Público, SALLES, Carlos Alberto ("Coisa julgada e extensão dos efeitos da sentença em matéria de direitos sociais constitucionais”, in GOZZOLI, Maria Clara; CIANCI, Mirna; CALMON, Petrônio e QUARTIERI, Rita. Em
} 
a respeito ${ }^{735}$. Em última análise, seria mesmo o Parquet a propor a ação, e se o órgão recebedor se recusasse, o respectivo conselho superior teria de designar outro representante, nos exatos moldes do que já ocorre em caso de ação civil pública.

Assim, o incidente de coletivização teria área de atuação no caso de direitos coletivos stricto sensu, ainda que objeto de multiplicidade de ações judicias. Ele, por sua própria natureza, é ainda mais abrangente do que o caso piloto: enquanto que o caso piloto se coloca em plano endoprocessual, compreendendo apenas as questões repetitivas já levadas a Juízo e potencializadas, porquanto multiplicadas - constituindo, assim, técnica que privilegia a isonomia -, o incidente de coletivização dá àquele que ainda não buscou o Judiciário a oportunidade de usufruir dos efeitos de decisão judicial que trata de um caso semelhante ao seu, porque ele trata de direitos coletivos stricto sensu. Daí a diferença terminológica entre o que, aqui, é denominado incidente de coletivização e o que os projetos do novo Código de Processo Civil e de revisão do Código de Defesa do Consumidor assim chamavam e, na verdade e como já se viu, mais se assemelha ao caso piloto aqui proposto ${ }^{736}$, o que foi corrigido nas versões mais recentes.

Nesse sentido, importa trazer a lume a proposta do Projeto e Código de Processo Civil. O capítulo intitulado da conversão da ação individual em ação coletiva traz a coletivização de assuntos que, como a saúde, tenham relevância social, em ações individuais cujo pedido possua: (a) alcance coletivo em função de tratar de bem coletivo e indivisível cuja ofensa afete, concomitantemente, a esfera jurídica do indivíduo e da coletividade (hipótese ação individual com efeitos coletivos); ou (b) como objetivo a solução de conflito plurilateral, cuja solução, pela natureza ou por disposição legal, deva

defesa de um novo sistema de processos coletivos. Estudos em homenagem à Ada Pellegrini Grinover. São Paulo: Saraiva, 2010).

${ }^{735}$ A solução encontrada pelo Anteprojeto de Código Brasileiro de Processos Coletivos (Artigo $8^{\circ}$, parágrafo único) para a questão parece adequada também nessa situação: se o Ministério Público não propuser a ação coletiva, o juiz ordenará a remessa das peças ao conselho superior respectivo, que poderá designar outro órgão ministerial ou insistirá na não propositura, motivadamente. Na mesma esteira se coloca o artigo 25 do APLPP.

${ }^{736}$ De acordo com notícia publicada no sítio eletrônico do STJ, "Incidente de coletivização é um novo instrumento que está sendo proposto ao CPC. O objetivo é transformar em uma única ação coletiva processos individuais semelhantes, para acelerar o trabalho da Justiça. Assim, sempre que uma nova ação surgir sobre algum assunto já decidido por incidente de coletivização - como, por exemplo, a contestação de assinatura básica de telefonia -, a decisão já produzida será automaticamente aplicada, sem a necessidade de tramitar novamente pela Justiça. Medida a ser aplicada somente em litígios que possam ser considerados de massa, o incidente de coletivização tem o objetivo ainda de evitar que ações semelhantes resultem em decisões diferentes, conforme entendimento de cada juiz responsável pela ação”, disponível em: <http://www.stj.jus.br/portal_stj/publicacao/engine.wsp?tmp.area=398\&tmp.texto=96448>, acesso em 20.12.2010, 23:33h. Vê-se, aqui, que o STJ amarra a multiplicidade de demandas ao incidente de coletivização, o que, depois, foi corrigido no Substitutivo da Câmara dos Deputados. Sobre o assunto, ver Item anterior. 
ser necessariamente uniforme, assegurando-se tratamento isonômico a todos os membros do grupo (caso de ações pseudoindivuais) ${ }^{737}$. São mecanismos de coletivização que, como o incidente ora proposto, têm lugar quando o objeto da causa seja coletivo em sentido estrito, ainda que ela, erradamente, seja apresentada como individual.

No caso de objeto coletivo em sentido estrito, a coisa julgada lançará sua autoridade pro et contra, ou seja, a improcedência também atingirá os autores dos feitos suspensos - caso a questão já tenha sido levada a juízo - e, inclusive, quem não propôs ação, embora sendo titular do direito discutido, como efeito natural da sentença que decide objeto indivisível, o que, de resto, já ocorre nas ações coletivas e na ação popular ${ }^{738}$. Isso significa que, no incidente de coletivização, a sentença pode prejudicar autores de ações individuais.

Nenhum problema a esse respeito. Se o objeto coletivo foi erradamente deduzido em juízo como individual, então o autor dessa medida singular não poderia alegar qualquer violação a direito seu, já que de individualidade não se trata. Questão diferente ocorreria caso esse autor cumulasse objetos coletivos e individuais: nesse caso, seria de rigor que os pedidos individuais fossem apartados dos coletivos, suspensos até julgamento destes e, em caso de improcedência dos coletivos, os individuais pudessem ser analisados $^{739}$.

É evidente que, na cena jurídica atual, o incidente de coletivização - e qualquer medida de coletivização, a propósito - possui um óbice: o atécnico e tão questionado artigo 16 da Lei n. 7.347/85 ${ }^{740}$. Estabelece a norma (como se fosse isso possível) a limitação territorial da sentença prolatada em uma ação civil pública.

A se manter esse entendimento, o incidente de coletivização seria relativizado e sua eficácia, tolhida, porque de nada adiantaria à associação sediada em São Paulo saber, a não ser como eventual argumento persuasivo, que a questão que ela levaria a juízo está já em franca discussão em uma ação civil pública proposta no Rio de Janeiro, porque, afinal, os efeitos da sentença prolatada alhures não contemplariam os associados paulistas, por mais que houvesse claríssima identidade de objeto. A verdade é que qualquer iniciativa inteligente ao tratamento coletivo de questões metaindividuais deve passar pelo

\footnotetext{
${ }^{737}$ Sobre essas modalidades de objeto, ver Item 5.1.2.

${ }^{738}$ Recorre-se, aqui, a GRINOVER que, na linha de CHIOVENDA e BARBOSA MOREIRA, considera que porque o objeto é incindível (caso dos direitos difusos e coletivos em sentido estrito), trata-se de ato único e indivisível exposto à impugnação de uma pluralidade de sujeitos, em absoluta identidade de situações jurídicas (“Coisa julgada Erga Omnes...", pp. 3-6).

${ }_{739} \mathrm{O} \S 4^{\circ}$ do art. 334 do Substitutivo da Câmara dos Deputados ao projeto de CPC anda na mesma trilha.

${ }^{740} \mathrm{~V}$. nota 696.
} 
expurgo dessa norma do sistema processual. É isso que propunha o projeto de lei que alterava a ação civil pública ${ }^{741}$ e, felizmente, é o que estabelece o $\$ 2^{\circ}$ do artigo 81-A do projeto de revisão do CDC, este, mais perto de ser positivado ${ }^{742}$.

Também a Corte Especial do STJ definiu, por dez votos a três, que não se aplica o óbice imposto pela Lei $n^{\circ}$ 9.494/97. De acordo com a Corte, para que a decisão proferida em ação civil pública tenha abrangência nacional basta que os afetados por tal decisão estejam distribuídos pelo Brasil. Nesse caso, a abrangência nacional dependeria do pedido e do domicílio dos beneficiários ${ }^{743}$. Trata-se, sem dúvida, de uma leitura que vai ao encontro das lições mais básicas de processo civil e de tutela jurisdicional coletiva, o que sói se espera do STJ. Este posicionamento é capaz de sedimentar o terreno para aplicação do trato coletivo do direito à saúde.

Tanto o caso piloto quanto o incidente de coletivização são medidas que, concretamente aplicadas, levariam não somente à amplitude do debate no processo, mas, também, à economia processual e, mais importante, ao tratamento igualitário de casos iguais. Uma vez uniformizada ou coletivizada a questão, as portas estariam abertas para um tratamento econômico, igualitário e racional da questão política levada ao crivo judicial.

A seguir será proposto outro remédio apto a constituir alternativa eficiente para priorizar o tratamento coletivo de direitos que, como a saúde, são universais: a expansão dos efeitos da decisão manifestada em caso individual.

\footnotetext{
741 Segundo o artigo 32, “A sentença no processo coletivo fará coisa julgada erga omnes, independentemente da competência territorial do órgão prolator ou do domicílio dos interessados." Por mais críticas que se possa fazer a esse projeto, uma releitura mitigadora do anteprojeto do Código Brasileiro de Processos Coletivos, ao menos os nefastos efeitos do atual artigo 16 da legislação correlata de regência deixarão de existir.

742 “Art. 81-A (...) $\$ 2^{\circ}$ Para as ações propostas a partir da entrada em vigor desta Lei, a competência territorial do órgão prolator ou o domicílio dos interessados não restringirão a coisa julgada de âmbito nacional ou regional."

${ }^{743}$ A decisão foi manifestada em recurso repetitivo e comemorada por representar uma revisão nos entendimentos anteriores do STJ, que insistiam em manter a eficácia da restrição territorial dos efeitos da decisão coletiva. De acordo com o Relator, Min. Luis Felipe SALOMÃO, a eficácia da decisão deve se pautar por seus limites objetivo e subjetivo - evidentemente, delimitados pelo pedido. Para ele, "A antiga jurisprudência do STJ, segundo a qual "a eficácia erga omnes circunscreve-se aos limites da jurisdição do tribunal competente para julgar o recurso ordinário" (REsp 293.407/SP, Quarta Turma, confirmado nos EREsp. n. 293.407/SP, Corte Especial), em hora mais que ansiada pela sociedade e pela comunidade jurídica, deve ser revista para atender ao real e legítimo propósito das ações coletivas, que é viabilizar um comando judicial célere e uniforme - em atenção à extensão do interesse metaindividual objetivado na lide."
} 
5.1.5 A Expansão Coletiva dos Efeitos da Decisão Manifestada em Ação Puramente Individual

Ao longo desta tese já se discorreu sobre os direitos universais e a necessidade, a eles inerente, de observância geral. Debateu-se, também, a noção de que tratar direitos universais como subjetivos é disfunção que causa pernicioso desequilíbrio na distribuição de bens, dentre os quais, da saúde. Aqui ficou clara a razoabilidade dos conceitos de justiça de Rawls e Dworkin e como as ações individuais que sindicam saúde violam ambas as teorias. Tal ideia serviu para apoiar a primazia das ações coletivas sobre as individuais.

Com base nas premissas, apresenta-se, como medida de racionalização, a proposta de expansão dos efeitos da sentença e da autoridade da coisa julgada observada em feitos individuais ou individuais homogêneos, de forma a que todas as pessoas que se coloquem em posição análoga à do autor sejam contempladas pela medida.

Não será fácil, contudo. Fosse assim, a solução já teria sido desenvolvida e, quem sabe, até implementada. O pensamento, em si, não é inédito: seu desenvolvimento, sobretudo no contexto desta pesquisa, é que será. A missão é harmonizar a proposta com a dúvida que inexoravelmente exsurge a partir da possibilidade de transformar a sentença manifestada em ação individual em decisão coletiva, a ultrapassar os limites da pretensão deduzida em juízo e a extrapolar o objeto do processo. Muitos são os obstáculos que se prostram no caminho do que será, aqui, idealizado, de ordem técnica e prática: em que momento ocorreria essa expansão? Como evitar que o demandado, vislumbrando a expansão metaindividual dos efeitos da sentença, aja para que tal não suceda e não aumente sua potencial contingência, reconhecendo a procedência do pedido ou oferecendo ao autor acordo? Teria de haver medida eleita para se operar a expansão ou ela poderia se dar em qualquer ação individual? A decisão de improcedência também seria expansiva? Veja-se, neste breve exercício de contraposição, que defender a ideia ora trazida a lume não é fácil.

Estes questionamentos serão considerados, mas sempre partindo e adotando como premissa básica a necessidade de universalização de direitos universais, além dos corolários empíricos que denotam que o Judiciário está ao alcance dos mais ricos e daqueles que conseguem movimentá-lo, em contrapartida aos que não têm recursos nem são aptos a agir. É tempo, pois, de desenvolver todas essas ideias. 
5.1.5.1 Dogmas do processo: objeto do feito, limites e autoridade da coisa julgada

No Item 3.2.4 já foi discutido como alguns dogmas do Direito Processual, autênticas verdades idealmente incontestes, podem e, diante das circunstâncias, devem ser revisitados e, mesmo, repensados. Quando se pensa em expandir efeitos da decisão manifestada em feito individual para toda a coletividade, obriga-se a enfrentar alguns dos grandes dogmas do processo civil clássico: o da congruência, da inércia e dos limites da coisa julgada, os dois primeiros ligados aos efeitos do objeto da lide, o último, à autoridade da decisão judicial impassível de modificação no mesmo processo.

A propósito, a autoridade da coisa julgada como efeito natural da decisão definitiva da qual não caiba mais recurso é medida de segurança jurídica, e isso não encontra dissonância na doutrina, na academia e na jurisprudência. Já na Constituição brasileira de 1934 a coisa julgada foi alçada ao status de direito fundamental ${ }^{744}$. A garantia prevaleceu até a atual Constituição, em que o instituto manteve seu status, sendo inderrogável inclusive pelo legislador constituinte derivado.

Trata-se a autoridade da coisa julgada um efeito que, naturalmente decorrente da decisão definitiva irrecorrível ${ }^{745}$, reveste de caráter imutável o dispositivo, a determinação (declaração, condenação ou constituição ${ }^{746}$ ) contida no fecho da decisão, seja ela sentença, acórdão ou decisão monocrática ${ }^{747}$. A coisa julgada é normalmente estudada, também, em termos de exceção, porque impede as partes do processo de reavivarem a mesma ação em novo processo (definição que abrange tanto os limites objetivos quanto os subjetivos da coisa julgada). É daqueles classificados pressupostos processuais negativos de constituição válida e regular do processo. Mas seu escopo é ainda maior: no processo em que se emanou decisão definitiva, da qual não mais caiba impugnação, não pode essa decisão ser afastada nem mesmo pela lei, conforme expressa previsão constitucional ${ }^{748}$.

\footnotetext{
${ }^{744}$ Artigo 113, Item 3, no Capítulo intitulado Dos Direitos e Garantias Individuais.

${ }^{745}$ Não foram tranquilas as posições que levaram ao conceito de que a autoridade da coisa julgada é efeito natural da sentença. Foi LIEBMAN que consagrou a ideia (LIEBMAN, Enrico Tullio. Eficácia e autoridade da sentença e outros escritos sobre a coisa julgada. $4^{\mathrm{a}}$ ed., São Paulo: Forense, 2006).

${ }^{746}$ Adota-se a classificação trinária das ações, que se observa, por todos, em GRINOVER, CINTRA e DINAMARCO. Teoria Geral do Processo..., p. 306 e em LIEBMAN, Enrico Tullio. Manual de Direito Processual Civil. $3^{\text {a }}$ ed. São Paulo: Malheiros, 2005, pp. 231-235.

${ }^{747}$ São tantas as decisões de fundo que, hodiernamente, podem ser veiculadas por decisões monocráticas (i.e., CPC, súmulas dos arts. 558 e 518, $\S 2^{\circ}$ ) que se há falar, sim, em coisa julgada sobre decisão monocrática. Nessa linha também perfilha o projeto de novo CPC.

${ }^{748}$ Artigo $5^{\circ}$, XXXVI.
} 
Outra não é a função da coisa julgada material senão a de proporcionar a segurança das relações jurídicas ${ }^{749}$. A imutabilidade da decisão emanada do Judiciário, que contém um comando, um mandamento a ser observado dali por diante de maneira inquestionável e definitiva, é medida de enaltecimento da função judicial e, logo, do império do Estado por via indireta, além de, sem dúvida, de segurança jurídica por via direta. É a segurança jurídica que é o objetivo da proteção dada pelo inciso XXXVI do artigo $5^{\circ}$ da Constituição, observada em cada um dos elementos ali colocados - inclusive a própria coisa julgada. De fato, é de se assumir o fim precípuo dessa garantia: o de gerar segurança jurídica, conferindo paz aos cidadãos ${ }^{750}$.

$\mathrm{O}$ valor dado à autoridade da coisa julgada era tamanho que se dizia ser ela capaz de transformar o preto no branco e o quadrado no redondo ${ }^{751}$. Tão relevante instituto, é bom frisar, possui esteios, sendo limitado quanto ao seu conteúdo e no que toca às pessoas que se submetem à sua autoridade.

A discussão a respeito dos efeitos da sentença e da autoridade da coisa julgada, sobretudo na esfera jurídica de terceiros, gerou debates acalorados e ainda não se encontra completamente pacificada. Relata Ada Pellegrini Grinover que vem do direito comum a ideia de que res inter alios iudicata aliis non praeiudicare, mas que a prática exigiu que determinados efeitos das sentenças se estendessem aos que guardavam interesse secundário na causa. Foi Chiovenda, baseado em Wach, que sentenciou que éramos todos obrigados a observar o julgado entre as partes do feito, não podendo por ele, todavia, sermos prejudicados. O conceito foi evoluído por Segni, Betti e Carnelutti, até que Liebman preceituou que os efeitos da sentença devem ser observados por todos, enquanto que a autoridade da coisa julgada obrigaria apenas as partes, podendo o prejudicado se opor a essa autoridade, teoria que, com imperfeições técnicas, foi abrigada na legislação processual civil brasileira de regência, no artigo $472^{752}$.

Ainda de acordo com Ada, Liebman inquietou-se quanto a objetos que eram incindíveis entre a parte do feito e terceiros. Daí surgiu a clássica análise, já inclusive indicada nesta tese, sobre a anulação de deliberação de assembleia de sociedade anônima. Para Liebman, o pedido de um sócio julgado procedente obrigaria os demais e impediria ações individuais, porque lhes faltaria interesse de agir; a improcedência manteria aberta a

\footnotetext{
749 DINAMARCO, Cândido Rangel. Instituições de Direito Processual Civil. 5 a ed. São Paulo: Malheiros, 2005 , p. 294.

${ }^{750}$ LIEBMAN, Enrico Tullio. Corso di Diritto Processuale Civile. Milano: Giuffré, 1952, p. 239.

${ }^{751}$ MEDINA, José Miguel Garcia e WAMBIER, Teresa Arruda Alvim. O dogma da coisa julgada: hipóteses de relativização. São Paulo: RT, 2005, p. 535.

752 GRINOVER, “Coisa Julgada Erga Omnes... ”, pp. 1-2.
} 
via individual $^{753}$. Liebman, então, resumia sua posição à falta ou não do interesse de agir dos demais sócios.

Ada discorda, com acerto, e para fustigar a posição de Liebman vale-se de Barbosa Moreira, que lança o instintivo argumento de que o sócio ou sócios remanescentes poderiam ter interesse em obter provimento diametralmente oposto ao do sócio que pleiteou a anulação, ou seja, eles poderiam querer manter a anulanda deliberação assemblear. Demais disso, a própria incindibilidade do objeto do processo faria com que, qualquer que fosse a solução dada, ela teria de ser idêntica para todos os titulares, inclusive para aqueles que não participaram do feito como parte. Procedente ou improcedente o pedido de anulação, os demais sócios sofreriam irremediavelmente suas consequências ${ }^{754}$. Assim sucede com os direitos que são indivisíveis - como visto e em tema de saúde, os difusos e coletivos stricto sensu.

A soberania da coisa julgada, ademais, está longe de ser cega, absoluta e irrestrita. Ilustrem-se exceções que confirmam a regra, todas previstas em lei: a ação rescisória, prevista no CPC, é o clássico exemplo de desafio à sua autoridade ${ }^{755}$; também o é a ação de nulidade do processo (querela nullitatis insanabile), cabível na hipótese de decisão passada em julgado em feito em que ocorrida ausente citação válida do réu ${ }^{756}$. E o que dizer da propalada coisa julgada rebus sic stantibus, legalmente aplicável no caso de relações continuativas em que se verifique modificação no estado de fato ou de direito ${ }^{757}$, e quando houver alteração do binômio possibilidade-necessidade na ação de alimentos passada em julgado ${ }^{758}$ ? Não se pode esquecer, evidentemente, da coisa julgada secundum eventum probationis, que, contemplada nas leis da ação popular, da ação civil pública e no CDC, preconiza que nova prova pode viabilizar a propositura de ambas as ações coletivas $^{759}$. Também no campo do aspecto subjetivo de nosso objeto de estudo, a suavização pode ser representada com a coisa julgada secundum eventum litis e o

\footnotetext{
${ }^{753}$ Idem, ibidem.

754 GRINOVER, “Coisa Julgada Erga Omnes...”, pp. 2-6.

${ }^{755}$ Cabível, de acordo com a jurisprudência, nas estritas hipóteses do artigo 485 do CPC.

756 Nesse sentido e apenas para pontuar, ver BEDAQUE, que, como mencionado. defende que, sendo improcedentes os pedidos, mesmo no caso de falta ou irregularidade de citação não haveria necessidade de ação anulatória, uma vez que ausente o prejuízo (Efetividade do Processo e Técnica Processual. São Paulo: Malheiros, 2006).

${ }^{757}$ Art. 471, I do CPC. Para DINAMARCO, qualquer sentença está sujeita à regra rebus sic stantibus, de modo que, sobrevindo fato que modifique a situação antes decidida, deverá o juiz adaptar o julgado para atendê-lo ao estado de fatos superveniente (Fundamentos do Processo Civil..., Tomo II, p. 1044).

${ }^{758}$ Art. $475-\mathrm{Q}, \S 3^{\circ}$ do CPC. Sobre a aplicação da regra rebus à sentença da ação de alimentos, v. JÚNIOR, Humberto Theodoro. Curso de Direito Processual Civil. 32ª ed., V. 1. Rio de Janeiro: Forense, 2000, p. 481.

${ }^{759}$ Discute-se o que seria a prova nova, mas isso não interessa ao argumento.
} 
transporte in utilibus da decisão coletiva para a ação individual ${ }^{760}$. Mais recentemente, o artigo 741, parágrafo único do CPC, eleito no bojo das modificações introduzidas pela Lei $\mathrm{n}^{\mathrm{o}} 11.232 / 2005$, passou a prever a coisa julgada inconstitucional, com a consequente inexigibilidade do titulo executivo fundado em lei ou ato normativo declarado inconstitucional pela Corte Suprema ${ }^{761}$.

O sistema possui válvulas de escape ao dogma da imperatividade da coisa julgada, cada qual representativa de determinado momento, mas todas convergindo para um mesmo pensamento: a coisa julgada sucumbe a valores considerados maiores pelo próprio sistema - por vezes o equívoco justificável do magistrado, por vezes a inconstitucionalidade latente ulteriormente descoberta, por vezes, ainda, a qualidade do direito em discussão. Se estes exemplos são pródigos em demonstrar que a coisa julgada não é, assim, intocável, a questão relacionada à qualidade do direito (que suporta as hipóteses do transporte in utilibus e das coisas julgadas secundum eventum litis e probationis) são as mais interessantes para esta tese.

Não sem críticas $^{762}$, o direito brasileiro incorporou a possibilidade de imutabilidade da sentença emanada em ações coletivas que discutam direitos individuais homogêneos em caso de procedência dos pedidos, sendo que a improcedência vincularia os titulares individuais apenas na hipótese de intervenção na ação coletiva respectiva. A coisa julgada secundum eventum litis funciona como tempero à legitimação concorrente e disjuntiva para as ações coletivas, filtro para evitar potencial representação inadequada, a bem de representar não apenas o direito do indivíduo, mas aquele direito cuja titularidade pertence a uma coletividade de pessoas e, destarte, possui relevância pública ${ }^{763}$. Os valores preservados, aqui, são dois: sem dúvida, a possibilidade de defesa adequada de um direito individual caso isso não ocorra na ação coletiva, mas, mais do que isso, a característica do direito peculiarmente discutido nessa espécie de demandas.

\footnotetext{
${ }^{760}$ Artigo 103 do CDC.

${ }^{761}$ DINAMARCO, Cândido Rangel. Nova Era do Processo Civil. $3^{\text {a }}$ ed. São Paulo: Malheiros, 2009. A terminologia caso julgado é usada em Portugal, notadamente no CPC português (o artigo $358^{\circ}$ trata do caso julgado material). MEDINA e WAMBIER anotam que outros aspectos da lei sobrepujam-se à irrestrita autoridade da coisa julgada, citando a antecipação de tutela, a alienação em execução provisória e a tutela específica (Coisa Julgada..., p. 535).

${ }^{762}$ Dentre outros, ver MESQUITA, José Ignácio Botelho de. "Na ação do consumidor, pode ser inútil a defesa do fornecedor", em Revista do Advogado n 33, pp. 80-82; GIDI, Antonio. Coisa Julgada e litispendência em ações coletivas. São Paulo: Saraiva, 1995, p. 67; DINAMARCO, Pedro da Silva. Ação Civil Pública. São Paulo: Saraiva, 2001, p. 103; ALVIM, Eduardo Arruda. "Coisa Julgada e litispendência no Anteprojeto de Código Brasileiro de processos Coletivos”, em Direito Processual Coletivo..., pp. 177178.

${ }^{763}$ GRINOVER, Código Brasileiro de Defesa do Consumidor..., pp. 923 a 931.
} 
$\mathrm{Na}$ coisa julgada secundum eventum probationis, o valor elevado do direito é ainda mais resguardado contra a autoridade cega da coisa julgada. Originada no texto positivo da Lei $n^{\circ} 4.717 / 65$, esta saída, nos dizeres de Kazuo Watanabe, deveu-se para evitar que possível colusão entre autor popular e réu acabasse por prejudicar o direito coletivo veiculado na ação em espeque ${ }^{764}$. Aqui a proteção se volta ao interesse transindividual. A autoridade da coisa julgada é relativizada em prol da qualidade do direito. É indiscutível que esses dois institutos - não por acaso, típicos das ações coletivas - representam clara suavização do dogma dos limites subjetivos (coisa julgada secundum eventum litis) e objetivos (coisa julgada secundum eventum probationis) da res iudicata.

As mitigações à força vinculante da coisa julgada nas ações coletivas são previstas em lei e, por isso mesmo, sua pertinência e cabimento são discutidas mais no campo teórico do que prático. Trata-se, pois, de contundentes exemplos de como a segurança da coisa julgada cedeu espaço à relevância do bem discutido. Agora, é o caso de examinar teoria que opera no campo da interpretação das normas vigentes, sem que haja lei específica autorizando suas bases.

Se, de um lado, a imperatividade que torna imutável a decisão judicial é medida de segurança jurídica, tanto quanto os outros institutos igualmente preconizados na norma constitucional que suporta, precipuamente, a coisa julgada ${ }^{765}$, de outro, a injustiça, o erro, a fraude e o desrespeito aos direitos fundamentais do indivíduo (por mais vagos que todos esses conceitos, em maior ou menor grau, possam parecer), materializados em decisão passada em julgado, são temas que incomodam alguns juristas de nomeada. Nesse sentido, é importante destacar quatro ordens de pensamento: a primeira, a teoria da relativização da coisa julgada ${ }^{766}$; a segunda, a possibilidade de mutabilidade da decisão desproporcional; a terceira, a coisa julgada secundum eventum probationis; e, por fim, o exame da coisa julgada à luz dos pedidos e causas de pedir.

Tão consagrada quanto controversa, a primeira tese, do professor Cândido Rangel Dinamarco, é detalhista e alicerçada em pensamentos de juristas de escol, como Eduardo Couture, Pontes de Miranda, Humberto Theodoro Jr., José Delgado e Hugo Nigro Mazzili. Ao professor do Largo São Francisco preocupavam situações em que o manto da autoridade da coisa julgada encobria a verdade por trás do quadro pintado nos autos, a falta de razoabilidade e proporcionalidade, a fraude, o erro e, mesmo, a injustiça ou a relevância

\footnotetext{
${ }^{764}$ WATANABE, Código Brasileiro de Defesa do Consumidor..., p. 948.

${ }^{765}$ Artigo $5^{\circ}$, XXXVI.

${ }^{766}$ DINAMARCO, Cândido Rangel. Nova Era do Processo Civil. $3^{\text {a }}$ ed. São Paulo: Malheiros, 2009, pp.
} 
do bem jurídico protegido. Elegeu, por isso, alguns parâmetros, uma proposta de sistematização para aplicação de sua teoria, ou seja, paradigmas observáveis quando a autoridade da coisa julgada devesse ser relevada, desconsiderada ou, em seu célebre termo, relativizada. A premissa metodológica que informa todo o raciocínio do professor, e que interessa neste estudo, é a da impossibilidade jurídica de convivência do julgado assim maculado com princípios e garantias ${ }^{767}$.

A premissa de Dinamarco revela que não pode sobressair a imutabilidade da coisa julgada em todos os casos em que se discutam princípios e garantias constitucionais $^{768}$. Diz ele, com acerto, que a proteção à coisa julgada é tão fundamental quanto todos os outros direitos e garantias que, no caso concreto, possam estar em jogo, como a dignidade humana, a intangibilidade do corpo ou o princípio federativo. Conclui que a segurança jurídica da autoridade da coisa julgada pode sucumbir, caso a caso, ao direito em discussão ${ }^{769}$, “(...) em casos em que a sentença passada em julgado encerra uma grave infração constitucional, ou resulta de uma fraude manifesta, ou atenta contra direitos fundamentais de elevada categoria (...),"770 - portanto, em claro paralelo à Teoria dos Princípios de Alexy. O ousado pensamento de Dinamarco, embora bem fundamentado, causaria temor nos operadores do Direito, porque abriria demais a porta para a rediscussão de matérias já decididas, o que, em um Brasil em que a decisão definitiva de um processo perdura anos a fio até ser conferida, poderia representar grave problema $^{771}$. Mas fato é que ela bem demonstra a crise conceitual da imutabilidade da coisa julgada.

\footnotetext{
${ }^{767}$ DINAMARCO, Nova Era..., 216-269.

${ }^{768}$ Claramente DINAMARCO usa essa terminologia não em seu sentido mais rigoroso, mas para determinar todas as situações em que, de acordo com suas próprias palavras, o direito constitucionalmente protegido sirva para garantir ao postulante sua felicidade (Nova Era..., p. 248).

${ }^{769}$ DINAMARCO, Nova Era..., p. 248.

770 DINAMARCO, Cândido Rangel. "Liebman e a cultura processual brasileira”, em Estudos em Homenagem à Professora Ada Pellegrini Grinover. Flávio Luiz YARSHELL e Mauricio Zanoide de MORAES (Org.). São Paulo: DPJ Editora, 2005, pp. 500-501.

${ }^{771}$ O próprio DINAMARCO, sempre ciente do mundo ao seu redor e de suas agruras, advertiu, ao defender a tese, quase que como resposta às críticas que sofria, que "é muito compreensível que uma tese dessa magnitude sistemática, colidente com pensamentos solidificados na cultura do processualista ao longo de milênios, cause preocupações entre os estudiosos e gere resistências e reações.” (pp. 261-262). Nelson NERY JR. é um dos principais expoentes contrários à relativização. Ele taxativamente argumenta que interpretar a coisa julgada é faceta de regimes totalitários, ofendendo-se frontalmente a Constituição. Alude essa possibilidade ao histórico (e lamentável) regime nazista, que possuía lei que permitia ao ministério público dizer se determinada sentença seria justa ou não, atendendo aos fundamentos do Reich e anseios do povo alemão ("Coisa Julgada e Estado Democrático de Direito", em Estudos em Homenagem à professora Ada Pellegrini Grinover, YARSHELL, Flávio Luiz e MORAES, Mauricio Zanoide (org.). São Paulo: DPJ Editora, 2005, p. 716-717).

Como dado histórico, a colocação de NERY Jr. é interessante. Mas tem-se, aqui, que revelar certa frustração com relação a todos aqueles que se levantam em face de novos pensamentos por os encararem subversivos ou
} 
Talvez dois casos ilustrem bem a questão enfrentada: imagine-se a declaração de paternidade de quem não é pai, ou a declaração de morte presumida de sujeito que não faleceu, ambas transitadas em julgado, mas cujas circunstâncias que apontam a verdade só sobreviriam ao conhecimento após decisão final da qual não cabia mais recurso. Será que a soberania da coisa julgada sobreviveria, mesmo nesses casos em que ela fosse contrária à verdade dos fatos? O STF já sinalizou que não, suavizando concretamente o dogma da autoridade absoluta da coisa julgada ${ }^{772}$. Dinamarco também cita outros casos em que o Judiciário deixou de aplicar, com o rigorismo de efeito, a imperatividade da coisa julgada ${ }^{773}$.

Se a proporcionalidade, ou melhor, a falta dela é apenas um dos elementos a poder justificar a relativização de Dinamarco, existe linha que defende que não pode sobreviver a coisa julgada se ela for exclusivamente desproporcional. Neste caso, a doutrina que se usa, mais uma vez, porquanto pioneira, é de Ada Pellegrini Grinover, em parecer que estudava caso concreto e foi, oportunamente, publicado como artigo. Dissertando sobre os princípios e sua colisão, com a necessária ponderação para resolução

contra a ordem das coisas. COPÉRNICO foi vitima daqueles que entendiam ser ele louco, por pregar que a Terra girava em torno do Sol, e não o contrário, estando o Sol no centro de nosso Sistema. GALILEU experimentou um verdadeiro calvário porque acompanhava COPÉRNICO, que foi duramente combatido até que sua ideia fosse infirmada - e, mais tarde confirmada de maneira genial por GALILEI. Evidentemente não seria adequada a comparação desses cientistas com DINAMARCO, já que de comparação não se trata, embora a genialidade do professor e jurista seja indiscutível. O que se quer dizer é que todos aqueles que inovam no pensamento enfrentam resistência. No caso específico da relativização da coisa julgada, parece um equívoco negar sua idoneidade ao fundamento do perigo que representaria sua aplicação prática. Se os juízes não estão capacitados a interpretar a situação concreta de forma a relativizar a autoridade da coisa julgada, o problema é outro e nada necessariamente tem que ver com autoritarismo. Se é certo que os contrapontos são desejáveis porque enriquecem o debate, que sejam eles mais corajosos e não se fundem no temor de situações hipotéticas. É preciso evoluir, com coragem, no pensamento, desprendidos de experiências passadas longínquas de uma sociedade absolutamente diferente da observada no Brasil hoje.

${ }^{772} \mathrm{RE} \mathrm{n}^{\circ}$ 363.889/DF, Rel. Min. Dias TOFFOLI, DJ em 10.6.2011. Neste recurso, discutia-se se poderia ser reproposta ação de menor visando ao reconhecimento de filiação. No primeiro caso, os pedidos foram julgados improcedentes porque não fora realizada a prova técnica que, quase com certeza total, declararia ou não a paternidade. Naquela oportunidade, o exame genético não foi realizado porque o autor não tinha meios para arcar com seus gastos, não custeados pelo Estado. Após o trânsito em julgado dessa decisão, sobreveio lei (Lei Distrital $n^{\circ}$ 1.097/96) determinando que o Estado fizesse frente aos custos de exames de DNA das pessoas que não fossem capazes de assim proceder. Animado com a lei, o menor apresentou a mesma ação já definitivamente decidida e, no recurso extremo, discutia-se, exatamente, se ali se aplicaria a exceção da coisa julgada. O Relator entendeu que a o novo processo poderia prosseguir, porque o juiz do primeiro caso, ao não determinar a realização do exame de DNA às custas do Estado, negou ao postulante acesso à justiça, o que fulminou a intangibilidade do dispositivo que ali se formou. Já o voto-vista do Ministro Luiz FUX chegou ao mesmo resultado, por fundamentos diferentes, quais sejam, de que, diante da colisão entre a autoridade constitucional da coisa julgada e outros direitos fundamentais, como o de filiação, corolário da própria dignidade da pessoa humana, deveria, no caso concreto, prevalecerem aqueles que, por ponderação, implicariam menor sacrifício para as partes envolvidas. $\mathrm{O}$ voto-vista é um rico apanhado das teorias e autores que dão sustentáculo à desconsideração da imutabilidade da coisa julgada diante de casos especiais.

${ }^{773}$ Como entendimento do STF no sentido de que não ofendia a coisa julgada a decisão que, na execução, determina nova avaliação de imóvel, se a anterior é baseada em laudo antigo (o valor preservado, aqui, seria o da justa indenização) e decisão do STJ superando a coisa julgada quando se verificou fraude em perícia para fixação de indenização em ação de desapropriação indireta (DINAMARCO, Nova Era..., pp. 307-308). 
da celeuma, a professora, com toda a razão, defende que a garantia da coisa julgada não escapa à colisão com outro postulado constitucional, quando isso ocorrer factualmente. No caso por ela analisado, o que estava em voga era o confronto entre coisa julgada e a justa indenização que onera o Poder Público em caso de desapropriação ${ }^{774}$. Entendeu Ada que a proporcionalidade (mais, ali, o reconhecimento do interesse público e o impedimento ao enriquecimento sem causa) justificaria que a coisa julgada cedesse sempre que não se verificasse a justa indenização no caso de expropriação. Concluiu Ada que, na espécie, a Fazenda Pública sempre poderia pretender o reconhecimento de inexistência de coisa julgada quando o valor definido em ação de desapropriação superasse a constitucional justa indenização ${ }^{775}$. Ada defende na espécie, então, a desconsideração da coisa julgada, e a base de seu raciocínio jurídico, portanto, também se correlaciona com a já analisada Teoria dos Princípios de Alexy.

O STJ já se posicionou no sentido de mitigação da segurança em ações de estado, hipóteses em que a coisa julgada deve ser interpretada modus in rebus, análise, ali, feita à luz da proporcionalidade. Segundo o aludido julgado, a Corte entendeu que em uma sociedade de homens livres, a justiça deve estar acima da segurança, porque sem justiça não há liberdade ${ }^{776}$. O paradigmático julgado ocorrido no REsp n ${ }^{\circ} 706.987 / R J$ revelou uma tendência espinhosa do Tribunal no entendimento da relativização da coisa julgada. O caso tratava de investigação de paternidade. O julgamento entendeu pela impossibilidade de desafio à coisa julgada, a não ser de acordo com a lei, em apertada votação: cinco a quatro. Dos votos que enfrentaram o entendimento majoritário, destacam-se os emanados pelo Min. Jorge Scartezzini, sinalizando que em caso envolvendo direito de família, a objeção de coisa julgada deveria ser afastada porque na hipótese, para ele, ocorrera flagrante injustiça, e pela Min. Nancy Andrighi, entendendo que era questão de dignidade da pessoa

\footnotetext{
${ }^{774}$ Cf. disposição expressa no art. $5^{\circ}$, XXIV da Constituição.

${ }^{775}$ GRINOVER, "Princípio da proporcionalidade...", pp. 58-82. O entendimento de Ada é muito semelhante ao que já foi exposto aqui, no sentido da colisão entre os limites da coisa julgada e a universalidade e a isonomia que cercam o direito à saúde.

Maria Berenice DIAS sustenta que, a mutação da sentença passada em julgado na ação de alimentos (como visto, sentença rebus sic stantibus) se justifica à luz da proporcionalidade. Ela entende que, para além da imutabilidade da coisa julgada, é preciso harmonizá-la com vistas ao atendimento de diretrizes mais relevantes ("Princípio da proporcionalidade para além da coisa julgada", disponível em: <http://www.mariab erenice.com.br/uploads/10_princ\%EDpio_da_proporcionalidade_para_al\%E9m_da_coisa_julgada.pdf >, acesso em 22.6.12, 13:47h). Luiz Guilherme MARINONI não concorda com a relativização e desafia os argumentos de seus defensores. Sobre a proporcionalidade, MARINONI diz que um dos escopos do processo é trazer às partes e à sociedade segurança, e que, se em alguns casos, o sistema produz situações indesejáveis, isso não significa ter a coisa julgada que ser, simplesmente, desconsiderada ("Relativizar a cois a julgada material?", em <http://www.abdpc.org.br/abdpc/artigos/Luiz\%20G.\%20Marinoni\%284\%29\%20formatado.pdf $>$, acesso em 9.7.12, 14:35h).

${ }^{776}$ REsp n ${ }^{\circ}$ 226.436/MG, $4^{\mathrm{a}}$ Turma, Rel. Min. Sálvio de Figueiredo TEIXEIRA, DJ em 28.6.2001.
} 
humana conhecer sua filiação e que, assim, deveria sucumbir a autoridade da coisa julgada $^{777}$. O Min. Castro Meira acompanhou a divergência, aduzindo que o advento de novas tecnologias, privilegiando-se a verdade real, poderia fazer com que a autoridade da coisa julgada fosse casuisticamente avaliada ${ }^{778}$.

No caso do exame de DNA, Ada dá outra leitura, igualmente aplicável e interessante: para ela, tratar-se-ia de hipótese de coisa julgada secundum eventum probationis, porque poderia ser modificada, em caso de improcedência dos pedidos originais, caso sobreviesse inquestionável prova da paternidade oriunda do exame. Dessa forma, a primeira decisão teria se embasado em conjunto probatório insuficiente, e o surgimento - mesmo por questões tecnológicas - de nova prova levaria à conclusão de que a primeira demanda fora decidida equivocamente, com o que não poderia a respectiva decisão passar em julgado. Em outras palavras, a prova nova teria o condão de desfazer a imutabilidade de coisa julgada. Ada ainda recorda que a possível mutabilidade da coisa julgada não é matéria infensa à legislação nacional, citando, como exemplo, a possibilidade de o impetrante de mandado de segurança se valer das vias ordinárias para perquirir o mesmo direito que havia cogitado na via do writ, cuja segurança fora denegada por insuficiência de provas (tendo, assim, feito coisa julgada formal e material). Lembra ela que a mesma coisa ocorre com o habeas corpus, em que novas provas não elidem uma nova impetração, mesmo diante de coisa julgada ${ }^{779}$.

Ada tem razão e sua leitura é muito próxima à necessidade de justiça que lastreia a relativização da imutabilidade da coisa julgada, mesmo em aparente desafio à segurança jurídica - e, para isso, ela não se vale nem da proporcionalidade, nem da potencial injustiça da decisão. Para ela, neste caso, trata-se de questão de prova: assumir que uma decisão não representou a verdade por falta de evidências é contrário à necessidade de que tal decisão tenha sido justa. E a ordem jurídica justa é o fim máximo do Judiciário.

Ada apresenta outro argumento que pode ser entendido como desafio ao dogma da intangibilidade da coisa julgada ${ }^{780}$ - embora se verá que, conforme seu argumento, a autoridade do instituto não é propriamente vergastada. Analisando ação que visava a anular escritura de filiação, com sentença de improcedência passada em julgado, a

\footnotetext{
${ }^{777}$ Voto-vista no REsp n ${ }^{\text {o }}$ 706.987/DF, Rel. Min. Humberto Gomes de BARROS, $2^{\text {a }}$ Seção, DJ em 15.5.2006

${ }^{778}$ REsp n ${ }^{\circ}$ 706.987/DF, Rel. Min. Humberto Gomes de BARROS, $2^{\text {a }}$ Seção, DJ em 15.5.2006.

${ }^{779}$ GRINOVER, Ada Pellegrini. Código de Defesa do Consumidor..., pp. 947-951.

780 Sistematicamente, a conclusão a que chegou GRINOVER inspirou e serviu como fundamento para a sustentação da tese de DINAMARCO: Ada, sempre visionária, foi usada por ele como argumento em prol da relativização excepcional da coisa julgada ("Relativizar...", Item 12).
} 
insigne professora concluiu ser cabível declaratória de inexistência de paternidade entre as mesmas partes da demanda original, porque, naquele caso, como em todos os outros, era preciso analisar o dispositivo transitado em julgado em conjunto com os motivos da sentença, tanto quanto a exata delimitação do objeto do processo depende de sua análise à luz das causas de pedir. Com efeito, para compreender o comando que transitou em julgado é preciso saber por quais motivos a decisão foi tomada ${ }^{781}$, daí a umbilical ligação entre um e outros, conexão que os torna imutavelmente interdependentes ${ }^{782}$. Isso autorizaria concluir, destarte, que a coisa julgada não constitui exceção quando forem diferentes os motivos, ainda que de uma mesma pretensão aparente.

Daí que, em sentido estrito, essa posição de Ada não desconsidera a coisa julgada, apenas deixa de aplicar sua autoridade ao que entende não estar a ela submetida; em sentido amplo, contudo, ela não deixa de questionar o descabimento da cega imutabilidade do dispositivo da decisão judicial.

De fato, parece que a autoridade da coisa julgada, enviesada do cunho absoluto, está em crise ou, antes, em processo de reflexão, o que foi bem resumido em pequena passagem de voto-vista proferido em recurso extraordinário: politicamente, a coisa julgada não está comprometida nem com a verdade, nem com a justiça da decisão ${ }^{783}$. Adicione-se que se esse compromisso não ocorre no campo político, muito menos ele sucede no jurídico, a não ser pelo esforço interpretativo defendido por aqueles que, como este autor, acreditam que a autoridade da coisa julgada não pode ser levada a ferro e fogo. Nem tanto ao mar, nem tanto à terra.

Não se defenderá aqui a relativização da coisa julgada tal como preconizada, mas, sim, a suavização de seus limites, ou, mais exatamente, a expansão de sua autoridade, quando isso se fizer necessário, ou seja, nas hipóteses em que o direito em debate seja acidentalmente coletivo (porque, por óbvio, se nos casos de direito difuso ou coletivo stricto sensu à saúde o objeto é indivisível, então a autoridade da coisa julgada se estenderá a todos seus respectivos titulares). A proposta ora conjeturada não se pode dar de lege ferenda: será preciso lei específica a esse respeito. As teorias até aqui demonstradas, todavia, são essenciais nesse mister. Se a autoridade da coisa julgada pode ser suavizada, também podem seus limites objetivos e subjetivos. Se, como visto, a autoridade da coisa

\footnotetext{
${ }^{781}$ LIEBMAN já reconhecia que a imutabilidade da coisa julgada incidia sobre o dispositivo em sentido substancial, ou seja, não apenas as palavras componentes do comando último da decisão (i.e., condeno, declaro, constituo), mas tudo o que da decisão tocar à pretensão do autor e a resistência do réu (Eficácia..., pp. 52-53)

${ }_{782}^{7}$ GRINOVER, Ada Pellegrini. O Processo. Estudos e Pareceres. $2^{\mathrm{a}}$ ed. São Paulo: DPJ, 2009.

${ }^{783}$ Do Min. Luiz FUX no voto-vista proferido no RE no $363.889 / \mathrm{DF}$, já mencionado.
} 
julgada tem por fim preservar a segurança jurídica, é preciso enfrentar em que grau a expansão dos efeitos da sentença e a imperatividade de seu comando para além das partes do processo individual violaria o princípio. O apoio das atuais teorias é importante, mas a tese aqui defendida é que a qualidade dos direitos em tema - direitos sociais, de uso universal e isonômico - já é, isoladamente, motivo suficiente para expandir os efeitos da sentença.

5.1.5.2 A expansão da autoridade da coisa julgada como medida de isonomia, remédio à patologia individual

Os postulados da racionalidade e eficiência que as ações de políticas públicas devem guardar passam, também, pelo dever de a decisão estatal atender a maior quantidade factível de pessoas, aplicando a solução mais adequada (i.e., mais eficaz e menos onerosa). Nas políticas públicas, a eficiência administrativa deve ser levada ao extremo $^{784}$, sempre alicerçada nos fundamentos ora colocados. O jogo político é um jogo de escolhas, todas elas sensíveis, muitas delas, trágicas, porque implicam em dar a alguns tirando de outros, justamente em razão da limitação dos recursos necessários a efetivar esses direitos $^{785}$.

Quando as escolhas se dão no ambiente dos Poderes majoritários há inequívoco impacto. Construir uma escola em dado bairro pode significar que, somente dali a dois exercícios, poder-se-á erigir um posto de saúde naquela mesma comunidade, embora ambas as necessidades sejam prementes e dignas de atendimento. Todavia, as decisões do Legislativo e do Executivo, pelo menos, implicam, via de regra, em que uma coletividade de pessoas seja beneficiada, mitigando os efeitos nocivos da limitação fática orçamentária. No Judiciário, as ações individuais, a par de também causarem impacto aos que não se aproveitam de seus efeitos, não beneficiam, no mais das vezes, a coletividade: a decisão é passível de outorgar a uma única pessoa bem que cabe a todas as outras em situação semelhante, forçando a Administração Pública a realocar seus fundos, deixando a descoberto, talvez, as necessidades de inúmeros outros cidadãos.

\footnotetext{
${ }^{784}$ Sobre eficiência administrativa no contexto das políticas públicas, ver Itens 2.4.2. e 3.2.1.

${ }^{785}$ BOBBITT e CALABRESI, Tragic Choices...
} 
Se a decisão dos Poderes majoritários em termos de políticas públicas não beneficia apenas uma pessoa, porque o Judiciário estaria apto a assim a proceder? Alguém diria: "ações individuais buscando medicamentos não veiculam matéria de políticas públicas”. Será mesmo? Para este autor, essa alegação está ancorada no pensamento que ele insiste em combater, qual seja, de que o direito à saúde deve ser tratado linearmente como direito subjetivo. Não deve. O direito à saúde é universal e a todos deve ser garantido em igualdade de oportunidades, por isso, a priori, ele é metaindividual. Ações individuais que buscam tratamentos e terapias sempre interferirão nas políticas públicas de saúde, seja porque a sentença que conceder o postulado reconhecerá a inação do responsável pela distribuição do bem buscado e, enfim, alcançado, seja porque o dinheiro necessário ao cumprimento da decisão individual sairá, no mais das vezes, da conta pública da saúde. Dessa forma, o pedido individual pode não necessariamente requerer política pública, mas a decisão correspondente sempre impactará a política pública existente.

Em termos de intervenção judicial nas políticas de saúde, o fenômeno individual só existe porque o sistema convive com essa possibilidade, já que, de um lado, considera os direitos sociais subjetivos (passíveis de exigibilidade pelo titular) e, de outro, dá ao jurisdicionado a garantia de inafastabilidade do Judiciário no exame de alegada lesão ou ameaça a direito. Mas essa realidade do sistema jurídico processual, longe de ser a mais apropriada, é tolerada.

O emprego dessa tolerância ao quanto hoje observado deriva de anos de individualismo no processo civil e de formalismo na atuação judicial, legado de épocas imemoriais que não mais se sustentam, que nesta sede já foram pinceladas e que, agora, não serão debatidas. O fato é que, atualmente, não é mais possível que se conviva sossegadamente com a ideia de que aqueles que recorrem ao Judiciário têm enquanto os que não o fazem, não têm e, possivelmente, não terão ${ }^{786}$, porque os recursos foram consumidos no atendimento das demandas individuas.

Com efeito, qual será o valor preponderante nesses casos, considerando-se que tanto um (o direito constitucional de ação, exercido individualmente, mas de impactos coletivos, neste caso) quanto os outros (todos os direitos ligados à distribuição pública de bens sociais, de cunho coletivo) são direitos fundamentais? Parece que deva existir, por

\footnotetext{
786 Claro que a asserção apresentada não é absoluta, porque existem situações manifestadas em ações individuais que tiram da inércia os Poderes majoritários, como ocorreu no caso da lei que garantiu acesso público a medicamentos do coquetel antirretroviral da AIDS.
} 
todo o exposto, tendência à prevalência da segunda categoria sobre a primeira, por medida de isonomia, distributividade e, ao fim e ao cabo, justiça ${ }^{787}$.

Claro que, do que é mais vanguardista a respeito da discussão do conteúdo daqueles direitos que compõem o chamado mínimo existencial, tanto o acesso à justiça quanto o alcance a bens sociais (como a educação, saúde, moradia e vestuário básicos) integrariam esse piso $^{788}$. E não se olvide que a própria observância da dignidade da pessoa humana - atingida pela convergência desses direitos sobre a pessoa do indivíduo e da sociedade - caracteriza limite à restrição dos direitos fundamentais ${ }^{789}$. Mas o fato é que, a pretexto da autonomia da vontade processual, que permite ao indivíduo correr ao Judiciário antes de se dirigir ao posto de saúde, não soa razoável sacrificar o direito de tantos outros que não tiveram a mesma oportunidade, sobretudo quando se sabe, empiricamente, que são aqueles que podem pagar advogados privados e que moram nos estados mais ricos da federação que usam o sistema judicial ${ }^{790}$.

Será possível, contudo, limitar o acesso do indivíduo ao Judiciário, sobretudo necessitando ele, de fato, de providência estatal que lhe é constitucionalmente assegurada? Vale dizer, é possível proibir jurisdicionado de propor medida requerendo a inscrição de seu filho em creche mantida pelo Poder Público? Parece que não. A cláusula da inafastabilidade do Judiciário não pode sofrer qualquer restrição de ordem absoluta, equivalente a uma proibição, de todo incompatível com direitos fundamentais. Ela, contudo, poderia ter seus contornos mais bem definidos neste caso, sendo limitada por fatores externos, a saber, a necessidade de observância isonômica e universal do direito à saúde. Seria o caso não de infirmar o acesso à justiça, mas de dar contornos interpretativos mais adequados à garantia constitucional, restringindo o uso de ações individuais a apenas excepcionais hipóteses no que toca às políticas públicas, como, inclusive, já se discutiu linhas antes. O que é preciso é pensar e desenhar a adoção de medida que leve

787 Como base de sua teoria dos direitos fundamentais, ALEXY sustenta que princípios prima facie assegurados podem, diante do caso concreto, sofrer restrições, sobretudo quando colidem com outros princípios igualmente observados prima facie (ALEXY, Teoria ..., em especial pp. 277-280). Assim, o direito individual de acesso ao Judiciário pode ser mitigado em razão da prevalência de princípios maiores, como a dignidade da pessoa humana.

${ }^{788}$ BARCELLOS, A eficácia jurídica..., pp. 327 e ss., sempre ressalvada a dificuldade de se estabelecer, preliminar e abstratamente, direitos que constituíam o núcleo duro do mínimo existencial.

789 SARLET, Ingo Wolfgang. Dignidade da Pessoa Humana e Direitos Fundamentais na Constituição Federal de 1988. $8^{\text {a }}$ ed. Porto Alegre: Livraria do Advogado Editora, 2010, pp. 135-142. Sobre as teorias da restrição e dos limites aos direitos fundamentais, ver Item 4.2.2.

${ }^{790}$ Ostentando a mesma inquietação, mas alegando a potencial violação da impessoalidade - princípio constitucional que norteia os atos de todo e qualquer agente administrativo, ver LUPION, Ricardo. "O direito fundamental à saúde e o princípio da impessoalidade", em SARLET e TIMM (coord.). Direitos Fundamentais..., pp. 347-358. Ele concorda não haver razão para que uma minoria tenha vantagens, em detrimento da coletividade, pela possibilidade do recurso às vias jurisdicionais (p. 354). 
racionalidade à decisão judicial sempre que o magistrado se coloque diante de ação individual dessa magnitude. Aí é que a expansão coletiva dos efeitos da decisão individual, mesmo transitada em julgado, apresenta-se como proposta viável.

A questão já foi analisada pela doutrina. Baseado nos mesmos motivos que levaram a esta proposição, Salles fala em extensão da coisa julgada como medida de harmonia entre a universalidade dos direitos sociais e a singularidade da resposta judicial. As posições defendidas por ele são extremamente interessantes: a primeira é que a Constituição já seria suficiente para equiparar todas as pessoas em uma mesma situação àquela que obteve sucesso em caso individual versando sobre bens sociais, por força da isonomia, universalidade e impessoalidade, esta última a impor à Administração que atenda a todos os cidadãos de igual forma, indiscriminadamente; a segunda contempla uma proposta de incorporação, no Projeto da nova ação civil pública (5.139/2009), de dispositivo que obrigue à Administração estender os efeitos do julgado individual a todas as pessoas que se encontrem na mesma posição, cabendo ao Ministério Público, fundado no inciso II do artigo 129 da Constituição, tomar providências nesse sentido ${ }^{791}$.

Ambas as posições são acertadas. De fato, uma interpretação sistemática do texto constitucional levaria à lógica conclusão que os efeitos da sentença individual dispondo sobre bens sociais deveriam ser automaticamente estendidos àqueles que também necessitam dos mesmos bens, embora não tenham ultrapassado as barreiras do juízo. $\mathrm{O}$ grande problema - também antevisto por Salles - é a falta de norma autorizadora, o que certamente o levou à proposição de dispositivo de lei que respondesse a essa necessidade e, daí, a segunda acertada posição ${ }^{792}$.

E não apenas. Mesmo a inteligência processual demonstra que não há possibilidade, dependendo do bem da vida tutelado, de extirpar do terceiro ou daquele que não participou no processo (mas, sim, pelo processo) a prestação que foi reconhecida em ação intentada por somente um indivíduo.

Mas o Judiciário também dá sinais do cabimento da expansão dos efeitos de decisões manifestadas em casos individuais. É o que ocorre na transcendência dos motivos

\footnotetext{
${ }^{791}$ SALLES, (“Coisa julgada..., pp. 143-158). SALLES narra caso em que ele, oficiando pelo Parquet em segundo grau, pediu a extensão dos efeitos de julgado que deferiu transporte especial para apenas um jurisdicionado, aquele que lançou mão de medida judicial. A decisão, atendo-se estritamente ao pedido, deferiu-o, ignorando - ainda mais se tratando de transporte - que outras pessoas com necessidades especiais pudessem ser contempladas. O Tribunal indeferiu o requerido pelo Procurador - hoje, Desembargador -, ao fundamento de que os pedidos não poderiam ser aditados naquela fase processual - claro exemplo de como os dogmas do processo limitam a eficácia da Constituição.

792 É nessa linha que perfilha a atual tendência à coletivização de demandas prevista nas legislações projetadas em maduro estado de votação no Congresso Nacional.
} 
ou abstração do controle difuso de constitucionalidade de algumas decisões que o Supremo considera terem de atingir situações análogas. Baseada na força normativa da Constituição, sua supremacia e necessidade de aplicação uniforme, na caracterização do Supremo como intérprete máximo e guardião da Carta e na dimensão política das decisões do Supremo, a Corte já decidiu, ao menos uma vez, ainda que em controle difuso de constitucionalidade, que a decisão deve ultrapassar as partes do processo. Analise-se mais detidamente dois importantes precedentes ligados à matéria.

No RE no 197.917/SP, o Supremo Tribunal Federal decidiu, mesmo no controle de constitucionalidade incidental, modular os efeitos da decisão correspondente, aplicando-os ex nunc e de forma geral, ainda que essa medida fosse típica das ações de controle concentrado de constitucionalidade. O julgado abriu caminho para uma nova discussão sobre os efetivos caminhos das declarações incidentais de inconstitucionalidade ${ }^{793}$.

A Recl. $\mathrm{n}^{\mathrm{o}} 4.335 / \mathrm{AC}^{794}$ enfrentou corajosamente o tema dos limites subjetivos da coisa julgada, verificando o alcance da declaração de inconstitucionalidade incidenter tantum. Declarada a inconstitucionalidade da vedação à progressão de regime em crimes hediondos de maneira incidental no $\mathrm{HC} \mathrm{n}^{\circ}$ 82.959-7, dez reclusos por crimes dessa natureza ingressaram no Supremo contra decisão do juízo das execuções penais de Rio Branco, que entendeu inaplicável aos reclamantes o precedente obtido no referido habeas corpus porque a declaração de inconstitucionalidade da lei de crimes hediondos, naquele caso, deu-se inter partes. Segundo a decisão reclamada, os efeitos erga omnes daquela decisão só poderiam ocorrer no caso de Resolução do Senado Federal estendendo seus efeitos, na forma do artigo 58, X da Constituição e de acordo com o preconizado no artigo 178 do Regimento Interno do Supremo Tribunal Federal.

O Relator, Min. Gilmar Mendes, propôs-se a analisar a natureza da resolução do Senado que conferiria eficácia oponível contra todos às decisões do Supremo em controle incidental de constitucionalidade. Ponderou que, dogmaticamente, uma única declaração de inconstitucionalidade pronunciada pelo Supremo Tribunal Federal deveria ser suficiente para expurgar os efeitos da norma respectiva. Apoiado em vários precedentes do próprio Tribunal em que os motivos determinantes foram transportados de determinado

\footnotetext{
${ }^{793} \mathrm{RE} \mathrm{n}^{\text {o }}$ 197.917/SP, Rel. Min. Mauricio CORRÊA, DJ em 7.5.2004 (caso Mira Estrela, relacionado à inconstitucionalidade de lei municipal que fixava o número de vereadores, contrariando o artigo 29 , IV da Constituição).

${ }^{794}$ Recl. no 4.335/AC - HC no 82.959-7/SP Rel. Min. Gilmar MENDES, DJ em 25.8.2006.
} 
caso para serem aplicados em outro, o relator defendeu a existência de motivos determinantes transcendentes, que dispensariam a resolução legislativa.

Mendes prosseguiu, sustentando que prova de seu pensamento era observável nas ações coletivas, cuja declaração de inconstitucionalidade teria o inevitável condão de se opor contra todos os representados ${ }^{795}$. Segundo ele, se as decisões dos processos coletivos possuem eficácia erga omnes, ficaria difícil justificar, nesses casos, a necessidade de Resolução do Senado Federal. Arrematou dizendo que em alguns casos - e como corolário da hipótese aventada - há uma verdadeira confusão entre o objeto da ação civil pública e o pedido de declaração de inconstitucionalidade ${ }^{796}$.

Se for verdade que esses julgados trataram de questões especificamente voltadas ao controle de constitucionalidade pelo Supremo, o que se pode deles extrair, principalmente do caso da inconstitucionalidade parcial da lei de crimes hediondos, é que, em certas circunstâncias, os limites subjetivos da coisa julgada devem ser suavizados ${ }^{797}$. Ao fim e ao cabo, o julgamento da reclamação significou medida de justiça: todas aquelas pessoas condenadas por crimes hediondos deveriam se aproveitar da declaração de inconstitucionalidade da norma materializada em ação individual.

Parece haver muita semelhança entre essa situação e aquela de quem consegue medicamento no Judiciário em ação individual. No caso da reclamação, o voto de Gilmar Mendes entendeu que, ainda não sendo parte do habeas corpus, os reclamantes deveriam fazer jus ao que ali ficou decidido - aliás, a aceitação da irresignação como reclamação é bem coerente com o entendimento - porque se encontravam na mesma situação fático-jurídica daquele que ingressou com o habeas corpus. É o que ocorre quando alguém obtém judicialmente tratamento para gripe A: sendo esse um direito universal e dispensável de maneira isonômica, é lógico, pela própria natureza do direito

\footnotetext{
${ }^{795}$ Mencionou Gilmar MENDES, inclusive, o entendimento do Tribunal a respeito dos efeitos gerais obtidos no Mandado de Segurança Coletivo no 11.824 (Rel. Min. Peçanha MARTINS, DJ em 27.5.2002), que tiveram o condão de albergar a prejudicialidade de ADIN que discutia o mesmo tema, a inconstitucionalidade do Provimento $n^{\circ}$ 556/97, do Conselho Superior da Magistratura (ADIN no 1.919, Rel. Min. Ellen GRACIE, j. em 7.4.2003). Ele resume seu raciocínio indagando qual o motivo de o Supremo, tendo reconhecido a expansão dos efeitos da decisão do Superior Tribunal de Justiça no referido mandado de segurança, não reconhecê-la nos feitos por ele próprio, Supremo, julgados.

${ }^{796}$ Criticando a questão da mutação constitucional e apoiando-se na análise da aludida reclamação, ver STRECK, Lênio Luiz, OLIVEIRA, Marcelo Andrade Cattoni de, e LIMA, Martonio Mont'Alverne Barreto Lima. “A Nova Perspectiva do Supremo Tribunal Federal sobre o Controle Difuso: Mutação constitucional e Limites da Legitimidade da Jurisdição Constitucional”, disponível em: <http://www.leniostreck.com.br/site/ wp-content/uploads/2011/10/4.pdf>, acesso em 11.12.13, 19:47h.

${ }^{797}$ É bom frisar, bem a propósito, que o empréstimo do paradigma do Supremo não contempla, nesta altura da tese, a discussão sobre os limites da jurisdição constitucional. O julgado é importante porque pretendeu, em última análise, tratar a todos os que se encontravam nas mesmas condições de maneira idêntica.
} 
discutido, que esse tratamento seja estendido para todos aqueles que se colocam nas mesmas condições do autor.

A aproximação entre o que ficou decidido na reclamação e o que se discute nesta tese é caracterizada pelo empréstimo, no voto vencedor, do exemplo das ações coletivas. O relator entendeu que o controle incidental de constitucionalidade nessas ações confunde-se com a própria inconstitucionalidade abstrata da norma impugnada, pela característica erga omnes ínsita às decisões. O que o Ministro diria, mas não o fez diretamente, é que se a questão ali colocada fosse ventilada em ação civil pública (embora a matéria assim não permitisse) a Resolução do Senado Federal seria dispensada pela própria natureza da sentença. Desse pensamento, é válido afirmar que ainda que determinadas pretensões sejam deduzidas pela via das ações individuais, a natureza do direito pode permitir que os efeitos da decisão futura sejam estendidos às pessoas que se coloquem na mesma posição - mas que não foram parte do feito.

Ora, já se discutiu, aqui, que os bens objetos das ações coletivas possuem características transindividuais, que tocam a uma gama de pessoas e, não apenas, a um mero indivíduo. Defende-se, também, a primazia da tutela coletiva sobre a individual em termos de direito à saúde. Se o direito à saúde é, por excelência, coletivo (em sentido largo), por mais que seja discutido em ações individuais, parece razoável, adequado e justo que ele receba um tratamento coletivo ainda que levado ao conhecimento do Estado por meio de um processo individual, a não ser que se trate de hipótese autorizativa do caso piloto, hipótese de uniformidade, não de coletivização.

Ao menos mais uma ilação se pode tirar do arrazoado da Reclamação, e ela parte do entendimento que o controle de políticas públicas não deixa de ser uma espécie de controle de constitucionalidade, na medida em que o Judiciário interfere na omissão Executivo-legislativa para cumprir a norma constitucional ${ }^{798}$. O pensamento vai ao encontro das concepções Hesseniana de força normativa da constituição ${ }^{799}$ e Kelseniana de supremacia da constituição ${ }^{800}$, é dizer, normas que se chocam com as disposições constitucionais são inconstitucionais. É controle de constitucionalidade desempenhado por cada magistrado no momento em que há decisão decretando a leniência do Estado e a

\footnotetext{
798 Nesse sentido, CANELA Jr., Oswaldo. A Efetivação dos direitos fundamentais através do processo coletivo: um novo modelo de jurisdição. Tese de doutoramento apresentada ao Departamento de Direito Processual da Universidade de São Paulo, orientada por Kazuo WATANABE. Na mesma linha, GRINOVER ("O controle...", p. 14).

799 HESSE, Konrad. A Força Normativa da Constituição (trad. Gilmar Ferreira Mendes). Porto Alegre: Sérgio Antônio Fabris Editor, 1991.

${ }^{800}$ KELSEN, Hans. Teoria Pura do Direito. $8^{\mathrm{a}}$ ed. São Paulo: Martins Fontes, 2008.
} 
necessidade de suprimento prático dessa omissão. Partindo deste pressuposto, há uma aproximação ainda maior entre o conteúdo da Reclamação e a proposta ora conjeturada, porque ali foi avaliado, em última análise, que o controle de constitucionalidade exercido pelo Judiciário, ainda que de forma difusa, dispensa a extensão erga omnes de seus efeitos por ato do Legislativo. Por que, então, a decisão que declara a inconstitucional omissão dos Poderes em implementar certa política de saúde, ainda que manifestada em caso individual, não poderia, nos moldes da decisão da reclamação, estender-se para todos aqueles que estão na mesma posição, sobretudo porque o direito à saúde é universal não apenas por sua característica imanente, mas por força expressa da Constituição?

Há outro aspecto a discutir. A clássica doutrina dos efeitos inter partes das decisões manifestadas em casos individuais possui fraquezas de per si quando o objeto discutido é o direito à saúde ou, de resto, qualquer direito universal.

Já se viu que o direito à saúde não pode ser entendido prima facie, mormente pelo Judiciário, como simples direito subjetivo. A despeito de ser indiscutível o poder de cada um de se dirigir ao juiz pedindo providências isoladas dessa natureza, é um grande erro encarar simplesmente como subjetivo esse direito, por tudo o que aqui já foi visto (i.e., universalidade, planejamento, escolhas, escassez). O liame jurídico verificado na observância concreta do direito à saúde não pode ser analisado de forma individual. $\mathrm{O}$ Estado se obriga não apenas a atender um, mas todos os cidadãos. Por isso, os cidadãos todos eles - possuem, além de seus vínculos próprios, um único vínculo que os liga ao Estado. Quando várias demandas individuais pleiteando a mesma providência são aforadas contra ato de determinado secretário de saúde, por exemplo, ou mesmo contra certa unidade da Federação, a liga única que une todos os demandantes ao réu é algo muito diferente da liberal concepção dos limites subjetivos da coisa julgada. Explica-se, exemplificando.

Imagine-se que o antibiótico amoxicilina tenha faltado nos postos de distribuição do SUS, o que motivou uma corrida ao Judiciário na busca pelo medicamento. Milhares de ações individuais são propostas, todas contra o Estado de São Paulo, pedindo a entrega do fármaco, não sua disponibilidade nos postos. Seria o caso de direito individual homogêneo. Sem dúvida que cada autor deve demonstrar interesse em propor sua medida, mas, invariavelmente, é um único vínculo entre essa miríade de pessoas e o Estado que está por trás, ao mesmo tempo, de cada uma e de todas as ações individuais. Sob o prisma tradicional dos limites subjetivos da coisa julgada, poderia ocorrer esdrúxula situação de, em alguns casos, o medicamento ser concedido e, em outros, negado, embora o réu de 
todas as ações fosse exatamente o mesmo e entre elas houvesse o predomínio de aspectos coletivos. Os efeitos do caso de procedência do pedido não podem ser aproveitados de uma em outra ação porque os autores, nesse exemplo, seriam diferentes. Contudo, considerando-se ser o vínculo jurídico que os liga à parte contrária apenas um, então ocorreria extensão automática dos efeitos de determinado pronunciamento para todos os demais autores.

Alguém pensaria: "mas o sistema é assim e convive-se há décadas com a possibilidade de pronunciamentos contraditório". Retorquir-se-ia afirmando que não é o caso do direito à saúde, que, insiste-se, é universal, qualidade que o coloca em posição completamente diferente daquela dos direitos com o que estamos - ou, antes, fomos acostumados a tratar. Insista-se que não é mais possível conviver pacatamente com situações como a exemplificada, manifestamente irracional, subversiva e injusta.

Basicamente, são estes exemplos concretos que apontam para a tendência de expansão dos efeitos de um julgado, ainda que manifestado em caso individual. É o Supremo interpretando a Constituição para conferir isonomia a situações análogas, nos mesmos moldes em que sustentado por Salles.

A hipótese aqui lançada, ademais, avança um pouco mais à tendência jurisprudencial ou o pensamento de Salles: é a de que quaisquer decisões tratadas como individuais acerca de bens sociais, aptas, portanto, a atingir uma coletividade, devam ser expandidas a partir do momento em que forem eficazes.

Mesmo a decisão individual eventualmente transitada em julgado, mas que tenha ventilado objeto predominantemente coletivo, como o caso de políticas de saúde, poderá ser expandida, fazendo com que a autoridade da res iudicata atinja, aí sim, quem não participou no processo. O que se sustenta, aqui, é a expansão dos efeitos manifestados em caso apresentado como individual à coletividade, quebrando-se, destarte, os clássicos paradigmas dos limites da coisa julgada (objetivos, não se olvide, porque o pedido individual não pretendeu beneficiar a mais pessoas que não o autor; e subjetivos, precisamente porque produz efeitos além das partes do feito).

O que se defende, assim, é que mesmo a decisão concedida em tutela antecipada possa ser coletivizada. Não é, propriamente, relativização, mas expansão do objeto e seus efeitos. Nesse enleio, não seria necessário haver confirmação do Supremo Tribunal Federal, ou que a decisão transitasse em julgado, ou que o Parquet requeresse a extensão dos efeitos do julgado individual: bastaria que a decisão fosse eficaz. A adoção desse modelo parte da premissa que qualquer decisão manifestada em um caso individual, 
cujo pano de fundo seja bem relacionado à saúde, caracterizado pela homogeneidade entre diversos titulares e que deixe à míngua tantos outros que não participem da ação, padece de vicio de isonomia e universalidade e deve, portanto, adequar-se de maneira a privilegiar esses parâmetros. De fato, não faria sentido aguardar o trânsito em julgado de decisão que, por exemplo, concedesse determinado tratamento terapêutico a um jurisdicionado, sendo que esse tratamento já estivesse em vigor para o autor da demanda em que decisão emergencial fora deflagrada no início do processo. Os efeitos nocivos da decisão individual devem ser combatidos desde quando observados. Por isso não é indicado aguardar o trânsito em julgado.

E que decisão teria potencial para ter eficácia expandida? Toda aquela que, reconhecendo omissão estatal de qualquer gênero em tema de saúde, pudesse ser aplicada a casos em igual situação, mas desde que essa expansão se mostrasse mais vantajosa, porque, senão, não haveria motivo para tanto. Seria o exemplo de ordem judicial de entrega de determinado medicamento ao portador de miocardiopatia dilatada; a sentença que definisse a obrigação estatal de prover vagas em creches em dado município para uma criança; o acórdão que assegurasse ao encarcerado o direito não ser abrigado em cela superlotada: todos os jurisdicionados em situação análoga, ainda que sem terem proposto ação qualquer, seriam beneficiados. Evidentemente que situações particularizadas podem afastar a expansão de efeitos sempre que elas forem preponderantes ${ }^{801}$. Em todos os outros casos, contudo, sempre que haja predominância do interesse metaindividual sobre o bem assegurado, a expansão deverá ter lugar.

Pela proposta, também a ampliação dos efeitos independeria de qualquer atuação estatal ou do Ministério Público, constando expressamente na decisão judicial. O juiz estaria vinculado a expandir os efeitos de sua ordem para todos os casos análogos não participantes da relação processual.

Alguém poderia apontar aparente paradoxo, que é o seguinte: linhas antes, nesta tese, defendeu-se a escassez como limite à intervenção judicial em políticas públicas. A solução que é agora proposta, em abstrato, deixaria de atender a uma só pessoa para obrigar o Estado a atender toda a coletividade, o que geraria mais custos e potencialmente agravaria o problema da escassez. Esse paradoxo, contudo, não se sustenta nem à primeira vista.

\footnotetext{
${ }^{801}$ Aqui é válido mostrar como o sistema já prevê a possibilidade de aplicação uniforme a situações análogas (como o caso dos institutos da repercussão geral em questão de multiplicidade de fundamentos idênticos e do recurso especial repetitivo), permitindo àquele cujas questões individuais de direito o coloquem fora da repetição requerer o processamento isolado de seu recurso - justamente por inexistir repetição.
} 
É que a solução da expansão dos efeitos da decisão individual deve obviamente caminhar em conjunto com as demais propostas aqui colocadas, sobretudo aquela que, adiante, pugnará pela aplicação do Experimentalismo na execução. A expansão dos efeitos da decisão deve evidentemente considerar todos os limites apresentados, a escassez, inclusive, por isso deverá respeitá-la. Como? Com planejamento progressivo de execução, soluções negociadas com o Poder Público, planejamento e o efetivo empenho para aquisição e projeção logística de distribuição do medicamento, ou de aleitamento dos beneficiados, ou de realização de tratamentos e terapias. Ao fim e ao cabo, a extensão dos efeitos da decisão pode até representar economia ao Erário, que deixará de comprar medicamentos ou promover internações a preço emergencial de mercado - caso das ações tratadas por individuais - para planejar tais atos - a um custo potencialmente menor.

É claro, também, que esta proposta precisa ser instrumentalizada de acordo com outros valores que não devem ser ignorados. Atem-se, precisamente, à oportunidade de dedução de defesa adequada por parte do Poder Público processado, à garantia ao autor da ação individual que ele não será prejudicado e aos mecanismos procedimentais a serem observados nesse caso. São medidas de segurança apresentadas a seguir.

5.1.5.3 Propostas de ferramental: como viabilizar, com razoável segurança, a expansão preconizada?

Apesar da adequação da ideia, é de se confessar não ser fácil dar-lhe concretude.

Dirigindo-se diretamente aos problemas apontados no item anterior, fale-se do primeiro. Para evitar que o réu apresente defesa que não leve em conta o potencial executivo e econômico da expansão dos efeitos da decisão - algo que, de individual, passaria a coletivo - o juiz, ao receber a inicial e se deparar com pedido que possua impactos coletivos - de novo, como o fornecimento de uma medicação, a inclusão em vaga escolar, a disponibilização de transporte público - deverá, imediatamente, decidir, fundamentadamente (decisão da qual caberia recurso), que aquele pedido, caso fosse tido por procedente, poderia ter sua eficácia expandida, citando e intimando a Administração desse conteúdo. Isso permitiria que o Estado estivesse ciente das consequências que 
poderiam advir do julgado. Anote-se, ainda neste contexto, que esta providência deveria constituir dever do magistrado, e, não, simples possibilidade.

É importante vislumbrar outro efeito que seria certamente observado se a solução apresentada fosse adotada: é que, sabedor o Estado do impacto da decisão que seria expandida, talvez fosse mais barato e adequado que ele apresentasse em juízo um plano para atendimento da demanda ${ }^{802}$, o que evitaria o desenvolvimento do processo (com toda a demora e insegurança que hoje ele gera). Essa advertência faria todo o sentido, sobretudo em um cenário em que a liminar individual fosse concedida somente em casos extremamente excepcionais. Se houver oportunidade de concessão de medida liminar regime altamente excepcional, frise-se -, o juiz provê-la-ia somente ao autor, ouviria a resposta do Estado e, só então, expandiria a eficácia do provimento.

A decisão de potencial expansão dos efeitos do decidido poderia ter lugar em qualquer momento do processo, de preferência, mas não obrigatoriamente, sempre antes da decisão final (sentença, decisão monocrática ou acórdão que expandisse os efeitos) e não necessitaria de referendo pelo tribunal ad quem. $\mathrm{O}$ exame da universalidade da matéria tratada e consequente expansão não careceria de confirmação. O controle pela corte poderia ser realizado em eventual recurso aviado por quem a decisão expansiva eventualmente prejudicaria.

Esta decisão teria por efeito automático a impossibilidade de transação somente com a participação do autor ou a aceitação do pedido pelo réu, como estratagema do demandado para evitar a expansão de efeitos, salvo se a aceitação ou transação irradiasse efeitos para todos aqueles que não participaram do processo e se encontrassem em situação semelhante à do autor. Caso alguma pessoa não concordasse com os termos do acordo, poderia propor sua ação individual, nos moldes do que acontece com as class actions certificadas sob a Rule (b) (3), concorde com a Rule 23 (e) (5) das U.S. Federal Rules of Civil Procedure ${ }^{803}$. Tal solução poderia inviabilizar aceitações de pedido ou acordos nessas hipóteses, mas diante do baixíssimo número desses expedientes, o que se observa, na prática, é o caso de valer a pena sacrificá-los em prol do tratamento mais racional, isonômico e universal da coisa coletiva. Se o Poder Público demandado pretender fechar acordo contemplando todas as pessoas na mesma situação do autor, então a finalidade da proposta terá sido atendida.

\footnotetext{
${ }^{802}$ Aliás, como é da própria inteligência do APLPP.

${ }^{803}$ Disponível em: <http://www.law.cornell.edu/rules/frcp/rule_23>, acesso em 4.5.12, 19:59h.
} 
Com relação aos eventuais demais processos em que se discuta a questão, a expansão poderá ocorrer em todos eles, valendo, então, as regras ordinárias de prevenção e conexão. Fixado o juízo prevento, todos os feitos serão ali reunidos, para ulterior julgamento. Assim, se "A", na Comarca de Santos, requer a concessão de tratamento para leucemia e "B", em Ribeirão Preto, pleiteia providência semelhante, ambas as ações deverão ser reunidas com base nas regras comuns de prevenção e conexão ${ }^{804}$ para serem julgadas em conjunto, sendo certo que a decisão em apenas uma delas bastaria para que o autor da outra também se aproveitasse.

Claro que ainda que não ocorresse a prevenção, problema não haveria. Vários processos individuais versando sobre um mesmo tema poderiam correr paralelamente, sendo que a decisão de procedência em um irradiaria efeitos sobre os demais, fazendo com que aqueles fossem imediatamente interrompidos, solução em todo presente nos mecanismos anteriormente aqui propostos.

Ato contínuo à decisão que expandisse os efeitos da vindoura sentença ou decisão interlocutória, o juiz intimaria o Ministério Público para oficiar na ação, podendo ele, como de rigor, aditar e emendar a inicial, recorrer e assumir o caso em hipótese de desistência do autor original. Essa seria a garantia de tratamento coletivo à questão expandida. $\mathrm{O}$ autor não perderia a titularidade da ação, mas seria acompanhado de perto pelo Parquet, a bem de seu dever institucional preconizado no artigo 129, II da Constituição.

Ao final, julgados procedentes os pedidos ou concedida tutela antecipada depois da ouvida do réu, sendo o caso, o juiz determinaria sua expansão, obrigando o Estado a atender a todas as pessoas que se colocassem em situação análoga, independentemente de qualquer decisão judicial, já estabelecendo, para o caso de recusa, as correspondentes sanções. Somente caso o Estado se recusasse à prestação é que o juízo agiria, provocado pelo interessado ou pelo Parquet, já com a execução das consequências preconizadas.

A expansão somente teria lugar em caso de procedência dos pedidos ou antecipação de seus efeitos. Como medida garantista, que visa a assegurar a isonomia, a universalidade e a maior eficácia da decisão, a expansão somente faz sentido se for para garantir direitos. Essa solução evitaria que demais pessoas em posição análoga à do autor, mas que não propuseram ação, fossem prejudicadas. Não se trata tal saída de qualquer

${ }^{804}$ Artigos 103 e 105 do CPC. 
novidade, já que o sistema contempla o transporte in utilibus dos efeitos da sentença coletiva para os casos individuais, sendo que a decisão coletiva de improcedência não vincula as demandas judiciais pessoais. In casu, parece ainda mais adequado que a expansão opere efeitos apenas para beneficiar os jurisdicionados, e não o contrário.

Questão de maior delicadeza ocorreria na hipótese de decisão de procedência expandida e sua inter-relação com processos análogos cuja decisão de improcedência já tivesse passado em julgado. Parece, nesse caso, que mesmo este jurisdicionado (de novo, que tem contra si decisão de improcedência passada em julgado) poderia se aproveitar dos efeitos da expansão. Se algum aspecto individual, contudo, fosse preponderante para a improcedência, de modo a impedir o aproveitamento, caberia ao Estado alegar essa exceção, provando que aquela hipótese não pode ser contemplada pela expansão de efeitos (lembrando-se, sempre, que a expansão não se aplica no caso de prevalência de fatores individuais que levem à improcedência).

Nessa hipótese - de novo, do autor que teve seu pedido apresentado como individual julgado definitivamente improcedente -, haveria, seguramente, a desconsideração da coisa julgada, e aí é de se valer de todo o cabedal teórico exposto linhas antes, que suaviza deveras o dogma correlato. Aqui, a autoridade da coisa julgada sucumbiria à universalidade e isonomia, qualidades congênitas e indissociáveis do direito à saúde.

Não se nega haver mais obstáculos de ordem prática para a plena eficácia material da proposta. Como os jurisdicionados saberão que existe decisão que os beneficia? Como será verificada a identidade de situações fáticas e jurídicas apta a permitir a extensão do julgado? Enfim, como o magistrado responsável por demanda individual saberá que aquele caso está abrangido por eficácia expandida de uma decisão?

Ora, a concretização deste remédio dependerá, em determinadas situações, da Administração Pública e, em outras, do Judiciário. A Administração Pública estará incumbida da primeira análise da identidade de situações ampla a permitir que a pessoa se aproveite da decisão expandida. O Judiciário, por sua vez, ficará inarredavelmente responsável por assegurar o fiel cumprimento à decisão - e isso significa que será ele a garantir que mesmo o jurisdicionado que não propôs ação receba o benefício contemplado na decisão expandida. A primeira providência, então, é dar ampla publicidade à eficácia da decisão expandida, de modo a permitir que os beneficiados possam exercer seus direitos.

Ato contínuo à expansão, pois, o magistrado ordenaria ao Poder Público ampla divulgação, que seria realizada por meio de anúncios em jornais e revistas de grande 
circulação, além de na televisão e por meio da internet ${ }^{805}$, via banners nos sítios eletrônicos do Executivo (principalmente, nos sítios dos órgãos de saúde e da administração central). Também nas páginas do Judiciário haveria anúncios. As informações levadas ao conhecimento público informariam como o jurisdicionado deveria proceder para se beneficiar da decisão, indicando website e um número gratuito de telefone para esclarecer dúvidas. A prova de identidade de situações fática e jurídica deveria ser deduzida e analisada pelo Executivo, de acordo com plano por ele traçado ${ }^{806}$, em um primeiro momento, e pelo Judiciário, em caso de controvérsia, negativa por parte do Poder Público ou demora na análise.

O magistrado responsável por assegurar a efetiva inclusão do jurisdicionado passível de aproveitamento da decisão estendida será o da vara especializada em políticas públicas, onde houver. Todas as demandas judiciais versando sobre políticas públicas devem ser canalizadas a magistrados que saibam lidar com a complexidade do tema. A decisão de expansão dos efeitos da sentença ou da decisão individual deve ser atribuição exclusiva do juiz especialista, nas comarcas ou seções em que ele existir, e do juiz competente para o processo e julgamento das causas cíveis, nas comarcas ou seções em que não houver o especialista.

Na hipótese de existir ação tratando de objeto que guarde identidade com outra anteriormente julgada cuja eficácia da decisão tenha sido expandida, o juiz especializado estaria apto a saber, previamente, se essa situação ocorreria. A estrutura montada em torno das ações que tratam de objetos correlatos a políticas públicas envolve, como se verá, o cadastramento dessas ações quando de sua distribuição e direcionamento aos juízos especiais ${ }^{807}$. Nesse cadastro também deverão constar as ações cuja eficácia da decisão foi ampliada, com a íntegra da decisão e súmula do objeto, de forma a permitir que o magistrado, direta e imediatamente, consiga identificar a identidade de ações que permita aplicação estendida. É o banco de dados que constituirá o coração do tratamento isonômico e universal da saúde objeto de discussão judicial.

\footnotetext{
${ }^{805}$ Sobre os custos dessas iniciativas, ver nota 720 e Item 5.5.1.2.

${ }^{806}$ Como será visto (Item 5.3.3.1), o magistrado responsável pela execução no caso da ação civil pública da Síndrome de Kanner tentou agir dessa maneira, determinando que as habilitações individuais, naquele caso, fizessem-se diretamente na Administração Pública. A decisão, nesse caso, foi acertada, mas a falta de preparo e infra-estrutura judicial fez com que as discussões surgidas nessas habilitações gerassem cada qual um processo individual autônomo, que ajudou a comprometer o andamento da vara. Por isso, insista-se, é preciso profunda modificação em todos os métodos hoje usados pelo Judiciário para sindicar políticas públicas. De nada adiantaria a expansão dos efeitos da decisão individual sem juízo especializado, sem ombudsman, sem pessoal adequado, sem cartório apropriado, o que será visto adiante.

${ }^{807}$ V. Item 5.3, em que será explicado o mecanismo dos juízos especializados.
} 
A segunda é a necessidade de, via de regra, sempre ouvir o Estado em ações individuais que pleiteiam a antecipação dos efeitos da tutela. Já que os Poderes não dialogam entre si, como visto, o juiz normalmente não conhece as estratégias, planos e programas do Executivo, com o que uma decisão sem a ouvida do réu poderia implicar em desnecessário desajuste nessas ações ${ }^{808}$. Com essa ouvida, o Poder Público poderá esclarecer ao juiz e ao autor não apenas as ações que já são objeto de planos e programas ligados ao direito ali perquirido, mas, também, que houve sentença com eficácia expandida e que o autor faz jus a dela se aproveitar.

Claro, tudo isso teria necessidade de ser disciplinado por lei. De lege lata, há barreiras de transposição extremamente complicadas.

A grande diferença da solução preconizada é que ela não abrange apenas as pessoas que, ultrapassando os típicos e já tratados obstáculos, lançaram mão de ações judiciais para buscar a medida; a decisão seria aproveitada por todos na mesma situação do autor, existindo ou não ação proposta. Bastaria, para tal aproveitamento, que o interessado se dirigisse diretamente ao órgão público e, comprovando sua condição, obtivesse a providência. Eventual descumprimento por parte do Poder Público levaria à reclamação para a conseguinte imposição das sanções de rito.

Nos Itens anteriores analisaram-se ferramentas para coletivização das demandas individuais postulando saúde. No próximo, será apresentada proposta referente às ações coletivas, proposta voltada fundamentalmente àqueles que as manejam, sobretudo o Ministério e a Defensoria Públicos, além das próprias entidades estatais e governamentais.

5.1.6 Formulação adequadamente ampla dos pedidos nas ações coletivas

Concordes que a coletivização das questões relacionadas à tutela judicial da saúde constitui medida, a um só tempo, de universalidade, equidade e isonomia, é de rigor analisar, agora, o modo como são deduzidos, em ações coletivas, pedidos de intervenção judicial em políticas públicas. A eficácia da decisão judicial respectiva será

\footnotetext{
${ }^{808}$ Como já noticiado, o APLPP estabelece que a antecipação de tutela somente terá lugar caso o pedido envolva mínimo existencial ou bem da vida assegurado em norma constitucional de maneira completa e acabada.
} 
preponderantemente marcada pelo modo como o pedido foi formulado. Se ele for hermético ou razoavelmente fechado e pontual, a medida sempre será tolhida em sua eficácia. Se, ao contrário, for ele aberto e amplo, a situação poderá mostrar-se bem diferente.

Caso uma ação coletiva buscando providências na área da saúde for deduzida com um pedido amplo, genérico, porém compreensível e factível, então a resposta dada em forma de decisão judicial poderá estabelecer providências que contemplem toda a sociedade e propiciem cenário propício à melhor execução. Quanto mais largo for o pleito, mais espaço haverá para o necessário desenho de ações políticas.

E isso é óbvio. A atividade de interpretar enunciados (como normas legais e decisões judiciais) é, sobretudo, atividade de preenchimento de lacunas inerentes ao conceito expressado de modo a dotar-lhes de concretude plena. É dizer, a intelecção de sentenças, normas e frases sempre depende da inteligência do intérprete, ou, mais simplesmente, do entendimento dele a respeito daquelas. Há uma distância entre o conceito e o resultado: quanto mais aberto o primeiro for, mais lacunas ele guardará, mais o intérprete terá de preenchê-las. Assim é quando a Constituição fala em redução das desigualdades regionais e em busca do pleno emprego, ou quando a lei civil fala em boafé e função social ${ }^{809}$. Afinal de contas, o processualista sabe definir o conteúdo do devido processo legal, mas certamente, se perguntados vários deles a respeito, cada um conceituálo-á diversamente, segundo sua própria ordem de preferências a respeito do que é mais relevante. Assim é com os juízes: a atividade judicial é fundamentalmente uma atividade de interpretação ${ }^{810}$.

No campo das políticas públicas, o cumprimento das decisões judiciais é, da mesma forma, fundamentalmente uma praxe interpretativa.

Não se duvida que, tradicionalmente, o pedido delimita a decisão que colocará termo ao processo. No processo individual, ele deve ser estritamente interpretado pelo magistrado, diz a lei ${ }^{811}$, sob pena de subversão tanto do princípio dispositivo quanto da inércia e da imparcialidade do juiz. No caso das ações coletivas, a teoria mais condizente dá conta que os pedidos têm de ser largamente interpretados, de maneira até

\footnotetext{
${ }^{809}$ Respectivamente, incisos VII e VIII do art. 170 da CF, arts. 113 e 422 e 421 do CC.

${ }^{810}$ FISS, Owen. "Objectivity and Interpretation”, in Stanford Law Review, V. 34, n 4, April 1982. Board of Trustees of the Leland Stanford Junior University, pp. 739-743.

811 Art. 293 do CPC. Nunca é demais rememorar que: (a) pedidos devem ser apresentados de forma certa e determinada (art. 286, CPC), salvo hipóteses excepcionais que demandam liquidação ulterior; e (b) sentenças que decidem fora, além ou aquém do quanto estritamente pedido são passíveis de anulação ou correção (arts. 128 e 460 do CPC).
} 
extensiva $^{812}$, de forma a propiciar que a guarida judicial dê o máximo que dela se espera, o que faz todo o sentido em virtude da natureza dos direitos geralmente objetos das ações transindividuais $^{813}$. Mesmo a lei projetada, como noticiado, contempla dispositivo que permite a modificação do pedido da ação coletiva até a sentença, desde que com segurança e boa-fé ${ }^{814}$.

Aliás, é mesmo verdade que, em função da própria natureza do objeto tipicamente tratado nas ações coletivas, o pedido será inescapavelmente amplo ${ }^{815}$. Contudo, é igualmente verdade que os pleitos de uma ação coletiva podem, dependendo de sua amplitude, frustrar todo o potencial da tutela judicial para a implementação da política pública almejada.

Caso concreto já foi explorado nesta tese ${ }^{816}$ : o pedido de construção de hospital para tratamento de toxicômanos, apresentado e aceito em ação coletiva. Foram dois os anos que o Judiciário mandou que o Executivo erigisse tal nosocômio, que compreenderia desde o encontro do terreno onde ele se localizaria até a contratação do pessoal e da empreiteira responsável pela edificação respectiva. Mostrou-se ser tal interregno irreal, mesmo à primeira vista. Coisa absolutamente diversa, contudo, ocorreria se o autor pedisse a efetivação de políticas de tratamento ao jovem dependente, com a implementação tanto de ações educativas quanto curativas - e a construção não de um, mas de alguns hospitais ou centros de tratamento. $\mathrm{O}$ desenho da respectiva execução estaria aberto, bastando que o comando genérico fosse observado.

Então, conquanto exista proximidade de edição de lei estabelecendo a possibilidade de flexibilização do pedido, de atuação incisiva do Ministério Público na guarda dos interesses levados à juízo e de ampla interpretação do pleito coletivo, pedido mal formulado, deficiente, omisso ou equivocado pode comprometer todas essas ferramentas.

\footnotetext{
${ }^{812}$ Assim se coloca o Código-Modelo de Processos Coletivos para a Ibero-América, art. 10 e o projetado Código Brasileiro de Processos Coletivos. Sobre o cabimento da extensão, ver MENDES, Aluisio Gonçalves de Castro. "O Anteprojeto de Código-Modelo de Processos Coletivos para os Países Ibero-Americanos e a Legislação Brasileira”, em Revista de Processo, São Paulo, nº 117, set./out. 2004, pp. 109-128.

${ }^{813}$ MARINONI entende que o artigo 84 do CDC - que se insere no âmbito do já mencionado microssistema de tutela dos direitos transindividuais - já confere ao juiz a possibilidade de flexibilizar o pedido, uma vez que ele pode tomar quaisquer medidas que equivalham ao adimplemento, ainda que não expressamente requeridas (prerrogativa, de resto, admitida também ao processo individual, por força do art. 461 do CPC), em MARINONI, Luís Guilherme. Técnica Processual e Tutela dos Direitos. São Paulo: RT, 2004, p. 136. O APLPP anda na mesma linha no art. 14.

${ }^{814}$ Art. 90-A do projeto de CDC.

${ }^{815}$ LEAL, Luciana de Oliveira. "A Coisa Julgada nas Ações Coletivas", p. 11, disponível em: <http://www.tj rj.jus.br/c/document_library/get_file?uuid=cce8be67-3e36-49f5-912b-219abbae66ea\&groupId=10136>, acesso em 13.8.2013, 13:48h.

${ }^{816} \mathrm{~V}$. Item 4.1.3.
} 
Comando genérico, porém bem definido quanto a seus propósitos, pode ser executado com maior facilidade quando o tema são ações complexas como políticas públicas, notadamente as de saúde. De fato, quanto mais aberto for o comando representado pela decisão judicial, melhor ela se amoldará às ações necessárias para dar cabo dos valores constitucionais protegidos pela mesma decisão. A decisão genérica nas ações coletivas consiste no cenário ideal para o Experimentalismo que se tratará em momento oportuno.

Um pedido insuficientemente deduzido em ação coletiva seria capaz de, apoiando-se nesse entendimento, ser alargado, de forma a corrigi-lo. O problema é definir em que consistiria tal correção. A prática pode revelar-se extremamente difícil, e a natureza do direito discutido seria capaz de agravar tal quadro. Mas essa é uma questão posterior. De fato, se parece de todo compatível com a natureza da tutela coletiva que seu pedido seja extensivamente interpretado, quando esse pedido envolve temas de políticas publicas, trata-se essa de constatação inescapável.

Políticas públicas precisam de planos e programas para implementação, que vão desde seu planejamento até a avaliação da sucessiva execução, que, aliás, é protraída no tempo, contínua, duradoura e sem limitação temporal bem definida. Dificilmente um pedido promovido por autor coletivo será capaz de fechar todos os aspectos de uma política de saúde. Ver-se-á, no momento apropriado, que as políticas públicas demandam experimentação, resultados muitas vezes advindos de tentativas nunca dantes implementadas, execução errática e repensada a todo o tempo. Um pedido fechado, ainda que em ação coletiva, não será efetivo.

Sendo o pedido coletivo apresentado de maneira genérica, o comando judicial também será amplo, dando margem ao preenchimento próprio da execução de políticas públicas de saúde. O pedido coletivo genérico, somado ao princípio da interpretação extensiva dos requerimentos judiciais coletivos, possibilitará ao juiz que adote decisão apta a ser preenchida quando de sua execução.

Não basta, assim, que seja apenas deduzida ação coletiva na tutela jurisdicional da saúde. É um bom começo, não se duvida, mas não a inteira história. É preciso que o autor elabore corretamente seu pedido, alargando-o tanto quanto for possível, deixando espaço para que o juiz o preencha, mediante a adoção das medidas executivas que oportunamente serão expostas ${ }^{817}$.

${ }^{817}$ No Item 5.5. 
5.1.7 O amplo debate entre os Poderes ${ }^{818}$

A coletivização da questão da saúde abre espaço para a concretização de uma providência de extrema relevância no trato da questão: o debate entre os Poderes. A questão da saúde e sua distribuição no Brasil, apesar de ser ponto nodal na problemática dos Poderes e dos serviços prestados pelo Estado, é desconhecida por boa parte dos atores que decidem a respeito, sobretudo, pelos juízes ${ }^{819}$.

A falta de diálogo entre os Poderes é circunstância gravíssima, imputável não apenas ao modelo institucional brasileiro, cuja autonomia dos Poderes do Estado é levada a extremos, quebrando totalmente a sua harmonia e o basilar sistema de checks and balances $^{820}$, mas também à própria ideia de Federação brasileira que, instalada em um território continental, dificulta sobremaneira as ações integradas dentro de um mesmo Poder $^{821}$. É absolutamente explicável que alguns juízes atuem como se inexistisse Executivo, apenas com a Constituição e a lei em seu gabinete, servindo de fundamento para o deferimento ou indeferimento de medidas relacionadas à saúde. Contudo, esta realidade não pode mais ter lugar.

É imprescindível que os juízes tenham acesso a todas as informações necessárias a respeito das ações realizadas pelos Poderes majoritários na área da saúde. Somente sabedores e certos dessas informações é que a decisão judicial pode ser considerada exauriente, ou, antes, ter percorrido todas as questões necessárias para o bom

\footnotetext{
${ }^{818}$ No Item 5.4.2. este tema será novamente abordado, com a diferença de que, enquanto neste Item o amplo debate ocorre no bojo da ação coletiva, ali esse debate é preventivo e se dá antes e independentemente da existência ou conjetura de qualquer potencial ação.

${ }^{819}$ DURAN FERREIRA, O Judiciário e as Políticas..., p. 29; MARINHO, Justiciabilidade..., além da pesquisa inédita realizada no bojo desta tese (Item 4.1.3).

${ }^{820} \mathrm{O}$ exemplo maior da falta de diálogo arraigada entre os Poderes no Brasil foram reiteradas atitudes desdenhosas do então presidente da República (2007-2010), após ter sido pecuniariamente sancionado pelo Tribunal Superior Eleitoral pelo ato de realizar campanha em prol de sua sucessora usando da máquina pública. Não poucas foram as vezes que aquela autoridade, ignorando as sanções, jocosamente desdenhava do Judiciário, demonstrando absoluta falta de respeito com a ordem constitucional. A este respeito, ver, sobre o comportamento daquele político: (i) <http://www1.folha.uol.com.br/folha/brasil/ult96u 712155.shtml>; (ii) <http://g1.globo.com/Noticias/Politica>; e, sobre sua declaração que reincidiria na condu ta ilícita: (iii) <http://www.conjur.com.br/2010-mar-26/tse-multa-lula-r10-mil-propaganda-antecipada-saopaulo>, acessos em 23.12.2010, 10:56h.

${ }^{821} \mathrm{O}$ próprio Judiciário já reconheceu que falta diálogo, além, por seu representante máximo, de que seria necessário repensar tanto a Federação brasileira quanto a organização judiciária, que leva, atualmente, a problemas como o fato de existirem comarcas dentro de um mesmo Estado que se situam a duas horas de jato da sede do Tribunal de Justiça (<http://www.conjur.com.br/2009-nov-27/judiciario-legislativo-concluemdialogo>, acesso em 23.12.2010, 10:40h).
} 
entendimento da demanda. Não se pretende, aqui, pugnar pela transformação do juiz em administrador, o que poderia ser entendido por alguns como o desvirtuamento fugaz de suas atividades peculiares; todavia, assumindo-se a premissa que, hoje, o magistrado exerce um novo e importante papel, um exercício de concessão de bens e direitos extremamente importantes à sociedade e em atendimento a tudo que se entende como Estado democrático moderno, é necessário que o juiz conheça todos os aspectos - técnicos, organizacionais, executivos - que envolvam as políticas públicas de saúde.

Ainda mais importante do que aguardar informações das ações da Administração Pública nos autos é procurar conhecer melhor como o Poder Público trata concretamente seu dever de prover saúde à população.

O locus mais eficiente para que esse diálogo ocorra se dá nas ações coletivas. Os meios de coleta de tais informações - como a convocação de audiências públicas em que se debate profundamente a questão, a realização de provas técnicas com a participação de inúmeros interessados, a intervenção de amicus curiae ${ }^{822}$ - pode ocorrer mais eficazmente quando se coletiviza a questão ${ }^{823}$. O debate entre os Poderes encontra fértil campo nas ações coletivas. É preciso chamar todos os interessados para a dialética e se o processo é o campo eleito para que essa discussão se trave, que seja ele um processo coletivo.

Os inúmeros casos já explorados nesta tese, que dão conta de haver decisões mandando que fossem entregues medicamentos presentes em postos de saúde, que condenam o Poder Público a erigir hospital em prazo exíguo e sem maiores preocupações a respeito de todas as densas formalidades necessárias, que entregam medicamentos análogos aos presentes nas listagens do SUS, mas fora das listagens, mostram bem a ausência de conhecimento, pelo Judiciário, das ações da Administração, perversa lógica da fria aplicação do argumento linear isolado neste estudo. No caso da saúde, e de políticas públicas em geral, o debate com a Administração Pública é imperativo.

$\mathrm{Na}$ introdução a respeito da teoria da massificação dos direitos, com a necessidade premente de adoção de um modelo coletivo de tutela jurisdicional, verificou-

\footnotetext{
${ }^{822}$ A intervenção oral ou escrita de amicus curiae em ações coletivas é contemplada no art. 90-J, Par. un. do projeto de CDC.

${ }^{823}$ Foi o que ocorreu na audiência pública convocada e levada a efeito no STF, a que já se fez alusão. No despacho de designação do colóquio, o Presidente da Corte deixou claro que a numerosidade dos pedidos de suspensão de tutela antecipada e, mesmo, das ações individuais em que se discutia a questão outorgavam legitimidade para a feitura do encontro. Ao seu fim e cabo, os dados coletados ali terminaram por embasar todas as decisões emanadas da mais alta corte judicial do país. O saldo, por mais que o conteúdo possa ser questionado, foi extremamente positivo e demonstrou como e porque o Judiciário deve dialogar com a sociedade civil.
} 
se a relevância do processo coletivo como instrumento de interesse público, basicamente por tudo o que ele representa: a garantia do direito de voz a minorias ou maiorias que, por não se articularem adequadamente, jamais seriam ouvidas; a possibilidade de uma decisão imparcial e técnica; a garantia ao contraditório e à ampla defesa dos plúrimos interesses envolvidos, sejam ou não contrapostos. Aí está a grande riqueza do tratamento da questão processual da saúde (e das questões de políticas públicas, enfim) como coletiva: o direito de manifestação e amplo debate, inclusive e precipuamente entre os Poderes, é enriquecedor e necessário.

Também inédita iniciativa tomada pelo Tribunal de Justiça de São Paulo lança ventos mais frescos sobre a problemática relação entre Poderes no que toca às políticas públicas. A Corte Bandeirante convocou audiência pública para tratar do vergonhoso déficit de vagas em creches municipais. O objetivo era encontrar um consenso para resolver o problema que desembocava em milhares de ações judiciais. Nos primeiros quatro meses de 2013, mais de sete mil crianças conseguiram vagas por ordem judicial. A primeira fase da audiência, que ouviu representantes da Prefeitura, da sociedade civil, da Defensoria Pública e do Ministério Público, não resultou em acordo ${ }^{824}$, tendo sido agendada nova rodada de negociações ${ }^{825}$, também infrutífera. Então, por decisão da Câmara Especial do Tribunal de Justiça, o Município de São Paulo foi condenado para, dentro de três anos, criar cento e cinquenta mil vagas nas creches e pré-escolas da Capital, sendo que metade das vagas deverá ser criada em dezoito meses ${ }^{826}$.

Trata-se de grata surpresa: o Judiciário assumindo sua veste de cogestor de políticas públicas e avocando para si a tarefa de promover uma solução consensual, bem aos moldes do que deve ocorrer em tema de políticas públicas, bem de acordo com o Experimentalismo que, mais à frente, nesta tese, defender-se-á como remédio. O consenso é fundamental na implementação de bens sociais. Ocorre, in casu, com a educação, mas nada obstaria medida análoga a suceder com a saúde. Infelizmente, no caso concreto, a solução não foi alcançada pelo consenso.

Há mais um ponto: o que ora se apresenta como proposta, é bom que se frise, envolve também o diálogo amplo entre magistrados. De fato, a independência e

\footnotetext{
824 <http://www.estadao.com.br/noticias/vidae,tj-sp-promove-audiencia-publica-sobre-a-falta-de-vagas-naeducacao-infantil,1065603,0.htm>, acesso em 30.9.2013, 18:51h.

825 <http://educacao.uol.com.br/noticias/2013/09/02/sem-acordo-tj-marca-nova-audiencia-sobre-vagas-emcreches-em-sp.htm>, acesso em 30.9.2013, 18:52h.

$826<$ http://www.migalhas.com.br/Quentes/17,MI192455,81042-

Camara+Especial+determina+que+prefeitura+de+SP+crie+novas+vagas+para>. Sobre outras medidas ligadas à execução desta decisão, v. Item 5.5.1.
} 
autonomia judiciais causam estranhos fenômenos como decisões absolutamente díspares em matérias idênticas, emanadas de juízes que dividem um mesmo gabinete. Quando se decide uma cobrança de dívida comercial, isso é tolerável; quando, todavia, a questão versa sobre políticas de saúde, não, em virtude dos postulados da universalidade e isonomia, arraigados a esse direito. Para que isso não ocorra, a coletivização de demandas é uma ferramenta, a expansão dos efeitos da sentença (que será vista mais adiante), é outra, e uma terceira é, de fato, o debate entre juízes e cortes a respeito das questões de saúde.

É louvável, nesse sentido, a iniciativa do CNJ de criação e manutenção do Fórum Nacional do Judiciário para a Saúde, local em que o tema é tratado e debatido. No mesmo sentido, a Recomendação $\mathrm{n}^{\circ} 31$ do mesmo CNJ exorta a ENFAM a promover seminários para - palavras do item II, $b$ da Resolução - maior entrosamento sobre a matéria. Mas é preciso mais. Esses fóruns devem se multiplicar, de forma a congregar magistrados para comentar suas experiências e, eventualmente, dar início a um entendimento uniforme, justamente para evitar desigualdades. O APLPP, cioso dessa necessidade, contempla tal providência, determinando encontros e reuniões periódicas sobre ações ligadas à saúde ${ }^{827}$.

Fechada a primeira fase da questão do diálogo entre Poderes, é tempo de estudar como que a formação jurídica pode colaborar com a racionalidade da dispensação judicial de saúde.

\subsection{A FORMAÇÃO JURÍDICA}

Nos Itens a seguir serão propostas mudanças na estrutura judicial, que é inadequada para a dispensação racional de saúde. De fato, o Judiciário de hoje nada possui de aparelhamento apropriado para o mister, considerando desde a preparação dos magistrados até a estrutura cartorial ${ }^{828}$. Para a correta judicialização da saúde, da forma em que proposta nesta tese, é imperativo categórico alterar alguns aspectos do funcionamento do Judiciário como ele é hoje. Começar-se-á pela formação dos juízes.

As escolas de Direito desempenham papel crucial na formação jurídica, e isso não se nega, pois são elas a principal fonte de ensino e aprendizado dessa ciência

\footnotetext{
${ }^{827}$ Art. 22 do Projeto.

${ }^{828}$ LOPES, Direitos Sociais..., pp. 137-138.
} 
social aplicada. A preocupação do conteúdo dos cursos tem levado a reformulações e reflexões sobre a melhor maneira de se ensinar o Direito. Com o Direito Processual não é diferente $^{829}$. Esta preocupação merece todo o relevo que lhe é dada.

A verdade, como adverte Kazuo Watanabe, é que a cultura jurídica brasileira é voltada à solução judicial, tida como conquista da civilização. Se, de fato, tal conquista é verdadeira, a tradição denota o foro como um lugar em que a solução será rígida, peremptória, garantida com privilégio ao certo ou errado, do tudo ou nada. É esse, segundo Watanabe, o desenho ensinado e aprendido em todas as faculdades de Direito do País, além de ser esse o modelo exigido para as principais carreiras jurídicas, como a advocacia, a magistratura e a promotoria. É a cultura da sentença a que alude o $\operatorname{professor}^{830}$.

Percebe-se, no que toca ao tema da judicialização das políticas públicas, que ainda muito se discute a legitimidade do Judiciário em tratar dessas questões, enquanto que o que deveria se discutir é como, diante de um caso concreto, outorgar a decisão mais racional, considerando-se os inúmeros aspectos que envolvem o problema - o que, deveras, é o objeto precípuo desta tese. Existem alguns assuntos que são passados totalmente ao largo do ensino jurídico basilar e que, com efeito, deveriam ser analisados de maneira mais profunda.

Há um aspecto sensível que, dentro deste tema, não se pode olvidar. É que ainda existe, sobretudo no Direito Processual, viés predominantemente individual na análise acadêmica do instrumento do processo. O modelo bipolar, usado para a resolução de conflitos privados e bem determinados, possui lugar de destaque nos cursos jurídicos, também porque está semelhantemente alocado na legislação, pelo menos, por enquanto ${ }^{831}$. Essa realidade precisa ser alterada. Os cursos jurídicos têm de evoluir.

\footnotetext{
${ }^{829}$ O Instituto Brasileiro de Direito Processual vislumbrou a promoção de um seminário sobre o ensino do Direito Processual, com amplo espectro de debate a respeito de como o tema é ensinado nos cursos de graduação e pós-graduação do Brasil (dias 3 a 5 de fevereiro de 2011 em Curitiba, Paraná, disponível em <http://www.ibep.com.br>, 25.12.2010, 17:17h).

830 WATANABE, Kazuo. "Cultura da sentença e cultura da pacificação", em Estudos em Homenagem à Ada..., pp. 684-690.

${ }^{831}$ Já há algum tempo, paulatinamente, a inteligência jurídica tem feito a norma ecoar os sons dos direitos coletivos em sentido lato, em que pese os tribunais ainda tratarem conflitos coletivos sob a lente individual, como, aliás, é demonstrado nesta tese. Então, o momento para o incremento dessa parte da doutrina processual não poderia ser mais apropriado. Em boa hora são costuradas normas que, vingando, abrirão caminho a uma nova especialização dentro da processualística, não apenas cingida aos bancos de pósgraduação ou a escolas específicas, mas, antes, incluídas na própria cadeira de Direito Processual da graduação. É nessa linha que se colocam o projeto de novo CPC, com a questão da multiplicidade de demandas e a coletivização, a revisão do CDC, com destaque à sua parte processual, e, claro, o APLPP.
} 
O novo modelo de processo civil e a contemporânea veste que assume a magistratura, sendo vetores de decisões que deveriam ser tomadas pelos Poderes majoritários, têm como inescapável impacto a necessidade de alteração do currículo dos cursos jurídicos. A partir do momento em que a miríade de questões envolvendo políticas públicas é levada ao Judiciário, não é apenas o juiz - embora, sobretudo, ele - quem deve se preocupar em dominar todos os aspectos ligados à celeuma, mas, também, todos os operadores do sistema - advogados, defensores, promotores. Daí a necessidade de se pensar em modelo de reformulação do ensino jurídico. E um tema que é de primeira ordem e deve ser analisado é o orçamento público, conforme já foi exposto.

Não se nega, contudo, que além de aprender as questões orçamentárias nos cursos e graduação, os magistrados devam lidar com o tema também nas escolas de formação e aperfeiçoamento próprias da carreira, passando a debatê-lo com a profundidade merecida.

5.2.1 O ensino de políticas públicas e Direito Sanitário como tema obrigatório em Direito Público

Uma das premissas fundamentais deste estudo é a de que os direitos têm custos. De fato e como já foi consignado, não existe garantia de direitos em um Estado que não tenha como custeá-los ${ }^{832}$. O Estado, como instituição, é mantido fundamentalmente por tributos. A partir do momento em se elege constitucionalmente prover alguns bens e serviços à população, o Erário servirá para custear todo o aparato constituído para bem prestar tais bens e serviços. Como visto, esse é o objeto de estudo da disciplina do orçamento público. Diante da realidade enfrentada pelo Judiciário de hoje e da assunção desse seu novo viés, é imperioso que o orçamento público seja estudado, e o quanto antes, nas escolas de Direito.

Outro pressuposto é o de que a tutela da saúde é tão complexa e peculiar que já se agrupou boa parte de seus aspectos sob a novel disciplina de Direito Sanitário ${ }^{833}$. Basicamente, seria o estudo aplicado de muitos dos temas apresentados nesta tese, desde a

${ }^{832}$ SUSTEIN e HOLMES, pp. 35-77.

${ }^{833}$ Ressalve-se que o preâmbulo da Constituição da OMS, de 1946, estabeleceu uma série de princípios relacionados ao tratamento internacional da saúde dos povos, o que ali foi denominado como direito sanitário internacional. 
estrutura jurídica que assegura a universalidade e isonomia da saúde até a análise do SUS, seus órgãos e atribuições, a administração e o trato judicial da saúde, as exceções oponíveis e, claro, o próprio estudo do orçamento aplicado à saúde.

Já se colocou, linhas antes, que o orçamento é um mistério, não porque faltem leis e normas a seu respeito, não porque a linguagem nelas empregada seja ininteligível, mas, sim, porque discussões travadas no foro judicial simplesmente não se arvoram em debater o tema com mais vagar. Juízes não falam sobre ele. Advogados do Estado o invocam irresponsavelmente para aduzir a impossibilidade de atendimento da demanda por meio da exceção da reserva do possível. O Ministério Público o trata de maneira superficial ${ }^{834}$. Nada obstante esse desconhecimento, as receitas e despesas do Estado estão intimamente ligadas ao provimento dos direitos, sobretudo aqueles objetos de prestação estatal e, destarte, passíveis de dedução em juízo. É importante que o orçamento seja desmistificado. Para isso, ele precisa ser estudado.

O orçamento público é assunto acadêmico, normalmente, nos cursos de pósgraduação, em especial, em sentido estrito ${ }^{835}$. Usualmente os cursos de graduação não se prestam a tratar dele em uma única aula: apenas subsidiariamente, provavelmente na disciplina de Direito Tributário, é mencionada, simplesmente, a existência de um orçamento estatal. Nos cursos preparatórios para concursos públicos o tema não é visto, o que é particularmente relevante se for considerado que a maior parte dos magistrados ingressa na carreira sem visitar os programas de pós-graduação e, quando o fazem, muitos não buscam o tema de Direito Financeiro ou Orçamentário, embora outros assuntos sejam igualmente relevantes ${ }^{836}$.

Com efeito, este estudo é pródigo em demonstrar que o Direito Sanitário é disciplina robusta, que deve ser analisada com mais vagar. Se o orçamento é importante sobretudo, conforme explorado, o da saúde, que tem disciplina própria -, os demais temas

\footnotetext{
${ }^{834}$ SUSTEIN e HOLMES (The Cost...) afirmam que, também nos Estados Unidos, as cortes judiciais não estão bem aparelhadas para trabalhar com a complicada tarefa de alocar eficientemente, nem ao menos corrigir aplicações ineficazes realizadas pelo Poder Público. Eles prosseguem, aduzindo tal deficiência não apenas à ausência das informações de que se valem os magistrados, mas, também, porque eles não são preparados a desempenhar esse mister (pp. 94-95).

${ }^{835}$ No Departamento de Direito do Estado já se ofereceu disciplina relacionada ao orçamento público, de responsabilidade do Professor CONTI.

${ }^{836} \mathrm{O}$ CNJ já se manifestou no sentido de recomendar à ENFAM que inclua a disciplina de Direito Sanitário como obrigatória para concursos de ingresso na carreira de magistrado ("CNJ começa a julgar propostas para criar varas de saúde no Brasil”, em O Globo, edição de 28.5.2013, disponível em: <http://oglobo.globo.com/ pais/cnj-comeca-julgar-proposta-para-criar-varas-de-saude-no-brasil-8524892>， acesso em 5.3.2013, 14:30h). É corolário do que enuncia a Recomendação CNJ nº 31/2010, II, $a$.
} 
que orbitam a tutela estatal da saúde demandam análise mais aprofundada, sobretudo no cenário hodierno.

Nesse tocante, o Ministério da Saúde, desde 2002, noticia oferecer, aos membros da magistratura federal e do Ministério Público, especialização em Direito Sanitário, que se dá à distância ${ }^{837}$. É opcional e, destarte, voluntário. Trata-se de iniciativa que vai ao encontro do que ora se propõe, embora de maneira mais tênue.

$\mathrm{O}$ direito à saúde deve, sim, ser objeto de estudo nos cursos jurídicos ${ }^{838}$. Por mais que pareça que nem todos os profissionais se depararão, um dia, com questões ligadas a políticas públicas, contidas aí as de saúde, o fato é que aqueles que, cedo ou tarde, trabalharem com Direito Administrativo, Constitucional ou Tributário, ou, ainda, pleitearem, na sua atividade habitual, alguma medida que tenha implicação financeira ligada ao Estado - como, por exemplo, em casos em que se busca o direito à saúde deverão ter, ao menos, conhecimentos básicos a respeito do orçamento, conhecimentos estes que a demanda atual recomenda serem adquiríveis nos cursos de graduação. Quem sabe uma disciplina ligada a políticas públicas, em geral, não cumpra tal papel?

O estudo desse tema mereceria, pelo menos, um semestre na graduação. Poderia ela, sem dúvida, ser uma matéria optativa, dentro de um rol fechado de assuntos, a exemplo do que acontece nos cursos de graduação em Direito da Universidade de São Paulo e da Pontifícia Universidade Católica de São Paulo. Mas a complexidade do tema dá ensejo à necessidade de uma análise acadêmica mais aprofundada, digna de, pelo menos, um semestre inteiro.

A disciplina que se propõe, de densidade fora de dúvida, poderia ser assim estruturada em curso de graduação:

- Introdução às políticas públicas, em que seriam explorados os incipientes aspectos ligados aos Poderes e à forma jurídica que lastreia a definição de políticas públicas, explorando os direitos que são seu objeto.

- O orçamento público, subtema que, fundado na noção que os direitos têm custos, analisaria as particularidades do orçamento público brasileiro.

\footnotetext{
${ }^{837}$ Cf. Caderno de Atividades - Curso de Capacitação de Conselheiros Estaduais e Municipais em Saúde. Brasília: Ministério da Saúde, 2002, p. 6.

${ }^{838}$ É de se referenciar o trabalho do Núcleo de Pesquisa em Direito Sanitário da USP, que tem por objeto estudar a difundir a disciplina de Direito Sanitário e sua multiplicidade de aspectos (<http://www.napdisa.prp .usp.br/index.php/pt_br/>, acesso em 2.12.2013, 13:17h).
} 
- Saúde, educação, transporte e habitação, em que haveria aprofundamento das ações tomadas pelo Poder Público nessas quatro rubricas.

- Intervenção jurisdicional em políticas públicas, em que seriam analisadas as virtudes e mazelas da tutela judicial de políticas públicas, estudando mecanismos de aperfeiçoamento, usando preferencialmente a metodologia de ensino e de avaliação do estudo de caso $^{839}$.

A disciplina proposta foi desenhada para um semestre, com quatro ciclos correspondentes aos temas apresentados, mas permite a extensão em até quatro semestres, com o alargamento e aprofundamento dos estudos em cada um dos tópicos, ou a segregação em assuntos mais relevantes, como o direito sanitário.

A disciplina de Direito Sanitário, se incluída nos cursos gerais de políticas públicas, aproveitaria deveras os assuntos ali tratados. Se oferecida de forma independente, como uma matéria de pós-graduação, por exemplo, ela poderia contar com o seguinte currículo:

- O direito à saúde no Brasil e no mundo, subtema que analisaria o tratamento da prestação pública de saúde no mundo - com estudo predominante sobre as regras da ONU e da OMS, sem perder de vista a análise comparada com outros países além de claro, como a Constituição trata o direito à saúde.

- O arcabouço jurídico da saúde e seu orçamento, em que seriam estudados os principais diplomas normativos que mostram qual a base jurídica do direito à saúde.

- O SUS e a saúde suplementar, em que haveria o estudo da estrutura e atribuições do SUS, além da interação entre saúde pública e saúde suplementar.

- Judiciário e políticas de saúde, em que seriam analisados as particularidades e efeitos da intervenção jurisdicional na tutela desse direito, aplicando-se a metodologia do estudo de caso.

\footnotetext{
${ }^{839} \mathrm{O}$ estudo de caso é uma metodologia pedagógica que propicia aos estudantes, vivenciando na pele um caso real, analisar os meandros desse caso e, assim, saber como a teoria se aplica a dilemas reais, além de aprender com a multiplicidade de assuntos que invariavelmente emergem do paradigma analisado. No campo das políticas públicas o estudo de casos encontra rico solo. Mais sobre como o método é aplicado na Harvard Law School pode ser verificado em <http://casestudies.law.harvard.edu/about-harvard-law-case-studies/>, acesso em 20.11.2013, 16:37h. Deste autor, ver Avaliação no curso de Direito em turmas de MBA: estudo de caso, seminários e júri simulado, monografia que lhe rendeu o grau de Especialista em Docência no Ensino Superior, conferido pela Universidade Anhembi-Morumbi (2013).
} 
Essa disciplina, na pós-graduação, é desenhada para durar dois semestres, podendo ser estendida até quatro semestres.

Quanto aos cursos de pós-graduação, então, esses poderiam abrigar desde análise mais pragmática e generalista a respeito da intervenção judicial em políticas públicas quanto permitir o aprofundamento em cada um dos grandes assuntos envolvidos, sempre com enfoque jurídico ${ }^{840}$.

5.2.2 A inclusão dos temas nos concursos públicos e na preparação dos juízes

Juízes, sobretudo, mais promotores e advogados públicos devem ser arguidos sobre políticas públicas e Direito Sanitário como critérios de seleção para o ingresso nas respectivas carreiras. Assumindo-se o caráter público do modelo de litigância - ou melhor, de debate - levado a juízo envolvendo políticas públicas, é necessário que os operadores do sistema judicial estejam efetivamente preparados para dialogar sobre o tema.

Sem dúvida. Considerando os problemas ligados à jurisdicionalização das políticas públicas, notadamente conectados à complexidade que a envolve, é preciso que aquele player que decide como e em que campo alocar recursos para desenvolver determinadas ações saiba o que faz. Sendo o juiz ator altamente demandado pela sociedade para tratar de temas ligados às propaladas políticas públicas, é quase instintivo o dever do magistrado de se preparar adequadamente para o desempenho da função.

A preparação dos juízes para o desempenho do seu crucial papel na estrutura de um Estado Democrático de Direito está prevista na Constituição da República. Antes de ingressar na carreira, o magistrado deve ser preparado por meio de cursos

\footnotetext{
${ }^{840}$ Fora do âmbito exclusivamente do Direito, mas da Administração, a Escola de Artes, Ciências e Humanidades da USP oferece o bacharelado em Gestão de Políticas Públicas, cuja qualidade, de acordo com a própria escola, é permitir que sejam conjugados os fundamentos teóricos de Política, Sociologia, Economia, Administração e Direito para capacitar os alunos a analisar e desenvolver políticas públicas com eficiência, efetividade e equidade, promovendo o bem-estar coletivo pelo competente uso dos recursos públicos (<http://www.each.usp.br/gpp/>, acesso em 20.11.2013, 17:00h).
} 
oficiais $^{841}$. Já ingresso, o juiz que frequentar programas oficiais de aperfeiçoamento contará com o respectivo aproveitamento para fins de aferição da promoção na carreira ${ }^{842}$.

Os Estados organizam suas próprias escolas de magistratura, mas a Emenda Constitucional $n^{\circ} 45 / 2004$ criou, vinculada ao Superior Tribunal de Justiça, a Escola Nacional de Formação e Aperfeiçoamento de Magistrados - ENFAM, responsável pela regulamentação dos cursos oficiais para o ingresso e promoção na carreira ${ }^{843}$. A ENFAM perfaz atividade de destaque na formação e aperfeiçoamento dos magistrados, sendo a responsável, dentre outras atribuições, por: (a) definir as diretrizes básicas para a formação e o aperfeiçoamento de juízes; (b) fomentar pesquisas, estudos e debates sobre temas relevantes para a prestação jurisdicional; e (c) estabelecer as diretrizes básicas e os requisitos mínimos para a realização dos concursos de ingresso na carreira ${ }^{844}$. Existe, portanto, um organismo nacional estruturado e regulamentado responsável pela formação e aprendizado do juiz.

Nota-se que a ENFAM possui como objetivo aproximar o Judiciário da realidade do cidadão. Casos como os ora tratados, que envolvem políticas públicas, sobretudo com o recorte metodológico da saúde, demonstram bem a necessidade de formação específica do magistrado para que ele se aproxime da realidade social. Com efeito, os juízes não sabem sequer as regras e normas ligadas ao SUS, quanto mais a realidade de um hospital público ou posto de saúde. Este caso, é verdade, demanda muito mais capacitação do que aquela que cursos teóricos podem prestar, mas, sem dúvida, o domínio da teoria sobre temas - jurídica e faticamente - tão complexos é imprescindível.

A hipótese ora lançada é confirmada pelas ações já tomadas pelo Poder judicante. Com efeito, a necessária capacitação específica de magistrados para tratar de temas como a saúde já chegou ao alto escalão do Judiciário brasileiro. Em 6 de dezembro de 2010, o CNJ anunciou, na abertura do $4^{\circ}$ Encontro Nacional do Judiciário, a capacitação

\footnotetext{
${ }^{841}$ Artigo 93, IV da Constituição.

${ }^{842}$ Artigo 93, II, $c$ da Constituição.

${ }^{843}$ Artigo 105, Par. um., I da Constituição. Os cursos são regulamentados pelas Resoluções do STJ nº 3/06, 1 e 2/07 e 5/08. Segundo notícia obtida no sítio eletrônico da ENFAM, "Desde sua criação, em 30 de dezembro de 2004, através da Emenda Constitucional $n^{o} 45$, a Escola Nacional de Formação e Aperfeiçoamento de Magistrados (Enfam) cumpre seu principal objetivo, que é definir as diretrizes básicas para a formação e o aperfeiçoamento dos mais de 15 mil magistrados brasileiros. Ao longo de 2010, além de capacitar mais da metade desses juízes, conforme determinação da Meta 8 do Judiciário, a Escola credenciou quase 300 cursos de escolas da magistratura instaladas em todas as unidades da Federação. Em parceria com o Conselho Nacional de Justiça, também elaborou dezenas de outros à distância. As escolas do TRF2, do Distrito Federal e de Pernambuco são as recordistas, com, respectivamente, 32, 26 e 21 cursos avalizados pela Enfam." (disponível em: <http://www.stj.jus.br/portal_stj/publicacao/engine.wsp?tmp.area= $1067 \&$ tmp.texto=100286>, acesso em 26.12.2010, 12:00h).

${ }^{844}<$ http://www.stj.jus.br/portal_stj/publicacao/engine.wsp?tmp.area=1024>, acesso em 26.12.2010, 12:08h.
} 
de três mil e duzentos magistrados para atuar em causas que envolvam saúde ${ }^{845}$. Esse dado apenas confirma, a um só tempo, as proposições aqui elencadas, da: (a) especialização dos juízos para o julgamento de questões de políticas públicas; e (b) necessidade de formação específica dos magistrados para lidar com o tema.

A importância da correta formação do juiz é instintiva para o atual cenário da magistratura nacional. Em sua atividade profissional, o juiz refletirá o aprendizado e os valores por ele apreendidos durante sua formação, além de, claro, pontos específicos de sua personalidade. A formação do juiz, hoje, não está focada como deveria nos temas relacionados à massificação do Direito. É preciso que se repense o modo e o conteúdo dos cursos ministrados aos magistrados, tanto antes quanto após ingresso na carreira ${ }^{846}$.

A inclusão das disciplinas sanitária e de políticas públicas não somente nos cursos ordinários de Direito, como, também, nos concursos e cursos de ingresso às carreiras públicas, bem como de respectivo aperfeiçoamento, gerará reação em cadeia que só contribuirá para a inescapável discussão orçamentária, sanitária e de todos os assuntos que os circundam. E a sociedade só terá a ganhar. Mais profissionais conhecendo as políticas públicas significa maior controle da res publica, maior transparência das finanças e, logo, um adjeto e desejável efeito de combate à improbidade e à corrupção ${ }^{847}$.

Não se pode, hoje em dia e diante do extenso quadro ora apresentado, conceber que um magistrado desconheça as questões mais recorrentes e basilares de políticas públicas, como o orçamento público. Aprovar um candidato para ingresso na carreira de juiz que não conheça tal tema é andar na contramão do desenvolvimento da atividade jurisdicional, é um paradoxo ao novo papel da magistratura. Não se pode, nem se deve admitir que a formação dos magistrados passe em branco pelo tema das políticas públicas, enfatizadas no Direito Sanitário. As fases dissertativa e oral, sobretudo, têm que avaliar o que o candidato conhece a respeito do assunto, porque esta é, afinal, questão que

\footnotetext{
$845<$ http://www.cnj.jus.br/index.php?option=com_content\&view=article\&catid=1\%3Anotas\&id=12994\%3A cnj-pretende-capacitar-300-juizes-para-atuar-na-area-de-saude\&Itemid 675>, acesso em 26.12.2010, 16:04h. Já há um projeto piloto em andamento, envolvendo trezentos juízes.

${ }^{846}$ Uma análise crítica da formação dos magistrados, inclusive à luz das transformações sociais e do novo papel do juiz é tecida por TEIXEIRA, Sálvio de Figueiredo. "A formação do juiz contemporâneo", disponível em: <http://www.cjf.jus.br/revista/numero4/artigo12.htm>, acesso em 26.12.2010, 11:35h.

847 Como é, aliás, a linha que vem sendo seguida por todos os países que se classificam como Democracias modernas. Nos EUA, o hodierno incremento do FCPA - Foreign Corrupt Practices Act de 1977 demonstra a preocupação com a corrupção administrativa praticada por corporações privadas. No Brasil, a Secretaria de Assuntos Legislativos do Ministério da Justiça encampou, em convênio com a Faculdade de Direito da Universidade de São Paulo, pesquisa sobre o tratamento judicial da Lei de Improbidade Administrativa (Lei $\mathrm{n}^{\mathrm{o}}$ 8.429/92), com vistas a seu aprimoramento. A pesquisa, da qual este autor tomou parte como pesquisador, foi coordenada por Susana Henriques da COSTA e Paulo Eduardo Alves dos SANTOS e tinha por consultora Ada Pellegrini GRINOVER. (A Eficácia do Sistema Jurídico de Prevenção e Combate à Improbidade Administrativa. Série Pensando o Direito. Brasília: Ministério da Justiça, 2011).
} 
toca ao próprio papel moderno da magistratura no Estado Democrático de Direito. Esta ideia, que surge incrustada repetidamente neste texto, deve estar clara e sempre presente. Ela é um dos pilares da judicialização racional de políticas públicas.

As escolas de magistratura, nesse contexto, devem desempenhar papel primordial, capacitando os magistrados para o julgamento de questões relacionadas a políticas públicas, que inevitavelmente envolverão o debate acerca do orçamento e outros espinhosos temas. Uma designação a uma vara especializada no assunto demandará inequívoco saber jurídico do magistrado respectivo. Mas é preciso ter em mente que um juiz pode assumir funções em uma comarca que não possua vara especializada. Daí a relevância de uma formação geral a respeito do tema.

Também as carreiras jurídicas públicas que trabalham diretamente com direitos sociais como a saúde devem possuir uma preocupação especial com Direito Sanitário e políticas públicas. Para o Ministério Público, para a Defensoria, para a Advocacia-Geral da União, para todas as carreiras que lidam com os temas, as políticas públicas, sobretudo de saúde, devem ser matéria recorrente.

Motivado por esta proposição, é hora de passar a falar da efetiva especialização dos magistrados, agora no exercício de sua função.

\subsection{A ESPECIALIZAÇÃO DOS MAGISTRADOS}

\subsubsection{A criação de juízos especializados}

Um dos pilares da eficaz ou da mais racional alocação de recursos púbicos pelo Judiciário é a especialização dos juízes e demais atores da cena judicial. A especialização do Judiciário não é novidade e já existe no sistema como forma de tratamento mais técnico de algumas questões cuja peculiaridade merece diferenciada $\operatorname{atenção~}^{848}$.

\footnotetext{
${ }^{848}$ A lei estabelece, por vezes, a criação de juízos especializados, como é o caso dos Juízos de Infância e Juventude (artigo 145 da Lei no 8.069/90, o Estatuto da Criança e do Adolescente). O próprio legislador já reconheceu que determinadas matérias demandam a especialização como forma de um melhor tratamento judicial. Mesmo as divisões mais típicas - como varas de execuções fiscais, varas fazendárias e previdenciárias - revelam a opção pela especialização em determinados assuntos.
} 
Assumir que existem especialistas e magistrados mais aptos do que outros para tratarem de certos assuntos é, simplesmente, questão de inteligência e humildade ${ }^{849}$.

No Poder Judiciário de São Paulo há, por exemplo, varas especializadas em família e sucessões (nos fóruns da Capital), outras especializadas em falência e recuperação judicial e, no Tribunal de Justiça, câmaras relacionadas a esse mesmo tema e ao meio ambiente. Outras, embora genéricas, julgam preferencialmente determinados assuntos, como é o caso da $4^{\text {a }}$ Câmara de Direito Privado decidindo causas que envolvem publicidade. O critério de tipificação, nesses casos, parece claro. Questões de família requerem uma habilidade pessoal própria do juiz. Temas de recuperação judicial envolvem conhecimento em questões de contabilidade e administração empresarial. Problemas ambientais, então, pertinem a uma gama de variáveis que a nem todo magistrado é dado saber. A publicidade tem disciplina toda própria, fortemente autorregulamentada. Parece ser este, exatamente, o caso dos temas envolvendo políticas públicas (lembrando-se, sempre, que essas próprias questões, sobretudo a ambiental, são importantes temas de políticas públicas).

Ainda há muito que se aprender no trato de políticas públicas, sobretudo no que toca à execução do julgado, que envolve enforcement protraído no tempo - e uma clara necessidade de gerenciamento da execução e experimental cumprimento do julgado ${ }^{850}$. O Judiciário como é concebido hoje, infelizmente, não está preparado para isso. Para que se demonstre o despreparo da magistratura (muito em função de alguns dogmas que precisam ser quebrados, frise-se), propõe-se, aqui, dois estudos de caso: o primeiro, da ação civil pública que envolveu a demanda, contra o Estado de São Paulo, de correto tratamento dos portadores da Síndrome de Kanner localizados no respectivo território; o segundo, da medida emergencial que ordenou à União a vacinação dos paranaenses contra a gripe $A$ em desrespeito ao calendário fixado pelo Ministério da Saúde.

A análise desses casos demonstra, simultaneamente, como o Judiciário é importante ator institucional decisivo em questões de políticas públicas e como os juízes carecem de mecanismos e preparação específica para lidar com o assunto ${ }^{851}$.

\footnotetext{
${ }^{849}$ A Min. Rosa WEBER, do Supremo Tribunal Federal, convocou, para auxiliá-la no julgamento do caso do Mensalão (pagamento, com dinheiro público, de mesada a parlamentares para votar favoravelmente ao governo nos projetos de seu interesse, levado a efeito na gestão do presidente Luiz Inácio Lula da Silva), juiz de primeiro grau considerado grande especialista no entendimento de crimes de corrupção e lavagem de dinheiro - o juiz Sérgio MORO -, assuntos altamente complexos. Se uma ministra da mais alta corte do Brasil assume ser necessário recorrer a especialistas, porque denegar a ideia dos juízos especializados?

${ }^{850}$ Temas que serão debatidos no Item 5.5.

${ }^{851}$ Novamente, invoque-se o APLPP para mostrar que a criação de juízos especializados é uma realidade que não escapou à disciplina proposta (artigo 29 projetado).
} 


\subsubsection{O Caso da Síndrome de Kanner}

A Síndrome de Kanner é uma das modalidades da moléstia conhecida por autismo. Esta patologia, que se manifesta nos três primeiros anos de idade, é uma disfunção global no desenvolvimento. $\mathrm{O}$ portador da doença tem alterada sua capacidade de comunicação, relacionamento e interação com o ambiente e a sociedade.

O tratamento da doença não é nada simples. De fato, o respectivo portador demanda cuidado e atenção de uma série de profissionais - dentre médicos (pediatras, neurologistas, psiquiatras), dentistas, psicólogos, fonoaudiólogos, fisioterapeutas, educadores, e outros ${ }^{852}$. Engana-se quem pensa que o autismo demanda providências, apenas, ligadas à saúde: a moléstia também faz com que seus pacientes devam ter assistência e, fundamentalmente, educação.

Efetivamente, tudo isso é dispendioso ${ }^{853}$ e requer severo investimento em infraestrutura apropriada para o tratamento do autista, que, por força soberana dos artigos $6^{\text {o }}, 196,197,205$ e 208 da Constituição, deve ser dispensado pelo Estado.

A Síndrome de Kanner, como toda a patologia, manifesta-se de forma diferente em cada indivíduo, logicamente por conta das características subjetivas próprias de cada um, mas é marcada por um rol de comportamentos, com o que lhe é permitido e recomendável o trato coletivo. Nada obstante as características individuais, a demandar graus de tratamento diversos, a doença é sempre definida por um núcleo comum, com o que o direito dos portadores deve ser caracterizado como coletivo em sentido lato ${ }^{854}$. Essa classificação, contudo, só ocorre por conta da prevalência das questões comuns sobre as individuais, estas, também fundamentais, principalmente para o respectivo tratamento ${ }^{855}$.

A verdade é que, apesar dos milhares de portadores da Síndrome de Kanner, seu interesse, considerando-se a massa daqueles alheios quando se trata de políticas de

852 Sobre a Síndrome de Kanner, consultar o website da Autism Society of America, a ASA (<http://www.autism-society.org >).

${ }^{853}$ A ASA estima que o custo de tratamento da patologia de uma criança autista, por toda a vida, varia de três milhões e quinhentos mil a cinco milhões de dólares, e os EUA estão lidando com um gasto anual de noventa bilhões de dólares (<http://www.autism-society.org/site/PageServer?pagename=about_home〉, acesso em 12 de junho de 2010 às $14: 27 \mathrm{~h})$.

${ }^{854}$ Artigo 81 da Lei ${ }^{\circ}$ 8.078/90. O título da obra de Teori Albino ZAVASCKI é bem emblemático (Processo coletivo: tutela de direitos coletivos e tutela coletiva de direitos. $2^{\mathrm{a}}$ ed. São Paulo: Editora RT, 2007).

${ }^{855} \mathrm{O}$ caso ora tratado é, por exemplo, diverso do caso Castano v. American Tobacco Co. (95-30725), de que já se tratou (v. nota 665). 
saúde e educação, é minoritário. Provavelmente a voz desses autistas jamais seria ouvida, com a relevância necessária, pelos Poderes Legislativo e Executivo. Os vultosos custos empregados no tratamento dessas pessoas certamente assusta o Estado - como ocorre no exemplo dos medicamentos excepcionais. Prova disso é que, ainda que antiga a Síndrome de Kanner, ainda que a Constituição obrigue o Poder Público a tratar as moléstias populacionais e a educar seus cidadãos, não havia política pública adequada, eficiente e merecida para o tratamento do autismo em qualquer de suas espécies. Não fosse, destarte, o Judiciário, o risco de o Estado jamais providenciar tratamento a essas pessoas seria consideravelmente alto. Daí mais uma justificativa empírica da intervenção jurisdicional nas políticas públicas.

O pedido deduzido na ação movida pelo Parquet caminhou, justamente, no sentido da natureza jurídica do direito perquirido ${ }^{856}$. De fato, o órgão ministerial requereu, na inicial, o provimento apto a condenar o Estado de São Paulo a custear o tratamento dos autistas residentes em seu território em entidades especializadas, já que, segundo o substituto processual autor, não havia qualquer entidade estatal em condições de prestar o adequado tratamento aos pacientes.

Apesar de o Estado se opor, tendo apresentado contestação alegando que vem adotando uma sistemática política de tratamento dos portadores da patologia, o juízo decidiu pela procedência dos pedidos ministeriais, o que foi confirmado em grau recursal. O provimento que passou em julgado mandava que os autistas se habilitassem diante do Secretário Estadual de Saúde para que houvesse a avaliação de quais os tratamentos a serem dispensados, tendo o órgão estatal trinta dias, a partir do requerimento protocolado, para providenciar a internação em entidade adequada, de preferência, próxima à residência do paciente.

Diante do cenário aqui exposto, ficam claros dois aspectos: (a) como mencionado, os direitos tutelados na ação em tela são daqueles conhecidos como coletivos, mas com um forte traço individual, considerando-se a advertência feita linhas antes (definição que se mostrará crucial na análise do caso); e (b) a providência requerida pelo Ministério Público - e concedida pelo Judiciário - implicou a formação de uma política pública inexistente de tratamento do autista, ou, pelo menos, a modificação de uma dessas políticas (se for considerada a alegação do Estado). As políticas almejadas, multifacetárias

${ }^{856}$ Autos no 053.00.027139-2, da 6 ${ }^{\text {a }}$ Vara da Fazenda Pública da Comarca da Capital do Estado de São Paulo. 
(porque envolviam educação, cultura, lazer e assistência), convergem para uma, apenas: o dever do Estado de prover saúde e educação adequada a seus cidadãos.

A fase de conhecimento da ação se resumiu às alegações das partes e análise das provas específicas a respeito da doença. Não se penetrou, como se devia, no universo das políticas, planos e planejamentos trabalhados pela Administração com relação aos pacientes. Discutiu-se, com maestria técnica, o direito e os aspectos teóricos da celeuma materializada no processo, mas houve um problema: não foram adequadamente isoladas e ponderadas as dificuldades que seriam geradas para a execução do julgado.

A $6^{\text {a }}$ Vara da Fazenda Pública da Comarca de São Paulo passou a respirar essa execução. Havia milhares de habilitações e extensas decisões, quase que diariamente. Havia até pessoas que, oriundas de todos os rincões do Estado, consultavam-se diretamente com o juiz, requerendo-lhe aconselhamentos. Aquele Juízo passou a se dedicar quase que exclusivamente à execução. Tudo isso pode ser constatado do andamento do feito, disponível eletronicamente ${ }^{857}$.

Este caráter trabalhoso da execução decorreu das próprias peculiaridades do caso tutelado: se cada paciente possui a Síndrome de Kanner com suas próprias particularidades, evidentemente que os tratamentos a serem prestados - e mesmo a instituição escolhida - não poderiam ser uniformes. Daí a característica individual, em que pese determinante medida de homogeneidade do direito. Daí o fato das habilitações serem individuais.

Nada de errado - e, aliás, muito natural - que as habilitações fossem processadas no juízo da execução do julgado coletivo. No caso em tela, definida a inação do Estado para com os pacientes, foi ele condenado a lhes propiciar adequado tratamento. Este é o dado coletivo do provimento. O dado individual toca, justamente, ao exame das características pessoais de cada um, mas fato é que havia o predomínio da questão comum, apta a justificar a tutela coletiva.

A execução foi muito complicada. Do exame das decisões manifestadas pelo Juízo, vê-se que o trabalho fora fervoroso, com decisões, muito extensas e estudadas, manifestadas no espaço de horas. Da forma como foi realizada, quase que a totalidade do trabalho do Juízo se voltou a tentar solucioná-la. O provimento concedido - de discussão perante a autoridade administrativa e possibilidade do Estado contestar a internação do paciente na instituição de sua escolha - fez com que, na prática, todo o debate a respeito da

${ }^{857}$ Disponível em: <http://www.tj.sp.gov.br>, acesso em 15.6.2010, 12:00h. 
adequação do tratamento fosse deslocado da Secretaria de Saúde para o juízo, evidente efeito reverso ao pretendido.

Não havia qualquer problema nesse contexto. Se a Administração Pública, por anos, não logrou êxito em dispensar aos portadores da doença tratamento adequado e digno e, por isso, o debate a respeito do conteúdo desse tratamento foi deslocado para o Judiciário, naturalmente o Judiciário é quem deveria adotar mecanismos para emanar a última palavra em termos da adequação da prestação pública. $\mathrm{O}$ aviamento do debate no Judiciário foi consequência ordinária e natural da inoperância do Estado.

Foi instaurado inquérito civil para apurar as condições de uma das instituições que o Poder Público apontava como adequada a propiciar o tratamento esperado. O Parquet, por sinal, adotou posturas um tanto contraditórias para quem era o substituto processual dos pacientes na fase de conhecimento, como aquela em que manifestou opinião dizendo que a execução do julgado estava cumprida, já que o Estado afirmara ter providenciado instituição adequada para o tratamento dos autistas. Àquela altura, portanto, para o órgão ministerial, o provimento judicial que assegurava o tratamento aos pacientes de autismo fora cumprido.

Os mais inusitados acontecimentos tiveram lugar nessa fase: houve exceções de suspeição do magistrado (acusado de não decidir a favor dos autistas), admoestação do juiz pelo Tribunal de Justiça e, enfim, seu afastamento da $6^{\text {a }}$ Vara da Fazenda Pública da Capital de São Paulo. A execução foi conduzida de maneira bastante questionável, de fato, e a prova disso foi não apenas a decisão que mandou ao Ministério Público que alocasse mais promotores e funcionários, e ao Tribunal de Justiça, juízes e servidores em todo o Estado, sem maiores ilações ${ }^{858}$, mas, principalmente, a decisão que

${ }^{858}$ A decisão a que se faz referência é a seguinte (autos no 053.00.027139-2): "Vistos. 1. Trata-se de ação
civil pública em que o executado Estado de São Paulo foi condenado a arcar com as custas integrais do
tratamento especializado, em regime integral ou não, dos autistas residentes no Estado de São Paulo, em
fase de execução, em que centenas de interessados, individualmente, promovem a habilitação para que o
julgado seja cumprido. Para facilitar o entendimento, de forma integral, reproduzo o dispositivo da
sentença: "ANTE O EXPOSTO e o mais que consta dos autos, JULGO PROCEDENTE a ação civil pública
movida pelo Ministério Público do Estado de São Paulo contra a Fazenda do Pública do Estado de São
Paulo, com fundamento no artigo 269 , inciso I, do código de Processo Civil, para CONDENÁLA (sic), até
que, se o quiser, providencie unidades especializadas próprias e gratuitas, nunca as existentes para o
tratamento de doentes mentais "comuns", para o tratamento de saúde, educacional e assistencial aos
autistas, em regime integral ou parcial especializado para todos os residentes no Estado de São Paulo, a: I-
Arcar com as custas integrais do tratamento (internação especializada ou em regime integral ou não), da
assistência, da educação e da saúde específicos, ou seja, custear tratamento especializado em entidade
adequada não estatal para o cuidado e assistência aos autistas residentes no Estado de São Paulo; II - Por
requerimento dos representantes legais ou responsáveis, acompanhado de atestado médico que comprove a
situação de autista, endereçado ao Exmo. Secretário de Estado da Saúde e protocolado na sede da
Secretaria de Estado da Saúde ou encaminhado por carta com aviso de recebimento, terá o Estado o prazo
de trinta (30) dias, a partir da data do protocolo ou do recebimento da carta registrada, conforme o caso, 
para providenciar, às suas expensas, instituição adequada para o tratamento do autista requerente. III - A instituição indicada ao autista solicitante pelo Estado deverá ser a mais próxima possível de sua residência $e$ de seus familiares, sendo que, porém, no corpo do requerimento poderá constar a instituição de preferência dos responsáveis ou representantes dos autistas, cabendo ao Estado fundamentar inviabilidade da indicação, se for 'o caso, e eleger outra entidade adequada. $V$ - $O$ regime de tratamento e atenção em período integral *ou parcial, sempre especializado, deverá ser especificado por prescrição médica no próprio atestado médico antes mencionado, devendo o Estado providenciar entidade com tais características. $V$ - Após o Estado providenciar a indicação da instituição deverá notificar o responsável pelo autista, fornecendo os dados necessários para o início do tratamento. Para a hipótese de descumprimento das obrigações de fazer dos itens I a $\mathrm{V}$, fixo a multa diária de $R \$ 50.000,00$ (cinqüenta mil reais), destinada ao Fundo Estadual de Interesses Meta individuais Lesados (artigo 13 da Lei Federal $n^{o}$ 7347/85), tendo a ré o prazo máximo de 30(trinta dias), a contar da intimação da presente decisão, para disponibilizar, de forma permanente, tal atendimento aos portadores de autismo." 3. Portanto, sob pena de ofensa à dignidade da Justiça e de litigância de má fé, depois de oito anos do ajuizamento da ação civil pública, é chegado o momento de resolver, definitivamente, a questão do tratamento dos autistas. 4. De um lado, é cômoda a situação do exeqüente Ministério Público porque, em tempos em tempos, paulatinamente, apenas se manifesta nos autos de cada habilitação limitando-se a lançar cota, com os simples dizeres de "Requeiro a manifestação da FESP sobre o teor da inicial" (sic) e não cria mecanismo de, uma vez por todas, exigir o cumprimento da sentença de forma global. 5. De outro, é cômoda a situação do Estado de São Paulo porque, nos autos de cada habilitação, apresenta informação individualizada da Secretaria da Saúde noticiando que houve disponibilização de vaga em uma determinada entidade cadastrada ou deposita valor para que seja expedida guia de levantamento pertinente ao custeio do tratamento em instituição privada ou agrava da decisão judicial pertinente a um caso isolado. 6. São inúmeros os comparecimentos pessoais de parentes dos autistas no cartório judicial, muitos deles pessoas sem recursos vindas de diversas regiões do Estado, os quais solicitam o empenho pessoal do magistrado para que recebam os seus valores ou que haja a internação em clínica privada. A partir de hoje, isso vai mudar (os interessados e os advogados devem, diretamente, procurar o Secretário de Estado da Saúde ou o Ministério Público). 7. Diante do número diminuto de escreventes na $6^{\circ}$ Ofício da Fazenda Pública da Capital (em torno de quatorze) e da notícia de que o Tribunal de Justiça pretende a relotação (sic) de 450 escreventes de primeira instância para ocupar o cargo de $2^{\circ}$ escrevente nos gabinetes dos ilustres desembargadores, não há pessoal para atender os parentes dos autistas que procuram o cartório judicial esperançosos de receber o auxílio objeto da condenação judicial. 8. Não cabe ao julgador, nos termos da sentença proferida, como vem sendo feito (atualmente), verificar a situação pessoal de cada autista e, particularmente, determinar o abrigo em uma determinada instituição; verificar se o atestado médico comprova ou não a condição de autista; mandar a executada providenciar o recolhimento do valor da mensalidade da instituição privada de educação; expedir guia de levantamento; suspender a internação; promover a remoção do autista para outra entidade especializada ou outras coisas do gênero. 9. Conforme o dispositivo da sentença, acima destacada, é o Secretário de Estado da Saúde que, a requerimento dos responsáveis do autista, mediante atestado médico comprobatório, deve verificar, individualmente, a instituição indicada ao paciente mais próximo possível de seus familiares, facultando-se a indicação de outra entidade adequada, se houver fundamentação válida para isso. 10. Não há, no dispositivo da sentença, previsão para que o juiz da execução substitua atividade cabente (sic), exclusivamente, ao Secretário de Saúde do Estado de São Paulo (o julgador não é médico para identificar um quadro de autismo, não sabe escolher a instituição mais adequada para cada caso específico e não possui conhecimento técnico para analisar a prescrição médica para saber qual é o regime de tratamento cabível a uma situação específica). 11. E, mesmo a Lei $n^{o}$ 7.347/85, a qual disciplina a ação civil pública, prever a possibilidade de habilitação dos interessados, notase que apenas um número reduzido de autistas (levando-se em conta a população de milhões de paulistas em todo Estado de São Paulo) está sendo beneficiado porque somente àqueles que contratam advogados particulares estão recebendo assistência estatal mediante ordem deste juízo. 12. É preciso que a sentença seja cumprida, em todos seus termos, porque o procedimento seguido pela executada (nítido caráter protelatório) e a postura adotada pelo Ministério Público, autor da ação (limita-se a lançar cotas nos autos das habilitações e não toma nenhuma providência para que o comando da sentença seja, efetivamente, respeitado) em nada contribuem para garantir assistência, educação e saúde específicos dos autistas. 13. Assim, para todos os autistas residentes no Estado de São Paulo, nos termos da sentença confirmada pela superior instância, como a executada Fazenda Estadual deve manter registro de quem procurou o serviço especializado, determino que o Estado de São Paulo, por intermédio da Secretaria de Estado da Saúde, diretamente, receba os requerimentos dos representantes legais ou responsáveis dos autistas, instruído com o atestado médico que comprove a situação clínica do paciente, a ser protocolado na Sede da Secretaria da Saúde (endereço: Av. Doutor Enéas de Carvalho Aguiar, $n^{\circ}$ 188, CEP no 05403-000, São Paulo, Capital) ou 
no gabinete do Secretário Estadual de Saúde, Dr. Luiz Roberto Barradas Barata (tel. 3066-8656/gabinete e 3085-4315/fax), e providencie, às suas expensas, em 30 dias, instituição adequada para o tratamento do autista, nos termos da sentença, fornecendo ao responsável pelo autista os dados necessários para o início do tratamento, efetuando os pagamentos (diretamente) às entidades indicadas, sob pena de aplicação da multa diária de $R \$ 50.000,00$. 14. Descumprido o comando desta determinação, de uma só vez, deverá o exeqüente Ministério Público providenciar, em jornais de grande circulação ou em rede de televisão, a convocação dos responsáveis pelos autistas para que, diretamente, forneçam à Secretaria de Estado de Saúde os documentos médicos necessários para fins de possibilitar a rápida assistência educacional aos pacientes, objetivando, nos próximos 90 dias, promover-se uma única e derradeira execução da sentença judicial aos que a procuraram, no prazo assinalado. A partir de então, na hipótese de inércia da administração estadual, determinar-se-á a execução do valor total da multa diária e o início do processo por improbidade administrativa dos agentes estatais. 15. Finalmente, recebido o tratamento de saúde, educacional e assistencial aos autistas, pertinentes à condenação judicial, na hipótese de algum responsável do autista discordar da forma do tratamento ou da indicação da clínica especializada pela Secretaria do Estado e da Saúde, deverá procurar o Ministério Público (Rua Riachuelo, 115, $3^{\circ}$ andar, sala 335, São Paulo, Capital, tel. 3119-9090/gabinete do GAESP ou 3119-9355/fax da Secretaria, aos cuidados do Dr. José Paulo França Piva, promotor responsável pelo caso), para que o próprio promova a execução complementar do julgado, de uma única só vez, com relação a todos os descontentes. 16. Valendo este despacho como oficio, solicito ao Procurador Geral de Justiça do Estado de São Paulo, ad referendum, do Conselho Superior do Ministério Público, que se digne a remeter ofício (ou comunicação por meio eletrônico ou publicação no Diário Oficial do Executivo), diante da natureza institucional da matéria, almejando ampliar o número de atendidos, a todos os promotores de justiça de todas as comarcas do Estado de São Paulo, a fim de que, nos limites territoriais de suas atribuições funcionais, por ocasião do atendimento à população nas promotorias (ou em contato com os comissários dos Juizados da Infância e Juventude), divulguem que os responsáveis pelos autistas, por força de sentença transitada em julgado e prolatada pelo juiz da $6^{a}$ Vara da Fazenda Pública, nos autos no 00.027139-2 (controle 1679), proposta pelo Ministério Público do Estado de São Paulo, deverão, diretamente, encaminhar requerimento ao Secretário de Estado da Saúde, protocolado na sede da Secretaria de Estado da Saúde (endereço: Av. Doutor Enéas de Carvalho Aguiar, $n^{\circ}$ 188, São Paulo, Capital, ou no gabinete do Secretário Estadual de Saúde, Dr. Luiz Roberto Barradas Barata (tel. 3066-8656/gabinete e 3085-4315/fax), instruído com atestado médico que comprove a situação de autista, para que a administração estadual, no prazo de 30 dias, às suas expensas, providencie instituição adequada para o tratamento de saúde, educacional e assistencial aos autistas. Além do mais, em decorrência do futuro aumento de interessados, solicita-se que o Ministério Público Paulista providencie o aumento de pessoal (promotores e oficiais de promotoria) para atender, adequadamente, os responsáveis pelos autistas, em todas as comarcas, notadamente a promotoria que atua no GAESP (Grupo de Atuação Especial de Saúde Pública e da Saúde do Consumidor, Rua Riachuelo, 115, 13º andar, sala 335, tel. 3119-9090 e 3119-9355/fax). 17. Valendo este despacho como oficio, solicito ao Presidente do Tribunal de Justiça do Estado de São Paulo, ad referendum, do Conselho Superior da Magistratura, que se digne a remeter ofício (ou comunicação por meio eletrônico ou publicação no Diário Eletrônico), diante da natureza institucional da matéria, almejando ampliar o número de atendidos, a todos os juízes de direito de todas as comarcas do Estado de São Paulo, a fim de que, nos limites territoriais de suas jurisdições, por ocasião do atendimento à população nos cartórios judiciais (ou em contato com os comissários dos Juizados da Infância e Juventude), divulguem que os responsáveis pelos autistas, por força de sentença transitada em julgado e prolatada pelo juiz da $6^{a}$ Vara da Fazenda Pública, nos autos $n^{\circ}$ 00.027139-2 (controle 1679), proposta pelo Ministério Público do Estado de São Paulo, deverão, diretamente, encaminhar requerimento ao Secretário de Estado da Saúde, protocolado na sede da Secretaria de Estado da Saúde (endereço: Av. Doutor Enéas de Carvalho Aguiar, $n^{\circ}$ 188, São Paulo, Capital, ou no gabinete do Secretário Estadual de Saúde, Dr. Luiz Roberto Barradas Barata (tel. 3066-8656/gabinete e 3085-4315/fax), instruído com atestado médico que comprove a situação de autista, para que a administração estadual, no prazo de 30 dias, às suas expensas, providencie instituição adequada para o tratamento de saúde, educacional e assistencial aos autistas. 18. Valendo este despacho como oficio, solicito ao Procurador Geral do Estado de São Paulo que se digne a remeter ofício (ou comunicação por meio eletrônico), diante da natureza institucional da matéria, almejando ampliar o número de atendidos, ao Secretário Estadual da Saúde, a fim de que, em razão do futuro aumento de pedidos da população, providencie o aumento do efetivo de pessoal para atendimento dos interessados, os quais, por força de sentença transitada em julgado e prolatada pelo juiz da $6^{a}$ Vara da Fazenda Pública, nos autos no 00.027139-2 (controle 1679), proposta pelo Ministério Público do Estado de São Paulo, deverão, diretamente, encaminhar requerimento ao Secretário de Estado da Saúde, protocolado na sede da Secretaria de Estado da Saúde (endereço: Av. Doutor Enéas de Carvalho Aguiar, $n^{\circ}$ 188, São Paulo, Capital, ou no gabinete do Secretário Estadual de Saúde, Dr. Luiz Roberto Barradas Barata (tel. 
extinguiu, a um só tempo, todas as habilitações individuais, transformando-as em execução coletiva, a ser conduzida pelo Ministério Público. Como se isso fosse possível.

A ingenuidade que emana da coletivização forçada do julgado casuístico é que é impossível adotar essa providência por uma simples ordem somente porque não é o juiz dotado do poder de desnaturar o direito discutido, definido, afinal, pelo pedido deduzido, e imobilizado pelo comando judicial. A elasticidade própria dos requerimentos em ações coletivas não contempla a transmudação do direito. Com efeito, como já discutido, o pedido de tratamento adequado aos portadores da Síndrome de Kanner detém, nada obstante prevalentes as questões coletivas, possuía traço individual pela própria natureza da moléstia. O tratamento respectivo não pode ser transformado em coletivo, em sentido estrito, ignorando-se as individualidades, por força de decisão judicial.

3066-8656/gabinete e 3085-4315/fax), instruído com atestado médico que comprove a situação de autista, para que a administração estadual, no prazo de 30 dias, às suas expensas, providencie instituição adequada para o tratamento de saúde, educacional e assistencial aos autistas, tomando-se ciência deste despacho judicial e do prazo recursal (a contar da data do protocolo deste ofício), sob pena de improbidade administrativa dos agentes públicos. 19. Valendo este despacho como oficio, solicito à Defensora Geral da Defensoria Pública do Estado de São Paulo (Dra. Cristina Guelfi, gabinete situado na Rua Boa Vista, $n^{o}$ 103, São Paulo, Capital) que se digne a remeter ofício (ou comunicação por meio eletrônico), diante da natureza institucional da matéria, almejando ampliar o número de atendidos, à Coordenação do Cível Central (grupo que cuida do caso dos autistas), aos cuidados da defensora pública, Dra. Juliana Nishina de Azevedo (Av. Liberdade, $n^{\circ}$ 32, tel. 3105-5799, ramal 317 ou 3101-2704 ? (sic) $8^{\circ}$ andar ? ? (sic) Coordenação do Cível Central? (sic), a qual dá atendimento aos interessados que não possuem condições econômicas de contratar advogado particular), a fim de que, em razão do futuro aumento de pedidos da população, providencie o aumento do efetivo de pessoal (defensores públicos e funcionários administrativos) para atendimento dos interessados, os quais, por força de sentença transitada em julgado e prolatada pelo juiz da $6^{a}$ Vara da Fazenda Pública, nos autos $n^{o}$ 00.027139-2 (controle 1679), proposta pelo Ministério Público do Estado de São Paulo, deverão, diretamente, encaminhar requerimento ao Secretário de Estado da Saúde, protocolado na sede da Secretaria de Estado da Saúde (endereço: Av. Doutor Enéas de Carvalho Aguiar, $n^{o}$ 188, São Paulo, Capital, ou no gabinete do Secretário Estadual de Saúde, Dr. Luiz Roberto Barradas Barata (tel. 3066-8656/gabinete e 3085-4315/fax), instruído com atestado médico que comprove a situação de autista, para que a administração estadual, no prazo de 30 dias, às suas expensas, providencie instituição adequada para o tratamento de saúde, educacional e assistencial aos autistas, tomando-se ciência deste despacho judicial e do prazo recursal (a contar da data do protocolo deste ofício), sob pena de improbidade administrativa dos agentes públicos. 19. A partir de agora, por isonomia aos demais autistas ainda não atendidos, todas as habilitações em curso serão extintas (carência superveniente da ação, nos termos do artigo 462 do Código de Processo Civil), não serão processadas novas habilitações (os interessados deverão, diretamente, diligenciar perante a Secretaria de Estado da Saúde) e o julgador somente intervirá para fins de execução da multa diária (não é necessária a presença física do interessado no cartório judicial). 20. O interessado descontente deverá, diretamente, procurar o Ministério Público (Rua Riachuelo, 115, $3^{\circ}$ andar, sala 335, São Paulo, Capital, Grupo de Atuação Especial de Saúde Pública e da Saúde do Consumidor? GAESP, te. 3119-9090 e 3119-9355/fax), o qual deverá ter a iniciativa de constatar (ou não), em cada caso específico, o descumprimento do julgado e, ao seu critério, executar a pena pecuniária diária ou ajuizar ação de improbidade administrativa em face dos agentes públicos negligentes, pois só assim a sentença será cumprida. 21. É preciso ter coragem para exigir o cumprimento da sentença judicial porque as decisões do Poder Judiciário não podem ser figurativas: os pedidos de intervenção federal no Estado de São Paulo, de impedimento do governador do Estado de São Paulo e de fiscalização do Poder Legislativo Estadual não podem ser descartados. 22. Servindo este despacho como ofício (lembrando que os autos principais estão fora do cartório judicial), remeta-se cópia desta decisão ao GAESP, aos cuidados do promotor do caso (Dr. José Paulo França Piva) e ao Secretário do Estado da Saúde (Dr. Luiz Roberto Barradas Barata). 23. Tratando-se de prazo comum, os autos não poderão ser retirados do cartório judicial. Int.” 
A coletivização forçada apenas revelou o absoluto despreparo dos atores da execução judicial. A sintomática adoção de uma providência como se fosse ela a solução do problema é o sinal desse despreparo. Fato é que tais dificuldades demonstram quão complicadas são as questões ligadas à administração de bens públicos por decisões judiciais.

Não há dúvida que o direito postulado pelo Ministério Público na ação estudada era social e, portanto, a ele aplicam-se todas as lições a respeito da universalidade já expendidas. Isso significa, basicamente, que eram duas as espécies de ações que poderiam veicular os direitos dos portadores da Síndrome de Kanner: uma puramente individual, em que o autista postulasse seu adequado tratamento e, precisamente, uma coletiva - tal qual aquela movida pelo Parquet.

A verdade, pelo defendido até aqui, é que, de fato, a ação coletiva era o meio mais apropriado para levar ao Judiciário o debate a respeito da proteção aos autistas, que fora esquecida pelo Estado; mas, diante do que se viu na medida em referência, fica a indagação: o sistema processual brasileiro é apto a fornecer instrumentos eficazes, úteis e adequados à boa prestação de uma tutela jurisdicional de políticas públicas? Antes: os magistrados estão efetivamente preparados para lidar com casos estruturais, como aqueles que envolvem políticas públicas?

No caso em espeque o problema ocorreu principalmente na execução: nem o Ministério Público, nem o Poder Judiciário tiveram paciência e destreza no processamento. O juízo, pelos mais variados motivos afetos à discussão - o número de pacientes habilitantes, a desídia do Estado em dar cabal cumprimento de suas obrigações constitucionais, a pressão pública em torno da execução, os interesses envolvidos, o tempo gasto para fazer frente a tantos pedidos por providências -, adotou uma medida extrema, coletivizando a execução, de forma a tratar por indivisível um objeto, naquela fase, muito mais similar a um direito individual homogêneo.

Todavia, talvez nem toda a paciência e destreza disponíveis poderiam solucionar um problema que é próprio da qualidade do direito tutelado. Da forma como foi elaborado o pedido, não havia outra maneira de se executar o julgado senão pela habilitação e ampla discussão, na fase de liquidação de sentença, das características próprias de cada paciente, e de quais os tratamentos e instituições que poderiam corresponder às necessidades de cada qual.

Suponha-se, então, que o pedido deduzido fosse outro: a condenação do Estado a instalar instituições e aparelhos destinados ao tratamento do autista, com a efetiva 
implementação da política pública até então inexistente. A execução de uma sentença de procedência deste pedido seria muito menos impactante quanto aos sujeitos envolvidos. Não haveria as inúmeras habilitações ou as discussões delas decorrentes. E isso ocorreria porque o pedido, neste caso e pela forma como foi realizado, era de providência difusa e, nem por isso, ele seria menos eficiente. Será que essa seria a solução para os males do julgado? Dois aspectos, nesse sentido, devem ser considerados.

O primeiro é que o pedido, se feito como proposto, não resolveria, curto prazo ou imediatamente, o problema dos pacientes. Requerer a instalação de instituições de tratamento implicaria - sem que houvesse uma tutela de urgência e, sendo ação civil pública, sem que ocorresse recurso do Poder Público para suspender a execução - obrigar o Estado a começar essas ações somente após o trânsito em julgado da sentença. Qualquer providência imediata ou de curto prazo - como, aliás, foi a requerida no caso ora analisado, com a internação em entidades particulares - envolveria ventilar direitos individuais homogêneos, retornando-se, destarte, ao problema das habilitações individuais.

O segundo é que o pedido difuso, como aquele proposto, apenas aparentemente facilitaria os trabalhos dos atores envolvidos. De fato, sua procedência resultaria no acompanhamento da construção dos edifícios, na contratação dos profissionais de saúde e educação, na avaliação periódica de performance desses especialistas, entre outras providências que, certamente, deveriam ser observadas para que fosse obtido um provimento jurisdicional de qualidade. Qualquer coisa que fugisse dessa lógica significaria intervenção judicial inócua na política pública, porque não garantiria o efetivo cumprimento dos comandos constitucionais que asseguram ao autista seu adequado tratamento. O pedido amplo, isoladamente, não resolve a complexa execução da política pública.

Ou seja, fosse individual homogêneo, fosse difuso, a dificuldade da efetivação da política pública requerida seria inerente ao pedido. Se é difícil para o Poder Executivo concretizar uma política pública, por que não seria complicado que o Judiciário controlasse tal concretização? O que se demonstra, com o exercício aqui realizado, é que a execução da sentença no caso do autismo poderia ser melhor, sem dúvida - fosse outro o pedido, fossem outros os atores -, mas não se pode culpar um ou outro pela ineficiência de uma decisão se os entraves à sua correta execução defluem do próprio direito discutido, ou dos dogmas impostos pelas normas processuais, pelos pensamentos dos processualistas e estrutura e preparo dos juízes e seus órgãos auxiliares. 
O problema observado na ação civil pública ora estudada não encontra sua solução somente na modificação do pedido, ou na alteração normativa ou decisão judicial que, repentinamente, chamasse de coletivo o direito individual homogêneo. O problema condiz, primeiramente, com a falta de estrutura judicial adequada a que este Poder faça jus às novas funções institucionais. Depois, falta cultura aos juízes para que sua leitura sobre as normas processuais se dê de maneira a adequá-las ao processo coletivo mais profícuo. A criação de juízos especializados em lidar com questões como a ora exposta viabilizaria uma tutela coletiva de qualidade. E isso também ficará bem demonstrado no segundo caso estudado.

\subsubsection{O Caso da vacinação paranaense contra a gripe A}

A gripe A foi uma pandemia que preocupou o mundo no ano de 2009. Originária de um vírus que infectava porcos (daí ser popularmente conhecida como gripe suína) ${ }^{859}$, a gripe A rapidamente se espalhou por boa parte do globo, chegando ao Brasil. Sua taxa de mortandade e o desconhecimento acerca de um medicamento que combatesse efetivamente o vírus causaram uma comoção mundial típica das endemias globais ${ }^{860}$.

Com estratégia de prevenção que envolveu, inclusive, a instalação de dispensadores de material antisséptico em prédios públicos - comportamento que veio para ficar -, o Brasil enfrentou a gripe A em 2009 sem maiores percalços, embora oitocentas e noventa e nove pessoas tenham falecido em território nacional em decorrência da doença $^{861}$. Sem vacina desenvolvida àquela altura, o foco da atuação estatal foi, efetivamente, a prevenção. A estratégia administrativa esperava que as pesquisas conseguissem encontrar uma vacina eficiente até o inverno do ano seguinte (2010), época em que o contágio de doenças respiratórias se exacerbaria.

\footnotetext{
${ }^{859} \mathrm{O}$ Influenza A ou vírus H1N1.

860 <http://www.combateagripesuina.com.br>, acesso em 2.1.2011, 18:31h. A situação, de fato, preocupava. Em 25 de abril de 2009, a OMS declarou estado de Emergência de Saúde Pública de Importância Internacional (ESPII), conforme definido no Regulamento Sanitário Internacional (RSI 2005). A resposta brasileira foi imediata: na mesma data, foi instituído o Gabinete Permanente de Emergência em Saúde Pública (GPESP), no Centro de Informações Estratégicas e Respostas em Vigilância em Saúde (CIEVS), da Secretaria de Vigilância em Saúde do Ministério da Saúde, com o objetivo de monitorar a situação mundial, bem como indicar as medidas adequadas a serem adotadas no Brasil.

${ }^{861}$ Isto de acordo com estatísticas apuradas em setembro de 2009 (<http://www1.folha.uol.com.br/folha/cotid iano/ult95u598181.shtml>, acesso em 2.1.2011, 18:36h).
} 
A tão esperada vacina foi desenvolvida a contento e, no início de 2010, o Ministério da Saúde comprou milhões de doses e desenhou um plano nacional de vacinação, que teria início em 5 de março de 2010 com a imunização, primeiro, dos trabalhadores na área da saúde, indígenas, gestantes e portadores de doenças crônicas (ora mais propensos ao contágio, ora mais propensos à mortandade), depois, para o grupo etário de risco, mais tarde, idosos e, por fim, a população remanescente. A estratégia, escalonada e descentralizada, envolvia embasamento técnico-científico, promovido pelo SUS, que priorizava o tratamento das pessoas que possuíam maior risco de contrair a moléstia ${ }^{862}$ ao redor de todo o Brasil.

Evidentemente que uma vacinação em escala nacional, considerando-se os valores territoriais continentais do Brasil, não poderia ser realizada de maneira desordenada e desorganizada. O que fez o Ministério da Saúde foi, com base em critérios científicos e de forma a assegurar a incolumidade da população, estabelecer um programa de vacinação que se perfaria totalmente em menos de dois meses e - o mais importante antes do inverno do ano de 2010, o que era prioridade do Estado. O planejamento conferiu eficácia à vacinação e conforto à população ${ }^{863}$.

O calendário estabelecido pela União não agradou ao Ministério Público do Estado do Paraná, o Estado brasileiro noticiado como o mais atingido em 2009. De acordo com o Parquet, os critérios científicos eleitos como parâmetros pelo Ministério da Saúde não consideravam as particularidades da realidade paranaense e, logo, deveriam ser revistos. De acordo com dados e estatísticas amealhadas pelo órgão ministerial, a União incluíra na vala comum a população do Nordeste, menos suscetível ao contágio, e do Sul, mais suscetível. Diante disso, ingressou com ação civil pública para obter o provimento jurisdicional apto a determinar que a população paranaense fosse prioritariamente vacinada $^{864}$.

Entendendo que os paradigmas escolhidos pela União para definir sua estratégia de imunização da população brasileira não consideravam adequadamente as

\footnotetext{
${ }^{862}$ De acordo com fontes oficiais do Ministério da Saúde, a estratégia se embasava em parâmetros da OMS. Conforme a escala, ao cabo de dois meses (até o dia 21 de maio de 2010), todos os brasileiros teriam à sua disposição a oportunidade de se imunizar contra o vírus H1N1 (<http://portal.saude.gov.br/portal/aplicac oes/noticias/default.cfm?pg=dspDetalheNoticia\&id_area=124\&CO_NOTICIA=11134>, acesso em 2.1.2011, $18: 48 h)$.

${ }^{863}$ A conscientização da população para afastar o pânico que envolve uma pandemia mundial foi etapa fundamental do sucesso do combate ao vírus, e a vacinação escalonada era parte integrante da estratégia, tendo sido ela desenhada de modo a evitar uma desenfreada - e desmotivada - corrida do povo aos postos de saúde, o que comprometeria severamente o seu funcionamento.

${ }^{864}$ Autos no 5002213-42.2010.404.7000/PR, Ministério Público Federal em face da União e do Estado do Paraná, feito distribuído à $2^{\mathrm{a}}$ Vara Federal de Curitiba.
} 
peculiaridades do caso paranaense, a magistrada resolveu antecipar os efeitos da tutela final para estabelecer, em síntese, o dever da União em adquirir, verbis, “(...) doses da vacina contra o vírus da Influenza A-H1N1 em quantitativo suficiente para suprir a demanda de toda a população do Estado do Paraná, no prazo máximo de 20 (vinte) dias a contar da ciência da presente decisão (...)”. Estabelecia mais a decisão, que o Estado do Paraná devesse submeter àquele juízo calendário para a distribuição da vacina em dez dias, com o que, caso aprovado, deveria ocorrer ampla divulgação a respeito. Terminou asseverando que, em caso de impossibilidade de cumprimento dos prazos nela previstos, poderia haver revisão, e seria o Parquet o responsável pela fiscalização do efetivo cumprimento da medida emergencial.

Da análise da decisão ora aludida é possível que se convença, de fato, que os paranaenses devessem ser imunizados de maneira prioritária em comparação com o calendário fixado pelo Ministério da Saúde. Ali a magistrada cotejou dados fornecidos pelas partes, já que a medida urgente não fora concedida de forma liminar, e chegou à conclusão que a incidência e a mortandade da doença eram, com efeito, maiores na Região Sul do que na Região Nordeste. Todavia, seria preciso comparar a decisão tanto com o pano de fundo da discussão quanto com suas consequências, de onde se tirará o inequívoco despreparo daquele juízo para lidar com o assunto.

O que fez a decisão ora estudada foi, a um só tempo, ignorar por completo toda estratégia e planejamento do Poder Público para imunizar a população brasileira. A estratégia era nacional, não regional, e rigorosamente parametrizada de acordo com as diretrizes da organização mundial de saúde, a mesma que estava controlando o tratamento mundial da gripe A. Para uma pandemia global, a decisão judicial elegeu como válidos critérios locais apenas embasada em dados que, embora sedutores, poderiam ser falsos.

Deveras, não é o simples fato das estatísticas apontarem 66,2 casos para 100 mil habitantes do Sul do Brasil contra 0,6 casos para 100 mil habitantes do Nordeste que autorizaria o juiz a solapar a estratégia nacional de imunização ao vírus H1N1 e privilegiar os moradores do Paraná. Não se sabe se esse é, tecnicamente, número relevante, ou número suficiente para autorizar que medidas extremadas fossem tomadas, como, por exemplo, priorizar o tratamento dos paranaenses. Da mesma forma, sob o ponto de vista técnico, pode ser irrelevante o número de 2,32 óbitos no Sul contra 0,05 óbitos no Nordeste, por 100 mil habitantes ${ }^{865}$. Seduzida pelos números, sem saber, no fundo, em que

\footnotetext{
${ }^{865}$ Todos estes dados estão contidos no corpo da decisão antecipatória em referência.
} 
eles cientificamente implicavam, a magistrada acabou violando, inocentemente, o acesso universal e igualitário às políticas de saúde, tão visto neste estudo. A decisão terminou por, sob o falso fundamento de se embasar em dados técnicos, imputar erro a toda a estratégia nacional e impor um privilégio territorial em detrimento dos mencionados dados - de resto, também certamente fulcrada em dados técnicos.

A decisão também padecia de lógica. As estatísticas consideradas faziam alusão à região Sul, enquanto que o pedido e a providência contemplavam apenas o Paraná, um dos três Estados que, formalmente, compõem aquela região do Brasil, e, por sinal, é o local mais ao Norte. Se o inverno era o problema, o fato de, em 2009, o Paraná ter sido o Estado mais atingido pela gripe A não significava, de conseguinte, que o mesmo se daria em 2010. Por que, então, a população do Rio Grande do Sul e de Santa Catarina não teria o mesmo direito de ser contemplada pela medida? E se isso ocorresse, como ficaria o Estado de São Paulo, vizinho ao Paraná e com população muito maior, já que as doses de vacina não mais obedeceriam a critérios técnicos, mas territoriais?

Pior: a decisão, ao fim e ao cabo, revelar-se-ia inútil. O Ministério da Saúde definiu o dia 21 de maio de 2010 como o derradeiro dia da campanha de vacinação. A decisão estabeleceu, em 12 de abril de 2010, que as doses suficientes para imunizar todos os paranaenses fossem adquiridas em vinte dias contados da intimação daquela decisão. Determinou, também, a apresentação de um calendário em dez dias contados do mesmo evento. Por fim, ressalvou a possibilidade de revisão dos prazos, caso ficasse constatada a impossibilidade material de seu cumprimento. Àquela altura a magistrada certamente não tinha o menor conhecimento sobre como seria realizado o calendário e nem como se daria a aquisição das doses - e isso se explica pela ressalva feita na decisão. Mas o fato é que, se a União fosse intimada no dia da prolação liminar, ela teria até a data de 3 de maio para adquirir as doses e, então, disponibilizá-las ao Estado do Paraná para o cumprimento do calendário. Bastava um atraso ou uma única discussão acerca do calendário ou das doses para o cumprimento da decisão ultrapassar o prazo protocolar da campanha, como mencionado, o dia 21 de maio de 2010.

É evidente que a decisão, fosse ela cumprida ${ }^{866}$, apenas atrapalharia - e muito - o planejamento que, desde o ano anterior, vinha sendo realizado pelo Ministério da

${ }^{866}$ Felizmente, o Presidente do Tribunal Regional da $4^{\text {a }}$ Região suspendeu a tutela antecipada (autos $n^{\circ}$ 0011099-66.2010.404.0000/PR) em 3 de maio de 2010. Na decisão, entendeu o Desembargador Federal que o plano do Ministério da Saúde estava alinhado à estratégia mundial de combate à doença, e que, diante do número limitado de doses da vacina, priorizar um grupo que não tinha porque se preocupar à luz de 
Saúde e que, no final, mostrou-se extremamente eficiente. A medida emergencial ora debatida somente demonstra como falta preparo aos magistrados quando se lida com questões de alta complexidade social, como a saúde.

Ambos os casos analisados demonstram que não apenas a criação de juízos especializados mitigaria os problemas ligados à implementação judicial de políticas públicas. É preciso que se altere, também, a execução desses julgados, tanto quanto o modo como pedidos são deduzidos e questões são levadas ao juiz. Mas a multiplicidade de pontos surgidos no quanto estudado demonstra a complexidade do juízo de políticas públicas. E a necessidade de criação das varas especializadas no assunto é uma necessidade premente. Afinal, ninguém questiona a necessidade de juízos especializados em falências e recuperações, ou família e sucessões, ou fazenda pública, ou meio ambiente, dada a inevitável densidade que os assuntos demandam. E não o demanda o juízo sobre políticas públicas, que, ao mesmo tempo, envolve tantos temas dificultosos e diferentes.

\subsubsection{Conclusão que emerge da análise casuística: os juízos especializados}

As decisões ora estudadas são pródigas em demonstrar como a criação de juízos especializados em políticas públicas é necessidade premente.

Os juízos especializados em políticas públicas seguem a mesma linha do que seriam as varas especializadas em tutelas coletivas ${ }^{867}$, tendo em vista a íntima relação de um e de outro assunto, não somente quanto ao próprio tema jurídico em si (i.e., a saúde, que é tema transindividual e de políticas públicas), mas, também e como decorrência, quanto às incalculáveis variáveis que circundam o julgamento de uma e outra matéria. A ideia da especialização dos juízos coletivos era e é colocada para fazer frente a um cenário de inoperância das ações coletivas, sobretudo no que tocava à sua execução, criando competências capazes de lidar adequadamente com a tormentosa tarefa de distribuir bens metaindividuais.

critérios científicos (os paranaenses) seria colocar em risco à vida daqueles que, efetivamente, precisavam da vacina aprioristicamente.

${ }^{867}$ Uma das soluções apontadas pela doutrina quanto à tutela jurisdicional coletiva é, justamente, a criação de juízos especializados. Assim previam tanto o Código Modelo de Processos Coletivos para a Ibero-América (artigo $40^{\circ}$ ) quanto o Código Brasileiro de Processos Coletivos (artigos 17 e 47), além do já mencionado APLPP. 
As particularidades técnicas do juízo de políticas públicas, seja na fase de conhecimento - com os debates e reflexões sobre temas que passam, como visto na introdução deste texto, desde Filosofia a Ciências Sociais -, seja na de execução - com a implementação gradativa da decisão - demandam que seja apontada a criação de varas especializadas como um dos remédios para a tutela jurisdicional de políticas públicas ${ }^{868}$. Com efeito, o que se assiste hoje - e as ações civis públicas envolvendo a Síndrome de Kanner e a vacinação paranaense contra a gripe A são os paradigmas - é a necessidade de dotação, ao Judiciário, de magistrados capazes de lidar com o multifacetário tema das políticas públicas. É nesse contexto que tanto a formação quanto a alocação desses magistrados cumpre papel primordial ${ }^{869}$.

Não se furta, contudo, de se apontar a extrema dificuldade prática a permear a instalação dessas varas especializadas.

Lidar com políticas públicas não pode ser para qualquer magistrado. Temas econômicos, financeiros e orçamentários, questões de administração de recursos e projetos, itens relacionados às especialidades de cada um dos direitos sob tal rubrica (i.e., saúde, educação, transporte, moradia, vestuário, lazer, cultura, esporte, previdência, assistência, emprego) serão invariavelmente enfrentados pelo juiz de políticas públicas. A questão é que nem todos eles têm aptidão ou, pior, vontade para tratar disso.

São obscuros os critérios de alocação dos recursos humanos da magistratura em suas respectivas comarcas ou seções. As escolhas são normalmente feitas pelos próprios candidatos, decidindo com base nas opções disponíveis. Normalmente os juízes optam motivados por seus interesses pessoais, seja porque a comarca é pacata, seja porque é mais rica, seja em razão de se localizar no litoral, ou no interior, ou perto de sua residência, seja, enfim, porque assumir aquela seção lhe trará promoções mais céleres. Raros são os juízes que investem em uma vara por vocação ou amor ao assunto que ali

\footnotetext{
${ }^{868}$ Sobre alguns dos motivos que justificam a adoção de juízos especializados em tutelas coletivas, concordando com os motivos aqui adotados, ver MENDES, Aluisio Gonçalves de Castro. "O Anteprojeto de Código Brasileiro de Processos Coletivos: visão geral e pontos sensíveis", em Direito Processual Coletivo..., pp. 19-20.

${ }^{809}$ O CNJ assim também reconhece. Em 28 de maio de 2013, o conselho deu início à análise da proposta de criação de juízos especializados para tratar das questões de saúde. A iniciativa partiu de um cidadão que perdeu sua filha de treze anos devido a uma forte crise de asma. Alegou o cidadão que ela foi vítima de negligência médica. Por ocasião do julgamento da proposta, o Min. Joaquim BARBOSA - ali, na qualidade de presidente do CNJ - declarou - todavia, sem votar - que a especialização seria medida de bom tom, sobretudo em um cenário de tamanha disparidade de provimentos em circunstâncias fáticas análogas. De acordo com ele, a especialização teria o condão não apenas de dar maior coesão às decisões em função de sua uniformidade, mas, também, para capacitar melhor os magistrados. ("CNJ começa a julgar propostas para criar varas de saúde no Brasil”, em O Globo, edição de 28.5.2013, disponível em: http://oglobo.globo.com/pa is/cnj-comeca-julgar-proposta-para-criar-varas-de-saude-no-brasil-8524892, acesso em 5.6.2013, 14:30h).
} 
enfrentarão. A questão das promoções e remoções é outro problema. Seus critérios são normalmente subjetivos, elas tendo sido realizadas, por longo período, por voto secreto e sem motivação ${ }^{870}$. A Lei Complementar n ${ }^{\circ}$ 35/79, Lei Orgânica da Magistratura, estabelece que as promoções efetivar-se-ão de acordo com o merecimento e a antiguidade. O primeiro critério é altamente subjetivo; o segundo, friamente objetivo, prefere ao primeiro. Isso porque o artigo 81 da aludida lei dá preferência às remoções ao revés das promoções por merecimento. As remoções são transferências no plano horizontal da carreira, o que significa que sempre as promoções serão informadas, primeiro, pela antiguidade (depois haverá remoções e somente depois, promoções por merecimento).

Em 2010 e para aclarar um pouco mais as normas sobre modificação de postos na carreira, o CNJ editou a Resolução $n^{\circ} 106$. O artigo $4^{\circ}$ da norma estipula parâmetros de avaliação dos magistrados para fins de promoção, dentre os quais o desempenho (que a norma define como aspecto qualitativo da prestação jurisdicional) e a produtividade (para a norma, aspecto quantitativo da prestação jurisdicional).

O desempenho leva em conta redação, clareza, objetividade, pertinência da doutrina e jurisprudência, quando citadas, e o respeito às súmulas dos tribunais superiores $^{871}$. A norma não esclarece o universo amostral de avaliação nem a forma como ela será feita. Esse critério pode ser maximamente avaliado com vinte pontos. Com trinta pontos entra a produtividade.

Sucede que a produtividade é medida erraticamente de acordo com o número de conciliações, audiências, decisões interlocutórias, sentenças prolatadas e, como um desses itens, o tempo médio de ocupação de uma vara. Veja-se, aí, que problema: uma ação que sindica políticas públicas, sendo preferencialmente coletiva, como aqui se defende, tramitará por algum tempo até ser definida, já que demandará oitiva do Poder Público, debates, análise de planos já em curso, discussão sobre aspectos financeiros, enfim, não se pode negar que uma ação em que trate de políticas públicas seja sempre mais dificultosa do que medidas individuais como cobranças e indenizações. Enquanto o juiz que lida com processos deste tipo prolatará “ $X$ ”sentenças, no mesmo período o juiz de políticas públicas terá sentenciado $1 / 100$ de " $\mathrm{X} " 872$.

\footnotetext{
${ }^{870}$ Cf. anota Francisco José Rodrigues de Oliveira NETO (“O Poder Judiciário em um Estado Periférico: os Direitos Fundamentais como Parâmetro Decisório", em COUTINHO, Jacinto Nelson de Miranda; FILHO, Roberto Fragale; e LOBÃO, Ronaldo (org.). Constituição \& Ativismo Judicial. Limites e Possibilidades da Norma Constitucional e da Decisão Judicial. Rio de Janeiro: Lúmen Juris Editora, 2011, p. 135).

${ }^{871}$ Art. $5^{\circ}$ da Resolução CNJ n ${ }^{\circ}$ 106/2010.

${ }^{872}$ Ver, a respeito, WATANABE (“Cultura da sentença...”), p. 687.
} 
E não apenas: a execução da sentença que definirá determinada política pública será certamente demorada, pela própria qualidade do bem entregue, a demandar planejamento e efetivação protraída no tempo. Além disso, o juiz atuará como legítimo gerente da execução, procurando, muitas vezes, apontar saídas que atendam os anseios de ambos os $\operatorname{lados}^{873}$. O juiz de políticas públicas deve possuir qualidades especiais, que ultrapassam a simples escolha pessoal no preenchimento dos postos.

O paralelo com as ações coletivas é inevitável. As ações coletivas são uma espécie de "patinho feio" da vara: o juiz a coloca de canto, os serventuários dão um jeito de posicionar seus autos atrás, bem atrás nas prateleiras. Os motivos para isso são os mesmos que arvoram este autor defender uma profunda alteração no Poder Judiciário, desde sua raiz: formar magistrados, dar-lhes estrutura adequada, promovê-los criteriosa e racionalmente.

De nada adiantaria pregar a especialização dos juízes em casos de políticas públicas se essa medida não advier irmanada a outras tantas. Nesta tese são apontadas algumas. Neste Item, defende-se que os juízes especializados em políticas públicas sejam escolhidos dentre aqueles que mais aptidão demonstrarem para tratar do tema, aferida por meio de critérios de seleção apropriados (i.e. provas, entrevistas, simulação de casos) e, uma vez assumindo o encargo, sejam avaliados periodicamente. Esses juízes devem possuir balizas especiais de promoção e ascensão na carreira, próprias daqueles que conseguiram ocupar tão importante posto.

É absolutamente lógico que, já que muito da relevância do Judiciário advém de sua atual intervenção em políticas públicas, os magistrados que lidem com esse tema sejam tratados diferentemente. As varas de políticas públicas serão disputadas por muitos, mas ocupadas por poucos, somente por aqueles que revelem qualidades próprias para o desempenho da tarefa.

Considerando que ainda que haja obstáculos, o juízo especializado em políticas públicas é, deveras, uma saída imprescindível para cercar as patologias no trato judicial do tema, sendo evidente que toda a estrutura que um juiz demanda também deve estar adaptada às particularidades de um juízo peculiar de políticas públicas. Nesse sentido, os funcionários do juízo, a estrutura do cartório, o atendimento pessoal, todos os aspectos do cotidiano forense devem ser adaptados a políticas públicas. E isto não é exagero. As varas têm que estar preparadas para receber interessados e ouvir seus reclamos, prestar

\footnotetext{
${ }^{873}$ Ideia que será desenvolvida no Item 5.5.2.
} 
informações especializadas, enfim, atender às necessidades sociais. Se as políticas públicas tocam a todos, porque configuram valores constitucionais eleitos na norma como os mais importantes da nação, então a integralidade de seus aspectos tem que ser tratados com o máximo de cuidado.

Poderia, aqui, caber a figura do Ombudsman sueco ou o Provedor do Povo português, pessoas que existem e que têm poder, inclusive, para tomar atitudes tendentes a fazer cumprir decisões judiciais ${ }^{874}$. Um ombudsman, por exemplo, seria capaz de ouvir de um jurisdicionado que o medicamento incluído na lista de dispensação obrigatória por ordem judicial não está disponível nos postos de saúde, levando ao juiz esse conhecimento. O ombudsman seria, assim, a ligação mais eloquente entre o jurisdicionado e o juiz ou o Special Master, ou o gerente da execução, que será tratado em item próprio (Item 5.5.1.2).

O caso ora estudado, ligado à Síndrome de Kanner, além de ser excelente exemplo sobre como poderia um ombudsman funcionar (porque o cartório recebeu pessoas de todos os cantos do Estado de São Paulo em busca de informações), também serve como parâmetro empírico de constatação de que a execução, no processo que envolve políticas públicas, deve ser diferenciada. Ali, a solução empregada precisa ser negociada entre Estado e jurisdicionados, com a intermediação do juiz, sub-rogação de pessoa especializada e fiscalização do Ministério Público, sendo ela frequentemente revisitada e avaliada de acordo com sua eficácia ou seu poder de atingir o que fora judicialmente determinado. O juiz, nesses casos, deve nomear um gerente da execução, contando, conforme for, com a ajuda de um terceiro que tenha conhecimento em administração de recursos. Tudo isto será sugerido no Item 5.5.

E como seria a organização desses juízos especialistas na matéria? Seriam eles instalados em todas as comarcas ou apenas naquelas mais importantes? Embora essa seja uma questão administrativa, cabe, aqui, expor pensamento deste autor a respeito.

Hoje a maior parte das comarcas e seções trata de direitos relacionados a políticas públicas. Em muitas delas, a ação judicial deflagra a preocupação do Executivo até então, dormente - em planejar ou, mesmo, executar a política faltante ${ }^{875}$. Carece de maiores comprovações o fato de que as demandas judiciais por itens como educação e

\footnotetext{
${ }^{874}$ MENDES, Alberto M. G. "O Provedor Municipal”, disponível em: <http://www.cm cascais.pt/NR/rdonlyr es/E0478FEE-FF75-4AEC-8C89-A99BB98D1FDC/4735/Ombudsman.pdf>, acesso em 5.1.2011, 20:29h.

${ }^{875}$ Foi o caso de São Luís do Paraitinga, cidade de 10.417 habitantes (cf. <http://www.saoluizdoparaitinga.sp .gov.br/index.php/dados-gerais>, acesso em 3.5.12, 13:32h). O Judiciário deu visibilidade ao grave problema habitacional relacionado aos loteamentos irregulares na região, provocado principalmente pelo Ministério Público local (CUNHA, Luciana Gross e GABBAY, Daniela Monteiro (coord.). O Desenho de Sistemas de Resolução Alternativa de Disputas para Conflitos de Interesse Público. Série Pensando o Direito, no 38. Brasília: Ministério da Justiça, 2011, pp. 34-36; 59).
} 
saúde são capilarizadas e espalhadas desde os menores Municípios até os Estados mais populosos.

Isso gera uma dificuldade, porque é irreal pensar que toda a comarca deva possuir vara especializada em políticas públicas. Em primeiro lugar, faltaria material humano; em segundo, talvez a demanda não comportasse os custos com a instalação da vara. Ao mesmo tempo, não se pode pensar em instalar esses juízos apenas nas Capitais, porque aí, certamente, haveria subdimensionamento. É preciso adotar uma proposição razoável: onde houver varas especializadas em assuntos da fazenda pública, também haverá varas específicas para políticas públicas. Essas varas são instaladas em comarcas que detém influência regional, como as de Santos, São José dos Campos e Campinas, no Estado de São Paulo. A característica regional das comarcas cobriria boa parte das demandas relacionadas a políticas públicas.

Nas comarcas menores, o juiz responsável pelas causas cíveis também seria o competente para as causas de políticas públicas, nos moldes do que ocorre hoje. A pouca intimidade com as questões seria amenizada pela formação diferenciada a ser garantida a todo e qualquer juiz ${ }^{876}$, que também contaria, a seu dispor, com todos os instrumentos de análise racional da jurisdição de políticas públicas, como o acesso aos cadastros. Qualquer imperfeição observada em primeiro grau poderia ser corrigida pelos tribunais, esses, sim, todos a organizar câmaras especializadas em políticas públicas.

Agora se tratará de outro importante remédio à atuação judicial patológica na seara das políticas públicas: o compêndio de dados e estatísticas a facilitar deveras o trabalho tanto do Executivo, quanto do Judiciário.

\subsection{ESTATÍSTICAS E AS INFORMAÇÕES}

Não se pode ordenar eficientemente uma sociedade sem dados e estatísticas. É preciso saber quantos brasileiros somos, quantos estão empregados, formal e informalmente, quanto se ganha em média, quem mora em casa própria, quem utiliza costumeiramente o SUS. São inúmeros os dados passíveis de coleta e que, efetivamente, devem ser compilados.

\footnotetext{
${ }^{876}$ Ver Item 5.2.
} 
A análise de dados e estatísticas permite ao administrador efetuar o diagnóstico de um potencial problema e abre caminhos para que se pensem em possíveis respostas. Os dados são essenciais para o planejamento governamental, coisa que, de resto, já se elegeu neste texto como do fundamento das ações e programas estatais de distribuição de bens públicos. A partir da quantidade de analfabetos por região a Administração poderá instalar com propriedade uma escola de ensino fundamental. Dependendo de qual for a incidência de doenças corriqueiras em certo território, a solução deverá ser a implantação de um posto de saúde. O número de brasileiros que não têm onde morar abrirá caminho para que o Poder Público trace uma nova política habitacional, e, assim, sucessivamente ${ }^{877}$.

Também as políticas judiciárias possuem importante apoio em dados e estatísticas. Na verdade, o Judiciário, por muito tempo, padeceu da absoluta falta de parâmetros confiáveis (i.e., número de processos distribuídos e julgados, número de sentenças terminativas, número de recursos, tempo médio de julgamento de uma causa), realidade observada até a criação, pela Emenda Constitucional n 45/2004, do CNJ, órgão que ficou responsável por condensar e dar roupagem estatística aos dados judiciais, inclusive para, justamente, diagnosticar os principais gargalos que merecem atenção do Estado a fim de se tornar possível a prestação de um serviço jurisdicional de qualidade ${ }^{878}$.

O CNJ criou, pela Resolução no 15/2006, o Sistema de Estatística do Poder Judiciário - SIEPJ, importante meio para a definição de estratégias e avaliação de gestão dos órgãos judiciais. De fato, da análise da base de dados Justiça em Números verifica-se o inédito e importante trabalho realizado pelo $\mathrm{CNJ}$, certamente fundamental para a focada atuação objetivando a melhora do sistema judiciário ${ }^{879}$.

O CNJ atua, também, na coleta e sistematização de dados relacionados a temas específicos. É o caso, por exemplo, do Cadastro Nacional de Improbidade Administrativa, criado em 2007 pela Resolução no 44, em que o Conselho congrega dados relacionados às condenações por improbidade administrativa em todas as esferas da

\footnotetext{
${ }^{877}$ A primazia da coleta dos dados nacionais é encargo do Instituto Brasileiro de Geografia e Estatística, o IBGE, que realiza pesquisas fundamentais para um adequado planejamento da Administração Pública federal (<http://www.ibge.gov.br>).

${ }^{878}$ Os incisos VI e VII do parágrafo $4^{\circ}$ do artigo 103-B da Constituição determinam dever o CNJ produzir, semestralmente, relatório sobre processos e sentenças prolatadas, por unidade da Federação e nos diferentes órgãos do Poder Judiciário, além de relatório anual propositivo das providências necessárias para o próximo exercício e da situação do Judiciário no país.

${ }^{879}$ Os dados, separados por tribunal, consideram desde o número de processos e recursos entrados e julgados, acórdãos publicados e decisões monocráticas prolatadas até o volume dos recursos financeiros utilizados por tribunal (i.e., despesas com pessoal, percentual das despesas confrontando-se o PIB - Produto Interno Bruto), disponível em: http://www.cnj.jus.br/index.php?option=com_content\&view=category\&layout=blog\&id=291, acesso em 26.12.2010, 13:22h.
} 
Federação, o que é mais um ponto favorável ao controle social dos atos da Administração Pública. O CNJ vem demonstrando uma expertise na compilação e análise de dados e estatísticas judiciais que não pode ser desprezada e, aliás, revela-se extremamente importante para os fins a que este estudo propõe.

Hoje, a maior parte dos dados depende do preenchimento de fichas físicas por parte dos magistrados. Amanhã, porém, esse expediente será dispensado. Com o incremento do processo eletrônico ${ }^{880}$, as informações transmitidas pelos magistrados poderão alimentar os bancos de dados do CNJ em tempo real, o que significará uma considerável economia de tempo e recursos, além de uma fidedignidade incomparável dos dados passados ${ }^{881}$.

Fala-se aqui, primordialmente, das informações que abastecem os magistrados, mas o reverso é também relevante. A Administração Pública se organiza para mapear dados relacionados às medidas judiciais que tratam de saúde. Além das informações já prestadas antes relacionadas a Minas Gerais e São Paulo, o Espírito Santo passou a coletar e sistematizar informações relevantes acerca desse tipo de ação, de forma a diagnosticar o problema. O mapeamento envolve questões como: (a) origem da prescrição médica (se pública ou particular); (b) município de origem dos demandantes; (c) autor (Defensoria, Ministério Público ou advogado particular); (d) magistrados responsáveis pelas decisões; (e) classificação dos medicamentos demandados (listado ou não, oncológico, essencial, excepcional, antirretroviral). Alguns achados são muito interessantes e acompanham o quanto já perfilhado nesta tese ${ }^{882}$.

\footnotetext{
${ }^{880}$ A Lei $\mathrm{n}^{\mathrm{o}}$ 11.419/06 estabelece as regras do processo eletrônico, algumas das quais são bem difundidas na prática, como, por exemplo, a realização de intimações por meio de diário oficial eletrônico, ou a apresentação eletrônica de petições (o que já ocorre nos tribunais superiores) e, mesmo, a informatização total do processo, como ocorre, dentre outros locais, no fórum regional da Freguesia do Ó e, mais recentemente, nas varas centrais do Judiciário da Capital do Estado de São Paulo. O processo eletrônico, ao tempo do depósito desta tese, já é uma realidade.

${ }^{881}$ Visando a dar celeridade ao processamento das ações coletivas, o artigo $9^{\circ}$ do Anteprojeto do Código Brasileiro de Processos Coletivos previa a realização dos atos judiciais preferencialmente de forma eletrônica. A Resolução CNJ n ${ }^{\circ}$ 31/2011 também recomenda que antes das medidas liminares sejam ouvidos os gestores da saúde, preferencialmente por meio eletrônico (Item I, b.3).

${ }^{882} \mathrm{Da}$ análise de trezentos e sessenta e ações promovidas em face do Estado do Espírito Santo e distribuídas entre janeiro e setembro de 2009 , verificou-se que $72 \%$ dos fármacos requeridos não eram listados - o que é indicativo de: (a) lacunas na elaboração das listas; (b) ineficiência das relações; (c) potencial cooptação de interesses; viu-se, também, que mais da metade das ações provinham de Cachoeiro do Itapemirim, município do interior (e não da Capital, Vitória) - potencialmente indicativo de manobra por parte de interessados para direcionar a distribuição para uma comarca mais simpática aos seus anseios; da amostra, quase $80 \%$ eram medidas propostas pelas Defensorias do Estado e da União - o que, nesse caso, contraria a máxima de que apenas pessoas bem fornidas de recursos recorrem ao Judiciário (TAVARES, Gerusa Rios Pessanha, et. al.. Diagnóstico das Ações Judiciais direcionadas à Secretaria de Estado da Saúde do Espírito Santo. III Congre sso Consad de Gestão Pública. Disponível em: <http://www.escoladegoverno.pr.gov.br/arquivos/File/Materia
} 
Sem dados e estatísticas confiáveis, os planos e programas não atingem o âmago da ação social, porque baseados em simples conjeturas ou impressões dos administradores. A colheita, análise e reflexão sobre dados empíricos, extraídos da realidade, são peças fundamentais de uma atuação estatal racional. E isso se estende ao Judiciário.

Corolário da relevância da colheita de dados e informações a respeito dos fenômenos sociais, principalmente, no nosso caso, aqueles levados a juízo, é de se ressaltar o papel que os cadastros de processos poderiam desempenhar, sobretudo no que toca às políticas públicas jurisdicionalizadas.

5.4.1 Os bancos de dados nacional, estaduais e regionais de processos, inquéritos civis e ajustamentos de conduta

Já foram destacados alguns aspectos práticos que demonstram como seria importante a catalogação e coleta de dados relacionados às medidas judiciais que versam sobre políticas públicas. Na verdade, os dados a respeito dos processos que, já existentes, têm por objeto questões de políticas públicas - como a saúde, por exemplo - são fundamentais para a tutela jurisdicional mais racional desses bens públicos. O cadastro projetado poderia proporcionar o cruzamento de dados entre ações individuais propostas versando sobre o mesmo objeto, o que daria ensejo ao incidente de coletivização. Esse cadastro também permitiria ao magistrado saber se determinada questão já fora submetida a juízo antes, e como foi julgada.

E não apenas. É preciso saber se o Ministério Público está agindo na defesa de determinada política pública. Seria necessário cadastro de inquéritos civis e ajustamentos de conduta para que as informações respectivas ficassem condensadas e à disposição dos respectivos órgãos e da sociedade, tudo para que: (a) a população atingida ou beneficiada tomasse efetiva providência para também influir ou aproveitar-se; e (b) evitar que órgãos diversos trabalhem sobre o mesmo aspecto, ou que um órgão do Parquet esteja elaborando ação civil pública para obter algo que já foi definido em ajustamento de conduta capitaneado por órgão diverso.

1_\%20CONSAD/paineis_III_congresso_consad/painel_9/diagnostico_das_acoes_judiciais_direcionadas_a_s ecretaria_de_estado_da_saude_do_espirito_santo.pdf>, acesso em 6.10.2013, 19:09h). 
O Anteprojeto do Código Brasileiro de Processos Coletivos cuidou de maneira delicada do tema ao prever um cadastro nacional de processos coletivos. De acordo com o artigo 20 da lei projetada, esse cadastro deveria ser mantido pelo CNJ e tinha por objetivo informar não apenas os juízes, mas, também, todos os interessados a respeito da existência e do objeto de todas as ações coletivas em tramitação. O cadastro contaria, ainda, com informações a respeito dos atos processuais mais relevantes (i.e., eventual antecipação dos efeitos da tutela, a sentença e seu conteúdo, os recursos e seu andamento).

Mais recentemente e nessa mesma linha, o APLPP aprimorou a leitura anterior dada pelo Anteprojeto do Código Brasileiro de Processos Coletivos, prevendo o amplo e imediato acesso às informações por meio da internet, além de também contemplar um cadastro nacional no âmbito do Ministério Público, para checar analogia entre inquéritos civis e compromissos de ajustamento de conduta espalhados pelo Brasil. A mesma ideia, com algumas diferentes nuances, consta, já em adiantada fase, do relatório de revisão do CDC: ali, os artigos 104-B e 104-C preveem a existência de cadastro nacional processos coletivos, mantido pelo $\mathrm{CNJ}$, e de outro cadastro nacional de inquéritos civis e compromissos de conduta, esse, organizado pelo Conselho Nacional do Ministério Público. Uma bela e necessária iniciativa, que anda na linha ora proposta.

Não se encontra qualquer óbice a que solução análoga seja empregada nas ações que envolvem temas de políticas públicas, até por sua umbilical relação com as ações coletivas. Se a finalidade do cadastro previsto na legislação projetada era, a um só tempo, propiciar ao juiz a análise de aspectos formais (como se ocorre conflito de competência) e materiais (ligados ao objeto da demanda) e, ao jurisdicionado, a verificação se aquela questão que o aflige já fora levada ao julgamento estatal de rigor.

É exatamente o que se pretende nesta seara. A pessoa que demanda a entrega de um medicamento pode verificar se já não existe outra ação - até mesmo coletiva - questionando a mesma obrigação. Pode checar, inclusive, se aquela ação não teve julgamento favorável aos postulantes, para fins de aproveitamento em seu caso. Pode, enfim, verificar se do conteúdo do eventual julgado nada lhe aproveita, como ocorreria, por exemplo, em ação que ordenasse a inclusão de certo fármaco nas listas de dispensação estatal obrigatória, coisa que, feita antes da procura por um advogado, evitaria a potencial e inevitável ação individual.

É preciso se pensar, com efeito, em outorgar ao CNJ e ao CNMP a tarefa de manter e alimentar uma completa base de dados sobre as ações, inquéritos civis e ajustamentos de conduta que possuam como objeto as políticas públicas. Nesse sentido, e 
quanto ao ajustamento de conduta, o Ministério Público também manteria, em sua base de dados, todos os termos dessa natureza ajustados com os órgãos públicos interessados ${ }^{883}$. A base de dados, realizada nos moldes do relatório Justiça em Números, consistiria um verdadeiro raio- $X$ da atuação jurisdicional no campo das políticas públicas, coisa que, hoje em dia, não se sabe como se dá, a não ser quando o Executivo divulga uma estatística do percentual imputável às decisões judiciais sobre a receita, por exemplo, destinada às ações administrativas de saúde ${ }^{884}$.

A base de dados das ações relacionadas a políticas públicas pode exercer papel ainda mais relevante do que viabilizar uma atuação jurisdicional mais racional e equilibrada: ela pode se transformar em um imprescindível centro de informações disponível à consulta do Poder Público que, com base nos dados encontrados, saberá quais as searas e assuntos mais judicialmente demandados e, portanto, delicados, merecedores de atenção por parte das políticas governamentais exercidas pelos Poderes majoritários.

Tome-se como exemplo o caso da saúde. Um banco de dados como o aqui proposto viabilizaria aos gestores da saúde conhecer: (a) quais os tratamentos ou medicamentos mais demandados em juízo; (b) quais as doenças que são o principal objeto das ações judiciais; (c) quais as regiões mais afetadas; (d) que programas e ações administrativas podem corresponder àquela dada demanda, dentre outros dados. Considerando-se que o jurisdicionado busca o Judiciário quando há omissão dos Poderes majoritários $^{885}$, então as informações constantes no banco de dados em questão são estratégicas para o Estado ${ }^{886}$.

$\mathrm{O}$ banco de dados nacional deveria ser mantido pelo $\mathrm{CNJ}$, e revelaria o banco-mestre, aquele que congregaria absolutamente todas as informações, de maneira sistematizada e estatística. Sem prejuízo, os Estados poderiam manter bancos estaduais e regionais, dependendo da relevância de algum evento, considerada essa possibilidade pelas dimensões continentais do Brasil. Os dados coletados pelos bancos estaduais e regionais

\footnotetext{
${ }^{883}$ Já que também eles são legitimados a tanto, cf. art. $5^{\circ}, \S 6^{\circ}$ da Lei no 7.347/85.

${ }^{884}$ Nesse diapasão, v. http://www.aen.pr.gov.br/modules/noticias/article.php?storyid=6233\&tit=Gastos-commandados-judiciais-de-medicamentos-crescem-10-vezes-em-dois-anos >, acesso em 27.12.2010, 14:33h.

${ }^{885}$ Constatação a que também chegou o Min. Gilmar MENDES (STA nºs 171, 211 e 278/2010; SS nº 3724 , 2944, 2361, 3345 e 3355/2010 e SL nº 47/2010, j. em 17.3.2010).

${ }^{886}$ O Estado de São Paulo possui medidas para informatizar as os dados relacionados às ações judiciais que tratam da questão da saúde, de modo a possibilitar a aquisição dos fármacos e custeio dos tratamentos mais concedidos pelo Judiciário. Essa coletânea de informações não serve, inacreditavelmente, para que o gestor estadual concentre suas ações estratégicas nos pontos que os dados revelam ser os mais delicados (SANTOS, José Sebastião dos; SOUZA, Hórtis Aparecido de; e UETA, Julieta. "A influência da gestão do sistema de saúde na utilização da via judicial para acesso a produtos e serviços”, em Direito à Vida e à Saúde..., p. 167).
} 
seriam divulgados pelos próprios Tribunais de Justiça, com o apoio do CNJ, sem prejuízo das informações constarem no banco nacional. Todos eles seriam cruzados.

A alimentação dos cadastros se iniciaria na distribuição. O responsável por analisar primeiramente a ação e classificá-la como apta a ser distribuída às varas especializadas em políticas públicas (e, também, daria o primeiro passo para coletivizar ou tratar uniformemente questão repetida) alimentaria, automaticamente, o banco com os dados primordiais como autor, réu, assunto principal (i.e., transporte, saúde, educação, moradia) objeto detalhado. Com o passar do tempo, nessa ficha do feito também constaria seu processamento e principais movimentações. As petições e decisões seriam digitalizadas. Se ele fosse ulteriormente remetido às varas comuns, porque o juiz de políticas entendeu não ser o caso de direcionamento especial, a baixa seria automática.

O mais importante: os bancos de dados seriam de acesso público. Para acessar, bastaria que o jurisdicionado se cadastrasse, a exemplo do que sucede hoje no sistema informativo processual do Tribunal de Justiça de São Paulo. Ao receber a inicial, o distribuidor obrigatoriamente consultaria o banco e, constatando a potencial identidade de ações, anotaria a circunstância e a remeteria à vara especializada em políticas públicas. Ali, far-se-ia o exame de identidade entre ações e, ela ocorrendo, ordenaria as providências necessárias (que poderiam variar desde a declaração de litispendência, conexão ou continência até solicitar ao outro juízo dados facilitadores para sua análise a respeito da questão).

O público (i.e., jurisdicionados, Ministério Público, Defensoria Pública), tendo franqueado o amplo acesso ao banco, poderia saber se aquele direito que pretende ver tutelado já está em discussão, em que sede, qual o status, dentre as informações cruciais para que se faça o exame de necessidade de se lançar mão de outra medida análoga.

Essa seria a forma mais racional e palatável de informações a respeito de como as políticas públicas são tratadas pelo Judiciário brasileiro. Faz-se ciente, contudo, que ela, de per si, não resolve todos os aspectos da concomitância de ações versando sobre políticas públicas. Duas ações coletivas pleiteando o tratamento dos doentes renais crônicos do Estado do Rio de Janeiro, por exemplo, podem gerar dificuldade no exame de litispendência, conexão e continência, sobretudo em virtude da amplitude interpretativa do objeto dessas ações, mas o que não se duvida é que ambas seriam conectas, daí a facilidade no processamento conjunto e mitigação do risco de decisões contraditórias e execução paradoxal. 
Além disso, é preciso, claro, que os juízes conheçam quais são as ações administrativas realizadas pelo Poder Executivo.

Por paralelo, o mesmo ocorreria com os cadastros afetos ao Ministério Público e à Defensoria Pública: nesse caso, cada membro responsável por instaurar procedimento ou, no caso do Parquet, concluir ajustamento de conduta ficaria obrigado a alimentar o cadastro, que seria organizado pelos respectivos órgãos superiores.

5.4.2 O conhecimento do Judiciário a respeito das ações administrativas. Atuações coordenadas

Como já ressaltado, juízes não podem julgar ignorando a miríade de ações tomadas pelo Poder Executivo na concretização de políticas públicas. Já se observou, sobretudo no Item 4.1.3, que um dos grandes motivos dos excessos judiciais na dispensação de bens públicos se deve ao absoluto desconhecimento, por parte dos magistrados, das ações levadas a efeito pela Administração.

As dificuldades para que isso ocorra são das mais variadas ordens, e compreendem desde o não entendimento dos dados publicados até o desinteresse do magistrado em buscá-los. É verdade que, hodiernamente, muito material é produzido a respeito das ações administrativas em campos de políticas públicas. No caso da saúde, por exemplo, é de fácil consulta os planos e programas nacionais e estaduais, além de documentos como a $\mathrm{PNM}^{887}$, o Plano Estadual de Saúde, do Estado de São Paulo ${ }^{888}$, as ações ligadas à prevenção e ao tratamento da $\operatorname{AIDS}^{889}$. Todos esses documentos estão ao alcance de um clique no computador. O problema está, justamente, na ação de clicar, e, muitas vezes, na de entendê-los.

É dever do magistrado, diante de um processo em que se discuta, por exemplo, o fornecimento de medicamentos para o tratamento da artrite reumatóide, consultar os instrumentos à sua disposição para verificar o que o Estado está realizando em termos de tratamento e cuidados aos portadores da moléstia. Aquela máxima de que o juiz

\footnotetext{
${ }^{887}<$ http://www.uff.br/ppgcaps/Texto\%208\%20-\%20AF.pdf>, acesso em 26.12.2010, 15:38h.

888 <http://www.saude.sp.gov.br/content/drespuwrot.mmp>, acesso em 26.12.2010, 15:35h. Aliás, o sítio eletrônico da Secretaria de Saúde do Estado de São Paulo é riquíssimo em demonstrar o trabalho desempenhado pela Administração Pública, que deve ser de conhecimento de todos, mormente do juiz.

$889<$ http://www.aids.gov.br/>.
} 
deve se ater apenas às alegações das partes e às provas dos autos não mais subsiste diante do novo modelo público de litigância. O juiz, destinatário da prova, deve agir proativamente, buscando informações que possam influenciar seu convencimento.

A simples busca na internet poderia evitar situações como aquela do magistrado que recebe um pedido de concessão liminar de um medicamento que está à disposição do postulante nos postos de saúde ${ }^{890}$. A análise da atuação da Administração na determinada política pública é fundamental para que o juiz não atormente o equilíbrio dos Poderes e preste uma tutela jurisdicional impertinente, porque ausente interesse processual a lastrear o pedido de providência.

Mas não basta a busca do magistrado, é preciso que também a Administração coopere com o Judiciário na prestação de informações estratégicas sobre seus planos e programas, e, isso, não somente no curso do processo, mas, sobretudo, antes da lide. Devem ocorrer colóquios entre a Administração e o Judiciário - aqueles membros que efetivamente forem judiciar temas ligados a serviços estatais - para a discussão a respeito das ações ligadas a políticas públicas. Nesse debate, inclusive, o ingresso de médicos e especialistas só seria salutar, como ocorreu na audiência pública que teve lugar no Supremo Tribunal Federal, já mencionada neste estudo.

Aos poucos a magistratura e os agentes públicos vêm percebendo essa necessidade de diálogo. O CNJ já defende parcerias com órgãos públicos para reduzir as demandas ligadas à saúde ${ }^{891}$. Como mencionado, o próprio CNJ instalou o Fórum Nacional do Judiciário para a Saúde, criado em agosto de 2010 para aperfeiçoamento de procedimentos, reforço à efetividade de processos na área da saúde e - o que é mais importante - a prevenção de novos conflitos. O colóquio concentra juízes, advogados, promotores, juristas, representantes do Executivo e até mesmo de operadoras de planos de saúde ${ }^{892}$.

Há outras iniciativas interessantes. Ao receber um pedido de concessão de medicamentos, os juízes das comarcas de Ribeirão Preto e Araraquara, no interior de São

\footnotetext{
${ }^{890}$ Como exemplo de uma ação estatal que pode resultar justamente na situação exemplificada estaria o pedido judicial de um medicamento incluído no programa Dose Certa. Desde 1995 o Estado de São Paulo instituiu o Programa Estadual de Assistência Farmacêutica Básica - "Dose Certa”, que garante a distribuição de medicamentos produzidos por um laboratório estadual, responsável pelo atendimento de $80 \%$ das doenças mais frequentes, como hipertensão arterial, diabetes, doenças cardiovasculares, pneumonia, asma, entre outras (BARATA e MENDES, “Uma proposta...”, p. 64).

$891<$ http://www.jusbrasil.com.br/noticias/2475238/cnj-defende-parcerias-com-orgaos-publicos-para-reduzirnumero-de-processos-relativos-a-saude>, acesso em 26.12.2010, 16:08h.

$892<$ http://www.jusbrasil.com.br/noticias/2469154/judiciario-tera-54-magistrados-responsaveis-por-

demandas-de-saude>, acesso em 26.12.2010, 16:14h.
} 
Paulo, submetem ao Poder Público um questionário para definir parâmetros que auxiliarão no deferimento ou não do pedido. Isso deriva de um protocolo conjunto adotado entre aqueles magistrados e as Secretarias Municipal e Estadual de Saúde. Existem relatos de experiências que demonstram o emprego de meios eletrônicos de comunicação entre juiz, postulante, advogado e uma comissão multidisciplinar capaz de avaliar a necessidade e a urgência da concessão da providência judicialmente pleiteada. Também no Estado do Rio Grande do Norte foi instituído o CIRADS - Comitê Interinstitucional de Resolução Administrativa de Demandas da Saúde, que congregava representantes da Defensoria Pública da União, das Procuradorias da União, do Estado do Rio Grande do Norte e do Município de Natal, bem como das Secretarias de Saúde daquele Estado e deste Município. A contribuição do CIRADS foi reconhecida pelo Ministério da Saúde em mensagem encaminhada ao Superior Tribunal de Justiça ${ }^{893}$.

Também o Tribunal de Justiça do Mato Grosso criou em 2011, em parceria com a Secretaria de Saúde do Estado, o NAT - Núcleo de Apoio Técnico - visando a dar apoio técnico aos juízes em ações que envolvessem saúde. O NAT é responsável, também, por abordar o tema no curso de formação para ingresso na carreira da magistratura do Estado de Mato Grosso. A iniciativa é reconhecida e noticiada pelo $\mathrm{CNJ}^{894}$.

Essas incipientes medidas ${ }^{895}$ não apenas demonstram como é fundamental o diálogo em um tema tão multifacetário como é a saúde e sua tutela judicial, mas, também, como o Judiciário lida com a falta de informações e ações coordenadas para uma dispensação mais proporcional e equilibrada de saúde. A atuação conjunta entre as diversas

${ }^{893}$ SANTOS, SOUZA e UETA, “A influência...”, pp. 171-172. Da mesma forma, em Santa Catarina o Judiciário organizou um Conselho Gestor de Medicamentos Judiciais, que tem por objetivo viabilizar o diálogo entre os Poderes, aprovação de práticas de gestão e interpretação de protocolos clínicos, realização de controle estatístico mensal de ações judiciais com esse tema e elaboração de um relatório semestral com as atividades do conselho (<http://app.tjsc.jus.br/noticias/listanoticia! viewNoticia.action?cdnoticia=21524〉, acesso em 30.12.2010, 12:50h).

${ }^{894}<$ http://www.cnj.jus.br/noticias/judiciario/19088:funcionamento-do-sus-e-tema-de-capacitacao-parafuturos-juizes-no-mt>, acesso em 16.8.2013, 21:37h.

${ }^{895}$ Incipientes no Brasil. Os Estados Unidos registram precedentes, como no caso Wyaat v. Stickey (325 F. Supp. 781 - M.D. Ala. 1971), em que o magistrado responsável determinou que os réus apresentassem, em seis meses, um plano para cumprimento da omissão inconstitucional. O juiz também se valeu do Departamento de Saúde, Educação e Bem-estar, ligado ao governo federal, que o auxiliou a implementar a decisão que ordenou a reparação da medida que violou o direito ao tratamento digno dos pacientes representados, a saber, o corte de verbas destinadas ao tratamento de pacientes com desordem mental no Bryce State Hospital em Tuscaloosa, Alabama. A questão acabou se transformando em debate a respeito do tratamento aos doentes mentais norte-americanos. O caso se iniciou em 23 de outubro de 1970 e sua implementação foi muito complicada, só tomando rumo adequado quando a corte indicou um master para gerir as atividades. Em 5 de dezembro de 2003 - trinta e três anos após deflagrado o feito - o Judiciário declarou que sua decisão estava implementada. A esse respeito, ver CARR, Lauren Wilson. "Wyaat v. Stickney: a Landmark", em Alabama Disabilities Advocacy Program Newsletter, July 2004, 1-3. Entre nós, o caso é comentado por BRASIL Jr., Samuel Meira; e CASTELLO, Juliana Justo Botelho. "O cumprimento coercitivo das decisões judiciais no tocante às políticas públicas”, em $O$ Controle..., p. 482-484. 
esferas de poder não pode ser entendida como uma violação à imparcialidade do magistrado, mas, ao contrário, só faz parte do enriquecimento das informações que esse magistrado usará quando estiver diante de um pedido de fornecimento de medicação, por exemplo.

\subsection{EXPERIMENTALISMO E GERÊNCIA DA EXECUÇÃO}

Para uma gestão racional e justa da coisa pública pela via do processo judicial não basta a modificação estrutural do Poder Judiciário: é preciso, também, alterar o instrumento, e isso já foi visto nesta tese. O modelo processual hoje contemplado pela legislação causa inevitáveis embaraços à assunção desse novel papel dos magistrados. Os acadêmicos que se debruçam sobre o estudo do tema já apontam a necessidade de mudança de paradigmas ${ }^{896}$.

É verdade que as sucessivas alterações legislativas dos últimos tempos, sobretudo no campo processual e com o escopo de conceder aos litigantes tutela tempestiva, chegaram a resultados duvidosos e que terminaram por engrossar o coro da crítica à simples modificação de normas como remédio para os males do processo ${ }^{897}$. O que se propõe, aqui, não é nada além do que a experiência mostra ser o possivelmente eficaz: a adoção de ações engajadas que, combinando alterações legislativas no instrumento com modificações de estrutura orgânica dos Poderes, possam levar a uma intervenção mais adequada e eficaz em políticas públicas.

As ideias doravante propostas se aplicam em dois momentos processuais distintos: a primeira age na decisão - e já foi vista, quando se pugnou pela extensão da autoridade da coisa julgada em casos coletivos que se mostram individuais -, enquanto que

\footnotetext{
${ }^{896}$ Não por menos que já foi desenhado um Anteprojeto de Lei de Processo de Políticas Públicas, já referido, para o qual modestamente colaborou este candidato ao titulo de doutor.

897 Comumente se refere às constantes reformas no recurso de agravo (primeiro, determinou-se que a interposição se daria diretamente no tribunal ad quem; depois, verificando-se o atravancamento das pautas das cortes pelo imenso número desses recursos, que eram distribuídos incontinenti e julgados preferencialmente às apelações, decidiu-se estabelecer, como regra, sua retenção nos autos. Fato é que, na prática, essa retenção pouco acontece e a reforma do agravo em nada alterou a morosidade dos tribunais) ou na inserção da ação monitória em nosso ordenamento jurídico (que, na prática, transformava-se em ação de conhecimento nos moldes de uma cobrança com os inescapáveis embargos monitórios) como exemplos de alterações legislativas que não atingiram resultados esperados. Mais proximamente, reformou-se a execução, tanto de sentença quanto as fundadas nos demais títulos executivos e agora, poucos anos depois, discute-se um novo Código de Processo Civil e altera-se, em vias de ser promulgado.
} 
as outras, na execução. Ambas são ligadas e passam, invariavelmente, pela releitura da coisa julgada, mas não deixam de gerar inquietação com relação a outros ricos conceitos do processo, como a legitimidade, encontrando dificuldades práticas relacionadas à competência, conexão e continência (questões que, de resto, não fogem aos obstáculos que se prostraram e prostram quanto à implementação efetiva das ações coletivas).

A leitura dos argumentos colocados a seguir deve ser feita a partir de uma lente muito especial: a de que o direito discutido molda o instrumento. A complexa categoria dos direitos que guarnecem o Estado hodierno (um complexo de direitos de abstenção, de ação e de solidariedade) e que, cada vez mais, são sindicados pelo Judiciário, não pode ser tutelada sob o pálio de um processo cunhado nas tradições do Século XIX. Se é certo que esse processo, de égide liberal, é altamente sofisticado e colaborou grandemente para a construção da sociedade como a conhecemos, é igualmente certo que alguns de seus dogmas não podem ser levados a ferro e fogo. Com efeito, o instrumento, já se disse, não pode ser um fim em si mesmo, mas mero veículo apto a fazer valer direitos $^{898}$. No caso dos processos em que se discutem direitos que são objetos de políticas levadas a efeito pelo Poder Público, o modelo tradicional implica diversos entraves a uma tutela mais eficaz e - insiste-se - justa dos bens públicos.

Está-se, aqui, na seara da justiça distributiva. A partir do momento em que o processo surge como meio de alcançar riquezas que a todos são dadas, não se pode lidar com o assunto de forma bilateral, marcada e retrospectiva, aspectos típicos da litigância do modelo exclusivamente liberal. É preciso, antes, que se crie foro apropriado para que a tutela atinja todas as pessoas que, nas mesmas condições do litigante - ainda sendo esse individual -, não puderam, ou não conseguiram se dirigir ao Judiciário ou aos Poderes majoritários na busca por seus direitos. Este tema é o pano de fundo da ideia da expansão coletiva dos efeitos da decisão individual, já colocada. Mas é tempo de ir adiante e trabalhar propostas para tornar mais eficiente a execução do julgado.

Como se tem hoje, a execução é insuficiente para lidar com a complexidade da concretização de ações naturalmente objeto de políticas públicas. Essas medidas judiciais envolvem análises estratégicas, são multidisciplinares e, muitas vezes, demandam mutabilidade com base na metodologia tentativa-erro. Trata-se de um cenário completamente diverso da execução rígida contemplada, hoje, pela lei processual brasileira. É este o assunto a ser tratado também neste capítulo, mais adiante.

\footnotetext{
${ }^{898}$ É este o pensamento basilar da doutrina instrumental de DINAMARCO, ALVARO e BEDAQUE.
} 
Que não se perca de vista, portanto, que as alterações legislativas devem sobrevir conjuntamente com ações práticas que as tornem plausíveis de execução e transformem o resultado respectivo em minimamente satisfatório. E que não se olvide de analisar o que será apresentado sob o matiz do especial e complexo direito sempre objeto de movimentação e entrega pelos governos. É somente com os olhos nessa premissa que a solução apresentada fará sentido.

Não apenas a fase de conhecimento dos processos judiciais relacionados a políticas públicas de saúde demandam reparo. Um dos mais tormentosos temas que tocam à judicialização de políticas públicas se dá quanto à execução dos respectivos julgados ${ }^{899}$. Como, em muitos casos, a decisão judicial modificará a política pública existente ou determinará a implantação de uma ação administrativa que, embora constitucionalmente preconizada, não foi, ainda, montada ou executada, o cumprimento da decisão judicial será diferido, sobretudo porque, em muitos casos, o comando judicial demandará ações sucessivas, progressivas, contínuas e, evidentemente, protraídas no tempo ${ }^{900}$.

Mais do que isso. Existem decisões judiciais que, por trabalhar temas tão complexos, acabam desestabilizando as instituições administrativas e, de conseguinte, seu modus operandi no que concerne à aplicação das políticas públicas. Há decisões que determinam a completa remodelação institucional a pretexto de garantir a observância dos direitos dos jurisdicionados.

No caso estudado, relacionado à Síndrome de Kanner, observou-se que o dispositivo da sentença continha uma série de comandos de complexo cumprimento, como, por exemplo, a internação do paciente em clínica especializada, preferencialmente em locais próximos ao da respectiva residência. Não se tem notícia certa, mas observou-se, provavelmente, não haver tais estabelecimentos no início da execução do julgado. O fato é que, diante disso, as clínicas teriam que ser construídas pelo Poder Público de forma a atender a toda a demanda por tratamento dos pacientes do Estado de São Paulo. Demais disso, como a condenação ordenou a dispensação de tratamento adequado, seria necessária fiscalização sobre se esse tratamento era ou não apropriado.

Decisões que envolvem políticas públicas são estruturais ${ }^{901}$ - sejam elas judiciais ou não -, variando, apenas, na intensidade. Decisões estruturais são capazes de

\footnotetext{
${ }^{899}$ Ver, sobre o tema, Item 5.3.1.1.

900 Sobre a nova tarefa contemporânea do Judiciário diante das demandas sociais por sua intervenção e a necessidade de um envolvimento maior dos juízes na execução de decisões relacionadas ao interesse público, ver SALLES (Exесис̧ão Judicial..., pp. 296-299).

${ }^{901}$ FISS, Um Novo Processo..., p. 90. Como já mencionado, esse tipo de decisão, diferenciada do modelo
} 
modificar, como conhecemos, determinada ação ou instituição estatal. Seria o caso, por exemplo, de uma ordem de retirada de ônibus das ruas do centro expandido da cidade de São Paulo por um problema, digamos, ambiental: todas as linhas existentes teriam que se adaptar, traçando novos itinerários, a Administração teria que desenvolver um meio de transporte alternativo para que os munícipes pudessem atingir as vias centrais, e assim por diante $^{902}$. Macrossoluções como as relacionadas com políticas públicas demandam concretização diferenciada. O que ocorreria, por exemplo, se em ação coletiva o juiz determinasse a internação de todos os pacientes de tuberculose no Brasil, sem que houvesse leitos? O "cumpra-se" puro e simples da tradicional decisão judicial já não mais serve para este novo cenário. É preciso planejamento, negociação e acordos, de forma a viabilizar a execução da decisão.

O caminho para o remédio negociado e não irremediavelmente atrelado à solução dada na fase de conhecimento foi inaugurado nos Estados Unidos, na execução do julgado em Brown v. Board of Education, o peculiarmente denominado Brown II. Ali, a flexibilização da execução foi medida de rigor, encontrada após acertos e desacertos na materialização da dessegregação desencadeada em Brown $I^{903}$. Sobre Brown, mais será exposto.

A grande celeuma que merece análise, uma vez assumindo o Judiciário esse novo papel, qual seja, o de vetor e concretizador de valores constitucionais albergados sobre o título de políticas públicas, refere-se ao despreparo dos juízes na tarefa de implementar suas decisões estruturais, seja pela falta de prática, seja pela ausência de instrumentos gerenciais e normativos à sua disposição. Assumir a premissa que o juiz pode e deve intervir em questões como a saúde é entender que esse mesmo juiz deva atuar no sentido de ver observada sua decisão, tornando-a efetiva.

tradicional de resolução de conflitos, já havia sido encontrada por Abraham CHAYES em 1976 (“The Role of the Judge..."). De fato, CHAYES, em inúmeras passagens desse seu importante texto, especificamente analisando a execução da decisão obtida no âmbito da chamada public interest litigation, preconizava que o remédio não guardava simetria com a violação, de sorte que era necessário que ele fosse negociado e, no mais das vezes, fosse proposto, inclusive, pelo réu, que teria mais condições de dizer como poderia ele planejar seus atos com vistas a eliminar a lesão discutida no processo (evidentemente, em caso de condenação). A porta à doutrina experimentalista foi, sem dúvida, aberta por CHAYES.

902 FISS analisa o modelo de adjudicação estrutural a partir do já mencionado Brown v. Board of Education, que marcou a interferência e regulação do sistema educacional norte americano pelo Judiciário ("The Forms of Justice", in Harvard Law Review V. 93, Nov/79).

903 A decisão em Brown II definiu, basicamente, que: (a) as autoridades responsáveis pelos estabelecimentos de ensino seriam responsáveis por resolver os problemas locais de implementação da decisão; (b) as cortes verificariam a boa-fé desses responsáveis nas soluções endereçadas; (c) o desenho dos mecanismos de operacionalidade da decisão deveria levar em conta a flexibilização, facilitação de ajustes e reconciliação das necessidades públicas e privadas, dentre outros aspectos. A preocupação com as dificuldades práticas de efetivação da decisão de dessegregação foi mitigada com a possibilidade de flexibilização dos métodos e análise local dos problemas. A respeito, ver VERÍSSIMO (A Judicialização dos conflitos..., pp. 48-50). 
É evidente que a atuação judicial na execução de um julgado emanado de um processo civil clássico e bipolar não demanda um papel tão importante do juiz: basta que a parte interessada o provoque para que ele, representando o Estado, tome medidas de coerção ou sub-rogação para fazer cumprir a condenação judicial. A entrega ou não da coisa, a feitura ou não da obrigação ou, ainda, o pagamento ou a adjudicação do bem penhorado satisfazem o credor e resolvem a execução clássica. Isso não ocorre, contudo, nas ações que ventilam políticas públicas: muitas delas não possuem, sequer, fim ${ }^{904}$.

Suponha-se o seguinte exemplo: o Ministério Público propõe ação coletiva para que o Estado seja compelido a assegurar o número mínimo de leitos hospitalares demandados pela população, hoje, atendida em percentual correspondente a apenas $50 \%$ do total da demanda. O pedido, tido por procedente, passa em julgado e o Estado é compelido a dotar o sistema de saúde do dobro dos números atuais de leitos. O Estado cumpre de forma gradual o julgado, mas o passar do tempo demonstra que teria sido mais eficiente construir mais um único hospital em determinada região da cidade, em que a demanda é maior, é bem dotada de transporte público e tem fácil acesso à maioria da população. O que fazer? Propor outra ação seria a resposta mais instintiva, já que a autoridade da coisa julgada se limita ao que fora determinado na decisão transitada, ou seja, a criação do dobro de leitos. Optando-se por essa via, como proceder com os leitos que foram criados, sem falar no desperdício de tempo e recursos envolvidos?

Neste exemplo, o atual estado de coisas do processo não deixaria opção senão outra ação, ignorando o equívoco da escolha anterior, que fora realizada pelo autor e acatada pelo juiz. Estar-se-ia, aqui, no campo dos limites objetivos da coisa julgada e, como já definido no parágrafo anterior, a imperatividade da decisão deveria se restringir somente ao que foi precisamente pleiteado, sob pena de anulação da execução que não se processou nos exatos termos do título executivo. Já neste escrito, a propósito, apontou-se a limitação dos efeitos da decisão às partes do processo, em sua concepção tradicional, como um grande entrave à implementação judicial de políticas públicas, que envolvem ações planejadas, programadas e dinâmicas altamente voláteis ${ }^{905}$. É preciso, agora, dar um passo adiante.

A falta de instrumentos e de disciplina normativa apropriada transforma a tutela jurisdicional executiva de políticas públicas em tutela patológica. O caso ligado à

\footnotetext{
904 Como extinguir uma execução de julgado que determina a observância de um currículo educacional adequado ou a gratuidade no transporte interestadual para maiores de cinquenta anos? São inúmeros os casos de medidas judiciais envolvendo políticas públicas cuja execução pode não possuir um fim definido.

${ }^{905}$ Item 3.2.4.
} 
Síndrome de Kanner é um exemplo claro do ocorrido: a julgar pelo número, intervalo e conteúdo das decisões, o magistrado sobrestou suas atividades ordinárias à frente da $6^{\text {a }}$ Vara da Fazenda Pública de São Paulo para se dedicar exclusivamente ao tratamento da ação civil pública em referência. Chegou-se ao ponto de, diante do exaustivo cenário, pensar que a coisa seria resolvida por uma única decisão que transformaria a execução individual (homogênea) - como, aliás, era o caso - em coletiva, ou que a determinação do aumento do número de promotores e magistrados no Estado de São Paulo viabilizaria o cumprimento do julgado.

Como sobreviver, então, aos rígidos dogmas presentes na execução de sentenças judiciais quando da concretização de decisões estruturais, capazes de definir uma política pública inteira? Como evitar que, a pretexto de seguir a norma, os magistrados acabem tolhendo a tutela merecida pelos jurisdicionados, ou terminem por distorcê-la, causando prejuízos ao interesse público?

Doravante serão expostas duas ideias, ligadas ao tema: a primeira é o estudo e prática do Experimentalismo, com a ruptura parcial do dogma de imutabilidade objetiva da coisa julgada; a segunda, que não sobrevive inteiramente sem a primeira, é transformar o juiz - ou um terceiro - em gerente da execução, valendo-se de assessoria especializada para seu cabal cumprimento.

5.5.1. Experimentalismo e a manobra para suavização do dogma dos limites objetivos da coisa julgada

Já se verificou que a litigância de ordem pública - public law litigation surgiu nos Estados Unidos tendo por grande expoente o caso Brown, que consiste em excelente exemplo de como as coisas podem ser complexas quando se penetra no coração de instituições estatais, muitas delas com hábitos consolidados há décadas. Naquele caso, os direitos assegurados eram, a um só tempo, de tratamento igual de pessoas iguais e de educação de qualidade para todos. Com base na $14^{\mathrm{a}}$ Emenda à Constituição dos Estados Unidos, a Suprema Corte entendeu que não poderia ocorrer segregação educacional e decidiu adotar a mesma metodologia de ensino e aprendizado a todos, independentemente de sua cor de pele. O problema era como fazer isso sobre questão enraizada na sociedade norte-americana. Não bastava apenas que se misturassem negros e brancos na mesma sala 
de aula; era preciso que as escolas adaptassem e uniformizassem seus currículos, que o transporte fosse alterado, que se encontrasse solução para $o$ fato de alguns estabelecimentos se situarem em bairros com predomínio de habitantes negros ${ }^{906}$. Passada a sentença, agora era hora de cumpri-la, o que se tornou tarefa altamente complexa.

As consequências da decisão que declarou inconstitucional o sistema educacional dual foram experimentadas por anos e anos, significando sucessivos e pesados investimentos do Poder Público. O Judiciário era, naturalmente, o gerente da execução, o garantidor da fidelidade entre as ações realizadas e a determinação judicial. O papel das cortes como gerentes da implementação gradual de políticas públicas por elas definidas estava começando. Já àquela época, a Suprema Corte dos Estados Unidos percebeu que não bastava ordenação direta, o já mencionado cumpra-se (como, de resto, é da cultura processual brasileira), mas, antes, era preciso adotar uma grande e ampla estratégia de efetiva execução da decisão de dessegregação.

As dificuldades surgidas a partir de Brown foram tamanhas que, cerca de um ano depois, a Suprema Corte desenhou como se daria a execução do julgado no mencionado Brown II. Ali, foram convocados em audiência, além do Procurador-Geral norte-americano, os Procuradores estaduais da Flórida, Carolina do Norte, Arkansas, Oklahoma, Maryland e Texas, cada um a levar ao Tribunal suas próprias particularidades, que obstaculizavam a execução. A Suprema Corte entendeu, então, que ninguém melhor do que os próprios profissionais de educação que atuavam nesses Estados para compreender e desenhar o modelo de transição, usando - como destacado na opinion de Brown II - de boa-fé. O controle dessa estratégia seria feito pelas cortes locais, mais afeitas às peculiaridades caso a caso. No delineamento e efetividade dos decrees oriundos do Judiciário a partir da atuação dos gestores da educação, deveriam os juízes se valer de flexibilidade para, quando se mostrassem inócuos, os remédios fossem redesenhados. Esses casos, segundo a Suprema Corte, deveriam ser guiados por princípios de equidade ${ }^{907}$. Brown II foi o prenúncio de uma doutrina da forma mais correta de executar decisões relacionadas a políticas públicas.

Não se escusa de asseverar, contudo - aliás, aqui é um dos pontos aonde este autor quer chegar -, que o caso Brown envolveu experiências fracassadas de execução.

\footnotetext{
906 Aspecto que só revela como a segregação racial educacional era apenas um efeito desse gravíssimo problema social.

907349 U.S. 294 (1955). Brown II textualmente determinou que deveriam ser necessariamente considerados, nos planos, aspectos como condições físicas do edifício da escola, sistema de transporte escolar, recursos humanos, revisão dos distritos escolares de forma a permitir que brancos estudassem em escolas originalmente para negros, e vice-e-versa, e a revisão das leis e regulamentos locais.
} 
O que se pensava ser o desmantelamento do sistema educacional segregacionista se tornou uma grande arena de debates, com decisões judiciais sistemáticas de 1968 a $1972^{908}$, decisões essas que estabeleciam diretrizes para a execução do julgado ${ }^{909}$. Os problemas na execução dos julgados, ligados à complexidade do tema, geraram a sensação de que a grande conquista da igualdade e educação em um dos três mais paradigmáticos casos da jurisprudência norte-americana não serviu para muito ${ }^{910}$. Com efeito, se Brown foi um marco a respeito do novo modelo de litigância, um baluarte da demonstração que o Judiciário não se prestava, somente, à resolução de controvérsias bipolarizadas, o mesmo sucesso não se pode dizer da concretização sua execução ${ }^{911}$, embora a Suprema Corte tivesse compreendido, com exatidão, a dimensão do problema em Brown II.

E com ele vieram os questionamentos. Estaria o Judiciário preparado para dar cabo de decisões que penetravam nas entranhas do Estado e da sociedade? Três das linhas de principais críticas a respeito são denominadas: (a) Instrumental, encabeçada por Donald L. Horowitz, para quem as cortes estão programadas para resolver controvérsias clássicas. Seria perigoso outorgar a elas a execução de políticas públicas ${ }^{912}$; (b) Histórica, capitaneada por Abraham Chayes, que entendia que o modelo de resolução de controvérsias clássicas, no Judiciário, tem prioridade relativamente a casos estruturais,

908 Principalmente nos Estados do Sul, como decorrência da promulgação do Civil Rights Act de 1964 (SABEL, Charles e SIMON, William H., "Destabilization Rights: How Public Litigation Succeeds", in Harvard Law Review, V. 17, n 4, Fevereiro 2004, pp. 8-9).

909 Nesse sentido, ver Green v. New Kent County (391 U.S. 430, 1968), determinando que instalações, funcionários, atividades extracurriculares e transporte deveriam ser dessegregadas; Alexander v. Holmes County [Mississipi] Board of Education (396 U.S. 19, 1969), estabelecendo que o Conselho de Educação só poderia operar escolas "unitárias", ou seja, dessegregadas; Swann v. Charlotte-Mecklenberg Board of Education (402 U.S. 1, 1971), determinando que o sistema de transportes deveria fazer o máximo possível em prol do unitarismo.

910 A sensação de fadiga a respeito do assunto, segundo SABEL e SIMON, deu-se porque existiam barreiras à dessegregação, principalmente por conta da cultura racista ou em virtude de circunstâncias em que o racismo não ficava muito claro ou, ainda, quando a segregação era originada não de ações governamentais, mas de opção do próprio indivíduo, devido à sua própria carga cultural ("Destabilization Rights...", p. 10).

${ }^{911}$ Um excerto crítico ao efetivo sucesso do caso Brown, mas apontando que essa decisão foi o gatilho para assegurar a integração racial nos Estados Unidos e realizando um interessante escorço histórico sobre seu desenrolar pode ser verificado em BINDER, Jamie S. "Brown v. the Board of Education: Success or Failure?", disponível em: <http://www.umbc.edu/che/tahlessons/pdf/Brown_v._the_Board_of_Education _Success_or_Failure(PrinterFriendly).pdf $>$, acesso em 3.1.2011, 14:52h.

Não se pode esquecer, também, que a dificuldade de implementação observada em Brown foi resultado da ideologia que se colocava como pano de fundo do julgado. Evidentemente que uma decisão judicial nos moldes do "cumpra-se" jamais mudaria a mente das pessoas - o que era o caso em Brown, em que as questões cultural e ideológica sobejavam o julgado. Ao fim e ao cabo, depois de anos de discussão e das cortes judiciais, não sem alguma reticência prévia, seguirem os ditames de Brown, a integração racial nos Estados Unidos tornou-se algo muito mais palpável, passível de internalização pela sociedade.

${ }^{912}$ HOROWITZ, Courts and Social..., pp. 255-274. FISS, “The Forms of Justice...” pp. 31-35. Entre nós, José Ignácio Botelho de MESQUITA flertou com a crítica instrumental em seu As Novas tendências do direito processual: uma contribuição para o seu reexame, 2002. 
precisamente por conta da experiência das cortes nesse mister ${ }^{913}$; e (c) Axiomática, de Lon Fuller, que justifica que as cortes não podem adjudicar temas de políticas públicas porque os juízes não possuem consentimento da sociedade para isso. Aproxima-se do questionamento a respeito da legitimação democrática dos magistrados ${ }^{914}$.

As críticas são respeitáveis, sem dúvida, mas não há nelas nada que deixe de justificar a competência do Judiciário para decidir e, principalmente, garantir a execução de suas próprias decisões. Ora, se o Judiciário está mais acostumado a resolver o processo civil clássico, isso não quer dizer que ele não possa ser aparelhado para efetivar decisões de interesse público. O fato é que todas essas críticas não são impeditivas da adequação judicial para sindicar questões atinentes a políticas públicas. Mas elas devem, sim, ser consideradas para repensar a forma como as cortes atuam em temas de políticas públicas.

No cenário atual, principalmente a crítica Instrumental possui razão de $\operatorname{ser}^{915}$. Horowitz, em 1977, analisou quatro casos para concluir pela impossibilidade das cortes adjudicarem políticas públicas. Para ele, "os problemas de visão, informação, gerenciamento e controle" observados na atuação judicial nos casos estudados referendavam sua hipótese ${ }^{916}$. O autor apurou a pouca intimidade dos juízes com questões complexas como as sociais, verificando déficit de informações e falha dos magistrados em desconsiderar os contextos factuais das questões colocadas nos processos. A semelhança com o que acontece na judicialização da saúde no Brasil é considerável. Por isso é preciso mudar o modo de agir e de ser das cortes. Aliás, esses são, justamente, os cenários e as celeumas tratados nesta tese.

De fato e como demonstrou Horowitz, o grande problema observado nos Estados Unidos - e que pode ser tranquilamente transposto ao Brasil -, foi a implementação fática dessas decisões, denominadas estruturais. Ali, a intervenção judicial em cinco campos (educação, saúde mental, prisões, segurança e habitação) mostrou

\footnotetext{
913 FISS, “The Forms of Justice...” pp. 35-39.

${ }^{914}$ FULLER, “The Forms and Limits..."; FISS, “The Forms of Justice...” pp. 39-44.

915 VERÍSSIMO trata da crítica instrumental (A Judicialização..., p. 77).

${ }^{916}$ HOROWITZ alude ao paradigma de North City Area Wide-Council, Inc. v. Secretary of Housing and Urban Development of Philapelphia (469 F.2d 1326), em que a autora, organização não-governamental sem fins lucrativos, mais alguns indivíduos, pretendiam alterar as políticas preconizadas no Philadelphia Model Cities Program. HOROWITZ apurou falha de informações relacionadas às tratativas que eram mantidas entre as partes interessadas, incapacidade da corte apurar o contexto social da discussão, ignorância sobre os eventos que ocorriam na prática, desconsideração dos argumentos dos gestores, entre outros aspectos que só foram amenizados porque os juízes entenderam - depois de muito tempo - que havia, na espécie, forças políticas sobre as quais eles não poderiam agir (Courts and Social..., p. 255).
} 
experiências fracassadas e exitosas na atuação judicial de concretização de políticas públicas $^{917}$.

Em casos como esses, tanto quanto naquele relacionado à Síndrome de Kanner, propõe-se aplicar a teoria intitulada Destabilization Rights, baseada na ideia de Experimentalismo $^{918}$. Em 2004, Charles Sabel e William H. Simons publicaram, em um volume da Harvard Law Review, um paradigmático artigo que teve como ousado desafio lançar algumas ideias sobre a execução de decisões judiciais estruturais, ou o que eles, naquela oportunidade, denominaram public law litigation ${ }^{919}$. A noção fulcral em tela é o rearranjo de instituições que continuamente falham em cumprir com suas (constitucionais) obrigações e permanecem imunes às forças tradicionais do processo político corretivo ${ }^{920}$.

O ensaio foca especificamente no estudo do que os autores denominam por remédio, ou seja, a solução encontrada pelas cortes para corrigir os problemas institucionais apontados - o que equivaleria, na nossa terminologia, à execução do julgado relacionado a políticas públicas. Da análise empírica sobre diversos casos trabalhados em um sistema que lidava com esse modelo de litigância muito antes do que o nosso próprio, os autores concluem que a aplicação concreta do Experimentalismo é a forma mais eficiente para atingir os objetivos públicos típicos de uma decisão judicial estrutural, e isso porque a decisão experimental é aquela que estabelece objetivos e metas a serem atingidas, ao invés de determinar precisamente como a execução deve ser realizada. A fase de execução no processo judicial estrutural tem um começo, talvez um meio, porém, quase nunca tem fim $^{921}$. Estabelecidas as metas a partir de standards mínimos ${ }^{922}$, as partes, em comum acordo e sempre atuando com boa-fe $e^{923}$, decidem como agir para alcançá-las por meio da eleição de normas provisórias ${ }^{924}$, tudo sob a supervisão e controle das cortes,

917 SABEL, Charles e SIMON, William H., "Destabilization Rights: How Public Litigation Succeeds", in Harvard Law Review, V. 17, $\mathrm{n}^{\circ}$ 4, Fevereiro/2004.

${ }^{918} \mathrm{O}$ experimentalismo democrático é a teoria que se propõe a repensar a sociedade, o Estado e as instituições sob o ponto de vista da realidade, experimentando novas soluções. Um dos maiores expoentes da doutrina experimentalista é Roberto MANGABEIRA UNGER, brasileiro que se tornou Professor Titular na Universidade de Harvard. Com um pensamento bastante ligado ao Realismo, UNGER entende que a visão do que é possível depende do entendimento do que é real. Para ele, a reinvenção contínua das instituições é a base da democracia (TEIXEIRA, Carlos Sávio. Experimentalismo e Democracia em Unger. São Paulo: Lua Nova, 2010, pp. 48-49).

${ }^{919}$ SABEL e SIMON, "Destabilization Rights...".

${ }^{920}$ SABEL e SIMON, "Destabilization Rights...", pp. 1 e 47.

${ }^{921}$ FISS, "Forms of Justice...", p. 23.

${ }^{922}$ Os standards são determinados com base em opiniões e consultas a técnicos, acadêmicos, expertos, isso se já não houver um caso prima facie, ou que constituiria um precedente de sucesso em que a decisão estrutural pudesse se embasar (SABEL e SIMON, "Destabilization Rights...", p. 48).

${ }^{923}$ É inequívoca a inspiração do modelo na decisão em Brown II, já referida.

${ }^{924} \mathrm{~A}$ que os autores denominam role-rule regime, em contraposição à estratégia command-and-control que emana de regras rigidamente estabelecidas pelo Judiciário. As normas provisórias que advêm dos julgados 
inclusive de acordo com periódicas avaliações de performance ${ }^{925}$. Conforme o resultado dessas avaliações, as normas provisórias podem ser revistas ${ }^{926}$.

Note-se que as diferenças encontradas nos Estados Unidos para os casos com que o Judiciário estava acostumado a lidar e os novos casos, concernentes à reforma estrutural, assemelham-se, e muito, aos entraves observados aqui, entre nós. Um bom exemplo é o abandono da estratégia command-and-control, em que o Judiciário manda cumprir, simplesmente, e com isso acredita exaurir seu serviço, para a doutrina do rolerule regime, uma estratégia aberta, flexível e altamente modificável de acordo com sua performance, periodicamente avaliada.

Da proposição ora colocada se tira uma analogia já aplicada no direito brasileiro: a execução dos planos de recuperação de empresas em situação de insolvência ${ }^{927}$. A recuperação judicial é um mecanismo em que, por meio de extensa negociação entre as partes interessadas (grosso modo, empresário, trabalhadores e credores), elege-se um plano privado para salvar a empresa da situação economicamente inviável, tudo sob a supervisão do juiz e a opinião do Ministério Público. O foco, nesta situação, é o de manter ou, antes, de salvar a empresa, considerando sua inequívoca função social e utilidade para a sociedade $\mathrm{e}^{928}$.

Ora, nos casos estruturais, os hard cases que envolvem políticas públicas, a efetivação da tutela jurisdicional não pode se submeter aos paradigmas do clássico processo civil. É preciso que o juiz, em conjunto com as partes, participe da definição do remédio, da solução que, emanada do Estado via Poder Judiciário, seja apta a efetivar da

experimentais são o coração da teoria, já que, de acordo com a avaliação realizada sobre tais regras, elas poderão ser revistas.

${ }_{925}$ Em 1989, a Suprema Corte do Texas declarou que o sistema educacional ali praticado estava em desacordo com a Constituição do Estado. Depois de rejeitar dois pacotes de mudanças propostas, a Corte referendou, de maneira provisória, propostas criando investimentos específicos em educação e um esquema de avaliação e prestação responsável de contas (accountability, embora não exista, em português, palavra que corresponda exatamente ao sentido inglês deste termo) relacionada ao sistema educacional. Sobre o assunto, ver SABEL e SIMON, "Destabilization Rights...", pp. 12-13.

${ }_{926}$ Este tipo de execução “(...) institucionaliza o processo de contínua aprendizagem e reconstrução." (SABEL e SIMON, "Destabilization Rights...", p. 5).

927 SABEL e SIMON também encontram essa analogia ("Destabilization Rights...", pp. 50-51), o que é bastante importante considerando a declarada influência que a lei brasileira de recuperação de empresas tira do diploma norte-americano que corresponde ao mesmo tema (o Chapter 11 do United States Bankruptcy Code).

${ }^{928}$ Não se tira outra ideia do artigo 47 da Lei no $11.101 / 05$, que escancara o objetivo da recuperação judicial: a superação da situação de crise, com a manutenção da fonte produtora, do emprego dos trabalhadores e dos interesses dos credores. 
política pública faltante, com eficiência e adequação realísticas. A atuação do juiz, nesse contexto, é crucial ${ }^{929}$.

A solução que aqui se propõe, verdade seja dita, requer certo abrandamento do comando da decisão judicial. Mesmo a analogia com a recuperação de empresas é válida apenas para demonstrar como o remédio para curar uma situação de crise pode ser negociado pelas partes, com a supervisão do órgão jurisdicional ${ }^{930}$. Supondo que uma decisão judicial sobre políticas públicas estabeleça apenas as metas a se chegar e o remédio - ou a forma de execução - seja negociado entre as partes, o não cumprimento dessas regras ou a não consecução dos fins almejados pela decisão judicial não levará à falência da instituição ${ }^{931}$, mas, por meio das avaliações sistemáticas e periódicas de performance, as regras podem ser revistas e aprimoradas. As partes envolvidas no problema efetivamente experimentam saídas para o cumprimento do comando judicial, e o juiz se torna o responsável por avaliar essas saídas. O remédio é negociado com o auxílio do juiz ${ }^{932}$, ou seja, a forma, a maneira de como aquela inconstitucionalidade declarada será sanada.

Então, são três as premissas da decisão experimentalista: (a) ela deve ser fruto de negociação; (b) ela adota regras provisórias e passíveis de revisão de acordo com a performance ou, melhor dizendo, sua aplicabilidade e eficácia no caso concreto $^{933}$; e (c) tudo deve ocorrer da maneira mais transparente possível ${ }^{934}$.

A prática provocará decisão judicial que fixa os pontos que devem ser percorridos para que aquela instituição se adéque à norma, de forma ampla e objetiva. Para se chegar a tais pontos, o juiz deve valer-se de peritos, técnicos, acadêmicos, enfim, de

929 Requerendo criatividade e flexibilidade na adoção do remédio, ver BRASIL Jr., Samuel Meira; e CASTELLO, Juliana Justo Botelho. "O cumprimento coercitivo...", em GRINOVER e KAZUO, $O$ Controle..., p. 476.

930 Ora, essa proposição também encontra eco no APLPP, sobretudo no artigo 11 projetado, em que está claro que, a qualquer tempo (na execução, inclusive) as partes poderão transigir sobre o cumprimento da obrigação, sua modalidade e prazos, ouvido o Parquet. O inovador anteprojeto de lei já antevê, portanto, soluções negociadas de execução, flertando com o experimentalismo.

931 Daí porque a comparação com a recuperação empresarial servir apenas para o objetivo indicado. Se a empresa não cumpre com o plano aprovado em assembleia, a solução adotada pelo juiz será decretar a quebra da sociedade (artigo 73, IV da Lei n ${ }^{\circ} 11.101 / 05$ ), e, não, rever as regras do plano de recuperação (o que seria o indicado sob o enfoque experimentalista).

932 O papel do juiz, nesse particular, é essencial e será mais bem delineado no Item 5.5.2.

933 No caso do déficit de vagas nas creches do Município de São Paulo, em 2013, o TJSP promoveu audiências públicas, reuniões e tentou negociar, mas, no final, proveu decisão obrigando o Poder Público municipal a criar cento e cinquenta mil vagas para o atendimento da educação infantil. Estabeleceu um plano progressivo para tanto (metade das vagas devem ser criadas em dezoito meses; a outra metade, nos outros dezoito), além de determinar apresentação ao Judiciário de relatório semestral com as providências tomadas e, dali sessenta dias, plano de ampliação de vagas e construção de estabelecimentos de ensino. A Folha de São Paulo bradou essa decisão como inédita - e, de fato, é mesmo, um prenúncio de que o Judiciário começa a entender o diferenciado processo judicial de políticas públicas ("Justiça manda Haddad cumprir promessas de vagas em creche", edição de 17.12.13, n 30.939, p. C4).

934 SABEL, SIMON, "Destabilization Rights...", pp. 52-57. 
especialistas que o possam auxiliar. Ele não pode desempenhar sozinho a complexa $\operatorname{tarefa}^{935}$.

De fato, a implementação de políticas públicas é, via de regra, lenta e gradual, e não prescinde de uma complexa atuação de diversos órgãos. No caso ora estudado, por exemplo, além do juiz e dos servidores, também promotores, agentes de saúde, médicos, pacientes, profissionais das mais variadas áreas tiveram que atuar de forma a procurar cumprir o comando judicial da melhor forma. O Estado certamente teve que afetar seus recursos - humanos e financeiros - para cumprir a decisão, o que o forçou a traçar um planejamento. Todo este esforço coletivo deveria ser maximizado, com a atuação conjunta dos atores para atingir o comum objetivo de dotar o Estado de meios para tratar adequadamente os pacientes de autismo.

Um exemplo de como o enfoque experimentalista poderia tornar uma política pública declarada inadequada pelo Judiciário mais racional e equilibrada trata-se, precisamente, do caso Brown. Como a tarefa que emanava da decisão judicial era policêntrica ${ }^{936}$ (no sentido de reunir inúmeras e variadas ações para fazer cumprir o direito de tratamento igualitário da $14^{\mathrm{a}}$ Emenda à Constituição norte-americana) e o assunto continha inafastável viés ideológico, a solução dependia da colaboração e conscientização de todos de todos: pais, alunos, mestres, sociedade, Administração Pública, conselho escolar. Não adiantava, apenas, estabelecer que o sistema de transporte devesse tratar a todos indistintamente; era preciso trazer negros para estudar em escolas tradicionais de brancos. Antes, contudo, tal possibilidade deveria ser conversada e negociada, a fim de que se pudesse evitar - ou, ao menos, minimizar - toda a carga preconceituosa que a decisão em Brown visava a dissipar. A Suprema Corte dos Estados Unidos anteviu, já em 1955 (Brown II), que a estratégia command-and-control seria totalmente inadequada à execução da desejada integração escolar.

É interessante a experiência Argentina, onde a Corte Suprema parece entender a peculiaridade das ações que versam sobre políticas públicas. No caso Beatriz Mendoza, em que associações, indivíduos e o Defensor Público da Nação pediram providências para obstar e reverter a contaminação da água em torno de Buenos Aires, o

\footnotetext{
${ }^{935}$ Aqui cabe mais uma referência ao inovador APLPP (Art. 19, parágrafos $2^{\circ}$ e $3^{\circ}$ ), quando estabelece que, depois de condenada, a Administração Pública deverá apresentar projeto detalhado de execução da política pública, com cronograma que será debatido entre autor, juiz, promotor e comissário (figura análoga ao Special Master de que se tratará).

${ }^{936}$ Termo continuamente empregado por FISS para contrapor o papel atual da Cortes, de definir o que ele denomina processo estrutural, àquele antigo, modelado pela bipolaridade, a controvérsia e o antagonismo de posições bem definido ("The Forms of Justice...”).
} 
Tribunal flexibilizou prazos preclusivos, ordenou ao Estado a apresentação de plano para o atendimento progressivo de metas atreladas a um cronograma, tudo de acordo com o quanto apurado em audiências públicas. Ordenou, ademais, a participação da sociedade civil no acompanhamento e controle da execução do plano, grupo coordenado pelo Defensor Público. O mesmo vem acontecendo em decisões questionando o encarceramento e a saúde pública ${ }^{937}$. Na Colômbia, semelhante tendência vem sendo observada ${ }^{938}$.

Em Beatriz Mendoza a execução observou notáveis problemas, na maior parte, relacionados ao cumprimento das obrigações definidas no plano apresentado à Corte. Dois anos após o que seria o início da execução de tal plano, as águas estavam ainda mais contaminadas. O inadimplemento gerou aplicação de astreintes, um sem-número de audiências públicas e a triste constatação de que tanto tempo havia passado sem qualquer progresso - ao contrário ${ }^{939}$.

Complexos como Brown ou Beatriz Mendoza, embora com outras nuances, são alguns casos que versam sobre saúde. Já se viram suas infindáveis variáveis, inclusive os impactos teóricos e práticos - como o orçamentário e o programático - que apenas uma única decisão judicial pode causar. O Experimentalismo, para os casos mais agudos e mais delicados que tratam de saúde, poderia ser uma solução mais adequada e pacificadora. Para que se verifique se, de fato, a doutrina experimentalista poderia se aplicar mais adequadamente ao tema da saúde, nas linhas seguintes se vislumbrará, apoiado no pensamento de Sabel e Simon, como uma decisão experimentalista resolveria os dois casos analisados e criticados neste trabalho como exemplos de decisões judiciais patológicas: o caso da Síndrome de Kanner e o caso da vacinação contra o Influenza 1 (H1N1 ou gripe A) ${ }^{940}$.

Quanto à ação civil pública que trata da Síndrome de Kanner, sintomático é o entendimento do magistrado responsável pelo caso estudado de que o problema da execução seria em parte resolvido com o aumento compulsório do número de juízes e promotores. Na sua filosofia, o magistrado extinguiu as habilitações individuais dos portadores da doença e coletivizou a execução, forçosa e erroneamente. Ambos esses

\footnotetext{
${ }^{937}$ BERIZONCE, Roberto Omar. "Los Conflictos de Interés Publico", em Revista de Derecho Procesal $\mathrm{n}^{\circ} 2$. Buenos Aires: 2011, pp. 84-88. Quanto à tutela da saúde, relata o autor haver série de decisões baseadas no amplo debate havido em audiências públicas que questionaram profundamente as políticas de saúde. Em um caso em que se discutia a eficácia de um hospital neuropsiquiátrico, a corte resolveu ordenar que a Municipalidade de Buenos Aires apresentasse plano que, cumprido, dotaria o hospital de condições de habitabilidade, com apresentação de etapas atreladas a um cronograma (p. 88).

${ }^{938}$ BERIZONCE, "Los Conflictos...,", pp. 81-92.

${ }^{939}$ BERIZONCE, "Los Conflictos...,", pp. 93-94.

${ }^{940}$ Itens 6.3.1.1 e 6.3.2.1, respectivamente.
} 
entendimentos só exprimiram o desespero do juiz em se livrar do cumprimento de sua própria sentença, sem se lembrar de que ele não poderia assim agir. Se atuou dessa maneira, o fez porque não contava nem com a colaboração dos atores envolvidos no caso, nem com a maleabilidade de uma decisão que pudesse ser alterada, caso a experiência prática revelasse não ser ela a mais adequada. Não há dúvida: naquele caso, as partes também não colaboraram com o magistrado. É a cultura da sentença agindo na prática.

Imagine-se que a sentença de procedência dos pedidos naquele caso pudesse se afastar um pouco do dogma processual da congruência ${ }^{941}$ e terminasse por, escapando dos estritos termos dos pedidos, eleger os objetivos que revelassem a adequada proteção estatal dos portadores do autismo. Com efeito, a decisão, hermeticamente fechada, outorgava pouquíssima maleabilidade para a sua respectiva execução, em função dos limites objetivos da coisa julgada ${ }^{942}$. Nesse sentido, absolutamente correta a ideia já descoberta pelos estudiosos do processo coletivo e que resultaram na ideia de interpretar o pedido muito mais com vistas ao objeto a ser tutelado do que, propriamente, de maneira restrita e rígida ${ }^{943}$. Igualmente correta se apresenta a formulação ampla dos pedidos em ação coletiva, defendida linhas antes.

Sem se olvidar das boas intenções do magistrado, ao invés de procurar fomentar o diálogo entre os envolvidos de forma a racionalizar o cumprimento do julgado, a sentença preferiu estabelecer regras fechadas e pouco flexíveis, como se estivesse

\footnotetext{
941 Embora seja um fundamental dado de segurança jurídica e estabilidade, a congruência comporta exceções. Sobre o assunto, ver MOREIRA, José Carlos Barbosa. "Correlação entre o pedido e a sentença." em Revista de Processo n ${ }^{\circ}$ 83. São Paulo: Editora Revista dos Tribunais, julho-set. 1996, p. 212. Recorda muito bem Carlos Alberto Alvaro de OLIVEIRA que as reformas de 1995 e 1996 no Código de Processo Civil português fizeram incluir no artigo 273 a possibilidade do autor reduzir ou ampliar o pedido em qualquer fase do processo até seu julgamento em primeira instância, o que mostra a evolução portuguesa quanto ao entendimento do que é adstrição ("Poderes do Juiz e Visão Cooperativa do Processo I" pp. 24-25, disponível em: <http:// www.abdpc.org.br/abdpc/artigos/Carlos\%20A\%20A\%20de\%20Oliveira\%20(8)\%20 f ormatado.pdf $>$, acesso em 3.1.2011, 18:55h). Sobre a tendência mundial de possibilidade de modificação de causas de pedir e pedidos, com notícias da Alemanha, Itália e do já citado Portugal, ver LUCON, Paulo Henrique dos Santos, e GABBAY, Daniela Monteiro. "Superação do Modelo Processual Rígido pelo Anteprojeto do Código Brasileiro de Processos Coletivos à Luz da Atividade Gerencial do Juiz”, em Direito Processual Coletivo..., pp. 89-93.

942 Como visto, os limites objetivos da coisa julgada são o parâmetro sobre a qual atuará a autoridade da imutabilidade da coisa julgada. Referem-se, concorde com o artigo 467 do Código de Processo Civil, ao dispositivo da sentença. Sobre o tema, ver LIEBMAN (Eficácia e Autoridade...).

${ }^{943}$ GRINOVER, "Direito Processual Coletivo...", p. 4. O artigo 5, Par. un. do Anteprojeto de Código Brasileiro de Processos Coletivos previa, inclusive e a exemplo da legislação lusa, a modificação dos pedidos e causas de pedir até a prolação da sentença, com a observância da boa-fé, da ausência de prejuízo e do contraditório. É o que acontece, atualmente, no projeto de revisão do CDC e no APLPP. No mesmo sentido estabelecia o artigo 10 do Código Modelo de Processos Coletivos para a Ibero-America. Sobre o assunto, ver LEONEL, Ricardo de Barros. "Causa de Pedir e Pedido nos Processos Coletivos: Uma Nova Equação para a Estabilização da Demanda”, em Direito Processual Coletivo..., pp. 145-160.
} 
resolvendo um conflito bipolar ${ }^{944}$. Talvez isso não acontecesse se o pedido fosse interpretado elasticamente, a exemplo das teorias empregadas aos processos $\operatorname{coletivos}^{945}$, já que - e apoiando-se no fato da interconexão entre processos coletivos e políticas públicas o que é aplicável no campo da tutela coletiva de direitos, o é, também, em temas de políticas públicas. A elaboração ampla e a interpretação elástica dos pedidos também, nesses casos, poderiam abrir caminho para o Experimentalismo, tanto quanto a ampla formulação dos pleitos, conforme aqui preconizada.

Ademais, a sentença foi prolatada de forma a prolongar lide havida entre Estado e portadores da síndrome, e não de maneira a gerar um saudável diálogo entre as partes. De fato, a decisão, por exemplo, estabelecia que a internação do doente deveria ocorrer em estabelecimento próximo à sua residência, mas o Estado poderia se contrapor a essa indicação, fundamentadamente. Esta era a senha para que o Estado se opusesse veementemente a toda e qualquer indicação feita pelos responsáveis pelo doente - o que acabou, de fato, ocorrendo ${ }^{946}$ - e transformasse a execução em uma medida sem solução.

Talvez lograsse mais sucesso a sentença que apenas fixasse os objetivos que deveriam ser alcançados pelo Estado (i.e., o Estado fica condenado a prover tratamento adequado aos pacientes da Síndrome de Kanner, por meio de um plano a ser apresentado ao juízo em noventa dias, a ser votado e aprovado em reunião que deverá ocorrer no prazo máximo de quarenta e cinco dias contados da apresentação) via adoção de regras provisórias, a serem previamente negociadas com os envolvidos (médicos, pacientes, Ministério Público, entidades privadas de tratamento), traçando plano com metas objetivamente expostas e totalmente transparentes, com avaliações periódicas das ações

\footnotetext{
${ }^{944}$ No caso em espeque, o Estado de São Paulo procurou direcionar o tratamento de todos os pacientes para a entidade denominada Casa de David, o que gerou infindáveis discussões - e, até mesmo, uma inesperada inspeção judicial no local - para verificar se aquele centro era adequado ao tratamento dos doentes.

945 Nos processos coletivos, a elasticidade na interpretação das causas de pedir e pedidos deriva da necessidade de se flexibilizar o rigorismo processual em face do bem jurídico tutelado, evitando que pedidos mal feitos possam prejudicar a obtenção do bem da vida. Se uma ação civil pública requer a condenação em dinheiro a título de indenização por poluição atmosférica de determinada fábrica, o juiz deveria poder, desconsiderando esse pedido, ordenar outra providência muito mais eficaz e consistente com a primazia do postulado de reparação integral que rege a tutela ambiental, como, por exemplo, a instalação de filtros. A este respeito, consultar SALLES. Execução Judicial..., p. 316.

${ }^{946}$ A crítica à atuação das partes, feita pelo magistrado, não poderia ser mais clara: "4. De um lado, é cômoda a situação do exeqüente Ministério Público porque, em tempos em tempos, paulatinamente, apenas se manifesta nos autos de cada habilitação limitando-se a lançar cota, com os simples dizeres de "Requeiro a manifestação da FESP sobre o teor da inicial" (sic) e não cria mecanismo de, uma vez por todas, exigir o cumprimento da sentença de forma global. 5. De outro, é cômoda a situação do Estado de São Paulo porque, nos autos de cada habilitação, apresenta informação individualizada da Secretaria da Saúde noticiando que houve disponibilização de vaga em uma determinada entidade cadastrada ou deposita valor para que seja expedida guia de levantamento pertinente ao custeio do tratamento em instituição privada ou agrava da decisão judicial pertinente a um caso isolado."
} 
tomadas para a implementação do plano e, sendo o caso, adaptação para eleição de novas regras.

Pense-se na seguinte situação, ainda usando o paradigma do caso do autismo: o Estado de São Paulo é condenado a dispensar saúde, educação e assistência aos portadores da moléstia. Sentam-se seus representantes com promotores, médicos, psicólogos, assistentes sociais, pais, pacientes, entidades privadas que cuidam do problema, enfim, os interessados de parte a parte. São estudadas alternativas e propostas soluções, dentro das expectativas e limitações de cada envolvido. É realizado um plano, submetido ao juízo e aprovado por ele. Iniciam-se as ações do Estado paulista para cumprir o plano, com a colaboração dos especialistas, pais e pacientes, sob fiscalização do Ministério Público e do juiz. Seria o caso de eleger um administrador da execução, assim como ocorre em outros países ${ }^{947}$. Trimestralmente, seria entregue ao juízo relatório com os resultados das ações; semestralmente, outro relatório consolidaria as ações realizadas, comparativamente com o plano traçado. Com resultados satisfatórios, o plano prosseguiria; se não fossem, as partes negociariam novamente outro remédio, submetendo à deliberação ao juízo. A sociedade civil, diante da publicidade de toda a discussão, poderia, eventualmente, intervir favoravelmente. Esta seria uma execução flexibilizada oriunda de uma decisão experimentalista.

No caso da vacinação paranaense contra a gripe $A$, o tempo envolvido na providência requerida não impedia que o enfoque experimentalista fosse abordado. As partes se reuniriam defronte do juiz e debateriam sobre a efetiva necessidade de modificação do plano pré-estabelecido. Constatada a necessidade e a prioridade de vacinação de certos grupos, seriam estabelecidas regras apropriadas para o Paraná (isso, assumindo que, de fato, o Parquet federal no Paraná tivesse razão), que poderiam ser revistas, caso não se revelassem apropriadas.

\footnotetext{
${ }^{947} \mathrm{Na}$ França as execuções civis são monopólio do huissier de justice, profissional liberal pertencente ao mercado privado que incumbe executar títulos judiciais e extrajudiciais (ver, a respeito, GUINOT, Thierry. L'huissier de justice: normes et valeurs. Ethique, déontologie, discipline et normes profesionnelles. Chambre Nationale des Huissiers de Justice: Paris, 2004). Na Itália, o comissario ad acta (Codice del Processo Amministrativo, art. 21) é um terceiro que auxilia o juízo administrativo di ottemperanza a cumprir suas decisões contra o poder público inerte. Nos Estados Unidos existe a figura do Special Master, nomeado pelo juiz para supervisionar e colaborar na implementação do remédio (FISS, The Forms of Justice..., p. 23). No caso Lewis, em que a Corte Distrital apontou um Special Master para identificar qual a melhor forma de assegurar o acesso ao Judiciário pelos presos (o pedido foi de instalação de bibliotecas de Direito nas prisões), foi emanada decisão estabelecendo o número de livros nas bibliotecas, as áreas de especialidade, o credenciamento dos presos, um curso introdutório de Direito. A Suprema Corte, presidida, ali, pelo juiz REHNQUIST, reverteu a ordem baseada no princípio majoritário e na inadequação da tutela ao pedido (SABEL e SIMON, "Destabilization Rights...”). Este tema voltará à baila no Item imediatamente posterior.
} 
Para fins de execução de decisões que envolvam políticas públicas, sobretudo no campo da saúde, o Experimentalismo e a consequente flexibilização são saídas. A adoção de um regime provisório, com ampla negociação (ou seja, diálogo entre interessados), boa-fé objetiva e mútua, além de publicidade e, principalmente, avaliação de performance em tudo combina com o interesse público em prestar serviços sociais adequados. Ao mesmo tempo, este tipo de sistemática lidaria melhor com os problemas normalmente enfrentados por essa estirpe de decisão, como as questões orçamentárias e técnicas que devem ser avaliadas no longo prazo.

O role-rule regime adotado pelo Experimentalismo seria aplicado na fase de execução, sem dúvida, mas podem existir situações em que os limites objetivos da coisa julgada constituam entrave. Alguém poderia infirmar o argumento, sustentando que se o dispositivo da sentença fosse genérico (i.e., qualquer coisa como garanta o município o ingresso de todas as crianças residentes em seus domínios às creches $)^{948}$, a coisa se resolveria na execução, aliás, como seria passível de se observar no atual regime das ações coletivas. A oposição é interessante: de fato, aplicando-se o Experimentalismo apenas na execução de uma sentença genérica, os resultados obtidos poderiam ser adequados, sem que, contudo, houvesse qualquer alteração no regime atual da coisa julgada. Acontece que, muitas vezes, os juízes não respondem genericamente. A amplitude do pedido e da decisão viabilizarão o Experimentalismo, mas somente elas não serão suficientes para a aplicação do remédio.

Por isso, reitere-se, os remédios são apresentados para aplicação concomitante, de forma que, ausente um, aplique-se outro, ou integrem-se todos eles ao mesmo tempo. Se hoje existem situações em que, como demonstrado, os limites da coisa julgada consistem entraves à exaustiva aplicação da execução mais completa, é preciso que se altere o atual regime da coisa julgada. Mas, de todos os remédios apresentados, talvez o enfoque experimentalista sobre a decisão estrutural em políticas públicas seja o mais importante, porque a decisão experimentalista envolve planejamento e execução continuada, providências típicas de políticas públicas.

Claro que todas as adaptações teriam que ser judicialmente referendadas. Lembre-se que, no modelo proposto, o juiz acompanha de perto a execução e sua avaliação, decidindo qual caminho percorrer com base nos subsídios que lhe são levados. O poder do juiz não é, neste modelo, mitigado, mas, sim, ampliado, sendo ele capaz de

\footnotetext{
${ }^{948}$ Que, no fundo, foi a decisão do AgReg em RE nº 436.996-6, Rel. Min. Celso de MELLO, já mencionada, que determinou ao Município de Santo André tal providência.
} 
rever um seu entendimento anterior caso esse se mostre inadequado na prática, ainda que passado em julgado.

É fato que o Brasil tem leis demais e que as últimas mostras de alteração legal não se exibiram tão empolgantes. Mas não é crível que tudo se resolveria na interpretação judicial, na analogia a situações como a da ação de alimentos ou da investigação de paternidade já tratadas. Iniciativas como esta, que propugnam uma alteração no regime da execução do julgado, têm de ser materializadas por meio de lei.

A exaustiva caminhada na implementação ou na correção de uma instituição incumbida de prestar serviços de saúde não pode ser tratada e regrada por um modelo rígido de interesses antagônicos. Soluções estruturais não são imediatistas, ao contrário, levam tempo. Insista-se: decisões policêntricas, apesar de possuírem começo e meio, podem nunca ter fim e envolvem a ampla relação do juiz com a instituição em desconformidade com a Constituição. A tarefa judicial não é declarar quem está certo ou errado, mas certificar-se de garantir a correção do equívoco que faz a instituição falhar em sua missão constitucional ${ }^{949}$.

A omissão do Estado na prestação de seus deveres constitucionais não pode ser vista com raiva ou ranço, mas, sim, como resultado natural da impossibilidade material de atendimento adequado à totalidade da demanda por esses serviços. A mudança ideológica no tratamento dessa omissão - por partes, seus substitutos e por juízes facilitaria deveras a negociação. A colaboração mútua decorrente da adoção do enfoque experimentalista seria uma importante ferramenta para evitar uma decisão judicial que não assegurasse, na plenitude, a observância do direito.

5.5.2 O juiz como gerente da execução de medidas relacionadas a políticas públicas

Como corolário dos argumentos já sustentados, exsurge a necessidade do magistrado assumir papel ativo na execução do julgado que envolve temas de políticas públicas, transformando-se de simples apoiador dos atos da parte interessada em verdadeiro agente da obtenção do bem da vida.

${ }^{949}$ FISS, The Forms of Justice..., p. 23. 
Não é de hoje que a moderna concepção da função do juiz reclama um seu papel mais contundente em todo o processado. Não se trata, aqui, de posicionar o magistrado como um dos principais atores do processo decisório contemporâneo, como o fazem Dworkin ${ }^{950}$ e Cappelletti ${ }^{951}$, e de acordo com o quanto abordado no Capítulo 2. O engrandecimento dos poderes do magistrado que as vozes mais modernas, principalmente no Brasil, passaram a reclamar condiz justamente com uma postura judicial no sentido de entregar à sociedade a tutela jurisdicional com presteza, qualidade e segurança ${ }^{952}$.

A postura mais atuante do magistrado, na fase de conhecimento, é tudo o que se defende ser necessário neste estudo. Levantar o debate entre Poderes, obter informações técnicas, pontuar questões orçamentárias, procurar atuar mais conjuntamente com as partes, fazendo o máximo para considerar, em sua atividade, toda a dificuldade e a multidisciplinaridade relacionada ao assunto é tarefa do juiz do conhecimento das políticas públicas. Este pensamento deflui como que automaticamente do que ora se sustenta. Mas é preciso, como contenção da decisão judicial patológica, que ocorra o maior êxito possível na execução, especialmente nessa estirpe de julgado, aquele que trabalha com as policêntricas questões ligadas a políticas de saúde, educação, lazer, proteção à família, à criança, ao adolescente, ao idoso, dentre outras.

O juiz da execução das políticas públicas não pode ser aquele que se fia cegamente à norma posta nem, a despeito de seu efusivo papel, avoca para si completamente a tarefa de resolver os problemas sociais brasileiros. O juiz da execução das políticas públicas deve promover o diálogo e o debate, ou, antes, propiciar a integração entre os atores do processo. Já se notou que a negociação e a discussão são os melhores caminhos para se definir o remédio, ou a solução do problema ligado a políticas públicas. É nesse mister que o juiz, primeiramente, deve atuar. O juiz da execução de políticas públicas deve ser muito mais Hermes, mas, às vezes, deve vestir as vestes de Hércules ${ }^{953}$ :

\footnotetext{
${ }^{950}$ DWORKIN. Sovereign Virtue... Taking Rigths Seriously... Law's Empire...

${ }^{951}$ CAPPELLETTI, Juízes Legisladores?

952 É a tônica que se observa em Poderes do Juiz e Tutela Jurisdicional: A Utilização Racional dos Poderes do Juiz como Forma de Obtenção da Tutela Jurisdicional Efetiva, Justa e Tempestiva (AMENDOEIRA Jr., Sidnei. São Paulo: Atlas, 2006). Sobre a demanda por um juiz mais atuante e menos inerte, ver, também, ALVARO. "Poderes do Juiz..."; sob um enfoque diverso, mais processual, PUOLI, José Carlos Baptista. Os Poderes do Juiz e as Reformas do Código de Processo Civil. São Paulo: Juarez de Oliveira, 2002; BEDAQUE, José Roberto dos Santos. Direito e Processo: Influência do Direito Material sobre o Processo. $4^{\text {a }}$ ed. São Paulo: Malheiros, 2006, p. 53. Efetividade do Processo e Técnica Processual. São Paulo: Malheiros, 2006, pp. 107-111.

${ }^{953}$ Não se poderia entrar neste tópico sem mencionar o lúdico (ele mesmo assim o qualifica - p. 172) e rico trabalho de François OST (“Jupiter, Hercules, Hermes: Tres Modelos de Juez”, trad. Isabel Lifante Vidal, em DOXA. Cuadernos de filosofía del derecho [Publicaciones periódicas], $\mathrm{n}^{\mathrm{o}}$ 14, Espanha: Universidad de Alicante, 1993).
} 
deve ser, por si ou por interposta pessoa por ele designada, um autêntico gerente ou administrador da execução. Uma ideia é importante para dar supedâneo ao ora proposto, e ela, de novo, vem dos Estados Unidos, mais precisamente, da doutrina e prática do case management.

O case management é, a um só tempo, doutrina e prática que sobrelevam a função judicial na condução do processo: o juiz, sob o enfoque apresentado, age como verdadeiro gerente do caso (em alusão à literal tradução do instituto), tomando as providências necessárias para assegurar a tutela justa, eficaz e expedita. $\mathrm{O}$ raciocínio a justificar o método é fácil: a Rule 1 das Federal Rules of Civil Procedure estabelece os objetivos do sistema judicial, a saber, assegurar justiça, presteza e economia em cada ação concretizada; o juiz, em todos os atos seus, deve agir incisivamente na busca desses ideais - e assim o fará como um administrador, um gerente, com o uso das ferramentas que estejam à sua disposição - as leis processuais e a inerente autoridade das cortes, mas sempre com equidade e baseados no senso comum ${ }^{954}$.

Sob a Rule 16 das Federal Rules of Civil Procedure, o juiz convoca uma conferência com os advogados - e, quando se mostrar vantajoso, também com as partes para definir um programa para o desenvolvimento do caso, atendendo aos três postulados de justiça, presteza e economia. Nessa ocasião o juiz definirá, com as partes, a respeito do que efetivamente se trata o caso e quais serão as grades questões. Verificará a possibilidade de acordo. Estabelecerá, também, prazos em que determinadas providências deverão ser tomadas $^{955}$.

Quanto ao discovery, reputado como, possivelmente, o expediente processual mais dispendioso, o juiz pode exigir dos advogados que usem meios mais econômicos para obter informações e evitar duplicidade de atos, exortando-os, ainda, a não assumir atitudes que se mostrem economicamente desproporcionais ao que está em jogo na causa. O magistrado pode, também, definir as regras de julgamento e o uso de procedimentos especiais para cada circunstância ${ }^{956}$. Enfim, as possibilidades são enormes, sempre mirando justiça, presteza e economia. Nascido nos Estados Unidos, o case management é bastante difundido no Canadá ${ }^{957}$.

\footnotetext{
${ }^{954}$ HIRSCH, Alan, e SCHWARZER, Willian W. The Elements of Case Management: a Pocket Guide for Judges. $2^{\text {nd }}$ edition. Federal Judicial Center: 2006, p. 1.

${ }_{955}$ HIRSCH e SCHW AZER, The Elements..., pp. 11-12.

${ }^{956}$ Op. Cit., pp. 13-20.

${ }^{957}$ De acordo com o sítio eletrônico do Advogado-Geral de Ontário, a serventia do case management é, basicamente, propiciar, desde logo, o contínuo controle judicial sobre a causa, os prazos para cada ato processual, o monitoramento constante para assegurar o cumprimento do quanto definido e prazos firmes par
} 
O papel do juiz no case management serve bem aos propósitos deste tópico.

Diante da multiplicidade de aspectos envolvidos, por exemplo, em caso que trate de saúde (i.e., questões técnicas sobre o tratamento, assuntos administrativos a respeito de competências, orçamento, planos, projetos e programas, temas de organização internacional de saúde, diferentes escalas e esferas de poder - federal, estadual, municipal e distrital, interesses múltiplos dos pacientes), o juiz deve se propor a ordenar o debate e a tratar a questão em uma macroestrutura (Hermes) $)^{958} \mathrm{e}$, ao mesmo tempo, tomar as providências para tornar efetivo o direito outorgado na sentença de conhecimento $(\text { Hércules })^{959}$.

O fato é que o juiz tem que capitanear o diálogo e a execução: é ele quem deve avaliar, em última análise, se a solução proposta ou requerida pelas partes é a melhor, sob o ponto de vista do bem jurídico tutelado; é ele quem deve pontuar o debate, estabelecendo as questões importantes, sem, contudo, fechar a janela para que outros pontos surjam; é ele quem deve fixar, depois de uma ampla discussão e negociação, quais os caminhos a seguir para uma distribuição mais equilibrada dos bens públicos que são inerentes a temas como saúde, educação, cultura, desporto, meio ambiente, lazer, vestuário, alimentação, dentre tantos outros, guiando os interessados por esse caminho ${ }^{960}$. A natural imparcialidade do juiz é medida que contribui decisivamente para uma função executiva gerencial.

a os procedimentos judiciários (<http://www.attorneygeneral.jus.gov.on.ca/english/about/pubs/lesage_code/c hapter_4.asp>, acesso em 23.11.2013, 17:19h).

${ }_{958}$ Hermes é o modelo equilibrado e moderno de juiz de OST: o juiz que é um mensageiro, um comunicador em rede, um meio termo entre o magistrado excessivamente positivista (Júpiter) e o absolutamente pragmático (Hércules), modelo ideal de solucionador de conflitos para a sociedade atual, diante da complexidade que se tornou a tutela hodierna de direitos. No artigo, muito mais vasto e denso do que o que se aproveita neste estudo, o professor belga atribui ao juiz Hermes a tarefa de "(...) integrar, en la construcción del sentido jurídico, las creaciones normativas que emanan de otras fuentes como la jurisprudencia, las costumbres, las convecciones internacionales, los principios generales del Derecho, la doctrina, etc." (“Jupiter, Hercules e Hermes...", nota 3, pp. 172-173).

${ }^{959}$ Hércules é o modelo pragmático de juiz de OST, aquele que invoca para si a tarefa de produzir o Direito. Para ele, não existe Direito que não seja o jurisprudencial. É o juiz assistencial, que concilia as famílias em crise, dirige empresas em dificuldades para, se possível, evitar sua quebra, aprecia se a interrupção voluntária da gravidez se justifica pela anencefalia fetal (“Jupiter, Hercules e Hermes...", p. 176). É evidente que, tanto quanto um magistrado Hermes, é importante a altivez e ação do juiz Hércules na concretização de políticas públicas.

${ }^{960}$ Relata BERIZONCE que o uso do método experimentalista foi observado na Argentina, no desenho do remédio para o caso Beatriz Mendoza, em que a Suprema Corte estabeleceu uma "microinstitucionalidad", fixando objetivos, determinando etapas de execução e correspondentes prazos, e a designação de um encarregado institucional pela execução do plano, atuando com autonomia e independência e membro da própria Administração Pública ("Los Conflictos...”, p. 83). Para SALLES, "Quanto maior o número de variáveis envolvidas no cumprimento de uma obrigação, como ocorre naqueles casos ambientais, envolvendo numerosos interessados e problemas implicados com difíceis questões técnicas, maior deverá será a capacidade judicial para responder a situação”. (Execução Judicial..., p. 297). 
Se adotado o enfoque experimentalista, a figura do juiz será essencial. É ele quem vai referendar as opções negociadas pelos atores, avaliar a performance das ações tomadas com base em tais opções, determinar a feitura de novo plano caso o negociado não esteja surtindo bons resultados. Os interessados vão poder recorrer ao juiz em caso de qualquer divergência, sempre lembrando que algum antagonismo de interesses, mesmo na melhor das hipóteses, ainda subsistirá, porque da essência da negociação.

O grande problema em que esbarra esta proposição é pragmático, e decorre da ideologia enraizada no formalismo processual exagerado. Ainda paira sobre a figura do magistrado certa inércia típica do modelo tradicional de resolução de controvérsias. O juiz essencialmente dogmático facilmente consegue se desvencilhar da tarefa de atuar incisivamente em prol da implementação de um direito: basta se ater rigorosamente às normas da legislação processual em vigor, informadas por linhas interpretativas que o exoneram de qualquer iniciativa (com brocardos como, i.e., "o que não está nos autos não está no mundo"961). A judicatura não pode mais se contentar em ser captadora de reclamações, mas deve se conformar, na plenitude, ao seu novo papel instituidor de direitos. Nesse sentido, tem razão Fiss quando anuncia que o juiz exerce o importante papel de dar significado aos valores constitucionais ${ }^{962}$ : e dar esse significado não prescinde de uma atitude mais atuante do magistrado.

A sonora reclamação dos técnicos repousa na falta de poderes para que o juiz, por ele próprio, possa adotar regras que visem a acelerar o procedimento com vistas a uma prestação judicial mais célere. A doutrina da instrumentalidade, tão brilhantemente difundida no Largo de São Francisco, possui como um de seus pilares o fortalecimento dos poderes do juiz com vistas a observar a efetividade da jurisdição ${ }^{963}$. No âmago, o que ora se propõe não é diferente: a necessidade de transformar o juiz em um instrumento de administração e gerência da execução de julgados concernentes a políticas públicas significa, justamente, usar a atitude judicial em prol da efetividade do julgado.

É imperiosa, portanto, a pró-atividade judicial, sobretudo na execução de políticas públicas. Nessa tarefa hercúlea, o juiz pode - e deve - valer-se de assistentes. Um

\footnotetext{
${ }^{961} \mathrm{Ou}$, em Latim, "qued non est in actis, non est in mundo". Apesar desta posição em tudo se contrapor à moderna linha instrumentalista do processo, ensinada com pioneirismo e maestria na Academia do Largo de São Francisco, ainda hoje é possível encontrar decisões judiciais que usam esse antipático postulado que, se de um lado, estimula a iniciativa da parte, de outro incita o juiz a permanecer em uma confortável posição de espera dessa iniciativa (v. TJSP, Apel. Cív. 992.05.018423-6, 34ª Câmara de Direito Privado, Rel. Des. Irineu PEDROTTI, julgado em 12.4.2010).

${ }^{962}$ FISS, “The Forms of Justice...", pp. 1-2.

963 DINAMARCO, A Instrumentalidade...; BEDAQUE, Efetividade do Processo...; OLIVEIRA, Do Formalismo...
} 
dos sistemas que, emprestados do estrangeiro, poderiam funcionar no Brasil é a figura já mencionada do Special Master. Nos Estados Unidos, o Special Master está institucionalmente previsto no ordenamento jurídico, e suas atividades, atribuições e poderes são regulados pela Rule 53 das Federal Rules of Civil Procedure ${ }^{964}$. Alhures, o Special Master é nomeado pelo juiz para a realização de determinadas incumbências, dentre as quais controlar as disposições ordenadas pelo magistrado e assentidas pelas partes, bem como colaborar ativamente na execução do julgado ${ }^{965}$. O Special Master norteamericano possui, também, destacada relevância na condução e definição de acordos relacionados à litigância de massa e outros temas multifacetários como a tutela do meio ambiente e a discriminação laboral ${ }^{966}$.

Os custos com o Special Master são suportados pelas partes. Como sempre, isso é causa de problemas, inclusive nos Estados Unidos, mas todos alhures concordam que os altos custos do especialista, ao fim e ao cabo, compensam diante dos benefícios aproveitados $^{967}$. Como o Master é indicado pelo juiz, há dado de completa imparcialidade, já que cada profissional conta com a confiança plena do magistrado (como idealmente ocorre com o perito do nosso processo civil). Se um Master possuir interesse na causa, deve declinar do encargo. As escolhas se dão com base ou na admiração do juiz pelo talento de certo especialista, ou de acordo com as referências científicas e prestadas por outros magistrados a respeito de determinado Master. Quando convocados para mediar um acordo, o juiz pode indicar mais de um Master para ser entrevistado e escolhido pelas partes, em comum acordo.

Os Special Masters são normalmente escolhidos pelos juízes para substituílos naquilo que eles são deficitários, seja por suas próprias e naturais carências, seja por imposição do sistema. Assim, “(...) juízes usam special masters para atender a certas

\footnotetext{
964 A íntegra da Regra 53 está disponível no sítio eletrônico da Universidade de Cornell (http://www.law.cornell.edu/rules/frcp/Rule53.htm, acesso em 4.1.2010, 19:16h).

965 "The Forms of Justice...", p. 23. SALLES anota a existência do receiver, em geral, pessoa designada pelo juiz em questões de propriedade, bens e administração de negócios, podendo preservar bens ainda sub judice, avaliá-los e, conforme o caso, promover sua alienação ("Injunctions e Contempt of Court em defesa do meio ambiente", em LUCON, Paulo Henrique dos Santos (Coord.) - Tutela coletiva: 20 anos da Lei de Ação Civil Pública e do Fundo de Defesa de Direitos Difusos, 15 anos do Código de Defesa do Consumidor. São Paulo: Atlas, 2006, p. 104).

${ }^{966}$ FEINBERG, Kenneth R. "Creative use of ADR, the court-appointed special settlement master", in 59 Alb. Law Review, $\mathrm{n}^{\circ} 881$ (1995-1996), pp. 881-893. O próprio autor foi Special Master em casos altamente relevantes, como, por exemplo, a discussão relacionada aos danos causados por asbestos e pelo agente laranja, além de, mais recentemente, pelo vazamento provocado pela British Petroleum no Golfo do México. ${ }^{967}$ Para não onerar as partes em demasia, alguns juízes acabam se valendo de auxiliares para agir como se Special Masters fossem (FARRELL, Margaret G. The Function and Legitimacy of Special Masters. 2 Widener L. Symp. J. 235 1997, p. 273). Sobre a questão custo-benefício, v. p. 274-275.
} 
demandas (...) como tempo, expertise, informalidade e humanidade."968. Algumas questões demandam dos juízes um tempo de devoção que eles não possuem, ao passo que Special Masters, afetados somente por determinado tema, podem a ele se dedicar de maneira ao aprofundamento necessário para resolução da celeuma.

Além disso, na saúde, Special Masters podem ajudar o juiz a lidar com questões que fogem à doutrina jurídica, de ordem financeira, epidemiológica, medicamentosa, cultural, de desenvolvimento humano, entre outras. Alguém argumentaria: “mas o que está sendo proposto é encontrado no sistema pátrio, e seu nome é perito: ele também deve ser imparcial e cuida de assuntos dos quais o juiz desconhece". Ora, a comparação, para esses fins, é descabida: no sistema brasileiro, o perito apresenta como resultado uma prova, enquanto que o Special Master é o mediador, o agente, o responsável por zelar pelo cumprimento das ordens emanadas pelo juiz. Os poderes do Special Master, aliás, são completamente diversos daqueles do perito. $\mathrm{O}$ perito brasileiro está muito mais para o Court-appointed Expert norte-americano do que para o Special Master ${ }^{969}$.

Além disso, por possuir mais tempo e executar tarefa epistemologicamente diferente daquela do juiz, o Special Master tem maior capacidade de tratar as partes com humanidade e menos formalidade que o cargo de magistrado exige, propiciando o diálogo e a aceitação das soluções propostas ${ }^{970}$.

Também na Itália existe uma figura ali conhecida como comissario ad acta, pessoa que, no contencioso administrativo, é nomeada para assegurar o efetivo cumprimento da decisão passada em julgado ${ }^{971}$. A origem desse auxiliar foi autorizada em 1928 pelo Conselho de Estado italiano que, independentemente de lei nesse sentido, permitiu que juízes se valessem de terceiros para fazer com que o Poder Público cumprisse os provimentos ordinários ${ }^{972}$. Depois disso e como efeito de sua gênese, o comissario ad

\footnotetext{
${ }^{968}$ FARREL, The Function..., p. 284.

${ }^{969}$ Sobre as diferenças entre o Special Master e o Court-appointed expert, ver FARREL, pp. 284-285.

${ }^{970}$ Essas características do special master foram as encontradas pelo grupo da Fundação Getúlio Vargas que analisou, no âmbito da Secretaria de Assuntos Legislativos do Ministério da Justiça, a aplicabilidade dessa figura nos mecanismos alternativos de resolução de conflitos de interesse público (O Desenho..., 2011, pp. 83-86).

${ }^{971}$ O Articolo 21 del Codice del Processo Amministrativo prevê e define o comissario ad acta, enquanto que o artigo 31 da mesma codificação estabelece que, na sentença de mérito, o juiz nomeia quem será o comissário designado para dar cabo ao julgado. Sobre o empréstimo do comissario ad acta ao direito brasileiro e aplicação quanto à execução de decisões relacionadas à políticas públicas, ver BRASIL Jr. e CASTELLO, “O Cumprimento...", p. 481.

${ }^{972} \mathrm{Na}$ Itália, o contencioso administrativo possui atriz extremamente importante, a Justiça Administrativa, competente por julgar questões que envolvam interesses legítimos oponíveis contra o Estado (casos, por exemplo, de desapropriação ou restrições administrativas na propriedade, ou, ainda, concessão de autorizações para o exercício de certa atividade). Sobre a Justiça Administrativa, ver MANNORI, Luca. "La
} 
acta foi incluído como tema exclusivo da jurisdição administrativa, ajudando o juiz a fazer cumprir uma decisão diante da inércia de cumprimento voluntário do poder público ${ }^{973}$. O comissario ad acta, portanto, é um mandatário do juízo, auxiliando a jurisdição por meio da efetiva execução e, assim, reafirmação da força das sentenças administrativas.

Aqui seria possível adotar medidas análogas. O juiz poderia, dentre cidadãos ou pessoas jurídicas com experiência em administração e, porque não, com histórico em questões do gênero ${ }^{974}$, eleger e nomear um deles para exercício da função de gerente da execução. Essa pessoa teria a incumbência de atuar diretivamente para cumprir o escopo do julgado ou do plano negociado entre as partes e demais atores. Seria ela o elo entre os implementadores - ou aqueles que teriam o ônus de agir - e o juiz ${ }^{975}$.

O gerente da execução se reportaria periodicamente ao juízo, relatando a evolução do cumprimento do julgado, quais as principais dificuldades e propostas para vencê-las, o que seria vital para a avaliação da performance preconizada pelo enfoque experimentalista. O juiz, com base nos trabalhos desse seu funcionário, ficaria mais liberto para apenas supervisionar as ações tomadas. Além de esta solução ganhar em eficiência porque o gerente da execução teria know-how para atuar nessa frente -, haveria inequívoco ganho na administração da justiça, já que o juiz conseguiria mais tempo para enfrentar sua infindável demanda, e o exemplo empírico que, uma vez mais, empresta-se é o do magistrado responsável pela execução da sentença por ele prolatada na ação civil pública relacionada à Síndrome de Kanner ${ }^{976}$.

O Special Master brasileiro, ou o Gerente da Execução, poderia ser - no caso da saúde, por exemplo - um antigo secretário da pasta, ou um médico, ou um

Nascita del Contencioso Amministrativo in Italia", em Quaderni Fiorentini per la storia del pensiero giuridico moderno, 19 (1990), Milano: Giuffre, 1990, pp. 717-728.

973 PRUDENZANO, Lorenzo. "Comissario ad acta", em Altalexpedia - Enciclopédia Giuridica Online, disponível em: <http://www.altalex.com/index.php?idnot=13680>, acesso em 8.7.12, 14:39h.

${ }^{974}$ Como a solução empregada pela Regra 23 (a) (4) das Federal Rules of Civil Procedures que, ao tratar da representatividade adequada, permite a exigência de que o representante seja avaliado, inclusive, de acordo com o histórico de sua atuação em temas da mesma natureza.

${ }^{975}$ De certa forma, a ideia, ainda que timidamente, já vem sendo preconizada pela doutrina. O Projeto de Lei de Ação Civil Pública, por exemplo, possui um artigo $61 \mathrm{com}$ a seguinte redação: “Art. 61. A liquidação $e$ execução do programa homologado judicialmente contarão com a supervisão do juiz, que poderá designar auxiliares técnicos, peritos ou observadores para assisti-lo". De igual maneira se coloca o $\$ 4^{\circ}$ do artigo $5^{\circ}$ do APLPP, assim como seu art. 19, que estabelece, precipuamente, que o juiz pode nomear comissário pertencente ou não à Administração Pública, podendo ser pessoa jurídica, para implementar e acompanhar as medidas necessárias à satisfação das obrigações. Nestes casos, o legislador projetista assumiu, a toda evidência, ser o juiz incapaz - ou capaz, desde que com muita dificuldade - de executar, na prática, um plano de prevenção ou reparação de danos aos direitos difusos, coletivos ou individuais homogêneos.

${ }^{976}$ Das notas colocadas no Item 5.3.1.1 e da consulta ao andamento eletrônico do caso se verifica, como já mencionado, que o trâmite da execução praticamente esgotou o trabalho do juiz, que publicava decisões de laudas inteiras em espaço de horas. 
administrador de hospitais - desde que de imparcialidade inquebrantável. Nesse sentido, o Gerente da Execução teria a prerrogativa, inclusive, participar no desenho do remédio, vale dizer, aconselhando e indicando, com base em sua expertise, a formação das regras que estabeleceriam como a execução deveria funcionar. Funcionariam eles a exemplo e com as mesmas prerrogativas que funcionam outros auxiliares do juízo, em especial, o perito ou, em analogia mais próxima e já tecida, o administrador da recuperação judicial ${ }^{977}$ : figurariam como profissionais de confiança do juízo e com formação técnica apropriada para conduzir questões complexas, revestidos da garantia da imparcialidade e com tarefas muito bem definidas, sendo condignamente remunerados ${ }^{978}$. No julgado experimental, portanto, o Gerente da Execução deveria ser aquele profissional que, indicado pelo juiz e aprovado pelas partes, estabelecer-se-ia como o responsável por conduzir a execução, envidando os melhores esforços para o cumprimento do mandamento judicial. Se a sentença e o plano de execução determinando o asfaltamento de todas as vias públicas da Cidade de São Paulo, o Gerente da Execução será aquele que desenhará e submeterá às partes um cronograma de implementação, dialogando com as partes e relatando os resultados ao juízo; se a sentença e o plano de execução determinaram a construção de dois hospitais em cidades não atendidas pelo SUS, o Gerente da Execução acompanhará e guiará todo o necessário para a feitura desses hospitais; se o julgado e o plano respectivo entenderem haver a necessidade de despoluição de uma bacia hidrográfica ocupada por indústrias poluentes, o Gerente da Execução é quem acompanhará, de perto, a desinstalação de dispositivos poluentes ou mitigação de seus efeitos. O gerente da execução é, no julgado coletivo, essencial.

Voltando-se à figura específica do magistrado, evidentemente que ele deve possuir meios apropriados para exercer seus dotes gerenciais. Daí a especialização e adequação da estrutura ${ }^{979}$ ganham mais relevância. Um cartório ligado ao cotidiano das necessidades que envolvem temas como saúde, educação e todos os outros já mencionados à exaustão neste estudo é medida de racionalidade, inteligência, equilíbrio e respeito com o jurisdicionado e cidadão. E é com racionalidade, inteligência, equilíbrio e respeito que todo e qualquer membro do Judiciário, principalmente o juiz, deve agir quando se deparar com um caso envolvendo políticas públicas.

\footnotetext{
977 O administrador judicial, principalmente na recuperação, é profissional que exerce função de uma importância para o sucesso do plano: ele é o elo entre credores, insolvente e juiz, exercendo todos os atos para conduzir o negócio e mediar essas relações ramificadas. As funções do administrador estão definidas, dentre outros, nos artigos 21 a 25 da Lei no $11.101 / 2005$.

${ }_{978}$ Algumas dessas que são, a propósito, regras do Special Master do Direito norte-americano.

${ }^{979}$ Itens 5.3 e 5.4.
} 
Em casos de políticas públicas, a decisão deve ser antecedida pelo amplo debate e até certo consenso entre os envolvidos, mas, sem dúvida, a execução deve ser negociada e flexível, passível de modificação sempre que os resultados esperados e prédefinidos não forem atingidos. Nesta tarefa, o juiz precisa de auxiliares, mas é ele quem deve comandar a execução. Não se espera do magistrado que domine profundamente todas as nuances da concretização de políticas públicas, até porque isso não seria crível; o que se espera, com sua novel formação, é que ele tenha capacidade gerencial, comandando a execução que será tocada por seus auxiliares. Esta é a ideia apresentada.

Mas sempre que se requer serviço que foge à mecânica tradicional do Judiciário, mormente em ações que envolvem o interesse público, uma questão sempre surge: quem arcará com os ônus financeiros do Gerente da Execução?

Sinceramente, não parece haver saída senão extrair as despesas imediatas oriundas das iniciativas apresentadas de um fundo. O fundo federal - FDD - e os fundos estaduais poderiam muito bem servir para custear as despesas com o gerente da execução. De lege lata, o FDD já poderia custear iniciativas como essa, já que o artigo $1^{\circ}$ da Lei que o disciplina - Lei $n^{o}$ 9.008/95 - destina seus recursos à proteção de outros interesses difusos e coletivos. É fora de dúvida que ações judiciais que versam políticas públicas são abrangidas por essa regra residual.

Aqui, pois, encerra-se o Capítulo destinado aos remédios para a patológica intervenção jurisdicional em políticas públicas de saúde. Encerra-se, também, a parte expositiva desta tese. Passe-se de imediato, pois, ao imprescindível fecho. 


\section{CONCLUSÕES}

O tema explorado nesta tese é instigante, encantador e extremamente importante: instigante porque desafiou a análise de questão tão complexa e diversificada quanto o papel do Judiciário na distribuição de alguns dos mais caros bens da sociedade, objetos de políticas públicas; encantador porque percorreu inúmeras áreas das ciências humanas e sociais aplicadas, todas a fornecer algum ponto para apoiar e provar as hipóteses apresentadas; e, enfim, extremamente importante porque ao mesmo tempo que escancara as mazelas brasileiras na distribuição da saúde, mostra que elas também ocorrem no Judiciário. Ao mesmo tempo em que evidencia a relevância do processo civil como instrumento social, denota suas imperfeições, lacunas e vicissitudes, arvorando-se a estabelecer limites e apresentar algumas saídas.

Ficou claro que não há como escapar ao controle judicial de atos administrativos. A supremacia e a força normativa da constituição, somadas à Judicial Review outorgam ao Judiciário o poder de suprir qualquer lacuna e infirmar qualquer ato que, assim por omissão quanto por ação, viole a ordem jurídica. O mesmo sucede com as políticas públicas: consistindo elas nas ações levadas a efeito pelo Poder Público para concretizar direitos, qualquer falha, excesso ou vazio que implique na inobservância da norma que lhe dá azo poderá ser objeto de escrutínio judicial. Nesse tocante e prima facie, goza de legalidade e legitimidade democrática a intervenção do Judiciário em políticas públicas.

É evidente, e não se furta de rememorar, porque também provado nesta tese, que a atividade administrativa e legislativa, ou seja, o atuar daqueles que têm a primazia por definir, planejar e executar políticas públicas, está sujeita à cooptação e captura por grupos de pressão, além dos interesses dos próprios legisladores e gestores, que podem fazer com que as políticas não sejam pautadas pelo melhor atendimento à população, mas, sim, desviadas para garantir aumento ou permanência no poder desses mesmos agentes. Nesse sentido, inclusive, sucumbiriam grupos com interesses minoritários que não conseguissem se articular.

Provou-se, neste estudo, que o papel do Judiciário como vetor democrático contramajoritário termina, em diversos casos, por equilibrar o jogo de forças do Estado em benefício da sociedade. Viu-se, também, que o processo civil e as garantias próprias da 
magistratura tornam o juiz um sujeito menos passível de sucumbir à captura por interesses alheios à letra da Constituição, da lei e demais normas. Daí ser o Judiciário peça nevrálgica da estrutura social do Estado democrático brasileiro.

Mas não a qualquer custo. Não a qualquer preço.

A intervenção jurisdicional em políticas públicas de hoje em dia vive delicado momento, um momento em que juízes que não estão acostumados, não foram formados e não conseguem raciocinar como administradores, tendo à sua disposição métodos e procedimentos inadequados, terminam por exarar decisões que impactam profundamente em políticas públicas já existentes, desestruturando deveras o planejamento e execução efetivados pela Administração Pública, a reboque de casos em que, efetivamente, ela falhou.

Com efeito, demonstrou-se que magistrados têm invariável tendência a enxergar um processo em que se discute certo dado de política pública de maneira bipolar, tipicamente derivada do modelo processual oitocentista, em que vigora a lógica do tudo ou nada: a procedência do pedido é vitória do autor e derrota da Administração; a improcedência, o contrário. É o que, no caso da saúde, denominou esse autor de argumento linear, basicamente encetado na seguinte fórmula: a Constituição estabelece o dever do Estado de prover saúde a todos, de maneira isonômica; o autor apresenta hipótese em que esse comando foi descumprido, já que ele precisa de medida de saúde que não lhe chegou; isso basta para que lhe seja outorgada, pelo Poder Público o bem almejado.

Entretanto, com políticas públicas não pode ocorrer desse modo - sobretudo as de saúde. Quedou demonstrado que a atuação estatal na entrega de direitos - não apenas, mas, principalmente, direitos sociais - não prescinde de extenso planejamento, estabelecimento de programas e estratégias que vão desde isolar quais serão as medidas tomadas e quanto custarão elas até a efetiva entrega ao cidadão. No caso da saúde, verificou-se como é complicado definir, inclusive, qual medicamento incluir nas listas de dispensação obrigatória; imagine-se determinar uma política inteira de tratamento a toxicômanos. A lógica de command-and-control, ou do cumpra-se, não se aplica às políticas públicas. Pois foram trazidos dados que provam que essa tônica e a do argumento linear imperam na intervenção do Judiciário em políticas públicas, sobretudo as de saúde.

Ora, ainda que o Legislativo e o Executivo dispusessem de todos os recursos possíveis e imagináveis - humanos, financeiros, informacionais - seria necessário planejamento para prover saúde à sociedade. Mas os recursos são escassos. E é precisamente essa sua inerente característica que torna o planejamento eficaz mais 
importante, porque somente por ele é que a saúde chegará, com qualidade, à maior parte da população. A escassez torna a definição de políticas públicas autêntico jogo de escolhas: escolhas entre aqueles que serão e outros que não serão contemplados.

Além da escassez, o direito à saúde possui particularidades que tornam ainda mais dramática sua tutela judicial: ele deve ser assegurado universalmente da forma mais abrangente possível e de maneira igualitária. Em outras palavras, absolutamente todas as pessoas, em igualdade de condições, têm direito aos meios preventivos e curativos de manutenção da boa saúde. Essas duas características tornam o direito à saúde especial, e complicam ainda mais a tarefa do magistrado, sobretudo em um país em que o abismo social é perceptível à primeira vista.

Não nos enganemos: ao decidir por atender ou não o pleito do autor, o juiz também, com frequência, realiza escolhas, embora assim ele não enxergue: ele opta por agraciar aquele que conseguiu transpor todos os obstáculos que o levaram a se eleger apto a obter uma decisão judicial em detrimento do outro, ou outros, que, nas mesmas condições, não puderam se valer de recursos que o colocasse, ou os colocassem, em posição análoga a do autor. O prejuízo dos demais ocorre porque o dinheiro que fará frente ao cumprimento da decisão judicial será, possivelmente, o mesmo que teria como destino o atendimento de demandas que beneficiariam, precisamente, o outro - ou outros. Os dados trazidos neste estudo demonstram o impacto no orçamento da saúde das decisões judiciais envolvendo a matéria. É a lógica do cobertor curto: para custear as decisões judiciais, políticas que contemplariam outros - às vezes, de forma ainda mais abrangente e eficaz não serão efetivadas. Daí que, ao decidir a respeito de políticas públicas - seja em ação individual ou coletiva - os magistrados devem entender que os direitos têm custos, daí porque conhecer o orçamento deve estar na ordem do dia.

Porque a ótica bipolar e o argumento linear respondem pela maioria das decisões judicias no campo da saúde, é o caso de se debruçar sobre o tema para, isolando os motivos determinantes e as decisões patológicas, fixar limites à atuação judicial e ofertar remédios, soluções para que a tutela jurisdicional da saúde se dê de forma mais racional e equilibrada. É verdade que alguns magistrados, sensíveis aos inúmeros aspectos que circundam o tema Judiciário e saúde, já têm tomado decisões que vão ao encontro do ora preconizado. Também se viu que há anteprojetos e projetos de lei que caminham na mesma linha seguida por esta tese. Trata-se, destarte, de prova da validade da pesquisa ora apresentada, ao mesmo tempo em que empolgam o autor os ventos de mudança.

Vamos, então, aos limites. 
Decisões judiciais que tutelam saúde devem se preocupar com a escassez e, assim, a reserva do possível deve fazer parte do repertório de inquirições do magistrado. Se o Poder Público demonstrar que não há reservas para custear a demanda autoral, o juiz precisa investigar se a ausência de fundos deriva de escolhas do administrador ou se, de fato, ela é fruto de escassez absoluta, ou, ainda, quem pagará a conta do deslocamento de receitas provocado pelo atendimento do pedido. Na primeira hipótese, a reserva do possível não poderá ser invocada, já que fruto de discricionariedade administrativa; no caso da escassez absoluta, a reserva do possível será oponível desde que inescrupulosamente provada, já que inexistentes recursos; por fim, quanto ao impacto orçamentário da decisão, o juiz deverá ponderar e decidir nos moldes da razoabilidade, outro limite.

Também o que deve ser judicialmente provido é o mínimo para assegurar dignidade ao jurisdicionado, e, aí, o mínimo existencial constitui outro parâmetro que precisa ser observado. Originalmente desenhado para assegurar direitos, neste estudo mostra-se que o mínimo existencial, no caso da saúde, serve para impor esteios ao usufruto de direitos, daí falar-se em aspecto bifronte do mínimo existencial, ou mínimo existencial sob viés negativo: na tutela jurisdicional da saúde, nenhum luxo será tolerado - daí que os produtos e procedimentos aprovados nos protocolos e incluídos no SUS e em suas listas constituem excelente parâmetro do que é mínimo.

Não basta demandar recursos nem ser apenas o mínimo: é preciso que o pedido guarde razoabilidade, é dizer, não serão concedidos requerimentos por medicamentos fora das listas se nelas houver fármaco equivalente; não será permitido tratamento no exterior se, no Brasil, houver alternativa razoavelmente eficaz. A razoabilidade é o justo equilíbrio balizado pela proibição de excesso e pela vedação à proteção insuficiente. Partindo das premissas que o direito à saúde é universal e deve ser isonomicamente prestado, além de que os recursos são escassos, qualquer medida judicial pleiteando saúde deverá passar pelo teste da proporcionalidade em sentido estrito, vale dizer, qual será a saída mais vantajosa e menos prejudicial às partes envolvidas - no caso, não o autor e o Estado, mas o autor e a coletividade de pessoas que também fazem jus à mesma saúde por ele pretendida.

Prosseguindo, é imperativo que o juiz conheça as ações sanitárias do Poder Público antes de decidir qualquer demanda em que o bem objetivado tenha relação com saúde. Essa providência eliminaria aleivosias como mandar o Poder Público entregar medicamento à disposição nos postos de saúde ou ordenar providência já em fase de execução pela Administração Pública. Por vezes o jurisdicionado simplesmente 
desconhece que existem medidas que atendem seu direito. Por vezes, igualmente o desconhecem os juízes. A falta de diálogo com a Administração Pública é um defeito elementar capaz de contaminar a tutela judicial. Por isso, via de regra, tutelas antecipatórias concedidas liminarmente devem ser exceção, não regra do sistema, e só devem ser concedidas se, de fato e comprovadamente, o risco correspondente for irreversível.

Há, enfim, como limites, dois balizadores particularmente aplicáveis à saúde: a preferência por medicamentos e tratamentos previstos nas listas públicas e a necessidade de registro prévio do medicamento no órgão sanitário. As relações públicas de fármacos e procedimentos norteiam as políticas de saúde no Brasil. Os itens ali estabelecidos serão os distribuídos na rede pública, e passam a figurar na lista depois que se mostrarem seguros, eficazes e econômicos. Por serem fruto de planejamento, tais itens são adquiridos pelo Estado por meio de certame licitatório na modalidade preço, o que gera maior economia ao Erário. Quanto ao registro, ele é ato indispensável à comercialização de qualquer medicamento ou equipamento de saúde, porque demanda análise prévia de segurança e eficácia. Se não forem registrados e, portanto, impassíveis de comercialização, não podem ser concedidos por decisão judicial, salvo raras exceções imputáveis à burocracia estatal desarrazoada.

É tempo, pois, dos remédios.

E o primeiro apresentado parte da premissa que, como universal que é, e como igualmente dispensável que deve ser, a melhor forma de guarida judicial do direito à saúde é a coletiva. Com o uso da tutela metaindividual, tanto a universalidade quanto a isonomia incrustadas na norma constitucional têm maior chance de serem atendidas. Difusa, coletiva ou individual homogênea a tutela à saúde requerida, o tratamento coletivo é o que garantirá aplicação abrangente e isonômica da solução encontrada. Daí derivam algumas conclusões que redundam nas saídas colocadas.

A ação individual que, inocentemente, requer certo medicamento, via de regra, distorce o adequado tratamento do direito à saúde. Primeiro, porque são essas ações individuais a maior causa de impacto nas políticas de saúde, já que são decididas como se de direito subjetivo puro e simples tratassem e não dão ao juiz a verdadeira noção dos reflexos de sua decisão. Tais medidas constituem campo propício para o surgimento de dois graves problemas: o primeiro, o exercício da chamada justiça de misericórdia, aquela que ganha a comoção do juiz, que deixa de decidir em base racionais para deliberar emocionalmente - quase sempre, a favor do autor; o segundo, o privilégio desmedido 
àqueles que enxergam e conseguem manejar os complicados instrumentos processuais e judiciários, à míngua da maioria da população, que não consegue. O estudo traz a prova da ocorrência casuística de ambos os nocivos fenômenos. A tutela coletiva é a única ferramenta capaz de relativizar, senão debelar esse uso patológico das ações individuais de saúde.

São, destarte, quatro os remédios propostos com vistas ao tratamento coletivo desse direito universal: o caso piloto, o incidente de coletivização, a expansão dos efeitos da decisão puramente individual e a formulação ampla do pedido na ação coletiva. O primeiro deles é mais instrumento de uniformização do que, propriamente, de coletivização, porque almeja tratar isonomicamente processos análogos.

O caso piloto trabalha com multiplicidade, ou seja, se ficar constatado que o objeto de certa ação guarda congruência com outras tantas, então poderá ser suscitado incidente para escolha de um caso, ou de casos que sejam representativos da controvérsia, para decisão a ser aplicada a todos os demais, tanto na hipótese de procedência, quanto na de improcedência, sempre que o direito em tela for puramente individual ou individual homogêneo.

No incidente de coletivização, basta uma única ação cujo objeto o juiz considere ter potencial coletivo para que ela seja coletivizada e, assim, abranja todas as pessoas na mesma situação do autor. A repetição de feitos também justificará a adoção da medida, mas desde que o que se discuta nesses processos sejam direitos difusos e coletivos, objetos precípuos do incidente. O que pode parecer agressivo e arbitrário, por extrair a autonomia individual, nada mais é do que absolutamente condizente com a qualidade do direito à saúde.

$\mathrm{Na}$ expansão dos efeitos da decisão puramente individual, a tutela antecipada, sentença exequível ou decisão transitada em julgado manifestada em ação individual poderá aproveitar a todos aqueles que se encontrem na mesma situação do autor, ou em que haja prevalência da comunhão de direitos, ou seja, casos de direitos individuais homogêneos. O remédio teria o condão de outorgar universalidade e isonomia a uma decisão que se apresenta como individual, mas, no fundo, poderia beneficiar inúmeras pessoas que se colocam em posição análoga. Para seu emprego, seria necessária a suavização dos dogmas da coisa julgada e seus limites subjetivos e objetivos, além da adstrição e da congruência. Para esta hipótese, tanto quanto para as duas anteriores, seria necessária modificação legislativa. 
Já a formulação ampla do pedido na ação coletiva não carece de qualquer novel legislação e poderia servir como gatilho para propiciar a maleabilidade necessária à execução do julgado coletivo em políticas públicas de saúde. Permitira mais, que poucos erros fossem cometidos no atendimento dos pedidos, relegando-se à execução as medidas concretas de implementação da política pública. O pedido hermético pode inviabilizar a adoção da melhor estratégia para conformar a prática da saúde à norma constitucional.

A ideia dos bancos de dados nacional, estadual e regional de ações que versam sobre políticas públicas, acompanhados, simetricamente, por paralelos quanto aos inquéritos civis, compromissos de ajustamento de conduta, além de procedimentos da Defensoria, são remédios de apoio que permitirão a aplicação das medidas tendentes à coletivização, além de proverem ao juiz, quando diante de um processo dessa natureza, retrato da dimensão do objeto com o qual está lidando. O sistema de consulta deve estar disponível já na distribuição, o que permitirá a reunião de feitos e procedimentos, a preferencialmente tramitar nos juízos especializados em políticas públicas.

Também, especificamente quanto aos juízes e a estrutura judiciária, são propostas a criação de juízos especializados em políticas públicas, a exigibilidade do tema nos concursos públicos e a formação dos magistrados. Como as políticas públicas são tema multifacetário que, portanto, envolve uma série de importantes aspectos - como há de se ter visto, a propósito, nesta tese - é preciso que se especializem os magistrados, criando varas específicas e formando juízes para lidarem com o tema. As varas seguiriam os mesmos critérios usados para estabelecimento de varas de fazenda e, onde não houvesse, o juiz cível da comarca, devidamente formado, estaria apto a melhorar o ofício de judiciar tais políticas.

Ademais, como remédios, a matéria de políticas públicas, com ênfase no Direito Sanitário, deveria ter lugar nos cursos jurídicos de graduação e pós-graduação, a fim de formar massa crítica para lidar com o assunto - e envolver não apenas juízes, mas advogados, promotores e juristas. Esboço de currículo foi apresentado no item que trata especialmente do tema.

No que toca às políticas públicas presentes no foro, como sucede com a saúde, amplo debate entre os Poderes deve ter lugar. Principalmente Executivo e Judiciário devem dialogar e debater não apenas para que cada um conheça o que está sucedendo com o outro, mas que se ajudem e se apoiem a evitar que assuntos que deveriam ser tratados no âmbito administrativo desemboquem nas ameias do Judiciário. 
O último remédio proposto talvez seja o mais importante: a execução do julgado de políticas públicas deve ser experimental, a fim de que, por meio de planejamento e sistema de periódico acompanhamento e avaliação, cheque-se se estão sendo tomadas as melhores medidas para o atendimento e dispensação daquele dado direito - no particular, a saúde. As medidas executivas devem ser negociadas e implementadas em conjunto entre interessados e Poder Público - e a presença deste é indispensável, porque tem o domínio da técnica e a chave do cofre. O juízo deve acompanhar a execução de tais medidas, valendo-se de um administrador, o Gerente da Execução, para lhe auxiliar e tomar a linha de frente na condução dos trabalhos. Se ficar constatado que determinada ação não surtiu os efeitos desejados, outra será pensada, planejada e executada. É o experimentalismo das ações. Só assim que haverá correção ou implementação da política pública faltante: o juiz e os interessados agirão como um tomador de contas das ações do Poder Público, tudo em função de um julgado experimentalista.

Tanto as propostas de limitação quanto os remédios apresentados devem ser entendidos em conjunto, vale dizer, eles devem ser aplicados concomitantemente. Ao mesmo tempo em que o juiz deve investigar o que é minimamente aceitável ao grupo que dele pleiteia certo bem, será de rigor inquirir quais são as ações já tomadas pela Administração Pública a respeito, e saber, em caso de ordenação da providência, se o Erário será suficiente para atender a todos os programas do Poder Público e, também, à decisão judicial, tudo isso em um cenário que atinja a todas as pessoas na mesma situação - mediante coletivização forçada ou expansão dos efeitos do julgado individual - e determinado por um juiz especialmente preparado para lidar com políticas públicas. Nesse cenário, o magistrado será assessorado por um gerente, pessoa qualificada, remunerada condignamente e altamente capaz de planejar, em conjunto com as partes e com o juiz, o desenho da execução da decisão, genérica, porém precisa, e amplamente interpretada.

Pretendeu-se propor medidas, destarte, de: (a) interpretação (i.e., acerca do pedido da ação coletiva ou coletivizada, da sentença e da aplicação do conceito de razoabilidade); (b) informação (i.e., sobre as ações análogas e as medidas que toma a Administração a respeito do pedido); (c) prova (i.e., aumento da investigação judicial sobre circunstâncias relacionadas ao registro, regularidade e custos dos medicamentos e terapias requeridos, além da própria análise orçamentária, da reserva do possível e do mínimo existencial); (d) flexibilização do procedimento (i.e., com a suavização dos dogmas da coisa julgada, congruência e inércia da jurisdição); (e) alteração da estrutura 
judicial e do procedimento (i.e., criação de juízos especializados, formação dos magistrados, assunção do papel do juiz como gestor da execução, criação de banco de dados sobre ações de políticas públicas, execução flexibilizada e experimental, auxílio do gerente da execução).

Da tese é possível observar que ações judiciais em que políticas públicas são discutidas devem ostentar sete características básicas:

a) o entendimento de que a jurisdição, no caso, é prospectiva e distributiva: as ações dessa estirpe envolvem, quando sindicam bens coletivos, o enfrentamento do aparato do Estado, desafiando a ordem das coisas para debelar o descumprimento de direitos. A decisão pode desestruturar uma política pública já em curso, ou estabelecer uma política inexistente, com o que também ela envolverá a execução de planos e programas típicos de políticas públicas. Como tais, esses planos e programas têm execução protraída no tempo e envolvem a distribuição, à população, de bens objeto de direitos sociais que devem ser dispensados pelo Poder Público. Nesta ação não funciona o tudo-ou-nada do modelo bipolar e oitocentista de processo civil.

b) o aumento dos poderes do juiz: o magistrado deve ter incrementados seus poderes tanto na fase de conhecimento quanto na execução. Será dele a responsabilidade por ordenar e instruir a causa de modo a atingir a finalidade estabelecida na norma. De fato, ele quem estabelecerá diálogo com Legislativo e, sobretudo, Executivo, ele quem zelará pela observância dos limites e aplicação dos remédios, ele quem se responsabilizará por dirigir a execução experimental.

c) a estrutura dialógica: o processo de políticas públicas não prescinde de amplo diálogo, que deve informar todas suas etapas. No início, o juiz deve ouvir do Poder Público quais ações tomadas e pertinentes ao que se demanda. O processo também deve abrir espaço para discussões sobre os dinheiros públicos e outros temas, como o mínimo existencial. Deve promover audiências, muitas das quais, públicas, com participação da sociedade civil. É preciso que o instrumento propicie o debate entre os próprios juízes, a fím de verificar quais são os gargalos no trato judicial de políticas públicas. Os amici curiae 
devem participar nos feitos de modo a enriquecer o debate. Processos como os vistos nesta tese devem buscar o diálogo.

d) a adoção de técnicas de uniformização e coletivização: já que políticas públicas envolvem dois atributos inarredáveis - a universalidade e a isonomia (sobretudo a saúde, por força normativa constitucional) - a ação individual deve ser excepcionalmente analisada, esforçando-se os atores do jogo processual, ao máximo, para coletivizar ou tratar uniformemente as questões.

e) a flexibilização de causas de pedir, pedidos, execução e dogmas processuais a eles ligados: o processo ora analisado não pode estar preso às clássicas regras, dogmas e princípios do processo civil tradicional quando eles conflitarem com a natureza dos bens em discussão. Os pedidos, por exemplo, devem ser formulados de maneira ampla, para propiciar comando genérico de sentença, o que facilitará a execução experimentalista. É medida de rigor que as modificações desses pedidos e de suas causas também sejam permitidas. A execução deve ultrapassar os freios objetivos e subjetivos que imobilizam a sentença, permitindo uma contínua revisão, avaliação e modificação, todos sabedores que ela pode não se esgotar, revelando contínuo processo de implementação da política em destaque.

f) a especial formação jurídica: os operadores de políticas públicas, sobretudo, os juízes, têm de possuir a peculiar formação jurídica necessária para lidar com a miríade de questões que envolvem o planejamento e a execução de políticas públicas, dominando, ainda que não com a profundidade de um financista, sanitarista ou pedagogo, noções do orçamento público, de Direito Sanitário, Educacional e outros objetos de distribuição estatal, além de administração, para bem conduzir a execução do julgado.

g) o emprego de estrutura judiciária apropriada: são necessários juízes e cartórios especializados em políticas públicas, a manutenção de cadastros de medidas judiciais, inquéritos civis, termos de ajustamento de conduta e congêneres, um agente que funcione 
como ombudsman para ouvir e gerenciar reclamos quanto à execução do julgado, além, claro, de um gerente da execução, especialista designado para levar a efeito a decisão, sendo dirigido pelo magistrado.

É com os olhos nestas características que operam as proposições apresentadas nesta tese, que não têm a pretensão de esgotarem o assunto, mas que devem ser empregadas integradamente, sem prejuízo de, caso uma delas se mostre impraticável, o sejam as demais - e, mesmo assim, com razoável êxito. Logra-se para que a tutela jurisdicional da saúde, nos casos em que se fizer necessária, dê-se com mais racionalidade e equilíbrio, privilegiando isonomia e universalidade. 


\section{BIBLIOGRAFIA ${ }^{980}$}

\section{Livros e periódicos jurídicos}

AFONSO DA SILVA, José. Aplicabilidade das Normas Constitucionais. $5^{\text {a }}$ ed. São Paulo: Editora Malheiros, 2001.

Editores, 2006.

. Curso de Direito Constitucional Positivo. 27 ed. São Paulo: Malheiros

Orçamento-Programa no Brasil. São Paulo: Revista dos Tribunais, 1972.

ALEXY, Robert. Conceito e Validade do Direito. São Paulo: Martins Fontes, 2009.

. Teoria dos Direitos Fundamentais. São Paulo: Malheiros, 2008.

ALVIM, Eduardo Arruda. "Coisa Julgada e litispendência no Anteprojeto de Código Brasileiro de processos Coletivos", em "Direito Processual Coletivo", em GRINOVER, Ada Pellegrini; MENDES, Aluisio Gonçalves de Castro e WATANABE, Kazuo (coord.). Direito Processual Coletivo e o Anteprojeto de Código Brasileiro de Processos Coletivos. São Paulo: Editora RT, 2008.

ALMEIDA, Carlos Otávio Ferreira. "O planejamento financeiro responsável: boa governança e desenvolvimento no Estado contemporâneo", em CONTI, José Mauricio, e SCAFF, Fernando Facury (coord.). Orçamentos Públicos e Direito Financeiro, São Paulo: Editora RT, 2011, pp. 578-599.

AMARO, Fernanda Pereira. "O serviço público sob a perspectiva da garantia constitucional de direitos humanos fundamentais", em Revista de Direito Constitucional, $\mathrm{n}^{\mathrm{o}} 50$, janeiro de 2005, pp. 116-118.

AMENDOEIRA Jr., Sidnei. Poderes do Juiz e Tutela Jurisdicional: A Utilização Racional dos Poderes do Juiz como Forma de Obtenção da Tutela Jurisdicional Efetiva, Justa e Tempestiva. São Paulo: Atlas, 2006.

${ }^{980}$ Organizadas de acordo com o Sistema Autor-Data, cf. NBR 6023, da Associação Brasileira de Normas Técnicas. 
ANDRADE, Paes e BONAVIDES, Paulo. História constitucional do Brasil. $3^{\mathrm{a}}$ ed. Rio de Janeiro: Editora Paz e Terra, 1991.

APPIO, Eduardo. Controle Judicial das Políticas Públicas, $1^{\text {a }}$ Ed. Curitiba: Juruá, 2008.

ARISTÓTELES. Ética a Nicômaco. Brasília: UnB, 1999. Política. São Paulo: Nova Cultural, 1999.

ARROW, Kenneth J. Social Choice and Individual Values, 1963, 2ª ed.

ASCH, Solomon Eliot. "Forming Impressions of Personality", in The Journal of Abnormal and Social Psyhcology, v. 41, 1946, pp. 258-290.

BADIN, Arthur Sanches. Controle Judicial de Políticas Públicas. Dissertação de Mestrado apresentada ao Departamento de Direito Econômico da Faculdade de Direito da Universidade de São Paulo, 2011.

BANDEIRA DE MELLO, Celso Antônio. Curso de Direito Administrativo, $21^{\mathrm{a}}$ ed., São Paulo: Malheiros, 2006.

Conteúdo Jurídico do Princípio da Igualdade. $3^{\mathrm{a}}$ ed., São Paulo:

Malheiros, 2010.

BARATA, Luís Roberto Barradas e MENDES, José Dínio Vaz. "Uma proposta de política de assistência farmacêutica para o SUS", em BIACHERIENE Ana Carla e SANTOS, José Sebastião dos (org.). Direito à Vida e à Saúde, . São Paulo: Atlas, 2010.

BARATA, Rita de Cássia Barradas e CHIEFFI, Ana Luiza. “Ações judiciais; estratégia da indústria farmacêutica para a introdução de novos medicamentos”, em Revista de Saúde Pública $n^{\circ}$ 44, pp. 421-429.

BARBOSA, Marília Costa. "Revisão da Teoria da Separação dos Poderes do Estado", em Rev. Cient. Fac. Lour. Filho - V. 5, n 1, 2006, pp. 1-16.

BARBOSA MOREIRA, José Carlos. Temas de Direito Processual-Terceira Série. Rio de Janeiro: Saraiva, 1984. 
Litisconsórcio Unitário. Rio de Janeiro: Forense, 1972.

. "Correlação entre o pedido e a sentença." em Revista de Processo no 83.

São Paulo: Editora Revista dos Tribunais, julho-set. 1996.

BARCELLOS, Ana Paula de. “Constitucionalização das políticas públicas em matéria de direitos fundamentais: o controle político-social e o controle jurídico no espaço democrático", em SARLET, Ingo Wolfgang, e TIMM, Luciano Benetti (coord.). Direitos fundamentais, orçamento e "reserva do possivel". Porto Alegre: Livraria do Advogado, 2008, pp. 111-147.

Renovar, 2002.

. A eficácia jurídica dos princípios constitucionais. Rio de Janeiro:

do Brasil", em Revista do Advogado n 99, Setembro de 2008, p. 84.

. "Judicialização, Ativismo Judicial e Legitimidade Democrática", em

COUTINHO, Jacinto Nelson de Miranda; FILHO, Roberto Fragale; e LOBÃO, Ronaldo (org.). Constituição \& Ativismo Judicial. Limites e Possibilidades da Norma

Constitucional e da Decisão Judicial. Rio de Janeiro: Lúmen Juris Editora, 2011, pp. 287288.

. Curso de Direito Constitucional Contemporâneo. São Paulo: Saraiva,

2009.

BEDAQUE, José Roberto dos Santos. Direito e Processo: Influência do Direito Material sobre o Processo. $4^{\text {a }}$ ed. São Paulo: Malheiros, 2006.

2006.

. Efetividade do Processo e Técnica Processual. São Paulo: Malheiros,

BENETON, Marco Antonio Hatem. "O Plano Plurianual, os contratos administrativos e a Teoria do Diálogo das Fontes: os exemplos de elos entre o Direito Financeiro e o Direito Administrativo", em CONTI, José Mauricio, e SCAFF, Fernando Facury (coord.).

Orçamentos Públicos e Direito Financeiro, São Paulo: Editora Revista dos Tribunais, 2011, pp. 601-617.

BERIZONCE, Roberto Omar. "Los Conflictos de Interés Publico", em Revista de Derecho Procesal n 2. Buenos Aires: 2011, pp. 84-88. 
BILCHITZ, David. "Justifying the Judicial Review of Fundamental Rights". Poverty and Fundamental Rights: The Justification and Enforcement of Socio-Economic Rights. Oxford: 2007, Oxford University Press, pp. 102/134

BISSI, Rythielle de Medeiros. "Reserva do Possível: Instrumento Inconstitucional Mitigador dos Direitos Fundamentais Sociais", em Revista Olhar Científico - Faculdades Associadas de Ariquemes, v. 1, nº 1, jan/jul 2010.

BITTENCOURT, Fernando Moutinho Ramalho e da GRAÇA, Luis Otávio Barroso. "Decisões judiciais e orçamento público no Brasil: uma aproximação empírica a uma relação emergente", em SARLET Ingo W. e TIMM, Luciano B. (org.). Direitos Fundamentais, Orçamento e `Reserva do Possível`, Porto Alegre: Livraria do Advogado Editora, 2008, pp. 217-263.

BOBBIO, Norberto. A Era dos Direitos. São Paulo: Martins Fontes, 1992

BONAVIDES, Paulo. Curso de Direito Constitucional, 25ª ed. São Paulo: Malheiros, 2010.

BORGES, Danielle da Costa Leite; UGÁ, Maria Alícia Dominguez. "Conflitos e impasses da judicialização na obtenção de medicamentos: as decisões de $1^{\mathrm{a}}$ instância instância nas ações individuais contra o Estado do Rio de Janeiro". Brasil. 2005. Cadernos Saúde Pública, Rio de Janeiro. 26(1):59-69. jan. 2010.

BORGES, Arleth Santos. "Papel do Poder Legislativo na produção de políticas públicas no Maranhão", apresentado na II Jornada Internacional de Políticas Públicas, promovida pela Universidade Federal do Maranhão em São Luís entre 23 e 25 de agosto de 2005.

BRASIL. Caderno de Atividades - Curso de Capacitação de Conselheiros Estaduais e Municipais em Saúde. Brasília: Ministério da Saúde, 2002.

. Manual de Direito Sanitário com Enfoque na Vigilância em Saúde.

Brasília: Ministério da Saúde, 2006.

BRASIL Jr., Samuel Meira; e CASTELLO, Juliana Justo Botelho. "O cumprimento coercitivo das decisões judiciais no tocante às políticas públicas”, em GRINOVER, Ada Pellegrini e WATANABE, Kazuo (coord.). O Controle Jurisdicional de Políticas Públicas. São Paulo: Forense (Gen), 2011, p. 482-484. 
BUCCI, Maria Paula Dallari, et. alli., "Buscando um Conceito de Políticas Públicas para a Concretização dos Direitos Humanos.”, em Direitos Humanos e Políticas Públicas, São Paulo: Polis, 2001.

. "O Conceito de Políticas Públicas em Direito", em Políticas Públicas:

reflexões sobre o conceito jurídico. São Paulo: Saraiva, 2006.

CALABRESI, Guido e BOBBIT, Philip. Tragic Choices - The conflicts society confront in the allocation of tragically scarce resources. New York and London: W. W. Norton \& Company, 1978.

CAMPOS, Francisco. "Orçamento - Natureza Jurídica”, em Revista de Direito Administrativo $\mathrm{n}^{\circ} 71$ - janeiro/março de 1973, p. 324 e seguintes.

CAMPOS, Roberto. O Século Esquisito. Rio de Janeiro: Topbooks, 1990.

CANELA Jr., Oswaldo. A Efetivação dos direitos fundamentais através do processo coletivo: um novo modelo de jurisdição. Tese de doutoramento apresentada ao Departamento de Direito Processual da Universidade de São Paulo, orientada por Kazuo Watanabe.

CANOTILHO, José Joaquim Gomes. Dignidade da Pessoa Humana e Direitos Fundamentais na Constituição Federal de 1988. Porto Alegre: Livraria do Advogado, 2001. Direito Constitucional e Teoria da Constituição. $3^{\mathrm{a}}$ ed., Coimbra,

Almedina

CAPPELLETTI, Mauro, e GARTH, Bryant. Access to Justice: The Worldwide Movement to Make Rights Effective. Trad. Ellen Gracie Northfleet (Acesso à Justiça), Porto Alegre, Sérgio Antonio Fabris Editor, reimpressão 2002.

CAPPELLETTI, Mauro. Juízes Legisladores? Porto Alegre: Sérgio Antonio Fabris Editor, 1999.

Juízes Irresponsáveis? Porto Alegre: Sérgio Antonio Fabris Editor, 1989.

. "Formações sociais e interesses coletivos diante da justiça civill". Revista de Processo, Ano II, $\mathrm{n}^{\circ}$ 5, Jan/Mar, 1977. 
CARNEIRO, Athos Gusmão. 'O 'cumprimento da sentença', conforme a Lei ${ }^{\circ}$ 11.232/2005. Parcial retorno ao medievalismo? Por que não?”, em Revista do Advogado ${ }^{o}$ 85, Maio/2006, pp. 13-35.

CARR, Lauren Wilson. "Wyaat v. Stickney: a Landmark", in Alabama Disabilities Advocacy Program Newsletter, July 2004, 1-3.

CARRAZZA, Roque Antonio. Curso de Direito Constitucional Tributário. $19^{\mathrm{a}}$ ed. São Paulo: Malheiros, 2003.

CARVALHO, André Castro. "O Impacto Orçamentário da Atuação do Poder Judiciário", em AMARAL Jr., José Levi Mello do (coord.). Estado de Direito e Ativismo Judicial,. São Paulo: Quartier Latin, 2010.

CASTRO, Carlos Roberto Siqueira. O Devido Processo Legal e os Princípios da Razoabilidade e da Proporcionalidade. $5^{\text {a }}$ edição. Rio de Janeiro: Forense, 2010.

CASTRO, Sebastião Helvecio Ramos. "Impacto desalocativo no orçamento público estadual em face de Decisões Judiciais". IV Prêmio SOF de Monografias. Belo Horizonte: 2010 .

CAVALIERI FILHO, Sérgio. Programa de Responsabilidade Civil, $9^{\mathrm{a}}$ ed., rev. e amp., Atlas: São Paulo, 2010

CHAYES, Abraham. "The Role of the Judge in Public Law Litigation", 89, in Harvard Law Review 1281 (1976).

CHEMIRINSKY, Erwin. "Foreword: the Vanishing Constitution", in Harvard Law Review 43, 71 (1989), p. 61.

CHIEFFI, Ana Luiza; CORREA, Maria Cecília M. M. A.; e FILHO, Michel Nattan. "SCodes: um novo sistema de informação sobre ações judiciais da Secretaria de Estado da Saúde de São Paulo.” Boletim BEPA 7(84) - 2010, pp. 18-30.

CHIOVENDA, Giuseppe. Instituzioni di Diritto Processuale Civile. Trad. Paolo Capitaneo. (Instituições de Direito Processual Civil), 2ª ed. Campinas: Bookseller, 2002. 
COMPARATO, Fábio Konder. "Ensaio sobre o juízo de constitucionalidade de políticas públicas", em Estudos em homenagem a Geraldo Ataliba. São Paulo: Malheiros Editores, 1997.

. "O Ministério Público na defesa dos direitos econômicos, sociais e culturais", em GRAU, Eros Roberto (org.). Estudos de direito constitucional em homenagem a José Afonso da Silva. São Paulo: Malheiros, 2003.

CONTI, José Mauricio. A Autonomia Financeira do Poder Judiciário. São Paulo: MP Editora, 2006.

COSTA, Susana Henriques e SILVA, Paulo Eduardo (coord.). A Eficácia do Sistema Jurídico de Prevenção e Combate à Improbidade Administrativa. Série Pensando o Direito. Brasília: Ministério da Justiça, 2011.

CUNHA, Luciana Gross e GABBAY, Daniela Monteiro (coord.). O Desenho de Sistemas de Resolução Alternativa de Disputas para Conflitos de Interesse Público. Série Pensando o Direito, no 38. Brasília: Ministério da Justiça, 2011.

CUNHA, Luciana Gross; BUENO, Rodrigo de Losso da Silveira; OLIVEIRA, Fabiana Luci de; SAMPAIO, Joelson de Oliveira; RAMOS, Luciana de Oliveira; KLINK, Yuri Campos. Relatório do ICJ Brasil referente ao $1^{\circ}$ Trimestre de 2012, Rio de Janeiro: Direito GV, 2012.

DALLARI, Dalmo. Elementos de Teoria Geral do Estado. 20ª ed. São Paulo: Saraiva, 1998.

DANTAS, Nara Soares. Medicamentos Excepcionais. Brasília: Escola Superior do Ministério Público da União, 2006

DEPRÁ, Aline Scaramussa e SOARES, Jussara Calmon Reis de Souza. "Ligações perigosas: indústria farmacêutica, associações de pacientes e as batalhas judiciais por acesso a medicamentos", em Physis Revista de Saúde Coletiva, Rio de Janeiro, 22 [1], 2012.

DI PIETRO, Maria Sylvia Zanella. "Discricionariedade Administrativa e Controle Judicial da Administração", em SALLES, Carlos Alberto de (org.). Processo Civil e Interesse Público-O processo como instrumento de defesa social. São Paulo: Editora RT, 2003.

DINAMARCO, Cândido Rangel. A Instrumentalidade do Processo, $3^{\text {a }}$ edição. São Paulo: Malheiros, 1993. 
Malheiros.

. Fundamentos do Processo Civil Moderno, $5^{\mathrm{a}}$ edição, Tomos I e II,

Editores, 2006

. Instituições de Direito Processual Civil. $5^{\mathrm{a}}$ ed., São Paulo: Malheiros

. Nova Era do Processo Civil. $3^{\mathrm{a}}$ ed. São Paulo: Malheiros, 2009

. Litisconsórcio, São Paulo: Editora RT, 1986.

DINAMARCO, Pedro da Silva. Ação Civil Pública. São Paulo: Saraiva, 2001.

DWORKIN, Ronald. A Virtude Soberana - A teoria e prática da igualdade. São Paulo: Martins Fontes, 2005.

Freedom's Law: The Moral Reading of The American Constitution.

Harvard University Press, 1997.

. Law's Empire. 1986: Library of Congress Cataloging-in-Publication

Data.

ELY, John Hart. Democracy and Distrust: A Theory of Judicial Review. Harvard University Press, 1980.

EPSTEIN, Lee; KNIGHT, Jack; and D. MARTIN, Andrew. "The Supreme Court as a Strategic National Policymaker”, in Emory Law Journal, v. 50, № 2, pp. 583-611.

FARBER, Daniel; FRICKEY, Philip. Law and Public Choice: A Critical Introduction. University of Chicago, 1991.

FARIA, Rodrigo Oliveira de. Natureza Jurídica do Orçamento e Flexibilidade Orçamentária. Dissertação de Mestrado apresentada na Faculdade de Direito da Universidade de São Paulo em 2009.

FARRELL, Margaret G. The Function and Legitimacy of Special Masters. 2 Widener L. Symp. J. 2351997. 
FEINBERG, Kenneth R. "Creative use of ADR, the court-appointed special settlement master." 59 Alb. Law Review, no 881 (1995-1996), pp. 881-893.

FERRAZ, Octávio Luiz da Motta, e VIEIRA, Fabiola Sulpino. "Direito à Saúde, Políticas Públicas e Desigualdades Sociais no Brasil: Equidade como princípio fundamental”, trabalho apresentado na Faculdade de Direito da Universidade de São Paulo em 2007 e submetido à revista Dados em maio de 2008.

FERRAZ, Octávio Luiz da Motta. Justiça Distributiva para Formigas e Cigarras, em Revista de Novos Estudos do CEBRAP, nº 77. São Paulo, março de 2007.

FERREIRA FILHO, Manoel Gonçalves. “O papel político do Judiciário na ordem constitucional vigente", em Revista do Advogado n 99, Setembro de 2008.

. "Os Direitos Fundamentais. Problemas jurídicos, particularmente em face da Constituição Brasileira de 1988”. Revista de Direito Administrativo n 203, jan/mar 1996, p.8.

FERREIRA, Camila Duran O Judiciário e as Políticas de Saúde no Brasil: o Caso AIDS, vencedor do Prêmio IPEA 40 anos em: Prêmio IPEA 40 anos: monografias premiadas. Brasília: IPEA, 2005.

FERREIRA, Camila Duran e FERRÃO, Brisa Lopes de Mello. "A Atuação do Judiciário na concretização dos direitos sociais: um estudo empírico do reconhecimento do direito à saúde como fundamental", em Revista da Faculdade de Direito da Fundação Escola Superior do Ministério Público, nº 1, 2007, pp. 131-150.

FERREIRA, Éder. "As ações individuais no controle judicial de políticas públicas”, em $O$ Controle Jurisdicional de Políticas Públicas. São Paulo: Forense (Gen), 2011, pp. 333-352

FILHO, Sérgio Assoni. "Controle de Constitucionalidade da Lei Orçamentária”, em CONTI, José Mauricio, e SCAFF, Fernando Facury (coord.). Orçamentos Públicos e Direito Financeiro, São Paulo: Editora Revista dos Tribunais, 2011, pp. 21-40.

FISS, Owen. Um Novo Processo Civil - Estudos Norte-Americanos sobre Jurisdição, Constituição e Sociedade. São Paulo: RT, 2004. 
. "Objectivity and Interpretation", in Stanford Law Review, V. 34, n 4, April 1982. Board of Trustees of the Leland Stanford Junior University, pp. 739-743.

FIGUEIREDO, Tatiana Aragão. Análise dos medicamentos fornecidos por mandado judicial na Comarca do Rio de Janeiro: a aplicação de evidências científicas no processo de tomada de decisão. Dissertação de Mestrado defendido na Escola Nacional de Saúde Pública Sérgio Arouca, março de 2010

FLEISCHACKER, Samuel. Uma breve história da justiça distributiva. São Paulo: Martins Fontes, 2006.

FRIEDMAN, Barry. "The History of the Countermajoritarian Difficulty, Part One: The Road to Judicial Supremacy", in NYU Law Review 333 (1998).

FULLER, Lon F. "The Forms and Limits of Adjudication", in Harvard Law Review 92 , 1978, pp. 353-398

GALANTER, Marc. “Afterword: Explaining Litigation”, in Law and Society Review, v. 9, 1975.

. "Compared to what: Assessing the quality of dispute processing", in Denver University Law Review, v. 66, n 3, 1989.

GALDINO, Flávio. Introdução à Teoria dos Custos dos Direitos: Direitos não Nascem em Árvores. Rio de Janeiro: Lúmen Juris, 2005.

GIL, Antonio Carlos. Como elaborar projetos de pesquisa. São Paulo: Atlas, 1991.

GIDI, Antonio. Coisa Julgada e litispendência em ações coletivas. São Paulo: Saraiva, 1995.

GLOPPEN, Siri. "Courts and Social Transformation: an Analytical Framework", in GARGARELLA, Roberto; DOMINGO, Pillar; e ROUX, Theunis. Courts and Social Transformation in New Democracies. Aldershot: Ashgate, 2006, pp. 35-39

GOZZOLI, Maria Clara, CIANCI, Mirna e CALMON, Petrônio, QUARTIERI, Rita (coord.). Em Defesa de um Novo Sistema de Processos Coletivos: Estudos em Homenagem à Ada Pellegrini Grinover. São Paulo: Saraiva, 2010. 
GRINOVER, Ada Pellegrini "Direito Processual Coletivo", em GRINOVER, Ada Pellegrini; MENDES, Aluisio Gonçalves de Castro; e WATANABE, Kazuo (coord.). Direito Processual Coletivo e o Anteprojeto de Código Brasileiro de Processos Coletivos. São Paulo: Editora RT, 2008.

. "O controle de políticas públicas pelo Poder Judiciário", em: O Processo - Estudos e Pareceres, São Paulo: Editora DPJ, pp. 36-57, $2^{\text {a }}$ ed., 2009.

. "Princípio da Proporcionalidade. Coisa julgada e justa indenização", em:

O Processo - Estudos e Pareceres, São Paulo: Editora DPJ, pp. 58-80, $2^{\mathrm{a}}$ ed., 2009.

. "A Coisa Julgada no Litisconsórcio Passivo Unitário. O Exemplo de Ações Coletivas e Individuais no Campo da Saúde", no prelo.

. "Coisa Julgada Erga Omnes, Secundum Eventum Litis e Secundum

Probationem", em Revista de Processo n 126, São Paulo: Editora Revista dos Tribunais, 2005.

GRINOVER, Ada Pellegrini, FERNANDES, Antonio Scarance e GOMES FILHO,

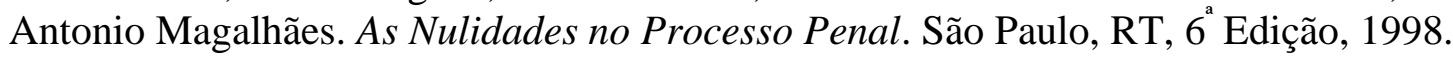

GUERRA F $F^{o}$, Willis Santiago. "Princípio da proporcionalidade e teoria do direito", em Direito constitucional - estudos em homenagem a Paulo Bonavides. Org. Eros Roberto Grau e Willis Santiago Guerra Filho. São Paulo: Malheiros Editores, 2001.

GUINOT, Thierry. L'huissier de justice: normes et valeurs. Ethique, déontologie, discipline et normes profesionnelles. Chambre Nationale des Huissiers de Justice: Paris, 2004.

GUTMANN, Amy e THOMPSON, Dennis. Democracy and Disagreement. Harvard: The President and Fellows of Harvard College, 1996

HARADA, Kiyoshi (Direito Financeiro e Tributário, 15ª ed. São Paulo: Atlas, 2006.

HART. H. L. A. O Conceito de Direito. São Paulo: Martins Fontes, 2009

Editor. Direito, Liberdade, Moralidade. Porto Alegre: Sergio Antonio Fabris 
HESSE, Konrad. A Força Normativa da Constituição (trad. Gilmar Ferreira Mendes). Porto Alegre: Sérgio Antônio Fabris Editor, 1991.

HIRSCHL, Ran. Toward Juristocracy: The Origins and Consequences of the New Constitutionalism. Cambridge: Harvard University Press, 2004.

HOROWITZ, Donald L. The Courts and Social Policy, Washington D.C.: The Brooking Institution, 1977.

JATENE, Adib D. et. all. "Biopsia Endomiocárdica do Ventrículo Direito - 9 anos (1978 a 1987)" em Arquivos Brasileiros de Cardiologia no 49, 1987, pp. 147-149.

JÚNIOR, Humberto Theodoro. Curso de Direito Processual Civil. 32a ed., V. 1. Rio de Janeiro: Forense, 2000.

KARMEL, Philip E. e PADEN, Peter R. "Fluid Recovery in Class Action Litigation", in New York Law Journal, December 26, 2006 edition.

KELSEN, Hans. Teoria Pura do Direito, 6a ed., Coimbra, Armênio Amado - Editora, 1984.

KOMESAR, Neil K. "A Job for Judges: The Judiciary and the Constitution in a Massive and Complex Society”, in Michigan Law Review, V. 86, Feb. 88, pp 690-693.

Imperfect Alternatives: Choosing Institutions in Law, Economics, and Public Policy. The University of Chicago Press, Ltd., London, 1994.

KRELL, Andreas. "Realização dos direitos fundamentais sociais mediante controle judicial da prestação dos serviços públicos básicos (uma visão comparativa)", em Revista de Informação Legislativa, ano 36, n¹44 out./dez., Brasília, 1999.

LABAND, Paul. Derecho Presupuestario. Tradução: José Zamit. Madrid: Instituto de Estudios Fiscales, 1979.

LABRA, M.E. "Análise de política e modos de policy making e intermediações de interesses: uma revisão", em PHISYS Revista de Saúde Coletiva. Rio de Janeiro: 9 (2):1999, p. 131-166. 
LAGE, Lívia Regina Savergnini Bissoli. "Políticas públicas como programas e ações para o atingimento dos objetivos sociais do Estado", em GRINOVER, Ada Pellegrini e WATANABE, Kazuo (coord.) O Controle Jurisdicional de Políticas Públicas. Rio de Janeiro: Forense, 2011, pp. 151-182.

LAGRASTA NETO, Caetano; OLIVEIRA NETO, Jaime Martins; e REZENDE FILHO, Durval Augusto. Panorama do Desempenho do Tribunal de Justiça de São Paulo (20032010). São Paulo: Letras Jurídicas, 2012

LASSALE, A Essência da Constituição, $5^{\mathrm{a}}$ ed., Rio de Janeiro: LumenJuris, 2000.

LEONEL, Ricardo de Barros. "Causa de Pedir e Pedido nos Processos Coletivos: Uma Nova Equação para a Estabilização da Demanda”, em GRINOVER, Ada Pellegrini; MENDES, Aluisio Gonçalves de Castro; e WATANABE, Kazuo (coord.). Direito Processual Coletivo e o Anteprojeto de Código Brasileiro de Processos Coletivos. São Paulo: Editora RT, 2008, pp. 145-160.

LIEBMAN, Enrico Tullio. Eficácia e Autoridade da Sentença. $2^{\mathrm{a}}$ edição. Rio de Janeiro: Revista Forense, 1981.

LINDBLOM, C.E. O Processo da Decisão Política. Brasília: UNB, 1981.

LOCHAGIN, Gabriel Loretto. "A unificação dos orçamentos públicos pela Constituição de 1988”, em CONTI, José Mauricio, e SCAFF, Fernando Facury (coord.). Orçamentos Públicos e Direito Financeiro, São Paulo: Editora Revista dos Tribunais, 2011, pp. 187202.

LONGO, Riolando. Avaliação da política energética e da política industrial no Brasil: do plano SALTE ao plano Brasil para Todos. Tese de doutoramento apresentado à Escola Politécnica da Universidade de São Paulo para a obtenção do grau de Doutor em Energia, São Paulo: 2009.

LOPES, José Reinaldo de Lima. Direitos Sociais - Teoria e Prática. São Paulo: Método, pp. 132-138.

. "Em torno da 'reserva do possível', em SARLET Ingo W. e TIMM Luciano B. (org.) Direitos Fundamentais, Orçamento e `Reserva do Possível , Porto Alegre: Livraria do Advogado Editora, 2008.

LOPES, Luciane Cruz (et. al.). "Uso racional de medicamentos antineoplásicos e ações judiciais no Estado de São Paulo”, em Revista de Saúde Pública nº 44 (2010). 
LUCON, Paulo Henrique dos Santos, e GABBAY, Daniela Monteiro. "Superação do Modelo Processual Rígido pelo Anteprojeto do Código Brasileiro de Processos Coletivos à Luz da Atividade Gerencial do Juiz", em GRINOVER, Ada Pellegrini; MENDES, Aluisio Gonçalves de Castro; e WATANABE, Kazuo (coord.). Direito Processual Coletivo e o Anteprojeto de Código Brasileiro de Processos Coletivos. São Paulo: Editora RT, 2008, pp. 89-93.

LUPION, Ricardo. "O direito fundamental à saúde e o princípio da impessoalidade", em SARLET, Ingo Wolfgang; e TIMM, Luciano Benetti (org.). Direitos Fundamentais, orçamento e "reserva do possível". Porto Alegre: Livraria do Advogado, 2008, pp. 347 358.

MADISON, James. "The Utility of the Union as a Safeguard Against Domestic Faction and Inssurection", in Daily Advertiser, November 22, 1787.

MALLOY, Robin Paul. Law and Market Economy: Reinterpeting the Values of Law and Economics. Cambridge University Press: 2000

MANCUSO, Rodolfo de Camargo. Interesses Difusos - Conceito e Legitimação de Agir, $6^{\text {a }}$ edição. São Paulo: Editora Revista dos Tribunais, 2004.

MANNORI, Luca. "La Nascita del Contencioso Amministrativo in Italia", em Quaderni Fiorentini per la storia del pensiero giuridico moderno, 19 (1990), Milano: Giuffre, 1990, pp. 717-728.

MARQUES, Floriano Azevedo. "Discricionariedade Administrativa e Controle Judicial da Administração", em SALLES, Carlos Alberto de (org.). Processo Civil e Interesse Público - O processo como instrumento de defesa social. Carlos Alberto de SALLES - org. - São Paulo: Editora RT, 2003.

MARINHO, Carolina Martins. Justiciabilidade dos direitos sociais: análise de julgados do direito à educação sob o enfoque da capacidade institucional. Dissertação de Mestrado apresentada ao Departamento de Teoria Geral e Filosofia do Direito da Faculdade de Direito da Universidade de São Paulo, São Paulo, 2009.

MARINONI, Luís Guilherme. Técnica Processual e Tutela dos Direitos. São Paulo: RT, 2004. 
MARQUES, Sílvia Badim, e DALLARI, Sueli Gandolfi. "Garantia do direito social à assistência farmacêutica no Estado de São Paulo", em Revista de Saúde Pública no 41 (2007), pp. 101-107.

MARTINS, Ricardo Chaves de Rezende. O Poder Legislativo e as Politicas Públicas Educacionais no Período 1995-2010. Brasília: Câmara dos Deputados, 2012.

MASHAW, Jerry L. "The Economics of Politics and the Understanding of Public Law, in Chicago-Kent Law Review, v. 65 - 1989.

MATUS, Carlos. Adeus, Senhor Presidente. Trad. Luís Felipe Rodrigues Del Riego. São Paulo: Fundap, 1997.

MEDAUAR, Odete. Direito Administrativo Moderno. 14 a ed. São Paulo: RT, 2010.

MEDINA, José Miguel Garcia e WAMBIER, Teresa Arruda Alvim. O dogma da coisa julgada: hipóteses de relativização. São Paulo: RT, 2005.

MEIRELLES, Hely Lopes. Direito Administrativo Brasileiro. 32ª ed. São Paulo: Malheiros Editores, 2006.

MENDES, Andréa Cristina Rosa e VIEIRA, Fabíola Sulpino. Evolução dos Gastos do Ministério da Saúde com Medicamentos. Ministério da Saúde: Brasília, 2007.

MENDES, Aluísio Gonçalves de Castro. Ações Coletivas no Direito Comparado e Nacional, $3^{\text {a }}$ ed., São Paulo: Editora Revista dos Tribunais, 2012.

. "O Anteprojeto de Código Brasileiro de Processos Coletivos: visão geral e pontos sensíveis", em Direito Processual Coletivo e o Anteprojeto de Código Brasileiro de Processos Coletivos, em GRINOVER, Ada Pellegrini; MENDES, Aluisio Gonçalves de Castro; e WATANABE, Kazuo (coord.). Direito Processual Coletivo e o Anteprojeto de Código Brasileiro de Processos Coletivos. São Paulo: Editora RT, 2008, pp. 19-20.

" 'O Anteprojeto de Código-Modelo de Processos Coletivos para os Países Ibero-Americanos e a Legislação Brasileira”, em Revista de Processo, São Paulo, $\mathrm{n}^{\circ} 117$, set./out. 2004, pp. 109-128.

MENDES, Gilmar. Moreira Alves e o Controle de Constitucionalidade no Brasil. São Paulo: Saraiva, 2004. 
MELLO, Cláudio Ari. Democracia constitucional e direitos fundamentais. Porto Alegre: Livraria do Advogado, 2004.

MERCURO, Nicholas; MEDEMA, Steven G. Economics and the Law. From Posner to Post-Modernism. Princenton Unversity Press.

MESQUITA, José Ignácio Botelho de. "Na ação do consumidor, pode ser inútil a defesa do fornecedor", em Revista do Advogado no 33.

MIRANDA, Jorge. "Os Direitos Fundamentais - Sua Dimensão Individual e Social”, EM Cadernos de Direito Constitucional e Ciência Política - 1 (out/dez de 1992).

MONTEIRO, Jorge Vianna. "Escolhas públicas no Brasil”, em Revista de Administração Pública, V. 41, Rio de Janeiro, 2007.

MONTESQUIEU, De l'espirit des lois, Paris: Chez Firmin Didot Freres, Libraries.

MULLENIX, Linda. "General Report - Common Law”, in GRINOVER, Ada Pellegrini; MULLENIX, Linda e WATANABE, Kazuo (coord.). Os Processos Coletivos nos países de Civil Law e Common Law. São Paulo: Editora RT, 302008, pp. 253-297

NATIONAL BIOETHICS ADVISORY COMMISSION. Ethical and Policy Issues in International Research: Clinical Trials in Developing Countries. National Bioethics Advisory Commission, 2001.

NERY Jr., Nelson. "Coisa Julgada e Estado Democrático de Direito", em YARSHELL, Flávio Luiz e MORAES, Mauricio Zanoide (org.). Estudos em Homenagem à professora Ada Pellegrini Grinover. São Paulo: DPJ Editora, 2005, p. 716-717.

NETO, José Rodrigues de Oliveira. "O Poder Judiciário em um Estado Periférico: os Direitos Fundamentais como Parâmetro Decisório", em COUTINHO, Jacinto Nelson de Miranda; FILHO, Roberto Fragale; e LOBÃO, Ronaldo (org.). Constituição \& Ativismo Judicial. Limites e Possibilidades da Norma Constitucional e da Decisão Judicial. Rio de Janeiro: Lúmen Juris Editora, 2011.

NOBRE Jr., Edilson Pereira. "O Direito Brasileiro e a Dignidade da Pessoa Humana”, em Revista dos Tribunais, $\mathrm{n}^{\mathrm{o}} 777$ (julho de 2000) 
OLIVEIRA, Carlos Alberto Alvaro. Do Formalismo no Processo Civil. Proposta de um formalismo-valorativo. $4^{\mathrm{a}}$ ed. São Paulo: Saraiva, 2010.

OLIVEIRA, Jaime A. de Araújo e TEIXEIRA, Sônia M. F. (Im)previência social: 60 anos de história da Previdência no Brasil. Petrópolis: Vozes, 1989

ONODERA, Marcus Vinícius Kiyoshi. "O controle judicial de políticas públicas por meio do mandado de injunção, ação direta de inconstitucionalidade por omissão e argüição de descumprimento de preceito fundamental. Contornos e Perspectivas", em GRINOVER, Ada Pellegrini e WATANABE, Kazuo (coord.) O Controle Jurisdicional de Políticas Públicas. Rio de Janeiro: Forense, 2011, pp. 419-450.

ORGANIZAÇÃO MUNDIAL DA SAÚDE. Relatório Mundial de Saúde 2010:

Financiamento dos Sistemas de Saúde: o caminho para a cobertura universal. Genebra, 2010 .

OST, François. "Jupiter, Hercules, Hermes: Tres Modelos de Juez", trad. Isabel Lifante Vidal, em DOXA. Cuadernos de filosofía del derecho [Publicaciones periódicas], $\mathrm{n}^{\circ} 14$, Espanha: Universidad de Alicante, 1993.

OSTROM, Elinor. Governing the Commons: The Evolution of Institutions for Collective Action. Cambridge, Cambridge University Press.

PEREIRA, Paulo Trigo. “A Teoria da Escolha Pública (public choice): uma abordagem neo-liberal?”, em Análise Social vol. XXXIII (141), 1997.

PEREIRA, Guilherme Setoguti Julio. Conteúdo do Provimento e Limites Objetivos e Subjetivos do Provimento e da Coisa Julgada na Impugnação de Decisões de Assembleias de Sociedades por Ações. Dissertação de Mestrado da área de Direito Processual, apresentada em 2013 e orientada por Flávio Luiz YARSHELL.

PIOLA, Sérgio Francisco. "Tendências do financiamento da Saúde", em Debates GV Saúde, Volume 2 - II Semestre, 2006.

PIOVESAN, Flávia. "Justiciabilidade dos Direitos Sociais e Econômicos: Desafios e Perspectivas", em SILVA, Roberto B. Dias (Org.). Direito Constitucional - temas atuais homenagem à Professora Leda Pereira da Mota. São Paulo: Método, 2007, v. , p. 59-74. 
PIOVESAN, Flávia e VIEIRA, Renato Stanziola. "Justiciabilidade dos direitos sociais e econômicos no Brasil: Desafios e Perspectivas", em Araucaria: Revista Iberoamericana de filosofía, política y humanidades, ISSN 1575-6823, No 15, 2006 , pp. 128-146.

PLATÃO. A República. Livro VI. São Paulo: Nova Cultural, 1997.

POSNER, Richard. Economic Analysis of the Law. $5^{\text {th }}$ ed., New York: Aspen Law \& Business, 1998.

PINKERTON, Michael H. "Castano v. American Tobacco Company: America's Nicotine Plaintiffs Have No Class”, em Lousiana Law Review, n 58 - 1998.

PUOLI, José Carlos Baptista. Os Poderes do Juiz e as Reformas do Código de Processo Civil. São Paulo: Juarez de Oliveira, 2002.

RALF-THOMAS Wittmann. "Il 'contenzioso di massa' in Germania", in Giorgetti ALESSANDRO e Valerio VALLEFUOCO, Il Contenzioso di massa in Italia, in Europa e nel mondo, Milão, Giuffrè, 2008.

RAWLS, John. A theory of justice. Cambridge: The Belknap Press of Harvard University Press, 1971. Justice as Fairness: a Restatement. ed. by Erin Kelly. Harvard University Press. . Justiça e Democracia. São Paulo: Martins Fontes, 2002. . O Direito dos Povos. São Paulo: Martins Fontes, 2004.

REYNOLDS, Willian L. Judicial Process in a Nutshell. $2^{\text {nd }}$ Edition. Maryland: West Group, 1991.

ROCHA, Rosália Carolina Kappel. “A Eficácia dos direitos Sociais e a Reserva do Possível”, em Revista da Advocacia-Geral da União, Ano V, 2005.

RODRIGUES, Marcelo Abelha. “Observações Críticas Acerca da Suspensão de Segurança na Ação Civil Pública”, em MILARÉ, Edis (coord.) A Ação Civil Pública após 20 anos, São Paulo: Editora RT, 2005 pp. 369-382. 
SABINO, Marco Antonio da Costa. "O processo judiciário como meio de tomada de decisões (sempre?)”, em Revista Dialética de Direito Processual, São Paulo: Dialética, n.75, p. 61-76, jun. 2009.

. "Quando o Judiciário ultrapassa seus limites institucionais e constitucionais: o Caso da Saúde", em GRINOVER, Ada Pellegrini e WATANABE, Kazuo (coord.) O Controle Jurisdicional de Politicas Públicas. Rio de Janeiro: Forense, 2011, pp. 353-386.

Avaliação no curso de Direito em turmas de MBA: estudo de caso, seminários e júri simulado, Monografia de Especialização em Docência no Ensino Superior, grau conferido pela Universidade Anhembi-Morumbi (2013)

SADEK, Maria Teresa (org.). Acesso à Justiça. São Paulo: Fundação Konrad Adenauer, 2001.

. "Judiciário e arena pública: um olhar a partir da Ciência Política", em GRINOVER, Ada Pellegrini e WATANABE, Kazuo (coord.) O Controle Jurisdicional de Políticas Públicas. Rio de Janeiro: Forense, 2011, pp. 1-32.

SALLES, Carlos Alberto de. Execução Judicial em Matéria Ambiental. São Paulo: Editora RT, 1999.

. "Execução Específica e Ação Civil Pública" em A Ação Civil Pública Após 20 Anos, Édis MILARÉ (coord.), São Paulo: Editora RT, 2005, pp. 85-96.

. "Políticas Públicas e a Legitimidade para a Defesa de Interesses Difusos e Coletivos", em Revista de Processo 121 (março de 2005). São Paulo: Editora RT.

. "Processo Civil de Interesse Público", em Processo Civil e Interesse Público - O processo como instrumento de defesa social. Carlos Alberto de SALLES org. - São Paulo: Editora RT, 2003.

"Coisa julgada e extensão dos efeitos da sentença em matéria de direitos sociais constitucionais", em GOZZOLI, Maria Clara; CIANCI, Mirna; CALMON, Petrônio e QUARTIERI, Rita. Em defesa de um novo sistema de processos coletivos.

Estudos em homenagem à Ada Pellegrini Grinover. São Paulo: Saraiva, 2010, pp. 143-158. 
."Processo civil de interesse público: uma nova perspectiva metodológica", em SUNDFELD, Carlos Ari e BUENO Cássio Scarpinella (orgs.). Direito Processual Público. A Fazenda Pública em Juízo. São Paulo: Malheiros, 2000.

SANTANA, José Lima. "O princípio constitucional da eficiência e o Sistema Único de Saúde (SUS)", em BIACHERIENE, Ana Carla e SANTOS, José Sebastião dos (org.). Direito à Vida e à Saúde, Ana Carla Biacheriene e José Sebastião dos Santos. São Paulo: Atlas, 2010, pp. 42/59.

SANTANA, Izaias José de. O Poder Judiciário e o controle do conteúdo das políticas públicas de saúde. Tese de Doutorado apresentada ao Departamento de Direito do Estado da Faculdade de Direito da Universidade de São Paulo, 2012.

SANTA HELENA, Eber Zoehler. Critérios e Procedimentos para Preservação da Objetividade no Exame de Compatibilidade e Adequação Orçamentária e Financeira de Proposições Legislativas. Brasília: Câmara dos Deputados, 2009.

SANCHES, Osvaldo Maldonado, apud de SILVA, Moacir Marques da. "A lógica do planejamento público à luz da Lei de Responsabilidade Fiscal”, em CONTI, José Mauricio, e SCAFF, Fernando Facury (coord.). Orçamentos Públicos e Direito Financeiro. São Paulo: Editora Revista dos Tribunais, 2011.

SANTOS, Boaventura de Sousa. Pela Mão de Alice: o social e o político na pósmodernidade. $2^{a}$ ed. São Paulo: Ed. Cortez, 1996.

SANTOS, Clilton Guimarães dos. Tutela jurisdicional aos Direitos Sociais. Tese de Doutorado apresentada ao Departamento de Direito Processual da Faculdade de Direito da Universidade de São Paulo, 2013.

SANTOS, José Sebastião dos; SOUZA, Hórtis Aparecido de; e UETA, Julieta. “A influência da gestão do sistema de saúde na utilização da via judicial para acesso a produtos e serviços”, em Direito à Vida e à Saúde, Ana Carla Biacheriene e José Sebastião dos Santos (org.). São Paulo: Atlas, 2010.

SARLET, Ingo Wolfgang. Dignidade da Pessoa Humana e Direitos Fundamentais na Constituição Federal de 1988. $8^{\text {a }}$ ed. Porto Alegre: Livraria do Advogado Editora, 2010, pp. 135-142.

SARLET, Ingo Wolfgang e FIGUEIREDO, Mariana Filchtiner. "Reserva do possível, mínimo existencial e direito à saúde: algumas aproximações”, em SARLET Ingo W. e 
TIMM Luciano B. (org.) Direitos Fundamentais, Orçamento e `Reserva do Possível`, , Porto Alegre: Livraria do Advogado Editora, 2008.

SCAFF, Fernando Facury. "Sentenças Aditivas, Direitos Sociais e Reserva do Possível”, em Revista Dialética de Direito Processual, nº 51 - junho de 2007, São Paulo: Ed. Dialética, 2007, pp. 79-99.

SCHREIBER, Anderson. A Proibição do Comportamento Contraditório: Tutela da confiança e venire contra factum proprium. Rio de Janeiro: Renovar, 2005.

SCWABE, Jürgen (Org.) Cinquenta Anos de Jurisprudência do Tribunal Constitucional Federal Alemão. Trad. Leonardo Martins. Montevideo: Fundação Konrad Adenauer, 2005.

SGARBOSSA, Luís Fernando. Crítica à Teoria dos Custos dos Direitos. V. I - Reserva do Possível. Porto Alegre: Sérgio Antonio Fabris Editor, 2010.

SMITH, Rogers M. 'Political Jurisprudence, the 'New Institutionalism' and the Future of Public Law”, in American Political Science Review, V. 82, n 1, March 1988, pp. 89-107.

SUNDFELD, Carlos Ari. Fundamentos de Direito Público, $3^{\mathrm{a}}$ ed. São Paulo: Malheiros, 1998.

SUSTEIN, Cass; HOLMES, Stephen. The Cost of Rights: Why Liberty Depends on Taxes. W. W. Norton \& Company. New York: 1999

SUSTEIN, Cass R. et alli., Predictably Incoherent Judgments, in Stanford Law Review, v. 54 pp. 1153 e ss., 2001-2002.

The Second Bill of Rights: FDR's Unfinished Revolution and Why we Need it More than Ever. Nova York: Basic Books, 2004

TATE, Neal C. "Why the expansion of judicial power? in The Global Expansion of Judicial Power. New York: New York University Press, 1995, pp. 27-31.

TAYLOR, Matthew M. “O Judiciário e as Políticas Públicas no Brasil”, em Revista de Ciências Sociais, Rio de Janeiro, Vol. 50, no 2, 2007, pp. 229 a 257. 
TEIXEIRA, Carlos Sávio. Experimentalismo e Democracia em Unger. São Paulo: Lua Nova, 2010.

TOCQUEVILlE, Alexis de. A Democracia na America. Vs. 1 e 2. $2^{\text {a }}$ edição. São Paulo: Martins Fontes Editora, 2005.

TORRES, Ricardo Lobo. "A Cidadania Multidimensional na Era dos Direitos", em TORRES, Ricardo Lobo (org.). Teoria dos Direitos Fundamentais. $2^{\mathrm{a}}$ ed., Rio de Janeiro: Renovar, 2001.

Tratado de Direito Constitucional, Financeiro e Tributário. $2^{\mathrm{a}}$ ed. Rio de Janeiro: Renovar, 2000, vol. 5.

. "O Mínimo Existencial, os Direitos Sociais e os Desafios de Natureza Orçamentária", em Direitos Fundamentais, Orçamento e "Reserva do Possível”, Porto Alegre: Livraria do Advogado Editora, 2008.

Os Direitos Humanos e a Tributação: imunidades e isonomia. Rio de Janeiro: Renovar, 1998.

TREANOR, William Michael. "Judicial Review Before Marbury”, in Stanford Law Review. V. 58, n 2 - November, 2005, pp. 455-562.

VALENTE, Manoel Adam Lacayo. "A Dimensão Jurídico-Constitucional na Formulação de Políticas Públicas: uma Perspectiva a ser Explorada", em Revista de Direito Administrativo $n^{\circ}$ 39. Rio de Janeiro: 2005.

VERÍSSIMO, Marcos Paulo. A judicialização dos conflitos de justiça distributiva no Brasil: o processo judicial no pós-1988. São Paulo: USP (tese de doutorado apresentada à Faculdade de Direito da Universidade de São Paulo), 2006.

VIANA, A. L. A. "Enfoques metodológicos em políticas públicas: novos referenciais para os estudos sobre políticas sociais", em CANESQUI, A. M. Ciências Sociais e Saúde. São Paulo: Hucitec/Abrasco, 1997.

VIEIRA, Fabíola Sulpino e ZUCCHI, Paola. "Distorções causadas pelas ações judiciais à política de medicamentos no Brasil”, em Revista de Saúde Pública no 41 (2007). 
VIGLIAR, José Marcelo Menezes. "A Lei 9.494, de 10 de setembro de 1997, e a nova disciplina da coisa julgada nas ações coletivas: inconstitucionalidade", em Revista dos Tribunais $\mathrm{n}^{\mathrm{o}} 745$ (novembro de 1997, 86ª ano), pp. 67-72.

VIGORITTI, Vincenzo. Interessi Colettivi e Processo - La Legitimazioni ad Agire, Milano, Giuffré, 1979.

Von ADAMOVICH, Eduardo Henrique Raimundo. "A justiça geométrica e o Anteprojeto de Código de Processos Coletivos: Elementos para uma justificativa Histórico Filosófica, ou por uma Visão atual do alcance e da função criadora da Jurisdição Coletiva", em GRINOVER, Ada Pellegrini; MENDES, Aluisio Gonçalves de Castro; e WATANABE, Kazuo (coord.). Direito Processual Coletivo e o Anteprojeto de Código Brasileiro de Processos Coletivos. São Paulo: Editora RT, 2008, pp 55-65.

WALDRON, Jeremy. Law and Disagreement, Oxford University Press, 1999. . A Dignidade da Legislação. São Paulo: Martins Fontes, 2003.

WATANABE, Kazuo, et. al. Código de Defesa do Consumidor Comentado pelos Autores do Anteprojeto. $9^{a}$ edição. Rio de Janeiro: Forense Universitária, 2007.

São Paulo, 3.8.04.

"Parecer no tocante à natureza jurídica da tarifa de assinatura telefônica".

. "Cultura da sentença e cultura da pacificação", em Estudos em

$\overline{\text { Homenagem à A }}$ da Pelegrini Grinover. São Paulo: DPJ, 2010, pp. 684-690

WEISS, Carlos. Direitos Humanos Contemporâneos. São Paulo: Malheiros Editores, 1990.

YEAZEL, Stephen C. "Collective Litigation as Collective Action", in University of Illinois Law Review, v. 1989.

ZANETTI Jr. Hermes. “A Teoria da Separação de Poderes e o estado democrático constitucional: funções de governo e funções de garantia", em GRINOVER, Ada Pellegrini e WATANABE, Kazuo (coord.) O Controle Jurisdicional de Políticas Públicas. Rio de Janeiro: Forense, 2011, pp. 33-72.

ZAVASCKI, Teori Albino. Processo coletivo: tutela de direitos coletivos e tutela coletiva de direitos. $2^{\mathrm{a}}$ ed. São Paulo: Editora RT, 2007 


\section{Referências eletrônicas, jornais e revistas}

\section{II.A. Documentos eletrônicos}

\section{II.A.1. Reportagens e notícias}

"2011 in review: key health issues", disponível em:

http://www.who.int/features/2011/year_review/en/index.html, acesso em 10.1.2012, $14: 15 \mathrm{~h}$.

“35,7\% dos curitibanos já não se lembram em quem votaram para vereador", disponível em: <http://www.gazetadopovo.com.br/vidapublica/conteudo.phtml?id=1332668\&tit=357dos-curitibanos-ja-nao-lembram-em-quem-votaram-para-vereador>, acesso em 6.7.2013, $21: 16 h$.

"R\$ 1 bi em remédios no lixo", disponível em:

<http://www.ecodebate.com.br/2010/04/26/r-1-bi-em-remedios-no-lixo-falhas-na-comprae-no-armazenamento-levam-a-desperdicio-de-medicamento-no-pais/>, acesso em 9.3.12, $20: 22 \mathrm{~h}$.

"Ações por remédios caros favorecem ricos, diz estudo", disponível em: $<$ http://www1.folha.uol.com.br/cotidiano/772062-acoes-por-remedios-caros-favorecemricos-diz-estudo.shtml>, acesso em 12.12.2011, 18:55h.

“Aumento do IPTU manterá subsídios ao transporte, diz Haddad”, disponível em: http://gl.globo.com/sao-paulo/noticia/2013/10/aumento-do-iptu-mantera-subsidios-aotransporte-diz-haddad.html, acesso em 15.11.2013, 14:24h.

"Barbosa diz que judicialização da saúde é tema superlativo" em Consultor Jurídico, edição de 3.6.2013, disponível em: <http://www.conjur.com.br/2013 jun 03/joaquim barbosa judicializacao saude problema

superlativo?utm_source=dlvr.it\&utm_medium=facebook>, acesso em 5.6.2013, 13:45h.

"Barbosa chama de sorrateira a criação de novos TRFs", disponível em: $<$ http://oglobo.globo.com/pais/barbosa-chama-de-sorrateira-criacao-de-novos-trfs8060997>, acesso em 2.6.2013, 21:30h. 
"Brasil gasta com presos quase triplo do custo com aluno", disponível em: $<$ http://oglobo.globo.com/educacao/brasil-gasta-com-presos-quase-triplo-do-custo-poraluno-3283167>, acesso em 22.2.12, 12:45h.

"Brasil tem novo recorde na arrecadação de impostos em janeiro", disponível em: <http://g1.globo.com/jornal-nacional/noticia/2012/02/brasil-tem-novo-recorde-naarrecadacao-de-impostos-em-janeiro.html>, acesso em 6.3.12, 13:45h.

"Carga tributária bate recorde e atinge 36,27\% do PIB em 2012, diz estudo", disponível em: <http://g1.globo.com/economia/seu-dinheiro/noticia/2013/03/carga-tributaria-baterecorde-e-atinge-3627-do-pib-em-2012-diz-estudo.html>, acesso em 15.11.2013, 14:53h.

“Carga tributária foi de 35\% do PIB em 2010, diz Instituto", disponível em: < http://g1.globo.com/economia/noticia/2011/03/carga-tributaria-foi-de-3513-do-pib-em2010-diz-instituto.html>, acesso em 6.3.12, 13:40h.

"CNJ começa a julgar propostas para criar varas de saúde no Brasil", em O Globo, edição de 28.5.2013, disponível em: <http://oglobo.globo.com/pais/cnj-comeca-julgar-propostapara-criar-varas-de-saude-no-brasil-8524892>, acesso em 5.3.2013, 14:30h

"Decisão judicial propicia segurança jurídica do SUS", disponível em http://pgeba.jusbrasil.com.br/noticias/1502850/decisao-judicial-promove-seguranca-juridica-do-sus, acesso em 2.11.11, 18:00h

"Déficit de vagas em creches de São Paulo a 127,4 mil crianças", disponível em: $<$ http://educacao.uol.com.br/noticias/2013/08/20/deficit-de-creches-de-sao-paulo-passa-de150-mil-vagas-aponta-estudo.htm>, acesso em 15.11.2013, 13:26h.

"De saída da Presidência do STF, Peluso critica colegas", disponível em: $<$ http://m.estadao.com.br/noticias/nacional,de-saida-da-presidencia-do-stf-peluso-criticacolegas,862207.htm.>, acesso em 7.6.2012, 14:49h

"Direito à vida se sobrepõe às questões de orçamento", disponível em: $<$ http://tjrn.jusbrasil.com.br/noticias/2467271/direito-a-vida-se-sobrepoe-as-questoes-deorcamento>, acesso em 14.5.12, 13:31h.

"Em estudo, CNJ diz que argumento para criação de novos TRFs é frágil, disponível em: <http://g1.globo.com/politica/noticia/2013/04/em-estudo-cnj-diz-que-argumento-paracriacao-de-novos-trfs-e-fragil.html>, acesso em 2.6.2013, 21:26h. 
"Fux dá decisão favorável aos produtores", disponível em: <http://oglobo.globo.com/econo mia/royalties-fux da decisao favoravel produtores votacao de vetos suspensa7077672>, acesso em 19.12.2012, 20:35h.

"Gasto do governo com remédios via ação judicial cresce 5.000\% em 6 anos", disponível em: <http://www.estadao.com.br/noticias/impresso,gasto-do-governo-com-remedios-viaacao-judicial-cresce-5000-em-6-anos,711740,0.htm>, acesso em 8.3.12, 22:14h.

"Gastos com plebiscito sobre a reforma política podem chegar a R \$ 500 milhões", disponível em: <http://ultimosegundo.ig.com.br/politica/2013-06-28/gastos-complebiscito-sobre-a-reforma-politica-podem-chegar-a-r-500-milhoes.html>, acesso em 30.6.2013, 18:14h.

"Gastos do SUS com ações judiciais passam de R \$ 170 mil para R \$ 132 milhões nos últimos oito anos", disponível em: <http://agenciabrasil.ebc.com.br/noticia/2011-0707/gastos-do-sus-com-acoes-judiciais-passam-de-r-170-mil-para-r-132-milhoes-nosultimos-oito-anos>, acesso em 9.3.12, 13:30h

"Governador de SP diz que irá vender helicóptero e extinguir 2 mil carros", disponível em: <http://g1.globo.com/sao-paulo/noticia/2013/06/governador-de-sp-diz-que-ira-venderhelicoptero-e-extinguir-2-mil-cargos.html>, acesso em 30.6.2013, 18:04h.

"Indústria usa ações judiciais para lucrar com medicamentos", disponível em: <http://ww w.estadao.com.br/estadaodehoje/20100726/not_imp585995,0.php>, acesso em 12.01.2011, 19:03h.

"Lei de Recursos Repetitivos pode se tornar obsoleta", disponível em:

$<$ http://www.conjur.com.br/2010-mai-02/entrevista-bruno-dantas-integrantes-comissaocpc>, acesso em 12.12.13, 7:43h.

"Manifestação em Brasília tem 3 presos e mais de 120 feridos", disponível em: <http://g1.globo.com/distrito-federal/noticia/2013/06/manifestacao-em-brasilia-tem-3presos-e-mais-de-120-feridos.html>, acesso em 6.7.2013, 20:50h.

"Manifestação segue para sede do governo de São Paulo", disponível em: $<$ http://mais.uol.com.br/view/s70pk4i6az2h/manifestacao-segue-para-sede-do-governo-desao-paulo-04024C1C3372D8A94326?types=A\&>, acesso em 6.7.2013, 20:55h.

"Manifestantes ocupam cobertura do Congresso Nacional em Brasília", disponível em: <http://g1.globo.com/bom-dia-brasil/noticia/2013/06/manifestantes-ocupam-cobertura-docongresso-nacional-em-brasilia.html $>$, acesso em 6.7.2013, 20:52h. 
"Manifestantes tentam invadir a Prefeitura de SP durante protesto", disponível em: <http://www1.folha.uol.com.br/cotidiano/2013/06/1297302-manifestantes-tentam-invadira-prefeitura-de-sp-durante-protesto.shtml>, acesso em 6.7.2013, 20:54h.

"Marajás de jaleco", disponível em: <http://www.istoe.com.br/reportagens/256069_MAR AJAS+DE+JALECO>, acesso em 27.7.2013, 15:36h.

"Na TV, Dilma diz que combetará malfeitos sem trégua", disponível em: <http://www.estadao.com.br/noticias/nacional,na-tv-dilma-diz-que-combatera-malfeitossem-tregua,796255,0.htm>, acesso em 6.7.2013. 21:02h.

"Nenhum dos Ministros demitidos por Dilma chegou a ser punido", disponível em: <http://www1.folha.uol.com.br/poder/1029153-nenhum-dos-ministros-demitidos-pordilma-chegou-a-ser-punido.shtml>, acesso em 6.7.2013, 21:05h.

“O paciente de R\$ 800 mil”, disponível em:

<http://revistaepoca.globo.com/tempo/noticia/2012/03/o-paciente-de-r-800-mil.html>, acesso em 11.5.12, 13:40h.

“Operação contra desvio de remédios prende 12 em SP e no Rio", disponível em: <http://g1.globo.com/sao-paulo/noticia/2012/02/operacao-contra-desvio-de-remediosprende-12-em-sp-e--no-rio.html>, acesso em 9.3.12, 20:10h.

“'Quórum vai ter, tenha fé' diz Renan sobre votação da MP dos Portos”, disponível em: $<$ h ttp://g1.globo.com/politica/noticia/2013/05/quorum-vai-ter-tenha-fe-diz-renan-sobrevotacao-de-mp-dos-portos.html>, acesso em 9.6.2013, 10:29h

"Pacientes do SUS relatam problemas mesmo em cidades bem avaliadas", disponível em: <http://g1.globo.com/brasil/noticia/2012/03/pacientes-do-sus-relatam-problemas-mesmoem-cidades-bem-avaliadas.html>, acesso em 2.3.12, 13:50h.

"Pesquisa indica que parte dos eleitores já não lembra em quem votou nas eleições", disponível em: <http://www1.folha.uol.com.br/poder/837795-pesquisa-indica-que-partedos-eleitores-ja-nao-lembra-em-quem-votou-nas-eleicoes.shtml>, acesso em 6.7.2013, $21: 14 \mathrm{~h}$.

"Presidente do STF faz duras críticas ao Congresso Nacional", disponível em: <http://g1.globo.com/videos/t/todos-os-videos/v/presidente-do-stf-faz-duras-criticas-aocongresso-nacional/2585353/>, acesso em 9.6.2013, 10:43h. 
"Processos na área da saúde passam de 240 mil", disponível em: $<$ http://saudefloripa33pj.wordpress.com/2011/04/28/processos-na-area-de-saude-passamde-240-mil/>, acesso em 21.11.11, 13:15h.

Programa Profissão Repórter exibido na Rede Globo em 5.6.12, disponível em: <http://g1.globo.com/profissao-reporter/noticia/2012/06/hospital-no-interior-do-maranhaotem-mais-funcionarios-do-que-pacientes.html>, acesso em 22.6.2012, 13:14h.

"Ranking de qualidade da educação coloca Brasil em penúltimo lugar", disponível em: <http://g1.globo.com/educacao/noticia/2012/11/ranking-de-qualidade-da-educacao-colocabrasil-em-penultimo-lugar.html>, acesso em 16.11.2013, 10:47h

"Registrar remédio na Anvisa vira batalha judicial”, Conjur, edição de 2.4.2013, disponível em: <http://www.conjur.com.br/2013-abr-02/industria-justica-acelerar-registro-remediosanvisa>, acesso em 17.6.2013, 13:43h.

"Saiba como variou o orçamento dos ministérios entre 2012 e 2013", disponível em: http://g1.globo.com/politica/noticia/2013/04/saiba-como-variou-o-orcamento-dosministerios-entre-2012-e-2013.html, acesso em 9.1.14, 9:00h.

"Saúde oferece duas novas vacinas para crianças a partir do $2^{\circ}$ Semestre", disponível em: $<$ http://www2.planalto.gov.br/imprensa/noticias-de-governo/saude-oferece-duas-novasvacinas-para-criancas-a-partir-do-2o-semestre>, acesso em 19.1.2012, 13:40h, reproduzida em <http://portalsaude.saude.gov.br/portalsaude/index.cfm>.

"Saúde amplia faixa etária para vacinação da Hepatite B", disponível em: <http://portalsaude.saude.gov.br/portalsaude/noticia/3890/162/saude-amplia-faixa-etariapara-vacinacao-de-hepatite-b.html>, acesso em 10.1.2012, 14:30h.

"Só no Brasil há saúde gratuita e universal, mas gasto privado é maior", disponível em: <http://www.cartamaior.com.br/templates/materiaMostrar.cfm?materia_id=18512>, acesso em 15.5.12, 14:13h.

"Suposta fraude leva CNJ a suspender pagamento de precatórios em RO", disponível em: <http://g1.globo.com/politica/noticia/2012/06/suposta-fraude-leva-cnj-suspenderpagamento-de-precatorios-em-ro.html>, acesso em 16.6.2012, 20:01h.

"SUS deve atualizar lista de remédio todo o ano", disponível em: <http://www1.folha.uol.com.br/folha/equilibrio/noticias/ult263u736201>.shtml, acesso em 12.01.2011, 18:59h. 
"SUS passa a distribuir pílula do dia seguinte sem receita médica", disponível em: http://drauziovarella.com.br/mulher-2/sus-passa-a-distribuir-pilula-do-dia-seguinte-semexigir-receita-medica/, acesso em 3.7.2013, 19:47h.

"SUS tem despesa recorde com ações judiciais", disponível em:

<http://www1.folha.uol.com.br/cotidiano/1199942-sus-tem-despesa-recorde-com-acoesjudiciais.shtml >, acesso em 15.7.2013, 6:55h.

“Tarso critica 'judicialização' da política”, disponível em:

<http://www.estadao.com.br/estadaodehoje/20090418/not_imp356871,0.php, acesso em 30.12.2010>, 11:56h.

“TJSP promove audiência pública sobre a falta de vagas na educação infantil”, disponível em: <http://www.estadao.com.br/noticias/vidae,tj-sp-promove-audiencia-publica-sobre-afalta-de-vagas-na-educacao-infantil,1065603,0.htm>, acesso em 30.9.2013, 18:51h.

“Usuário de plano de saúde terá número do Cartão do SUS", disponível em: $<$ http://veja.abril.com.br/noticia/saude/usuario-de-plano-de-saude-tera-numero-do-cartaosus>, acesso em 15.5.12, 14:19h.

"Vacinação contra a paralisia infantil termina nesta sexta feira no DF", disponível em: $<$ http://g1.globo.com/distrito-federal/noticia/2013/06/vacinacao-contra-paralisia-infantiltermina-nesta-sexta-feira-no-df.html>, acesso em 3.7.2013, 19:50h.

\section{II.A.2. Documentos, artigos e obras}

ADVOCACIA-GERAL DA UNIÃO, Intervenção judicial na saúde pública. Panorama no âmbito da Justiça Federal e Apontamentos na seara das Justiças Estaduais. Brasília: Advocacia-Geral da União, Introdução, disponível em: <http://portalsaude.saude.gov.br/portalsaude/arquivos/Panorama.pdf>, acesso em 15.7.2013, 7:43h.

ANDRIGHI, Fátima Nancy. "Estrutura e Dinâmica do Poder Judiciário Norte-Americano: aspectos de composição judicial e extrajudicial de litígios", disponível em:

<http://bdjur.stj.gov.br/xmlui/bitstream/handle/2011/1538/Estrutura_Dinâmica_Poder.pdf ? sequence $=4>$, acesso em 13.6.2010, 20:20h.

AMARAL, Gilberto Luiz, AMARAL, Letícia Mary Fernandes do, OLENIKE, João Eloi. Cálculo do IRBES (Índice de Retorno de Bem Estar à Sociedade) - Estudo sobre a Carga Tributária/PIB x IDH. Curitiba: Instituto Brasileiro de Planejamento Tributário, abril de 2013, disponível em: <https://www.ibpt.org.br/img/uploads/novelty/est 
udo/787/ESTUDOFINALSOBRECARGATRIBUTARIAPIBXIDHIRBESMARCO2013.p df>, acesso em 15.11.2013, 15:01h.

ARENHART, Sérgio Cruz. "As Ações Coletivas e o controle das políticas públicas pelo Poder Judiciário", em JusNavigandi, disponível em:

<http://jus2.uol.com.br/doutrina/texto.asp?id=7177>, acesso em 24.10.2008, 20:30h.

BARROSO, Luís Roberto. "A Ordem Econômica Constitucional e os Limites à Atuação Estatal no Controle de Preços”, em Revista Diálogo Jurídico, Salvador, CAJ - Centro de Atualização Jurídica, $n^{\circ}$ 14, junho/agosto de 2002, p. 21, disponível em: <http://www.direitopublico.com.br>, acesso em 14.8.2013, 14:33h.

. "A americanização do Direito Constitucional e seus paradoxos:

teoria e jurisprudência constitucional no mundo contemporâneo", disponível em: <http://w ww.luisrobertobarroso.com.br/wp content/themes/LRB/pdf/a_americanizacao_do_direito_ constitucional_e_seus_paradoxos.pdf>, acesso em 6.7.2013, 23:00h.

. "O Constitucionalismo Democrático no Brasil: Crônica de um Sucesso I mprevisto", p. 9, disponível em: <http://www.luisrobertobarroso.com.br/wp.content/upload s/2012/12/O.constitucionalismo.democratico.no.Brasil.pdf >, acesso em 10.6.2013, 14:33h.

BINDER, Jamie S. "Brown v. the Board of Education: Success or Failure?", disponível em:<http://www.umbc.edu/che/tahlessons/pdf/Brown_v._the_Board_of_Education_Succes s_or_Failure(PrinterFriendly).pdf>, acesso em 3.1.2011, 14:52h.

BRASIL, Manual Básico da Farmácia Popular do Brasil, disponível em: <http://portal.sa ude.gov.br/portal/arquivos/pdf/manual_basico_fp1170511.pdf>, acesso em 8.2.2, 13:40h.

Ministério da Justiça. Balanço Social 2007/2008 disponível em <http://portal.mj.gov.br/cfdd/data/Pages/MJ038B8D53PTBRNN.htm>, acesso em 20.12.2010, 23:18h.

BUNDERSMINISTERIUM DER JUSTIZ, "The German 'Capital Market Model Case Act'”, disponível em: <http://www.clglaw.eu/cmsimages/Publications/German\%20Capital $\% 20$ Markets\%20Case.pdf $>$, acesso em 30.9.2013, 15:02h.

" "Reform of German Model Proceedings Act planned", disponível em:

<http://globalclassactions.stanford.edu/sites/default/files/documents/Reform\%20of\%20Ger man\%20Model\%20Proceedings\%20Act\%20planned.pdf $>$, acesso em 30.9.2013, 15:26h. 
EUROPEAN COMISSION. Evaluation of the effectiveness and efficiency of collective redress mechanisms in the European Union - country report Germany. European Comission, 2008, disponível em: <http://ec.europa.eu/consumers/redress_cons/de-countryreport-final.pdf $>$, acesso em 30.9.2013, 15:48h

FALCÃO, Francisco. “Os juízes e a justiça”, disponível em: <http://www.cnj.jus.br/atosadministrativos/atos-da-presidencia/433-informacoes-para/imprensa/artigos/13339-osjuizes-e-a-justica>, acesso em 9.7.2013, 16:38h.

FILHO, Ives Gandra da Silva Martins. "Evolução Histórica da Estrutura Judiciária Brasileira”, em Revista Jurídica da Presidência da República. Brasília: V. 1, no 5 (set/1999 ), disponível em: <http://www.planalto.gov.br/ccivil_03/revista/Rev_05/evol_historica.htm $>$, acesso em 10.6.2013, 19:20h

FRANCO, Denise, PIRES, Natália, Terrazas, Fernanda, VILLELA, Mariana e WANG, Daniel. "Judiciário e fornecimento de insulinas análogas pelo sistema público de saúde: direitos, ciência e políticas públicas”. Casoteca Direito GV - Produção de Casos 2011, disponível em: <http://direitogv.fgv.br/sites/direitogv.fgv.br/files/insulinas_analogas __nota_de_ensino.pdf $>$, acesso em 15.8.2013, 22:13h.

FREY, Klaus. Políticas Públicas: Um Debate Conceitual e Reflexões Referentes à Prática da Análise de Políticas Públicas no Brasil, disponível em: <http://www.usp.br/procam/novosartigosparaaulas>, acesso em 2.7.2008, 7:04h.

GOLDBERG, Daniel K. “Controle de Políticas Públicas pelo Judiciário: Welfarismo em um mundo Imperfeito", disponível em: <http://www.ipea.gov.br/sites/000/2/livros/regulac aonobrasil/Arq07_Cap03.pdf>, acesso em 10.10.2010, 10:00h.

GONTIJO, Valter. "Orçamento Brasil. Evolução Histórica no Brasil”, disponível em: <http ://www2.camara.gov.br/atividade legislativa/orcamentobrasil/cidadao/entenda/cursopo/His toricoBrasil>, acesso em 8.6.12, 16:13h

KLIMA. Gergely. "Tradition, Revisionism, and Truth: coming to grips with the 'Lochner Era",, disponível em: <http://lawlib.wlu.edu/lexopus/works/391-1.pdf>, acesso em 6.7.2013, 15:34h.

LEAL, Luciana de Oliveira. "A Coisa Julgada nas Ações Coletivas”, p. 11, disponível em: <http://www.tjrj.jus.br/c/document_library/get_file?uuid=cce8be67-3e36-49f5-912b219abbae66ea\&groupId=10136>, acesso em 13.8.2013, 13:48h. 
MARINONI, Luiz Guilherme. "Relativizar a coisa julgada material?”, disponível em: <http://www.abdpc.org.br/abdpc/artigos/Luiz\%20G.\%20Marinoni\%284\%29\%20formatado.pdf $>$, acesso em 9.7.12, 14:35h.

MENDES, Gilmar. "Os Direitos Fundamentais e seus múltiplos significados na ordem constitucional”, em Revista Jurídica Virtual, Brasília,V.2, no 13 (junho/1999), disponível em: <http://www.planalto.gov.br/ccivil_03/revista/Rev_14/direitos_fund.htm>, acesso em 17.7.2013, 21:43h.

MENDES, Alberto M. G. “O Provedor Municipal”, disponível em: $<$ http://www.cmcascais.pt/NR/rdonlyres/E0478FEE-FF75-4AEC-8C89-

A99BB98D1FDC/4735/Ombudsman.pdf>, acesso em 5.1.2011, 20:29h

MONTESQUIEU. O Espírito das Leis, disponível: em <http://pensamentosnomadas.files. wordpress.com/2012/04/montesquieu-o-espirito-das-leis.pdf >, acesso em 9.6.2013, 17:14h

NOBLAT, Ricardo. "Greve dos médicos do SUS", disponível em: <http://oglobo.globo.com/pais/noblat/posts/2011/10/26/a-greve-dos-medicos-do-suseditorial-413320.asp>, acesso em 19.11.11, 20:57h.

OLIVEIRA, Carlos Alberto Alvaro. "Poderes do Juiz e Visão Cooperativa do Processo I", disponível em: <http://www.abdpc.org.br/abdpc/artigos/Carlos\%20A\%20A\%20de\%20 Oliveira\%20(8)\%20-formatado.pdf $>$, acesso em 3.1.2011, 18:55h.

PRUDENZANO, Lorenzo. "Comissario ad acta", em Altalexpedia - Enciclopédia Giuridica Online, disponível em: <http://www.altalex.com/index.php?idnot=13680>, acesso em 8.7.12, 14:39h.

RIBEIRO, Cristina Hamdar. "A Lei dos Recursos Repetitivos e os Princípios do Direito Processual Civil Brasileiro", em Revista Eletrônica de Direito Processual-REDP, V. V. Rio de Janeiro: Universidade Estadual do Rio de Janeiro, pp. 629/630, disponível em: <htt p://www.redp.com.br/arquivos/redp_5a_edicao.pdf>, acesso em 30.9.2013, 16:20h (pp. 614-691).

STANFORD ENCYCLOPEDIA OF PHILOSOPHY. Prisioner Dillema, disponível em: < http://plato.stanford.edu/entries/prisoner-dilemma/>, acesso em 19.12.2010, 19:11h.

STRECK, Lênio Luiz, OLIVEIRA, Marcelo Andrade Cattoni de, e LIMA, Martonio Mont'Alverne Barreto Lima. “A Nova Perspectiva do Supremo Tribunal Federal sobre o Controle Difuso: Mutação constitucional e Limites da Legitimidade da Jurisdição 
Constitucional", disponível em: <http://www.leniostreck.com.br/site/wpcontent/uploads/2011/10/4.pdf, acesso em 11.12.13, 19:47h.

TAVARES, Gerusa Rios Pessanha, et. al. Diagnóstico das Ações Judiciais direcionadas à Secretaria de Estado da Saúde do Espírito Santo. III Congresso Consad de Gestão Pública. Disponível em: <http://www.escoladegoverno.pr.gov.br/arquivos/File/Material_\%20CON SAD/paineis_III_congresso_consad/painel_9/diagnostico_das_acoes_judiciais_direcionad as_a_secretaria_de_estado_da_saude_do_espirito_santo.pdf>, acesso em 6.10.2013, 19:09h

TEIXEIRA, Sálvio de Figueiredo. "A formação do juiz contemporâneo", disponível em <http://www.cjf.jus.br/revista/numero4/artigo12.htm>, acesso em 26.12.2010, 11:35h.

UNIVERSITY OF BERKELEY, "The Common Law and Civil Law Traditions". The Robbins Collection. School of Law of Universitiy of California at Berkeley, disponível em: < http://www.law.berkeley.edu/library/robbins/CommonLawCivilLawTraditions.html>, acesso em 10.6.13, 13:17h.

\section{II.A.3. Sítios eletrônicos}

<http://app.tjsc.jus.br/noticias/listanoticia!viewNoticia.action?cdnoticia=21524>, acesso em 30.12.2010, 12:50h.

<http://dab.saude.gov.br/atencaobasica.php>, acesso em 9.7.2013, 10:55h.

<http://dab.saude.gov.br/atencaobasica.php>, acesso em 9.7.2013, 11:22h.

<http://fantastico.globo.com/Jornalismo/FANT/0,,MUL777176-5605,00>, acesso em 9.3.12, 14:15h.

<http://geraldoalckminpsdb.blogspot.com.br/2012/06/geraldo-alckmin-vai-justicacontra.html>, acesso em 13.6.2012, 20:04h.

<http://g1.globo.com/Noticias/Politica>, acesso em 23.12.2010, 10:56h.

<http://g1.globo.com/Noticias/Brasil/0,MUL1004668-5598,00.html>, acesso em 22.2.12, $12: 37 \mathrm{~h}$. 
<http://g1.globo.com/pa/para/noticia/2013/06/jutica-obriga-construcao-de-hospitalmaterno-infantil-no-para.html>, acesso em 28.7.2013, 18:46h.

<http://g1.globo.com/fantastico/noticia/2013/09/sus-cobrou-por-parto-em-homem-eoperacao-de-prostata-em-mulher.html>, acesso em 15.11.2013, 17:27.

<http://g1.globo.com/ciencia-e-saude/noticia/2012/03/de-0-10-indice-do-governo-da-nota54-saude-publica-no-brasil.html>, acesso em 1.3.2012, 20:05h.

<http://ias2.epharmatecnologia.com.br/sa/sec/newsdtl_dtl?p_informa=20403>, acesso em 9.3.12, $14: 17 \mathrm{~h}$.

<http://m.g1.globo.com/politica/noticia/2013/06/para-48-dos-entrevistados-saude-e-maiorproblema-do-pais.html?hash=3>, acesso em 14.7.2013, 18:06h.

<http://portal.anvisa.gov.br/wps/content/Anvisa+Portal/Anvisa/Inicio/Alimentos>, acesso em 14.7.2013, 11:38h.

<http://portal.saude.gov.br/portal/arquivos/pdf/rename2010.pdf>, acesso em 4 de junho de 2010, 20:23h.

<https://esaj.tjsp.jus.br/cjsg/resultadoCompleta.do>, acesso em 15.7.2013, 6:10h.

<http://www.adaction.org>, acesso em 12.4.2011, 18:33h.

<http://www.aen.pr.gov.br/modules/noticias/article.php?storyid=6233\&tit=Gastos-commandados-judiciais-de-medicamentos-crescem-10-vezes-em-dois-anos >, acesso em 27.12.2010, 14:33h.

<http://www.aids.gov.br/>, acesso em 2.10.2008, 14:34h.

<http://www.autism-society.org>, acesso em 12.6.2010, 14:20h.

<http://www.autism-society.org/site/PageServer?pagename=about_home >, acesso em 12.6.2010, 14:27h. 
<http://www.brasil.gov.br/sobre/o-brasil/estrutura/organizacao-do-governo/print>, acesso em 5.7.2013, 22:15h.

<http://www.camara.gov.br/sileg/integras/651669.pdf>, acesso em 20.12.2010, 22:30h

<http://casestudies.law.harvard.edu/about-harvard-law-case-studies/>, acesso em 20.11.2013, 16:37h.

<http://www.cjf.jus.br/revista/numero4/artigo12.htm>, acesso em 26.12.2010, 11:35h.

<http://www.cnj.jus.br>, acesso em 12.12.2012, 14:33h.

<http://www.cnj.jus.br/index.php?option=com_content\&view=category\&layout=blog\&id= 291>, acesso em 26.12.2010, 13:22h.

<http://www.cnj.jus.br/noticias/judiciario/19088:funcionamento-do-sus-e-tema-decapacitacao-para-futuros-juizes-no-mt $>$, acesso em 16.8.2013, 21:37h.

<http://www.cnj.jus.br/index.php?option=com_content\&view=article\&catid=1\%3Anotas \& $\mathrm{id}=12994 \% 3 \mathrm{Acnj}$-pretende-capacitar-300-juizes-para-atuar-na-area-de-saude $\&$ Itemid 675>, acesso em 26.12.2010, 16:04h.

$<$ http://www.cnj.jus.br/index.php?option=com_content\&view=article\&catid=1\%3Anotas\& id=12994\%3Acnj-pretende-capacitar-300-juizes-para-atuar-na-area-de-saude \&Itemid 675>, acesso em 26.12.2010, 16:04h.

$<$ http://www.cnj.jus.br/index.php?option=com_content\&view=article \&id=11083:portariano-93-de-17-de-maio-de-2010\&catid=58:portarias-da-presidia\&Itemid=511 >, acesso em 15.10.10, 17:11h.

<http://www.cnj.jus.br/noticias/cnj/14986:acoes-contra-planos-de-saude-seraomonitoradas-pelo-cnj>, acesso em 12.7.12, 20:35h

<http://www.combateagripesuina.com.br>, acesso em 2.1.2011, 18:31h.

<http://www.conjur.com.br/dl/sentenca-acp-crack-hospital.pdf>, acesso em 28.7.2013, 18:17h. 
<http://www.conjur.com.br/2012-jul-11/espirito-santo-construir-hospitaldependentesquimicos-2014>, acesso em 11.7.2011, 18:40h.

<http://www.conjur.com.br/2010-mar-26/tse-multa-lula-r10-mil-propaganda-antecipadasao-paulo>, acesso em 23.12.2010, 10:56h.

<http://www.conjur.com.br/2009-nov-27/judiciario-legislativo-concluem-dialogo>, acesso em 23.12.2010, 10:40h.

<http://www.contasabertas.com.br/WebSite/Noticias/DetalheNoticias.aspx? Id=1222\&Asp xAutoDetectCookieSupport=1>, acesso em 2.6.2013, 20:00h.

<http://www.direitoprocessual.org.br>, acesso em 3.1.2010, 14:47h.

<http://www.doencadegaucher.com.br/pacientes/conheca_doenca_de_gaucher/o-quanto-ecomum-a-doenca-de-gaucher>, acesso em 29.9.2013, 16:17h.

<http://www.each.usp.br/gpp/>, acesso em 20.11.2013, 17:00h.

<http://www.funasa.gov.br/internet/museuCronHis.asp>, acesso em 19.1.2012, 14:17h

<http://www.ibep.com.br>, 25.12.2010, 17:17h.

<http://www.ibge.gov.br>, acesso em 2.7.2012, 8:15h.

<http://www.impostometro.com.br/>, acessos em 6.3.12, 13:43h e 25.7.2013, 13:45h.

$<$ http://www.jusbrasil.com.br/noticias/2475238/cnj-defende-parcerias-com-orgaospublicos-para-reduzir-numero-de-processos-relativos-a-saude>, acesso em 26.12.2010, 16:08h.

<http://www.jusbrasil.com.br/noticias/2469154/judiciario-tera-54-magistradosresponsaveis-por-demandas-de-saude>, acesso em 26.12.2010, 16:14h.

<http://www.law.cornell.edu/rules/frcp/rule_23>, acesso em 4.5.12, 19:59h.

<http://www.napdisa.prp.usp.br/index.php/pt_br/>, acesso em 2.12.2013, 13:17h 
<http://www.portal.saude.gov.br/portal/profissional/área.ccfm?id_area=1337>, acesso em 6.11.2010, 21:23h.

<http://www.portal.saude.gov.br/portal/aplicacoes/noticias/default.cfm?pg=dspDetalheNot icia\&id_area=124\&CO_NOTICIA=11134>, acesso em 2.1.2011, 18:48h.

<http://portal.saude.gov.br/portal/saude/Gestor/area.cfm?id_area=378>, acesso em 14.7.2013, 15:49h).

<http://portal.saude.gov.br/portal/saude/Gestor/area.cfm?id_area=378>, acesso em 14.7.2013, 16:06h.

<http://www.prefeitura.sp.gov.br/cidade/secretarias/saude/hospital_municipal_infantil_me nino_jesus/>, acesso em 3.7.2013, 19:35h.

http://www.saude.gov.br/medicamentos, acesso em 2.10.2011, 13:15.

<http://www.saude.sp.gov.br/content/drespuwrot.mmp>, acesso em 26.12.2010, 15:35h.

<http://www.senado.gov.br/senado/novocpc/pdf/Anteprojeto.pdf $>$, acesso em 19.12.2010, $20: 24 \mathrm{~h}$

<http://www.stf.jus.br/portal/cms/verTexto.asp?servico=processoAudienciaPublicaSaude> , acesso em 16.7.2013, 20:33h.

<http://www.stj.jus.br/portal_stj/publicacao/engine.wsp?tmp.area=1067\&tmp.texto=10028 6>, acesso em 26.12.2010, 12:00h

<http://www.stj.jus.br/portal_stj/publicacao/engine.wsp?tmp.area=1024>, acesso em 26.12.2010, 12:08h.

<http://www.stj.jus.br/portal_stj/publicacao/engine.wsp?tmp.area=398\&tmp.texto=96448> , acesso em 20.12.2010, 23:33h.

$<$ http://www.stj.jus.br/portal_stj/publicacao/engine.wsp?tmp.area=1067\&tmp.texto=10028 6>, acesso em 26.12.2010, 12:00h. 
<http://www.stj.jus.br/portal_stj/publicacao/engine.wsp?tmp.area=1024>, acesso em 26.12.2010, 12:08h.

<http://www.tj.sp.gov.br>, acesso em 15.6.2010, 12:00h.

<http://www.uff.br/ppgcaps/Texto\%208\%20-\%20AF.pdf>, acesso em 26.12.2010, 15:38h.

<http://www.who.int/selection_medicines/committees/expert/17/WEB_unedited_16th_LIS T.pdf>, acesso em 6.11.2010, 23:14h.

<http://www.who.int/medicines/publications/essentialmedicines/en/>, acesso em 6.11.2010, 23:06h

<http://www1.folha.uol.com.br/folha/cotidiano/ult95u598181.shtml>, acesso em 2.1.2011, $18: 36 h$.

<http://www1.folha.uol.com.br/folha/brasil/ult96u712155.shtml>, acesso em 23.12.2010, $10: 56 h$.

<http://www2.camara.gov.br/agencia/noticias/SAUDE/192120-MEDICAMENTOSMAIS-CAROS-FORNECIDOS-PELO-SUS.html>, acesso em 9.3.12, 13:44h).

<http://www2.camara.gov.br/atividadelegislativa/orcamentobrasil/cidadao/entenda/cursopo /HistoricoBrasil>, acesso em 8.6.12, 16:33h.

<http://www12.senado.gov.br/noticias/entenda-o-assunto/emendas-ao-orcamento>, acesso em 28.7.2013, 11:44h.

\section{II.B. Jornais e Revistas}

“ANS apertou cobrança a planos, diz ex-chefe", em Folha de São Paulo, edição de 5.6.2013, n 30.744 , p. C10

"Cadeia de resultados", Editorial publicado na Folha de São Paulo, edição de 28.3.12, p. A2. 
"Câmara dá o $1^{\circ}$ passo para tentar tirar poder do STF", em $O$ Globo, edição de 25.4.2013, $\mathrm{n}^{\mathrm{o}} 29.116$, capa e pp. 3-5.

"Cristina Kirchner anuncia pacote para o Judiciário", em Folha de São Paulo, edição de 9.2.2013, nº 30.717, p. A17.

"Congresso vive 'faz de conta', diz ministro", em Folha de São Paulo, edição de 3.1.2013, $\mathrm{n}^{\mathrm{o}} 30.591$, p. A6.

"Desabrigados de 2008 em Santa Catarina ainda aguardam moradia”, em $O$ Globo, edição de 10 de janeiro de 2012, n $^{\circ} 28.645$, p. 4.

"Congresso decide esperar STF para votar Orçamento", em Folha de São Paulo, 19.2.2013, no 30.638, p. A6.

"Falta mais eficiência ao SUS do que verba, afirma estudo", em Folha de São Paulo, edição de 9.12.13, nº 30.931, Capa e pp. C1 e C3.

“Gargalo tributário”, em Folha de São Paulo, edição de 19.5.2013, n 30.727, p. B9.

"Gasto com pessoal cresce e cria risco para governadores". Folha de São Paulo, edição de 19.3.12, p. A4.

"Governo não cumpre corte de gastos como prometido". O Globo, edição de 12.12.11, p. 11.

"Há alternativa para verba de novos tribunais", em Folha de São Paulo, edição de 4.6.2013, no 30.743, p. A15.

"Hospitais federais têm fila de 12,5 mil à espera de cirurgia", em $O$ Globo, edição de 11.12.13, no 29.346, chamada de Capa e p. 14.

"Justiça manda Haddad cumprir promessas de vagas em creche", em Folha de São Paulo, edição de 17.12.13, n 30.939, p. C4.

“O Polvo no Poder”, Capa de Veja, edição n 2.182, de 15.9.2010.

“Prisões Lotadas", Editorial da Folha de São Paulo, edição de 23.2.12, p. A2. 
"STF libera Congresso para votar vetos como quiser", em Folha de São Paulo, edição de 28.2.2013, n 30.647, p. A8.

"SUS só é bom para 2\% dos brasileiros, diz ministério", em $O$ Globo, chamada de Capa da edição de 2.3.12.

“Temer derruba plebiscito e, sob pressão, volta atrás", em $O$ Globo, edição de 5.7.2013, n 29.187, Capa e pp. 2-6.

"Terceirização submete saúde pública ao mercado", entrevista de Dom Odilo Scherer à Folha de São Paulo, edição de 5.3.12, p. A16.

"Três mil e sessenta vetos pendem de decisão no Congresso", em $O$ Globo, edição de 19.12.2012, no 28.989, capa e pp. 31-32.

"Vozes em um mundo distante", em Revista Veja, edição de 10.7.2013, n 2.329, pp. 6061 .

Canadian Medical Association Journal, junho de 2007, p. 176.

Folha de São Paulo, edição de 20.6.2013, n 30.759, Capa e pp. C1-C5.

O Globo, edição de 11.10.2011, Segundo Caderno, pp. 23-24.

O Globo, edição de 28.8.2012, nº 28.876, coluna de Merval PEREIRA, p. 4.

O Globo, edição de 26.4.12, n 28.752, p. 16.

O Globo, edição de 26.4.12, nº 28.752, p. 36.

O Globo, edição de 7.3.12, p. 3 .

Revista Veja, edição no 2.196 - 22 de dezembro de 2010 - pp. 118-121. 


\section{II.C. Artigos em jornais}

BARATA, Luís Roberto Barradas. "Regulamentar é o melhor caminho - É positivo que o Estado seja obrigado por decisão judicial a fornecer certos medicamentos", Folha de São Paulo, edição de 17.3.2007, p. A3.

BINENBOJM, Gustavo. "O Supremo e a agenda legislativa", em $O$ Globo, edição de 27.2.2013, n' 29.059, p. 21.

COLLUCCI, Cláudia e WESTIN, Ricardo. "Indústria Farmacêutica financia ONGs". Folha de São Paulo, 18.5.2005, p. C1.

FERRAZ, Octávio Luiz da Motta. "Direito à Saúde, Escassez e o Judiciário", em Folha de São Paulo, edição de 10.8.2007, p. A3. . “De quem é o SUS?”, em Folha de São Paulo, edição de 20.12.2007, p.

A3.

PIOVESAN, Flávia. "O resgate dos direitos humanos”, em $O$ Globo, no 28.759, edição de 3.5.12, p. 7.

MARTINS, Ives Gandra da Silva. "Os dois Supremos", artigo publicado na Folha de São Paulo em 25 de abril de 2012, n 30.338, p. A3.

SCHWARTSMAN, Hélio. "Dilema carcerário", em Folha de São Paulo, edição de 28.3.12, p. A2.

\section{II.D. Legislação, normas, projetos de lei e recomendações}

$\underline{B R A S I L}$

Constituição.

Emenda à Constituição no 29/2000.

Proposta de Emenda à Constituição no 37/2011. 
Código Civil.

Código de Processo Civil.

Código de Defesa do Consumidor.

Lei Complementar $n^{\circ} 101 / 2000$.

Lei Complementar no 141/2012.

Lei $n^{\circ} 4.320 / 64$.

Lei $n^{\circ} 4.717 / 65$.

Decreto-lei n $^{0}$ 200/67

Lei ${ }^{\circ} 6.360 / 76$.

Lei $n^{\circ} 7.347 / 85$.

Lei ${ }^{\circ} 8.080 / 90$.

Lei ${ }^{\circ} 8.142 / 90$.

Lei ${ }^{\circ} 8.257 / 91$.

Lei $n^{\circ} 9.008 / 95$.

Lei ${ }^{\circ}$ 9.313/96.

Lei $n^{\circ}$ 9.782/99.

Lei no 9.787/99. 
Lei $\mathrm{n}^{\circ} 10.741 / 03$.

Lei $\mathrm{n}^{\circ}$ 11.101/05.

Lei $\mathrm{n}^{\mathrm{o}} 11.347 / 06$.

Lei $\mathrm{n}^{\mathrm{o}} 11.419 / 06$.

Lei $n^{\circ} 12.037 / 09$.

Lei $\mathrm{n}^{\mathrm{0}} 12.401 / 11$.

Lei $n^{\circ} 12.527 / 11$.

Lei $\mathrm{n}^{\mathrm{o}}$ 12.732/12.

Lei $n^{\circ} 12.846 / 13$.

Projeto de Lei n 5.139/2009.

Projeto de Lei do novo Código de Processo Civil.

Projeto de Lei de revisão do Código de Defesa do Consumidor.

Regimento Interno da Câmara dos Deputados.

Portaria Ministério da Saúde no 763/94.

Portaria Ministério da Saúde no 204/GM/07.

Portaria Ministério da Saúde n².577/GM/06.

Portaria COMARE n ${ }^{\circ}$ 1/2008. 
Portaria Ministério do Orçamento e Gestão nº 42/99.

DISTRITO FEDERAL

Lei Distrital nº 1.097/96.

CONSELHO SUPERIOR DA MAGISTRATURA

Provimento $n^{\circ} 556 / 97$.

\section{CONSELHO NACIONAL DE JUSTICA}

Resolução CNJ nº 15/2006.

Resolução CNJ nº 44/2007.

Resolução CNJ nº 31/2010.

Resolução CNJ n ${ }^{0}$ 106/2010.

Recomendação CNJ nº 39/2012.

REPPUBLICA ITALIANA

Codice del Processo Amministrativo.

\section{UNITED STATES OF AMERICA}

Federal Rules of Civil Procedure.

Rule 1.

Rule 23.

US Private Securities Litigation Reform Act. 
United States Bankruptcy Code.

Foreign Corrupt Practices Act.

$\underline{\text { REINO DE ESPAÑA }}$

Ley de La Jurisdicción Administrativa (LJCA, 29/1998).

ORGANIZAÇÃO DAS NAÇÕES UNIDAS

Pacto Interamericano de Direitos Econômicos, Sociais e Culturais.

ORGANIZAÇÃO MUNDIAL DE SAÚDE

Constituição (1946).

Resolução 58.33 da Assembleia Mundial da Saúde (2005).

INSTITUTO IBERO-AMERICANO DE DIREITO PROCESSUAL

Código-Modelo de Processos Coletivos para a Ibero-América.

\section{II.E. Jurisprudência}

SUPREMO TRIBUNAL FEDERAL

ADIN nº 829/DF, Rel. Min. Carlos VELLOSO, j. em 14.4.93.

MC em ADIN no 1.407/DF, Rel. Min. Sepúlveda PERTENCE, j. em 7.3.96

PET no 1.246-1/SC, Min. Celso de MELLO, DJ em 13.2.97. 
RE n o 247.900/RS, Rel. Min. Marco AURÉLIO, j. em 20.9.1999, DJ em 27.10.99.

RE n 195.192/RS, Rel. Min. Marco AURÉLIO, DJ em 31. 3.2000.

AgReg no RE $n^{\circ}$ 271.286/RS, Rel. Min. Celso de MELLO, j. em 12.9.2000, DJ em 24.11.2000.

ADIN nº 1.919/SP, Rel. Min. Ellen GRACIE, j. em 7.4.03.

ADPF n ${ }^{\circ}$ 45-9/DF, Rel. Min. Celso de MELLO, j. em 29.4.04, DJ em 4.5.04.

RE $n^{\circ}$ 197.917/SP, Rel. Min. Mauricio CORRÊA, DJ em 7.5.04.

AgReg no RE no 410.715/SP, Rel. Min. Celso de MELLO, DJU em 3.2.06.

Recl. $n^{\circ}$ 4.335/AC no HC no 82.959-7/SP Rel. Min. Gilmar MENDES, DJ em 25.8.06.

ADIN nº 3.305/DF, Rel. Min. Eros GRAU, j. em 13.9.06.

$\mathrm{SS} \mathrm{n}^{\circ}$ 3.073/RN, Min. Ellen GRACIE, j. em 9.2.2007, DJ em 14.12.07.

AgReg na STA nº 223/PE, Rel. Min. Ellen GRACIE, j. em 14.4.08.

STA 278-6/AL, Rel. Min. Gilmar MENDES, j. em 22.10.08.

STA no 244/PR, Min. Gilmar MENDES, j. em 19.9.2009, DJ em 24.4.09.

MS n 28627, Rel. Min. Celso de MELLO, j. em 20.02.2010, DJ em 01.03.10.

STA n ${ }^{\circ}$ 171/PR, Min. Gilmar MENDES, j. em 17.3.10.

STA no 211/RJ, Min. Gilmar MENDES, j. em 17.3.10.

STA nº 278/AL, Min. Gilmar MENDES, j. em 17.3.10. 
$\mathrm{SS} \mathrm{n}^{\mathrm{o}}$ 3724/CE, Min. Gilmar MENDES, j. em 17.3.10.

$\mathrm{SS} \mathrm{n}^{\circ}$ 2944/PB, Min. Gilmar MENDES, j. em 17.3.10.

$\mathrm{SS} \mathrm{n}^{\circ}$ 2361/MG, Min. Gilmar MENDES, j. em 17.3.10.

$\mathrm{SS} \mathrm{n}^{\circ}$ 3345/RN, Min. Gilmar MENDES, j. em 17.3.10.

$\mathrm{SS} \mathrm{n}^{\circ}$ 3355/RN, Min. Gilmar MENDES, j. em 17.3.10.

SL no 47/2010, rel. Min. Gilmar MENDES, j. em 17.3.10.

$\mathrm{SS} \mathrm{n}^{\circ}$ 3.989/PI, Min. Gilmar MENDES j. em 7.4.2010, DJ em 15.4.10.

STA nº 283/PR, Min. Gilmar MENDES, j. em 7.4.2010, DJ em 15.4.10.

$\mathrm{SS} \mathrm{n}^{\circ}$ 3.962/SE, Min. Gilmar MENDES, j. em 7.4.2010, DJ em 15.4.10.

SS n ${ }^{\circ}$ 4.045/CE, Min. Gilmar MENDES, j. em 7.4.2010, DJ em 15.4.10.

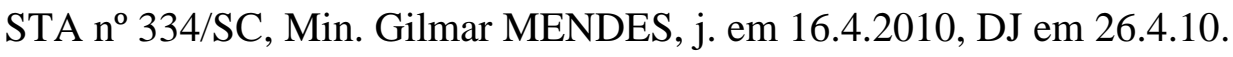

STA nº 434/BA, Min. Gilmar MENDES, j. em 16.4.2010, DJ em 26.4.10.

STA n ${ }^{\circ}$ 421/PE, Min. Gilmar MENDES, j. em 20.4.2010, DJ em 30.4.10.

SL no 256/TO, Min. Gilmar MENDES, j. em 20.4.2010, DJ em 30.4.10.

STA no 424/SC, Min. Gilmar MENDES, j. em 20.4.2010, DJ em 30.4.10.

STA no 260/SC, Min. Gilmar MENDES, j. em 20.4.2010, DJ em 30.4.10. 
AgReg na STA nº 175/CE, Rel. Min. Gilmar MENDES, DJ em 30.4.10.

RE n ${ }^{\circ}$ 363.889/DF, Rel. Min. Dias TOFFOLI, DJ em 10.6.11.

RE no 368.564/DF, Rel. Min. Menezes DIREITO, Rel. para o acórdão Min. Marco AURÉLIO, DJ em 10.8.11.

RE nº 657.718RG/MG, Pleno, Rel. Min. Marco AURÉLIO, DJ em 9.3.12.

ADPF nº 54, Rel. Min. Marco AURÉLIO, DJ em 30.4.13.

SUPERIOR TRIBUNAL DE JUSTICA

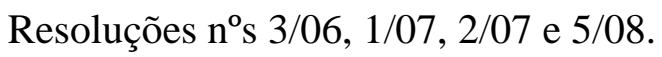

REsp nº 226.436/MG, $4^{\mathrm{a}}$ T., Rel. Min. Sálvio de Figueiredo TEIXEIRA, DJ em 28.6.01.

MS Coletivo n 11.824, Rel. Min. Peçanha MARTINS, DJ em 27.5.02.

REsp n⿳3 353.147/DF, $2^{\text {a }}$ T, Rel. Min. Franciulli NETO, DJ em 18.8.03.

REsp n ${ }^{\circ}$ 706.987/DF, Rel. Min. Humberto Gomes de BARROS, $2^{\text {a }}$ Seção, DJ em 15.5.06.

REsp nº 801.005/SP, Rel. Min. Teori ZAVASCKI, j. em 20.3.07.

REsp nº 592.693/MT, Rel. Min. Teori ZAVASCKI, j. em 7.8.07.

REsp n ${ }^{\text {o }}$ 1.110.549/RS, $2^{\text {a }}$ Seção, Rel. Min. Sidnei BENETTI, DJ em 14.12.09.

EDcl nos EDcl nos EDcl no AgRg no REsp n 1.028.835/DF, $1^{\text {a }} \mathrm{T}$, Rel. Min. Luiz FUX, DJ em 2.3.10.

RMS nº 24.584/SP, Rel. Min. Napoleão Nunes MAIA FILHO, j. em 9.2.10, DJ em 8.3.10. 
REsp n ${ }^{\circ}$ 706.987/RJ, $3^{\text {a }}$ T., Rel. Min. Humberto Gomes de BARROS, DJ em 8.4.10.

REsp n ${ }^{\text {1 }}$ 1.185.474/SC. $2^{\mathrm{a}}$ T. Rel. Min. Humberto MARTINS, j. em 20.4.10.

$\operatorname{SLS~n}^{\circ}$ 1.570/RS, Rel. Min. Pres. Ari PARGENDLER, j. em 30.4.13.

REsp n ${ }^{\circ}$ 1.069.810/RS, $1^{\text {a }}$ Seção, Rel. Min. Napoleão Nunes Maia FILHO, DJ em 6.11.13.

\section{TRIBUNAL DE JUSTIÇA DO ESTADO DE SÃO PAULO}

Apel. nº 0000667-91.2012.8.26.0219, Rel. José Luiz Gavião de ALMEIDA, $3^{\text {a }}$ Câmara de Direito Público, j. em 30.4.13.

Apel. nº 0011175-43.2012.8.26.0269, Rel. José Luiz Gavião de ALMEIDA, $3^{\text {a }}$ Câmara de Direito Público, j. em 21.5.13.

Apel. $\mathrm{n}^{\circ}$ 0014453-97.2010.8.26.0309, Rel. Jarbas GOMES, 8ª Câmara de Direito Público, j. em 19.6.13.

Apel. nº 0003381-55.2009.8.26.0663, Rel. Paulo Barcellos GATTI, 4 ${ }^{\text {a }}$ Câmara de Direito Público, j. em 24.6.13.

Apel. ${ }^{\circ}$ 0017293-60.2010.8.26.0348, Rel. Paulo Barcellos GATTI, 4 ${ }^{\text {a }}$ Câmara de Direito Público, j. em 24.6.13.

Apel. n ${ }^{\circ}$ 9000296-06.2010.8.26.0037, Rel. Marrey UINT, $3{ }^{\text {a }}$ Câmara de Direito Público, j. em 25.6.13.

Apel. 0007640-67.2011.8.26.0358, Rel. Marrey UINT, $3^{\text {a }}$ Câmara de Direito Público, j. em 25.6.13.

Apel. $n^{\circ}$ 0032062-42.2012.8.26.0562, Rel. Cristina COTROFE, $8^{\mathrm{a}}$ Câmara de Direito Público, j. em 26.6.13.

Apel. nº 0017410-56.2009.8.26.0196. Rel. Des. Manoel RIBEIRO, 8ª Câmara de Direito Público, j. em 26.6.13.

Apel. nº 0031161-83.2011.8.26.0053, Rel. Paulo Barcellos GATTI, 4 Câmara de Direito Público, j. em 6.7.13. 
Apel. nº 0004751-80.2011.8.26.0572, Rel. Burza NETO, 12 Câmara de Direito Público, j. em 6.7.13.

Apel. 0006237-30.2011.8.26.0272, Rel. Burza NETO, 12a Câmara de Direito Público, j. em 6.7.13.

Apel. 0019291-76.2012.8.26.0224, Rel. Burza NETO, 12a Câmara de Direito Público, j. em 6.7.13.

Apel. 0028063-56.2012.8.26.0053, Rel. Burza NETO, 12a Câmara de Direito Público, j. em 6.7.13.

0012890-69.2012.8.26.0286, Rel. Burza NETO, 12ª Câmara de Direito Público, j. em 6.7.13.

Apel. 0025164-85.2012.8.26.0053, Rel. Burza NETO, 12ª Câmara de Direito Público, j. em 6.7.13.

Apel. 0000003-88.2013.8.26.0554, Rel. Burza NETO, 12ª Câmara de Direito Público, j. em 6.7.13.

Apel. 0001236-85.2012.8.26.0189, Rel. Burza NETO, 12ª Câmara de Direito Público, j. em 6.7.13.

Apel. 0050171-56.2009.8.26.0224, Rel. Burza NETO, 12a Câmara de Direito Público, j. em 6.7.13.

Apel. 0001893-78.2011.8.26.0248, Rel. Burza NETO, 12ª Câmara de Direito Público, j. em 6.7.13.

Reexame Necessário n ${ }^{\circ}$ 0002132-79.2012.8.26.0076, Rel. Burza NETO, $12^{\text {a }}$ Câmara de Direito Público, j. em 6.7.13.

Reexame Necessário no 0003383-51.2012.8.26.0394, Rel. Burza NETO, 12ª Câmara de Direito Público, j. em 6.7.13. 
Reexame Necessário nº 0001632-19.2011.8.26.0441, Rel. Burza NETO, 12ª Câmara de Direito Público, j. em 6.7.13.

JUSTIÇA FEDERAL - SEÇÃO JUDICIÁRIA DE CURITIBA

Autos n ${ }^{\mathrm{o}}$ 5002213-42.2010.404.7000/PR, 2 $2^{\mathrm{a}}$ Vara Federal.

JUSTICAA ESTADUAL DO ESPÍRITO SANTO

Autos n ${ }^{\circ}$ 024.09.013938-7, $2^{\text {a }}$ Vara da Fazenda Pública de Vitória, Espírito Santo. Sentença de 2.7.2012.

SUPREMA CORTE DOS ESTADOS UNIDOS:

165 U.S. 578 (1897).

432 U.S. $464,474$.

347 U.S. 483 (1954).

349 U.S. 294 (1955).

391 U.S. 430 (1968).

396 U.S. 19 (1969).

402 U.S. 1 (1971).

410 U.S. 113 (1973).

417 U.S. 156 (1974).

490 U.S. 755 (1989). 
COURT OF APPEALS OF ALABAMA

325 F. Supp. 781 - M.D. Ala. (1971).

$\underline{5^{T H} \text { CIRCUIT COURT OF APPEALS }}$

95-30725.

469 F.2d 1326. 